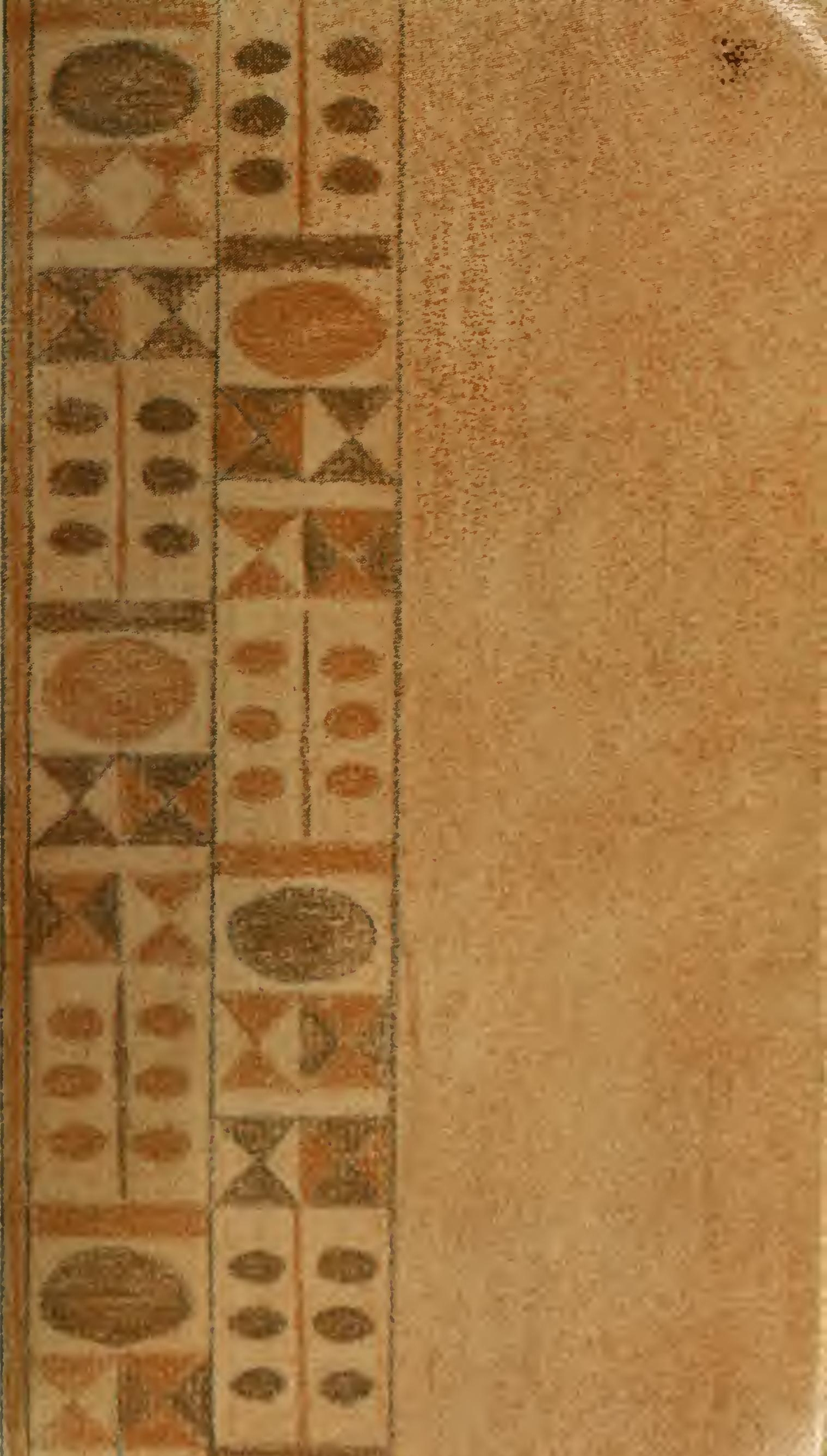





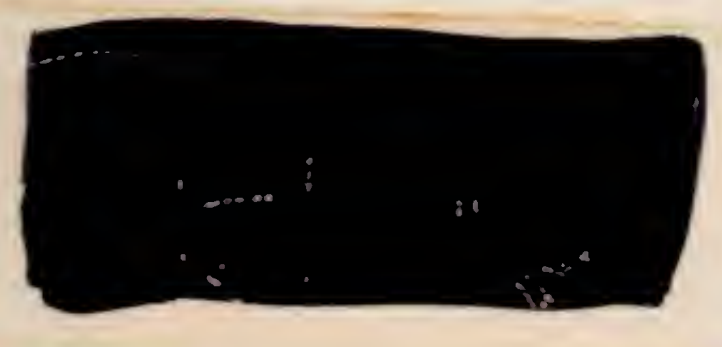



Digitized by the Internet Archive in 2013 

TIIE

$=$

\section{DESCENT OF MAN,}

$\triangle \times D$

\section{SELECTION IN RELATION TO SEX.}

BY

CHARLES DARTIN, M. A., F.R.S., ETC.

WTTII HLLISTRATIONS

IN THO VOLUISG. - TOL.I.

NEW York:

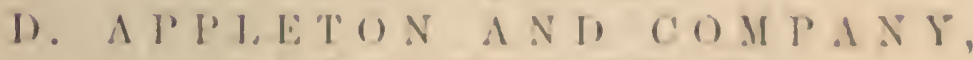

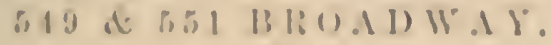

15.1.

Library of

The Church College of Hawaii 



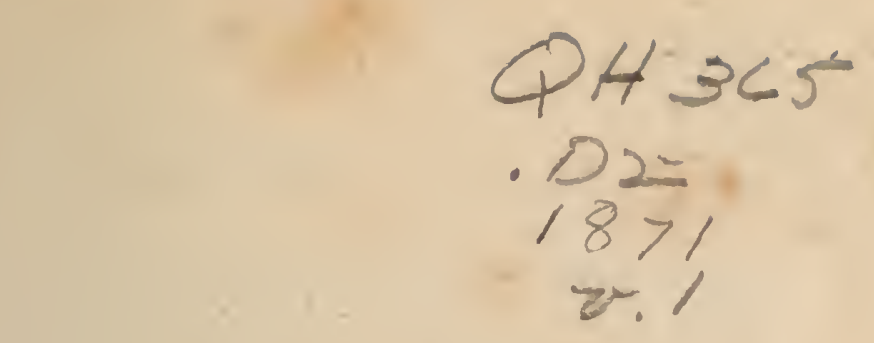

\section{In: $11 \mathrm{H}$ \\ C O N TENTS.}

Introdection, . $\quad \cdot \quad \cdot \quad \cdot \quad \cdot \quad \cdot \quad \cdot \quad \cdot \quad$. Page 1

PART I.

\section{THE DESCENT OR ORIGIN OF MAN.}

\section{$\checkmark$ CHAPTER I.}

THE EVIDENCE OF THE DESCENT OF MAN FROM SOME LOWER FORM.

Nature of the Evidence bearing on the Origin of Man.-Homologous struetures in Man and the Lower Animals.-Miscellaneous Points of Correspondenec.-Development.-Rudimentary Structures, Muscles, Senscorgans, IIair, Bones, Reproductive Organs, ete.-The Bearing of these three great Classes of Facts on the Origin of Man, . . . p. 9

\section{CHAPTER II.}

COMPARISON OF TIL MENTAL POWERS OF MAN AND THE LOWLIR ANLMALS.

'L'he Difference in Mental Power between the Highest $\Lambda$ pe and the Lowest Savage, imnense.-Ccrtain Instincts in eommon.-Tho linotions.Curiosity.-Initation.-Attention.-Memory.-Imarination.-Renson. -Progressive Improvement.-Tools und Weapons used by Animals. -Ianguagre.-Self-Conseiousness.-Senso of Besuty.-Bulief in God, Spiritual $\Lambda$ geneies, Superstitions, . . . . . . p. 33

\section{CHAP'TEIR III.}

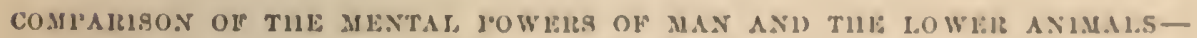
continued.

Tho Morul Scnse.-Fundanentul Proposition.-Tho Qualitics of Sucial Animnls.-Origin of Suciubility.-Sitrmgglo betwent Oppused lnntincts. - Mnu u Socinl Animul.-Tho more culuring sociul Iustincts

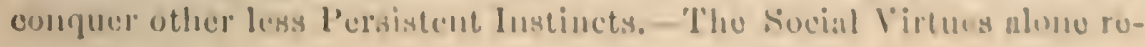


garded by Savages.-The Self-regarding Virtues aequired at a Later Stage of Development.-The Importance of the Judgment of the Members of the same Community on Conduct.-Transmission of Moral Tendeneics.-Summary, . • • . • • page 67

\section{$\checkmark$ CIIAPTER IV.}

ON THE MANNER OF DEVELOPMENT OF MAN FROM SOME LOWER FORM.

Variability of Body and Mind in Man.-Inleritance.-Causes of Variability.-Laws of Variation the same in Man as in the Lower Animals. -Direct Aetion of the Conditions of Life.-Effects of the Increased Uso and Disuse of Parts.-Arrested Development.-Reversion.-Correlated Variation.-Rate of Inerease.-Cheeks to Inerease.-Natural Seleetion.-Man the most Dominant Animal in the World.-Importanee of his Corporeal Strueture.-The Causes whieh have led to his beeoming crect.-Consequent Changes of Structure.-Deerease in Size of the Canine Teeth. - Inereased Size and Altered Shape of the Skull.-Nakedness.-Absenee of a Tail.-Defeneeless Condition of Man, • • • • • • • • • • • . p. 103

\section{CHAPTER V.}

ON THE DEVELOPMENT OF TIIE INTELLECTUAL AND MORAL FACULTIES DURING PRIMEVAL AND CIVILIZED TIMES.

The Advaneement of the Intellectual Powers through Natural Seleetion.Importanee of Imitation.- -Soeial and Moral Faeulties. - Their Development within the Limits of the same Tribe.-Natural Selection as affeeting Civilized Nations. - Evidenee that Civilized Nations were onee barbarous, . • • • • • • • • • . p. 152

\section{CHAPTER VI.}

ON TIIE AFFINITIES AND GENEALOGY OF MAN.

Position of Man in the Animal Series.-The Natural System genealogieal. -Adaptive Characters of Slight Value.-Various Small Points of Resemblanec between Man and the Quadrumana.-Rank of Man in the Natural System.-Birtliplaee and Antiquity of Man.-Absenee of Fossil Conneeting-links.-Lower Stages in the Genealogy of Man, as inferred, firstly from his Affinities and seeondly from his Strueture.Early Androgynous Condition of the Vertebrata.-Conelusion, p. 178 


\section{$\checkmark$ CHAPTER VII.}

ON THE RACES OF MTAN.

The Nature and Value of Specifie Charaeters.-Applieation to the Races of Man.-Arguments in favor of, and opposed to, ranking the Soealled Raees of Man as Distinet Speeies.-Sub-species.-Monogenists and PolJgenists. - Convergence of Character.-Numerous Points of Resemblance in Body and Mind between the most Distinet Raees of Man.-The State of Man when he first spread over the Earth.-Eaeh Raee not desecnded from a Single Pair.-The Extinetion of Raees.'The Formation of Raees. - The Effeets of Crossing. - Sliglit Influenee of the Direet $\Delta$ etion of the Conditions of Life.-Slight or no Influenee of Natural Selection.-Sexual Selection, . • . . page 206

\section{PART II.}

\section{SEXUAL SELECTION.}

\section{CIIAPTER VIII.}

PRINCIPLES OF SEXUAL SELECTION.

Secondary Sexual Charaeters. - Sexual Seleetion.-Manner of Aetion.Exeess of Males.-Polygamy. - The Male alone generally moditicl through Sexual Selection.-Eagerness of the Male.-Variability of the Male.-Choiee exerted by the Female.-Sexual eompared with Natural Seleetion.-Inlieritanee, at Corresponding Periods of Life, at Corresponding Seasons of the Year, and as limited by Sex.-Lelations between the Several Forms of Inlieritanee.-Causes why one Sex and the Young are not modified through Sexual Seleetion.-Supplenent on the Iroportional Numbers of the two Sexes throngliout the Animal Kingdon.-On the Limitation of the Numbers of tho two Sexes through Natural Selection, . . . . . . . p. 2tis

\section{CILAPTER IX.}

BECONDAIY BEXUAI, CHARACTEIS IN THF LOWER CLASSLS OF THE A.IMA. KINGUOM.

'Theso Charneters absent in the Lowest Clusses. - Brillimert Colors. -Mol1usca.-Amelids.-Crustacea, Seendary Sexial Characters strongly developed; Dimorphism; ('olor; "luntaeters not necpured before Natmrity.-Fipilers, Sexual Colors of; Stridulution ly tho Mates.Mylispodil, 


\section{CIIAP'TER X. \\ SECONDARY SEXUAL CHARACTEIS OF IXSECTS.}

Diversified Struetures possessed by the Males for scizing the Females.Differenees between the Sexes, of which the Meaning is not understood.-Differenee in Size between the Sexes.-Thysanura.-Diptera. -Hemiptera.-Homoptera, Musieal Powers possessed by the Males alone.-Orthoptern, Musieal Instruments of the Males, mueh diversified in Strueture; Pugnaeity; Colors.-Neuroptera, Scxual Differences in Color.-IInmenoptera, Pugnacity and Colors.-Coleoptera, Colors; furnished with Great Horns, apparently as an Ornament; Battles; Stridulating Organs generally common to Botlı Sexes, - page 331

\section{CIAPTER XI.}

LSECTS, continued.-ORDER LEPIDOPTERA.

Courtship of Butterflies.-Battles.-Ticking Noise.-Colors common to Botl Sexes, or more brilliant in the Males.-Examples. - Not due to the Direet Aetion of the Conditions of Life.-Colors adapted for Protection.-Colors of Moths.-Display.-Pereeptive Powers of the Lepidoptera.-Variability.-Causes of the Differenee in Color between the Males and Females.-Mimiery, Female Butterflies more brilliantly colored than the Males.-Bright Colors of Caterpillars.-Summary and Coneluding Remarks on the Secondary Sexual Charaeters of Inscets.-Birds and Insects conpared, . . . . . p. 874 


\section{IN'TRODUCTION.}

'Tne nature of the following work will be best under. stood by a bricf account of how it came to be written. During many years I collected notes on the origin or descent of man, without any intention of publishing on the subject, but rather with the determination not to publish, as I thought that I should thus only ard to the prejudices against my views. It seemed to me sufficient to indicate, in the first edition of my 'Origin of Species,' that by this work "light would be thrown on the origin of man and his history;" and this implies that man must be included with other organic beings in amy general conclusion respecting his mamer of appearance on this earth. Now the case wear's a wholly ditlierent aspect. When a naturalist like Carl Vugt ventures to say in his address as President of the National Iustitution of Geneva (1569), "personne, en Europe au moins, n'oses plus sontenir la création indépendanto et de tontes picices, dos espices," it is manifiot that at 
least a large number of naturalists m:sst admit that species are the modified descendants of other species; and this especially holds good with the younger and rising naturalists. The greater number accept the agency of natural selection; though some urge, whether with justice the future must decide, that I have greatly overrated its importance. Of the older and honored chiefs in natural science, many unfortunately are still opposed to evolution in every form.

In consequence of the views now adopted by most naturalists, and which will ultimately, as in every other case, be followed by other men, I have been led to put together my notes, so as to see how far the general conclusions arrived at in my former works were applicable to man. This seemed all the more desirable as I had never deliberately applied these views to a species taken singly. When we confine our attention to any one form, we are deprived of the weighty arguments derived from the nature of the affinities which connect together whole groups of organisms-their geographical distribution in past and present times, and their geological succession. The homological structure, embryological development, and rudimentary organs of a species, whether it be man or any other animal, to which our attention may be directed, remain to be considered; but these great classes of facts afford, as it appears to me, ample and conclusive evidence in favor of the principle of gradual evolution. Tle strong sup- 
port derived from the other arguments should, however, always be kept before the mind.

The sole object of this work is to consider, firstly, whether man, like every other species, is descended from some preëxisting form; secondly, the manner of his development; and thirdly, the value of the differences between the so-called races of man. As I shall confine myself to these points, it will not be necessary to describe in detail the differences between the sereral races-an enormous subject, which lias been fully discussed in many valuable works. The high antiquity of man has recently been demonstrated by the labors of a host of eminent men, beginning with M. Bouclier de Perthes; and this is the indispensable basis for understanding lis origin. I shall, therefore, take this conclusion for granted, and may refer my readers to the admirable treatises of Sir Charles Lyell, Sir John Lubbock, and others. Nor shall I have occision to du more than to allude to the amount of difference between man and the anthropomorphous apes; for Prof. Inxley, in the opinion of most competent judges, has conclusively slown that in every single visible character man differs less from the higher apes than these do from the lower members of the same order of Primates.

This work contains hardly any origrinal ficets in regard to man; but, as the conchusions at which I arrived, after drawing up a romgh draft, appeaned to me interesting, I thought that they mightit interot 
others. It has often and confidently been asserted, that man's origin can never be known: but ignorance more frequently begets confidence than does knowledge : it is those who know little, and not those who know much, who so positively assert that this or that problem will never be solved by science. The conclusion that man is the co-descendant with other species of some ancient, lower, and extinct form, is not in any degree new. Lamarck long ago came to this conclusion, which has lately been maintained by several eminent naturalists and philosopler's; for instance, by Wallace, Huxley, Lyell, Vogt, Lubbock, Büchner, Rolle, etc., ${ }^{1}$ and especially by Häckel. This last naturalist, besides his great work, 'Generelle Morplologie' (1866), has recently (1868, with a second edit. 1870) published his 'Natürliche Schöpfungsgeschichte,' in which he fully discusses the genealogy of man. If this work had appeared before

${ }^{1} \Lambda$ s the works of the first-named authors are so well known, I need not give the titles; but, as those of the latter are less well known in Ergland, I will give them: 'Sechs Vorlesungen über die Darwin'sehe 'Theorie:' zwiete Auflage, 1868, von Dr. L. Büchner; translated into French under the title 'Conférences sur la Théorie Darwinienne,' 1869. 'Der Menseh, im Lichte der Darwin'sche Lehre,' 1865, von Dr. F. Rolle. I will not attempt to give references to all the authors who have taken the same side of the question. Thus G. Canestrini has published (' $\Lambda \mathrm{n}$ nuario della Soc. d. Nat.,' Modena, 1867, p. 81) a very curious paper on rudimentary eharacters, as bearing on the origin of man. Another work has (1869) been published by Dr: Barrago Franeesco, bearing in Italian the title of "Man, made in the image of God, was also made in the image of the ape." 
my essay had been written, I should probably never have completed it. Almost all the conclusions at which I have arrived I find confirmed by this naturalist, whose knowledge on many points is much fuller than mine. Wherever I have added any fact or view from Prof. Häckel's writings, I give his authority in the text, other statements I leave as they originally stood in my manuscript, occasionally giving in the foot-notes references to his works, as a confirmation of the more doubtful or interesting points.

During many years it has seemed to me highly probable that sexual selection has played an important part in differentiating the races of man; but in my 'Origin of Species' (first edition, p. 199) I contented myself by merely alluding to this belief. When I came to apply this view to man, I found it indispensable to treat the whole subject in full detail. ${ }^{2}$ Consequently the second part of the present work, treating of sexual selection, has extended to an inordinate leneth, compared with the first part; but this could not be avoided.

I had intended adding to the present rolumes an esisity on the expression of the various emotions by man and the lower animals. My attention was called to this fubject many. years ago hy Sir Charles Bell's admirable

2'rof. Hiickel is tho sole anthor who, since the publicntion of the 'Origin,' lans discusted, in lis surons works, in a rery nble manme r, tho suloject of resual selection, mad hata secen its full imporenuec. 
work. This illustrious anatomist maintains that man is endowed with certain muscles solely for the sake of expressing his emotions. As this view is obviously opposed to the belief that man is descended from some other and lower form, it was necessary for me to consider it. I likewise wished to ascertain how far the emotions are expressed in the same manner by the different races of man. But, owing to the length of the present work, I have thought it better to reserve my essay, which is partially completed, for separate publication. 
PART I.

THE DESCENT OR ORIGIN OF MAN. 



\title{
THE DESCENT OF MAN.
}

\author{
C II A P'TER I.
}

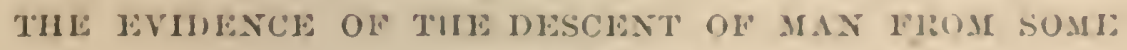
LOWLI: HURM.

Nuture of the lividence bearing on the Origin of Man.-Homologens struet. ures in Man und the Lower Aumals. -Misecllaneous l'oints of C'orrcspoudence.-Development.-Kudimentary Struetures, Muscles, semeorguns, Hair, Bones, Reproductive Orgms, cte.-Thu Be:aring of theso three grent Classes of Facts on the Origin of Man.

Hs: who wishes to decide whether man is the morlifich descendant of some preëxisting form, would probably liret inguire whether man varies, howerer slighly, in hodily structure and in mcontal fisculties; and if so, whether the variations are tramsmitted to his oflspring in accorilunce with the laws which preval with the howe animals; smeh as that of the transmission of characters to the same ane or sex. Agrain, are the variations the result, as fur as our ignorance permits us to jurlge, of the same general camers, and are they governed by the same general laws, as in the

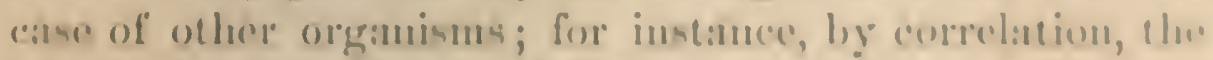

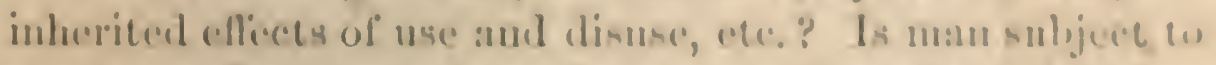

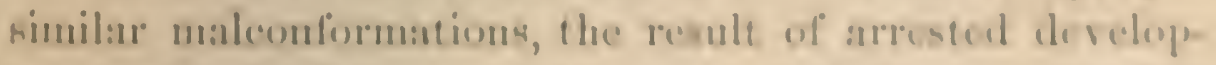

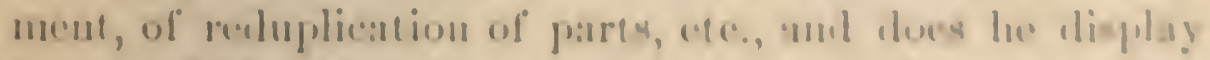

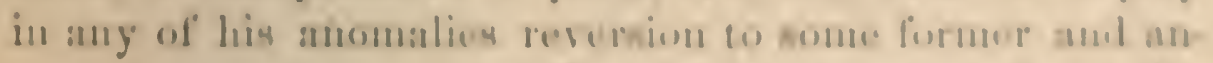

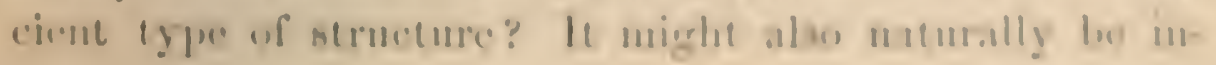


quired whether man, like so many other animals, has given rise to varieties and sub-races, diflering but slightly from cach other, or to races differing so much that they must be classed as doubtful species? How are such races distributed over the world; and how, when crossed; do they react on each other, both in the first and succecding generations? And so with many other points.

The inquirer would next come to the important point, whether unan tends to increase at so rapid a rate, as to lead to occasional serere struggles for existence, and consequently to beneficial variations, whether in body or mind, being preserved, and injurious ones eliminated. I)o the races or species of men, whichever term may be applied, encroach on and replace each other, so that some finally become extinct? We shall see that all these questions, as indeed is obrious in respect to most of them, must be answered in the aftirmatire, in the same manner as with the lower animals. But the several considerations just referred to may be conveniently deferred for a time; and we will first see how far the bodily structure of man shows traces, more or less plain, of his descent from some lower form. In the two succecling chinpters the mental powers of man, in comparison with those of the lower animals, will be considered.

The Bodily Structure of 7 Tun.-It is notorious that man is constructed on the same general type or model with other mammals. All the bones in his skeleton can be compared with corresponting bones in a monkey, bat, or seal. So it is with his muscles, nerves, blood-ressels, and internal viscera. The brain, the most important of all the organs, follows the same liw, as shown by Inuxley and other anatomists. Bischoff," who is a hostile witness, admits that every chief fissure and fold in the brain of

'Girosshiruwindungen des Minchen,' 1868, s. 96. 
man has its aualogy in that of the orang; but he adds that at no period of development do their braius perfectly agree; nor could this be expected, for otherwi-e their inental powers would have been the same. Vulpian remarks: "Les diffërences réclles qui existent entre l'oncífhale de l'homme et celui des singes supéricurs, sont bien ninimes. Il ue faut pas se farre d'illusions a cet égard. L'homme est bien plus pris des singes anthropomorphus par les caractères anatomiques de son cerreau que coux-ci ne le sont non-seulcment des autres mamnifires, mais mêmes de certains quadrumanes, des guenons et dies ma"acques." But it would be smperthous here to grive further details on the correspondence between man and the highter manmals in the structure of the hratus and anll other parts of the body.

It may, however, be wortls while to specify as few points, not directly or olviously connected with strme? ure, by which this correrpondence or relationship is well shov: 3 .

Man is liable to receive from the lower animals, and to communieate to them, certain discases, as hydrophubin, varoba, the glanders, ete.; and this fact proves the close tinilarity of their tissnes and blood, both in minute struct ure and compusition, far more flanly than does thesir comparien undur the bet mioroscope, or by the und of the hiet chenical analysis. Mortegs are lialule to many of the same non-contagioun discisen as we are; thus limge gere, who carefully olseorred for a longe timse the Cebues

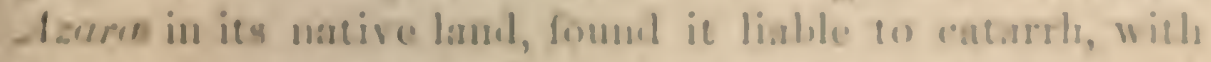

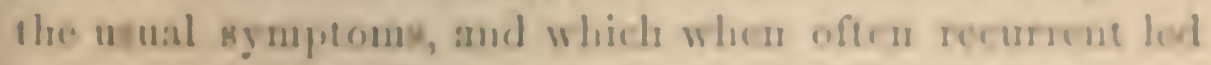

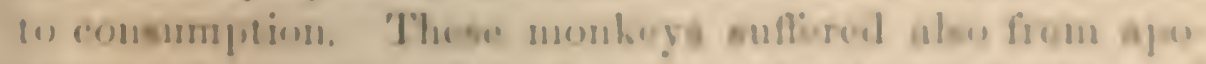
plexy, inflimmation of the bownts, and catanat in the ere.

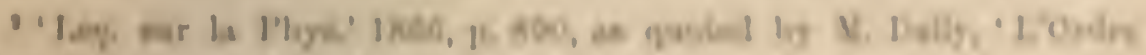

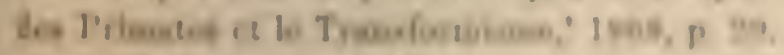

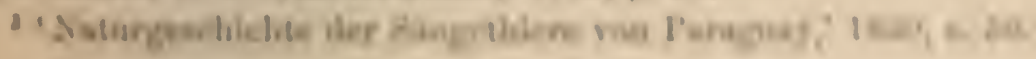


The younger ones when shedding their milk-teeth often died from fever. Medicines produced the same effect on them as on us. Many kinds of monkeys have a strong taste for ten, coffee, and spirituous liquors: they will also, as I have myself seen, smoke tobacco with pleasure. Brehm asserts that the natives of northeastern Africa catch the wild baboons by exposing vessels with strong beer, by which they are made drunk. He has seen some of these animals, which he kept in confinement, in this state; and he gives a laughable account of their behavior and strange grimaces. On the following morning they were very cross and dismal; they held their aching heads with both hands and wore a most pitiable expression; when beer or wine was offered them, they turned away with disgust, but relished the juice of lemous." An American monkey, an Ateles, after getting drunk on brandy, would never touch it again, and thus was wiser than many men. 'These trifling facts prove how similar the nerves of taste must be in monkeys and man, and how similarly their whole nerrous system is affected.

Man is infested with internal parasites, sometimes causing fatal effects, and is plagued by exterual parasites, all of which belong to the same genera or families with those infesting other mammals. Man is subject like other mammals, birds, and eren insects, to that mysterious liww, which causes certain normal processes, such as gestation, as well as the maturation and duration of various diseases, to follow lunar periods." His wounds are reparred by the same process of healing; and the stumps left after the

- Brehm, 'Thierleben,' B. i. 1864, 8. $75,86$. On the Atcles, s. 105. For other analogous statements, see $8.25,10 \%$.

- With respect to insects sce Dr. Iaycock 'On a Gencral Law of Vital Periodicity', IBritish Association, 1512. 1)r. Macculloch, 'Silliman's North American Jounal of Schence,' rol, xrii. p. 305, has scen a dog suffering from tertian ague. 
amputation of his limbs occasionally poseces, especially during an carly cmbryonic period, some power of regen. eration, as in the lowest animals."

The whole process of that most important function, the reproduction of the species, is strikingly the sane in all manunals, from the first act of courtship by the male' to the birth and nurturing of the young. Monkeges are hurn in almost as helpless a condition as our own infunts; and in certain gentra the young diflier fully as usuch in appearauce from the adules, as do our children from thir full-grown parents. It has been urged by some writers as an iupportant distinction, that with man the ycung arrive at maturity at a much later age than with any other animal: but if we look to the races of mashiml which inhahit tropical countries the diffirence is not great, for the orang is believed not to be adult till the age of from ten to fiftecn years.' Man diflers from womm in size, hodily strongth, hairyuess, etc., as well as in miud, in the name mamer as do the iwo sexes of many manmals. It is, in short, scarcely posible to exaggerate the close wot-

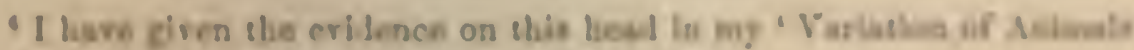

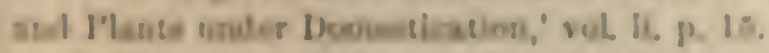

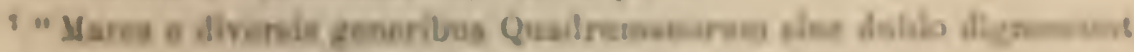

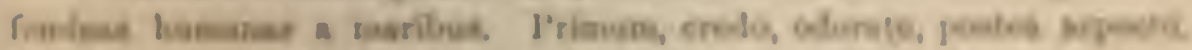

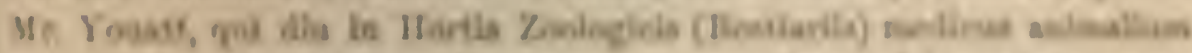

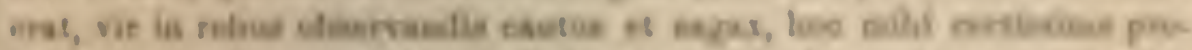

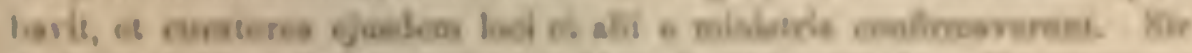

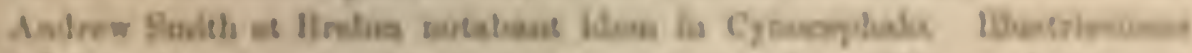

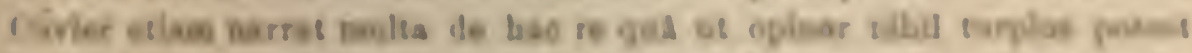

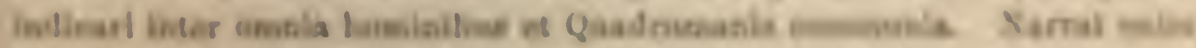

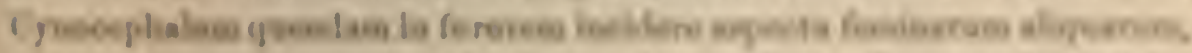

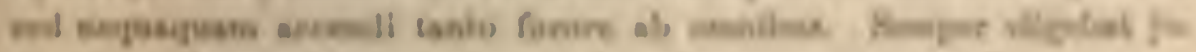

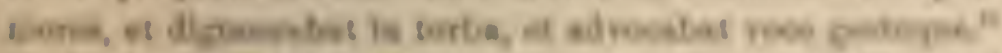

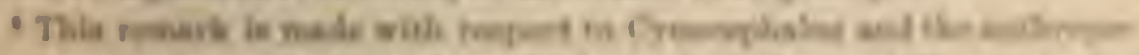

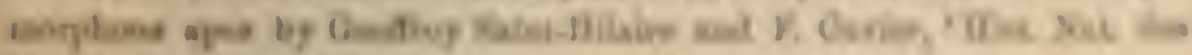

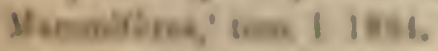

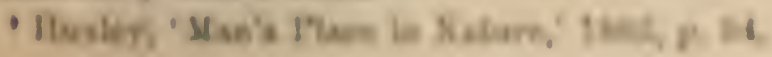


respondence in general structure, in the minute structure of the tissues, in chemical composition, and in constitution, letween man and the ligher animals, especially the anthropomorphous apes.

I:mbryonic Development.-Man is developed from an orule, about the 125th of an inch in diameter, which diflers in no respect from the ovules of other animals. The embryo itself at a very carly period can hardly be distinguished from that of other members of the vertebrate kingdom. At this period the arteries run in archlike branches, as if to carry the blood to branchix which are not present in the higher vertebrata, though the slits on the sides of the neck still remain $(f, g$, fig. 1 ), marking their former position. At a somewhat later period, when the extremities are developed, "the fect of lizards and mammals," as the illustrious Von. Baer remarks, "the wings and feet of birds, no less than the hands and fect of man, all arise from the same fundamental form." It is, says Prof. Huxley, "quite in the latter stages of development that the young human being presents marked differences from the young ape, while the latter departs as much from the dog in its developments, as the man docs. Startling as this last asscrtion may appear to be, it is demonstrably truc."

As some of my readers may never hare seen a drawing of an embryo, I have given one of man and another of a dog, at about the same carly stage of development, carcfully copicd from two works of undoubted accuracy."

10 'Man's Place in Nature,' 1863, p. 67.

11 The human embryo (upper fig.) is from Ecker, 'Icones Phys.,' 1851-1859, tab. xxx. fig. 2. This embryo was ten lines in leugth, so that the drawing is much magnified. The embryo of the dog is from Biechoff, 'Fntwicklungsgeschichte des IIunde-Eies,' 1815, tab. xi. fig. 42 в. This draring is fire times magnified, the embryo being 25 days old. The 

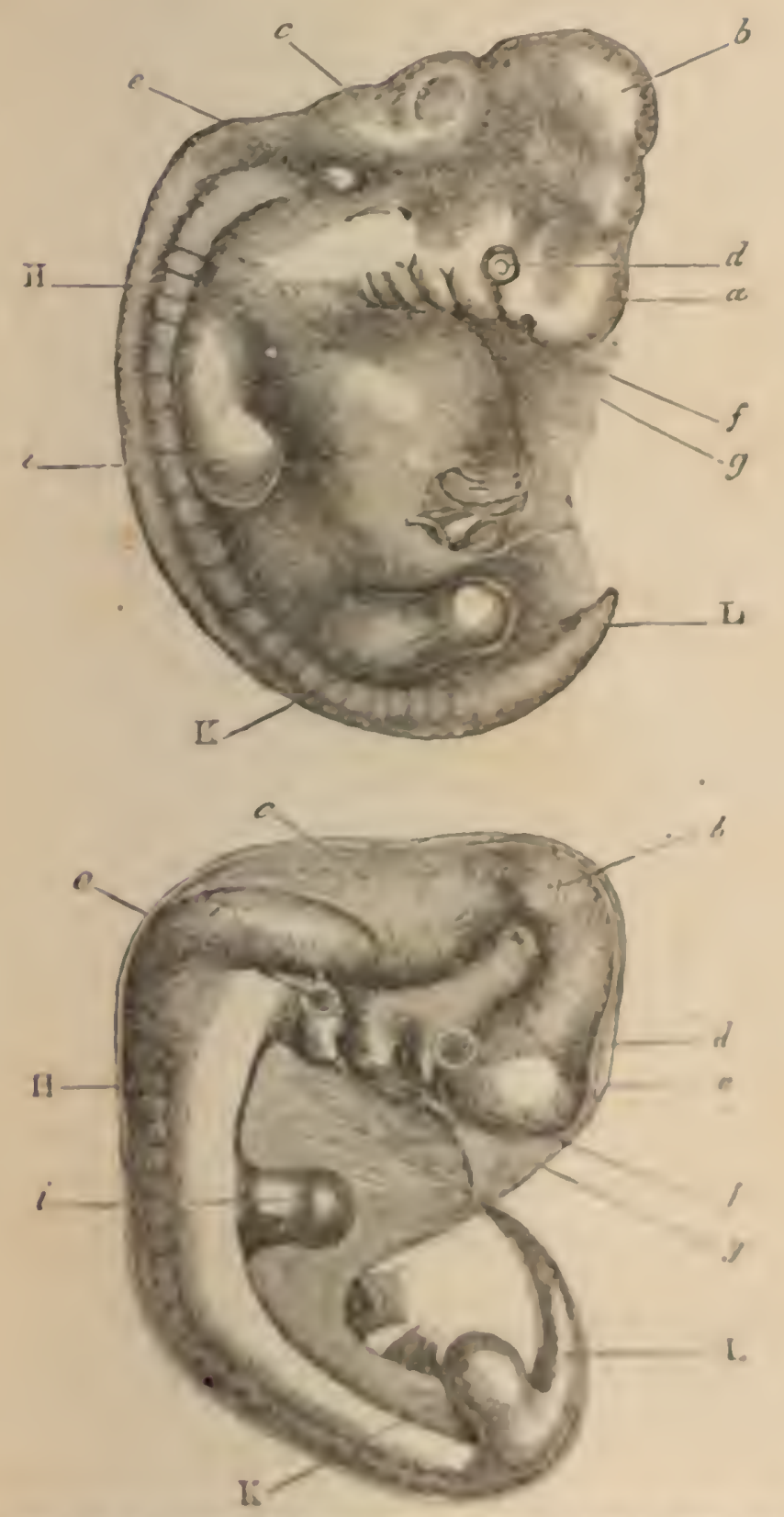

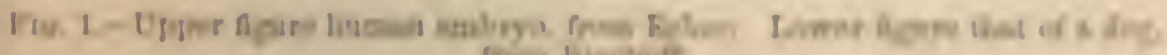
m. Biscenfin

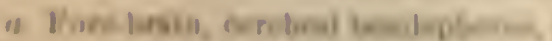
ir

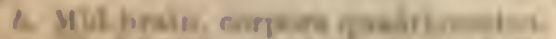

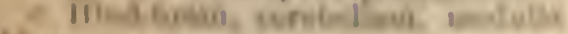
eAlumatis a. $1 \mathrm{~m}$

t Bar.

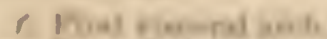

M.

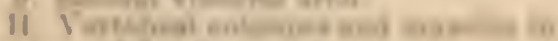

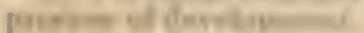

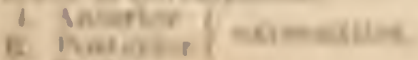

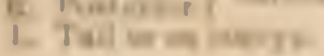


After the foregoing statements made by such high authorities, it would be superfluous on my part to give a number of borrowed details, showing that the embryo of man closely resembles that of other mammals. It may, however, be added that the human embryo likewise resembles in various points of structure certain low forms when adult. For instance, the heart at first exists as a simple pulsating vessel; the excreta are voided through a cloacal passage; and the os coccyx projects like a true tail, "extending considerably beyond the rudimentary legs." "In the embryos of all air-breathing vertebrates, certain glands called the corpora Wolffiana, correspond with and act like the kidneys of mature fishes. ${ }^{13}$ Even at a later embryonic period, some striking resemblances between man and the lower animals may be observed. Bischoff says that the convolutions of the brain in a human foetus at the end of the seventh month reach about the same stage of derelopment as in a baboon when adult." The great toe, as Prof. Owen remarks, "which forms the fulcrum when standing or walking, is perhaps the most characteristic peculiarity in the human structure;" but in an embryo, about an inch in length, Prof. Wyman ${ }^{10}$ found that the great toe was shorter than the others, and, instead of being parallel to them, projected at an angle from the side of the foot, thus corresponding with the permanent condi-

internal riscera have been omitted, and the uterine appendages in botl: drawings remored. I was directed to these figures by Prof. IIuxley, from whose work, 'Man's Place in Nature,' the idea of giving them was taken. IIïclicl has also giren analogous drawings in lis 'Schüpfungsgeschichte.'

18 Prof. Wyman in 'Proc. of American Acad. of Sciences,' rol. iv. 1860, p. 17.

13 Owen, 'Anatomy of Vetebrates,' vol. i. p. 633

is 'Dic Grosshirnwindungen des Menschen,' 1868, s. 95

15 'Anatomy of Vertebrates,' vol. ii. p. 553.

16 'Proc. Soc. Nat. Uist.' Boston, 1863, vol. ix. p. 185. 
tion of this part in the quadrumana." I will conclude with a quotation from IIuxley;, who, after asking, dous man originate in a difierent way from a dog, birl, frog, or tists? says, "the reply is not douheful for is moncent; witlout question, the mode of origin and the early stages of the development of man are identical with those of the animals inmediatcly below him in the scale: without a doube in these respects, he is far nearer to apes, than the apes are to the dog.".

Ruediments.-This suljoce, thongh not intrinsically more inportant than the last $t$ wo, will for several resuons be here treated with more fulness. ${ }^{\text {so }}$ Sot one of the ligher animals can be named which does not bear some part in a rudimentary condition; and man furms no excoption to the rule. Rudinentary organs muse he disthinguisled from those that are nasecent ; thenghts in some anerg the distinction is not easy. The former are virler alsolutely useles, such as the mamnate of male quadrupeds, or the incioor tecth of ruminamts which nerir eut thronght the grums; or they are of surch slight service to the ir procint posseseors, that wo cammot nuppose that they were dereloped muler the comlitions wlich now exist. Organe in this heter state are not strietly rulimentary. lut they are tomling in this dimetion. Naesont organs, on the other hatul, though not fully derelopel, sere of bight

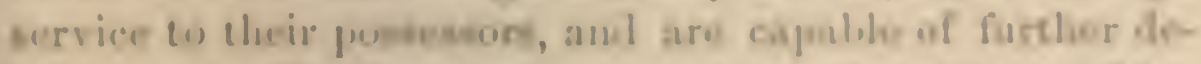
selopment. Rindimontary organs aro cminenely noriablo; and this is partly intelligille, as the y are nantere or morly

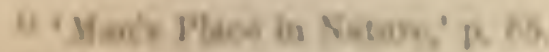

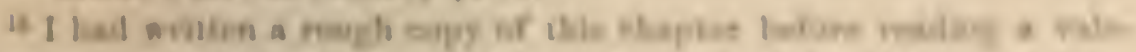

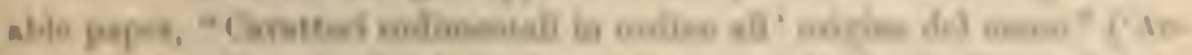

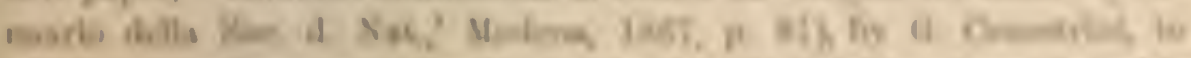

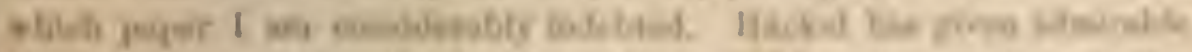

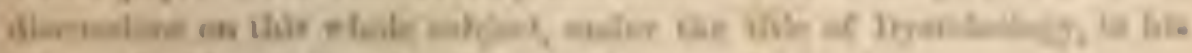

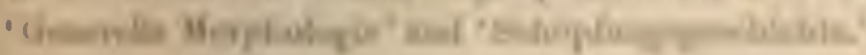


useless, and consequently are no longer subjected to nat. ural selection. They often become wholly suppressed. When this occurs, they are nevertheless liable to occasional reappearance through reversion; and this is a circumstance weli worthy of attention.

Disuse at that period of life, when an organ is chiefly used, and this is generally during maturity, together with inheritance at a corresponding period of life, seem to have been the chief agents in causing organs to become rudimentary. 'The term "disuse" does not relate merely to the lessened action of muscles, but includes a diminished flow of blood to a part or organ, from being subjected to fewer alternations of pressure, or from becoming in any way less habitually active. Rudiments, however, may occur in one sex of parts normally present in the other sex; and such rudiments, as we shall hereafter see, liave often originated in a distinct manner. In some cases organs have been reduced by means of natural sclection, from having become injurious to the species under changed habits of life. 'The process of reduction is probably often aided through the two principles of compensation and economy of growth; but the later stages of reduction, after disuse lias done all that can fairly be attributed to it, and when the saving to be effected by the economy of growth would be very small, ${ }^{10}$ are difficult to understand. 'The final and complete suppression of a part, already useless and much reduced in size, in which ease neither compensation nor cconomy can come into play, is perhaps intelligible by the aid of the hypothesis of pangenesis, and apparently in no other way. But as the whole subject of rudimentary organs has been fully discussed and illustrated in my former works, ${ }^{20}$ I need here say no more on this licad.

12 Some good criticisms on this subject have been given by Messrs. Muric and Mivart, in 'T'ransact. Zoolog. Soc.' 1869, vol, vii. p. 92.

so 'Variation of Animals and Plants under Domestication,' vol. ii. pp. 317 and 397 . See also 'Origin of Species,' 5 th edit. P. 535. 
Rudiments of various muscles have been observed in many parts of the human body ${ }^{21}$ and not a few muscles, which are regularly present in some of the lower animals cam occasionally be detected in man in a grently reduced condition. Every one must have noticed the porer which many animals, especially horses, possess of moving or twitching their skin; and this is cflected by the panniculus carnosus. Remnants of this muscle in an eflicient state are found in various parts of our bodies; for instance, on the forchesd, by which the eychrows are raised. 'The platysma myoides, which is well dereloped on the neck, belongs to this system, but cannot be roluntarily brought into action. Prof. 'Turner, of Elinburgh, has occusionally detected, as he informs me, muscular fasciculi in fire different situations, namely, in the axillas, near the scapnla, etc., all of which must be referred to the system of the panniculus. He lias also shown ${ }^{23}$ that the musculus sternalis or sternalis brutorum, which is not an extension of the rectus abdominalis, but is closely allied to the pamiculus, occurred in the proportion of about three per cent. in upward of six humdred bodies: he alds, that this muscle affiorls "an excellent illustration of the statement that occasional and rulimentary structures are enpecially linble to variation in arrangement."

Some fow perouns have the power of contrating the mperficiul muscles on their scalpa; nud these museles are in a variable and partially rudimentary contition. N. A. 1.e Candolle has commmicated to me a curions inetunes of the longecontinued pereistence or inheritanee of this

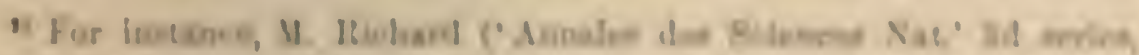

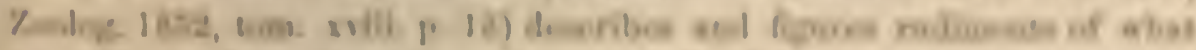

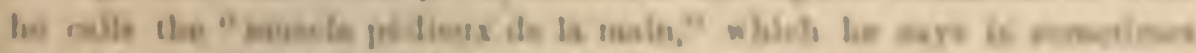

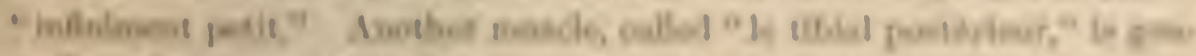

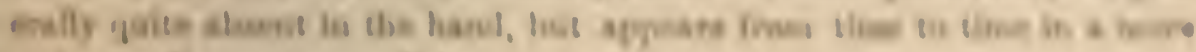

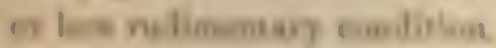

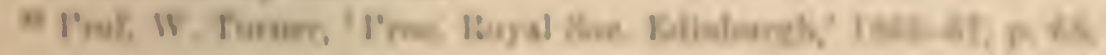


power, as well as of its unusual derelopment. He knows a family in which one member, the present head of a family, could, when a youth, pitch sereral heary books from his head by the movement of the scalp alone; and he won wagers by performing this feat. IIis fither, uncle, graudfather, and all his three children, possess the same power to the same unusual degree. This family became divided eight generations ago into two branches; so that the head of the above-mentioned branch is cousin in the seventh degree to the head of the other branch. This distant cousin resides in another part of France, and, on being asked whether he possessed the same faculty, in. mediately exhibited his power. This case offers a good illustration how persistently an absolutely useless faculty may be transmitted.

The extrinsic muscles which serve to move the whole external ear, and the intrinsic muscles which move the different parts, all of which belong to the system of the pamniculus, are in a rudimentary condition in man; they are also variable in development, or at least in function. I have seen one man who could draw his ears forward, and another who could draw them backward $;^{23}$ and, from what one of these persons told me, it is probable that most of us, by often touching our cars and thus directing our attention toward them, conld by repeated trials recover some power of movement. The faculty of erecting the ears and of directing them to different points of the compass, is no doubt of the highest service to many animals, as they thus perceive the point of danger; but I have nerer heard of a man who possessed the least power of crecting his ears-the one movement which might be of use to him. The whole external shell of the ear may be considered a rudiment, together with the various folds and prominenees

${ }^{23}$ Canestrini quotes IIyrt. ('Annuario dells Soc. dei Naturalisti,' Slodena, 186 ', p. 97 ) to the same effect. 
(holix and anti-helix, tragus and anti-tragus, ctc.) which in the lower animals streugthen and support the car when rect, without alding much to its weight. Some author, however, suppose that the cartilage of the shell serves (1) transmit vibrations to the acoustic nerve; but Mr. Tuynbee, ${ }^{21}$ after collecting all the known crilence on this heal, conclueles that the external shell is of $n 0$ distinct use. 'The cars of the chimpanzee and orang are curioms lihe those of man, and I am assured by the keepers in the \%on. logiral Gardeus that these amimals neter move or ereit them; so that they are in an equally rudimentary condition, at far as function is concerneel, as in man. Why these animals, as well as the procenitors of mam, should have lost the power of erecting their cars we cambet sar. It may he, though I am not quite satistien with this $\mathrm{i}$ w, that owing to their arboreal habits and great strenget they were but little expoesd to danger, and so duriug a leugthcusel period moved their ears but little, and thus gralually lent the power of moving them. This would be at purallet rase with that of those large and heary birds, which from inhabiting oceanic islands lave not beco erposal to the attueks of heaste of prey, and hare conerguently last the power of using their wings for Aliglı.

The colebrated scuptor, Mr. Woolner, informe tae of one litule peobliarity in the esernal ear, whicls be has oflen olserved loth in men atud women, and of $w$ biels he

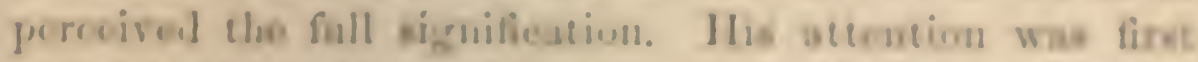
eallod to the sulject while at work on his ligure of Thel. fo which he had givon poined earn. He wat chue lid to examine the clan of variowe monhers, aud sulecrusaily

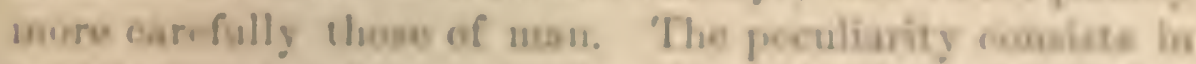

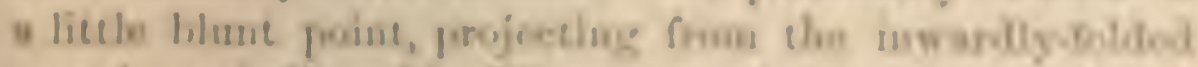
suarcin, or belix. Mr. Wooluer made an oravs monlel of

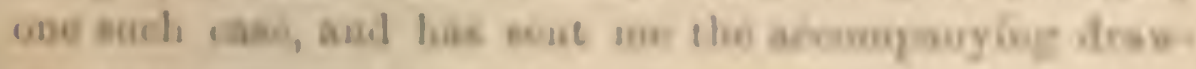

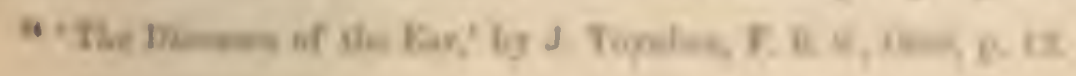


ing. (Fig. 2.) These points not only project inward, but often a little outward, so that they are visible when the head is viewed from directly in front or behind. They are

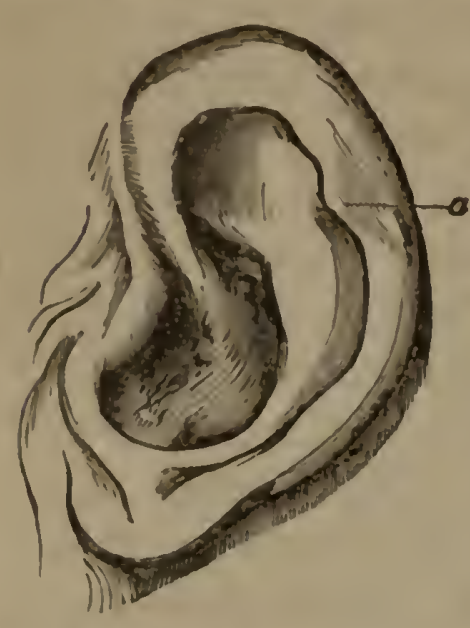

Fra. 2.-Human Far, modellerl and drawn by Mr. Woolner.

a. The projecting point. variable in size and somewhat in position, standing either a little higher or lower; and they sometimes occur in one ear and not on the other. Now the meaning of these projections is not, I think, doubtful; but it may be thought that they offer too trifling a character to be worth notice. 'This thought, however, is as false as it is natural. Every character, however slight, must be the result of some definite cause; and if it occurs in many individuals deserves consideration.

The helix obviously consists of the extreme margin of the ear folded inward; and this folding appears to be in some manner connected with the whole external ear, being permanently pressed backward. In many monkeys, which do not stand high in the order, as baboons and some species of macacus, ${ }^{26}$ the upper portion of the ear is slightly pointed, and the margin is not at all folded inward; but if the margin were to be thus folded, a slight point would necessarily project inward and probably a little outward. This could actually be observed in a specimen of the Atcles beelzcbuth in the Zoological Gardens; and we may safely conclude that it is a similar structure-a vestige of formerly-pointed ears-which occasionally reappears in man.

The nictitating membrane, or third eyelid, with its

${ }_{25}$ See also some remarks, nnd the drawings of the ears of the Lemu. roidea, in Messrs. Murie and Mivart's excellent paper in 'Transact. Zoo. log. Soc.' vol. rii. 1869,'Tp. 6 and 90. 
accessory muscles and other structures, is cpecially well developed in birds, and is of much functional importance to them, as it cam be rapidly dratn across the whole cyoba1l. It is found in some reptiles and amplibians, and in certain fishes, as in slarks. It is farly well developed in the two lower divisions of the mammalian series, nandy, in the monotremata and nursupials, and in some few of the higler mammals, as in the walrus. Fut in man, the fuidrunatua, aud most other mammals, it exists, as is adlmitted by all anatomists, as a more rudiment, called the sunilunar fuld. ${ }^{20}$

The sense of sincell is of the hienteet importance to the grcater number of mammals-io some, as tlac ruminauts, in warning them of danger; to others, as the carnivora, in finling their prey; to others, as the wild-boar, for hoth purposes combined. But the scruec of smell is of extrenely slightecrvien, if any, crent to savaecs, iu whom it is generally more highly developed than in the eivilized races. It dres not wam them of danerer, nor gnide them to their food; nor does it prevent the lispuintux from slecping in the most felid atmosphere, nor many surages from eating half-pustrid meat. 'llose whe beliere in the priuciple of gradual crolution, will not readily admit that this seane in its prosat state was originally actuired by uma, as he nuw eriets. No donbe he inhrita the powrer in an enfoobled aud for far mulimentary condition, from some cally progenitor, to whom it was higlily scrvisealile and by whon it was contimally used. We can thes pulaps undentand how it is, ns Dr. Maudeley has eruly

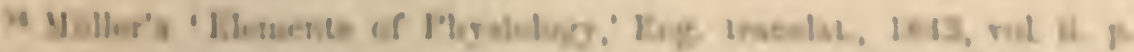

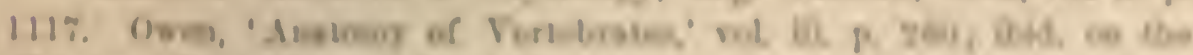

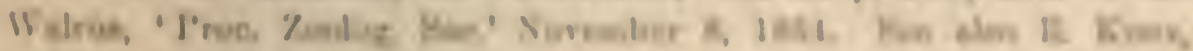

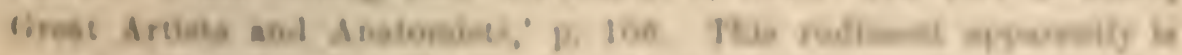

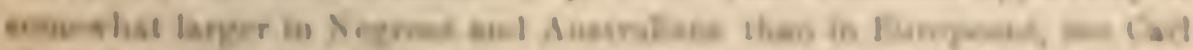

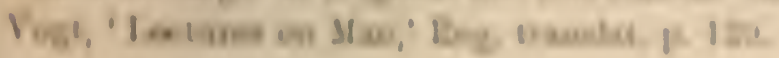


remarked, ${ }^{27}$ that the sense of smell in man "is singularly eflectire in recalling vividly the ideas and images of forgotten seenes and places;" for we see in those animals, which have this sense highly dereloped, such as dogs and horses, that old recollections of persons and places are strongly associated with their odor.

Man differs conspicuously from all the other Primates in being almost naked. But a few short, stracgrgling hairs are found over the greater part of the body in the male sex, and fine down on that of the female sex. In indiriduals belonging to the same race these hairs are highly variable, not only in abundance, but likewise in position: thus the shoulders in some Europeans are quite naked, while in others they bear thick tufts of hair. ${ }^{28}$ There can be little doubt that the hairs thus seattered over the body are the rudiments of the uniform hairy coat of the lower animals. This view is rendered all the more probable, as it is known that fine, short, and pale-colored hairs on the limbs and other parts of the body occasionally become developed into "thickset, long, and rather coarse dirk hairs," when abnormally nourished near old-standing inflimed surfaces. ${ }^{20}$

I am informed by Mr. Palget that persons belonging to the same family often have a few hairs in their cyebrows much longer thin the others; so that this slight peculiarity seems to be inherited. These hairs apparently represent the vibrissa, which are used as organs of touch by many of the lower animals. In a young chimpanzee I observed that a few upright, rather long, hairs projected

27 'The Physiolngy and Pathology of Jind,' 2d edit. 1868, p. 134.

:y Eschricht, Ceber dic Richtung der Haare am menschlichsen Körper, 'Müller's Archiv für Anat. und Phys.' 1837, s. 17. I shall often have to refer to this very curious paper.

"Paget, 'Lecetures on Surgical Patlsology,' 1853, rol. i. 1. 71. 
abore the eyce, where the true eyebrows, if presut, would hase stood.

The fine wool-like hair, or so-called lanugo, wills whinh the luman fuetus during the sixth month is thichly covcreel, ofliers a more curious case. It is first developed during the fifth month, on the egebrowe and face, and especially romel the mouth, where it is much longer than that on the heal. A mustache of this kimd was olserset by Fechriche" on a fomale fortus; but this is not so surpri-ing a cirumatance as it may at firot appear, for the iwo nexu generally resemble cach other in all cxcerunl characens during an early perion of growel. "The diren. tion and arrangement of the hairs on all parts of the footad hody are the same as in the adult, but are subjeet fo much variability. 'The whole surfice, ineluling eren the forelond aml ears, it thus thiekly clothed; lut it is a signilicant foet that the poilus of the liamila and the sules of the feet are quite naked, like tho inforior eurfoen of all four ereremities in mone of the lower animals. An this ean harilly he an aeridental coincidneo, we mute coneider tbo

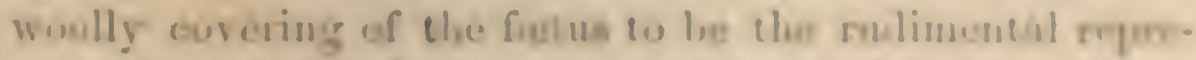
ocntative of the fint pormamost wat of hair in thom unamonals whinh are harn lasiry. This nepresutskine is wonch more conpleto, in aocond woo with the vaud law of

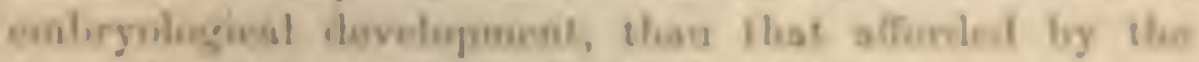
etraxellug baire on the bods of the oulde.

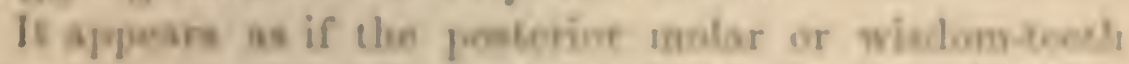
were tenting to bocome rodimentary lis the mome efviliand

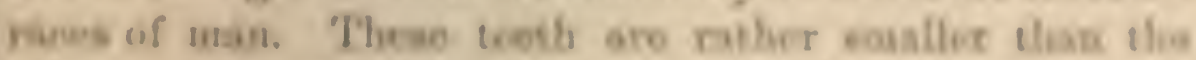

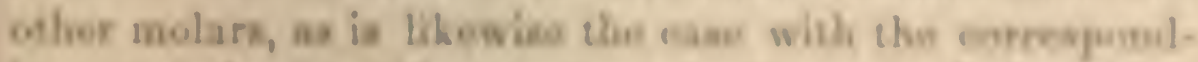
inc tueth in the chimpanze and orang; and they hase

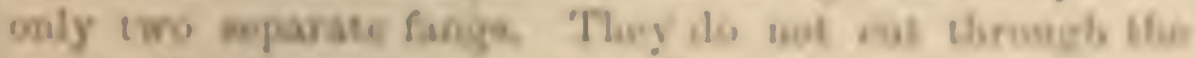

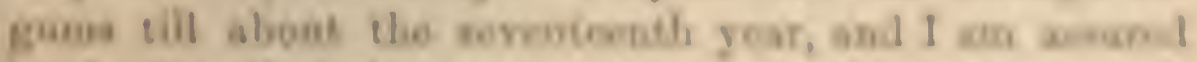

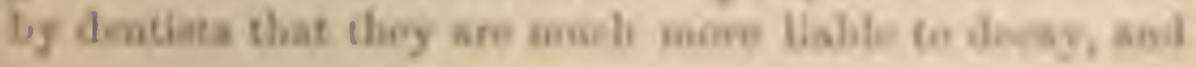


are earlier lost, than the other teeth. It is also remarkalble that they are much more liable to vary both in structure and in the period of their development than the other teeth." In the Melanian races, on the other hand, the wisdom-tecth are usually furnished with three separate fangs, and are generally sound: they also differ from the other molars in size less than in the Cancasian races.s. Prof. Schatfhausen accounts for this difference between the races by "the posterior dental portion of the jaw being always shortened" in those that are civilized, and this shortening may, I presume, be safely attributed to civilized men habitually feeding on soft, cooked fool, and thus using their jaws less. I am informed by Mr. Brace that it is becoming quite a common practice in the United States to remove some of the molar teeth of children, as the jaw does not grow large enough for the perfect derelopment of the normal number.

With respect to the alinentary canil, I have met with an accont of only a single rudiment, namely, the vermiform appendage of the caecum. The caecum is a branch or diverticulun of the intestine, ending in a cul-de-sae, and it is extremely long in many of the lower vegetable-feeding mammals. In the marsupial koala it is actually more than thrice as long as the whole body." It is sometimes produced into a long, gradnally-tapering point, and is sometimes constricted in parts. It appears as if, in consequence of changed dict or halbits, the cascum had become much slortened in various animals, the vermiform appendage being left as a rudiment of the shortened part. 'That

81 Dr. Webb, 'Teeth in Man and the Anthropoid Apes,' as quoted by Dr. C. Carter Blake in 'Anthropological Review,' July, 1867, p. 299.

39 Owen, 'Anatomy of Yertebrates,' rol. iii. pp. 320, 321, 325.

as 'On the primitire Form of the Skull,' Fing. translat. in 'Anthro poingical Review,' Oct. 1868, p. 426.

st Owen, 'Anatomy of Tertebrates,' vol. iii. pp. 416, 431, 441. 
this appendage is a rudincut, we may infer from it mall size, and from the evidence which Prof. Canctriui bs has collected of it voriability in man. It is vccanionally quite alsent, or again is largely dercloped. The pussage is sometimes completely closed for half or two-thirds of ite frugth, with the terminal part consinting of a flatuened folid crpansion. In the orang this appendage is loug aud convoluted; in man it arises from the end of the shurt eaceun, and is coususuly from four 11 five inclies in lougth, being only about tho thiril of an inds in dismerer. Not euly is it awless, list it is nomesimus the enure of drath, of whieh fact I have hateds hored two inatamos;

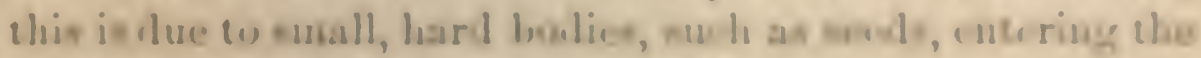
pawage and can iuge inflammarion."

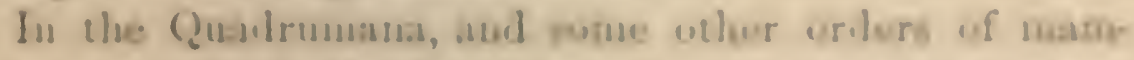
mals, opecially in the Caruivora, there is a pasoge nor

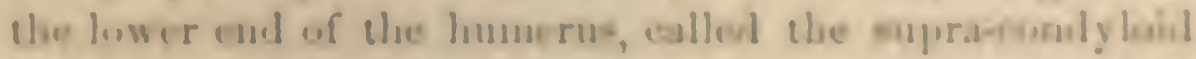
foranen, through which the grat nerve of the foretimb

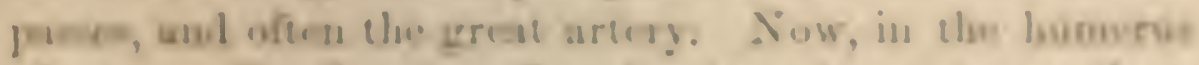

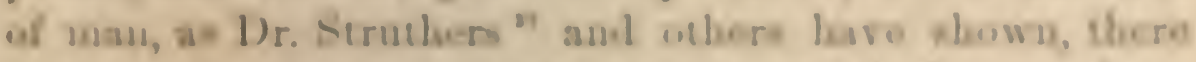

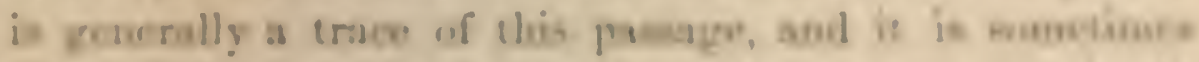

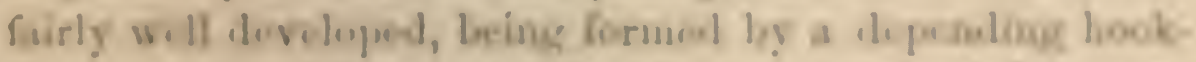

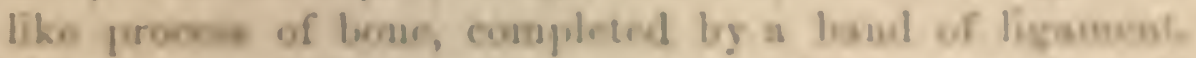
When jeesent the great ucrve insariably pases though

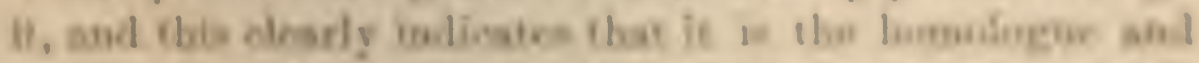

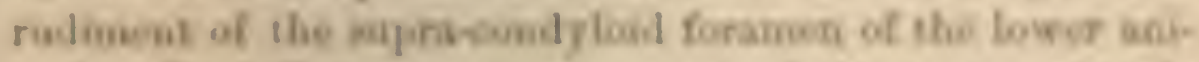

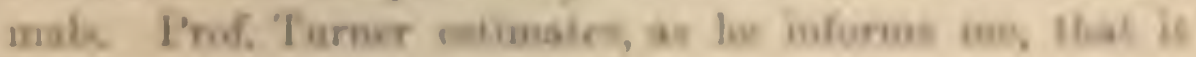

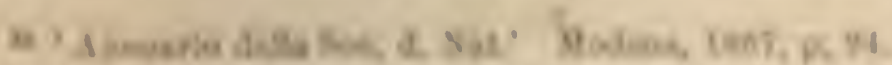

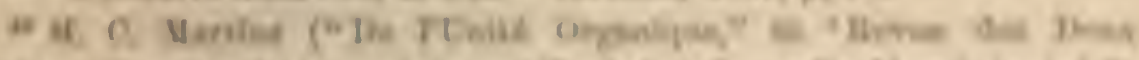

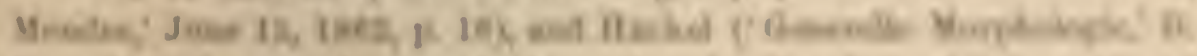

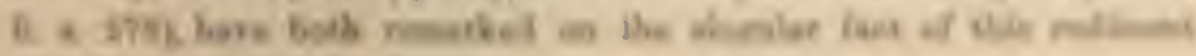
neviles vouiles dans.

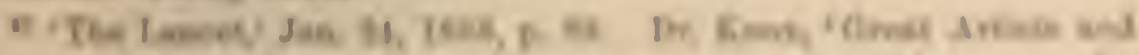

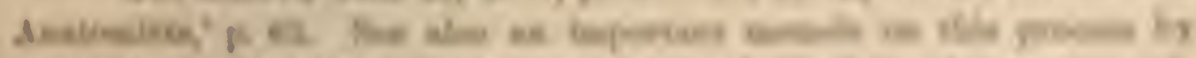

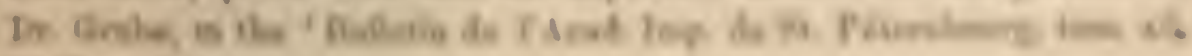

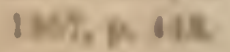


oceurs in about one per cent. of recent skeletons; but, during ancient times, it appears to have been much more common. Mr. Busk ${ }^{38}$ has collected the following evidence on this head: Prof. Broca "noticed the perforation in four and a half per cent. of the arm-bones collected in the 'Cimeticre du Sud' at Paris; and in the Grotto of Orrony, the contents of which are referred to the Bronze period, as many as eight liumeri out of thirty-two were perforated; but this extraordinary proportion, he thinks, might be due to the cavern having been a sort of 'family vault.' Again, M. Dupont found thirty per cent. of perforated bones in the eaves of the Vallcy of the Lesse, belonging to the Reindeer period; while M. Leguay, in a sort of dolmen at Argentenil, observed twenty-fire per cent. to be perforated; and M. Pruuer-Bey found twentysix per cent. in the same condition in bones from Vauréal. Nor sliould it be left umoticed that M. Pruner-Bey states that this condition is common in Guanche skeletons." The fact that ancient races, in this and several other cases, more frequently present structures which resemble those of the lower animals than do the modern races, is interesting. One chief cause seems to be that ancient races stand somewlat nearer than modern races in the long line of descent to their remote animal-like proggenitors.

The os coecrx in man, though functionless as a tail, plainly represents this part in other vertebrate animals. At an carly cmbryonic period it is free, and, as we have seen, projects beyond the lower extremitics. In certain rare and anomalous cases it lias been known, aceording to Isidore Geoffroy St.-Hilaire and others, ${ }^{39}$ to form a small

ss "On the Cares of Gibraltar," "Transact. Internat. Congress of Prehist. Arch.' Third Session, 1869, p. 54.

${ }^{30}$ Quatrefages has lately collected the evidence on this sulject. Rerue des Cours Scientifiques,' 1867-'6\&, p. 625. 
catcrual rudiment of a tail. 'The os euecyx is slort, u-ually including only four vertchre; and these are in a rudi. mental condition, for they com-ist, with the execption of the basal one, of the ceutrum aloue." 'They are furni-hud with some small intreles; one of which, as I am informed by Prof. 'Turner, has becu expresely described ly 'Theile as a rudimentary repetition of the extensor of the tail, which is so largely developed in many mammals.

'The spinal cord in man extends ouly as for downard at the last doral or first lumbar vurtelora; lut a threallike structure (the filum cominale) rums down the asis of the eacal part of the ppinal canal, and even aloug the back of the coceggeal bones. The upper part of this filanent, as Prof. Turner informs ne, is undoubtedly lomologots with the phinal cord; but the luwer part appareut! canrists merely of the gia mater, or vascular invetiug tum mbrane. Eisen in this cate the on coceyx may be suld to powers a vesige of to important a prunture as the npiaal cord, though no longer enelosed within a houg cansl. 'The following fact, for whicl I am ales indebted to Prot.

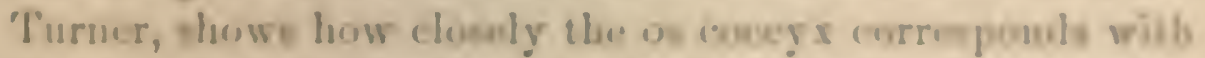
the true tail in the low animals: I.Iuch ha ha* rewotly

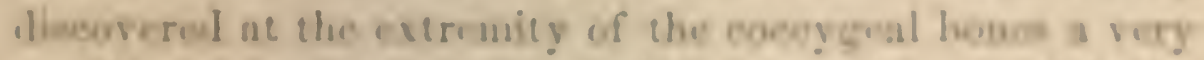
peotstiar cossolatiol body, wheh is costlumoos with the whilly aeral artery; and the dicousery led firaum abd

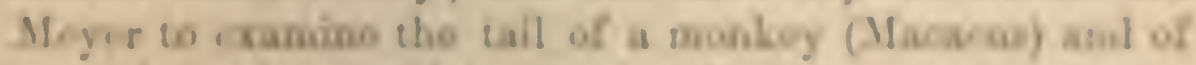
s rat, in both of whits they forud, though not at the $\alpha$ irvulty, a vimilarly cousolined body.

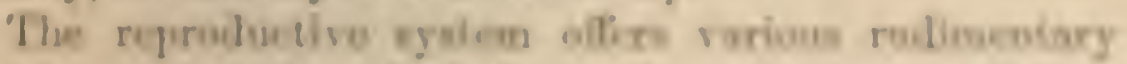

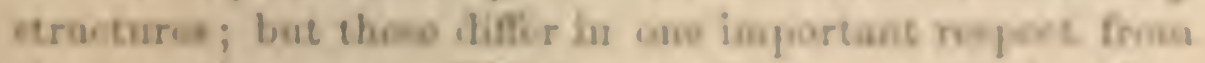
the firvuning caves. We aro not bero couccrood with a

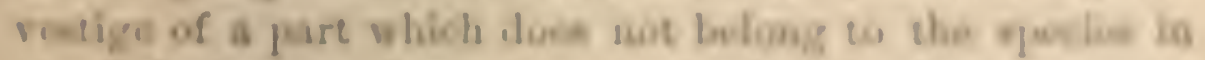

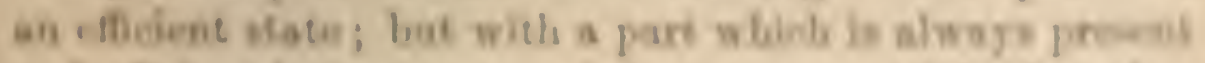

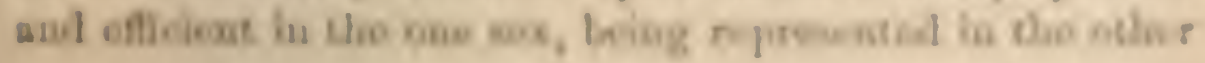


by a mere rudiment. Nevertheless, the occurrence of such rudiments is as difticult to explain on the belicf of the separate creation of each species, as in the foregoing cases. IIercafter I shall have to recur to these rudiments, and shall show that their presence generally depends merely on inheritance; namely, on parts acquired by one sex having been partially transmitted to the other. Here I will only give some instances of such rudiments. It is well known that in the males of all mammals, including man, rudimentary mamme exist. 'These, in several instances, have become well developed, and have yielded a copious supply of milk. Their essential identity in the two sexes is likewise shown by their oceasional sympathetic enlargement in both during an attack of the incasles. The vesicula mostatica, which has been observed in many male mammals, is now universally acknowledged to be the homologue of the female uterus, together with the connected passage. It is impossible to read Leuckart's able description of this organ, and his reasoning, without admitting the justness of his conclusion. This is especially clear in the case of those mammals in which the true fumale uterus bifurcates, for in the males of these the vesicula likewise bifurcates. ${ }^{41}$ Some additional rudimentary structures belonging to the reproductive system might here have been adduced. ${ }^{43}$

The bearing of the three great classes of facts now given is unmistakable. But it would be superfluous here fully to recapitulate the line of argument given in detail

${ }^{41}$ Leuckart, in Todd's 'Cyclop. of Anat.' 1849-'52, vol. iv. p. 1415. In man this organ is only from three to six lines in length, but, like so many other rudimentary parts, it is rariable in derelopment as well as in other characters.

42 Sec, on this subject, Owen, 'Anatomy of Tertebrates,' rol. iii. pp. $675,676,706$. 
in my 'Origin of Species.' 'The homolugical con-truetion of the whole frame in the numbers of the same clas is intelligible, if we admit their descent from a common progenitor, together with their subsequent adaptation to diversified conditions. On any other view the similarity of pattern between the hand of a man or monkey, the foot of a hor-e, the flipper of a seal, the wing of at hat, ctce, is utterly inexplicable. It is no scientific explanation to astert that they have all been formed on the same ideal plan. With re-pect to development, we can elcarly under-tant, on the principle of variations superveniug at a rather late cmbryonic period, and being inherited at a correyonding period, how it is that the cmberos of womlerfully diflierest fintus should still retsin, more or lees perfectly, the structwte of their common progenitur. No ofher esplanation has ever been given of the uarvellous fact that the combrgo of a man, dogn, seal, bat, reptile, ete., can at first harilly he distimguished from each other. In corder to under-tand the cxistence of rulimentary organs, we have ouly to sup

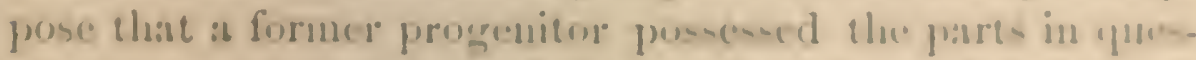
tion in a perfect state, and that under changeal halies of life they became greatly rolued, cither from simple dis. use, or through the uatural selection of eluese indiriduals

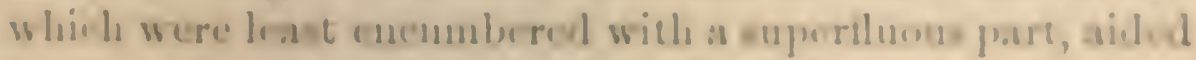

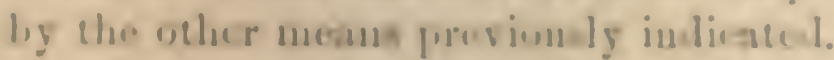

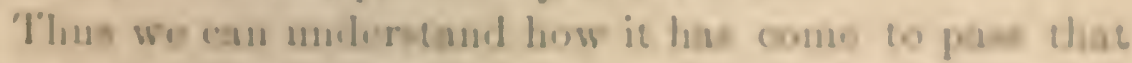

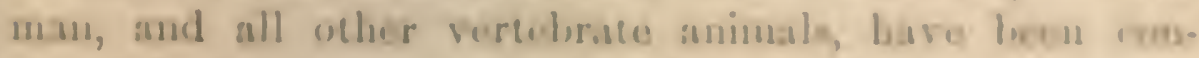

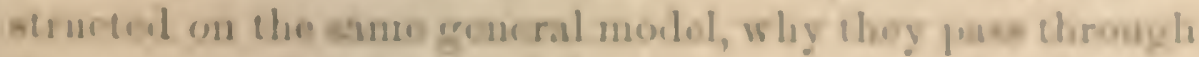

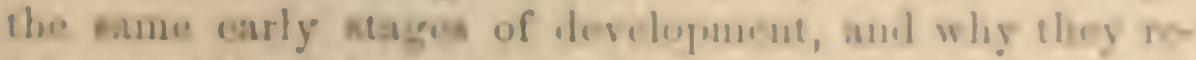
thin eortain rudiments in common. Comsequenty wo ought frankly to admit thrir community of desove : to thke any ofler riew, in to sulnit that our own struetare, and

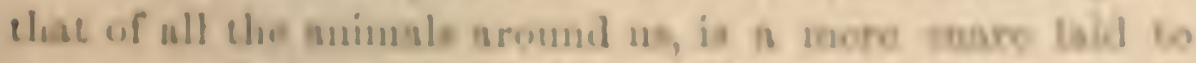

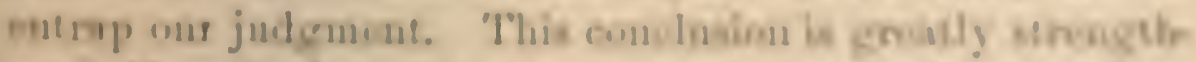

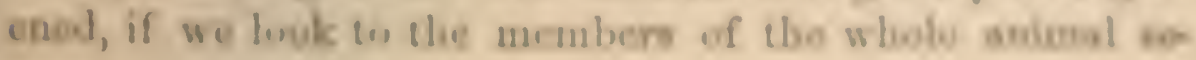


ries, and consider the evidence derived from their aftinities or classification, their geographical distribution, and geological succession. It is only our natural prejudice, and that arrogance which made our forefathers declare that they were descended from demi-gods, which lead us to demur to this conclusion. But the time will before long come when it will be thought wonderful that naturalists, who were well acquainted with the comparative structure and development of man and other mammals, should have believed that each was the work of a separate act of creation. 


\title{
C II $\triangle \mathrm{P}$ T E R II.
}

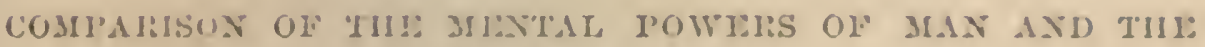 \\ I.OWIIS ANIMALS.
}

I'he I)ifference in Mental Power between the Ilighest Ape and the LomeSarnece, snnensc.-Certain Instincts in common.- Tho linotions.Curio-ity.-Initation.-Attcution.-Mcmory.-Imagiusticn.-Reaton. -Progressivo Improvencut.-Tools nud Weapons used by Arimal. - Lnuguage.-Sclf-Consciousness.-Senso of Benuty.-Bulief in Gad, Spiritual Agencics, Superstitions.

Wr: Lave seen in the last chapter that man bears in his bonlily structure clear traces of his descent from some lower form; but it may be urged that, as man difliers so greatly in his mental power from all other animals, there mus lee sume error in this conclusion. No donlt the diflerence in this respent is cuormons, cren if wo complare the mind of once of the lowest sas:igrea, who has no words to ergrem any mmber lighur than four, and who uecs no alsimet terms for the commonest oljects or atheretions, with that of the most highly-organized ape. The diflerence would, u) dombt, still remain immsnce, even if ome of the higher apes had becen improverl or civilized a moch as a dog has bren in comparients with its parent-form, the wolf or jackl.

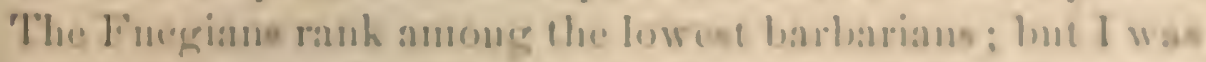
conlimally struck wilh nuprine how doenly the three va.

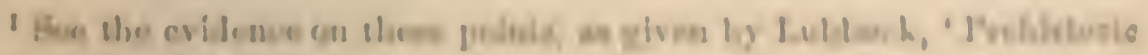
Time, ' P. 95, , io. 
tives on board H. M. S. "Bcagle," who had lived some years in England, and coukd talk a little English, resembled us in disposition, and in most of our mental faculties. If no organic being excepting man had possessed any mental power, or if his powers had been of a wholly different nature from those of the lower animals, then we should never have been able to convince ourselves that our high faculties had been gradually developed. But it can be clearly shown that there is no fundamental difference of this kind. We must also admit that there is a much wider interval in mental power between one of the lowest fishes, as a lamprey or lancelet, and one of the higher apes, than between an ape and man; yet this immense interval is filled up by numberless gradations.

Nor is the difference slight in moral disposition between a barbarian, such as the man described by the old navigator Byron, who dashed his child on the rocks for dropping a basket of sea-urchins, and a Howard or Clarkson; and in intellect, between a savarge who does not.use any abstract terms, and a Newton or Shakespeare. Differenees of this kind between the highest men of the highest races and the lowest savages, are comnected by the finest gradations. Therefore it is possible that they might pass and be dereloped into each other.

My object in this chapter is solely to show that there is no fundamental difference between man and the higher mammals in their mental faculties. Each division of the subject might have been extended into a separate essay, but must here be treated briefly. As no classification of the mental powers has been universally accepted, I shall arrange my remarks in the order most convenient for my purpose, and will select those facts which have most struck me, with the hope that they may produce some effect on the reader.

With respect to animals very low in the scale, I shall 
have to give some additional farts under. Sexual Selection, showing that their incntal powers are higher than might have been expected. The variability of the faculties in the individuals of the same species is an important point for us, and some few illustrations will here be griven. But it would be superfluous to enter into many detrils on this heal, for I have fouml, on frequent inquiry, that it is the unatimous opinion of all those who have long attented to animals of many kinds, including birds, that the individuats difier greatly in every mental distacteristic. In what manner the mental powers were first developed in the lowest organisms, is as hopeless an inquiry as how life fir-t originated. These are problens for the distant future, if they are ever to be solved by man.

As man possesses the same sonses with the lower animals, his fundancental intuitions must be the tame. Man lats also sone few instincts in common, as that of self-prete ervation, sexual love, the love of the mother for her newborn offypring, the power possessed by the latter of sucking, and so forth. But man, perlaps, has somewhint fewer instincts thin thoae posesesed by the animals which come nest to him in the series. The orang in the Eastern is. and-, and the chimpanze in $\Delta$ frie:s, build platforma, on which they sleopl; and, as both species follow the sane liabit, it might be argued that this was dne to instimet, but we camot feed sure that it is not the resule of both animals having similar wants, and posseseing similar power of reasoning. These apes, as wo may assunne, avoid the nany poisonous fruits of the tropies, and man has no en-h buowledge; but as our dometic sminals, wheas taken to forvigu lands, and when firte enroed one in the spring. often eat poisonous herbs, which they afterwiral aroiel, we caumet fiel sure that the supes de not learn from the ir own

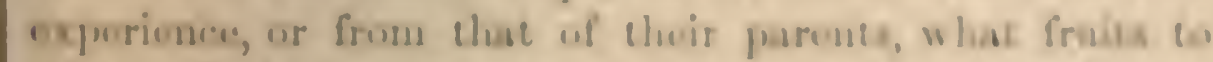
welest. It is, however, cortain, at wo shall piresestly tos, 
that apes have an instinctive dread of serpents, and probably of other dangerous animals.

The fewness and the comparative simplicity of the instincts in the higher animals are remarkable in contrast with those of the loweranimals. Cuvier maintaned that instinct and intelligence stand in an inverse ratio to each other ; and some have thought that the intellectual faculties of the higher animals have been gradually developed from their instincts. But Pouchet, in an interesting essay, ${ }^{2}$ has shown that no such inverse ratio really exists. Those insects which possess the most wonderful instincts are certainly the most intelligent. In the vertebrate series, the least intelligent members, namely fishes and amphibians, do not possess complex instincts; and among mammals the animal most remarkable for its instincts, namely the beaver, is highly intelligent, as will be admitted by erery one who has read Mr. Morgan's excellent account of this animal.

Although the first dawnings of intelligence, according to Mr. Herbert Spencer," have been developed through the multiplication and coürdination of reflex actions, and although many of the simpler instiuets graduate into actions of this kind, and can hardly be distinguished from them, as in the case of young animals sucking, yet the more complex instincts seem to lave originated independently of intelligence. I am, however, far from wislning to deny that instinctive actions may lose their fixed and untaught character, and be replaced by others performed by the aid of the free will. On the other hand, some intelligent actrons-as when birds on oceanic islands first learn to aroid man-after being performed during many generations, become converted into instincts, and are inherited. They

\& 'I'Instinct chez les Inecetes.' 'Rerue des Deux Mondes,' Fib. 1570, р. 690.

3 'The American Bearer and his Worka,' 1868.

- 'The Priuciples of P'sychology,' 2d edit. 1870, pp. 418-143. 
may thon be said wo be decraded in characier. for they are no longer performed thromgh reaton or from experience. But the greater number of the more complex in-tinets appear to have been gained in a wholly diflirent mauner, through the natural selection of rariations of simpler inmtinctive action:. Such variations appear to ariec frum the same mknown causcs acting on the cerelural organintion, which imbee sheht variations or imlividual difiercuces in chlier parts of the body; and these variation, owing to our imoranen, are often raid to ariws spontanounly. We con, I think, come to mo other conclision with reppect to the oricin of the more cotuples instuots, when we reflece on the marrellow in tiunes of sterile worker-ants and bees, which leave no oflepring to inherit the cfivets of experience and of molitied habit.

Alehough a high degroe of intelligence is certainly complatible with the exincues of complex inctiner, an we sen in the inwers just ramed and in the bessers, it is not improbable that they may to a cortain certent intorfore

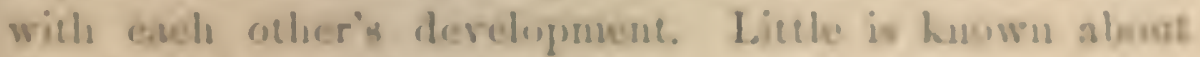
the fonctions of the brain, lut we ran peroeire that, as the incelleitual puwers heoome highls derelingol, the w. riout parta of the brvin mate ho conuocted lig tho moet

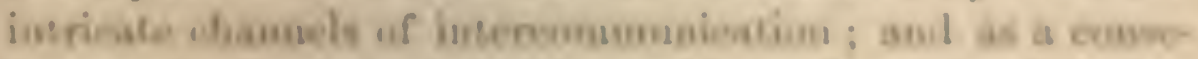

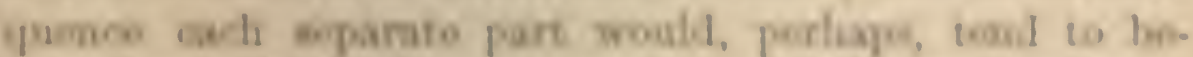

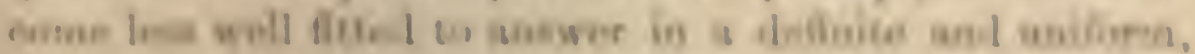

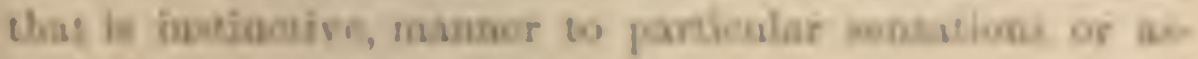
sumialiens.

I kave thoicche this Algresiods warth goving. herane

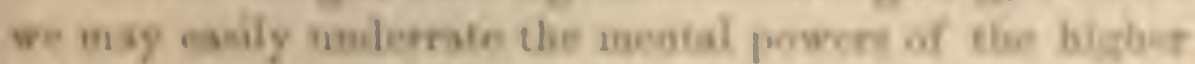

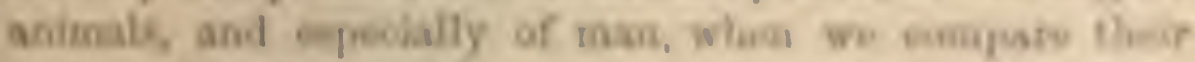

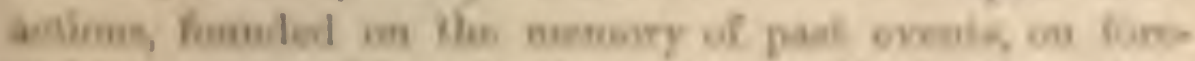

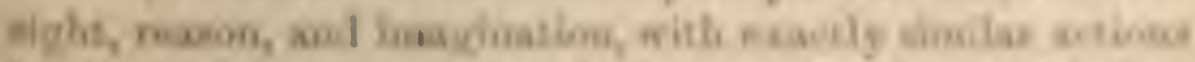

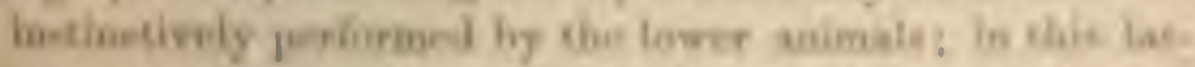
uer call, tho cupadiy of prormiag fuch actions fisnour 
been gained, step by step, through the variability of the mental organs and natural selection, without any conscious intelligence on the part of the animal during each successive generation. No doubt, as $\mathrm{Mr}$. Wallace has argued, much of the intelligent work done by man is due to imitation, and not to reason; but there is this great difference between his actions and many of those performed by the lower animals, namely, that man cannot, on his first trial, make, for instance, a stone hatchet or a canoc, through his power of imitation. He has to learn his work by practice; a beaver, on the other hand, can make its dam or canal, and a bird its nest, as well, or nearly as well, the first time it tries, as when old and experienced.

To return to our immediate subject : the lower animals, like man, manifestly feel pleasure and pain, happiness and misery. Happiness is never better exhibited than by young animals, such as puppies, kittens, lambs, etc., when playing together, like our own children. Even insects play together, as lias been described by that excellent observer, P. Huber, ${ }^{\circ}$ who saw ants chasing and pretending to bite each otlıer, like so many puppies.

The fact that the lower animals are excited by the sane emotions as ourselves is so well established, that it will not be necessary to weary the reader by many details. Terror acts in the same manner on them as on us, causing the muscles to tremble, the heart to palpitate, the sphincters to be relaxed, and the lian to stand on end. Suspicion, the offipring of fear, is eminently characteristic of most wild animals. Courage and timidity are extremely rariable qualities in the individuals of the same species, as is plainly seen in our dog.. Some dogs and horses are ill-tempered, and easily turn sulky; others are goortempered; and these qualities are. certainly inherited.

s 'Contributions to the Theory of Natural Selection,' 1870, p. 212.

- 'Recherches sur les Mours des Fourmis,' 1810, p. 1 i3. 
Every one knows how liable animals are to furious rage, and low plainly they show it. Many anecdotes, probalily true, have been published on the long-delayed and artful revenge of various animals. The accurate Rengger and brothm state that the Ameriean and African monkeys which they kept tame, cortainly revenged themselve. The love of a dog for his master is notorions; in the agony of death he has been known to caress his master, and every one lass lieard of the dog snffering under vivisection, who licked the hand of the operator; this man, unless he had a heart of stone, mus have felt remorec to the last hour of his life. As Whewell has remarked, "Who that reads the touching instances of matcrual afiection, related so often of the wonen of all nations, and of the fumales of all animals, can dunbt that the principle of action is the sane in the two cases?"

We see maternal aflection exhibited in the most trifling details; thus Rengger observed an Amorican monke! (a (C.bus) carefully driving away the flies which plagued her infont; and Durancel saw a Hylobates wathing the focon of her young ones in a stream. So inteme is the grief of fomale monkey for the lons of their goung, that it insariably caused the desth of certain himls kept under ennfinemu ut loy lirelum in North Afriea. Orphau-monkeye wore alwars adopted and carfinly gruarded by the of her mom.

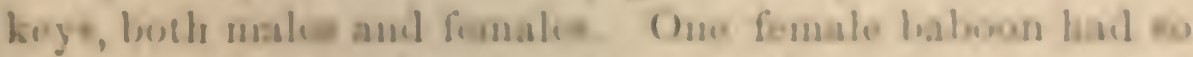

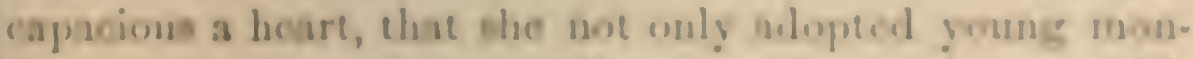

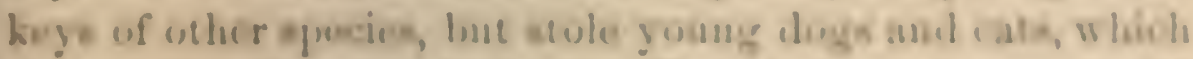
the continually earried aboul. Her kindnes, howerer, did

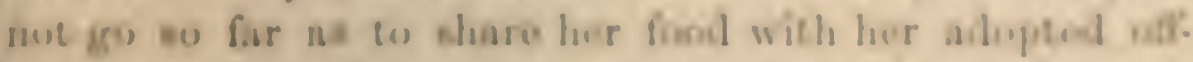

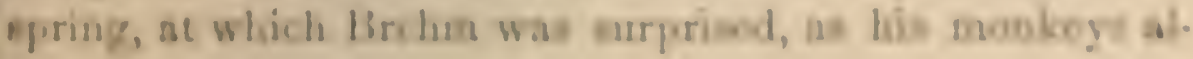

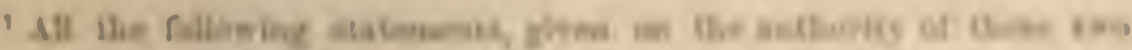

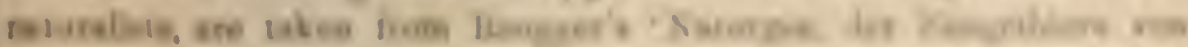

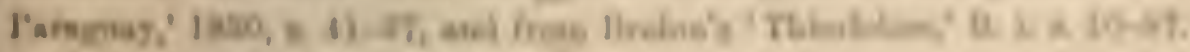

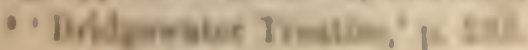


ways divided every thing quite fairly with their own young ones. An adopted kitten scratched the above-mentioned affectionate baboon, who certainly had a fine intellect, for she was much astonished at being scratched, and immediately examined the kitten's feet, and without more ado bit off the claws. In the Zoological Gardens, I heard from the keeper that an old baboon (C. chacma) had adopted a Rhesus monkey; but when a young drill and mandrill were placed in the cage, she seemed to perceive that these monkeys, though distinct species, were her nearer relatives, for she at once rejected the Rhesus and adopted both of them. The young Rhesus, as I saw, was greatly discontented at being thus rejected, and it would, like a naughty child, annoy and attack the young drill and mandrill whenever it could do so with safety, this conduct exciting great indignation in the old baboon. Monkeys will also, according to Brehm, defend their master when attacked by any one, as well as $\operatorname{dog} s$ to whom they are attached, from the attacks of other dogs. But we here trench on the subject of sympathy, to which I shall recur. Some of Brehm's monkeys took much delight in teasing, in various ingenious ways, a certain old dog whom they disliked, as well as other animals.

Most of the more complex emotions are common to the higher animals and ourselves. Every one has seen how jealous a dog is of his master's affection, if lavished on any other creature; and I have observed the same fact with monkeys. This shows that animals not only love, but have the desire to be loved. Animals manifestly feel emulation. They love approbation or praise; and a dog carrying a basket for his master cxhibits in a high degree self-complacency or pride. There can, I think, be no doubt that a dog feels shame, as distinct from fear, and something rery like modesty when begging too often for food. $\Lambda$ great dog scorns the snarling of a little $\log$, and this 
may be called magnaminity. Several obscriers lave stated that monkeys certainly dislike being laughed at; and they sometimes invent imagimary offiuces. In the Zoological Gardens I saw a baboon who always gon ime a furious rage when his kecper took ont a letter or borke and read it aloud to him; and his rage was so violent that. as I witnessed on one occasion, lie hit his own lerg till the blood flowed.

We will now turn to the more intellectual emotions and faculies, which are very important, as forming the bisis for the developunent of the higher mental powers. Animals manifestly cujoy excitcment amel sufler from emui, as may be seen with doge, and, accrorling to lienesgror, with monkeys. All animals feel womler, and many exhilit curiosity. They sometimes sufter frum this later quality, as when the hunter plays antics aud thus attraces them; I lave witucsed this with decr, and so it is with the wary chamois, and with some kinds of wild-ilucks. Brelun gires a curions aceount of the imstinclive dreal which his monkegs cxhibited toward suakes; lut their corionity was bo great that they comld not deaist from woatonally tatiating their horror in a most human falion, ly lifting up the did of the box in which eloce sumes wore hepe. I was so much surprised at his accoume, that I touk

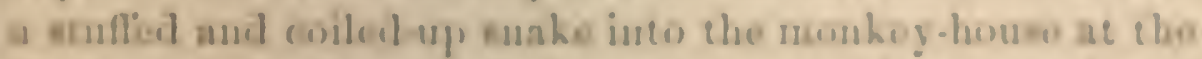

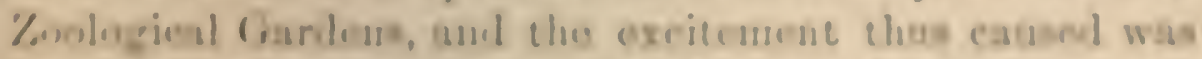

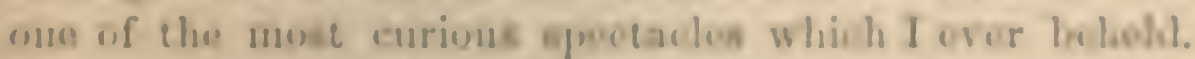

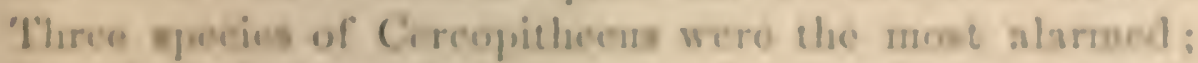
they dhehed alone their aged nud uleered sharp signal cries of danger, which were undentood by the otber monheys. A fow young urumbegs nul one uth Ambis boloon alone took no notion of the enakir. I then plaesd

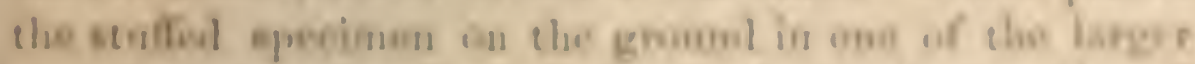
ompartments, Afor a time all the monkeys collected

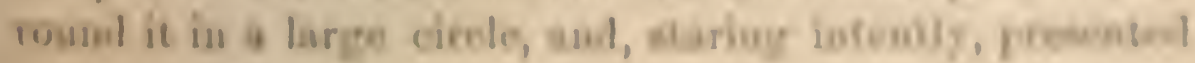


a most ludicrous appearance. They became extremely nervous; so that when a wooden ball, with which they were familiar as a plaything, was accidentally moved in the straw, under which it was partly hidden, they all instantly started away. These monkeys behaved very differently when a dead fish, a mouse, and some other new objects, were placed in their cages; for, though at first frightened, they soon approached, handled and examined them. I then placed a live snake in a paper bag, with the mouth loosely closed, in one of the larger compartments. One of the monkeys immediately approached, cautiously opened the bag a little, peeped in, and instantly dashed away. Then I witnessed what Brehm has described, for monkey after monkey, with head raised high and turned on one side, could not resist taking momentary peeps into the upright bag, at the dreadful object lying quiet at the bottom. It would almost appear as if monkeys had some notion of zoological aftinities, for those kept by Brehm exhibited a strange, though mistaken, instinctive dread of innocent lizards and frogs. An orang, also, has been known to be much alarmed at the first sight of a turtle.

The priuciple of Imitation is strong in man, and especially in man in a barbarous state. Desor ${ }^{10}$ has remarked that no animal voluntarily imitates an action performed by man, until in the ascending scale we come to monkeys, which are well known to be ridiculous mockers. Aninals, however, sometimes imitate each others' actions : thus two species of wolves, which had been reared by dogs, learned to bark, as does sometimes the jackal," but whether this can be called roluntary imitation is another question.

9 W. C. I. Martin, 'Nat. Hist. of Mammalia,' 1811, p. 405.

10 Qunted by Vogt, 'Mremoire sur les Mlicrocéphales,' 1S67, p. 168.

11 'The Variation of Animals and Plants under Domestication,' rol. i. p. 27. 
From one account which I have read, there is reason to believe that puppies nursed by cats sometimes learn to lick their feet and thus to clean their faces: it is at least certain, as I lear from a perfectly trustwortly fricul, that some $\operatorname{logs}$ behave in this mamer. Birts imitate tlse songs of their parents, and sometimes those of other birds; and parrots are notorious imitators of any sound which they often hear.

Hardly any faculty is more important for the intellectual progress of man than the power of Altention. Auimals clearly manifest this power, as when a cat watelies by a hole and prepares to spring on its prey. Will animals sometimes become so absorbed when thus engaged, that they may be easily approached. Mr. Bartlett lans giveu me a curious proof how rariable this faculty is in monkeyg. A man who trains nonkeys to act usel to purchase common kinds from the Zoological Society at the price of five poumls for each; lut lie oflired to give double the price, if he might keep three or four of them for a fow lays, in order to select one. When asked how he could poreibly so soon learn whether a particular moukey would turn out a good actor, he answered that it all depromed on their power of atcention. If when he was talking and crphining any thing in a monkey, its sttention whe casily distracted, as lyg a $11 y$ on the wall or other triblisg object, the case wax hopelen. If loo tried hy fumislumene to make su iustentise monkey art, it curned sulky. On the other hand, a monkey whith cerefully aecesuled to him could alwags be traisud.

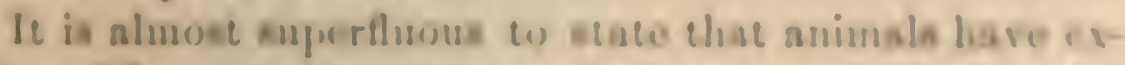
exllune Memorice for poctons and places. A baboon ate tho

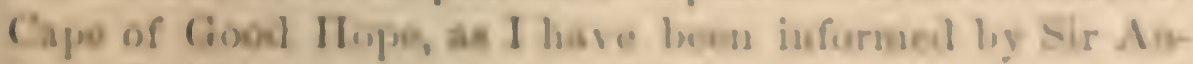

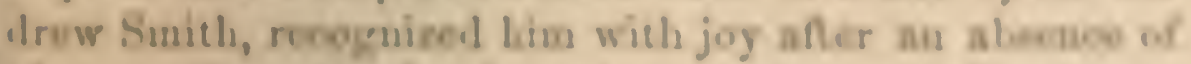

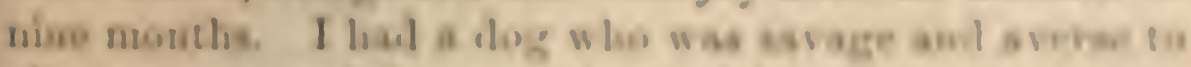
all strangere, and I purpose Is tried his amenory after an 
absence of five years and two days. I went near the stable where he lived, and shouted to him in my old manner; he showed no joy, but instantly followed me ont walking and obeyed me, exactly as if I had parted with him only half an hour before. $\Lambda$ train of old associations, dormant during five years, had thus been instantaneously a wakened in his mind. Even ants, as P. Huber ${ }^{12}$ has clearly shown, recognized their fellow-ants belonging to the same community after a separation of four months. Animals can certainly by some means judge of the intervals of time between recurrent events.

'The Imagination is one of the highest prerogatives of man. By this faculty he unites, independently of the will, former images and ideas, and thus creates brilliant and novel results. A poet, as Jean Paul Richter remarks, ${ }^{13}$ "who must reflect whether lie shall make a character say yes or no-to the devil with him; he is only a stupid corpse." Dreaming gives us the best notion of this power; as Jean Paul again says, "The dream is an involuntary art of poetry." The value of the products of our imagination depends of course on the number, accuracy, and clearness of our impressions; on our judgrnent and taste in selecting or rejecting the involuntary combinations, and to a certain extent on our power of voluntarily combining them. As dogs, cats, horses, and probalbly all the higher animals, even birds, as is stated on good authority, "have vivid dreams, and this is shown by their movements and voice, we must admit that they possess some power of imagination.

Of all the ficulties of the human mind, it will, I presume, be admitted that Reason stands at the summit.

12 'Les Ifours des Fournis,' 1810, p. 150.

13 Quoted in Dr. Maudsley's 'Physiology and 'Patholowy of Mrind,' 1868, pp. 19, 220 .

' Dr. Jerdon, 'Pirds of India,' vol. i. 1862 p. xxi. 
Few persous any longer dispute that animals powess some power of reasoning. Animals may contantly be scen us pause, dclibcrate, and resolve. It is a significant fact, that the more the habits of any particular animal are studicd by a naturalist, the more he attributes to reasen

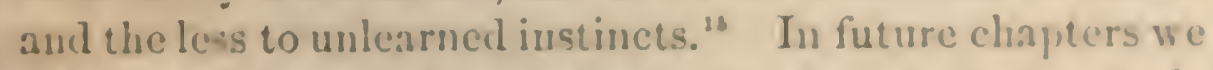
blatl see that some animals extrencly low in the scale apparently display a certain amount of reason. No doube it is often difticult to distinguish between the power of reason and that of instinct. 'Thus Dr. Hages, in lis work on 'The Open Polar Sea,' repatedly remarke that his dogs, instead of continuing to draw the stedges in a contpact body, diverged and separated when they came to thin ice, so that their weight might be nore erenly dietributed. This was often the first warning and notioe which the trarellers receired that the ice was leceming thin and dangerous. Now, did the doggs act thas from the esperience of each individual, or from the example of the older and wiser doge, or from an inherited habit, that is, froun an instinct? 'This instinct miglut possithly hase arien kince the time, long agn, when dogs were first ew. ployed by the natison in drawing their sledges; or the

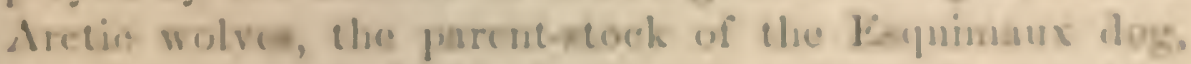
may lase sogptired this instince, impelling them not to attiek their proy in a close pack when on thin liese. Coretions of this hind a re neet dittichle w anewrer.

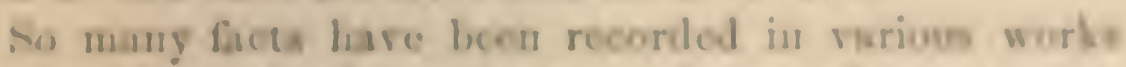

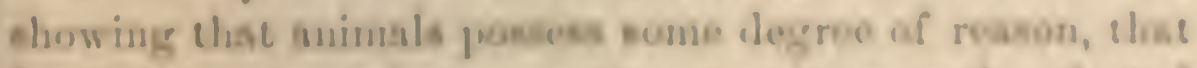
1 will liere gire only two or three intunees, ant bentistod

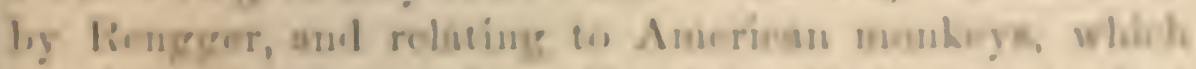
ntame low in tlu ir orter. He states that when be fores

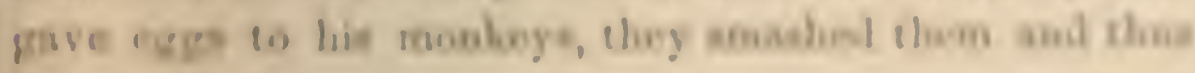

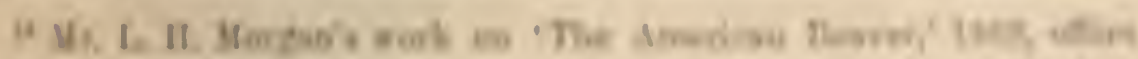

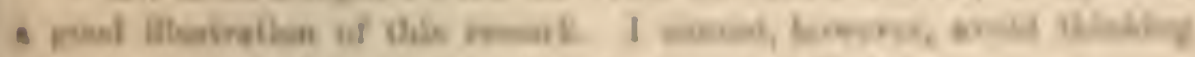

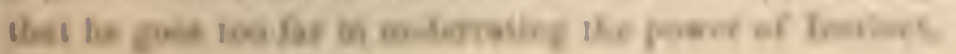


lost much of their contents; afterward they gently hit one end against some hard body, and picked off the bits of shell with their fingers. After cutting themselves only once with any sharp tool, they would not touch it again, or would handle it with the greatest care. Lumps of sugar were often given them wrapped up in paper; and Rengger sometimes put a live wasp in the paper, so that in hastily unfolding it they got stung; after this had once happened, they always first held the packet to their ears to detect any movement within. Any one who is not convinced by such facts as these, and by what he may observe with his own dogs, that animals can reason, would not be convinced by any thing that I could add. Nevertheless I will give one case with respect to dogs, as it rests on two distinct observers, and can hardly depend on the modification of any instinct.

$\mathrm{Mr}$. Colquhoun ${ }^{18}$ winged two wild-ducks, which fell on the opposite side of a stream; his retriever tried to bring over both at once, but could not succeed; she then, though never before known to ruffle a feather, deliberately killed one, brought over the other, and returned for the dead bird. Colonel Hutchinson relates that two partridges were shot at once, one being killed, the other wounded; the latter ran away, and was caught by the retriever, who on her return came across the dead bird; "she stopped, evidently greatly puzzled, and after one or two trials, finding she could not take it up without permitting the escape of the winged bird, she considered a moment, then deliberately murdered it by giving it a serere crunch, and afterward brought away both together. This was the only known instance of her ever having wilfully injured any game." IIere we have reason, though not quite perfect, for the retriever might have brought the wounded

16 'The Moor and the Loch,' p. 45. Colonel Hutchinson on 'Dos' Breaking,' 1850, p. 46. 
bird first and then returned for the dead onc, as in the casce of the two wild-ducks.

The muletcers in South America say, "I will not grive you the mule whose step is casiest, but la mas racional, -the one that reasons best;" and Humboldt ${ }^{28}$ adds, "this popular expression, dictated by long experience, combats the system of animated machines, better perhaps than all the arguments of speculative philosophy."

It has, I think, now becn shown that man and the higher animals, especially the Primates, have some few instincts in common. All have the same scuses, intuitions, and scusations-similar passions, aftections, and carorions, even the more complex ones; they feel womler and curioxity; they possess the same faculties of imitation, attention, memory, imagination, and reason, thongh in very diflorent degrees. Nevertheless many authors have insisted that man is separated through his uncutal faculties by an impassable barrice from all the lower animals. I formorly male a collection of above a seore of such aphor risus, but they are not worth giving, as their wille dittircuce and number prove the diffenlty, if not the impunliblity, of the attempt. It has heon asorted that mant alone is capalble of progressive improvencent; that he alone makes use of teols or lire, domesticales other animals, poetoses property, or employs languago; that no other animal is self-concious, comprolumls itsolf, lass the fower of abstraction, or poneceses general illeas; thaz man alone has a nenses of beanty, is liable to coprice, hes the foeling of gratitule, uygetery, etco; helieves in fiol, or in cuclowed with a conscionec. I will hazaril a fow romsis on the more importane and interestimg of thos puines

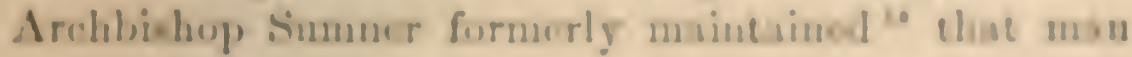

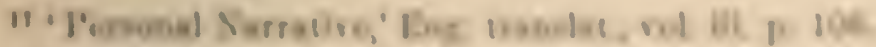

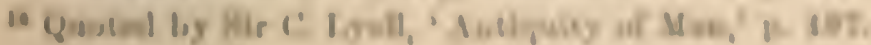


alone is capable of progressive improvement. With animals, looking first to the individual, crery one who hats hat any experience in setting traps knows that young animals cam be caught mucle more easily than old ones; and they can be much more easily approached by an enemy. Even with respect to old animals, it is impossible to eatch many in the same place and in the same lind of trap, or to destroy them by the same kind of poison ; yet it is improbable that all should hare partaken of the poison, and inpossible that all should have been caught in the trap. They must learn caution by secing their brethren caught or poisoned. In North America, where the fur-bearing animals have long been pursued, they cxhibit, according to the unanimous testimony of all observers, an almost incredible amount of sagacity, caution, and cunning; but trapping has been there so long carried on that inheritance may have come into play.

If we look to successive generations, or to the race, there is no doubt that birds and other animals gradually both acquire and lose cattion in relation to man or other cucmies; ${ }^{10}$ and this cantion is certainly in chief part an inherited habit or instinct, but in part tlie result of individual experience. $\mathbf{A}$ good observer, Leroy, ${ }^{20}$ states that in districts where foxes are much hunted, the young when they first leare their burrows are incontestably much more wary than the old ones in districts where they are not much disturbed.

Our domestic dogs are descended from wolves and jackals, ${ }^{21}$ and though they may not have gained in cun-

19 "Journal of Researches during the Voyage of the "Beagle," '1845, b. 398. 'Origin of Specica,' 5th edit. p. 260.

90 ' Lettres Phil. sur l'Intelligence des Animaux,' nourelle edit. 180:, p. 86.

"See the evidence on this head in chap. i. vol. i. 'On the Variation of Animals ant Plants under Domestication.' 
hand to the other end, and use it in the proper mamer as a lever. In the cases just mentioned stones and sticks were employed as implements; but they are likewise used as weapons. Brehm ${ }^{28}$ states, on the anthority of the wellknown traveller Schimper, that in Abyssinia when the baboons belonging to one species ( $C$. gelacta) descend in troops from the monntains to plunder the fields, they sometimes encounter troops of another species (C. hamadryas), and then a fight ensues. The Geladas roll down great stoues, which the IIamadryas try to aroid, and then both species, making a great uproar, rush furiously against each other. Brehm, when accompanying the Duke of Coburg-Gotha, aided in an attack with fire-arms on a troop of baboons in the pass of Mensa in Abyssinia. 'The baboons in return rolled so many stones down the mountain, some as large as a man's head, that the attackers had to beat a hasty retreat; and the pass was actually for a time closed against the caravan. It deserves notice that these baboons thus acted in concert. Mr. Wallace ${ }^{26}$ on three occasions saw female orangs, accompanied by their young, "breaking off" branches and the great spiny fruit of the Durian-tree, with every appearance of rage; causing such a shower of missiles as effectually kept us from approaching too wear the tree."

In the Zoological Gardens a monkey which had weak teeth used to break open nuts with a stone; and I was assured by the keepers that this animal, after using the stone, hid it in the straw, and would not let any other monkey touch it. Here, then, we have the idea of property; but this idea is common to every dog with a bone, and to most or all birds with their nests.

The Duke of Argyll ${ }^{27}$ remarks, that the fashioning of 25 ' Thierleben,' B. i. s. $79,82$. 26 ' The Jralay Archipelago,' vol. i. 1869, p. 87. 27 'Primeval Man,' 1869, pp. 145, 147. 
an implement for a special purpose is absulutely peculiar to man; and he considers that this forms an imuseasurable gulf between him and the brutes. It is no loubt: very important distinction, lut there apjears to me much truth in Sir J. Lublock's suggestion, " that when primeval man first used tlint-stonces for any purpose, he would have accilentally splintered them, and wonhl then have used the sharp, fragmente. From this stej it would be a fmall one to intentionally break the tlints, and not a very wile stcy to ruldy fashion them. 'This later alvance, lowever, may have takeu loner argese, if we may judge lyg

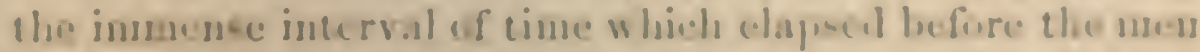
of the neolithe prioul touk to grinding and polishing their stonce tools. In breaking the slintes, as sir J. I.uls. bech lihewise remarks, sparks would hase becu animed,

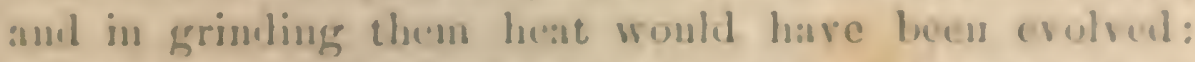
"Ihus the two uaual methoils of ohtaining fire may have originated." 'The unture of fire would hare heen kunw in the many voleanic regions where lasa occosionally thws through forcen. The anthrupousorphous apes, guided probably by instince, huild for themeloce compor rary platerms; but as many intinces are largerly con.

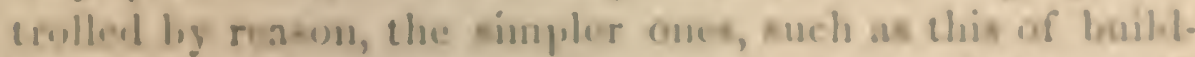
ing a plisform, miclie rodily pase into a volumery and couscious ant. The uraus is kuew 10 coser icalf at uighe wiels the hara of the loudanu; and Rireher states

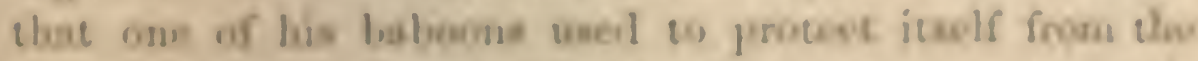
hat of the eun ly throwing a straw mat oror ita loved.

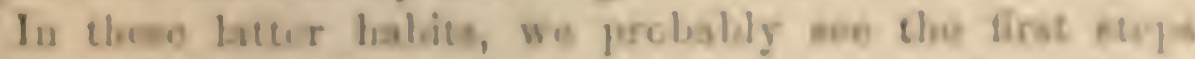

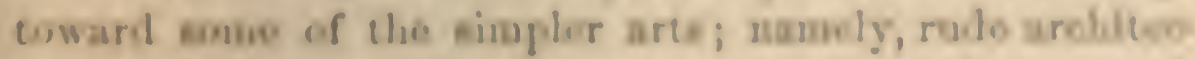
ture and iroes, at theg aroee amose the sarly jingenh torn of man.

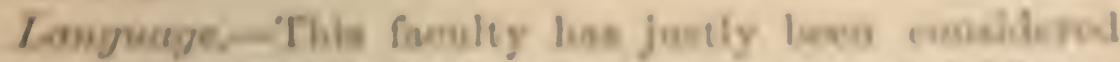

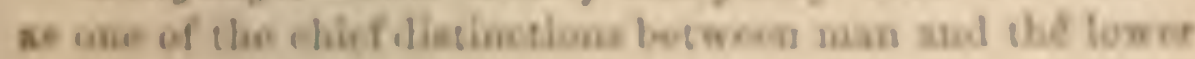

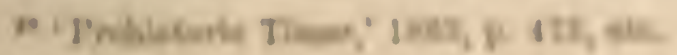


animals. But man, as a highly competent julge, Archbishop Whatcly remarks, "is not the only animal that can make use of language to express what is passing in his mind, and can understand, more or less, what is so expressed by another." 20 In Palaguay the Celus ararco when excited utters at least six distinct somds, which cxcite in other monkeys sinilar emotions. ${ }^{20}$ 'The movements of the features and gestures of moukeys are understood by us, and they partly understand ours, as Reugger and others declare. It is a more remarkable fact that the log, since being domesticated, has learned to bark" in at least four or five distinct tones. Although barking is a new art, no doubt the wild species, the parents of the dor, expressed their feelings by cries of various kinds. With the domesticated dog we have the bark of eagerness, as in the chase; that of anger; the yelping or howling bark of despair, as when shut up; that of joy, as when starting on a walk with his master; and the very distinct one of demand or supplication, as when wishing for a door or window to be opened.

Articulate language is, however, peculiar to man; but he uses in cominon with the lower animals inarticulate cries to express his meaning, aided by grestures aud the movements of the muscles of the face. 'Th This especially holds good with the more simple and rivid feclings, which are but little commected with our higher intelligence. Our cries of pain, fear, surprise, anger, together with their appropriate actions, and the murmur of a

23 Quoted in 'Anthropological Review,' 18G, p. 158.

${ }^{30}$ liengeger, ibid. 8. 45.

31 See my 'Variation of Animals and Plants under Domesticntion,' vol. i. p. 27.

32 See a diacussion on this subject in Mr. F. B. Tylor's rery interesting work, 'Researches into the Iarly History of Mankind,' 1665, claps. ii. $10 \mathrm{iv}$. 
their song round." Nestlings which have learned the song of a distinct species, as with the eanary-birds educated in the Tyrol, teach and transmit their new song to their oflspring. The slight natural differences of song in the same species inhabiting different districts may be appositely compared, as Barrington remarks, "to provincial dialeets;" and the songs of allied though distinct species may be compared with the langunges of distinct races of nian. I have giren the foregoing details to show that an instinctive tendency to acquire an art is not a peculiarity confined to man.

With respect to the origin of articulate language, after having read on the one side the highly-interesting works of Mr. Iensleigh Wedgwood, the Rev. F. Farrar, and Prof. Schleicher, ${ }^{34}$ and the celebrated lectures of Prof. Max Müller on the other side, I cannot doubt that language owes its origin to the imitation and modification, aided by signs and gestures, of rarious natural sounds, the roices of other animals, and man's own instinctive cries. When we treat of sexual selection we shall see that primeral man, or rather some early progenitor of man, probably used his roice largely, as does one of the gibbon-apes at the present day, in producing true musical cadences, that is in singing; we may conclude from a widely-spread analogy that this power woukd have been especially exerted during the courtship of the sexes, serving to express rarious emotions, as love, jealousy, triumph, and serving as a challenge to their rivals. The imitation by articulate sounds of musical cries might have given

3: 'On the Origin of Language,' by H. Wedgrood, 1866. 'Chapters on Language,' by the Rer. F. W. Farrar, 1865. These works are most interesting. Sce also 'De la Phys. et de Parole,' par Albert Lemoine, 1865, p. 190. The work on this subject, by the late Prof. Aug. Schleicher, has been translated by Dr. Bikkers into English, under the title of 'Darwinism tested by the Science of Language,' 1869. 
rise to words expressive of various complex cuntions. As bearing on the subject of imitation, the strong tendency in our nearest allies, the monkeys, in microceplatalous idiots, and in the barbarous races of mankiurl, to initite whatever they hear descrves notice. As monhey cortainly understand much that is said to them ly man, and as in a state of nature they utter signal-cries of danger to their fellows," it does not appear altoguher increalilje, that some unusually wise ape-like amimal should have thoughlic of imitating the growl of a beast of proy, so as (1) iudicate to his fellow-mouheys the nature of the ex. pected danger. And this would have becu a first neph in the furmation of a language.

As the roice was used more and more, the rocal oreans would have been strengelsened and perfected through the principle of the inherited effects of use; aml this would have reacted on the power of speech. But the relation between the continucd use of language and the development of the brain has no doubt been far more inportant. 'The mental powers in some early progenilor of uan unut hare becu nore highly dereloperl than iu any pristing apm, before even the most imperfect form of fprech could have come inte use; but we ans contiolensly

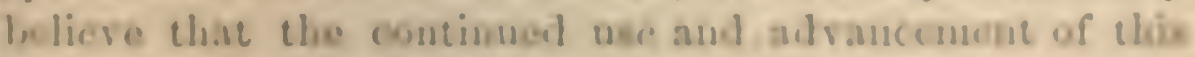
power would have resected on the mind ly andiling and vnemunging it to carry on long traina of thouche. A

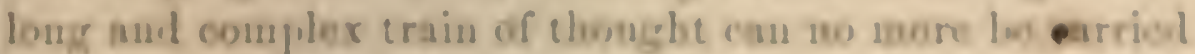
on withoue the aid of words, whether spohes or sllent, than a lone calculation without the nue of figures of aleshra. It appoars, aleo, thac es un undisary eraise of thenght

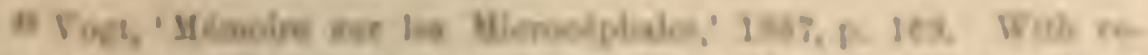

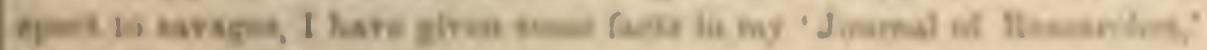
cte. $1 \pm 15,8,2 \pi n$

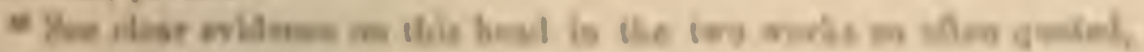
v) Inabe ned Beateren. 
almost requne some form of language, for the dumb, deal, and blind frirl, Laura Bridguna, was observed to use her lingers while dreaming." Nevertheless a long suceession of yivid and connected ideas may pass through the mind without the aid of any form of language, as we may infur from the prolonged dreams of dogs. We have, also, secu that retriever-dogs are able to reason to a certain cotent; and this they manifestly do without the aid of languarge. 'The intimate comection between the brain, as it is now developed in us, and the ficulty of specch, is well slown by those curious cases of brain-lisease, in which speech is specially afficted, as when the power to remenber substantives is lost, while other worls can be correctly used." There is no more improbability in the eflects of the continued use of the rocal and mental organs being inherited, than in the case of handwriting, which depends partly on the structure of the hamd and partly on the disposition of the mind; and handwriting is certainly inlerited. ${ }^{20}$

Why the organs now used for speceh should have been originally perfected for this purpose, mather than any other organs, it is not diflicult to sec. Ants have consillcrable powers of intercommunication hy means of their antenne, as shown by IIuber, who derotes a whole chapr tor to their language. We might have used our finger's as coficicut instruments, for a person with practice can report to a deaf man crery word of a specels rapilly delivered at a public mecting; but the loss of our hamds,

3: See remarks on this head by Dr. Maudsley, "The Physiolngy and P'athology of Hind,' 2d elit. 1868, p. 199.

as Many curious cates have been recorded. Sec, for insance, 'Inquiries concerning the Intellectual Powen,' hy Jr. Abercrombic, 16s8, p. 150.

39 'The Yariation of Animals and Plantw under Dometication,' rol ii. p. 6. 


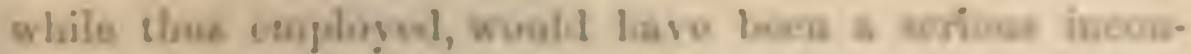
vasience. As all tbe bigher momevals powese verat ur-

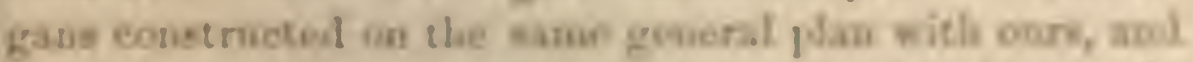

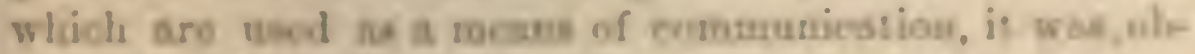
vinat!y yruhathe, if the prower of communication had to be improvel, that thewe newe creas woull bave hewa will forther develoged; sanl this hat beor efleceed by the

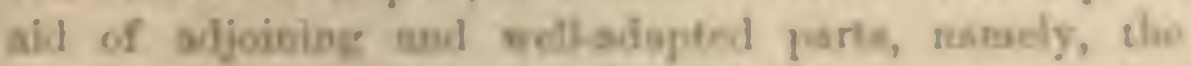

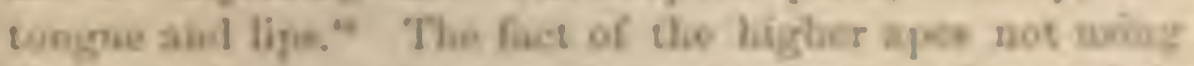
to ir vocal orpone for npereb, so doube ilcpabils no their inedligenes wot laving bees endiciencly sulvanod. The

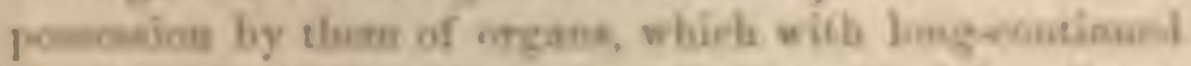

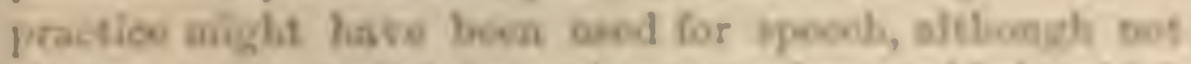

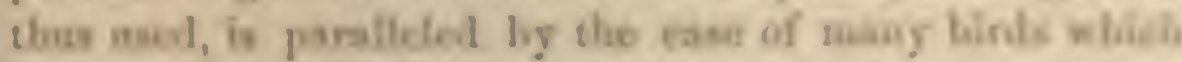

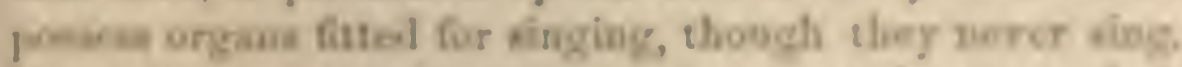

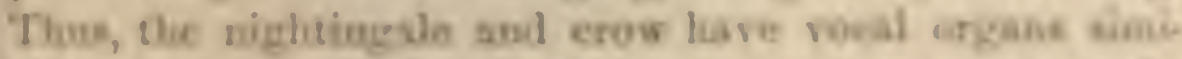

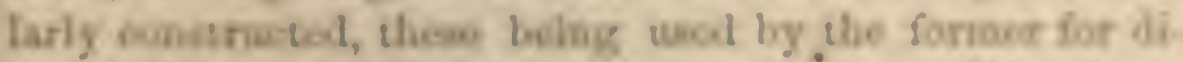

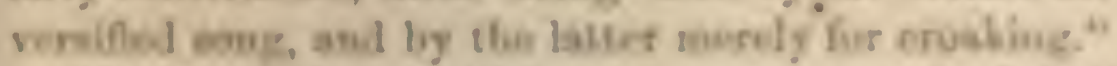

The fonmation of diffenos languapre and of distlese

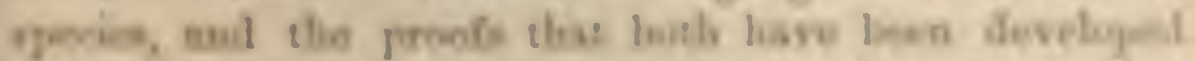

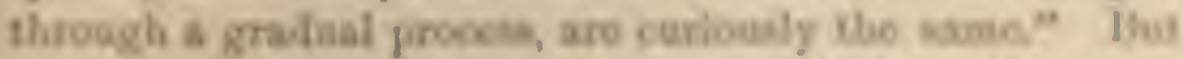

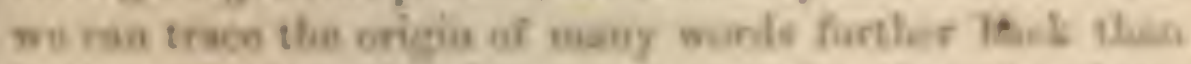

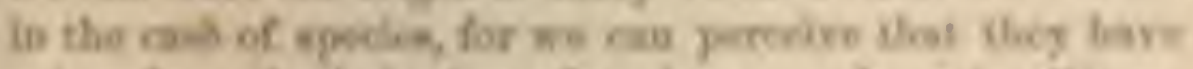

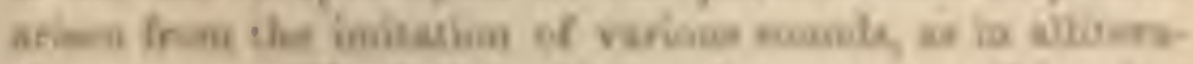

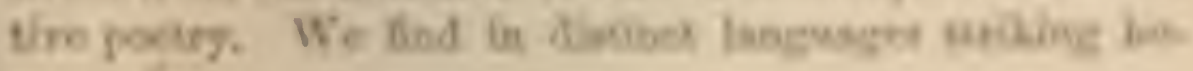

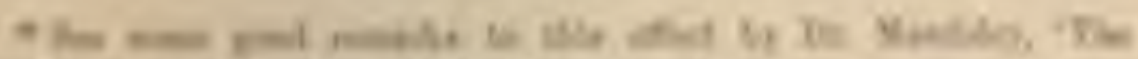

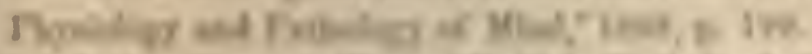

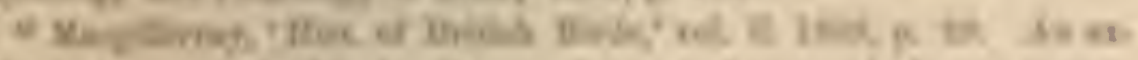

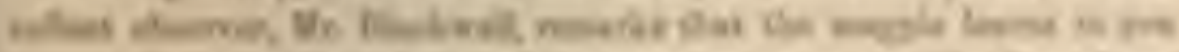

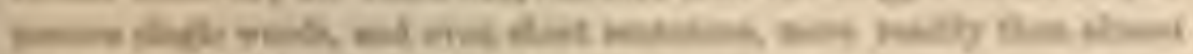

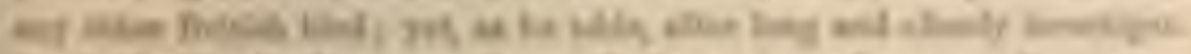

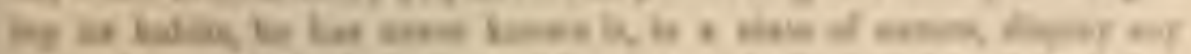

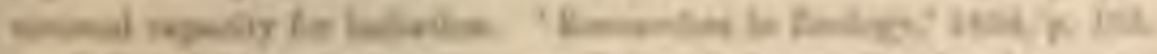

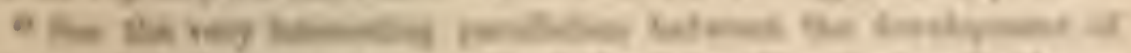

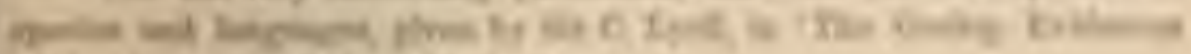

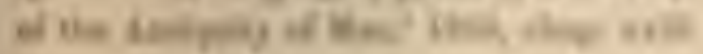


mologies due to community of descent, and analogies duc to a similar process of formation. The manner in which certain letters or sounds change when others change is very like correlated growth. We hare in both eases the reduplication of parts, the effects of long-continued use, and so forth. The frequent presence of rudiments, both in languages and in species, is still more remarkable. The letter $m$ in the word $a m$, means $I$; so that in the expression $I \mathrm{~cm}$, a superfluous and useless rudiment has been retained. In the spelling also of words, letters often remain as the rudiments of ancient forms of pronunciation. Languages, like organic beings, can be classed in groups under groups; and they can be classed either naturally, according to descent, or artificially by other characters. Dominant languages and dialects spread widely and lead to the gradual extinction of other tongues. A language, like a species, when once extinct, never, as Sir C. Iyell remarks, reappears. The same language never has two birthplaces. Distinct languages may be crossed or blended together, ${ }^{3}$ We see variability in every tongue, and new words are continually cropping up; but as there is a linit to the powers of the memory, single words, like whole languages, gradually become extinct. As Max Maller " has well remarked: "A struggle for life is constantly going on among the words and grammatical forms in each language. The better, the shorter, the casier forms are constantly gaining the upper hand, and they owe their success to their own inherent virtuc." 'To these more important causes of the survival of certain words, mere novelty may, I think, be added; for there is in the mind of man a strong love for slight changes in all things. The survival or preservation

${ }^{43}$ See remarks to this effect by the Rev. F. W. Farrar, in an interest. in r article, cutitled "Ihilology and Darwinism," in 'Nature,' March 24, $18 \% 0$, r. 528 .

4 'Nature,' Jan. 6, 1870, [1. 257. 
of certain fovored words in the struggele for cxistence is natural selection.

The perfectly regular and wonderfully complicx construction of the languages of many barharous nations tas often been adranced as a proof, either of the divine origin of these languaged, or of the ligh art and former civiliza. tion of their foundens. Thus F. von sililegel writes: "In those languages which appear to be at the lowest gende of intellectual culeure, wo frequently oberve a very ligh and chborate degree of art in their grammatical etructure. This it ofwevilly the case with the Basque and the Lape ponian, and many of the American languager." ". Lat it it atauredly an crror to speak of any languago as sul are in the scuse of its laving been elaborately and mothodielly formed. Philologita now admit that anjugations, declentions, ete., originally existed as distinct words, since joined ingetlier; and as nueh words exprese the ancuet obvious relations betweon oljects and perwonk, it is not war. prising that they should hase beon used by the mean of

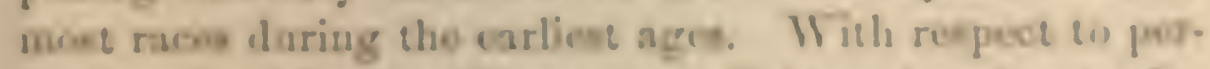
foction, the following illustration will beet show how caily

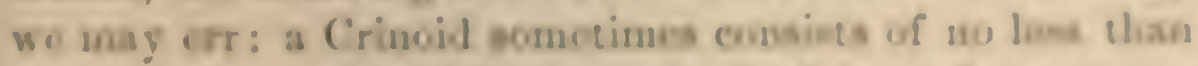
150,000 plives of shell," all smaged with porfoct ograme-

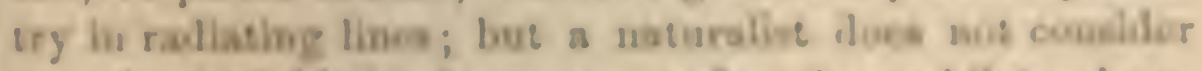

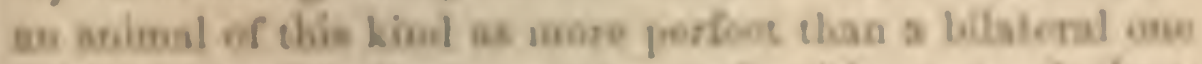

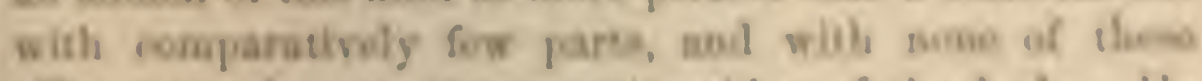

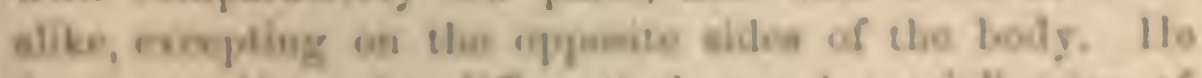

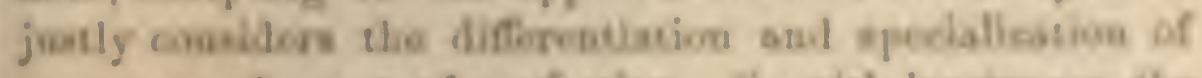

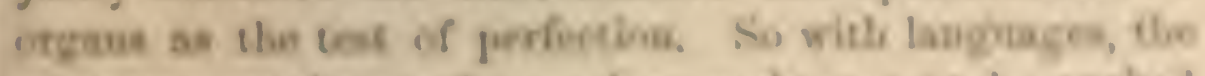

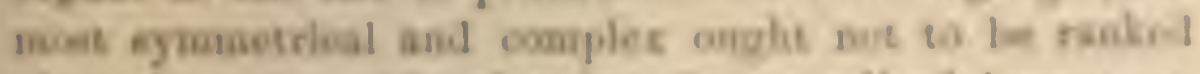

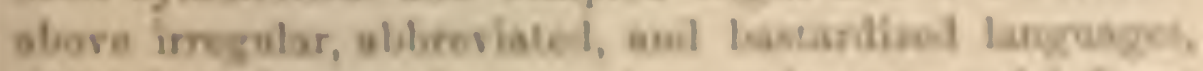
whe hl have borrowed exprestre wonle abd unefol firmes

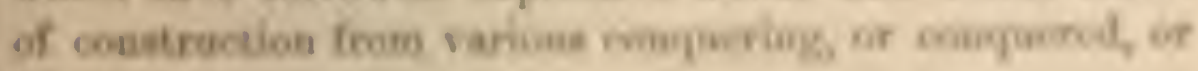
imalgont nows.

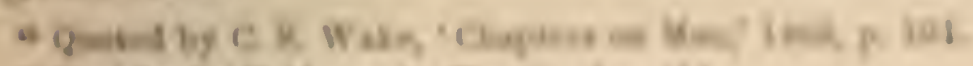

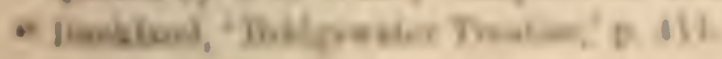


From these few and imperfect remarks, I conclude that the extremely complex and regular construction of many barbarous languages is no proof that they owe their origin to a special act of creation. ${ }^{47}$ Nor, as we have seen, does the faculty of articulate speech in itself ofler any insuperable objection to the beliof that man has been developed fiom some lower form.

Self-conscionsness, Individuality, Abstraction, General Tileas, etc.-It would be useless to attempt discussing these high faculties, which, according to several recent writers, make the sole and complete distinction between man and the brutes, for hardly two authors agree in their definitions. Such faculties could not have been fully developed in man until his mental powers had advanced to a high standard, and this implies the use of a perfect language. No one supposes that one of the lower animals reflects whence he comes or whither he goes-what is death, or what is life, and so forth. But can we feel sure that an old dog with an excellent memory, and some power of imagination, as shown by his dreams, never reflects on his past pleasures in the chase? and this would be a form of self-consciousness. On the other hand, as Buchner ${ }^{48}$ has remarked, how little can the hard-worked wife of a degraded Australian savage, who uses hardly any abstract words, and cannot count above four, exert her self-consciousness, or reflect on the nature of her own existence!

That animals retain their mental individuality is unquestionable. When my voice awakened a train of old associations in the mind of the above-mentioned dog, he must have retained his mental individuality, although

${ }^{47}$ See some good remarks on the simplification of languages, by Sir J. Lubbock, 'Origin of Civilization,' 1870, p. 278.

4s 'Conferences sur la Théorie Darwinienne,' French translat., 186ะ, p. 132. 
every atom of his brain had probally undergonc clange more than once during the interval of five years. This dog miglit have hrouglit forward the argument lately alvanced to crush all evolutionists, and said, "I aljide anil all mental moods and all material changes. . . 'The teaching that atoms leave their impressions as legacies to other atoms falling into the places they lave racated is contradictory of the utterance of conscionsues, and is therefore filse; but it is the teaching necessitated by erolutionism, consequently the hypothesis is a false onc." "o

Sense of Beculy. - This semse has been declared to bo peculiar to man. But when we behold male birls chaboratcely displaying their plumes and splendid colurs before the females, while other birds not thus decorated mako no such display, it is imposible to doubt that the females almire the beaty of their male partners. As romen everywhere deck themselves with these plumes, the beauty of such ornouncuts canuot be disputed. The Bower-birds

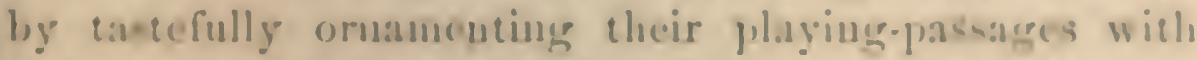
gayly-colored objects, as do certain humming-birds their uists, ofler alditional evillence that thry possend a seusus of besuty. So with the soug of birds, the sweet etruins poured forth lig the males duriug the seaton of love aro

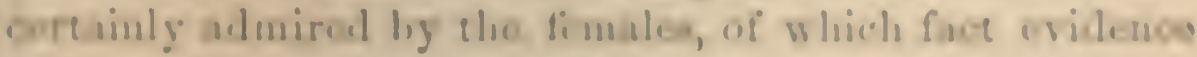

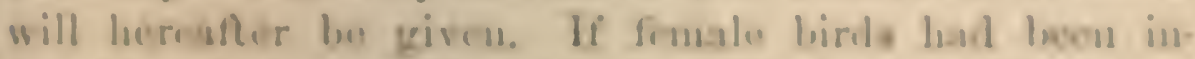
tapuble of apprecintiug the houstiful colors, the orm

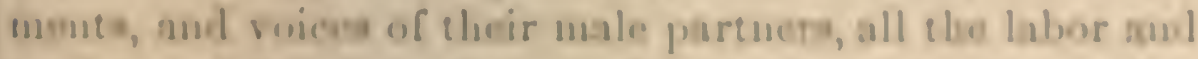

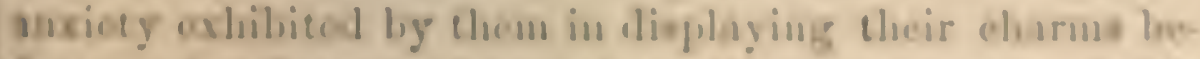
bire the fimales would have been thrown nwag; and ebla

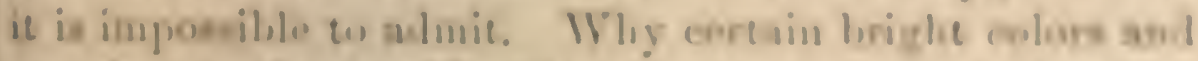

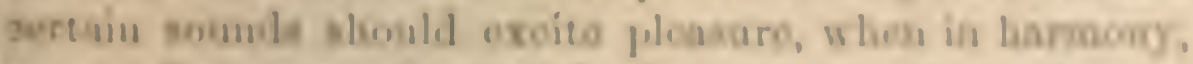

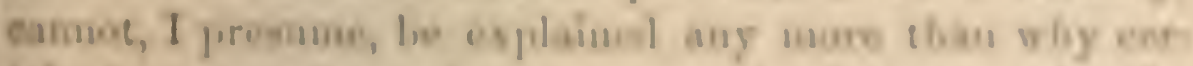

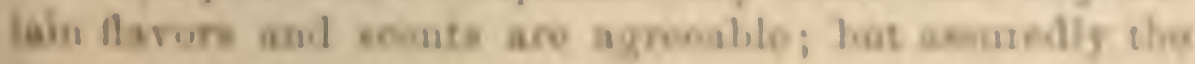


same colors and the same sounds are almired by us and by many of the lower animals.

The taste for the beautiful, at least as far as female heauty is concerued, is not of a special nature in the human mind; for it differs widely in the different races of man, as will hereafter be shown, and is not quite the same even in tle diflerent nations of the same race. Judging from the hideons ornaments and the equally hideous inusic admired by most savages, it might be urged that their asthetic faculty was not so lighly developed as in certain animals, for instance, in birds. Obviously no animal would be capable of admiring such scenes as the heaveus at night, a beantiful landscape, or refined music; but such high tastes, depending as they do on culture and complex associations, are not enjoyed by barbarians or by uneducated persous.

Many of the faculties, which have been of inestimable service to man for his progressive advancement, such as the powers of the imagination, wonder, curiosity, an undefined sense of beanty, a tendency to imitation, and the love of excitement or novelty, could not fail to have led to the most capricious changes of customs and fashions. I liave alluded to this point, because a recent writer ${ }^{\text {so }}$ has oddly fixed on Caprice "as one of the most remarkable and typical differences between savages and brutes." But not only can we perceive how it is that man is capricious, but the lower animals are, as we shall hereafter see, capricious in their affections, aversions, and sense of beanty. There is also grood reason to suspect that they love novelty, for its own sake.

Belief in Goct-Religion.-There is no evidence that man was aboriginally endowed with the ennolbling belief in the existence of an Omnipotent God. On the contrary, so 'The Spectator,' Dec. 4, 1S69, p. 1130. 
there is ampee evidence, derived not from hasty tratellers, but from men who have long recided with savages, that numcrous races have existed and still exist, who have no idca of one or more gods, and who have no works in their languages to express such an idea." The question is of conre wholly distiuct from that higher one, whether there rexists a Creator and Ruler of the universe; and this has heen answered in the aftirnative by the highest intellects that have erer lived.

If, however, we include under the term "religion" the betiof in unseen or spiritual agencies, the ease is wholly diflerent ; for this belief secuss to he almost universal with the less civilized races. Nor is it difficult to comprelieml how it arose. As soon as the important faculies of the imagination, wonder, and curiosity, together with some power of reasoning, had become partially dereloped, man would naturally have craved to understand what wan paning around him, and have raguely specnlated on his own eximence. As.Mr. M'Lenusu" has remarked, "Some explanation of the phenomena of life, a man must feign for linuelf; and io judge from the miversality of it, the simplet hypothesis, and the first to oceur to men, secms to have been that matural plecuemena are aseribalole in the promece in animals, plants, and thinge, and fo the forese of Nature, of surh fpirits proupting to sethen as

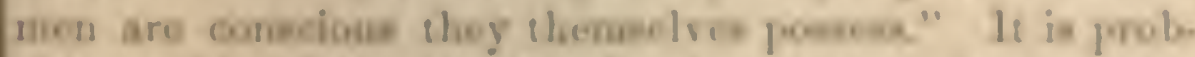
ahle, as Mr. Tylor bas diarly sliown, that iresme mas have first girus rime to the notion of spirtes; for narages

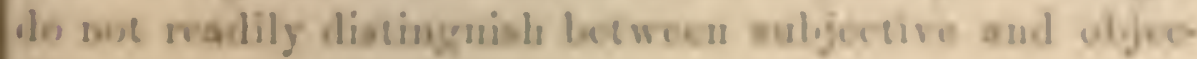

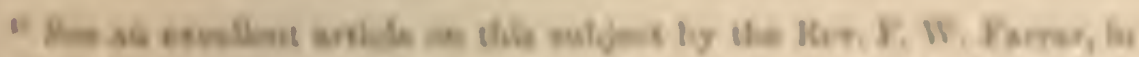

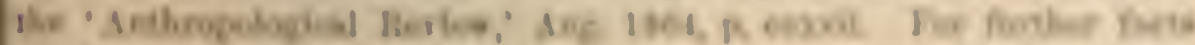

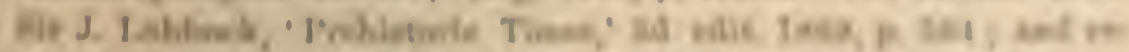

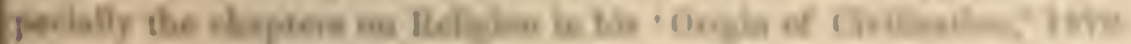

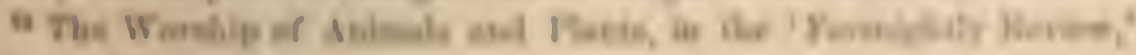
(a) $1,1005,8,1 \mathrm{n}$ 
tive impressions. When a savage dreams, the figures which appear befure him are believed to have come from a distance and to stand over him; or "the soul of the dreamer goes out on its travels, and comes home with a remembrance of what it has seen." os But until the abovenamed faculties of imagination, curiosity, reason, etc., haul been fairly well developed in the mind of man, his dreams would not have led him to believe in spirits, any moro than in the case of a dog.

The tendency in sarages to imagine that natural objects and agencies are animated by spiritual or living essences, is perliaps illustrated by a little fact which I once noticed: My dog, a full-grown and very sensible animal, was lying on the lawn during a hot and still day; but at a little distance a slight breeze occasionally moved an open parasol, which would have been wholly disregarded by the dog, had any one stood near it. $\Lambda$ s it was, every time that the parasol slightly moved, the dog growled fiercely and barked. He must, I think, have reasoned to himself in a rapid and unconscious mamer, that move-

53 Tylor, 'Farly IIistory of Mankind,' 1865, p. 6. Sec also the three striking ehapters on the Development of Religion, in Lubbock's 'Origin of Civilization,' 18ro. In a like manner Mr. Herbert Speneer, in his ingenious essay in the 'Fortnightly Review' (May 1, 1870, p. 535), accounts for the earlicst forms of religious belief throughout the world, by man being led through dreans, shadows, and other causes, to look at linnself as a double essenec, corporeal and spiritual. $\Lambda$ s the spiritual being is supposed to exist after death and to be powerful, it is propitiated by various gifts and ceremonies, and its aid invoked. He then further shows that names or nicknames giren from some animal or other object to the early promenitors or founders of a tribc, are supposed after a long interval to represent the real progenitor of the tribe; and such animal or object is then naturally belicred still to exist as a spirit, is held sacred, and worshipped as a god. Nerertheless I cannot but suspeet that there is a still earlier and ruder stage, when any thing which manifests power or morement is thonght to be endowed with some form of life, and with mental facultics analogous to our own. 


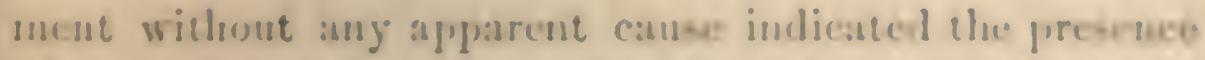
of forme strange living agent, and uo stronger lad a righe ti) be on lis terriory.

The belice in spiritual ageme-ion would eatily pas =e is? the belic in the existence of once or more gods. Jior sarages would uaturally attribute (s) spiries the mame pas sions, the same lobe of rengeasuce or simplest form of jus.

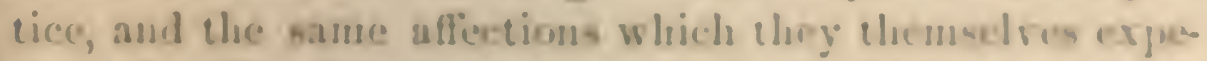
ricucol. "lhe Fungiand appuear to he in this roppere is su intermediate ernolition, for when thenurgen on hoard the

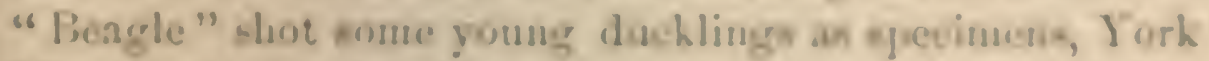
Minster declarol in the nowe solemm manuer, "Olı! Mr. liguoe, mucls rain, murls "now, hlow muclı; "sul this was "bilently a retributive punishment for wastis hrman

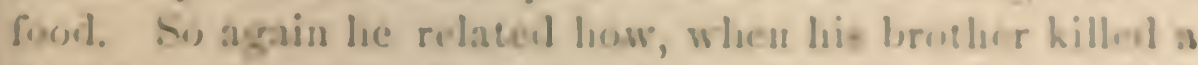
"wild man," storms loug raged, mucls roin amal smow foll. lie we could serer diksoser that elar Fuegisul beliovel in what we should call a Giod, or procticed an! roligious

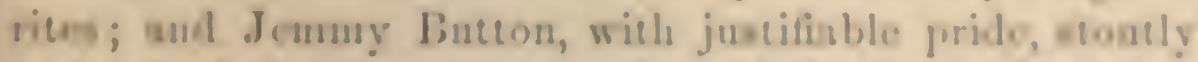

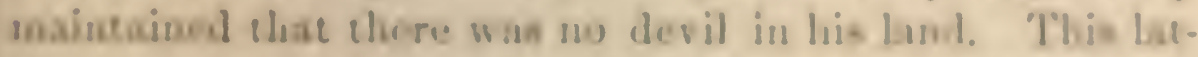

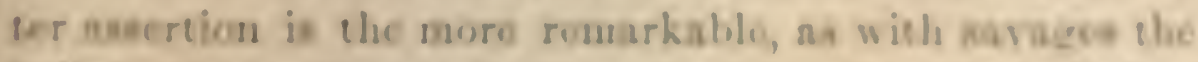

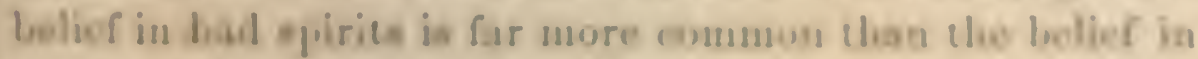
groud rvirik

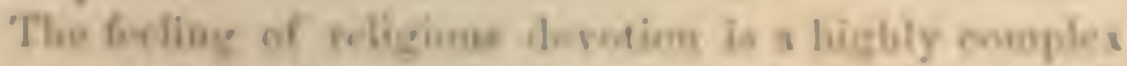

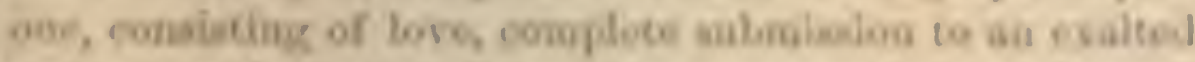

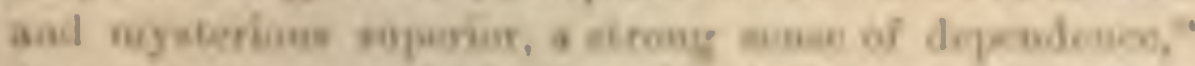

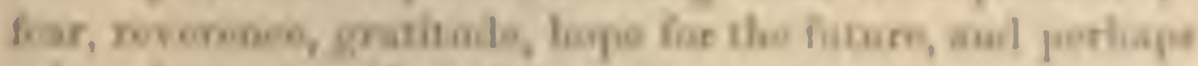

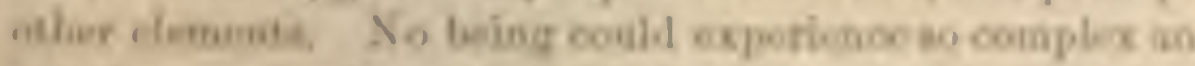

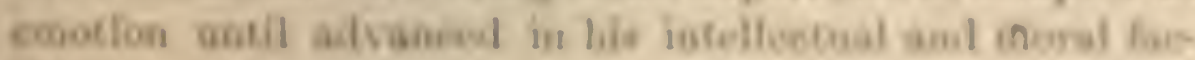

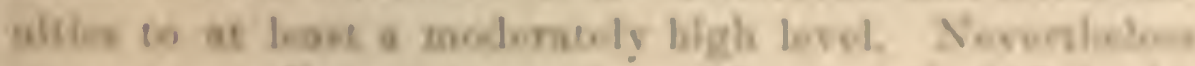

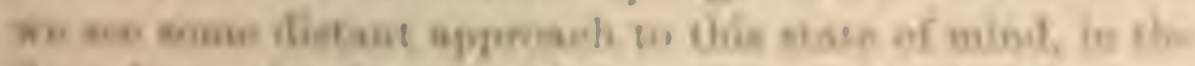

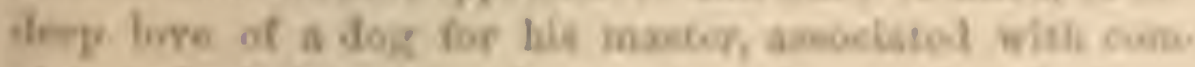

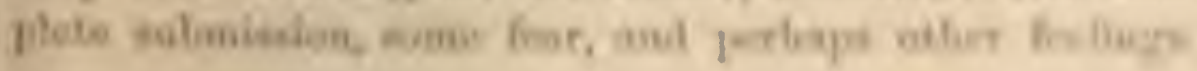

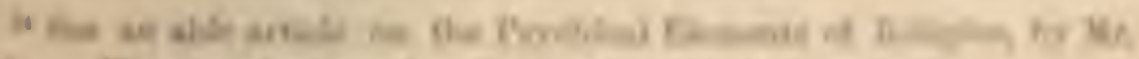

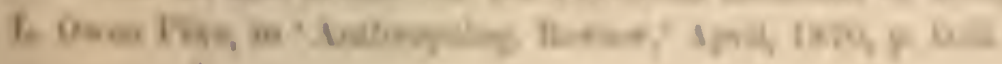


The behavior of a dogr when returning to his master after an absence, and, as I may add, of a monkey to his belored kecper, is widely diflerent from that toward their fellows. In the latter case the transports of joy appear to be somewhat less, and the sense of equality is shown in every action. Prof. Braubach "s goes so far as to maintain that a dog looks on his master is on a god.

The same high mental faculties which first led man to believe in unseen spiritual agencies, then in fetishism, polythcism, and ultimately in monotheism, would infallibly lead him, as long as his reasoning powers remained poorly developed, to various strange superstitions and customs. Many of these are terrible to think of-such as the sacrifice of human beings to a blood-loving god; the trial of innocent persons by the ordeal of poison or fire; witchcraft, etc.-yet it is well occasionally to reflect on these superstitions, for they show us what an infinite debt of gratitude we owe to the improvement of our reason, to science, and our accumulated knowledge. ${ }^{\text {bo }} \Lambda$ s Sir J. Lubbock has well observed, "it is not too much to say that the horrible dread of unknown eril hangs like a thick clond over savage life, and embitters every pleasure." These miserable and indirect consequences of our highest faculties may be compared with the incidental and occasional mistakes of the instincts of the lower aninals.

s5 'Religion, Moral, etc., der Darwin'schen Art-Lchre,' 1869, s. 53.

50 'Prehistoric Times,' $2 d$ edit. p. 571. In thls work (at p. 553) there will be foumd an excellent account of the many strange and capri. cious customs of sarages. 


\section{P TEIR III.}

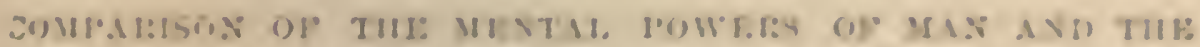

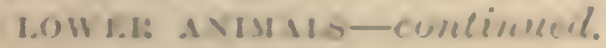

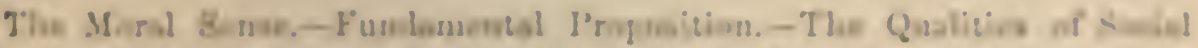

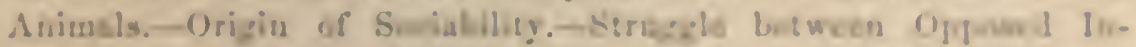

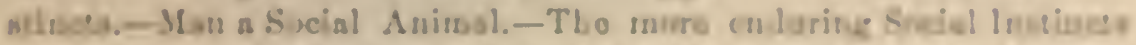

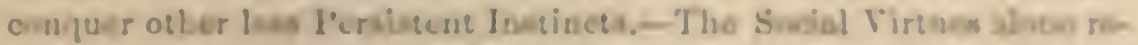

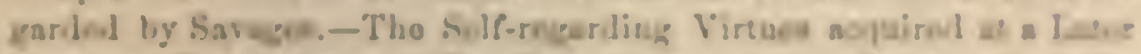

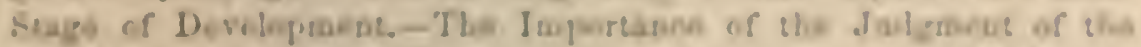

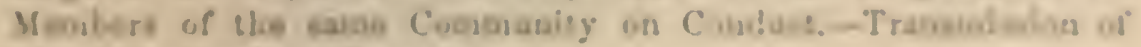

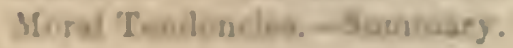

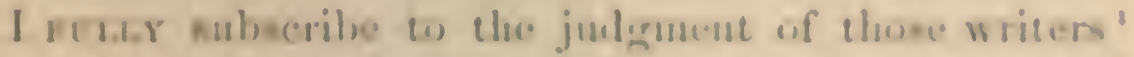

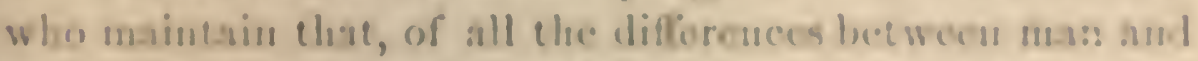

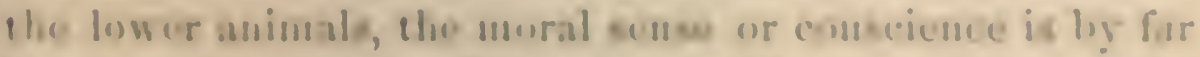

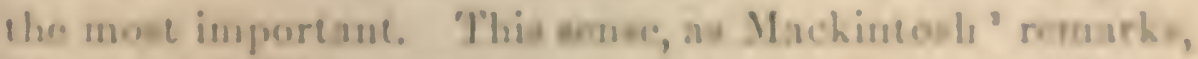

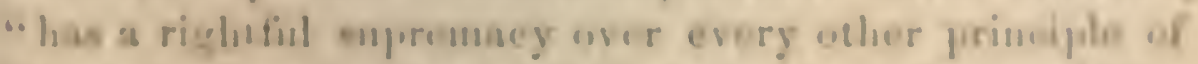

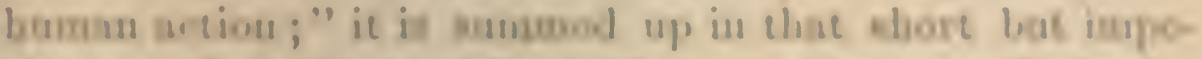

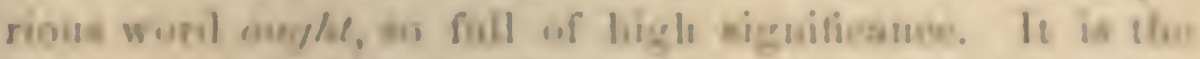
moes notile of all the netributre of mas, baling him with-

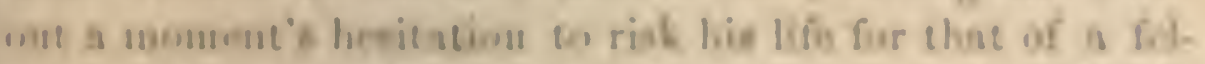

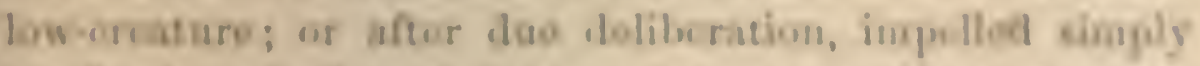

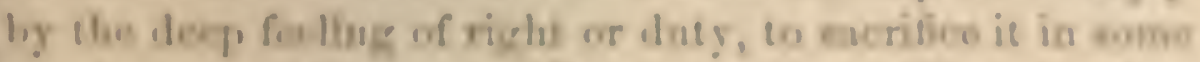

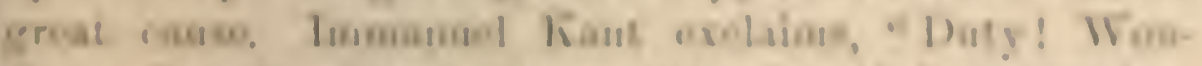
droue thoughie, elast morkese selelier by fond insinusuos,

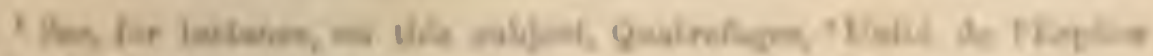

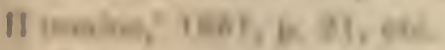

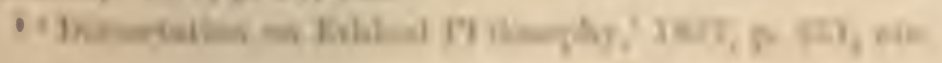


flattery, nor by any threat, but merely by holding up thy naked law in the soul, and so extorting for thyself always reverence, if not always obedience; before whom all apietites are dumb, however secertly they rebel; whence thy original?

This great question has been discussed by many writers ${ }^{4}$ of consummate ability; and my sole cxcuse for touching on it is the impossibility of here prassing it over, and beeause, as far as I know, no one has approached it exchsively from the side of natural history. The investigation possesses, also, some independent interest, as an attempt to sce how far the study of the lower animals can throw light on one of the highest psychical faculties of man.

The following proposition seems to me in a high degree probable-namely, that any animal whatever, endowed with well-marked social instincts, would inevitably acquire a moral sense or conscience, as soon as its intellect.

'Metaphysies of Ethics,' translated by J. W. Semple, Edinburgh, 1836, p. 136.

4 Mr. I3ain gires a list ('Mental and Moral Science,' 1868, pp. 513-725) of twenty-six Britisin anthors who have written on this subject, and whose names are familiar to erery reader; to these, Mr. Jain's own name, and thosc of Mr. Lecky, Mr. Shadworth Hodgson, and Sir J. Lubbock, as well as of others, may be added.

B Sir B. Brodic, after observing that man is a social animal ('Psjehological Inquiries,' 1554, p. 192), asks the pregnant question, "Ought not this to settle the disputed question as to the existenec of a moral sense?" Similar ideas lave probably occurred to many persons, as they did long ago to Mareus Aurelius. Mr. J. S. Mill speaks, in his celebrated work, 'Ctilitarianism' (1861, p. 46), of the social feelings as a "powerful uatural sentiment," and as "the natural basis of sentiment for utilitarian morality;" but, on the previous page, he says, "If, as is my own belief, the moral feelings are not innate, but acquired, they are not for that reason less natural." It is with hesitation that I renture to differ from so profound a thinker, but it ean liardly be disputed that the social feclings are instinetive or iunate in the lower animals; and why should they not be so in un:n? Mr. Bain (sec, for instance, "The Fimotions and the Will," 1865, 
ual powern lad bocome as well deselopeal, or murly as well descleped, as is man. Fur, girstly, 2l.e sovial iu.

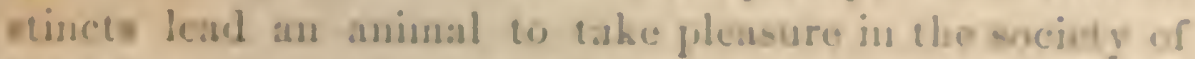
its folluws, (1) feel a cortain amount of sympothy with them, and to perform various services for them. 'The ser. vious may be of a definite and erielenty in-tinctive anture; or there may be only a wiels aud resdiness, an with mont of the lighter socisl mimsls, 26 aill the ir fellows in certain general wayt. Lut these folinga and services are l,y m mode extemded to all the iudivicliale of the somo spocios,

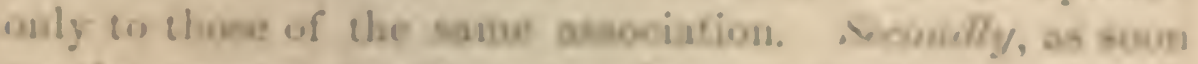
a the mental focultios lal lecewe bighly derologeal, intages of all past actions and motiven would be inces.

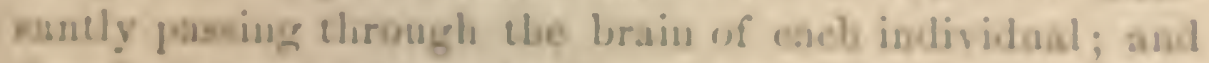

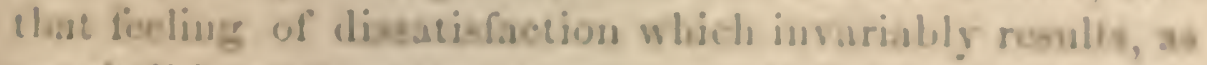

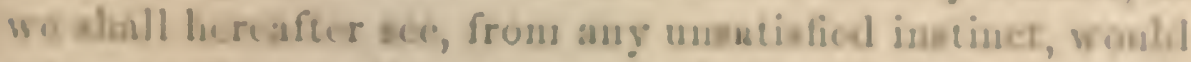
arian, as ofen an it was peroeised that the cudurise and

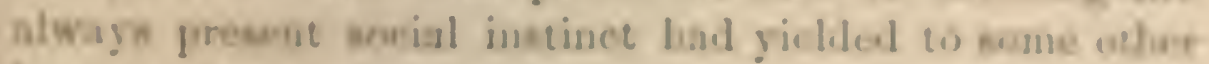

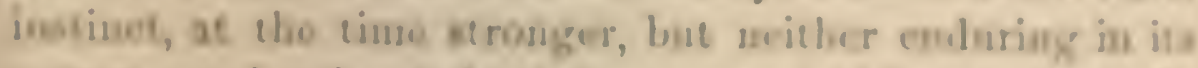
suture, un lasing lefind it a sery risil impresine. I is clear tlat many iustumetive desires, such as that of hum ger, are in thair nature of abon daracien; anl aflec laciug

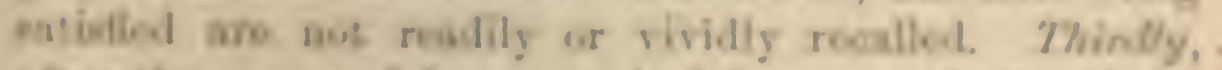

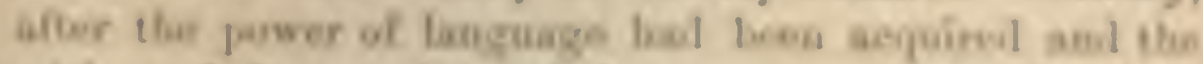

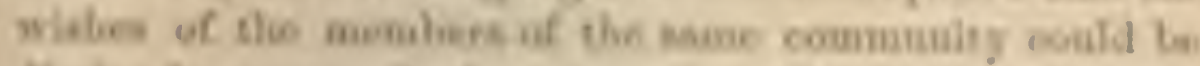

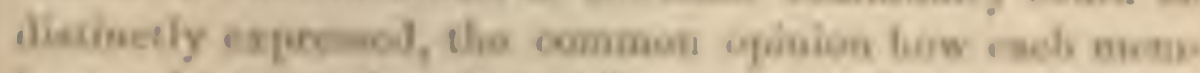

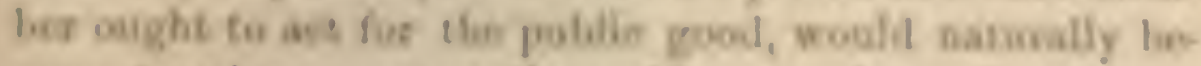

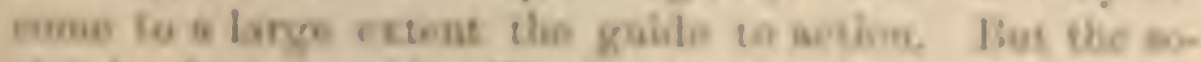

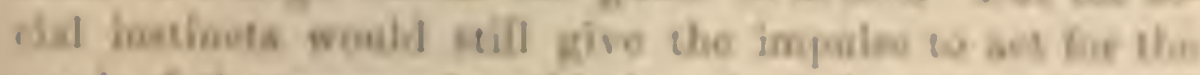

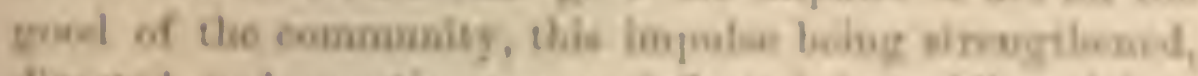

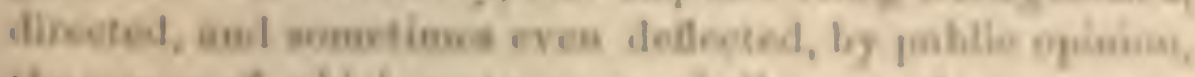

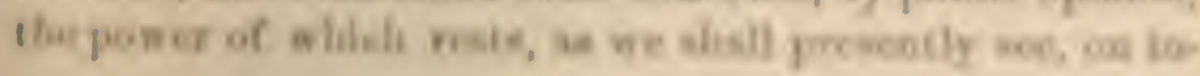

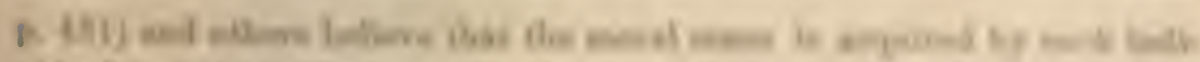

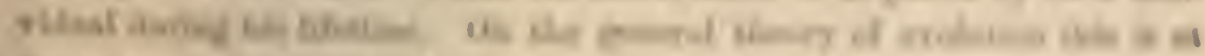

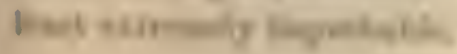


stinctive sympathy. Tastly, habit in the individual would ultimately play a very important part in gruiding the conduct of each nember; for the social instincts and impulses, like all other instincts, would be greatly strengtlened by habit, as would obedience to the wishes and judgment of the community. These several subordinate propositions must now be discussed; and some of them at considerable length.

It may be well first to premise that I do not wish to maintain that any strictly social animal, if its intellectual faculties were to become as active and as highly developed as in man, would acquire exactly the same moral sense as ours. In the same manner as various animals have some sense of beauty, though they admire widely different objects, so they might have a sense of right and wrong, though led by it to follow widely different lines of conduct. If, for instance, to take an extreme case, men were reared under precisely the same conditions as hivebees, there can hardly be a donbt that our ummarried fe males wonld, like the worker-bees, think it a saered duty to kill their brothers, and mothers would strive to kill their fortile daughters; and no one would think of interfering. - Nevertheless the bee, or any other social animal, would in our supposed case gain, as it appears to me, some feeling of right and wrong, or a conscience. For each individual would have an inward sense of possessing certain stronger or more endnring instincts, and others less strong or enduring; so that there wonld often be a struggle which impulse should be followed; and satisfaction or dissatisfaction would be felt, as past impressions were compared during their incessant passage through the mind. In this case an inward monitor would tell the animal that it would have been better to have followed the one inpulse rather than the other. The oue course ought to have been followed: the one would have been right 


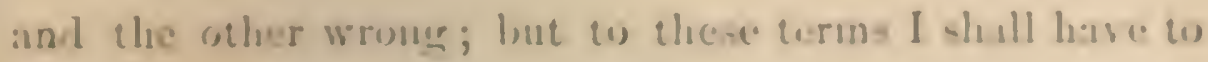
recur.

Socinbility- Amimals of many kimols are surial; we fiml cven distuct specics living together, as with sume

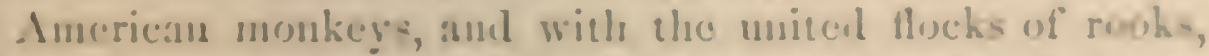
jackdaws, and starliugs. Mau flows tho same focling in his stroug love for the don, which the dog returns with

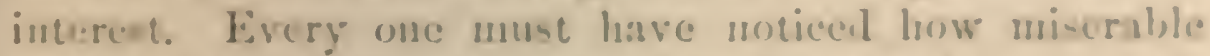
hortes, dogs, theep', etc., are when soparated frum their companions; and what affection at least the two formor

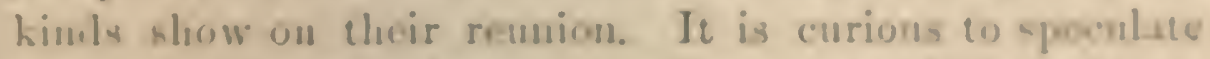

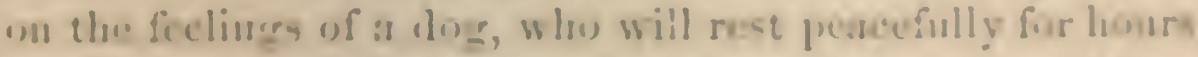
in a ronm with his maser or amg of tho fumily, withome the leass notice being tasken of him; lus, if lufi fur a s lurt timd ly himself, barks or howls dismally. 11 e will comfine our atcution to the highor social animale, excluliug imsecte, although these abl each other in num! important wagk. J'se mane commons service which the ligher animals porform for encli othor, is the warming evele other of lamger by mesus of the moited semses uf all. liotry

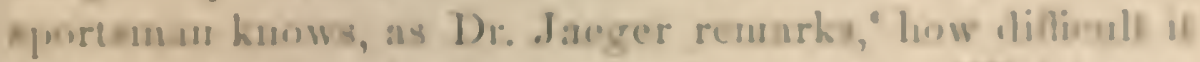

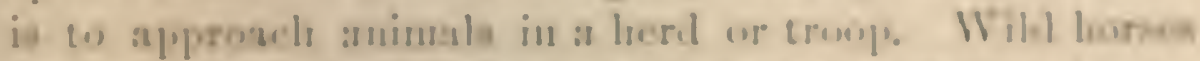

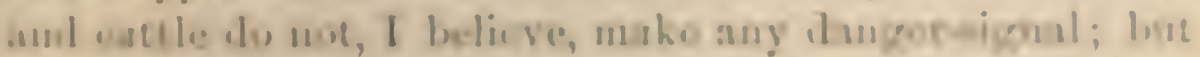

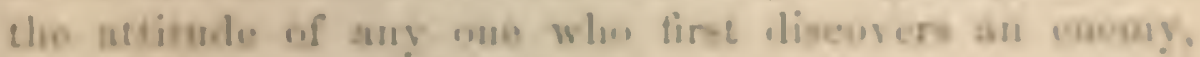

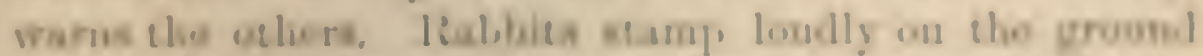

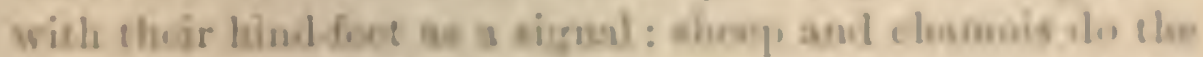

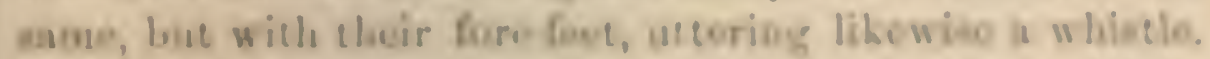

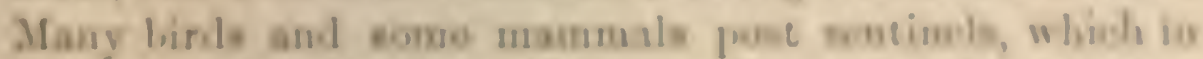

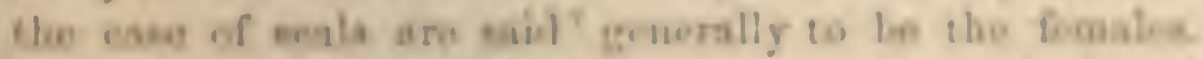

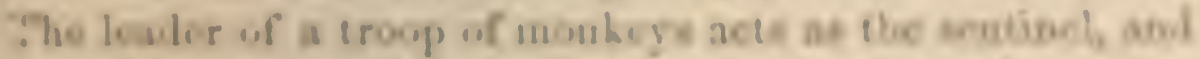

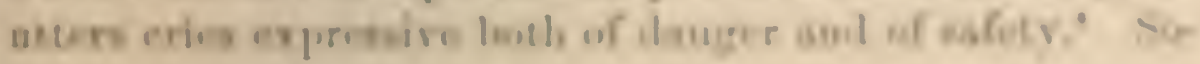

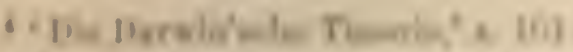

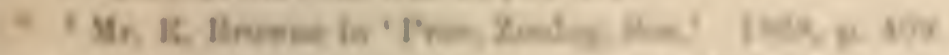

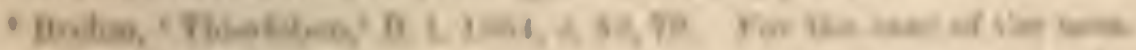

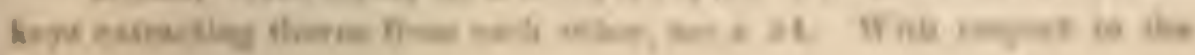


cial animals perform many little services for each other: horices nibble, and rows lick each other, on any spot which itches: monkeys seareh for cach other's catcrual parasites; and Brolun states that, after a troop of the Cercupithecus arisco-viridis has rushed through a thorny brake, each monkey stretches itsclf on a branch, and another monkey sitting by "conscientionsly" examines its fur and catracts erery thorn or burr.

Auimals also render more important services to cach other: thus wolves and some other beasts of prey lunt in packs, and aid each other in attacking their victims. Pelicans fish in concert. The IImatryas baboons turu over stones to find insects, cte.; and when they conne to a large one, as many as can stand romud, turn it over togrether aud share the booty. Social animals mutually defend each other. 'The males of smme ruminants come to the front when there is langer and defent the herd with their horns. I shall also in a futmre chapter give cases of two young will-bulls attacking an old one in concert, and of two stallions together trying to drive away a third stallion from a troop of mares. Frohn encomtered in Alyssinia a great troop of baboons which were crossing a valley: some hal alrendy ascended the opposite momtain, and some were still in the valley: the latter were attacked by the dogs, but the old males immediately lnurica down from the rocks, and with mouths widely openced roared so fearfully, that the dogs precipitately retreated. They were again encouraged to the attack; but by this time all the baboons had reascended the lieights, excepting a young one, abont six months old, who, londly callin, tor aid, climbed on a block of rock aud was surrounded.

IIanadryas turning orer stones, the fact is given $(\$ .76)$ on the evidenco of Alvarez, whose obervations Brehn thinks quite trustworthy. For thi cases of the ohi male babouns attuking the dons, see 8.79 ; and, with re. spect to the eaghi, s. nit. 
Now onr of the largest unales, a tne hero, came dowa again from the mumsain, sow!y west to the yousg one,

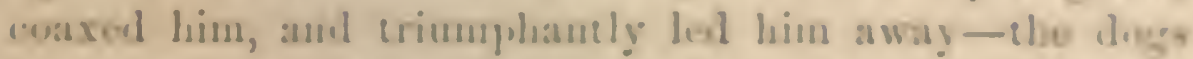
bing ton much astonishel to mahe an attach. I camot reiet giring another secuc which was witnened lig this sume unturalist; au ragle seizod a poung Circopithecus, which, by clinging (n) a l,ranch, was not at onee carriod ofl; it crind luwlly for seivases, upon which the otlice

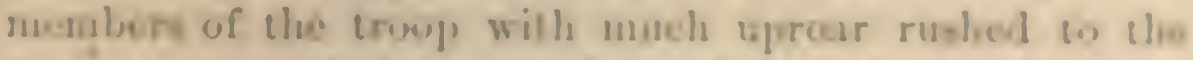
reseuc, surcotmded the agle, and pollod out so many featherk, that he wio lenger eliongle of his prory, but onty low to ecopo. 'This eagle, as Jirclim remarke, aesureally would neser again attoek a monhry in a troop.

It is certain that askociated accisuals buse a foeling ut

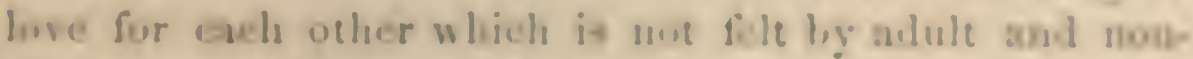

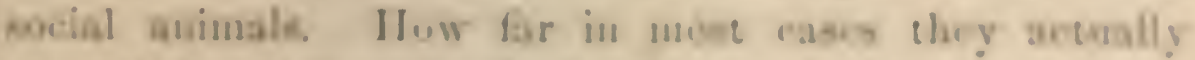
sympthise wille carls other's pains and pleasures is more

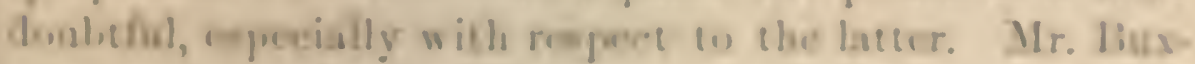

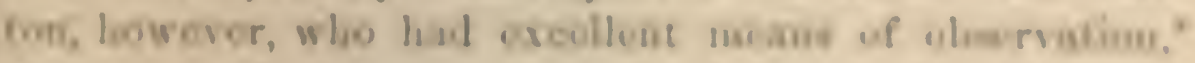
stafen that his nuesws, which lived ino in Norfolk, took

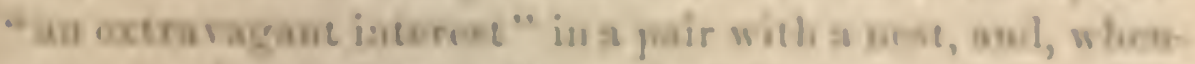
evor the femsle loft it, the wan umronuded bs a troop

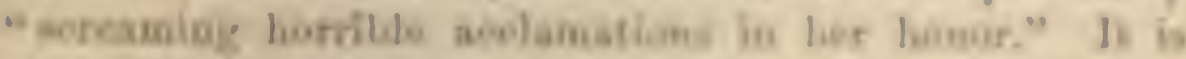

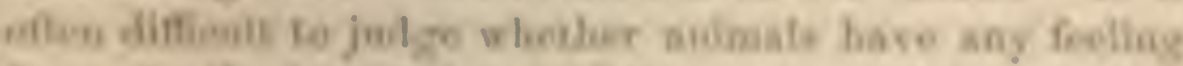

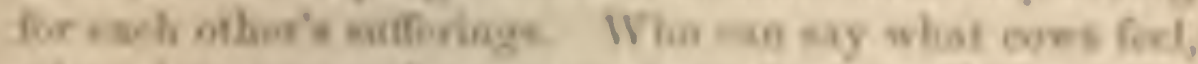

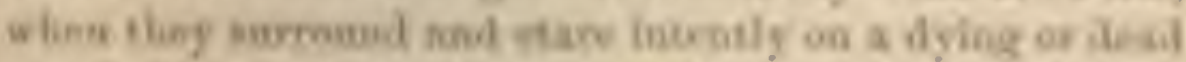

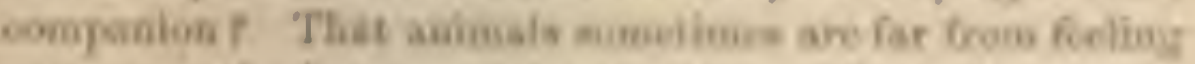

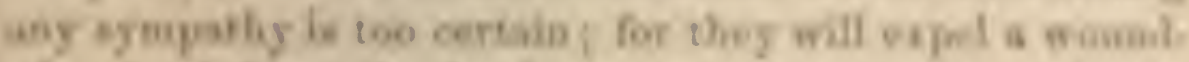
ef animal frein the bewl, of gore in worey it to doatb. Whe fe stmost the blanket fact in materal bistory, saless

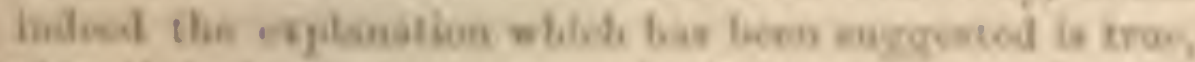

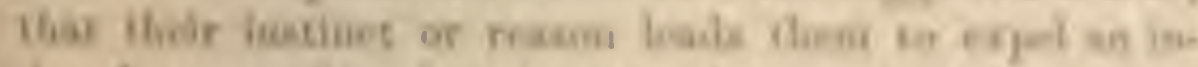

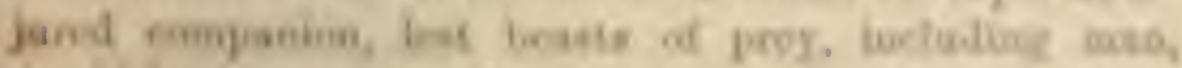

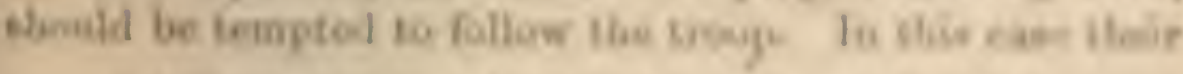


conduct is not much worse than that of the North American Indians who leave their feeble comrades to perish on the plains, or the Feegeans, who, when their parents get old or fall ill, bury them alive. ${ }^{10}$

Many animals, however, certainly sympathize with each other's distress or danger. 'This is the case even with birds; Captain Stansbury ${ }^{11}$ found, on a salt lake in Utah, an old and completely blind pelican, which was very fiat, and must have been long and well fed by his companions. Mr. Blyth, as he informs me, saw Indian crows feccling two or three of their companions which were blind; and I have heard of an amalogous case with the domestic cock. We may, if we choose, call these actions instinctive; but such cases are much too rare for the development of any special instinct. ${ }^{12}$ I have myself seen a dog, who nerer passed a great friend of his, a cat which lay sick in a basket, without giving her a few licks with his tongue, the surest sign of lind feeling in a dog.

It must be called sympathy that leads a conrageous dog to fly at any one who strikes his master, as lie certininly will. I saw a person pretending to beat a ladly who hatd a very timid little dog on her lap, and the trial had never before been made. The little creature instantly jumped away, but, after the pretended beating was over, it was really pathetic to see how perseveringly he tried to lick his mistress's fice and comfort her. Brelmm ${ }^{13}$ states that when a baboon in confinement was pursued to be

10 Sir J. Lubbock, 'Prehistoric Times,' $2 \mathrm{~d}$ edit. p. 416.

11 Is quoted by Mr. I. I. Morgan, 'The American Beaver,' 1868, p. 272. Captain Stansbury also gives an interesting account of the manmer in which a rery young pelican, carried away by a strong stream, was guided and encouraged in its attempts to reach the shore by half a dozen old birds.

12 As Mr. Bain states, "effective aid to a sufferer springs from sym. pathy proper:" 'Mental and Moral Scicuce,' 1868, p. 21..

13 'Thicrlebcn,' 13. i. s. 85. 
puni-lied, the others tried to protect him. It must hare becor syupathy in the cases ahore given which led the baboons and Cercopitheci to defend their young conrmles from the dogs and the cagle. I will give only one other instance of sympathetic and heroic conduct in a little Anerican monkey. Several years ago a kecper at the Zoological Gardens, showed me some deep and scarecly lusulcul wounds on the nape of his nect, inflicterl on him while kuecling on the floor ly a fieree baboon. The litule Ancriean moukey, who was a warm friend of this hecper, lived iu the same larege compartment, and was lreadfully afraid of the great babonn. Nerertlucles, as som as he taw his friend the berper in peril, he rushed to the resene, and by screams and bites so distracted the baboeu that the man was able to cospe, after rmming great risk, as the surgeon who attended him thonght, of his life.

Besillos love and sympathy, animals exhilit other yual. itice which in us would be called moral; and I agrece with Agraseiz" tliat dogs posaess sumcthing rerg like a cen-

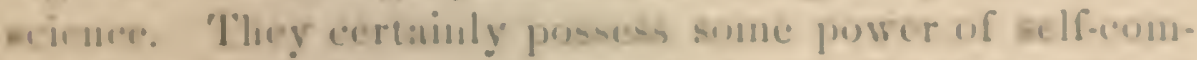
innd, and this does not appear to be wholly the rosult of

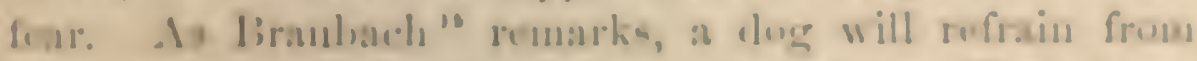

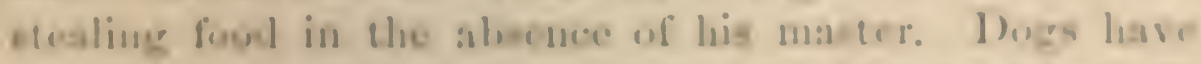

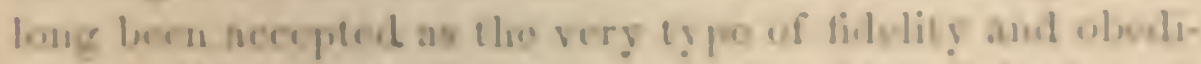
uner. All animala living un a body which defeod cach wher or futuck the ir monies in ouncert, minte be in soms

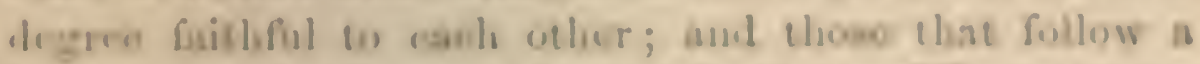

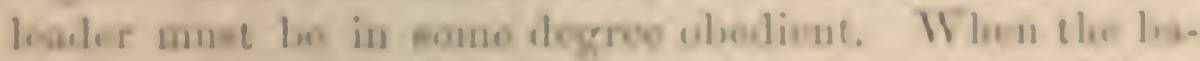

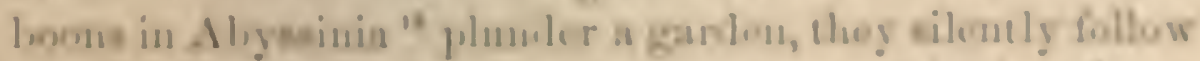
thir levler; and if an impruelent poung tuimsl makes a

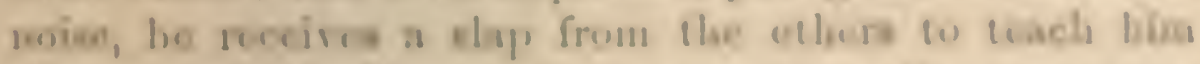

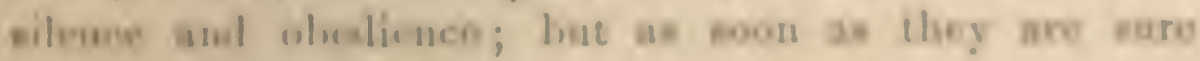

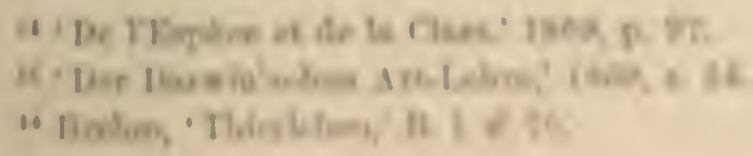


that there is no danger, all show their joy hy much el:unor.

With respect to the impulse which leads certain animals to associate together, and to aid each other in many ways, we may infer that in most cases they aro impelled by the same sense of satisfaction or pleasure which they experience in performing other instinctive actions; or by the sane sense of dissatisfiction, as in other cases of prevonted instinctive actions. We see this in innmerable instances, and it is illustrated in.as striking manner by the acquired instinets of our domesticated minals; thus a young shepherd-dog delights in driving and running round at flock of shcep, but not in worrying them; a young foxhomd delights in lnuting a fox, while some other kinds of dogrs, as I have witnessed, utterly disregard foxes. What a strong feeling of inward satistaction must impel a bird, so full of activity, to brood day after day orer her egrgs! Migratury birds are miserable if prevented from migrating, and perhaps they enjoy starting on their longr flight. Some few instincts are detemined solely by painful feelings, as by fear, which leats to self-prescrvation, or is specially directed against certain enemies. No one, I presume, can analyze the sensatious of pleasure or pain. In many cases, however, it is probable that instincts are persistently followed from the mere foree of inlseritauce, without the stimulus of either pleasnre or pain. A young pointer when it first scents gane, apparently cammot help pointing A squirrel in a eage who pats the muts which it camnot cat, as if to bury them in the ground, can liarlly be thought to act thus either from pleasure or pain. Hence the common assimption that men mist be impelled to erery action by expericncing some pleasure or fain may be erroncous. Although a labit may be blindly and implicitly followed, independently of any pleasure or pain felt at the moment, yet if it be forcibly and abruptly checked, a ragne 
sense of disesti-faction is entuc rally experienced; and this is especially irue in regard (1) permous of fecble intedlect.

It lass often bern asenmed that animale were in the linst place reudered social, and that they fest as a conse. quence uscomfortable when scparated from each uther, aud comfurtable while together; hut it is a more probable view that these neusations were first eveloped, in oriler that thuse animes whieh would protic by living in som

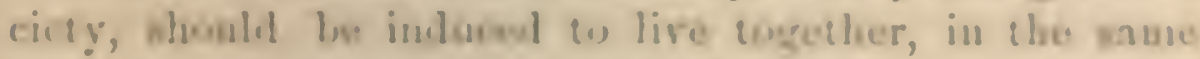
masuer as tlie nowo of liunger and the pleasure of eating

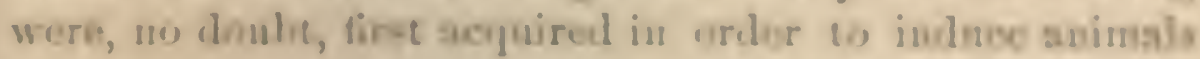
to ens. The foeling of pleamore from noviots is yrobably au ealcu-iou of the pareutal or filial aficctions; ama this

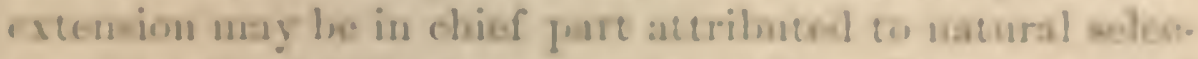
sion, lut porhapo in part to mere babit. Jor with thoso

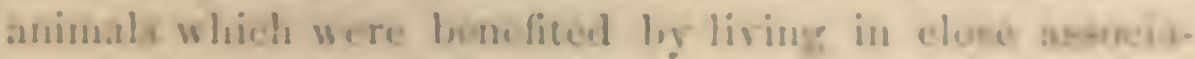
tion, the indiridulg which took the greatent ploascere in

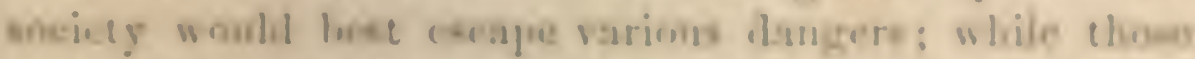

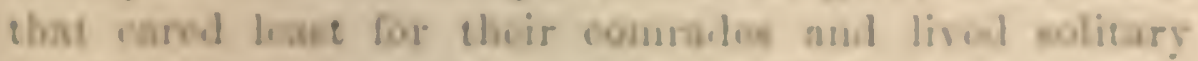

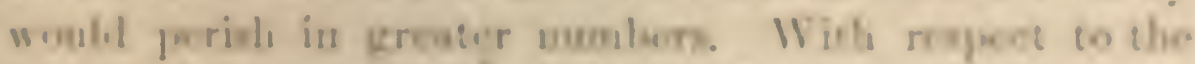
origin of the parental and filial aflection, whirls spyar. ently list at the hosis of the hooial affincions, it is bopolas

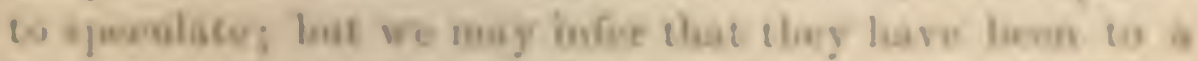

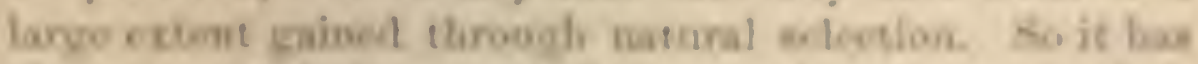

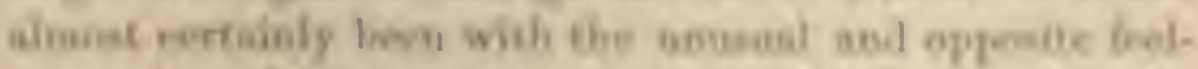
ine of lisurod bolerewe the niahat rolatloms, an with the

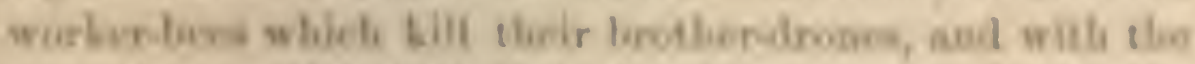

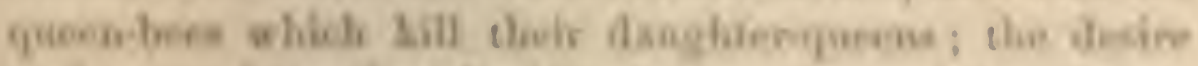
to deserey, ibstead of loving, theie meares rutatioos hor-

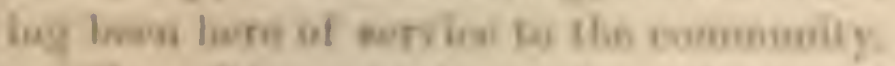

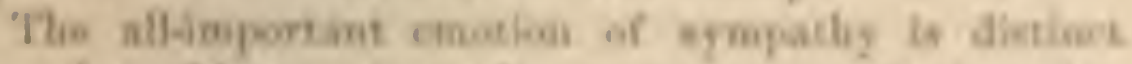

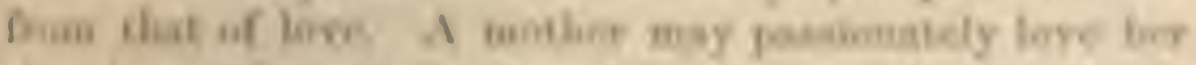

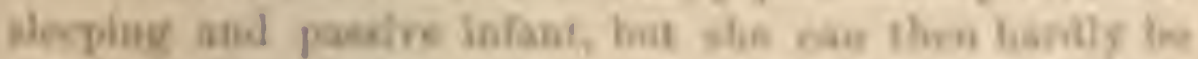

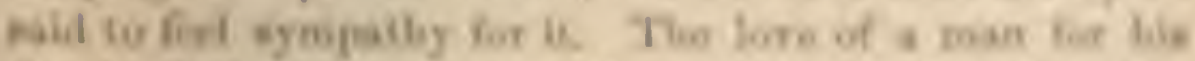

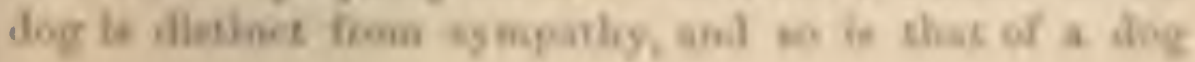


for his master. Adam Smith formerly argued, as has Mr. Bain recently, that the basis of sympathy lies in our strong retentireness of former states of pain or pleasure. Hence, "the sight of another person cnduring hunger, cold, fatigne, revives in us some recollection of these states, which are painful eren in idea." We are thus inpelled to relieve the sufferings of another, in order that our own painful feelings may be at the same time relieved. In like mamner we are led to participate in the pleasures of others. ${ }^{17}$ But I cannot see how this view explains the filct that sympathy is excited in an immeasurably stronger decree lyy a beloved than by an indiflerent person. The mere sight of suffering, independently of love, would suffice to call up in us vivid recollections and associations. Sympathy may at first have originated in the manner above suggested; but it secms now to have become an instinct, which is especially directed toward belored objects, in the sane manner as fear with animals is especially directed against certain enemies. As sympathy is thus directed, the mutnal love of the members of the same community will extend its linits. No doubt a tiger or lion fecls sympathy for the sufferings of its own young, but not for any other animal. With strietly social animals the fecling will be more or less extended to all the associated members, as we know to be the ease. With mankind sclfishness, experience, and imitation, probably atd, as Mr. Bain has slown, to the power of sympathy;

1: Sece the first and striking chapter in Adan Smith's 'Theory of Moral Sentiments.' Also Mr. Bain's 'Mcntal and Moral Science,' 1 S68, p. 211, and 275-282. Mr. Main states that "sympathy is, indirectly, a source of pleasure to the sympathizer ;" and he accounts for this through reciprocity. IIe remarks that "the person benefited, or others in his stead, may make up, by sympathy and good oflices returned, for all the facrifice." But if, as appears to le the case, synpathy is strictly an instinet, ita cxcrcise wonld give direct pleasure, in the same manuer as the exercise, as before renarked, of alno-t erery other inetinct. 
Lim we are led by the lope of receiring gonl in resurn w, perfiorm acts of sympathetie kinduces to othere; and thero can le no dould that the feeling of sympathy is maeh berengthenced ly habit. In however complex a mannor this fecling may hare originated, as it if one of hiels im. portance to all those animals which aid and defend weth wher, it will have been incrcased, through natural seleetion; for those communities which ineluded the greates umuler of the unot smupatheria zumbers, would flowrish bot and fear the greatest utumler of ofty yritg.

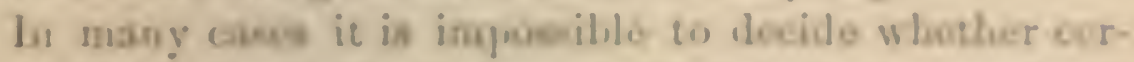
tain social iustince hore beon arynired throngh astars

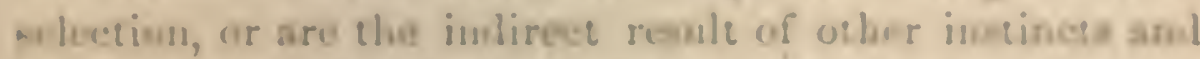

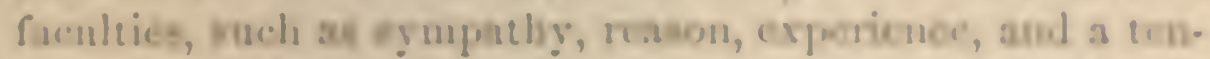
then 10 infitation; or agaill, whether thes are sinply the monlt of long-eomimed balit. So romarkable an instue

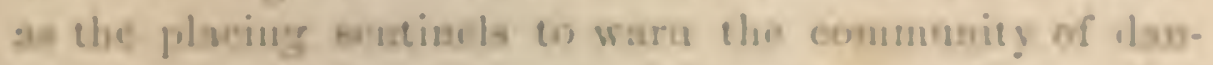
ger, eus bon!ly liave Inson the indiroce resale of ang ether

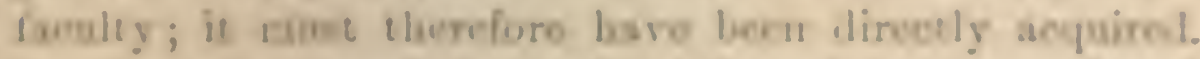

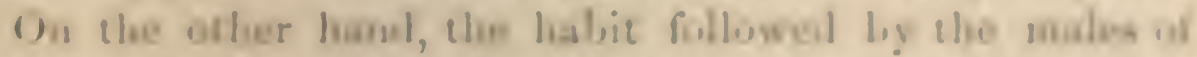
notue eocial strimale, of dofonding the commanity and of altapking thic enewios or their prey in cumens, way per

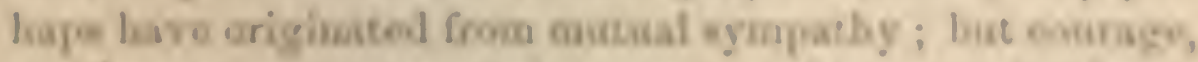

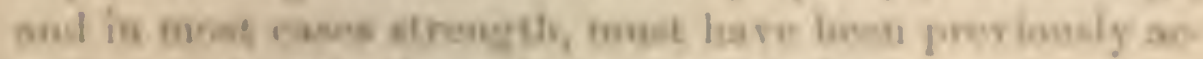
quico-l, probably through naturat aclescion.

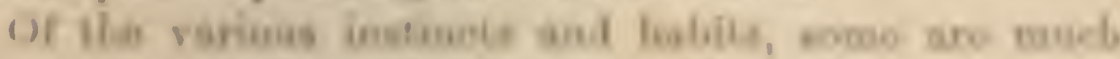

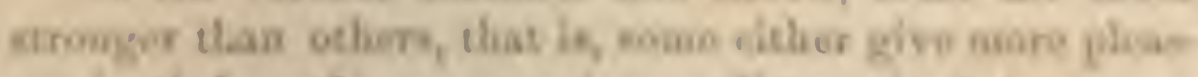

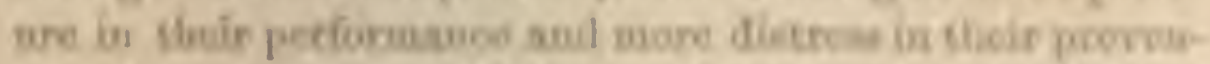

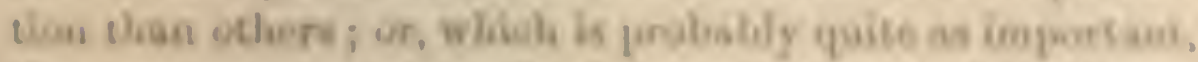

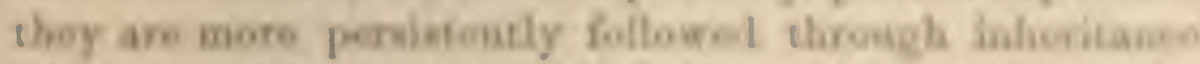

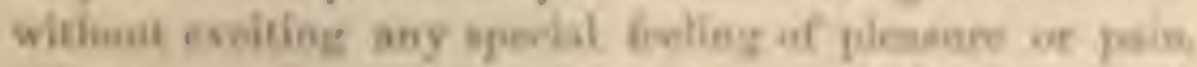

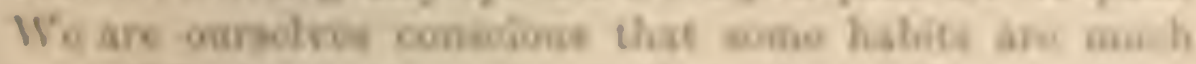

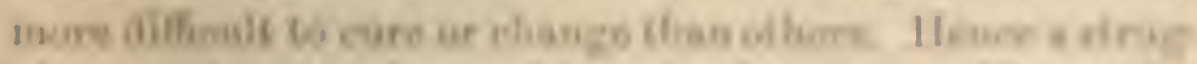

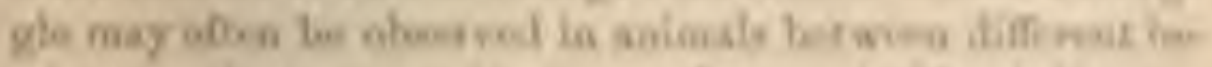

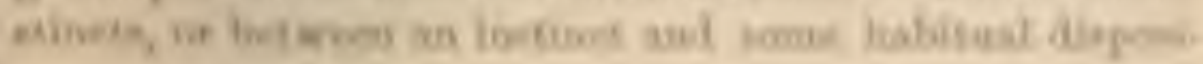


tion; as when a dog rushes after a hare, is rebuked, pauses, hesitates, pursues agrain or returus ashamed to his master; or as between the love of a female dog for her young puppies and for her master, for she may be secn to slink away to them, as if half ashamed of not accompanying her master. But the most curious instance known to me of one instinct conquering another, is the migratory instinct conquering the maternal instinct. The former is wonderfully strong; a confined bird will at the proper season beat her breast against the wires of her cage, until it is bare and bloody. It causes young salmon to leap out of the fresh water, where they could still continue to live, and thus unintentionally to commit suicide. Every one knows how strong the maternal instinct is, leading even timid birds to face great danger, though with hesitation and in opposition to the instinct of self-preservation. Nevertheless the migratory instinct is so powerful that late in the autumn swallows and house-martins frequently desert their tender young, leaving them to perish miserably in their nests. ${ }^{18}$

Tre can perceive that an instinctive impulse, if it be in any way more beneficial to a species than some other or opposed instinct, would be rendered the more potent of the two through natural selection; for the individuals which had it most strongly developed would survire in

18 This fact, the Rev. L. Jenyus states (see his edition of 'White's Nat. IIst. of Selborne,' 1853, p. 201) was first recorded by the illustrious Jenner, in 'I'hil. Transact.' 1821, and has sinec been confirmed by scveral observers, especially by Mr. Blackwall. This latter eareful observer cxamined, late in the autumn, during two years, thirty-six nests; he found that twelre contained young dead birds, five contained eggs on the point of being hatehed, and three eggs not nearly hatehed. Many birds not yet old enough for a prolonged flight are likewise deserted and left behind. Sec Blackwall, 'Researehes in Zoology', 1834, pp. 108, 118. For some additional eridenec, although this is not wauted, see Leroy, 'Irettres Phil.' 1502, p. 217. 
larerer numbers. Whether this is the ease with the migratory in comparison with the maternal instinct, may well be doubted. 'Tlie great persistence or stcaly action of the former at certain seasons of the ycar during the whole disy, may gire it for a time paramount force.

Mran a sociul animal.-Most persons alnit that man is a social being. We see this in his dislike of solitude, and in his wish for socicty beyond that of his own fimily. Sulitary confinement is one of the severest pumshments which ean be inflicter. Some authors suppose that man primevally lived in single families; but at the present disy, though single fumilies, or only two or three togrether, ro:m the solitudes of some savage linds, they are always, as far as I can discover, friendly with other funilics inhabiting the same district. Such families oocasionally mect in council, and they unite for their common defence. It is morgment against savage man being a social animal, llat the tribes inhabiting aljacent distriots are almost always at war with cach other; for the social inAlincts never extend to all the imlividuals of the same suncies. Jutlging from the analogy of the greater mumlere of the Quadrumana, it is probible that the early apelike progenitors of man were lihew ise social; but this is not of nuch importance for us. Although man, as he now arists. has few special instincts, having luat any which his early progenitors mag hase possosocul, this is no reison why he slionld not hate retained from an estremeIy remote period fome degree of instinctive lore and sympathy for his follows. We sure indeed all conscions that

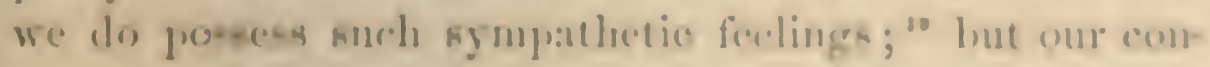

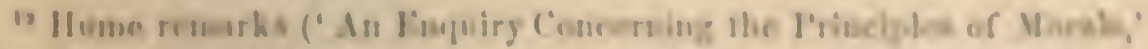

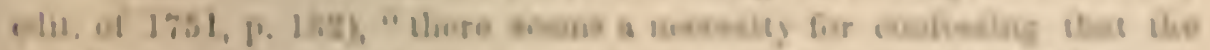

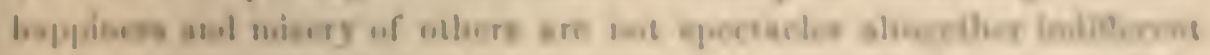

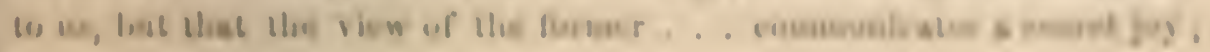


sciousness does not tell us whether they are instinctive, having originated long ago in the same manner as with the lower animals, or whether they have been acquired by each of us during our early years. As man is a social animal, it is also probable that he would inherit a tendency to be faithful to his comrades, for this quality is common to most social animals. He would in like manner possess some capacity for self-command, and perhaps of obedience to the leader of the community. He would from an inherited tendency still be willing to defend, in concert with others, his fellow-men, and would be ready to aid them in any way which did not too greatly interfere with his own welfare or his own strong desires.

The social animals which stand at the bottom of the scale are guided almost exclusively, and those which stand higher in the scale are largely guided, in the aid which they give to the members of the same community, by special instincts; but they are likewise in part impelled by mutual lore and sympathy, assisted appareutly by some amount of reason. Although man, as just remarked, has no special instincts to tell him how to aid his fellowmen, he still has the impulse, and with his improved intellectual fuculties would uaturally be much guided in this respect by reason and experience. Instinctive sympathy would, also, cause him to value highly the approbation of his fellow-men; for, as Mr. Bain has clearly shown, ${ }^{20}$ the love of praise and the strong fecling of glory, and the still stronger horror of scorn and infamy, "are due to the workings of sympathy." Consequently man would be greatly influenced by the wishes, approbation, and blame of his fellow-men, as expressed by their gestures and language. Thus the social iustincts, which must have been

the appearance of the latter . . throws a melancholy damf, orer the imaurination."

20 'Mental and Mor:l Science,' 1868, p. 254. 
acquirced by man in a very rude state, and probal,ly even by his early ape-like progenitors, still grive the impulse tu many of his best actions; but his actions are langely dutermined by the expressed wishes and judgunent of lis fellow-men, and unfortunatcly still oftence hy his own strong, selfish desires. Iiut as the feclings of love and symplathy and the power of sclf-eommand become strengtlcned by habit, and as the power of reasoning becomes clearer so tlat man can appreciate the justice of the judgncents of his fellow-men, he will fied himsclf impelled, indepemlently of any pleasure or pain folt at the moment, fo rentin lines of conluct. He may then say, I am the supremc juilge of my own conduct, mot, in the worils of liant, I will not in my own lectson violate the dignity of lummanity.

The more culning Social Instincts congune the less Persistent Jnstincts.-We have, howerer, not as yet contmidered the main point, on which the whole quention of the moral sense hingres. Why should a matu feed that he onehthe to olug one instinctive desire rather than amother? Why does he bitferly regret it he has gielded to the stronger

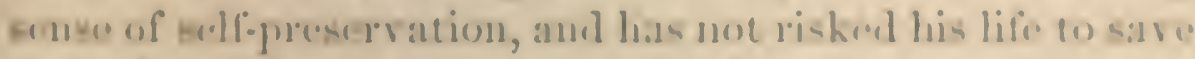
llat of a fellow-reature; or why dere he reoret having neolen food from severe homger?

It is evileut in the lime place, thut with manhind the

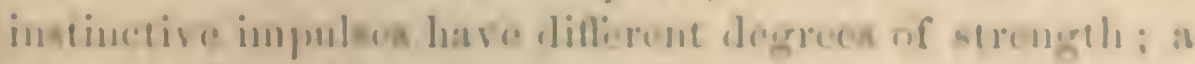
young and timid mothe ureed ly the matornal iuntiuct will, wilhout a momout's heritation, loun the greatest dan.

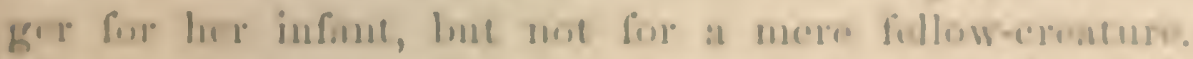

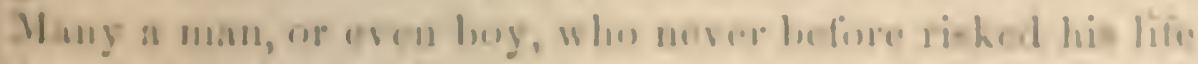

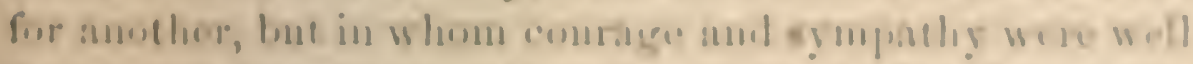

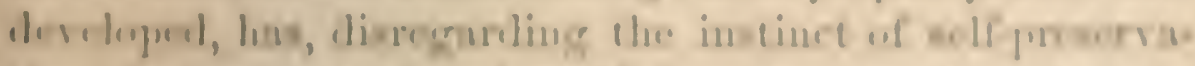

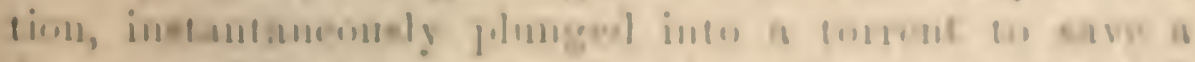

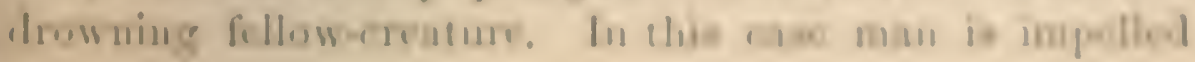


by the same instinctive motive, which canscel the lorroic little American monkey, formerly described, to attack tho great and dreaded baboon, to save his keeper. Such actions as the above appear to be the simple result of the greater strength of the social or maternal instincts tham of any other instinct or motive; for they are performed too instantaneously for reflection, or for the sensation of pleasure or pain ; though if prevented distress would be caticed.

I am aware that some persons maintain that actions perfurmed impulsively, as in the above cases, do not come under the deminion of the moral sense, and camnot be (alled moral. They confine this term to actions done delibcratcly, after a victory over opposing desires, or to actions prompted by some lofty motive. But it appears scarcely possible to draw any clear line of distinction of this kind; though the distinction may be real. As far as exalted motives are concerned, many instances have been recorded of barbarians, destitute of any fecling of general benevolence toward mankind, and not gruided by any religrious motive, who have deliberately as prisoners sacrifiecel their lives, ${ }^{21}$ rather than betray their comrades; and surcly their conduct ought to be considered as moral. $\Lambda$ s far as deliberation and the victory over opposing motives are concerned, animals may be seen doubting between opposed instincts, as in rescuing their offspring or comrades from danger; yet their actions, though done for the good of others, are not ealled moral. Moreover, an action repeatedly performed by us, will at last be done without deliberation or lesitation, and can then hardly be distinguished from an instinct; yet surely no one will pretend that an action thus done ceases to be moral. On the con-

21 I hate giren one such case, nanchy, of three Patagonian Indiaus who preferred being shot, one after the other, to betraying the plaus of their companions in war ('Journal of lesearelese', 1815, P. 103). 
irary, we all fect that an act counot he considerel as pro fen.t, or as performed in the most noble manuer, unlese is be donc impulsively, without deliberntion or eftort, in the same maner as by a man in whom the regui-ite qualities are inuate. He who is forced to orereme his fear or waut of sympatly befure he acts, leserves, however, in one way ligher credit than the man whose inuate divposition leads lim to a goos act without effort. Is we cansot istisguish botwen motive, we rank all acioms of a ertaik class as moral, when they ane perfirumed by a sanal helog. A moral lecing it one wbo ia capable of oomparing bis pant and future actions or motives, and of approving or diesp proving of them. We have no roason to suppoes that any uf the lower aninuls have this eapacily; therefore when a noukey facou danger of resowe its comrade, or thes charev of an orplan-moukey, we du sure call is somduce moral. Jiut in the case of man, who aloue can wich or tainty be runked as a moral leine, actions of a cortain - lass are allid moral, whether perfirmad deliberawy afher a struggle with oppowing moeires, or from the efticus

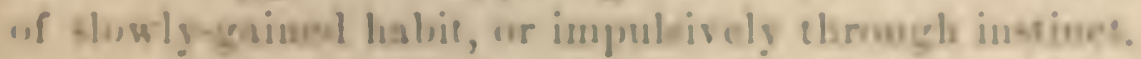

But io rieurn to our more inme-liaw sabject; athongts

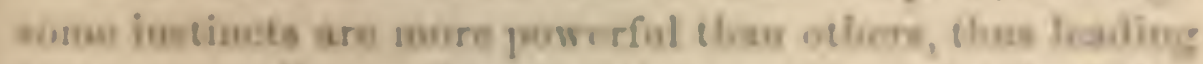

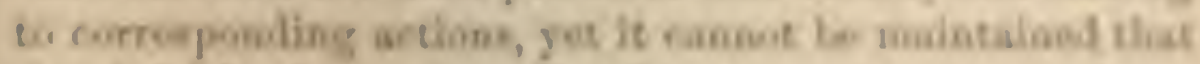

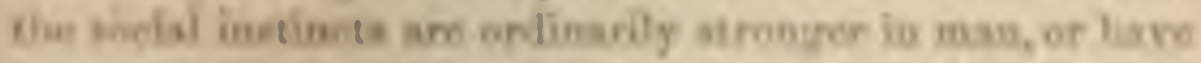

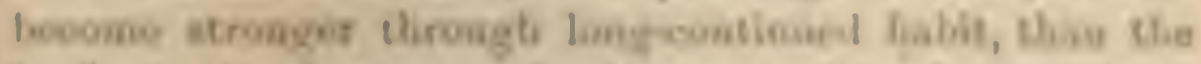

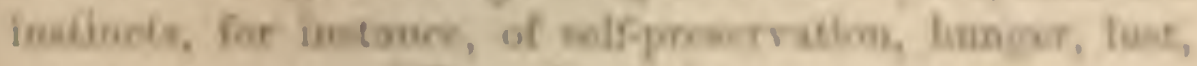

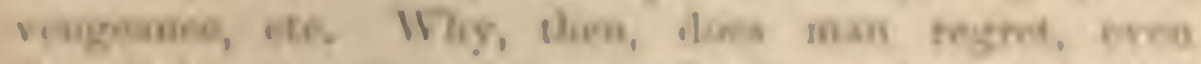

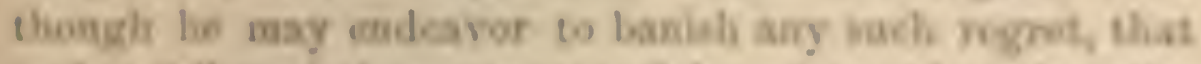

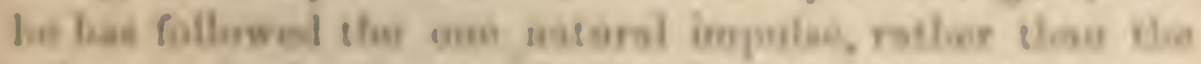

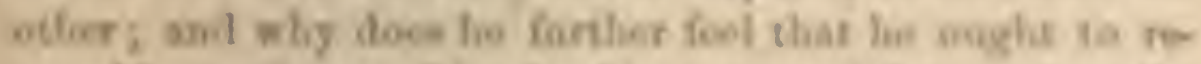

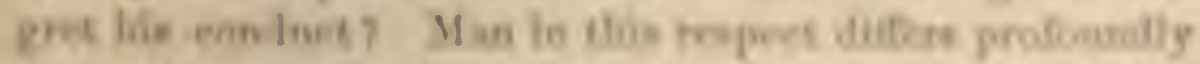

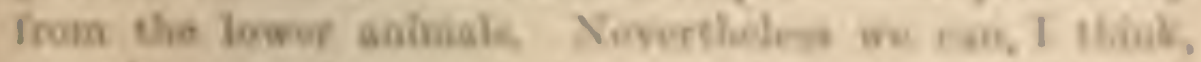

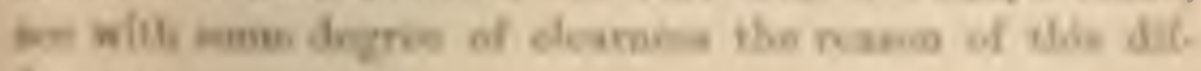
foreme. 
Man, from the activity of his mental faculties, cannot aroid reflection; past inpressions and images are incessantly passing through his mind with distinctness. Now with those animals which live permanently in a body, the social instincts are ever present and persistent. Such animals are always ready to utter the danger-signal, to defend the community, and to give aid to their fellows in accordance with their habits; they feel at all times, without the stimulus of any special passion or desire, some degree of love and sympathy for them; they are mhappy if long separated from them, and always happy to be in their company. So it is with ourselves. A man who possessed no trace of such feclings would be an umnatural monster. On the other liand, the desire to satisfy hunger, or any jassion, such as rengeance, is in its nature temporary, and can for a time be fully satisfici. Nor is it easy, perhaps liardly possible, to eall up with complete vividness the fecling, for instance, of hunger; nor, indeed, as has often been remarked, of any suffiring. 'The instinct of sclf-preservation is not felt except in the presence of danger"; and many a coward has thought himself brave until he has met his enemy face to face. The wish for another man's property is, perlupes, as persistent a desire as any that can be named; but eren in this case the satisfiction of actual possession is generally a weaker fecling than the desire; many a thicf, if not an lubitual one, after sucess has wondered why he stole some article.

Thus, as man camnot prevent old impressions continually repassing through his mind, he will be compelled to compare the weaker impressions of, for instance, past hunger, or of vengemee satisfied or danger avoided at the cost of other men, with the instinet of sympatly and grood. will to his fellows, which is still present, and ever in some degree active in his mind. He will then feel in his imagrnation that a stronger instinct has yickled to one which 
now seme comptratirely weak; aml then thas sease of diesatisfaction will incritably be felt with which man is ondowed, like crery other animal, in orter that his in sinces may be obiged. The case before given, of ste rastlow, atlords an illustation, 2buugh of a reversed naturv, of a cemporary, though for the time strongly gu nietan, intinct confueriug another instinct which in usuall! desainat orer all others. Al the jrivger season these liruls acent all bay lowg to be impresed with the dewire th aigrate; their habits elange; they becume rovine, are

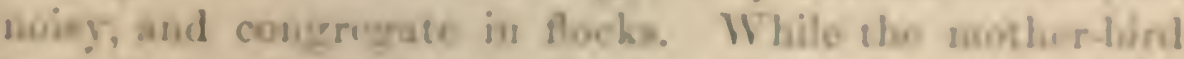
is freding or broodiug orur her motlingk, the mecnal io. stimet is probalily uronger than the migratory; hat the in tince which is more jursinteut gain the vietors, and at last, at a monent whon ler pousg ome are nat in right. she sakes thight and dieers thesu. When srrived at the

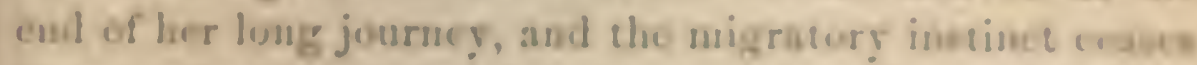

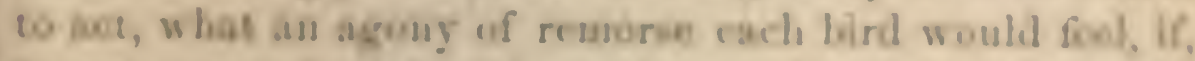

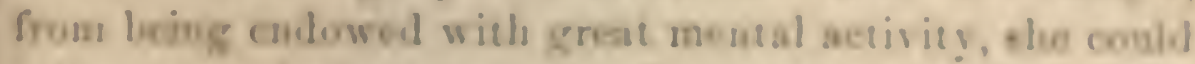

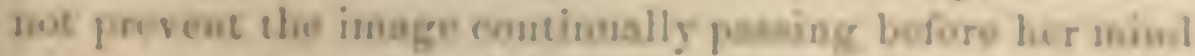
of ler young ones perisling in the hask worth from cold and humger!

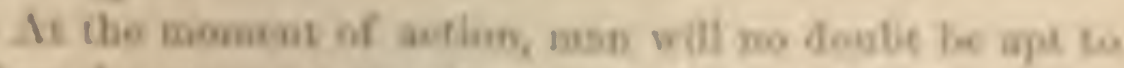

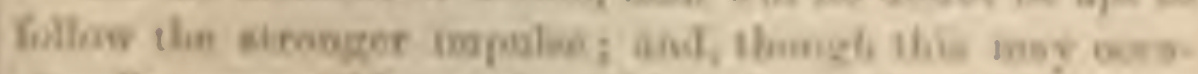

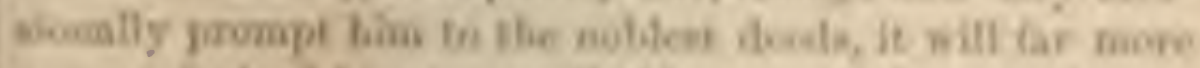

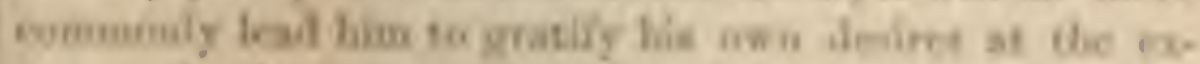

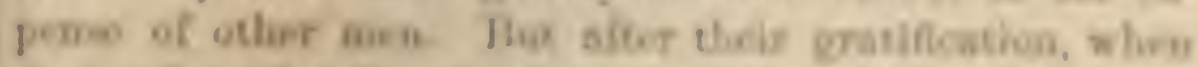

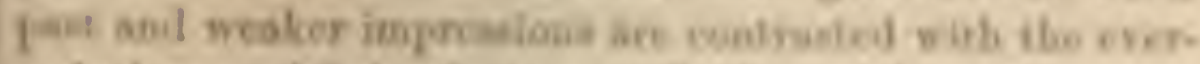

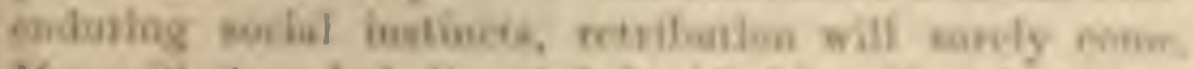

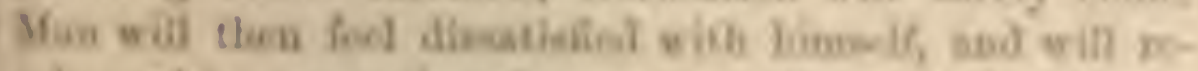

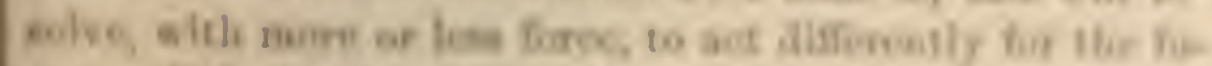

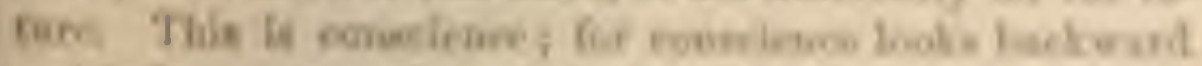

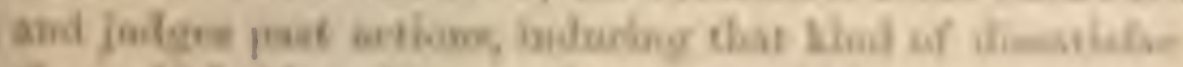

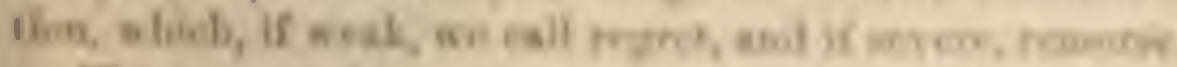

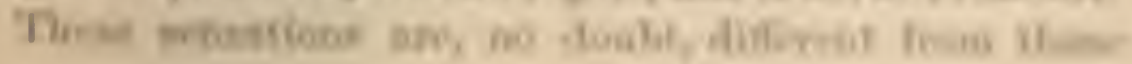


'xperieneed when other instincts or desires are left unsatistied; but every unsatisfied instinct las its own proper prompting sensation, as we recognize with hunger, thirst, ctc. Man thus prompted, will through long habit acquire sucli perfect self-comm:md, that his desires and passions will at last instantly yich to his social sympathies, and there will no longer be a struggle between them. The still humgry, or the still revengeful man will not think of stealing food, or of wreaking his vengeance. It is possible, or, as we shall hereafter see, even probal,le, that the liabit of self-command may, like other habits, be inherited. Thus at last man comes to feel, through acquired, amd, perhaps, inherited habit, that it is best for him to obey his more persistent instincts. The inperious worl ought seems merely to employ the consciousness of the existenco of a persistent iustinct, either innate or partly acquired, serving him as a guide, though liable to be disobeyed. We hardly use the word ought in a metaphorical sense when we sily hounds ought to lumt, pointers to point, and retrievers to retrieve their game. If they fail thus to act, they fail in their duty and act wrongly.

If any desire or instinct, leading to an action opposed to the grood of others, still appears to a man, when recalled to mind, as strong as, or stronger than, his social instinct, le will feel no keen regret at having followed it; lut lie will be conscious that if his conduct were known to his fellows, it would mect with their dis:uprobation; and few are so destitute of syupathy as not to feel discomfort when this is realized. If he has no such sympathy, and if his desires leading to bud actions are at the time strong, and when recalled are not overmastered by the persistent social instincts, then he is essentiully a bitd man; ${ }^{23}$ and the

${ }^{2}$ Dr. Prosper Despine, in his 'P'schologic Naturelle, 1869 ('nm. i. p. 213 ; tom. ii. p. 16?), gives many curious cases of the worst crininals, who apparently have been entirely destitute of conscience. 
Eole restrainiug motive left is the for of pmishuest, and the convietion that in the longrem it woukd be best for lis own soltish interests to regaril the goned of uthers rather than his own.

It is obvious that every one may with an eat! cems. ecience gratify his own desira, if they do not inceriese with his sucial intincts, that is, with the geved of uetuen; but in order to te quite free from elf-reproach, or at leat of auxiety, it is almoet necisary for bim turatoil the disrppoobation, wbether reatonable or not, of lis fellow-moon.

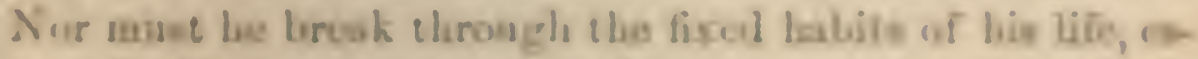

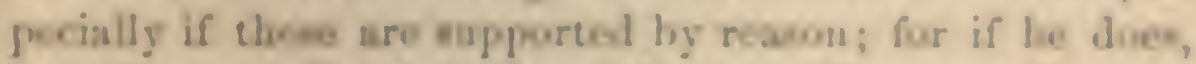

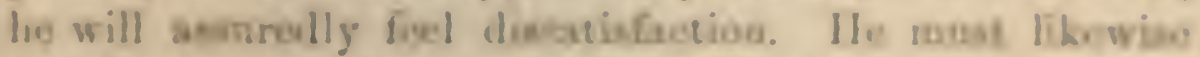
aroid the reprobation of the one God or gonks, in when,

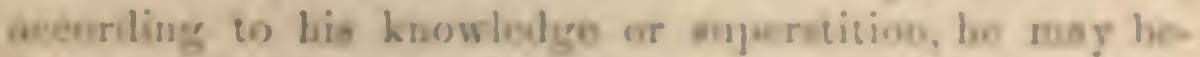
lieve; bat in this cane the alitional for of tis ino punist. weat ofven mperwaes.

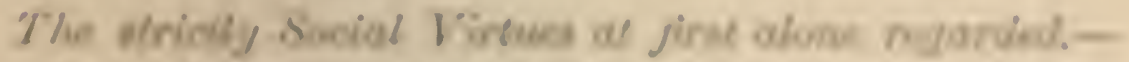
The ahore view of the tirnt grigin aud watore uf the ruiral moin, which telle us wher wo onght $20 \mathrm{do}$, and of the cons.

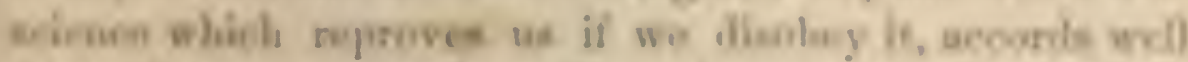

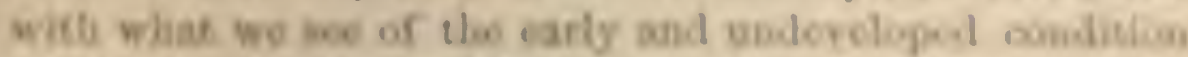

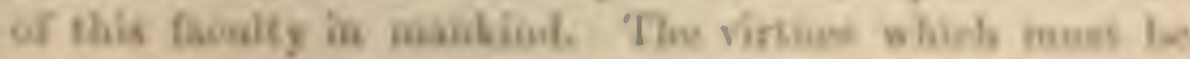

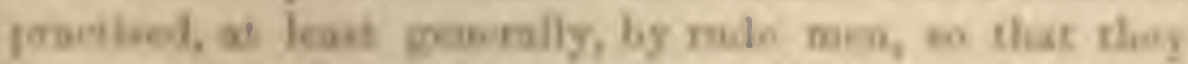

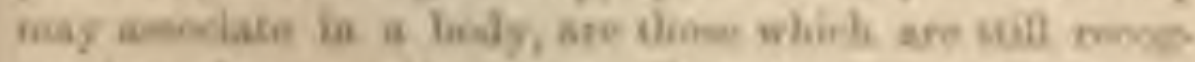

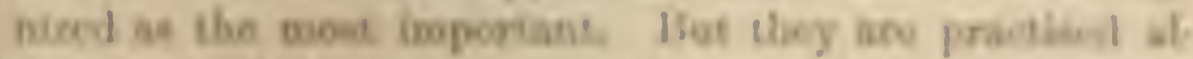

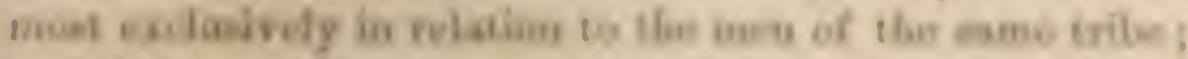

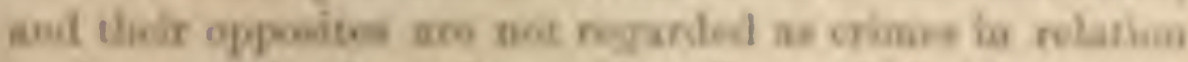

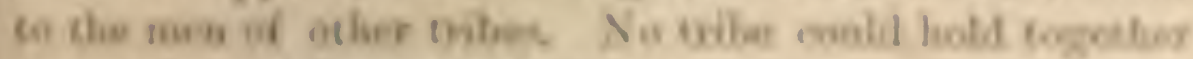

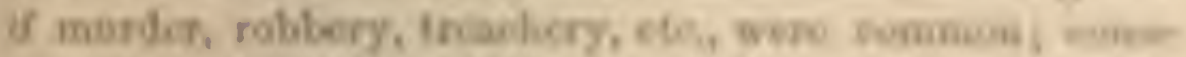

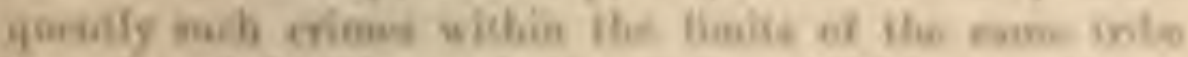

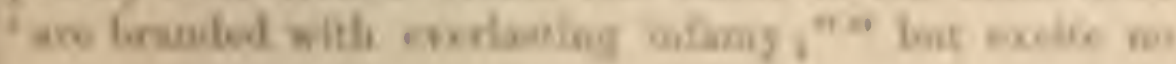

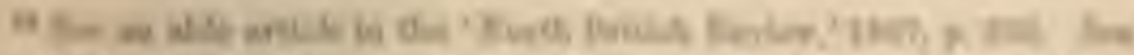

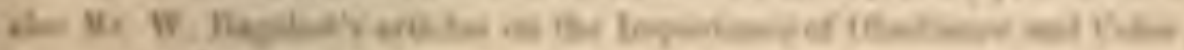
8 
such sentiment beyond these limits. A North-American Indian is well pleased with himeelf, and is honored by others, when he scalps a man of another tribe; and a l)yak. cuts ofl the head of an unoflending person and dries it as a trophy. The murder of infints has prevailed on the largest scale throughout the world, ${ }^{23}$ and has met with no reproach; but infanticide, cepecially of females, las been thought to be good for the tribe, or at least not injurious. Suicide during former times was not generally considered as a crime, ${ }^{23}$ but rather, from the courage displayed, as an honorable act; and it is still largely practised by some semi-civilized nations without reproach, for the loss to a nation of a single individual is not felt; whatever the explanation may be, suicide, as I liear from Sir. J. Lubbock, is rarely practised by the lowest barbarians. It lias been recorded that an Indian Thug conscientiously regretted that he had not strangled and robbed as many travellers as thid his father before him. In a rude state of civilization the robbery of strangers is, indeed, generally considered as honorable.

The great sin of Slavery has becn almo:t miveral, and flaves have often been treated in an infumous manner. $\Lambda$ s butrbarians do not regard the opinion of their women, wives are commonly treated like slaves. Most sarages are utterly indifferent to the sufferings of strangers, or even delight in witnessing them. It is well known that the women and childen of the North-American Indians aided in torturing their cnemies. Some savages take a horrid pleasure

sence to Primitive Man, in the 'Iortnightly lieview,' 1567, p. 529, and 1868, p. $45 \%$, ctc.

2s The fullest account which $I$ have met with is by Dr. Gerland, in lis ' Leber das Aussterben der Naturvïlıcr,' 1565 ; but I slall have to recur to the subject of infanticide in a future cliapter.

${ }^{35}$ See the very interesting discussion on Sulcide in Lccliy's 'Ilistory of Furopcan Ilorals,' rol. i. 1S69, p. 22.3. 
in crueley to anisals," and humanity will them is an cmhuswn rirluce. Nevcrelucles, foelings of sympathy asod hindne, are common, cpeeially during sichnen, beiwou the members of the same tribe, and are anotince erirnded beyoud the linnits of the tribe. Mnngo Park's tomeliung acosunt of the kisulnes of the negros wonen of the interior to him is well kurown. Mang intanoes could lne given of the molde tid. lity of sampes eoward eash other, bat not to firugers; common coporience jusition the masin of the Spaniard, "Nerrs, nerer trast an Indian."

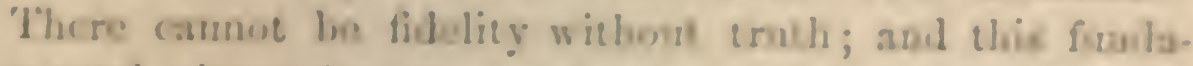
mental virtuc is not rare betwom the menbers of tho eame tribe; tlus Munge Park licard the negro womun teatiug their young chililren les love the truels. This,

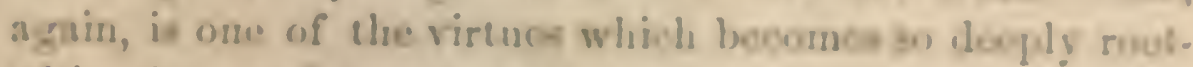
al in the mind that it is sometionot practived ly sovacre. oven at a high out, wward stragers; but to lin w yeur

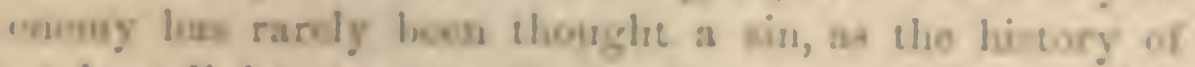
modern difoloma $y$ fon plainly eliow. As hoon as a ińle

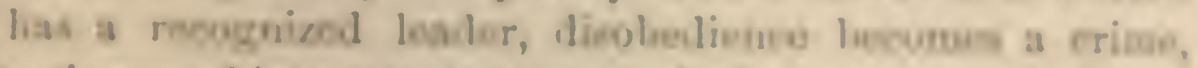

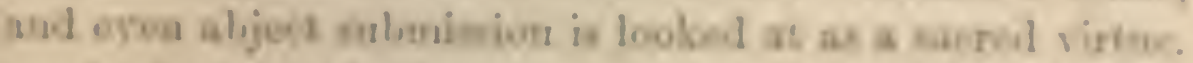

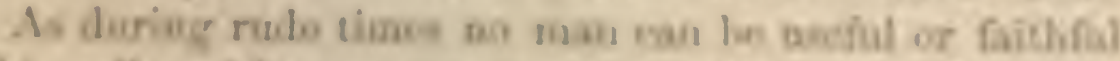

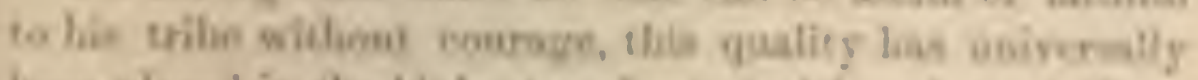

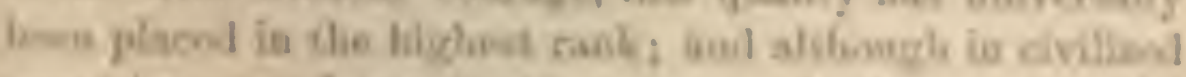

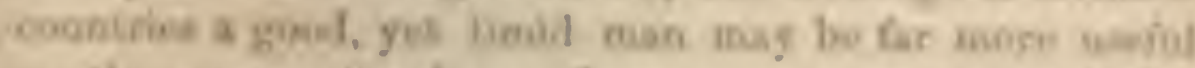

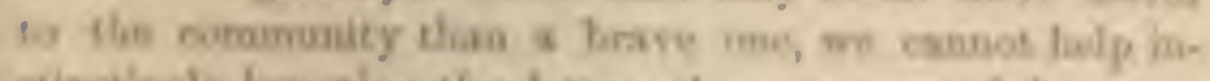

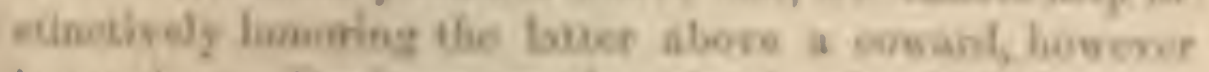

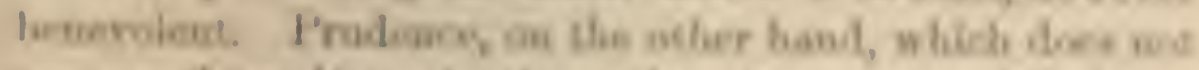

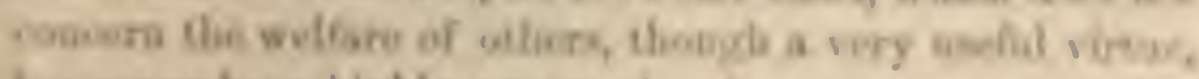

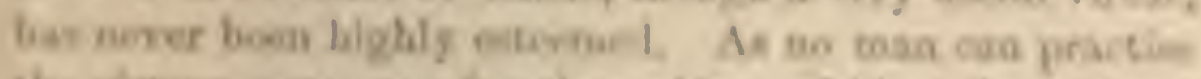

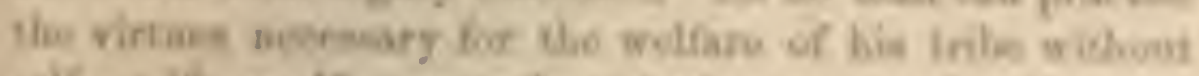

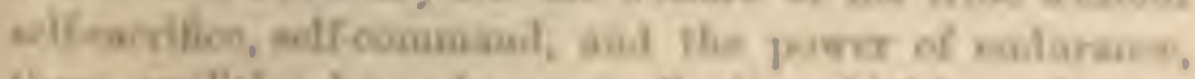

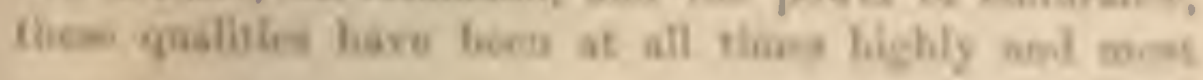

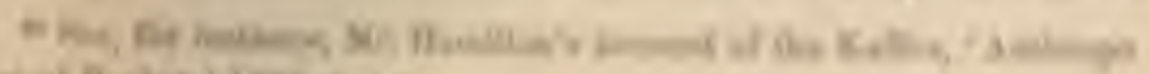

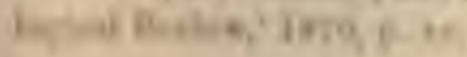


justly valued. 'The Amerienu savage roluntarily submits without a groan to tho most horrid tortures 20 prore and strengthen his fortitude and courage; and we eamot holp admiring him, or even an Indian Fakir, who, from a foolisls religious motive, swings surpended by a hook buried in lis tlesh.

The other self-regarding virture, which do nut obvions. Iy, thongh they may really, aflect the welfare of the tribe, have never been esteemed by sarages, though now highly appreciated by civilized nations. The greatest intemperance with savages is no reproach. Their utter licentiousuess, not to mention unnatural crimes, is something asinmding." As soon, however, as marriage, whether polyganous or monogamous, becomes common, jenlonty will lead to the inculention of female virtue; and this being honored, will tend to Fpreal to the ummarricel fomales. How sowly it spreads to the male sex we see at the prescut day. Chastity cuinenty requires self-command, therefure it has been honored from a very early period in the moral listory of civilized man. As a consequence of this, the sunselesa practice of celibacy has been ranked from a remote periol as a rirtue." The hatred of indecency, which appears to us so natural as to be thonglit imate, :mat which is so valuable an aid in chastity, is a moltern virtue, appertaining exclusively, as Sir fi. Siaunton remarks," to civilized life. 'This is shown hy the ancient religions rites of rarions nations, by the drawings on the walls of Pompeii, and by the practices of many karages.

We have now secn that artions are regarded by tar. agea, and were probslily so regarded by primeral man, as grood or bad, solely an theg affice in an ubviont mamer

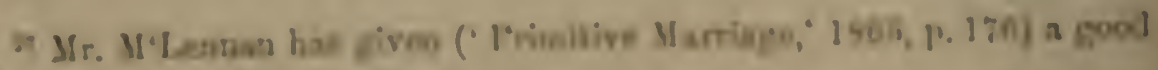
enlection of facts as thie has.

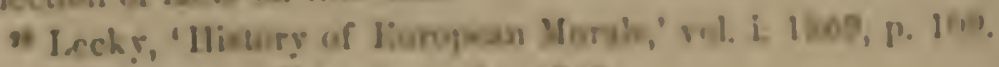

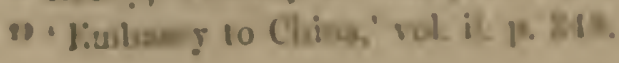




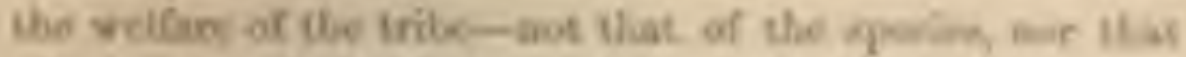

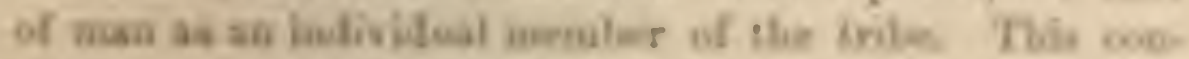

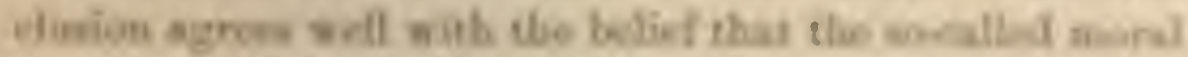

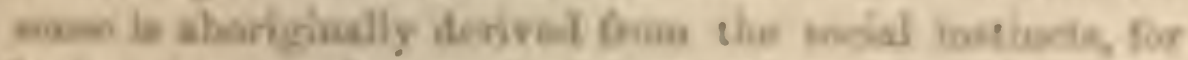

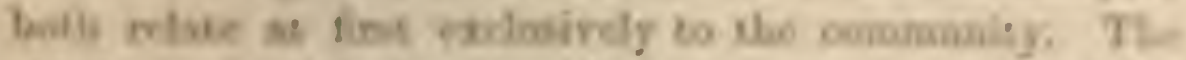

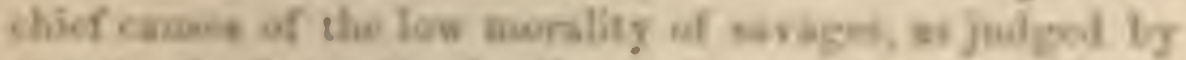

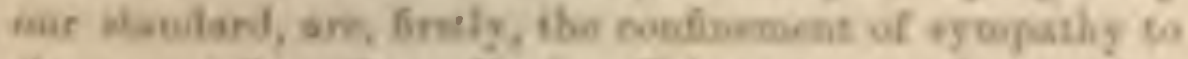

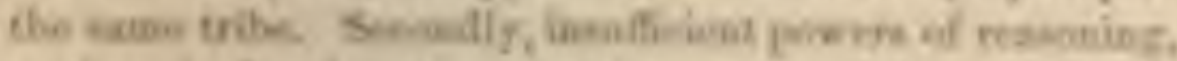

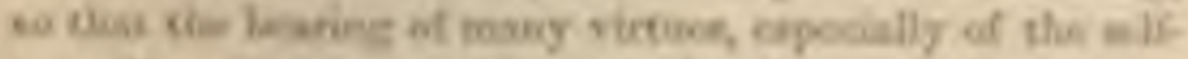

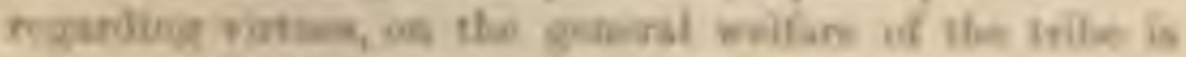

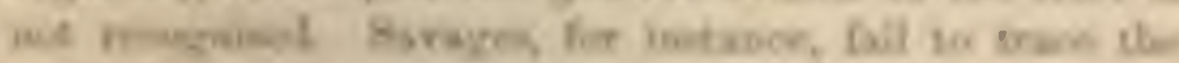

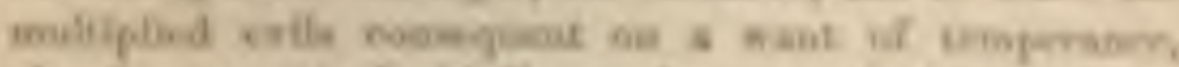

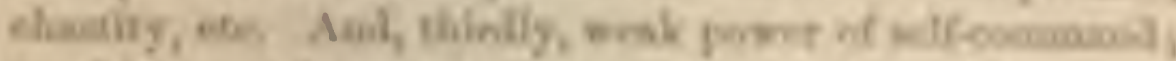

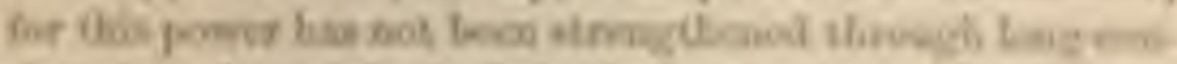

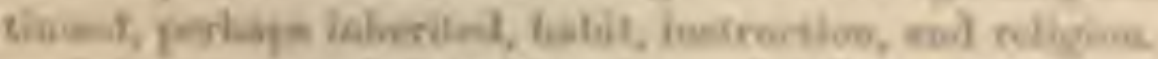

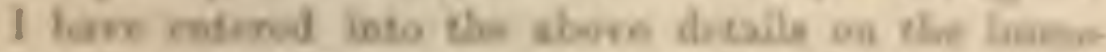

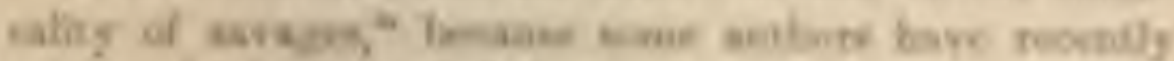

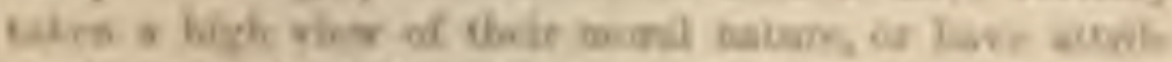

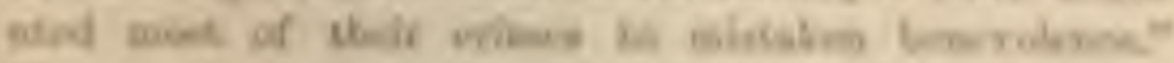

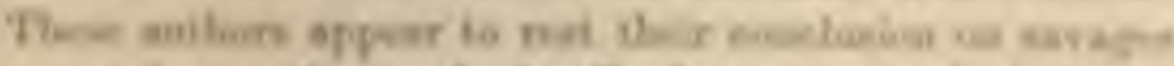

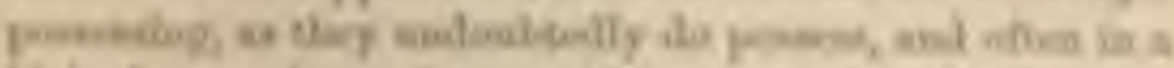

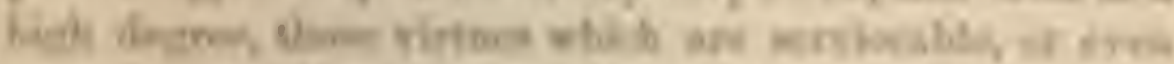

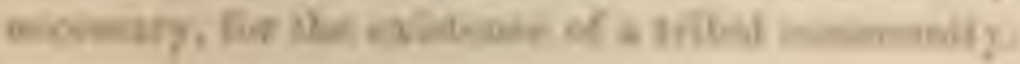

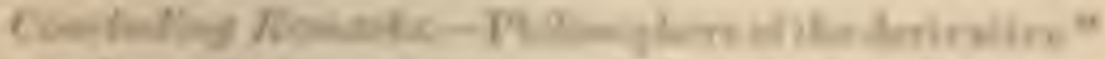

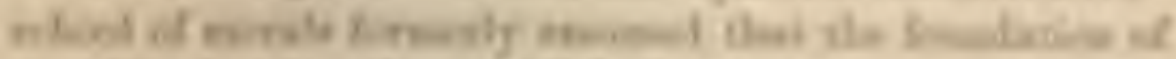

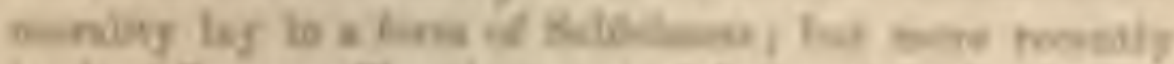

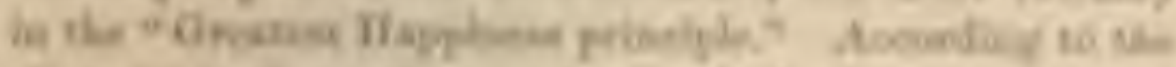

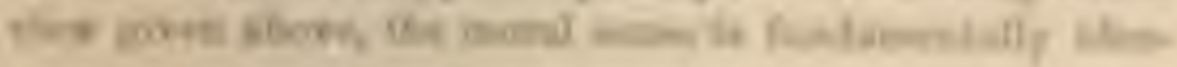

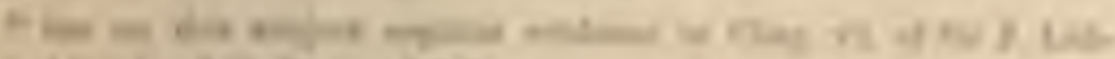

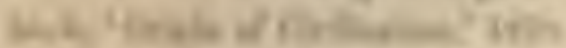

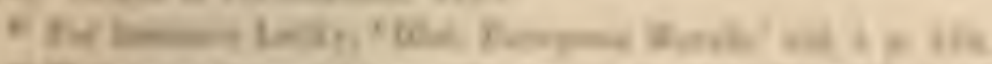

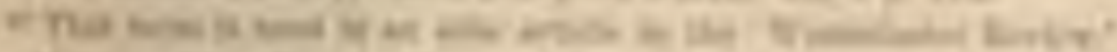

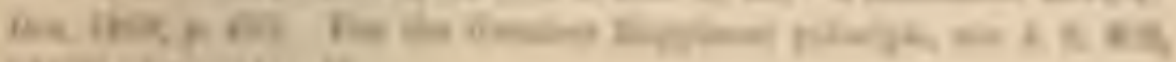

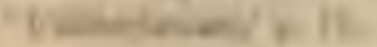


lical with the social instincts; and in the case of the lower animals it wonld be absurel to speak of these inslincts ats having heen developed from sclfishness, or for the happlines of the community. 'They have, however, certainly been developed for the general grood of the community. The term, greneral grood, may be delined as the means by which the greatest possible number of individuals e:an be reared in full vigror and health, with all their facullies perfect, muler the conditions to which they are exposerl. Is the social instincts both of man and the lower animals have no dimbt been dereloped by the same steps, it would le advisable, if fouml practicable, to use the same definition in both cases, and to take, as the test of morality, the grencral grood or welf:ue of the community, rathere than the reneral hajpiness; but this definition would perhaps reynire some limitation on accomt of political ethics.

When a man risks his life to sare that of a fellowcrature, it seems more appropriate to say that he acts for the greucral good or wellire, rather than for the general happiness of mankind. No doubt the welfare and the happliness of the indiridual usually coincide; and a confonted, happy tribe will tlomish better than oue that is discontented and unhappy. We have seen that, at an early period in the history of man, the expressed wishes of the community will have naturally influenced to a large extent the conduct of each member; and as all wish for happiness, the "greatest lappiness principle" will have become a most important secondary guide and object; the social instincts, including sympathy, always serving as the primary impulice and guide. 'Thus the reproach of litying the foundation of the most noble part of our natue in the base principle of selfishness is remored; muless indecd the satisfaction which erery animal feels when it follows its proper instincts, and the dissatisfaction folt when prevented, be called sellish. 


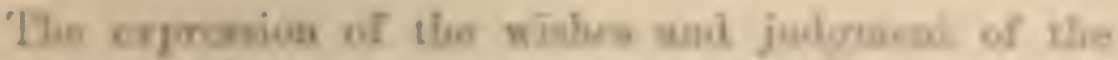
we whers of the same coisanaily, se finst lig oral sed

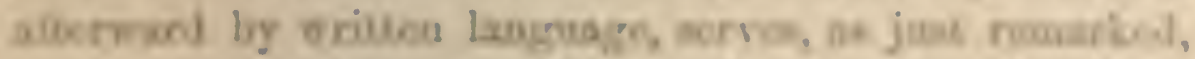

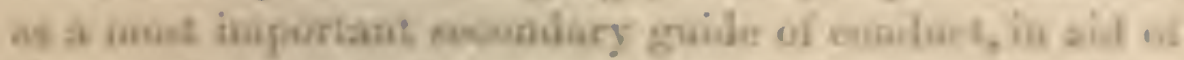

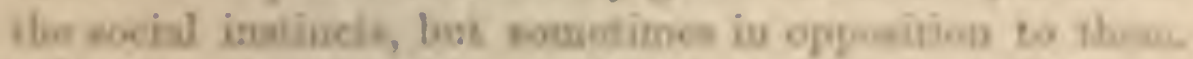
This latue face is well esemplified hy thin Las ef Momer. the is Cle lase of the opision of onr oquele, and not of all

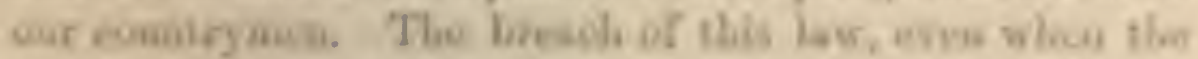

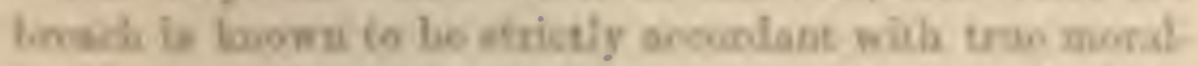

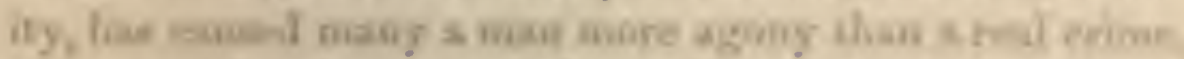

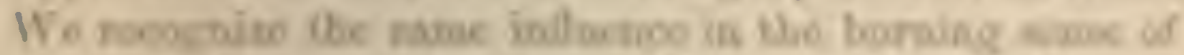

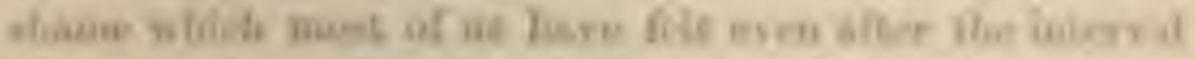

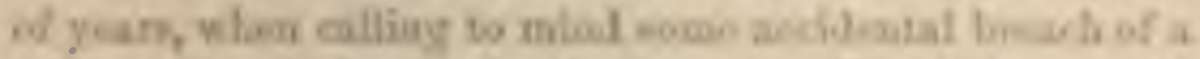

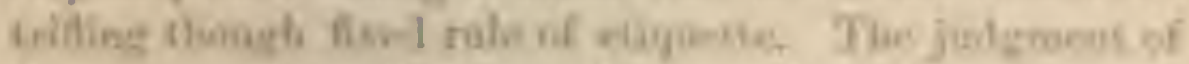

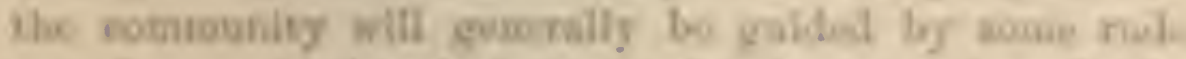

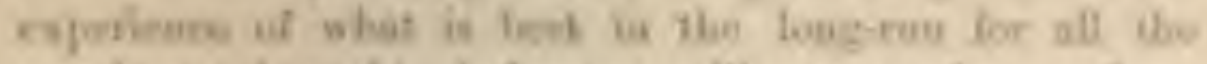
nembers; bat this Judement will mat rasts ore inm

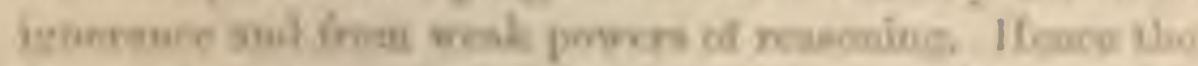

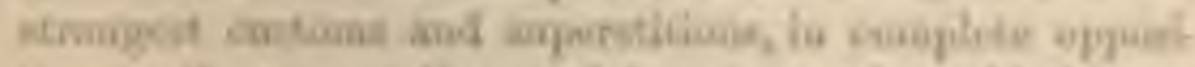

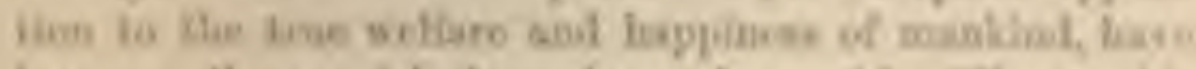

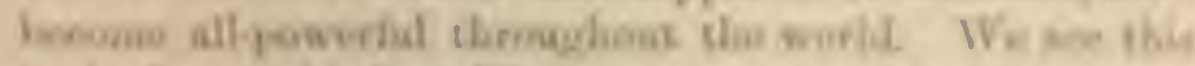

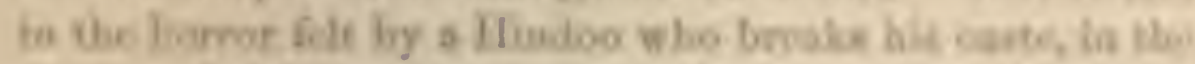

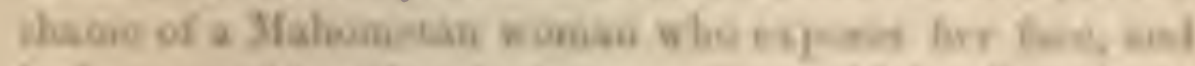

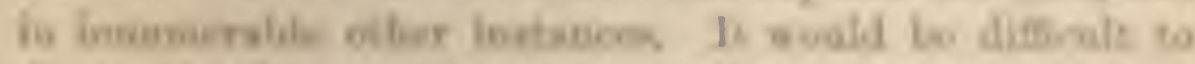

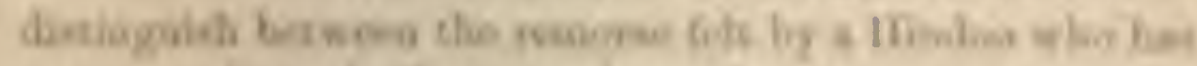

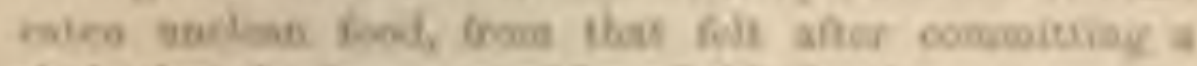

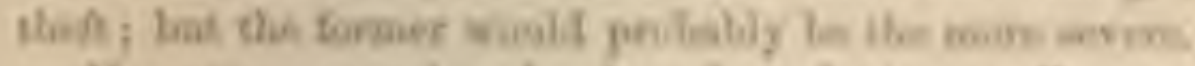

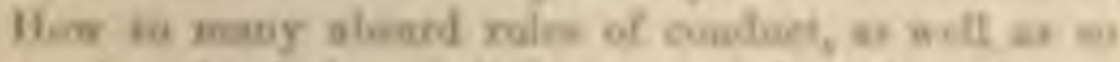

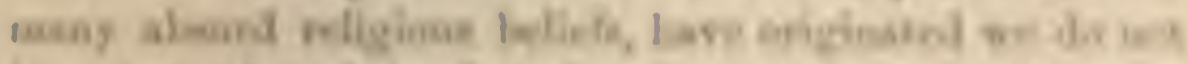

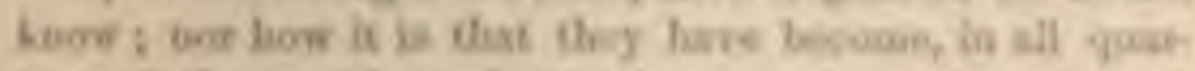

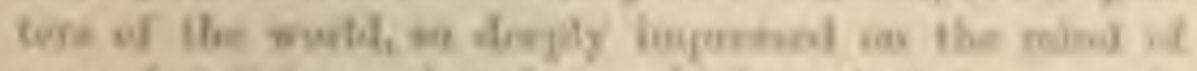

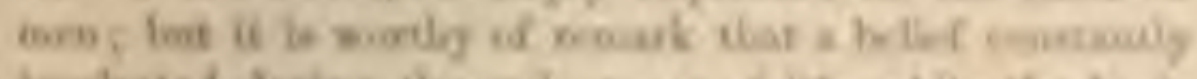

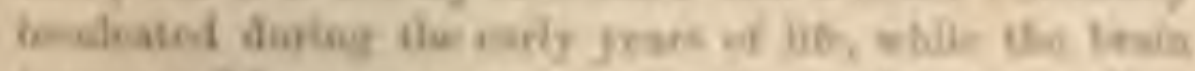

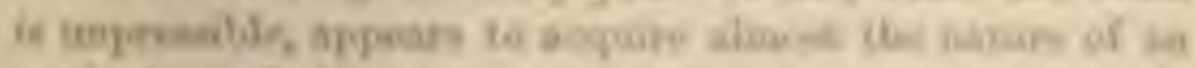

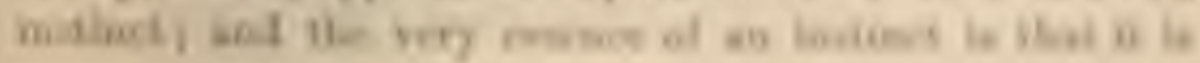


followed independently of reason. Neither can we say why certin admirable virtnes, such as the love of truth, are much more highly appreciated by some satvage tribes than hy others;" nor, agan, why sinilar diflerenees prevail cren among civilized nations. Knowing how firmly fixed many strange custons and superstitions lave becone, we need feel no surprise that the self-regarding virtues shonld now appear to us so natural, snpported as they are by reason, as to be thonght innate, although they were not valued by man in his early condition.

Notwithstanding many sonrces of doubt, man cau generally and readily distingnish between the higher and lower moral rules. The higher are founded on the social instincts, and relate to the welfure of others. They are supported by the approbation of our fellow-men and by renson. The lower rules, though some of them when implying self-sacrifice hardly descrve to be ealled lower, relate chiefly to self, and owe their origin to public opinion, when matnred by cexperience and culivated for they are not practised ly rude tribes.

As man adrances in civilization, and small tribes are united into larger communities, the simplest reason wonld tell cach individual that he onght to extend his social instincts and sympathies to all the members of the same nation, thongh personally unknown to him. This point being once reached, there is only an artificial barrier to prevent his sympathies cxtending to the men of all nations and races. If, indeed, such nen are separated from him by great differences in appearance or habits, experience unfortmately shows us how long it is before we look at them as onr fellow-creatures. Sympathy beyond the confines of man, that is, humanity to the lower animals, secms

38 Good instances are given by M. Wallace in 'ścecicntific Opinion,' Sept. 15, 1\$69; and marn fully in lis ' ('untributions to the Theory of Situral Selection,' 1570, p. .ins. 
(1) he one of the lateot moral aequivitions. It is apparently unfelt ly sarages, eseepe toward their pets. Hew lietes the old Romans knew of it is shown by their abhorrent ghaliasorial exhibitions. The very ilea of hamaniey, as fas at I coubl obsorve, was suew to mose of the fiatudios of the Pampas. 'This virtue, oue of the solslese with whieh nusu is endowel, sens to arise incilentully from ous sympathies beeomisg murs teuder and more wide! dillised, until they are extended to all hontint beings. As mon as this rirtue is houred and provinod by sowe fow $\mathrm{xach}$, if preade throngh iastraction and example to then gonng. sul ereutually through gublie opioion.

The bighes neggo in moral culcuno at ohich we can arrive, is when we reouguise that wrenght to coverul our thougles, and "not evon is inmoet thought wo think sgais

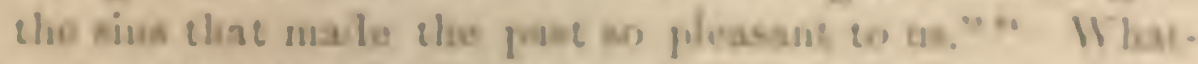
ever maka any lad action fasiliar of the min?, nemlen

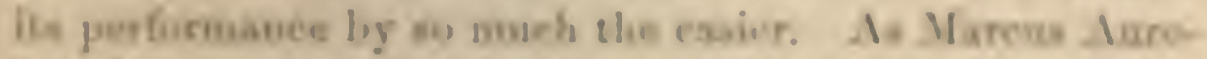

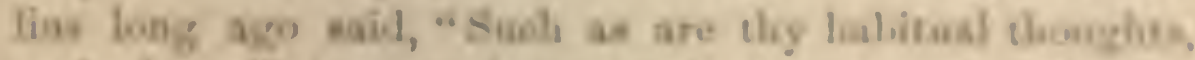
suph alas will be the elosecter of toy mind; for the noul in dyod by the thoughte" 4

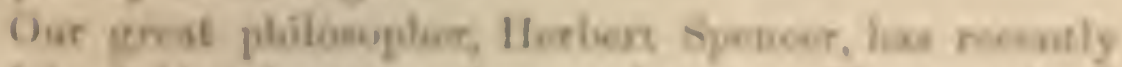

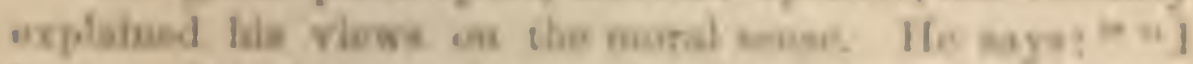

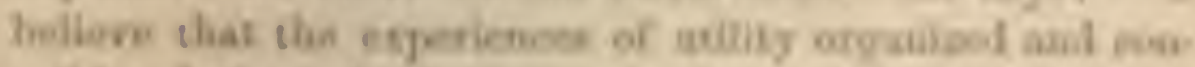

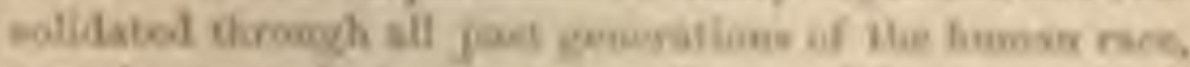

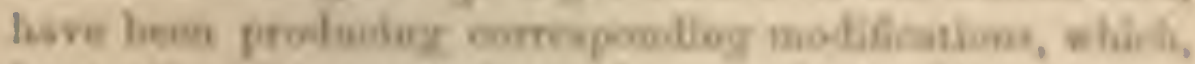

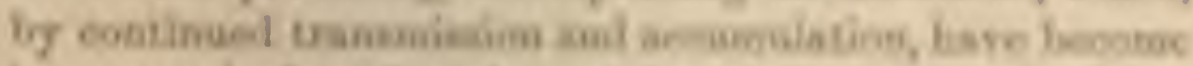

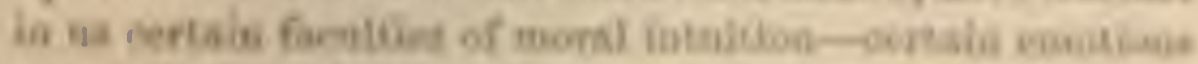

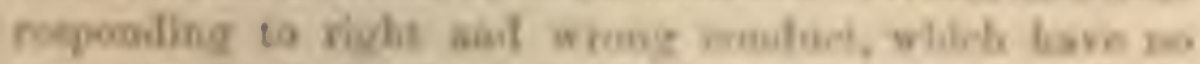

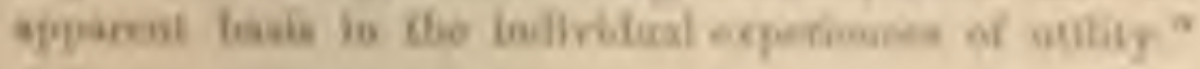

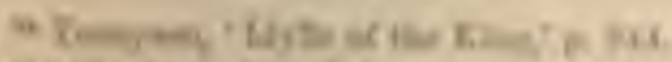

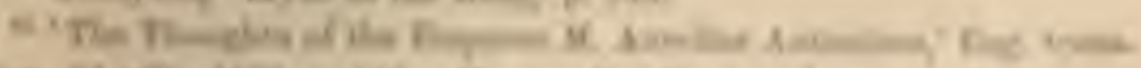

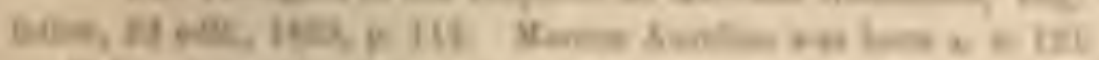
nin

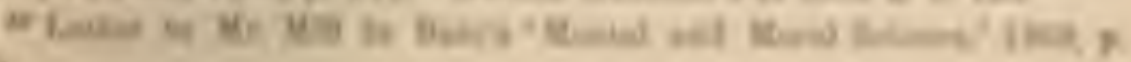


There is not the least inherent improbability, as it seems to $\mathrm{me}$, in virtuous tendencies being more or less strongly inherited; for, not to mention the various dispositions and habits transmitted by many of our domestic animals, I have heard of cases in whicli a desire to steal and a tendency to lie appeared to run in families of the upper ranks; and as stealing is so rare a crime in the wealthy classes, we can hardly account by accidental coincidence for the tendency occurring in two or three members of the same filmily. If bad tendencies are transmitted, it is probable that good ones are likewise transmitted. Excepting through the principle of the transmission of moral tendencies, we cannot understand the differences believed to exist in this respect between the various races of mankind. We have, however, as yet, hardly sufficient cridence on this head.

Even the partial transmission of virtuous tendencies would be an immense assistance to the primary impulse derived directly from the social instincts, and indirectly from the approbation of our fellow-men. $\Lambda$ dmitting for the moment that virtuous tendencies are inherited, it appears probable, at least in such cases as chastity, temperance, humanity to animals, etc., that they become first impressed on the mental organization through habit, instruction, and example, continued during several generations in the same family, and in a quite subordinate degree, or not at all, by the individuals possessing such virtues, having succeeded best in the struggle for life. My chief source of doubt with respect to any such inheritance, is that senseless customs, superstitions, and tastes, such as the horror of a IIindoo for unclean food, ought on the sane principle to be transmitted. Although this in itself is perhaps not less probable than that animals should acquire inherited tastes for certain kinds of food or fear of certain foes, I have not met with any evidence in support 
of the transmission of superstitious customs or senseless labits.

Finally, the social instincts which no doubt were acquired by man, as by the lower amimals, for the good of the community, will from the first hare given to him some wish to aid his fellows, and some feeling of sympathy. Such impulses will have served him at a very caly period as a rude rule of right and wroug. J3ut as man gralually alranced in intellectual power and was crialled to trace the more remote con-equences of his actions; as lie acquired suflicient hnowleclge to reject baneful customs and superstitions; as he regarded more and more not only the welfare but the happiness of his fellow. mon; as from haljit, following on beucfeial experiunce, instruction, and cxample, his sympathics became more tender and widely diflused, so as in crenet to the mru wi all races, to the imbecile, the maimed, and other unlied mombers of socicty, amel fimally to the lower ani-

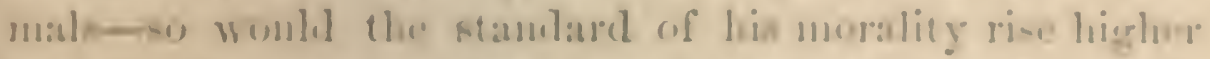

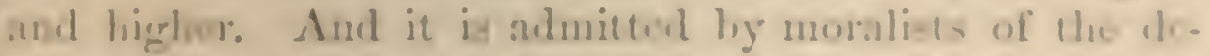
tivalive foluobl and by bome intuitioniete, that the slandad of morality has risen since an caty prow in the liswy of แ1แ1."

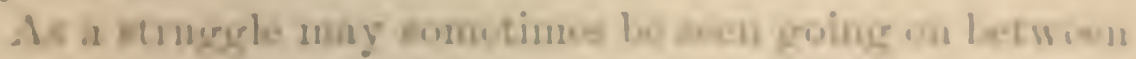
the rarions inetime of the lown animals, it is mot sus

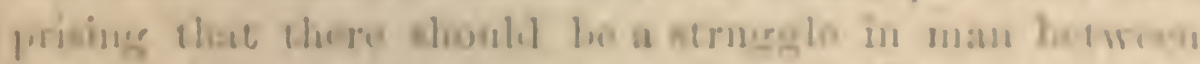
lis soaihl intinces, witls thije deriscl sirturs, and he

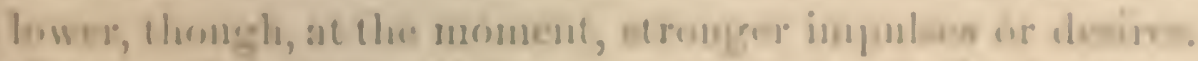

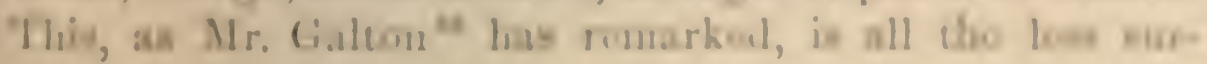

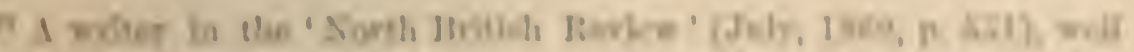

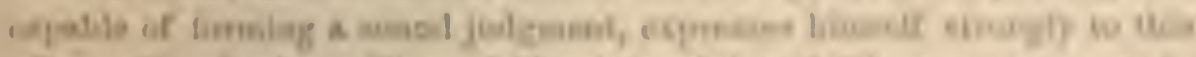

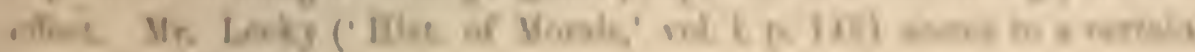
nime in milarkls.

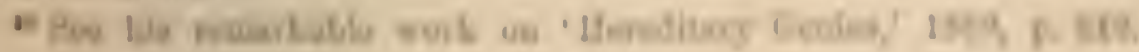


prising, as man has emerged from a state of barbarism within a comparatively recent period. After having yielded to some temptation, we feel a sense of dissatisfaction, analogous to that felt from other unsatisfied instincts, called in this case conscience; for we cannot prevent past images and impressions continually passing through our minds, and these in their weakened state we compare with the erer-present social instincts, or with habits gained in early youth and strengthened during our whole lives, perhaps inlierited, so that they are at last rendered almost as strong as instincts. Looking to future generations, there is no cause to fear that the social instincts will grow weaker, and we may expect that virtuous hatbits will grow stronger, becoming perhaps fixed by inheritance. In this case the struggle between our higher and lower impnlses will be less severe, and virtue will be trimplamt.

Summary of the last two Chapters.-There can be no doubt that the difference between the mind of the lowest man and that of the highest animal is immense. An anthropomorphous ape, if he could take a displassionate vicw of his own case, would admit that though he could form an artful plan to plunder a garden-though he could use stones for fighting or for breaking open nuts, yet that the thought of fashioning a stone into a tool was quite beyond his scope. Still less, as he would admit, could he follow out a train of metaphysical reasoning, or solve a mathematical prol,lem, or reflect on Goul, or atmire a gramd natural seche. Some apes, howerer, woulil probably declare that they conld and did atmire the beatity of the colored skin and fur of their partuers in marriage. They would admit, that though they could make other apes understant by crics some of their perceptions and simpler The Dulke of Argyll ('P'rimeval Man,' 1869, p. 188) lias some groorl ra. marks on the contest in man's nature between right and wrong. 
wants, the notion of cxpresing definite idest lis de sioik sounds had neser crosted their mindt. 'They might insine that they were rady is add their fellow-spus of the sarne truop in many ways, to risk their lives fur thum, aus ws take charege of their orpliaus; but they would be foreol to ackuowledge that diziuterosted love for all lirigg creatures, the most noble attribute of man, was quite be romel this (*)inj.rehension.

Nevertheleas the diftirence in mind between man and the liginer atiuals, great as it is, is certuibly oue of degre and not of kind. We hise noen thant the essure and interfioss, the rarious cunetions and faculies, suels an love,

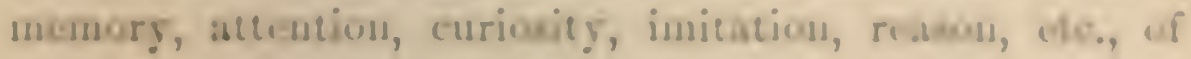
which man loust, may be fouml in an incipient, or evels

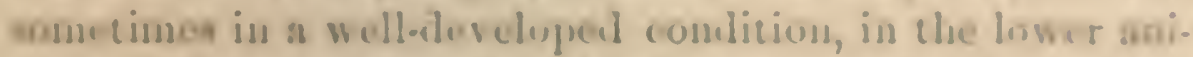

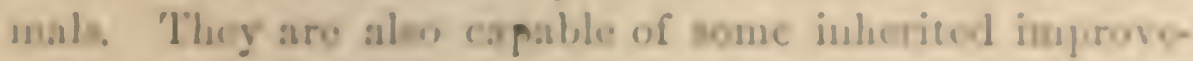

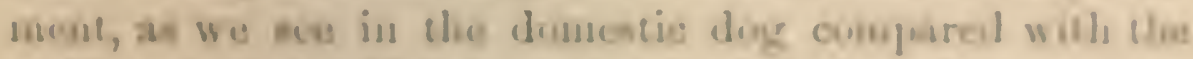
wolf or jucksl. If it be maintained that curtain powor,

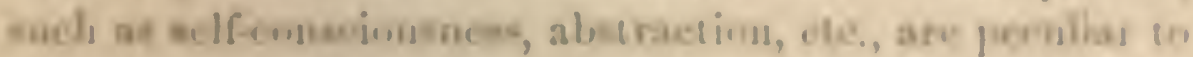

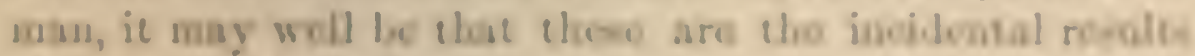

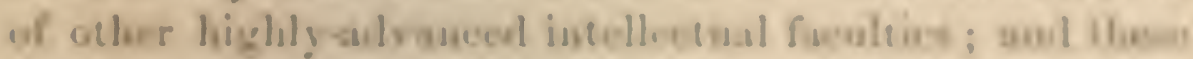
again are maiuly the recalt of the routinusd wern of a

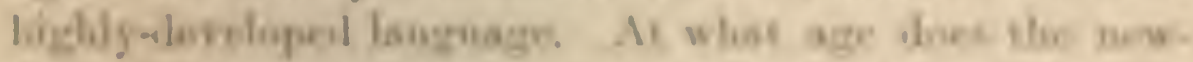
bom infint pescas the power-of abeiraotion, or tecoune

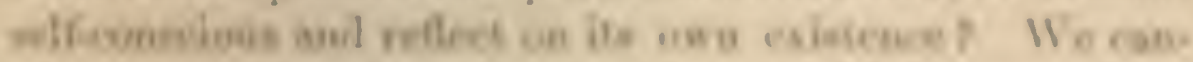

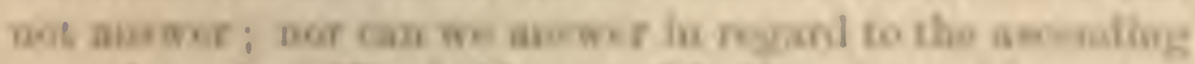

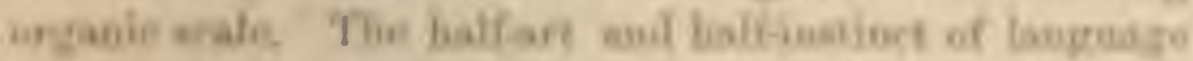

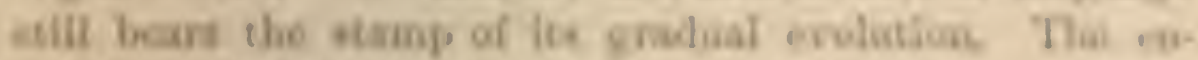

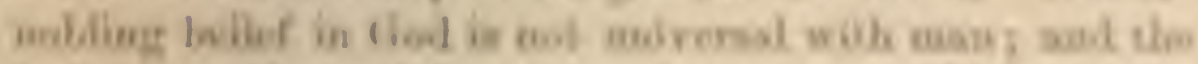

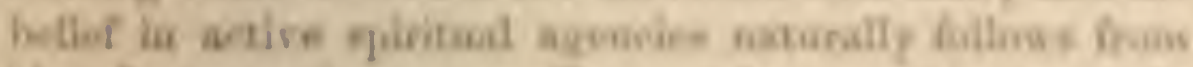

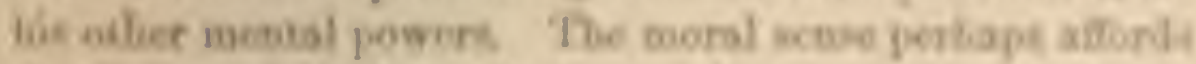

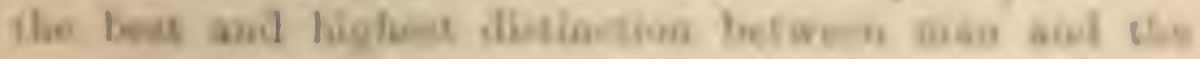

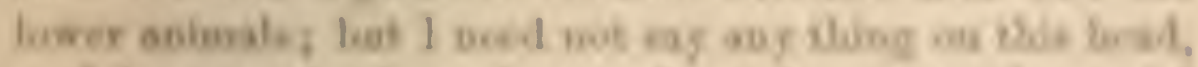

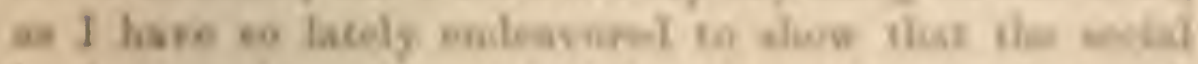

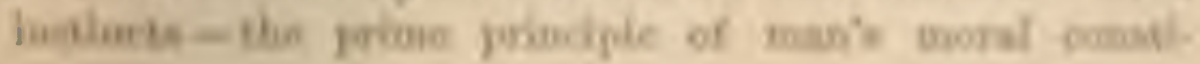


tution" - with the aid of actire intellectual powers and the eflects of habit, naturally lead to the golden rule, "As ye would that men should do to you, do ye to them likewise;" and this lies at the foundation of morality.

In a future chapter I shall make some few remarks on the probable steps and means by which the several mental and moral faculties of man have been gradually erolved. That this at least is possible onglit not to be denicd, when we daily see their development in every infant; and when we may trace a perfect gradation from the mind of an utter idiot, lower than that of the lowest animal, to the mind of a Newton.

"2 'The Thoughts of Marcus Aurclius,' ctc., p. 139. 


\section{OHAPTEIR IV.}

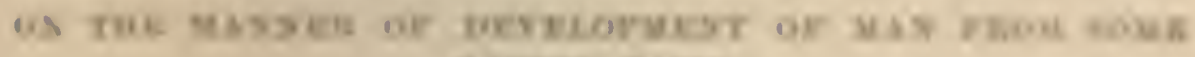
Bowron Eorice.

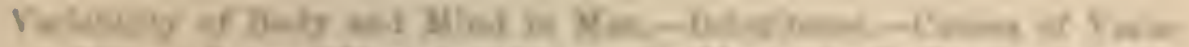

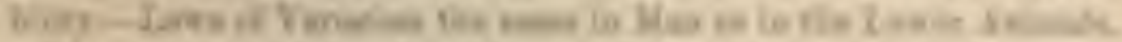

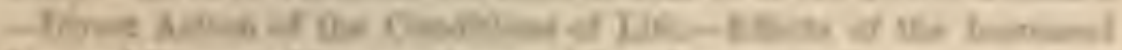

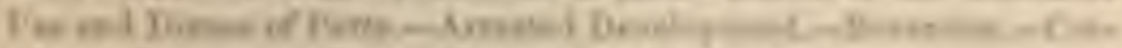

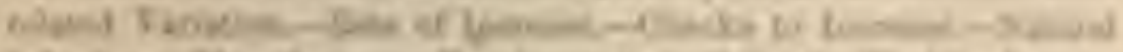

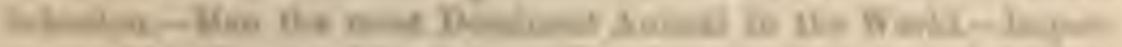

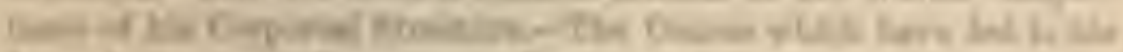

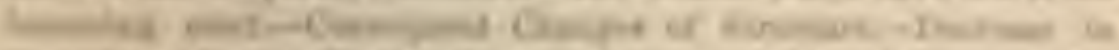

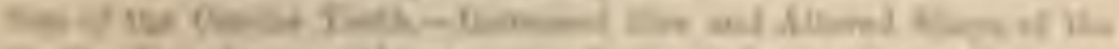

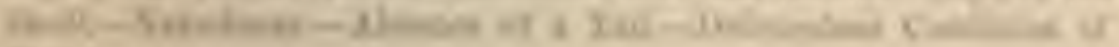
ins.

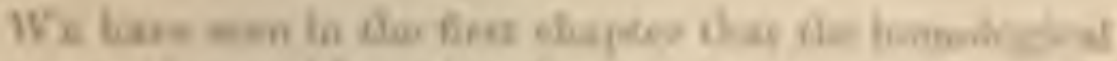

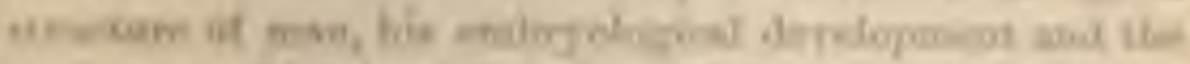

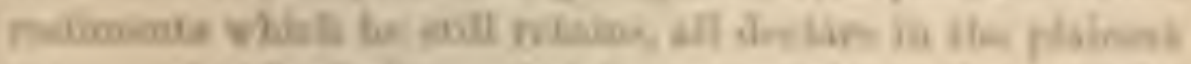

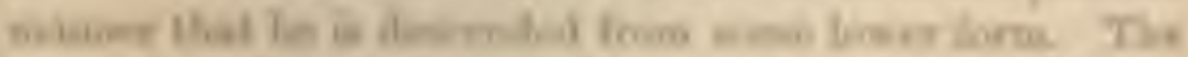

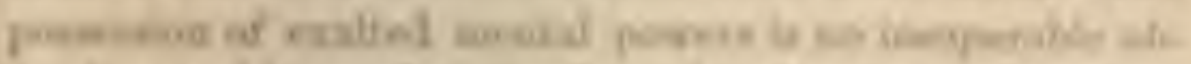

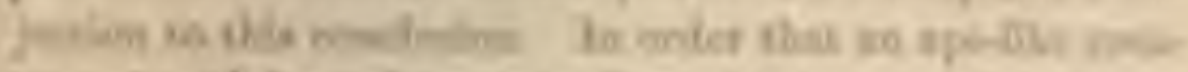

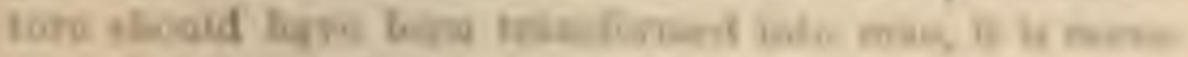

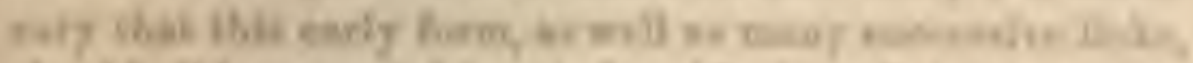

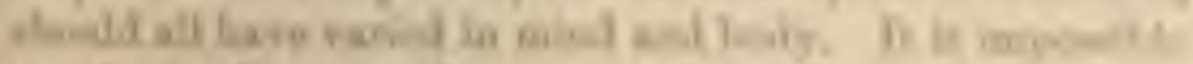

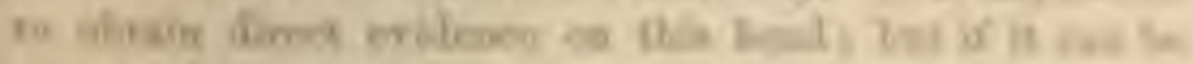

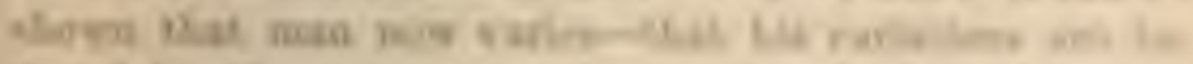

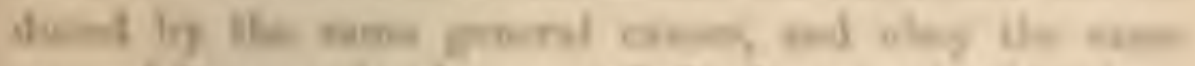

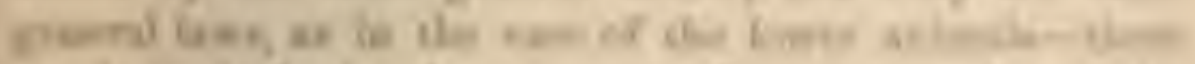

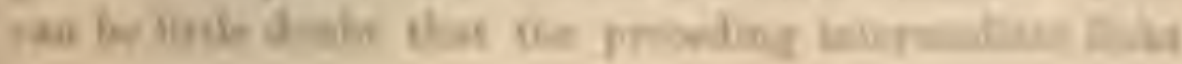


varied in a like namuer. The rariations at eacle fuceorsire stige of descent tnust, aleo, lase leou in some manner aceumulated and fixed.

The facts and conclutions to be giren in this chapter relate almost exelusircly to the probable means by which the transformation of man lins been eflected, at far an his bodily structure is concerned. The fullowing chapter will be deroted to the development of his intellectual and moral faculties. But the present discuenion likewise beas on the origin of the diflerent races or species of mankind, whicherer term may be preferred.

It is manfere that man is now suljece to much variability. No two individuals of the same race are quite alike. We may compare millions of faces, and each will be distiut. There is an equally great anount of diversity in the proportions and dimensious of the various parts of the body; the length of the legs being one of the must variable joints.' Althongh in sone quarters of the world an elongated skull, and in other quarters a short shull frevails, get there is great dirersity of shaje eren within the linite of the same race, as with the aburigines of Anerica and South Australia-the latter a race "protably as pure and homogenewus in blood, custumn, and language, as any in existence"-and oven with the inhahitants of so con. lined an area as the S.undwich lalands.' An eminent dentiet aseures me that there is nearly as much diversity in the toeth as in the features. The chict arteries to fre ypentl: run in ahnormal courses, that it lans been found usiful for surgical purposes to calculate from 12,000

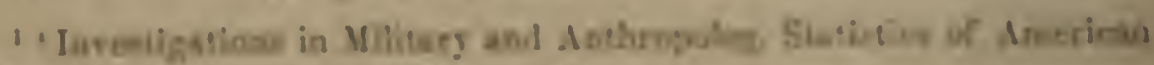
Seldien,' 1.5 13. A. Cioull, 15ei, p. 2se.

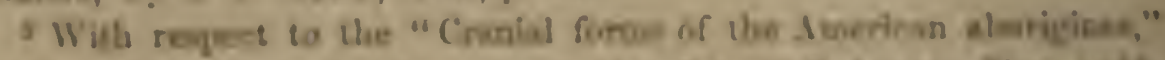

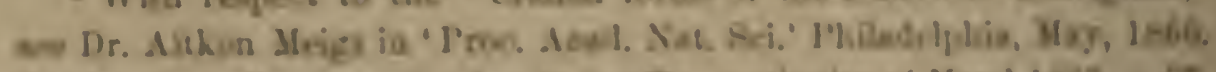

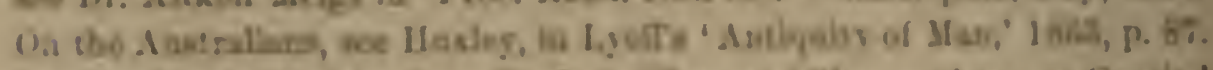

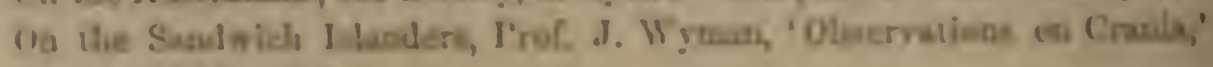
livetoa, 1855, p. 15. 


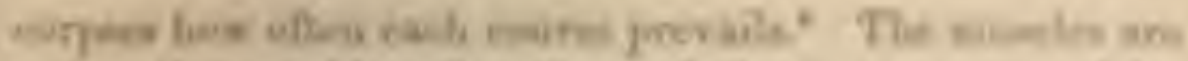

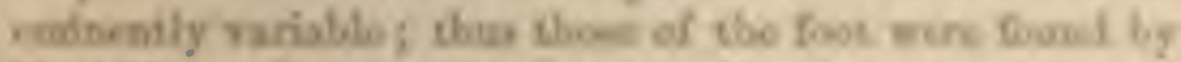

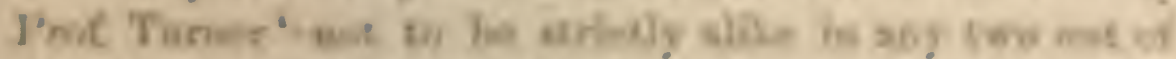

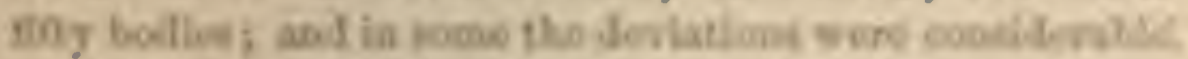

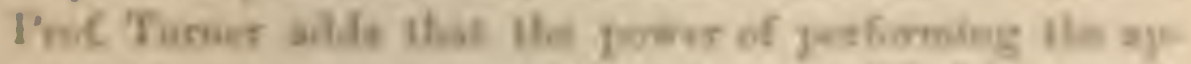

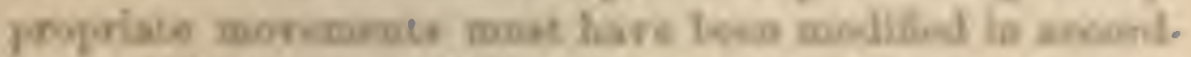

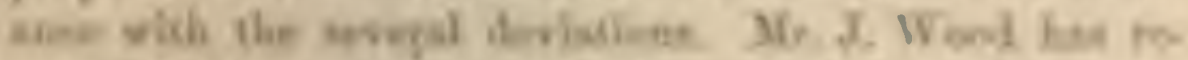

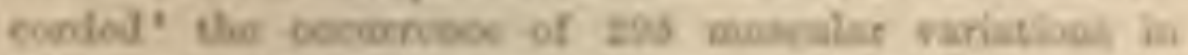

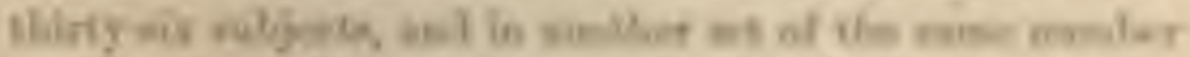

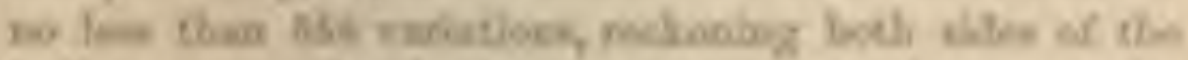

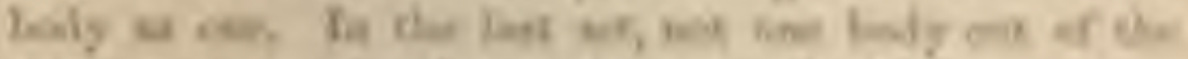

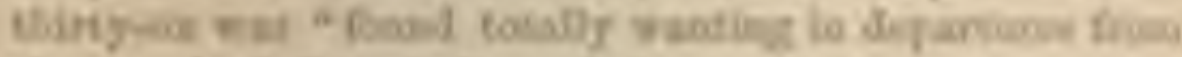

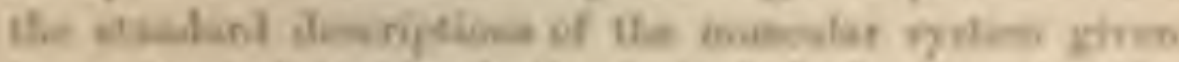

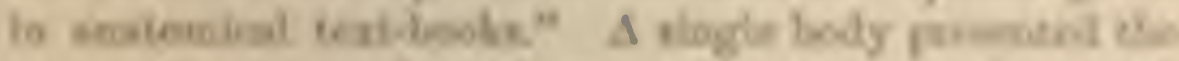

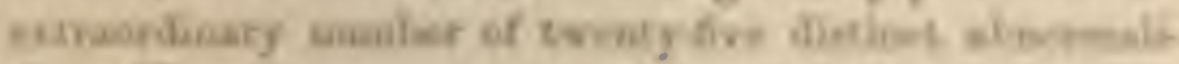

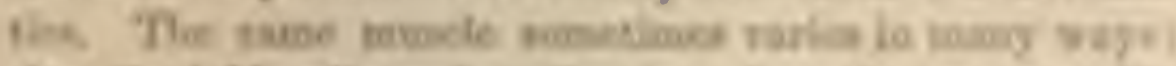

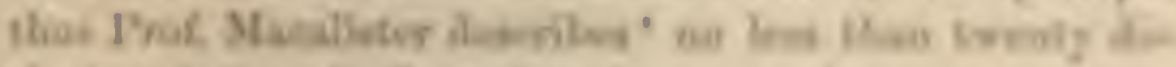

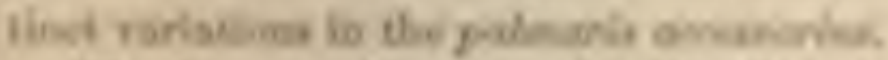

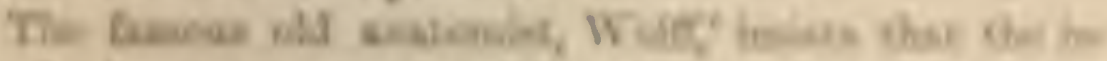

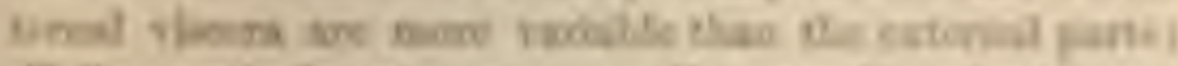

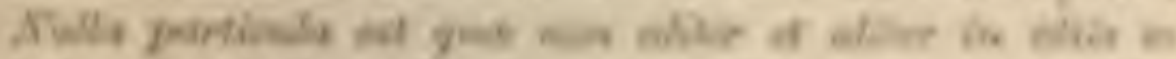

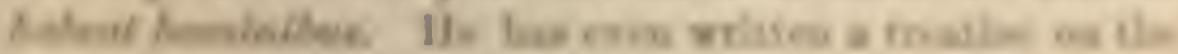

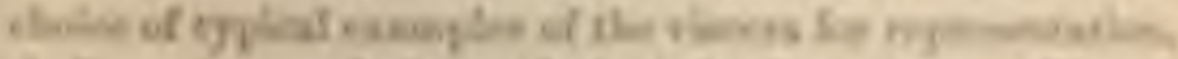

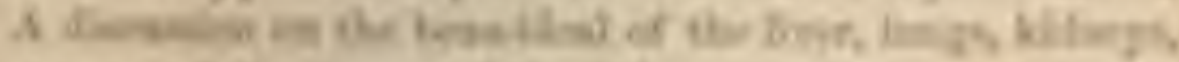

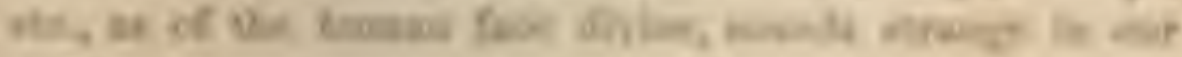
$\operatorname{rsh}$

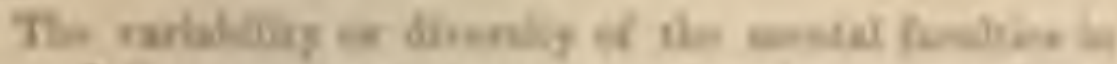

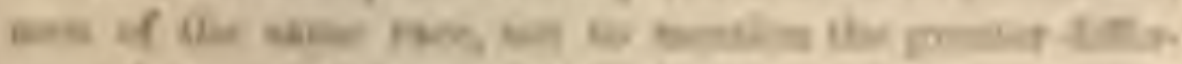

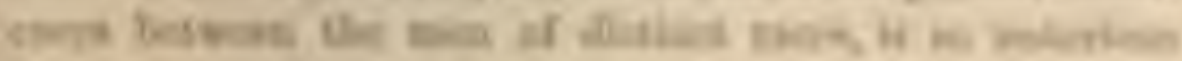

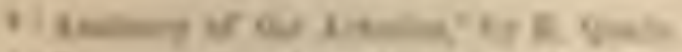

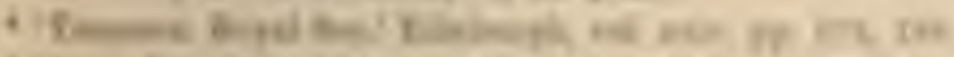

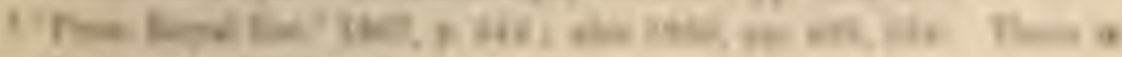

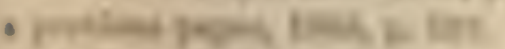

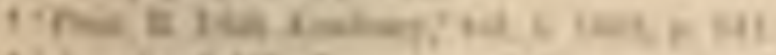

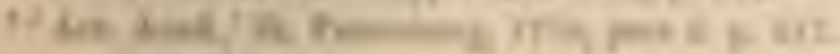


that not a word need here be said. So it is with the lower animals, as has been illustrated by a few examples in the last chapter. All who have had charge of menageries almit this fact, and we see it planinly in our dogs and other domestic animals. Bridum expecially insists that each individual monkey of those which he kept under confincment in Africa latd its own peculiar disposition and temper: he mentions one baboon remarkable for its high intelligence; and the keepers in the Zoologrieal Gardens pointed out to me a monkey, belonging to the N('w World division, equally remarkal, for intelligenec. Renggere, ulso, insists on the diversity in the various mental charatcter's of the monkeys of the same species which he kept in Paraguay; and this diversity, as he adds, is partly iunate, and partly the result of the mannere in which they have been treated or educated.

I have elsewhere ${ }^{2}$ so fully discusserl the suljeget of Inheritance that I need here add hardly any thing. $\Lambda$ greatcer number of facts have becen collected with respeet to the transmission of the most trifling, as well as of the most important characters in man than in any of the lower animals; though the facts are copious enough with respect to the latter. So in regard to mental qualitics, their transmission is manifest in onr dogs, horse's, and other domestic animals. Besides special tastes and habits, general intelligence, courage, bad and good temper, etc., are certainly transmitted. With man we see similar fatets in almost every family; and we now know through the admirable labors of Mrr. Galton ${ }^{10}$ that genius, which implies a

${ }^{8}$ Irehn, 'Thierleben,' I. i. s. 59, 87. Iienogger, 'Süngethiere ron Paraguag,' s. $5 \%$.

' 'Variation of Auimals and I'lants under Domestication,' rol. ii, chap. xii. 1369.

10 'Hereditary (ienus: an Inquiry into its Laws and Consequences,' 
wonlerfully complex comlination of high fuentios, icnkls in le inleried; and, on the otlue hami, it is tor, oresin that inanity and deteriorated andat powen likowion num in the same fandice.

With respect to the castes of iariability wo wro in all

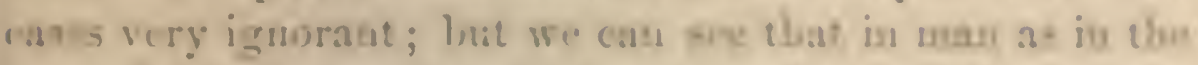
fuwcr atimal, they stand it some rolation widl the som.

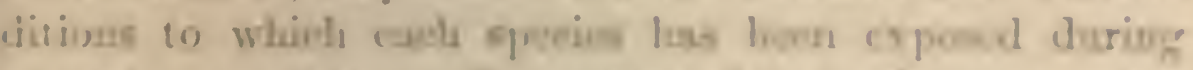

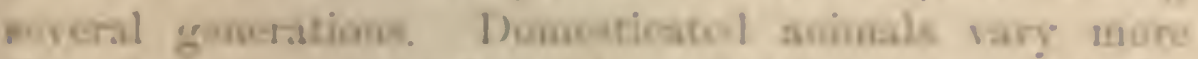

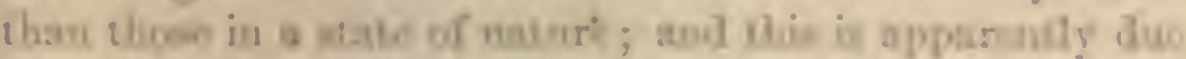

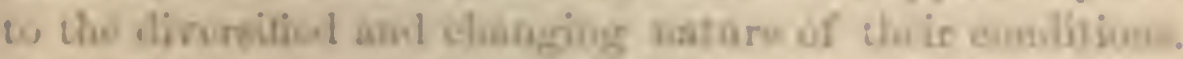

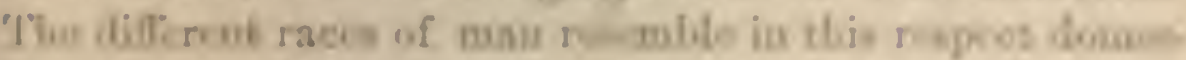

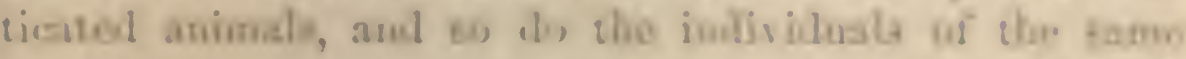

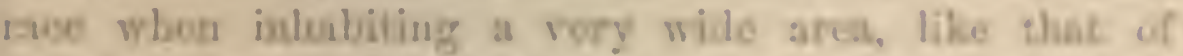

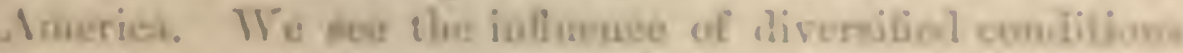
in the moro civilized nation, the members of which in.

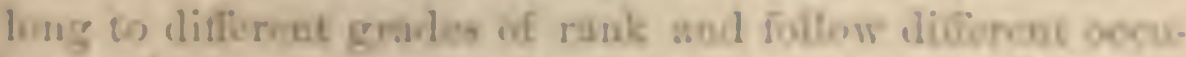

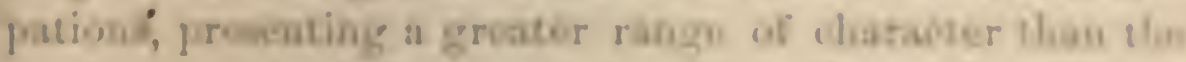

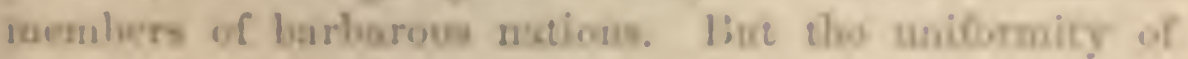

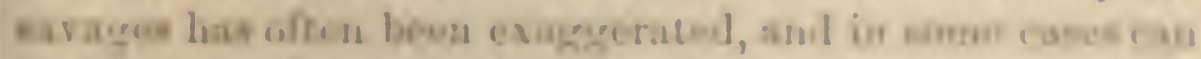
lardly be caid to esiet." It is neroriledias ats arror is

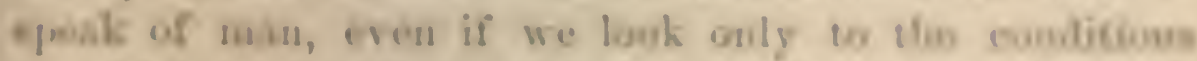

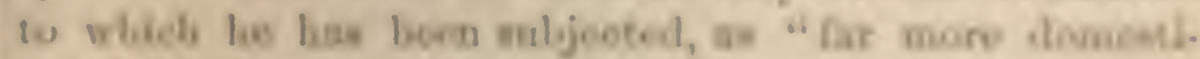

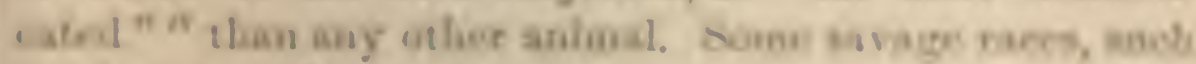

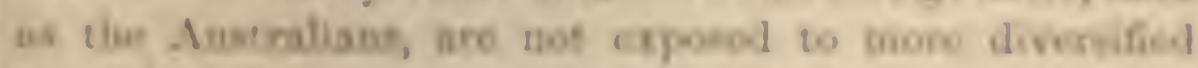

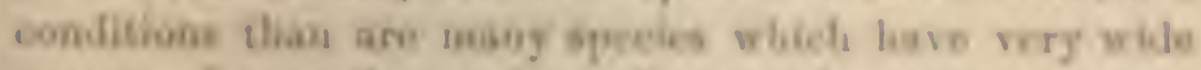
ronges. In zmother and mabl mom important wopect.

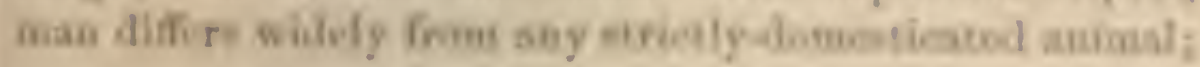

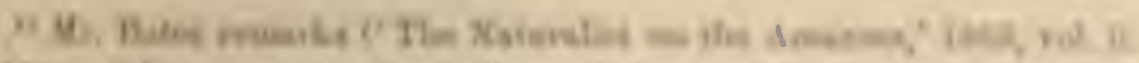

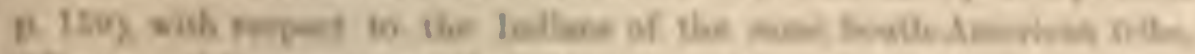

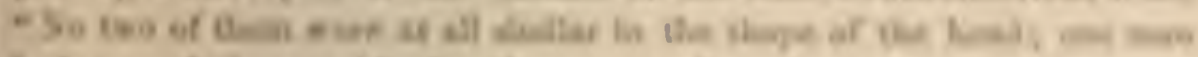

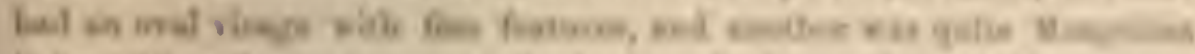

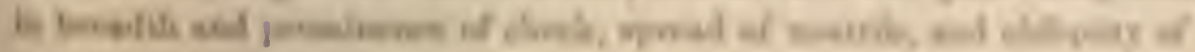
19en $"$

(4)

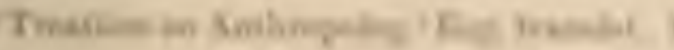


for his breeding has not been controlled, either through methodical or unconscious selection. No race or borly of men has been so conpletely subjugated by other men, that certain individuals have been preserved and thus unconsciously sclected, from being in some way more uscful to their masters. Nor have certain male and female individuals been intentionally picked out and matched, except in the well-known case of the Prussian grenadiers; and in this case man obeyed, as might have been expected, the law of methodical sclection; for it is asserted that many tall men were reared in the villages inhabited by the grenadiers with their tall wives.

If we consider all the races of man, as forming a singrle species, his range is enormous; but some separate races, as the Americans and Polynesians, have very wide ranges. It is a well-known law that widely-ranging species are much more variable than species with restricted ranges; and the variability of man may with more truth be conpared with that of widely-ranging species, than with that of domesticated animals.

Not only does variability appear to be indnced in man and the lower animals by the same gencral causes, but in both the same characters are afficted in a closcly analogous manner. This has been proved in such full detail by Godron and Quatrefages, that I need here only refer to their works. ${ }^{13}$ Monstrosities, which graduate into slight variations, are likewise so similar in man and the lower animals, that the same classification and the same terms can be used for both, as may be seen in Isidore Geoffroy St.-IHilaire's great work." ${ }^{14}$ 'This is a necessary

13 Godron, 'De l'Espice,' 1559, tom. ii. livre 3. Quatrefages, 'CnitG de l'Espèce Ilumaine,' 1S61. Also Lectures on Anthropology, given in the 'Revue des Cours Scientifiques,' 1866-1868.

14 'Ilist. Gen. et l'art. des Anomalies de l'Organisation,' in three vol unes, tom. i. 1832 . 
conscquence of the same laws of change prevaling throughout the animal kingrlom. In my work on the variation of domestic animals, I have atempted to arrange in a rude fashion the laws of variation under the following heads: The direct and definite action of changel conditions, as shown by all or nearly all the in dividuals of the same species varying in the same manur under the same circumstances. The clliects of the longcontinued use or disuse of jarta. 'The coheeion of homol. ogons parts. 'The rariability of muleiple jarts. Connpeneation of growth; but of this law I have found wa grood intances in the case of unan. Thre thects of the muchanical presure of one part on another; as of the pels in on the cranium of the infunt in the womb. Arrest of ilo. rulopment, lealing to the diminution or suppression of parts. The reappearauce of long-loet characters through revernon. Ant latly, correlated rariation. All thease topealled lawa apply cqually to man and the lower animals; and most of them cren in plants. It wonld be superflusu here (1) diseuses all of the m; "hue eoseral am so importunt for us, that they must be treated at considor. ahle lengels.

The direse and s-jinife aceion of elangod conditions.-

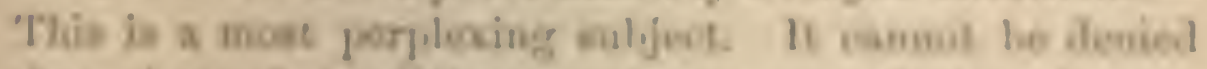

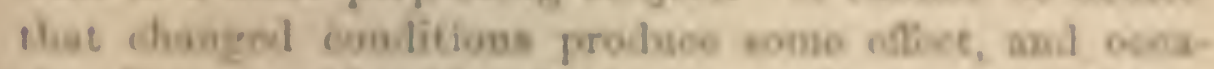

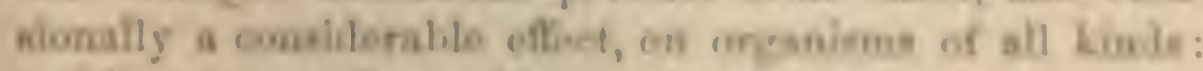
aud it scems at fint probalse ilat, if enflicient time wore allowo-l, this woulit in the invarisble noult. Liat I have

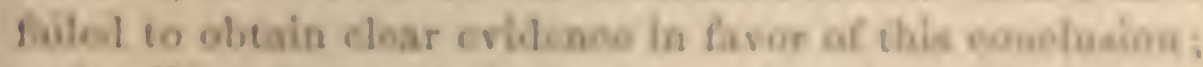

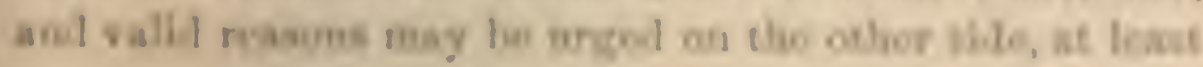

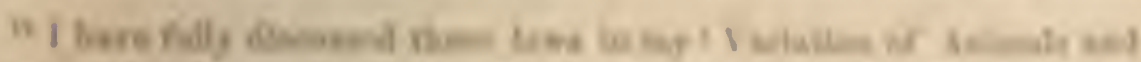

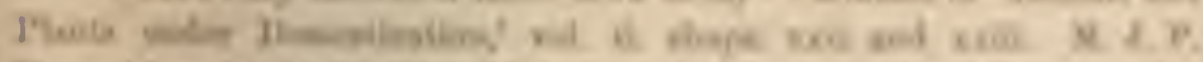

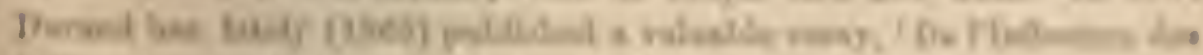

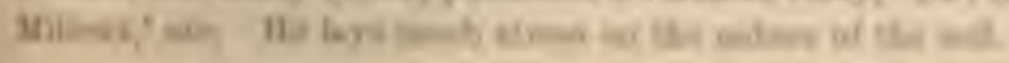


as far as the innumerable structures are concerned, which are adapted for special ends. There can, however, be no doubt that changed conditions induce an almost indefinite amount of fluctuating variability, by which the whole organization is rendered in some degree plastic.

In the United States, above 1,000,000 soldiers, who served in the late war, were measured, and the States in which they were born and reared recorded. ${ }^{26}$ From this astonishing number of observations it is proved that local influences of some kind act directly on stature; and we further learn that "the State where the physical growth has in great measure taken place, and the State of birth, which indicates the ancestry, secm to exert a marked influence on the stature." For instance, it is established, "that residence in the Western States, during the years of growth, tends to produce increase of stature." On the other hand, it is certain that with sailors, their manner of life delays growth, as shown "by the great difference between the statures of soldiers and sailors at the ages of seventeen and eighteen years." Mr. B. A. Gould endeavored to ascertain the nature of the influences which thus act on stature; but he arrived only at negative results, namely, that they did not relate to climate, the elevation of the land, soil, or even "in any controlling degree" to the abundance or need of the comforts of life. This latter conclusion is directly opposed to that arrived at by Villermé from the statistics of the height of the conscripts in different parts of France. When we compare the differences in stature between the Polynesian chiefs and the lower orders within the same islands, or between the inhabitants of the fertile volcanic and low barren coral islands of the same ocean, ${ }^{17}$ or again between the

18 'Investigations in Military and Anthrop. Statistics,' etc., 1869, by B. A. Gould, pp. $93,107,126,131,134$.

${ }^{17}$ For the Polynesians, see Prichard's 'Physical Hist. of Mankind,' 
Fucgians on the eastern and western shores of their country, where the means of subsistence are very different, it is scarcely possible to aroid the conclusion that better food and greater comfort do influence stature. But the preceding statements show how difficult it is to arrive at any precise result. Dr. Beddoe has lately proved that, with the inhabitants of Britain, residence in town and certain occupations hare a deteriorating influence on height; and he infers that the result is to a certain extent inherited, as is likewise the case in the United States. Dr. Beddoe further believes that wherever a "race attains its maximum of physical development, it rises hightest in energy and moral vigor." 18

Whether external conditions produce any other direct effect on man is not known. It might have been expected that differences of climate would have had a marked influence, as the Jungs and kidneys are brought into fnller activity under a low temperature, and the liver and skin under a high one. ${ }^{10}$ It was formerly thought that the color of the skin and the character of the hair were determined by light or heat; and although it can hardly be denied that some eflect is thus produced, almost all observers now agree that the effect has been rery small, eren after exposure during many ages. lint this sulject will be more proprery dischesed when we treat of the diffirent races of mankind. With our domestic anmals there are grounds for believing that cold and damp directly affect the growth of the hair; but I have not met with any cridence on this head in the case of man.

vol. v. 1817, 1pp. 115, 283. Also Godron, 'Do l'lispèce,' tom, ii. 1). 2s!?. There is also a remarkable diflerence in apperance between the clusely.

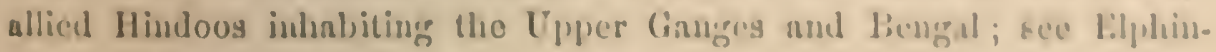
ntonc's 'llistory of India,' vol. i. p. 321.

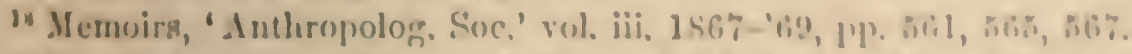

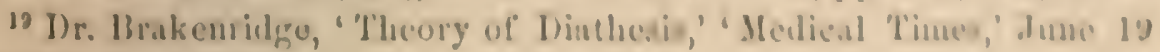
and July $17,1869$. 
Eiffects of the increased Use and Disuse of Perts.It is well known that use strengthens the muscles in the individual, and complete disuse, or the destruction of the proper nerve, weakens them. When the eye is destroyed the optic nerre often becomes atrophied. When an artery is tied, the lateral channels increase not only in diameter, but in the thickness and strength of their coats. When one kidney censes acting from disease, the other increases in size and does double work. Bones increase not only in thickness, but in length, from carrying a greater weight. ${ }^{20}$ Different occupations habitually followed lead to changed proportions in various parts of the body. Thus it was clearly asecrtained by the United States Commission ${ }^{21}$ that the legs of the sailors employed in the late war were longer by 0.217 of an inch than those of the soldiers, though the sailors were on an arerage shorter men; while their arms were shorter by 1.09 of an inch, and therefore out of proportion shorter in relation to their lesser height. This shortness of the arms is apparently due to their greater use, and is an unexpected result; but sailors chicfly use their arms in pulling and not in supporting weights. 'The girth of the neck and the deptl of the instep are greater, while the circumference of the chest, waist, and hips, is less in sailors than in soldiers.

Whether the several foregoing modifications would become liereditary, if the same habits of life were followed during many generations, is not known, but is probable. Rengger ${ }^{22}$ attributes the thin legs and thick arms of the Payaguas Indians to suecessive generations having passed

:I lare giren authorities for these screral statcinents in my 'Variation of Animals under I)omestication,' vol. ii. pl). 297-300. Dr. Jaceger, "Ueber das Lüngenwachsthum der Knochen," 'Jenaisehen Zcitschrift,' 13. v. Ileft i.

21 'Investignations,' ctc. By B. A. Gould, 1S69, 1. 289.

2: 'Siugethice von Paraguar,' 1830, s. 4. 
nearly their whole lires in cances, with elucir borer extronities motionicse. Other writes have come to a similar conclusion in other analogons mases. Acording to Cranz, who lised for a lomg time with the Emulumars, "the natires believe that ingenuity and dererity in sesh(atching (their highest art and virtue) is hereditary; there is really something in it, for the son of a celebratiol neal. catcher will diatinguieh himaelf though bo bet his futher in childhood." Jiut in clis cane it is mental spritude, "juite as much as lnolily trueture, which appeare to the

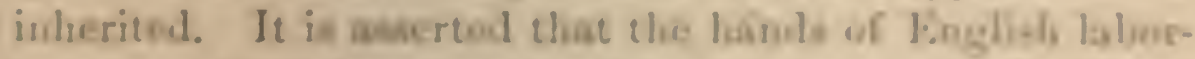
ers are at lireh larger than thowe of tho gemtry." lirom the correlation whinh esiets, at leat in some enes," he tween the derelojment of the creremities and of the jawn,

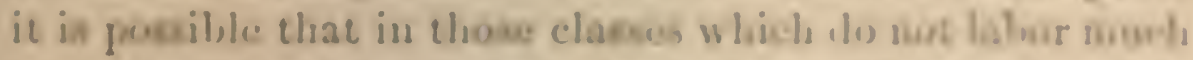
with their lanade and foet, the jaws would bo molueed in size from this couse. That they are generolly susllio in relined and cirilied men thas in hard-worling mon or

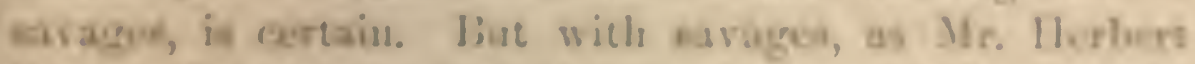
Xpencer" has remarked, the greater one of the jawn in chesirg coaris, uloonkel fond, wondil aet in a direct man-

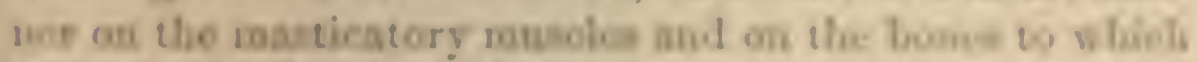

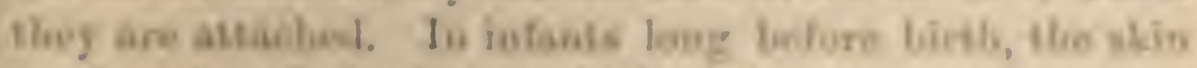

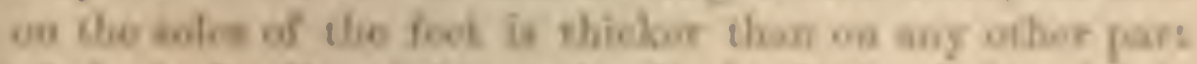

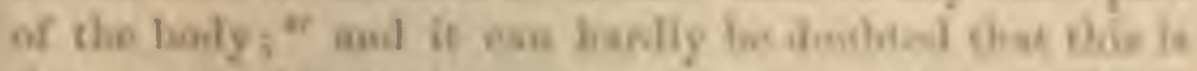

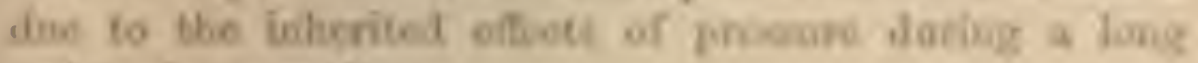
neries of igemerablius:

If is Duwillar to erey com that watolinaken sad vor

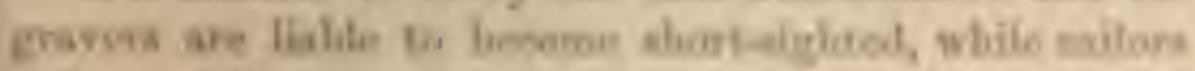

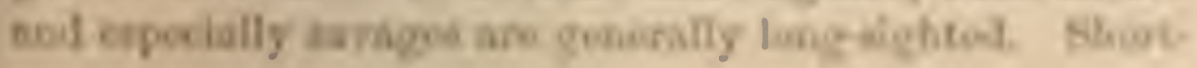

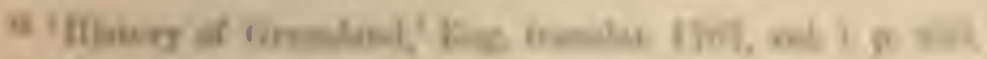

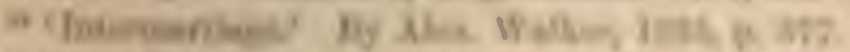

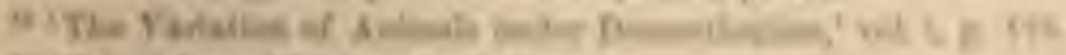

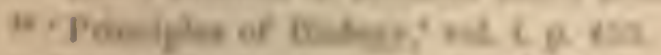

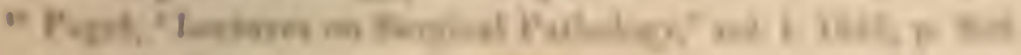


sight and long-sight certainly tend to be inlserited." The inferiority of Europeans, in comparison with savages, in eye-sight and in the other senses, is no doubt the accumulated and transmitted effect of lessened use during many generations; for Rengger ${ }^{20}$ states that he has repeatedly observed Europeans, who had been brought up and spent their whole lives with the wild Indians, who nevertheless did not equal them in the sharpness of their senses. The same naturalist observes that the eavities in the skull for the reception of the several sense-organs are larger in the American aborigines than in Europeans; and this no doubt indicates a corresponding difference in the dimensions of the organs themselves. Blumenbach has also remarked on the large size of the nasal cavities in the skulls of the American aborigines, and connects this fact with their remarkably acute power of smell. The Mongolians of the plains of Northern Asia, according to Pallas, have wonderfully perfect senses; and Prichard believes that the great breadth of their skulls across the zygomas fullows from their highly-developed scuse-organs. ${ }^{20}$

The Quechua Indians inhabit the lofty plateanx of Peru, and Alcide d'Orbigny states "s that from continually breathing a highly rarefied atmosphere they have acquired chests and lungs of extraordinary dimensions. The cells,

23 'The Tariation of Animals under Domestication,' vol.ii. p. 8 .

:9 'Siugethiere von I'uraguay,' s. \&, 10. I have had good opportunities for obscrving the cxtraordinary power of eyesight in the Fuegians. See also Lawrenee ('Lectures on Physiology', etc., 1522, p. 401) on this same sulject. II. Giraud.Teulon has recently collected ('Revuc dea Cours Scientifiques,' 1870, p. 625) a large and raluable body of evidence proving that the cause of short-sight, "C Cest le travail assidu, de pris."

so Prichard, 'I'hys. Hist. of Mankind,' on the authority of Mlumen. bach, vol. i. 1851, p. 811 ; for the statcucnt by I'allas, rol. ir. 1814, p. 407.

8t Quoted hy Prichard, 'Reacarche into the l'hys. Mizt. of Maukind, rol. s. p. 163. 
cren without measmrement, that these peculiarities had all decreased; and on measurement their bolies were found not to be so much elongated as those of the men on the high plateau; while their femora had become somewlat lengtlencel, as had their tibiar, but in a less derrece. The actual measurements may be seen by consulting Mr. Forbes's memoir. From these valuable observations, there can, I think, be no doubt that residence during many gencrations at a great eleration tends, hoth directly and indireclly, to induce inherited modifications in the proportions of the bolly."

Although man may not have been much modified during the latter stages of lis existence throngh the increaser or decreased use of parts, the facts now given show that lis liability in this respect has not been lost; and we positively know that the same law holds good with the lower animals. Consequently we may infer that, when at a remote epoch the progenitors of man were in a transitional state, and were changing from quadrupeds into bipeds, natural selection would probably have been greatly aider by the inherited effects of the increased or diminished use of the difiereut parts of the body.

Arrests of Deedomment.-Arresterl development differs from arrested growth, as parts in the former statc continue to grow while still retaining their early conlition. Various monstrositics come under this head, and some are known to be occasionally inherited, as a cleftpalate. It will suffice for our purpose to refer to the arrested brain-elevelopment of microcephalous illots, as described in Togt's great memoir." Their skulls are

23. Dr. Wilckens ('Iondurirtlucland. Wuchenhlat?,' No. 1n, 1869) has lately publisted an intcreating ceny showing how dometic animals, which live in mountainous regieas, have their founes molified.

34 'Mlémoire sur les dlicroc (phates,' 1867, pp. 50, 125, 16?, 171, 191, 198. 


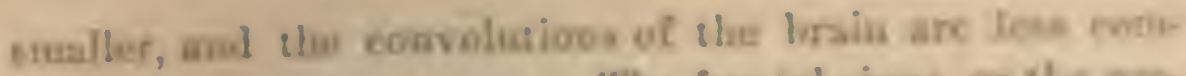
plox, thau in normal nere. The frosial niuse, ot the poo

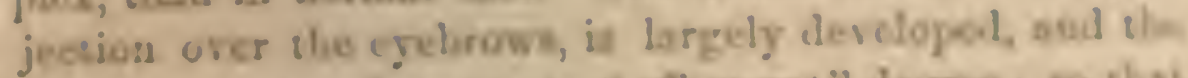
jaws are jirognathoos tu ste "If inoyane" degree; to thas these idiota sotaewlat reacmlith the lower irpos of mankind. Their intelligcoce nod mose of their mental facul. lins ane extmoely fieble. They camber acquire the power

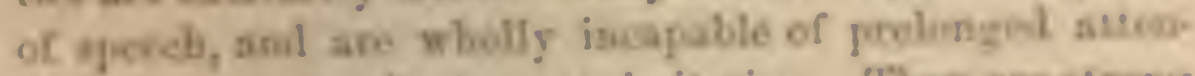
ther, bat ane much given to iwitacion. They ane strosg

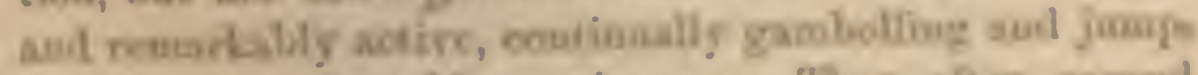

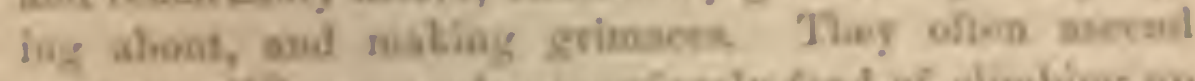

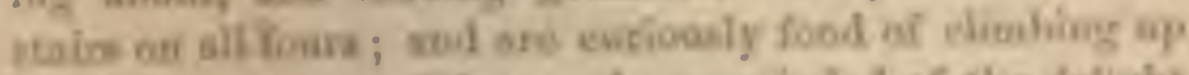

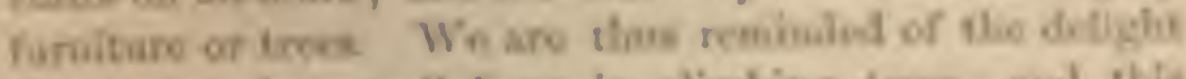
hlowa by almome all bogt in eliabiog trow; sud tha

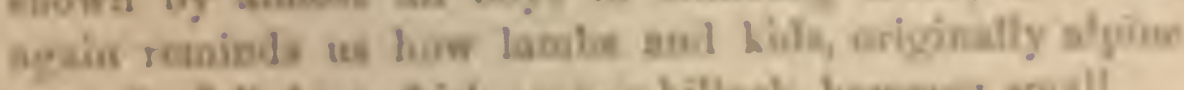
abiosts, Jelight to frist os ong hillock, lowwere! wnall.

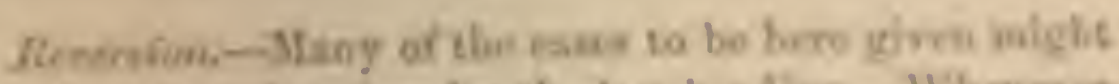
hase bern iosrodeisd molex the tase brasting. Wheveres

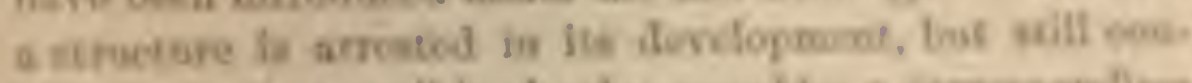

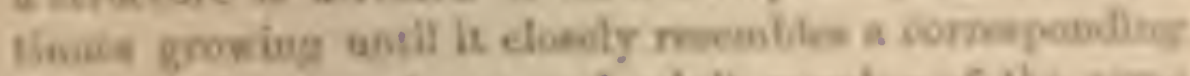

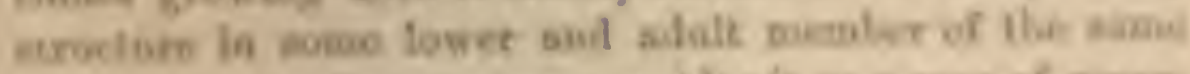

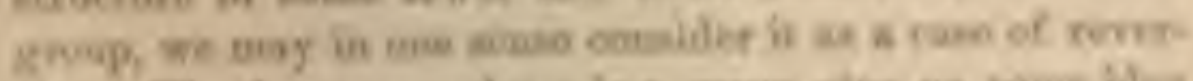
ciom. The luser roveless is a group give wa nowas Mina

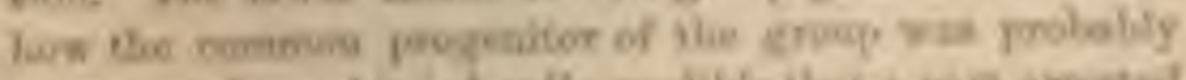

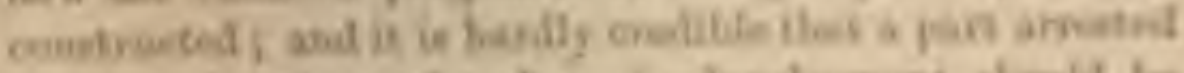

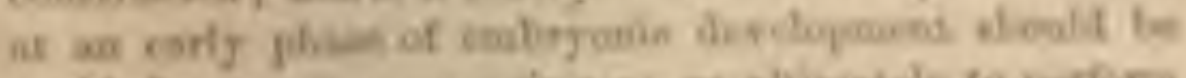

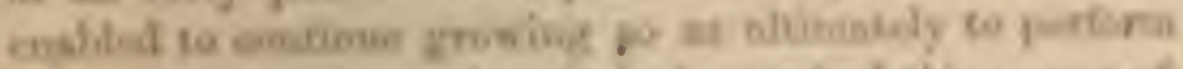

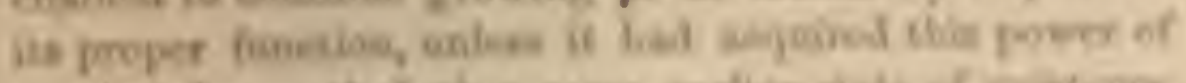

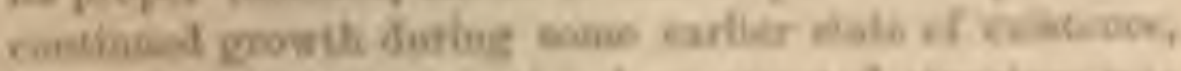

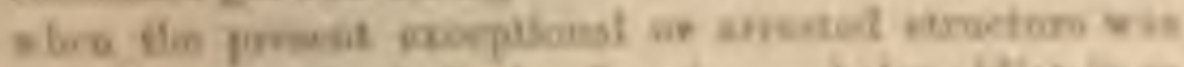

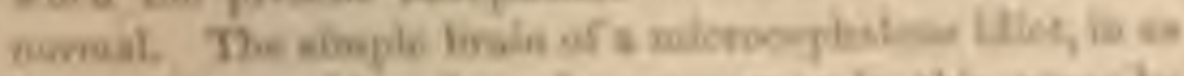

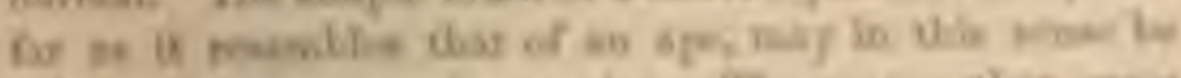

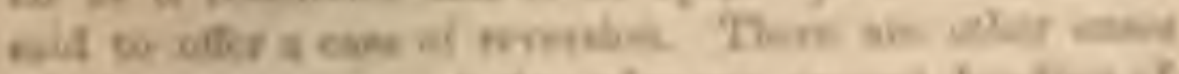

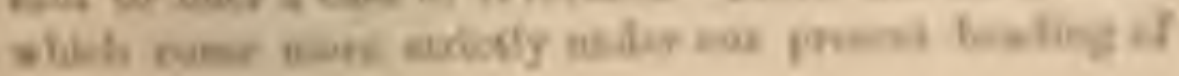


reversion. Cenain structures, regnlarly oceurring in the lower members of the group to which man belongs, veen. vionally make their appearance in him, though not found in the normal human embrgo; or, if preent in the sur. mal human embryo, they become developod in an ahnormal manner, thongh this manner of derclopment is proper to the lower members of the eame group. These remashs will be rendered clearer by the following illustration.

In various mammals the uterus graduates from a double orgau with two dietinct orifices and two pawages, an in the marsmpials, into a single organ, thowing uo vigus of doubleness erept a slight interual fult, as in the higher apes ant man. The rodents exhibit a perfect series of grailatious between these two extrene states. In all mamunals the nterus is dereloped from two kimple primitire tubes, the inferior portions of which furm the curnua; and it is in the worls of Dr. Farre "hy the coalesecence of the two cormua at their lower extremities that the boly of the utcrus is formed in man; while in those animaln in which no midlle portion or body existe, the cornua remain um. mited. As the derclopment of the uterus procects, the two cornua beconic gradually shorter, until at length they are lost, or, as it were, absorbed into the body of the utcrus." The angles of the uterus are still produced into cornua, cren so high in the scale an in the lower apes, and their allies the lemurs.

Now in women aumalous cases are not very infrequent, in which the mature. uterus is furnished with cormus, or is partially divided into two ongans; and such cates, according to Owen, repeat "thic grade of concentrative developucnt," attained by certain rodents. Here perhapis we have an iustance of a simple arrest of cmbryomc derclopment, with subseguent growth and perfoct functional derclopment, for cither side of the partially double utcrus is capable of performing the proper oflice 


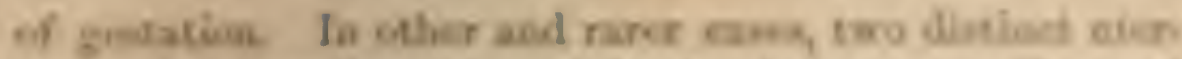

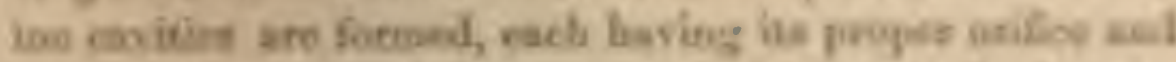
jomags" So ewhi wage in poumd thoogb dariog the

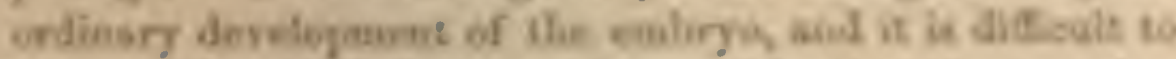

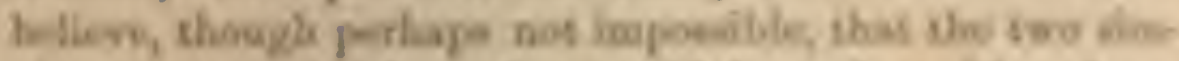

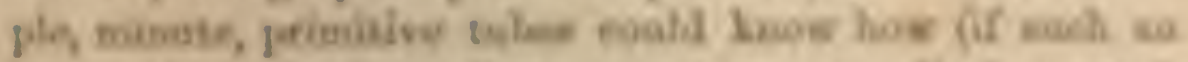

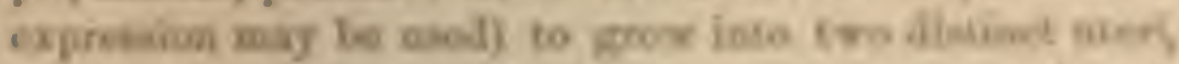

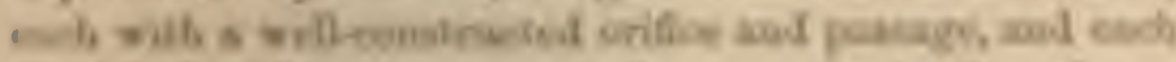

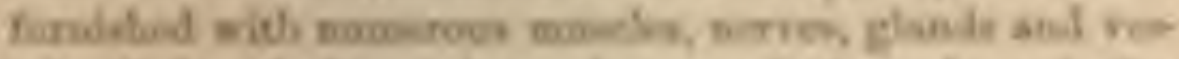

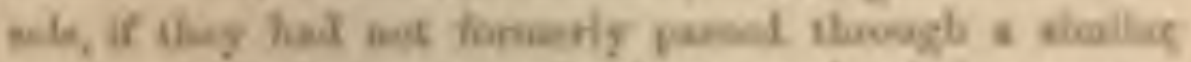

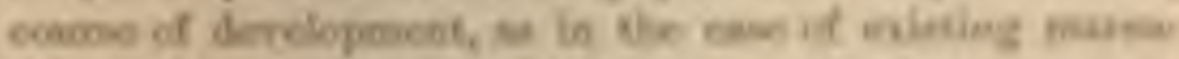

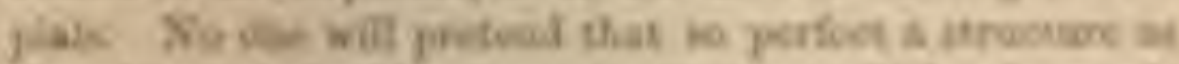

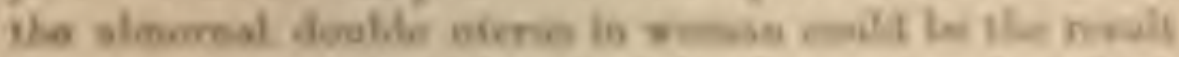

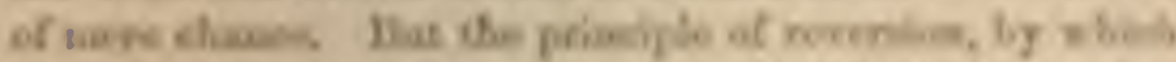

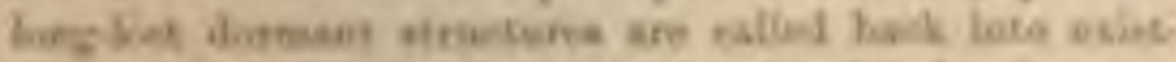
nub, wigh wro at be goile for the full derelogoms

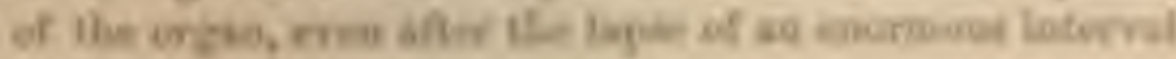
of bowe

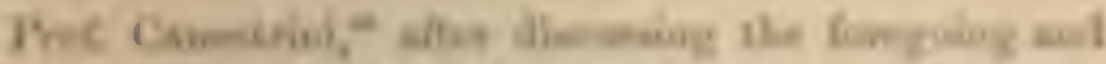

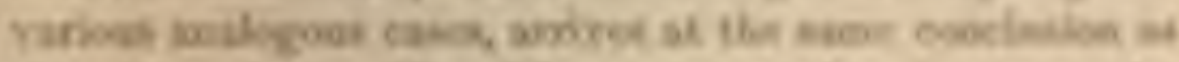

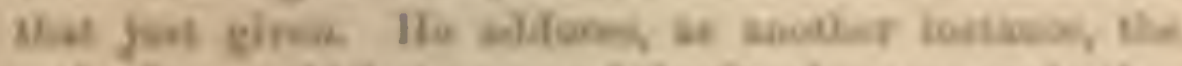

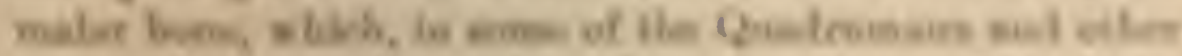

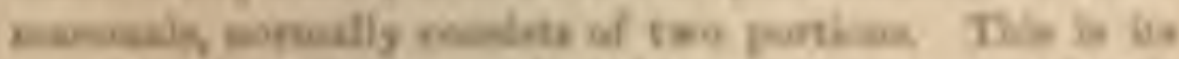

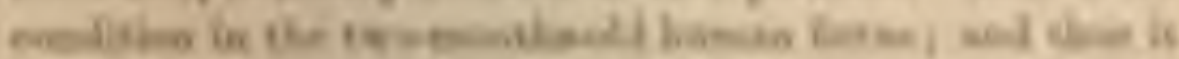

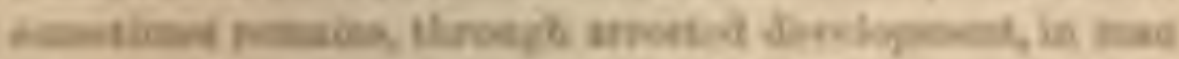

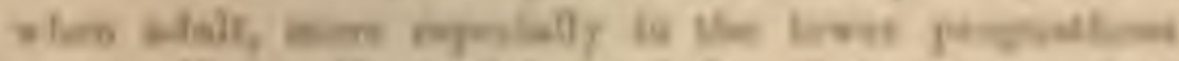

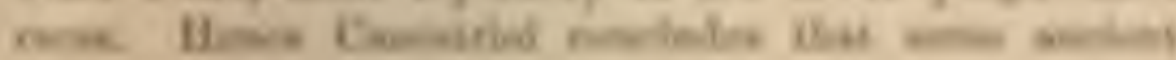

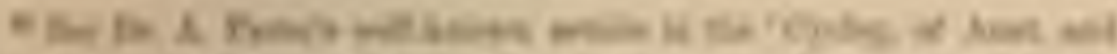

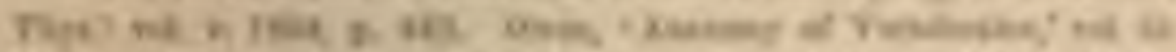

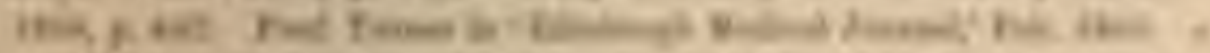

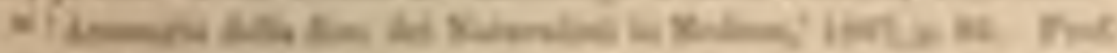

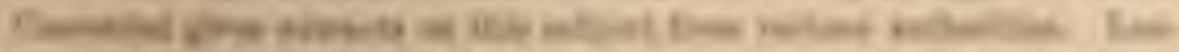

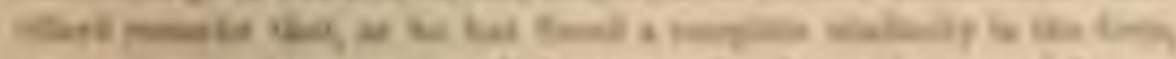

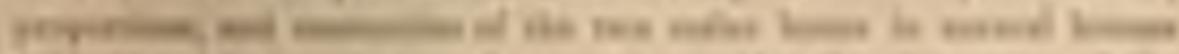

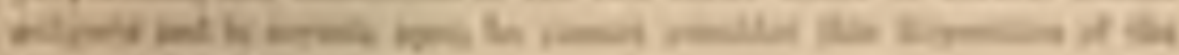

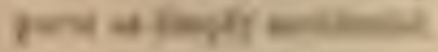


progenitor of man must hare posscased this lone normally divided into two portions, which subsequently becane fused together. In man the frontal bone cousists of a single piece, bnt in the embryo and in children, and in almost all the lower mammals, it consists of two picces suparated by a distinct suture. 'This suture occasiunally persists, more or less distiuctly, in man after maturity, and more frequently in ancient than in recent crania, especially as Canestrini has observed in those exlumed from the Drilt and belongiug to the brachycephalic type. Here agrain le comes to the same conclusion as in the analogrons case of the malar bones. In this and other instauces presently to be griven, the canse of ancient races apyloaching the lower animals in certain characters more frequently than do the molern races, appears to be that the latter stand at a somewhat greater distance in the long line of descent from their carly semi-human procrenitors.

Varions other anomalies in man, more or less analogrons with the turegroing, have been alvanced by ditfurent anthors ${ }^{37}$ as cases of reversion; lut these secm not a little donbtful, for we have to descend extremely luw in the mammalian scries before we find such structures norninally present. ${ }^{90}$

$87 A$ whole scries of eases is giren by Isid. Geofroy st.-Ilikire, 'Hist. des Anomalies,' tom. iii. p. $43 \%$.

${ }^{36}$ In my 'Variation of Animals under Domestication' (rol. ii. 1'. 5i) I attributed the not very rare enses of supernuncrary mamma in women to reversion. I was led to this as a probuble conclution, by the additionel mamma being generally placed synuetrically on the breast, and more (-) pecially frou one case, in which a siugle oficient mamma oecurrel in - the inguinal regrion of a woman, the daughter of anotler woman with ruperuunerary mamux. Iiut Prof. Preyer ('Der liamff un daa I)ascin,' $1869,8.45)$ states that mamme erratice luve hech hnown to oecur in other situations, eren ou the back; so that the forec of my aryument is greatly weakenet or perhaps quite deitroged.

With much lesitation I, in the sane work (1ol. ii., P. 12), attributcd the frepuent cases of polydactylism in mes to reversion. I was partly led 


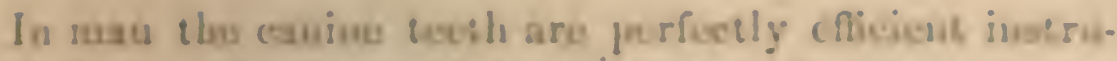
mones for mastication. But their true canine charscter, as 1)wos" remarka, "it inlicuted by the conical form of the cruwn, which terminatea in an obtuse point, it convex ousward and flat or subeoneare within, at the baee of which warface there it a feeble yrominence. 'The conical form in luen espreased in the Melanian races, especially the Ameraliars. The canine ia more deeply implaried, and by is atumger fase, that the iucinom." Neverlbalese this toulds so longer acrves man as a meetial weapon for teariag his

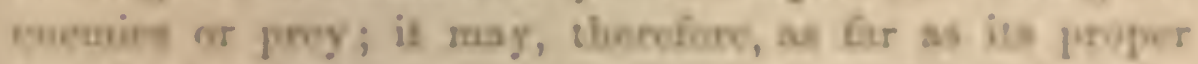
fanetion if comecrned, the comaliend a rodimewtary. In

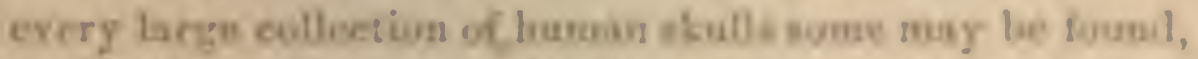
at Ifwhel " observes, with the eanise tecth projecing

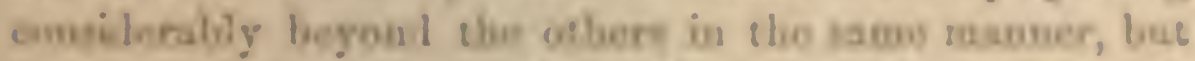

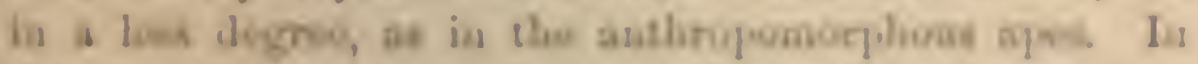
thase rass, opet paos becwers the teoth in the ore jow

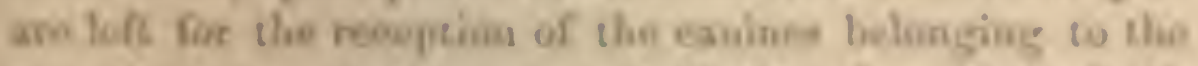

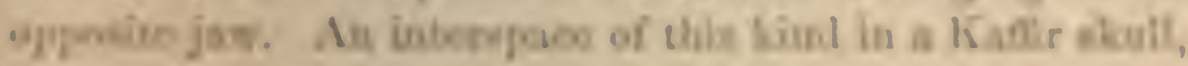

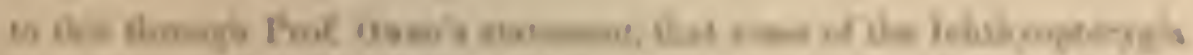

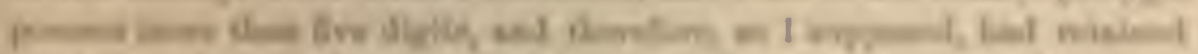

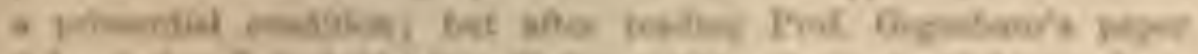

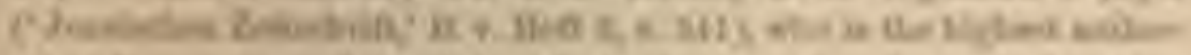

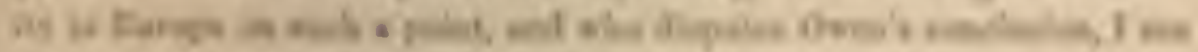

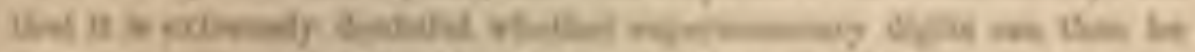

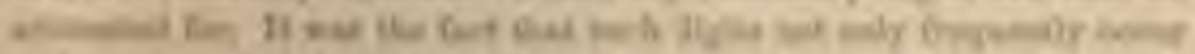

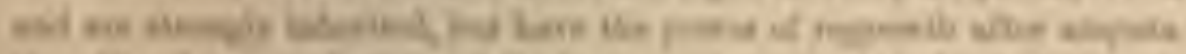

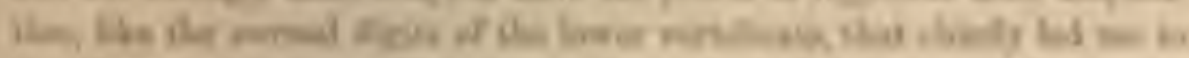

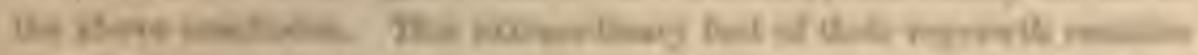

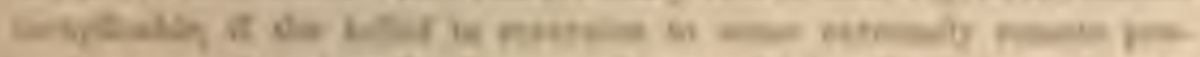

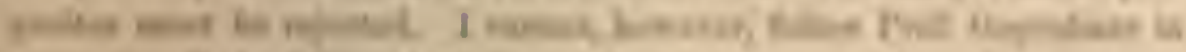

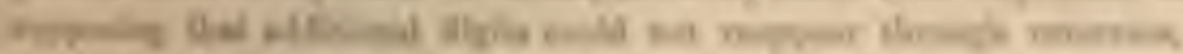

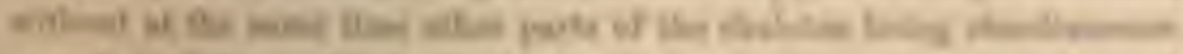

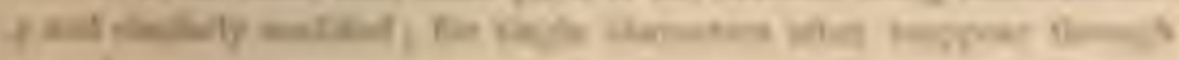
rexeslas

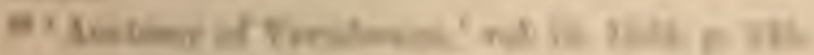

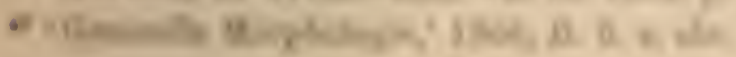


figured by Wagner, is surprisingly wide." Considering how few ancient skulls lave been examined in comparison with recent skulls, it is an interesting fact that in at least three cases the canines project largely; and in the Naulette jaw they are spoken of as enormous."

The males alone of the antliropomorphous apes have their canines fully dereloped; but in the female gorilla, and in a less degree in the female orang, these teeth projeet considerably beyond the others; therefore the fact that women sometimes have, as I have been assured, considerably projecting canimes, is no serious objection to the belief that their occasional great development in man is a case of reversion to an ape-like progenitor. He who rejects with scorn the belief that the shape of his own canines, and their occasional great development in other men, are due to our early progenitors having been provided with these formidable weapons, will probably reveal by suecring the line of his descent. For, though he no longer intends, nor has the power, to use these teeth as weapons, he will uncousciously retract his "suarling muscles" (thus named by Sir C. Bell)"s so as to expose them ready for action, like a dog prepared to fight.

Many muscles are occasionally developed in man, which are proper to the Quadrumana or other mammals. Professor Vlacovich" examined forty male subjects, and found a muscle, called by him the ischiopubic, in nineteen of them; in three others there was a ligament which represented this muscle; and in the remaining eighteen no trace of it. Ont of thirty female subjects this muscle was developed on both sides in only two, but in three

41 Carl Vogt's 'Iectures on Man, Fing. trantht. 1S61, p. 151.

4 C. Carter Blake, on a jaw from La Naulette, 'Anthropolog. Review, 156\%, p. 295. Schaamlausen, ihid. 1868, p. 426 .

"33 'The Anatomy of Expression,' 1814, Ip. 110, 131.

"s Quoted hy I'rof. Canestrini in the 'A muario,' ete., 1867, 1. 90. 
otlices the rudimentary ligancut was yresul. This musche, therefore, appears to be much unore common in the male than in the female sex; and on the principle of the descent of man from some luwer form, its presence ean le understood; fur, it has been deterted in sureral of the lower animals, and in all of these it serses csclunively to aid the male in the act of reproduction.

Mr. J. Wuod, in his valual, e nerica of papers," has minusely desoribed a ras musuler of muenlar rariations in man, which resemble ummal stractarve in the lowor snimals. Jooking only to the amedes w kieh dowly roonmble thene rngularly present in our nearot allies, the Quadrmana, tliog are too ntmeroub to be here even fpocifived. In a viugle thate suljech, hasing a atrong bodily frame and well formed skull, no lens than sescu ususeular variations were olerred, all of which plainly repreconed mosclea jroper to various hinds of apes. This man, for inatance, bad on beth silles uf his neck a true and powor. ful "ledoer clacioulin," such ax is fotud in all hisels of syos, and which is sail to eceur in shout une out af sisty lroman enlives." Agnir, thie man lad "a ppecial stduner of the metalarwal hene of the filld dighe, sael, as Prol. Jlixley and Mr. Flower lave whewn to val

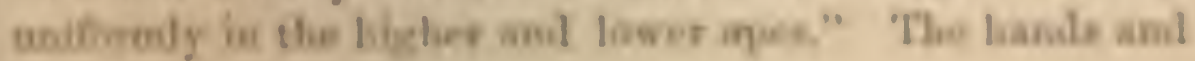

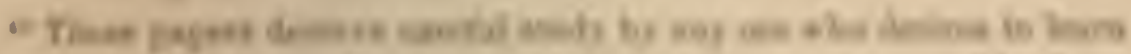

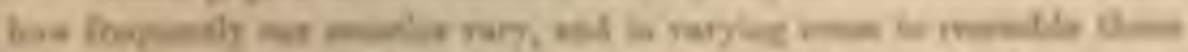

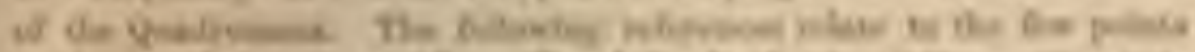

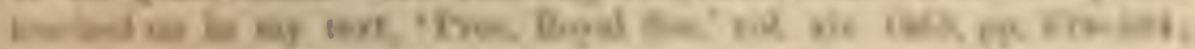

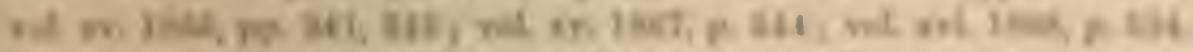

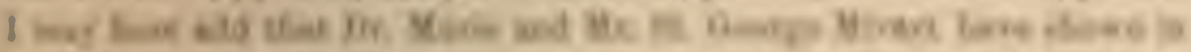

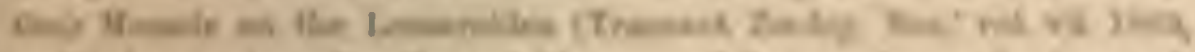

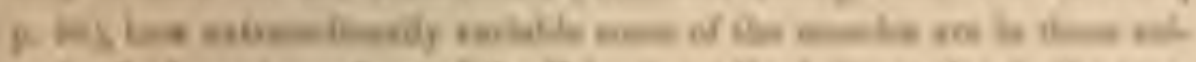

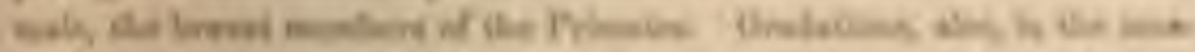

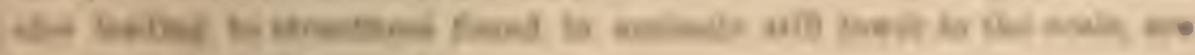

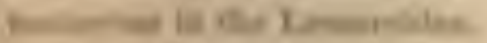

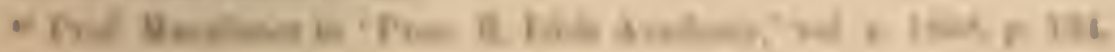


arms of man are eminently characteristic structures, but their unseles are extremely liable to vary, go as to resemble the corresponding unscles in the lower animals." Such rescmblances are either complete and perfect or inperfect, yet in this latter case manifetly of a transitional nature. Certain variations are more common in man, and ofhers in woman, without our being able to assign any reason. Mr. Wood, aficr describing numcrous cases, makes the following pregruant remark: "Notable departures from the ordinary type of the muscular structuren run in grooves or dircetions, which must be taken to indieate some unknown factor, of much importance to a comprelensive hnowledge of general and scientific anatomy." ".

That this unknown factor is reversion to a former state of existence may be almitted as in the highest degree probible. It is quite incredible that a man sliould through mere accident almormally rencmble, in no less than seven of his muecles, certain apes, if there had been no grenctic connection between them. On the other hame, if man is descended from some ape-like creature, no ralid reason can be arsigned why certain muscles should not

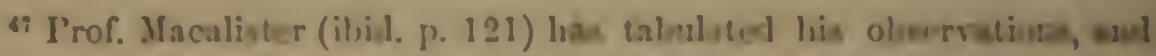

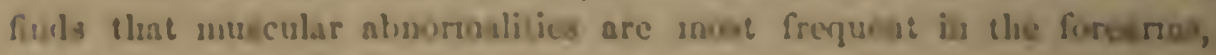
seooully in the face, thirt!ly in the foot, etc.

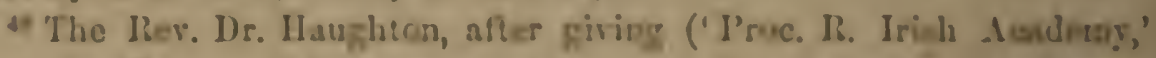

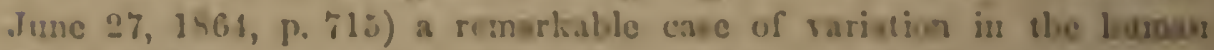

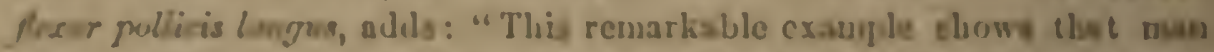

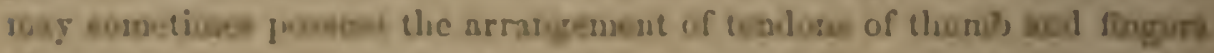

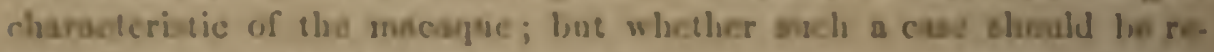

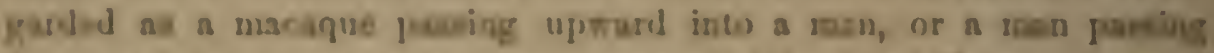

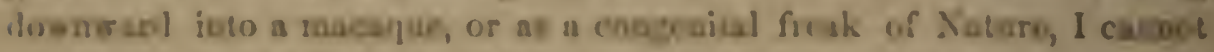

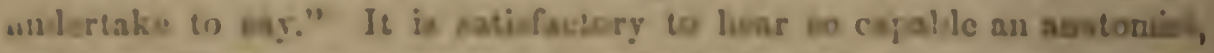

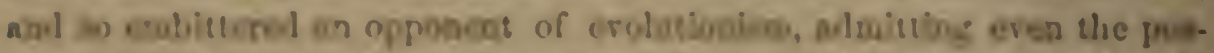

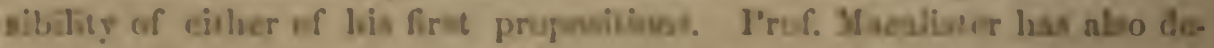

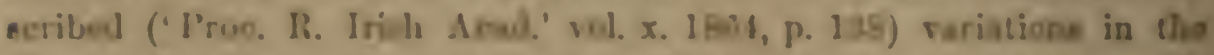

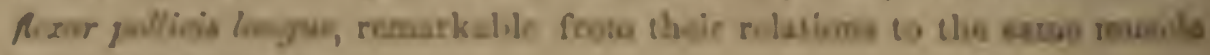
In tic Quadrumisa. 


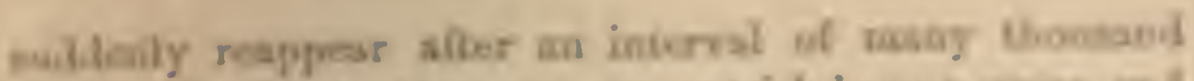
procratione, in ile name maboer an wieb bornes, sums, and

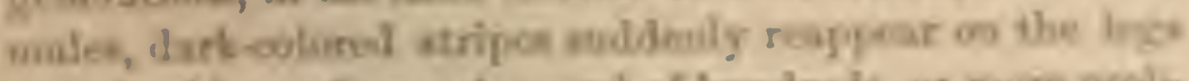

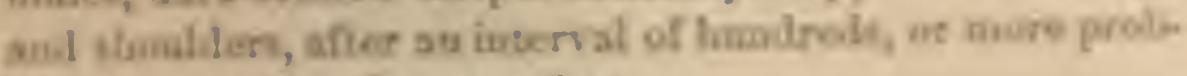
ably thouseds, of generatious.

The sarious cases of reverkiog aco wo eliats ntacod to thoe of rulinu mary orgase givew in tho font chaplet.

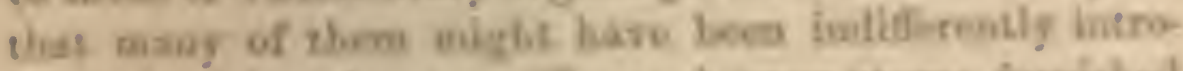

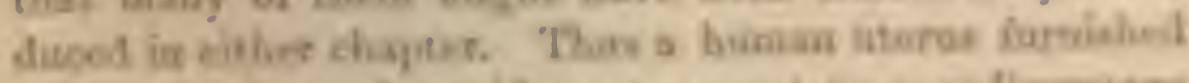

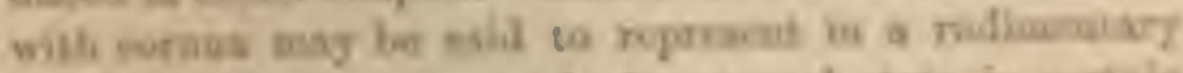

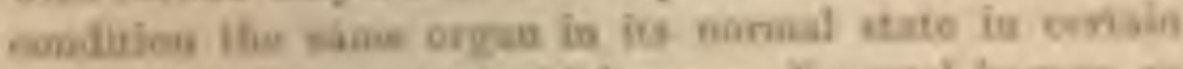

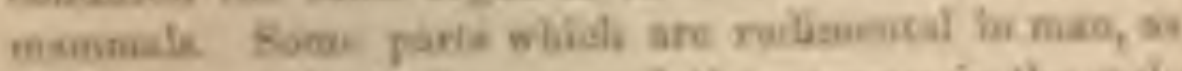

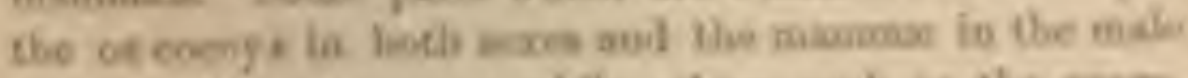

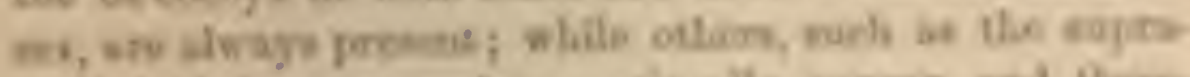

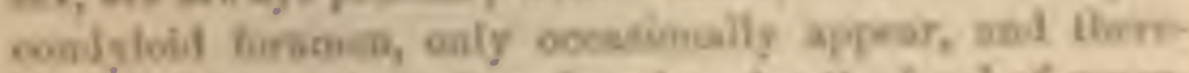

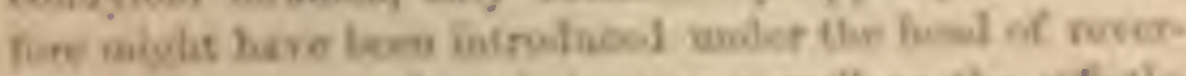

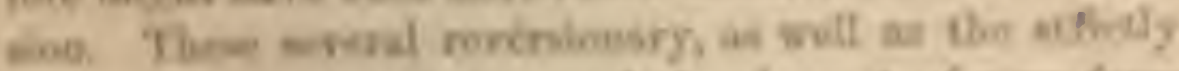

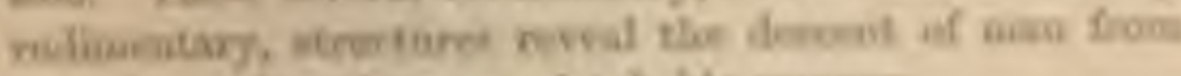

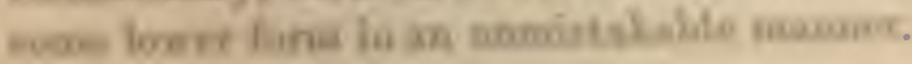

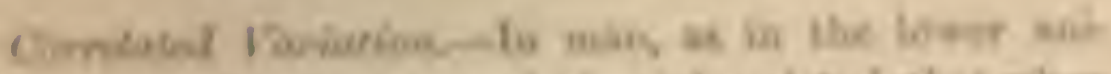

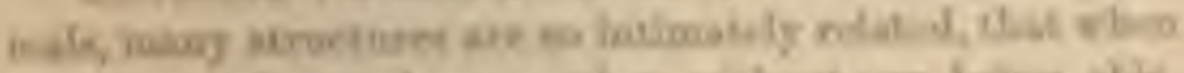

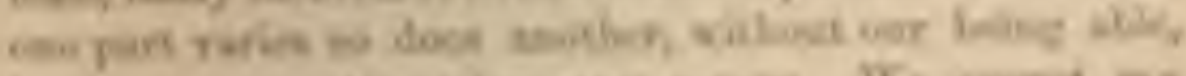

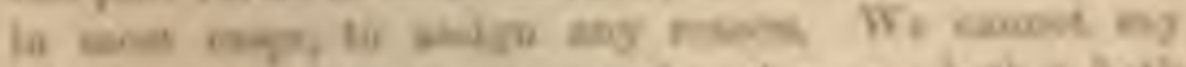

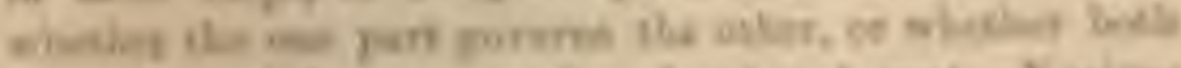

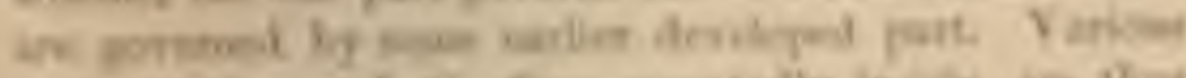

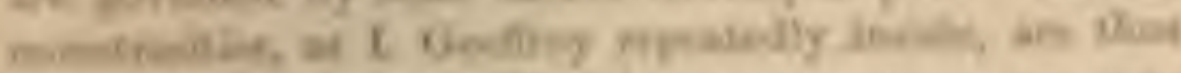

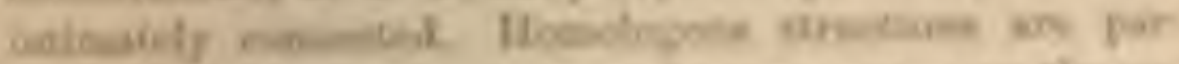

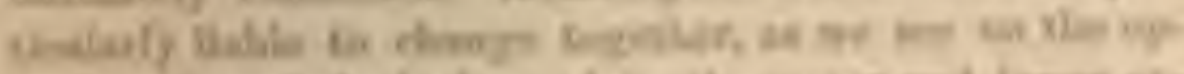

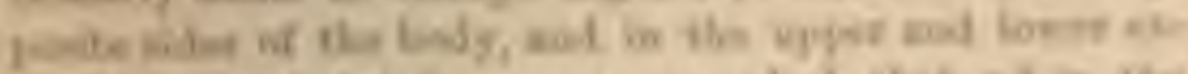

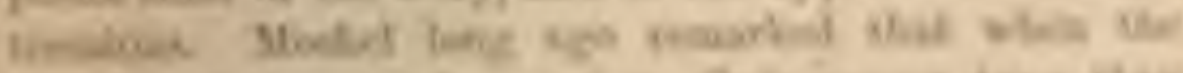

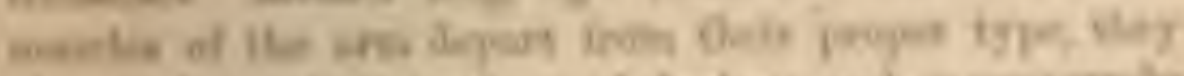

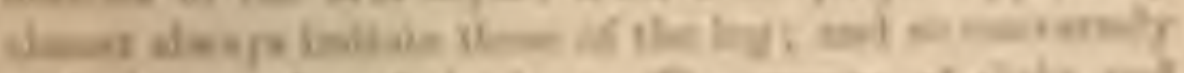

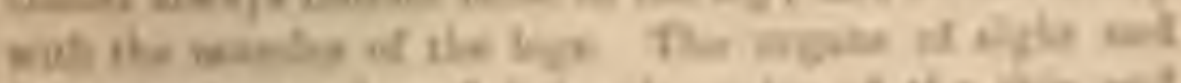

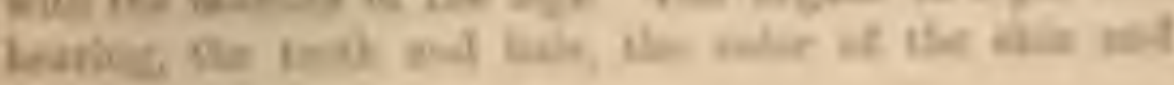


hair, color and constitution, are more or less correlated." I'rof. Schaaffhausen first drew attention to the relation apparently existing between a muscular frame aud strongly-pronoumeed supra-orbital ridges, which are so characteristic of the lower races of man.

besides the variations which ean be grouped with more or less probability under the foregoing heads, there is a large class of variations which may be provisionally called spontancous, for they appear, owing to our ignorance, to arise without any exciting cause. It can, however, be shown that such variations, whether consisting of slight individual differences, or of strongly-marked and abrupt deviations of structure, depend much more on the constitution of the organism than on the nature of the conditions to which it has been subjected. ${ }^{.6}$

Iiate of Inerease.-Civilized populations have been known under favorable conditions, as in the United States, to double their number in twenty-five years; and, according to a calculation by Euler, this might occur in a little over twelve years. ${ }^{61} \quad \Lambda$ the former rate the present population of the United States, namely, thirty millions, would in 657 years cover the whole terraqueous globe so thickly, that four men would have to stand op each square yard of surface. 'The primary or fundamental check to the continued increase of man is the difliculty of gaining subsistence and of living in comfort. We may infer that this is the case from what we see, for instance, in the United States, where subsistence is easy and there is

4) The authorities for these sereral statements are giren in my 'Varintion of Animals under Domestication,' rol. ii. pp. 320-335.

v) This whole sulject has been discussed in chap. xxiii. vol. ii. of $m y$ 'Variation of Animals and Plants under Domestication.'

${ }^{51}$ Sec the erer-memorable 'Essay on the l'rinciple of Population,' by the Rer. T. Malthus, vol. i. 1826, ply. ci, 517. 
plenty of room. If such means were suddenly doubled in Great Britain, our number would be quickly doubled. With civilized nations the above primary check acts chiefly by restraining marriages. The greater deatli-rate of infants in the poorest classes is also very importan; as wcll as the greater mortality at all ages, and from various diserses, of the inhabitants of crowded and mi:crable liouses. The effects of severe epidenices and wars are soon counterbalanced, and more than counterbalaneed, in nations pluced under favorable conditions. Einigration also comes in aid as a temporary clieck, but not to ang great crent with the extrenely poor cliteses.

Thire is reason (1) suspect, as Malelus laas remarked, that the reproductive power is actually less in harbaruus than in cirilized races. We know nothing positively on this licad, for witls sarages no census las been tahen; lut from the concurrent testimony of missionaries, and of others who hase long resided withs such people, it appears that their fomilios are tosully small, and large ones rare. Thin may be partly accounted forr, as it is belioved, by the women suchling their infants fur a prolongel

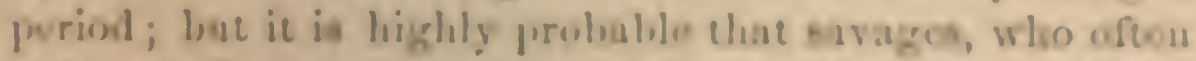

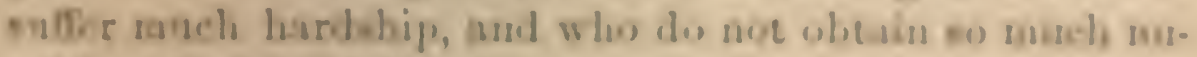

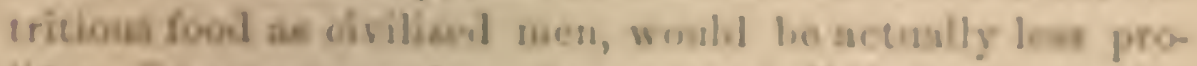
the. I leare sleown in a former work, " that all our de. mesticated gaailreju-ls and hirls, and all our coltiratod plasts, are roore fortilo thas the corrorponding species is a ente of nature. It is so ralid objectiot to this one-

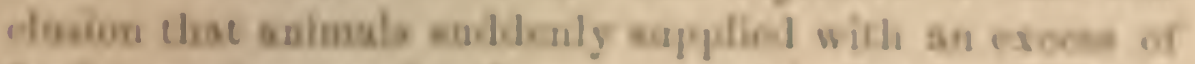
food, of when nondered iery fis, and that moes plasts

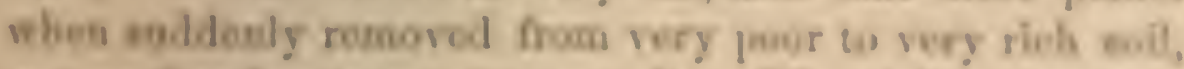

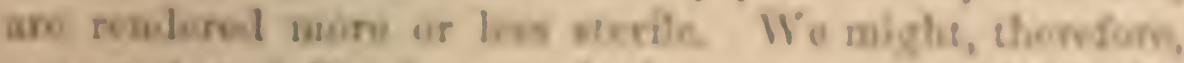

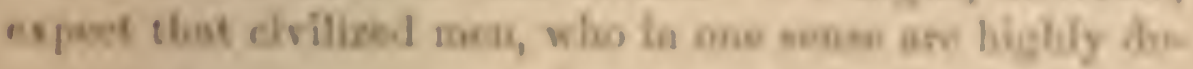

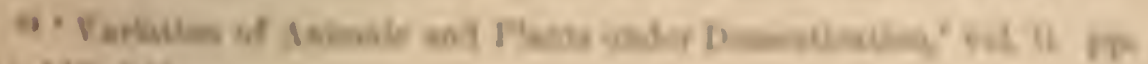
111,115, xas 
mesticated, would be more prolifie than wild men. It is also probable that the increased fertility of civilized nations would become, as with our dometic animals, an inlecrited character: it is at least known that with mankind at tendenoy to produce twins runs in families."

Notwithetanding that savages appear to be less prolilic than civilized people, they would no donbt rapidly increase if their numbers were not by some means rigidly kept down. The Santali, or hill-tribes of India, have recently atiorded a good illustration of this fact; for they hare increased, as shown by Mr. Innter, "at an extraordinary rate since raccination has been introduced, other pestilences mitigated, and war sternly repressed. This increase, however, would not have been possible hat not these rule people spread into the adjoining districts and worked for hire. Sirvages ahmost always marry; yct there is some prudential restraint, for they do not contmonly marry at the earliest possible age, The young men are often required to show that they can support a wife, and they generally have first to earn the price with which to purchase her from her parents. With savages the difliculty of obtaining sulsintence ocencionally limits their number in a mucls more direct manner than with civilized people, for all tribes periodically suffer from severe famines. At such times savages are forced to derour much bad food, and their health can hardly fail to be in. jured. Many accomts have been published of their protruling stomachs amd cmaciated limbs after and during lamines. They are then, also, compelled to wanter mueh abont, and their infants, as I was assured in Anstralia, perish in large numbers. As famines are periodical, defending chicfly on extreme seasons, all tribes must fluc-

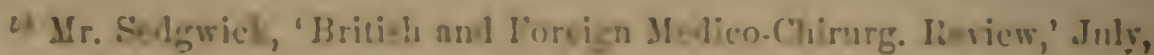
1563, p. 170.

" 'TLe Anuals of liural Isengal,' by W. W. IFunter, 15C8, P. $25 \%$. 


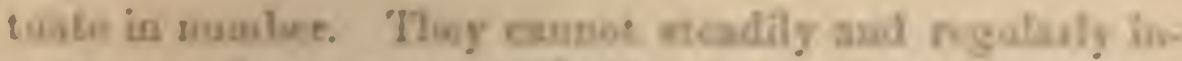
crean, an there in mo artilicisl incrome in the muply of

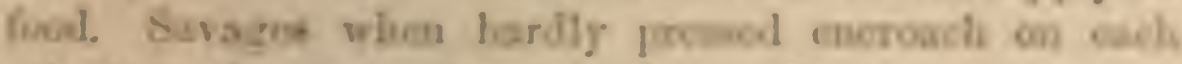
oflicril wrritorio, and war is ibe result ; bue they ser judied stroes afvays at war with their neighbors. They

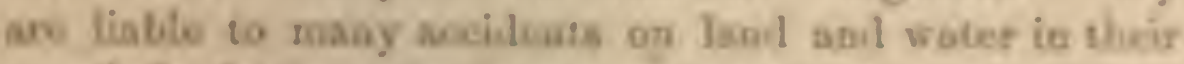
eserch for bond; abd in sowe countrics thoy mot suffir

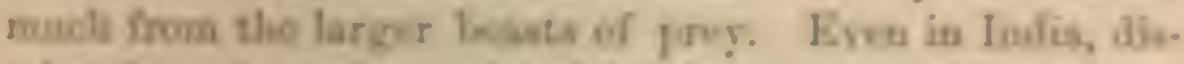
itits bave face depopulated by the raracua of tigors.

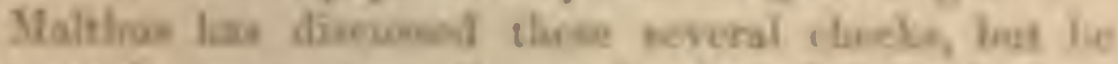

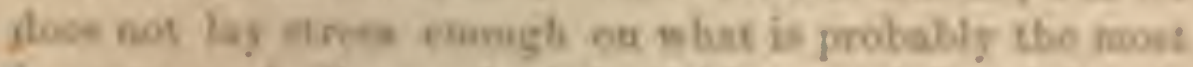
ienporase of all, namely infascicide, erpocially of beasth

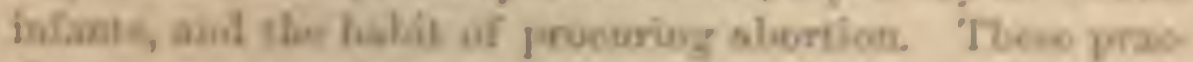

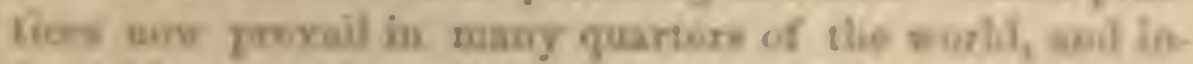

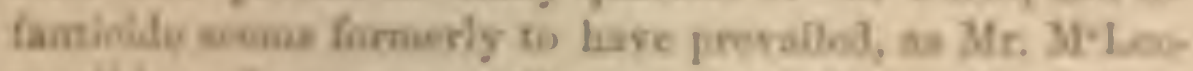
fanth hes sbown, on a vill more cetemive nealy. The

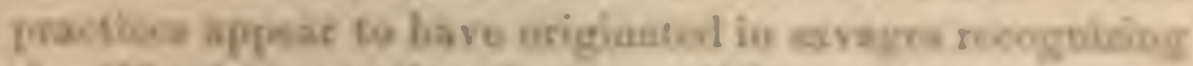

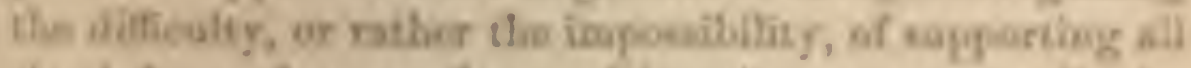
the infases that are haren. Lecotionement may abo te

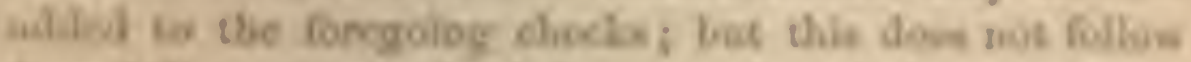

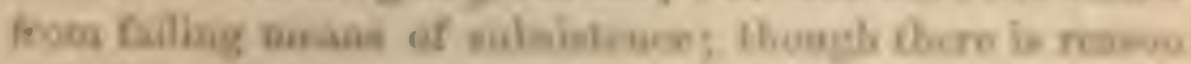

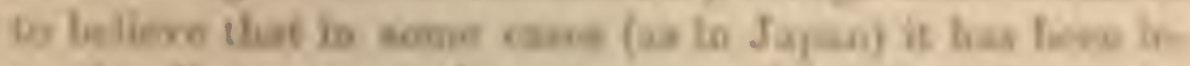

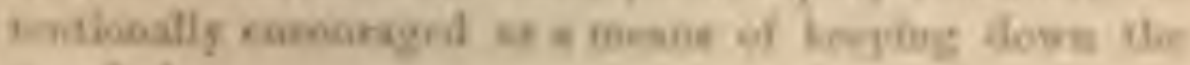
yeg alation.

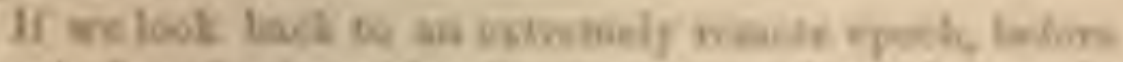

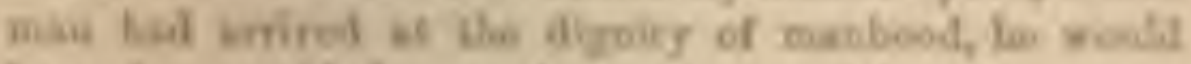

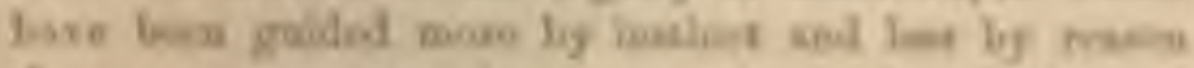

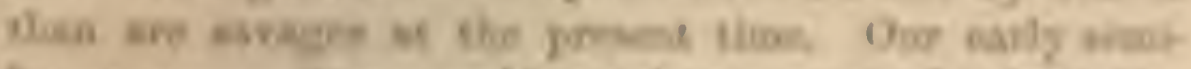

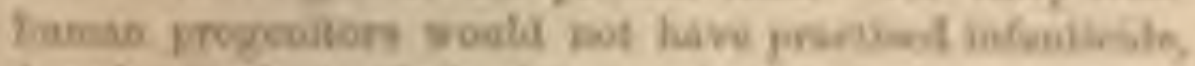

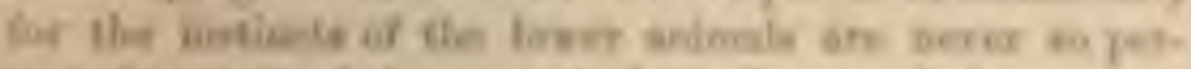

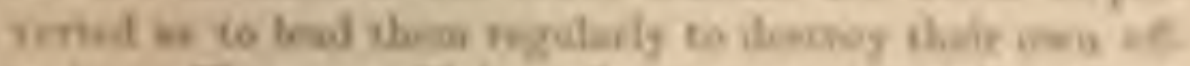

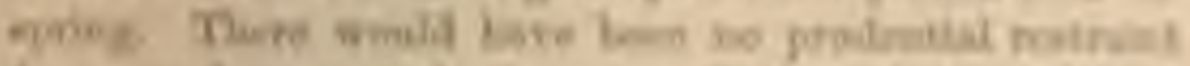

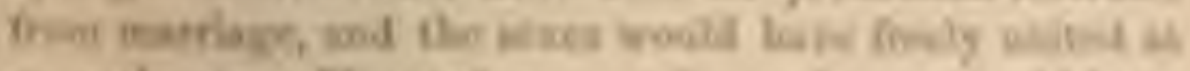

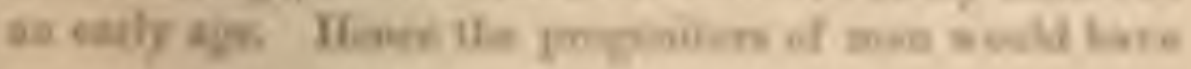

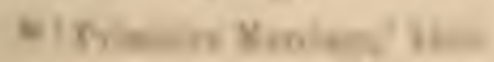


tended to inerease rapidly, but checks of some lind, either periodical or constamt, must liave kept down their numbers, even more sererely than with existing savages. What the precise nature of these checks may have been, we cannot say, any more than with most other animals. We know that horses and cattle, which are not highly prolific animals, when first turned loose in South America, increased at an cuormous rate. The slowest breeder of all known animals, namely the elephant, would in a few thousand years stock the whole world. The increase of every species of monkey must be clrecked by some means; but not, as Brelmm remarks, by the attacks of beasts of prey. No one will assme that the actual power of reproduction in the wild horses and eattle of America was at first in any sensible degree increased; or that, as each district became fully stocked, this same power was diminished. No doubt in this case, and in all others, many checks concur, and different checks under diflirent cirenmstances; periodical dearths, depending on unfavorable seasons, being probably the most inportant of all. So it will have been witl the early progenitors of man.

Nulurul Sulection.-We have now seen that man is variable in boly and mind; and that the rariations are induced, eitluer directly or indirectly, by the same general causes, and obey the same general laws, as with the lower animals. Man lras spread widely over the face of the cartlr, and must lave been exposed, during his incessant migrations, ${ }^{\text {to }}$ to the most diversified conditions. The inlabbitants of Tierra del Fuego, the Cape of Good Hope, and Tasmania in the one hemisphere, and of the Arctic regions in the other, must have passed through many climates and changed their labits many times, before they

4 See some good remarks to this eflect by W. Stanley Jerons, "A Deduction from Darwin's Theory," 'Nature,' 1869, p. 231. 
reached thir premen laswes." The esty pengersiturs of man mu*t alio have tencled, tile all oilier animale, to have

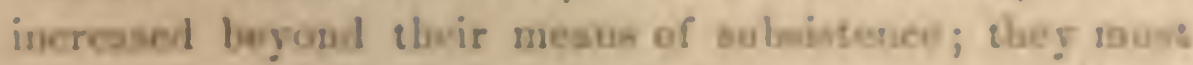
therufure oced ionall! hare been exponed to a smuggle for

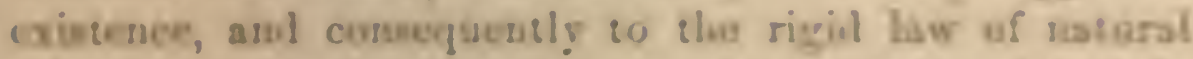
entresion. Penuficial variations of all binds vill thus, it ber ocesuionally ur labitually, bave leen proasrel, and injuriota ous climinated. I do not nefor to kengly-

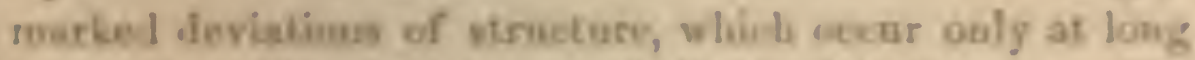
intervals of time, bat to mere fiulividual diffononos. We

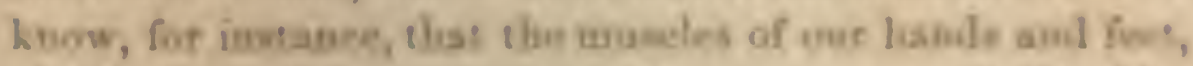
which determine our powere of movenent, are liables, like Howe of the lower animst," "2 inersasut variahilles. If, then, the apelike progenitoce of mas whiob inbabtiol ang

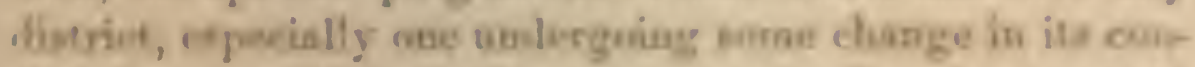
ditions, were divided into two oqual bodles, tbe oue bate

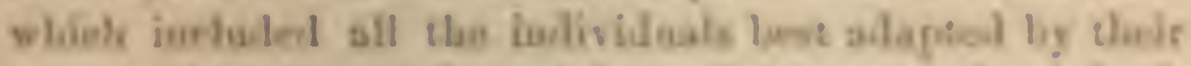

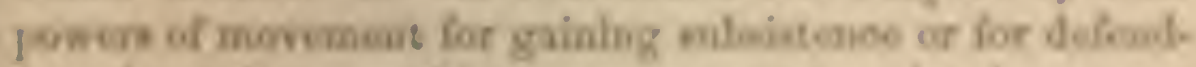

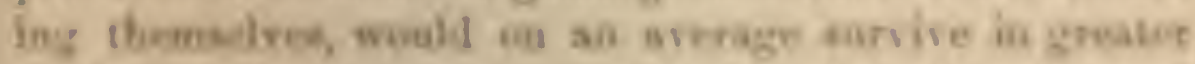
mambir and prowreate more -oflopring than tho ofbor abel Ires wellewlewel hall

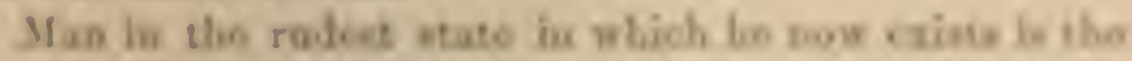

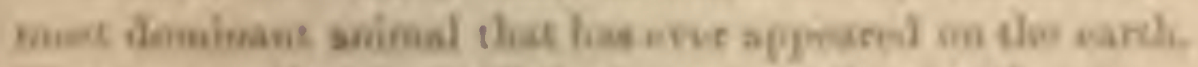

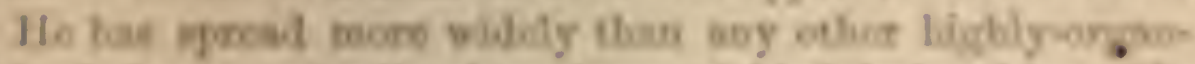

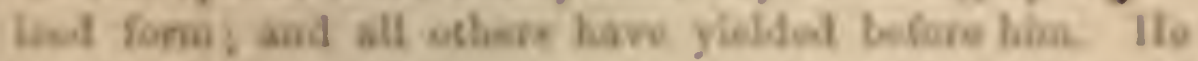

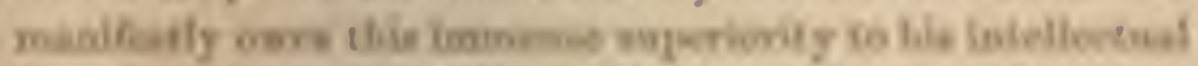

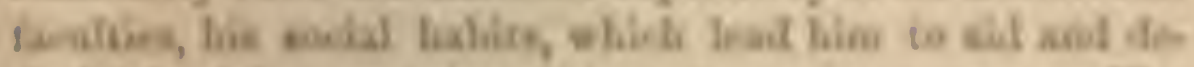

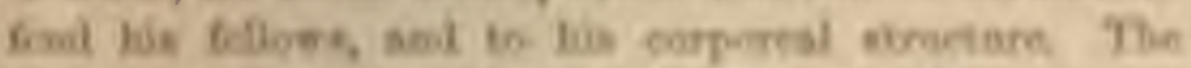

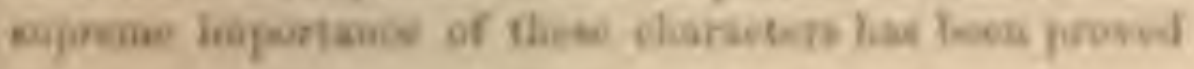

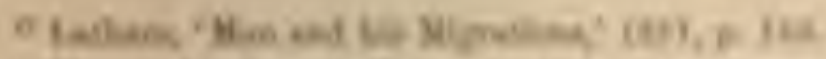

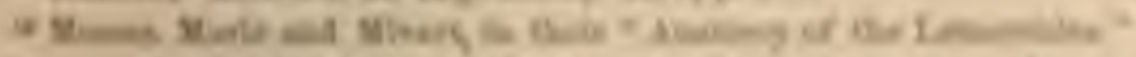

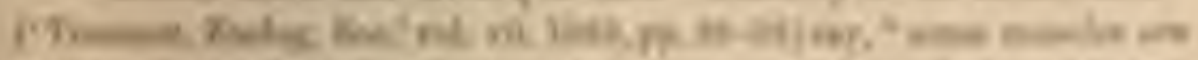

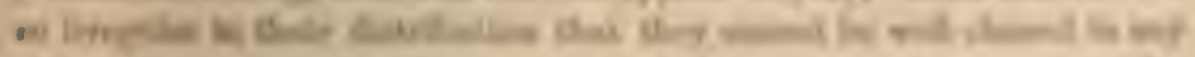

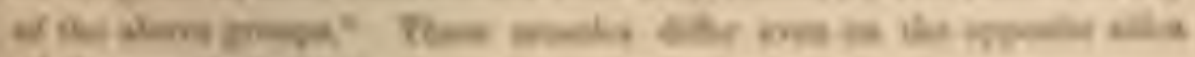

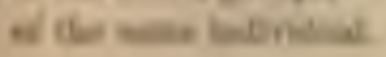


by the tinal arbitrament of the battle for life. Through his powers of intellect, articulate language las been crolved; and on this his wonderful advancement has minimly depended. If has invente? and is able to use various weapons, tools, trapse, cte., with which he defents himself, kills.or catches prey, and otherwise obtains fool. IIe has made rafts or camoes on which to fish or cross over to neighboring fertile islands. IIe has discovered the art of making fire, by which hard and stringy roots can be rendered digestible, and poisonous roots or herbs innocuous. This last discorery, probably the greatest, excepting language, ever male by min, dates from before the dawn of histury. These sereral inrentions, by which min in the ruclest state has become so preëminent, are the direct result of the derelopment of his powers of observation, memory, curiosity, imagrination, and reason. I camot, therefore, understand how it is that Mrr. Wallice ${ }^{\text {on }}$ maintains, that "natmal selection could only have cndowed the savage with a brain a little superior to that of an ape."

Although the intellectual powers and social habits of

"9 '(Quarterly lieviow, April, 1869, 1). 392. This subject is wore fully di cuesed in Mr. Wullace's 'Coutributions to the Theory of Natural Sclution,' 1570, in which all the essavs referred to in this work are sepublished. The 'Essay on Jan' lais been ably criticised by Prof. Clapa. rèle, one of the most distinguislıed zoologists in Europe, in an articlo published in the 'Bibliotheipue Universelle,' June, 18\%0. The remark quoted in ing tert will surprise every one who has read Ifr. Wallacc s celebrated paper on "The Origin of Hunan liaces deduced from the Theory of Natural Selection,' originally publinlied in the 'Antliropolozic.ll licview; May, 1864, p. clriii. I cansot licre re.i=t quoting a mo $t$ just runark by Sir J. Iubbock ('Irchistoric Tinca,' 1565, p. 179) is reference to this paper, namelr, that Mr. Wallace, "with claracteritic useclfulınes, a cribes it (i c., the ilca of natural selectiou) unretervedly to Mir. Jawiu, although, as is well hnown, lie struck out tho ilea iul. pesulestly, aus pullislued it, thou fo not with the saue chabration, at the same tiuc." 
man afe of paramurst importance to his, we gaus so: unilernte t!in importassee of this bodily struceurs, to which valjest the romsisiles of this chapter will he deroted. The derclopment of tles intellectasl $\operatorname{sen}$ socisl or maral foculties will be divensed in the followiog elaiptor.

fipen to hasumer will grocikion is sia eas mater, ah evry ove who has tried to leart carponery will alwai? To throw a nope wisb an troe an uim os eas a Kurgisn hu dofoudiag himedf, or in killing hirkls, requires tho bost ceseumanate perfaction in the corcelatel actios of tho

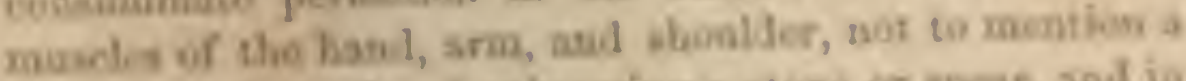

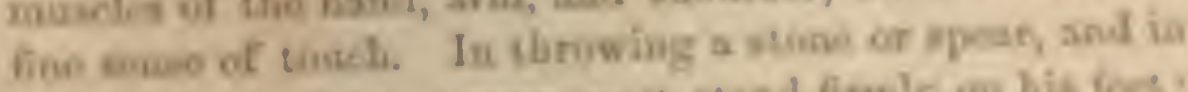
many velier acvious, a man rouls nand fruly ow hiv fors: wat thit segin domasds the perfore anduptation of no-

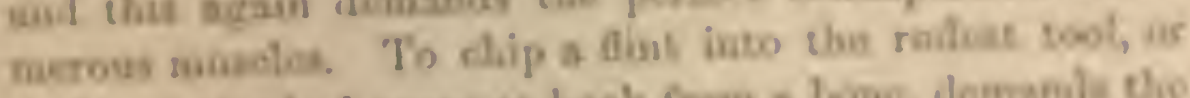

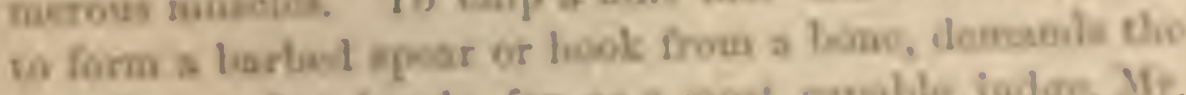
now of s purfice band; for, an a mone cupalle jodge, Mf.

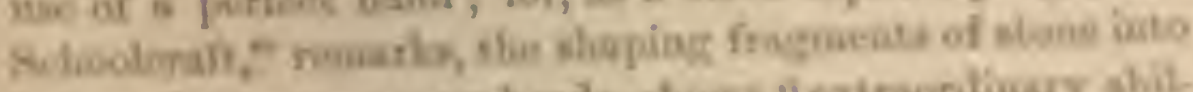

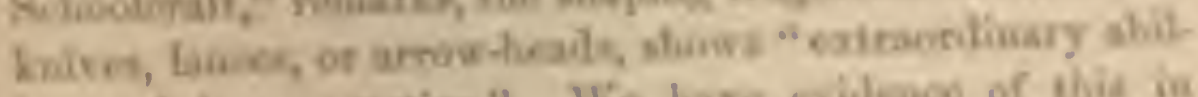

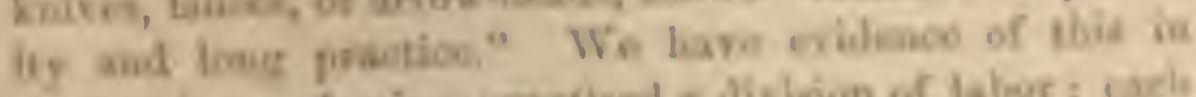

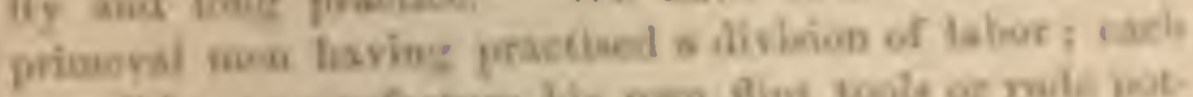

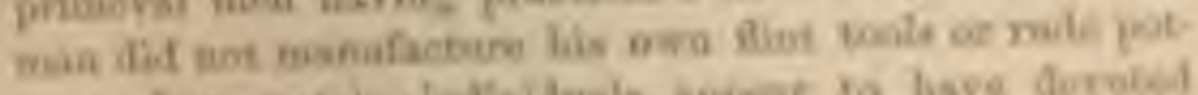

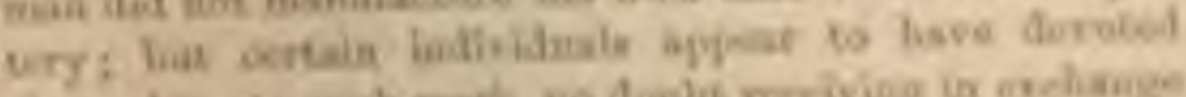

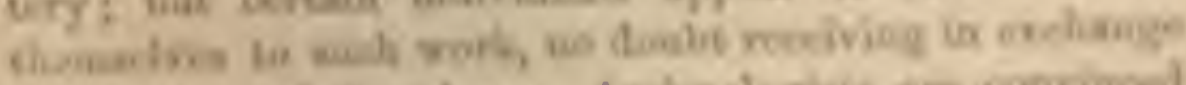

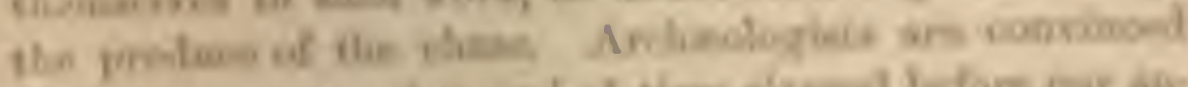

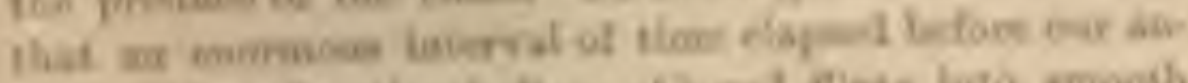

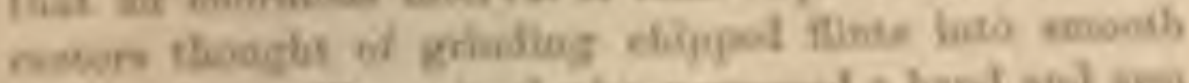

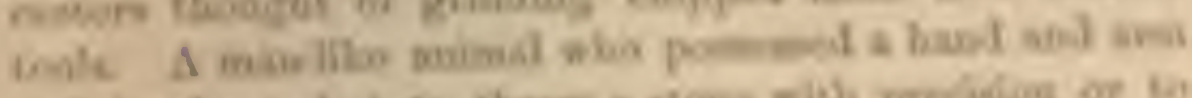

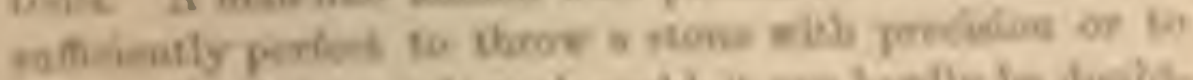

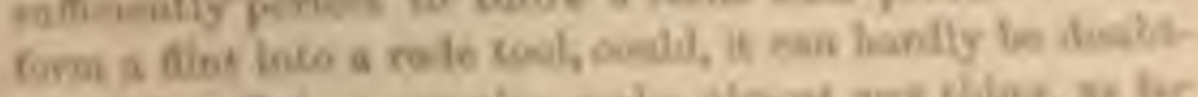

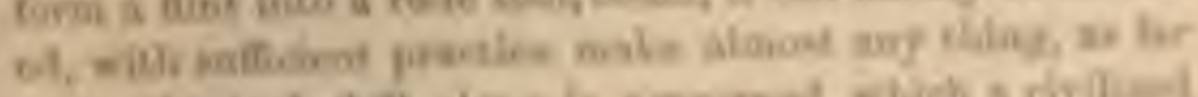

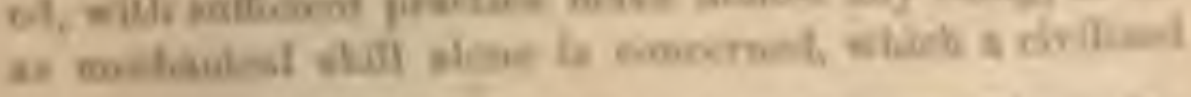

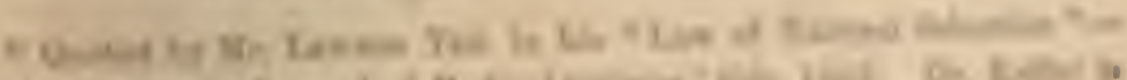

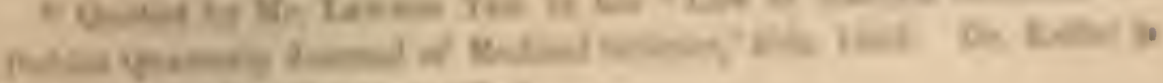

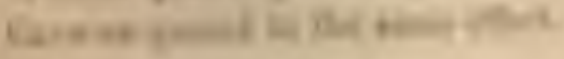


man can make. The structure of the hand in this respect may be compared with that of the rocal orgars, which in the apes are used for uttering various signal-cries, or, as in one species, musical cadences; but in man closely similar rocal organs have become adapted through the inherited effects of use for the uttcrance of articulate lauguage.

Turning now to the nearest allies of man, and therefore to the best representatives of our early progenitors, we find that the hands in the Quadrumana are constructed on the same general pattern as in us, but are far less perfectly adapted for diversified uses. Their hands do not serve so well as the fect of a dog for locomotion; as may be seen in those monkeys which walk on the outer margins of the palms, or on the backs of their bent fingers, as in the chimpanzee and orang. ${ }^{01}$ 'Their hands, however, are admirably adapted for climbing trees. Monkeys seize thin branches or ropes, with the thumb on one side and the fingers and palm on the other side, in the same manner as we do. They can thus also carry rather large objects, such as the neck of a bottle, to their mouths. Baboons turn over stones and scratch up roots with their hands. They seize nuts, insects, or other small objects, with the thumb in opposition to the fingers, and no doubt they thus extract eggs and the young from the nests of birds. American monkeys beat the wild oranges on the branches until the rind is cracked, and then tear it off with the fingers of the two hands. Other monkeys open mussel-shells with the two thumbs. With their fingers they pull out thorns and burs, and hunt for each other's parasites. In a state of Nature they break open hard fruits with the aid of stones. They roll down stones or throw them at their enemies; nevertheless, they perform these various actions clumsily, and they are quite unable, as I have myself seen, to throw a stone with precision.

${ }^{62}$ Orren, 'Anatomy of Vertebrates,' vol. iii. P. 71. 
It seems to me far from true that becauso "oljects are grasped clumsily" by monheys, "a much less specialized organ of prehension" would have served them "as well as their present hands. On the contrary, I sec no reason to doubt that a more perfectly constructed hand would have been an advantage to them, provided, and it is importint to note this, that their hauds had not thus been rendered less well adapted for climbiug trecs. We may suspect that a perfect hand would have been disodvantaencous for climbing; as the most arboreal monkeys in the world, namely Ateles in America and Iylobates in Asia, either have their thumbs much relueed in size and even rudimentary, or their fingers l'artially colverest, no that their hands are conserted into mere graspinghooks."

As soon as some ancient member in the great series of the Primates came, owing to a change in its manner of frocuring subsistence, or to a change in the conditions of its uative country, to live somowhat less on trees and more on the grouml, its manuer of progreseion would have ber n modified; and in this case it would hare had to boconce cether more stricty quadrupedal ur hipedal. lia. hoots frequent hilly and rocky dietriets, and only from nowemity climb up high trees; " and they have acyuiral elmont the gait of a dog. Mun alone lus becomo a biped;

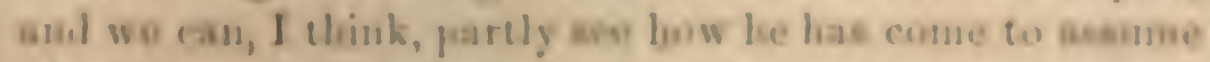
bie crect attitude, which forms one of tho mon compries.

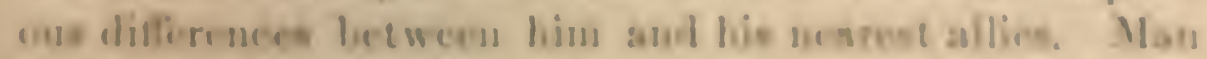
could not bare actained lis present domisme postion is the roetl without the the of lis hands, which are no ad.

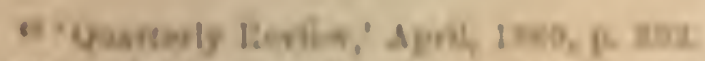

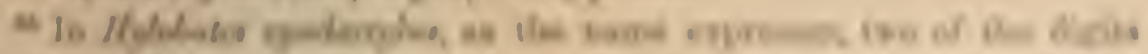

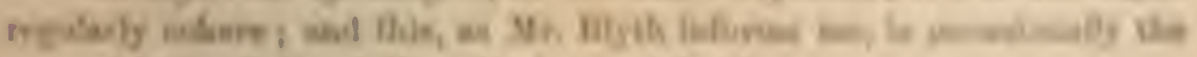

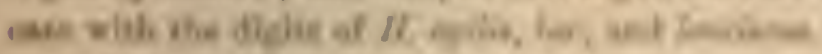

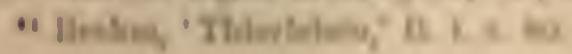


mirably adapted to act in obedience to his will. $\Delta$ s Sir C. Bell ${ }^{\circ}$ insists, "the land supplies all instruments, and by its correspondence with the intellect gives him universal dominion." But the hands and arms could hardly have become perfect enough to hare manufictured weapons, or to have hurled stones and spenes with a true aim, as long as they were habitually used for locomotion and for supporting the whole weight of the body, or as long as they were especially well adapted, as previously remarked, for climbing trees. Such rough treatment would also have blunted the sense of touch, on which their delicate use lingely depends. From these causes alone it would liave heen an advantage to man to have become a biped; but for many actions it is almost necessary that both arms and the whole upper part of the body should be free; and he must for this end stand firmly on his fect. 'To gain this great advantage, the fect hare been rendered flat, and the great-toe peculiarly modified, though this has entailed the loss of the power of prehension. It accords with the principle of the division of physiological labor, which prevails throughout the animal kingdom, that, as the hands became perfected for prehension, the feet should have become perfected for support and locomotion. With some savages, however, the foot has not altogether lost its prehensile power, as shown by their manner of climbing trees and of using them in other ways. ${ }^{\text {"o }}$

If it be an advantage to man to have his hands and

es "The H:und, its JIcchani:m," etc. 'Brilgewater Treatisc,' 1S33, 1. 38.

68 IIickel lias an excellent discussion on the step̧s by whicis man became a biped: 'Natürliche Schüpfungsgeschichte,' 1S68, s. 507. Jr. Büclner ('Conférenees sur la Thćoric Darwinicnic,' 1S69, p. 135) has giren good cases of the use of the foot as a prehensile organ by man; also on the mauner of progression of the higher apes to which I allude in the following pararraph : see also Owen ('Inatomy of Vertelurates,' rol. iii. p. 71 ) on tlis latter subject. 
arms free and to atand firmly on his feet, of which there can be to doulut from lis prcünincut suecess in the battle of life, then I can see no reason why it should not have becu alvantageous to the progenitors of man to have become more and more crect or bipedal. 'They wombl this have beca better able to have defended themselses with stones or clubs, or to have attached their jory, or atherwisc obtained food. 'Tlıe best-constructed individuals would in the long-run lave succected licst, and have survivel in larger vumbers. If the gorilla and a few allied furms had become extinct, it might have been argued with great force and appareut truth, that an animal could not fave bexu gralually couverted frotu a qualruped into a bipel; as all the individuals in an intermedinte conditun would have been miscrably ill-fited for progeresion. bin we know (and this is well worthy of reflection) that serral hinds of apes are now acenally in this ivermediace condicion; and un one douber that they are on the whoble well alupted for their conditions of life. 'Thus the gorills runs witls a sidelong shambling gait, lut suore consunuly progroses by resing on its bemt hosnde. Tho longe-arowed afres ceeasionally une their surmb like crutedors, sw ioging thir bodies forward betweon them, and souse kinds of

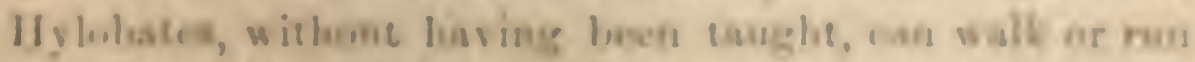

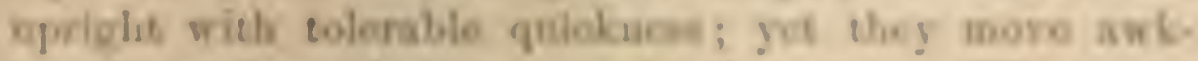

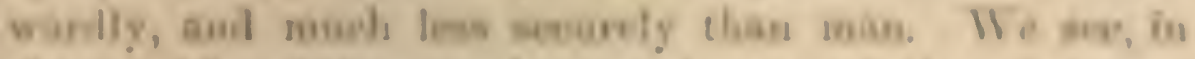
soor, with exlating monkege nrinu gralations lectwen I form of prochosim sifiedy likr elise of a itusdropol anel that of a lifpel or man.

As the proyenitors of man bocams more and more

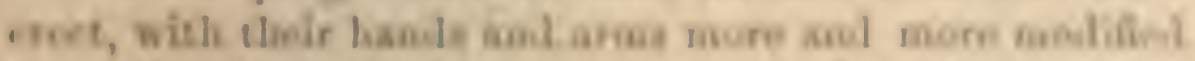

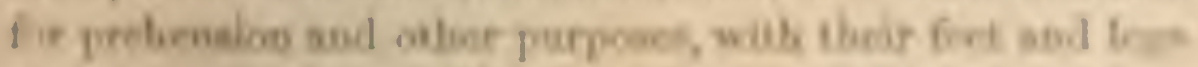

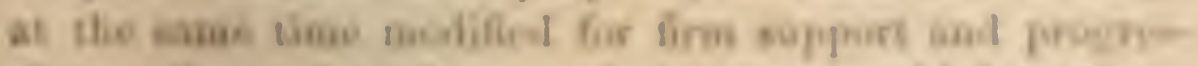

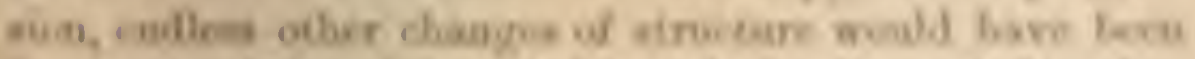

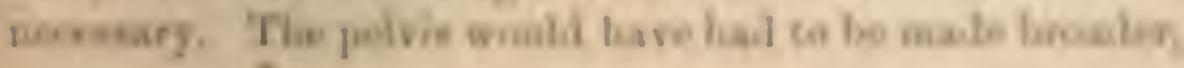


the spine peculiarly curved and the head fixed in an altered position, and all these changes have been attained by man. Prof. Schaafthausen ${ }^{87}$ maintains that " the powerful mastoid processes of the human skull are the result of his erect position;" and these processes are absent in the orang, chimpanzee, etc., and are smaller in the gorilla than in man. Various other structures might here have been specified, which appear connected with man's crect position. It is very difficult to decide how far all these correlated modifications are the result of natural sclection, and how far of the inherited effects of the increased use of certain parts, or of the action of one part on another. No doubt these meaus of change act and react on each other: thus when certain muscles, and the crests of bone to which they are attached, become enlarged by habitual use, this shows that certain actions are habitually performed and must be serviceable. Hence the individuals which performed them best, would tend to survive in greater numbers.

The free use of the arms and hands, partly the cause and partly the result of man's erect position, appears to have led in an indirect manner to other modifications of structure. The early male progenitors of man were, as previously stated, probably furnished with great canine tecth; but as they gradually acquired the habit of using stones, clubs, or other weapons, for fighting with their encmies, they would have used their jaws and tecth less and less. In this case, the jaws, together with the tecth, would hare become reduced in size, as we may feel sure from innumerable analogous cases. In a future chapter we bhall meet with a closely-parallel case, in the recluction or complete disappearance of the camine tecth in male rumi-

6: "On the Primitive Form of the Sliull," translated in "AnthropioIogrical Reriew;' Oct. 1868, p. 428. Owen ('Anatomy of Vertebrates,' rol. ii. 1866, p. 551 ) on the mastoid processes in the higher apes. 
nants, apparenty in relation with the development of their horns; and in horses, in relation with their habit of tighting with their incisor tects and hoofs.

In the adult male anthropomorplious apes, as liarimeyer, ${ }^{e s}$ and others have insisted, it is precisely the effect which the jaw-muscles by their great developuncnt have prodneed on the skull, that causes it to diflier so greatly in mamy respects from that of. man, and has given to it "a truly frighteful physinguomy." 'Therefore, as the jaws and tecth in the progenitors of man gralually become renlucel in siz, the alult skull wouhl have presented nearly the same characters which it oflirs in the young of the anthropomorplious apese, and would thus have come to rescuble more nearly that of rexisting man. A great relnction of the camine tecth in the males wombl almost certainly, as we shall hereafter sec, have aflected through inheritance the teeth of the fumales.

As the various mental faculice have gradually aleroloped, the lorain would almost rertainly have become larger. Ni) once, I presume, doubts that the larere size of the brain in man, relatively to his boly, in comparison to that of the gorilla or orang, is elosely comseced with his ligher montal powern. We meet with elomelyoumbgous fisea with insera, in which she cerrliral panflis are of extmomlinary dimopsions in atote; there ganglia in all the Iymunglera being unar times larger than in tha los in. telligut ordors, wuh an beotea." (In the nilier lased, wo

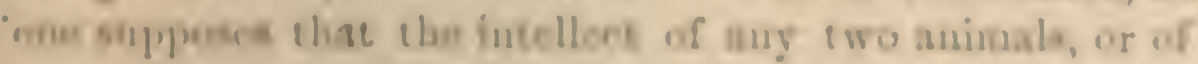

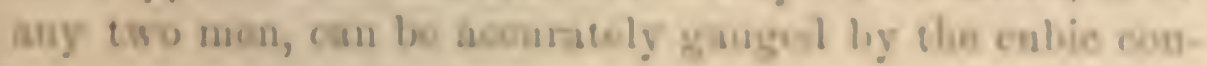

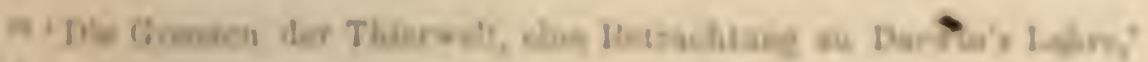
1 iscas, ob.

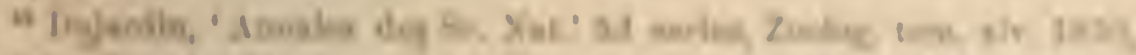

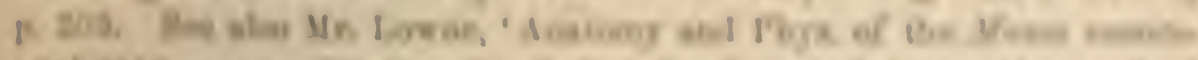

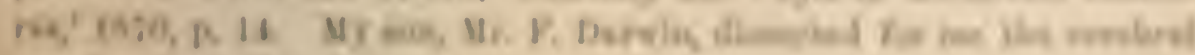

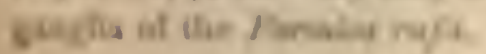


tents of their skulls. It is certain that there may be extraordinary mental activity with an extremely small absolute mass of nervous matter; thus the wonderfully diversified instincts, mental powers, and affections of ants, are generally known, yet their cerebral ganglia are not so large us the quarter of a small pin's head. Under this latter point of view, the brain of an ant is one of the most marvellous atoms of matter in the world, perhaps more marrellous than the brain of man.

The belief that there exists in man some close relation between the size of the brain and the development of the intellectual faculties is supported by the comparison of the skulls of sarage and civilized races, of ancient and modern people, and by the analogy of the whole vertebrate series. 1).. J. Baruard Davis has proved ${ }^{70}$ by many careful measurements, that the mean internal capacity of the skull in Europeans is 92.3 cubic inclies; in Americans 87.5; in $\Lambda$ siatics $8 \% .1$; and in Australians only 81.9 inches. Prof. Broca ${ }^{n}$ found that skulls from graves in Paris of the nineteenth century, were larger than those from vaults of the twelfth century, in the proportion of 1484 to 1426 ; and Prichard is persuaded that the present inhabitants of Britain have "much more eapacious brain-cases" than the ancient inhabitants. Nevertheless it must be admitted that some skulls of very high antiquity, such as the famous one of Neanderthal, are well dereloped and capacious. With respect to the lower animals, M. E. Lartet, ${ }^{72}$ by comparing the crania of tertiary and recent mammals, belonging to the same groups, has come to the remarkable conclusicen that the brain is generally larger and the conrolutions more complex in the more recent form. On the

:0 'Philosophical Transactions,' 1SG?, p. 513.

$" 1$ Quoted in C. Vogt's 'Lectures on Mlan,' Fing. translat. 1564, r'P. SS, 90. I'richard, 'Phyg. Hist. of Ifankind,' rol. i. 1S:, p. :,

"' 'Comptes Rendus des Séances,' ctr., June 1, 1 \$ 68. 
other band, I have slown"s that the lorains of domentic ralblits are comsiderably reduced in balk, in comparisu with those of the wild rablit, or hare; and this may he auriluted is their laving been doedy confineul duringe uasy generations, en that lheg have exerted but litele the in intellect, instincit, fenses, and rolumarg novement.

'The grulually-inereating weight of the brain and shull in man unse have influenced the desclopment of ife supporing tpimal colum, more eqgecially. While be was bocoming oree?. As this clasuge of ponition was Ining lomgle abont, the intornal prosure of the lorain will, alio, la we influenced the furm of the skull : fur mang facts show how eaily the shall is thus aftected. Fithologien mbleve that it is modilich l,g the kiml of eralle in whieh

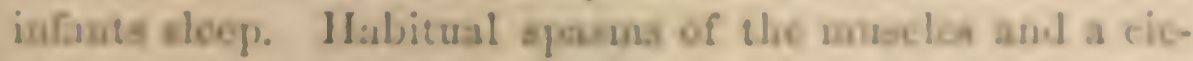
alrie from a servere burn have permasemely mulifed tbe

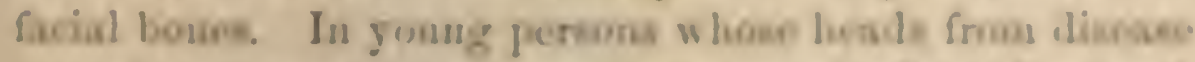
lave locome fixod eithur videwags or backwarl, one of

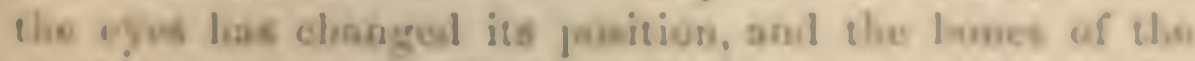
skuil have been modilied; and this apparend!s resale

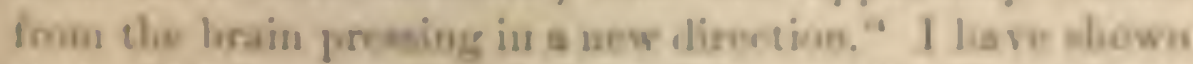
that wikh longeaned mibite, crou no irifling a coneo as

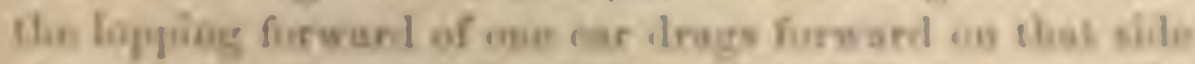

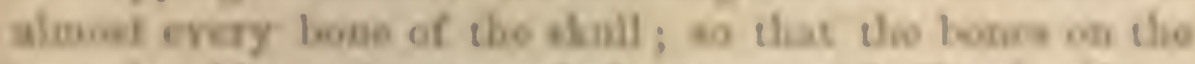

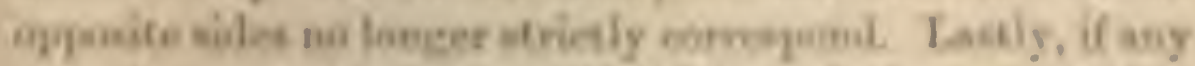

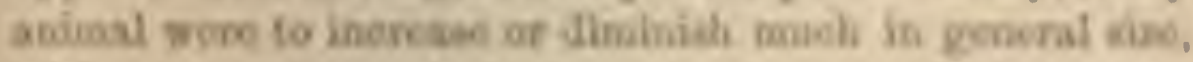

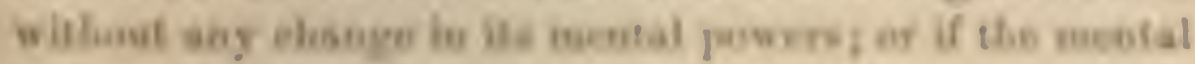

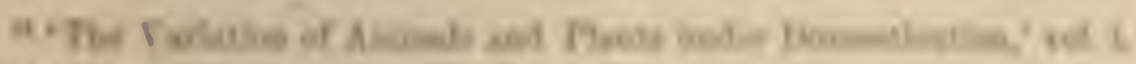
to 130.12.

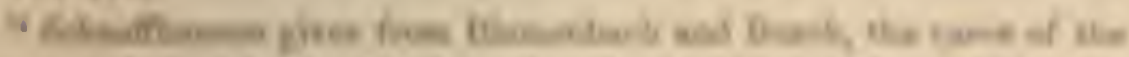

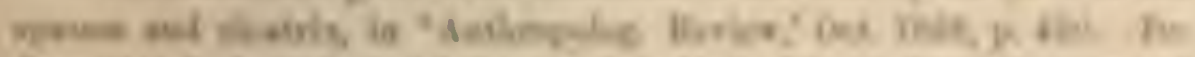

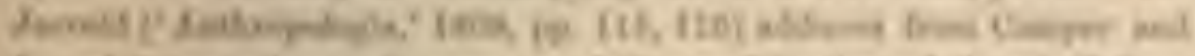

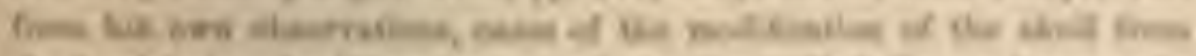

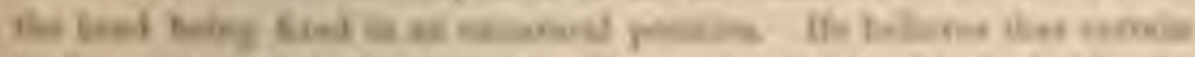

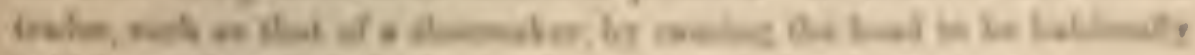

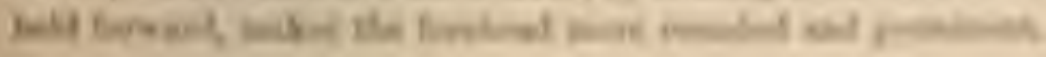


powers were to be nuch increased, or diminished, without any great change in the size of the body; the shape of the skull wonld almost certainly be altered. I infer this from my observations on domestic rabbits, some kinds of which hare become very much larger than the wild animal, while others have retained nearly the same size, but in both cases the brain has been much reduced rel:ttircly to the size of the body. Now I was at first much surprised by finding that in all these rabbits the skull had become elongated or dolichocephalio; for instance, of two skulls of nearly equal breadth, the one from a wild rabbit and the other from a large domestic kind, the former was only 3.15 , and the latter 4.3 inches in length." One of the most marked distinctions in different races of man is that the skull in some is clongated, and in others rounded; and liere the cxplanation snggested by the case of the rabbits may partially hold good; for Welcker finds that "short men incline more to braclycephaly, and tall men to dolichocephaly;" and tall men may be compared with the larger and longer-bodicd rabbits, all of which have clongated skulls, or are dolichocephalic.

from these several facts we can to a certain extent understand the means through which the great sime and nore or less rounded form of the skull hias been acquirerl by man; and these are characters eminently distinctive of him in comparison with the lower animals.

Another most conspicuous difference between man and the lower animals is the nakedness of his skin. Whales and dolphins (Cetacea), dugongs (Sirenia), and the hippopotamus, are naked; and this may be adrantageous to them for grliding through the water; nor would it be in-

is 'Vriation of Animals,' etce, vol. i. p. 117 on the chongation of the skull; p. 119, on the effect of the lopping of one car.

"G Quoted by Schaamhauscn, in 'Anthropolo". Review,' Oct. 1Sc8, [1. 112. 
jurious to dlem from the low of wamotb, so the rpecirs n livels inlathit the colder rogiona are grote ced by a thick lager of binbles, sersing tbe eswe purpoue at ilie fur of

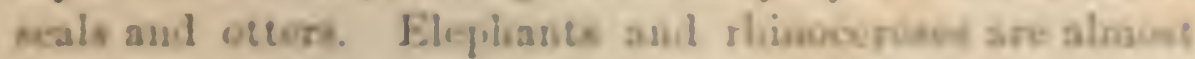
hairlon; and, as certein cxtixce vpecies whinh formandy livel under an aretis elimate vere covered wisl hag wnol or hair, it wonld almoet appear an if the exining rpocfor

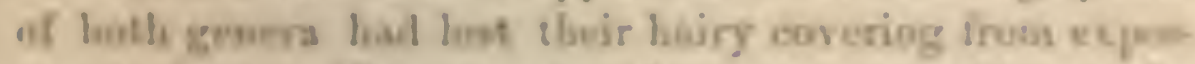
ure to litat. This appran the mere yrobable, an the

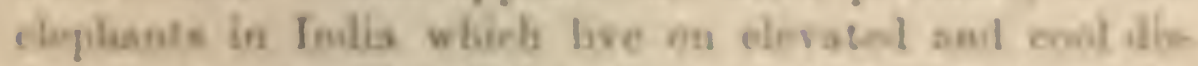
tricte are suore bairy" than thowe on the lowlamb. May oe theu befer that man leramo divesed of hair from far. iug aboviginalty inlabited wome eropical land: 'The facs

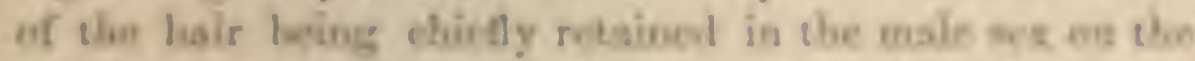
chest and faes, and is both wext at the junction of all

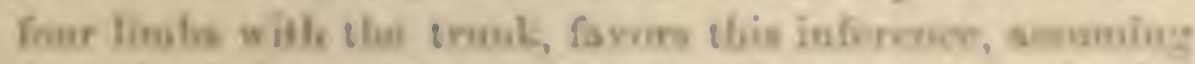
that the hale wa lout hefore man lectume erest; for the

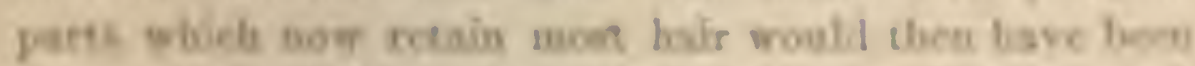

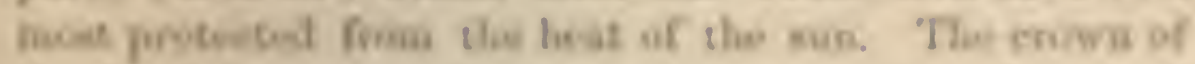

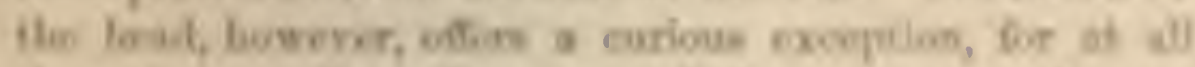

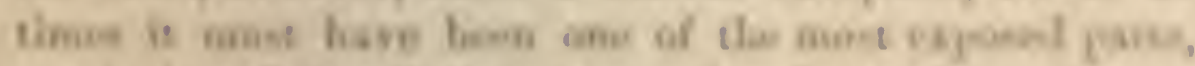
get it is tbickly clothod with lain. In this mopert mate

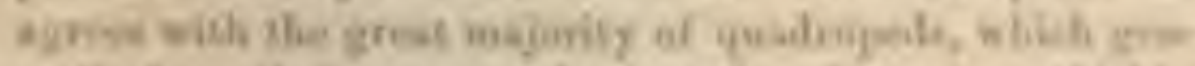
rally fove their wper and expoied sarbers mone thelly

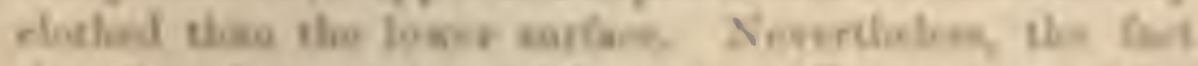

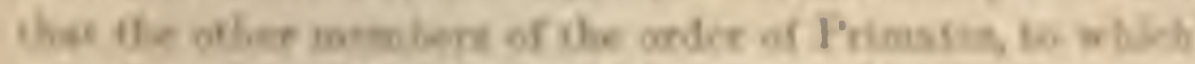

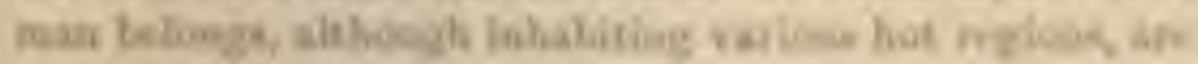

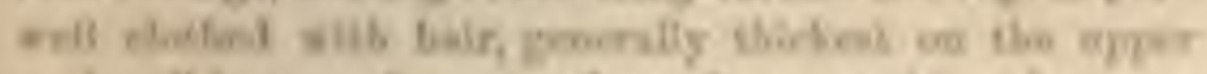

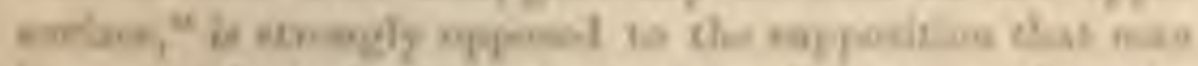

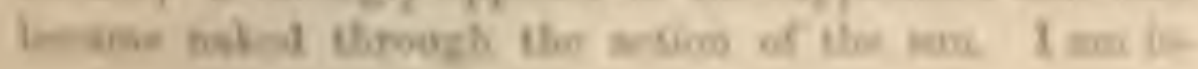

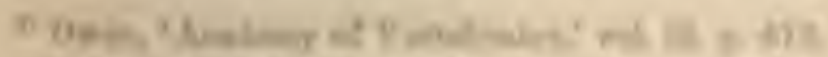

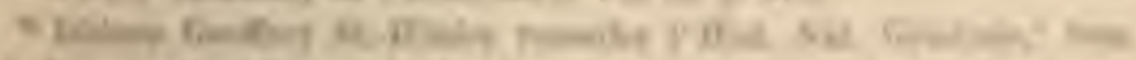

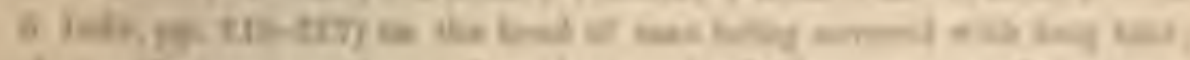

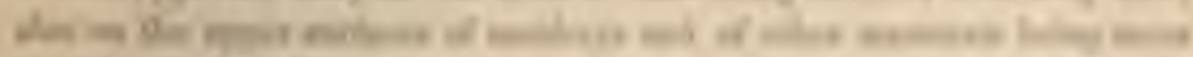

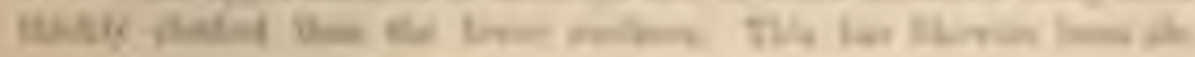


clined to beliere, as we shall see under sexual selection, that min, or rather primarily woman, becane divested of hair for ornamental purposes; and according to this belicf it is not surprising that man should difler so greatly in hairiness from all his lower brethren, for characters gained through sexual selection often differ in clusely-related forms to an extraordinary degree.

According to a popular impression, the absence of a tail is eminently distinctive of man; but as those apes which come nearest to man are destitute of this organ, its disappearance does not especially conceru us. Nevertheless it may be well to own that no explanation, as fitr as I an aware, has ever been given of the loss of the tail by certain apes and man. Its loss, however, is not surprising, for it sometimes diflers remarkably in length in species of the same genera: thus in some species of Macacus the tail is longer than the whole body, consisting of twenty-four vertebra; in others it consists of a scarcelyvisible stump, containing only threc or four vertebrx. In some kinds of baboons there are twenty-five, while in the mandrill there are ten very small stunted caudal vertebrit, or, according to Cuvier, ${ }^{70}$ sometimes only five. This great diversity in the structure and length of the tail in animals belonging to the same genera, and following nearly the same habits of life, renders it probable that the tail is not of much importance to them; and if so, we might lave expected that it would sometimes have become more or less rudimentary, in accordance with what we incessantly see

serred by various authors. Prof. P. Gerrais ('Hist. Nat. des MammiPires,' tom. i. 1854, p. 28), howerer, states that in the Gorilla the hair is thinner on the back, where it is partly rubbed off, than on the lower surface.

i9 Mr. St. George Mivart, 'Proc. Zoolog. Soc.' 1865, pp. 562, 583. Dr. J. E. Cray, 'Cat. Brit. Mus. : Skeletons.' Owen, 'Anatomy of Vertebrates,' vol. ii. p. 517. Isilure Geoflioy, 'Uist. Nat. Gén.' tom. ii. p. 214. 
with otlier structures. The tail almost always tapens tow:urd the end, whether it be long or short; and this, I presume, results from the atrophy, through disuse, of the terminal muscles, together with their arteries and nerves, leading to the atrophy of the teruinal bones. With respect to the os coccyx, which in man and the higher apes manifestly consists of the few basul and tapering segments of an ordinary tail, I have heard it asked how could these bave become completely cmbedded within the boly; bue there is no difliculty in this respect, fur in many monkeys the basal segments of the true tail are thus embedidel. For inatance, Mr. Murie informs me that in the sheleton of it not full-erown Macacus inornatus, he comuted nine or inu caudal vertebra, which alenecher were only 1.8 inch in lengegh. Of these the three basal ones appeared to hase bern embedded; the remainder forming the free part of the tail, which was only one inch in length, and half an inch in diameter. Here, then, the thre cubediled cambl

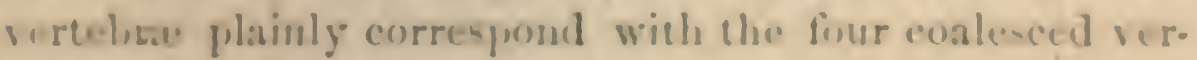
tobon of the human os enecys.

I lave now endearond to show that some of the most diesiuctive sharaters of man have in all probability ben noquircl, cither dirodty, or moro comuconly indireets, through natural selection. Wo elombl bear in mimil thas

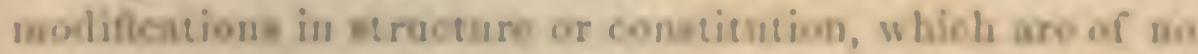

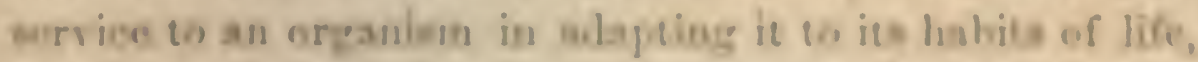

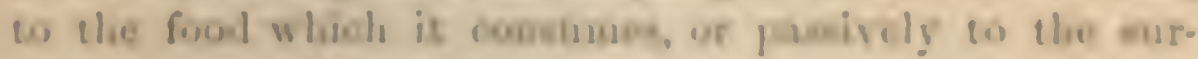

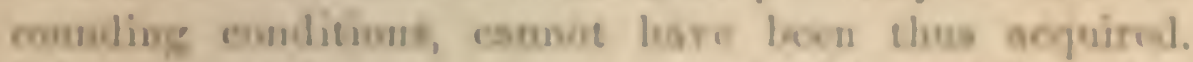

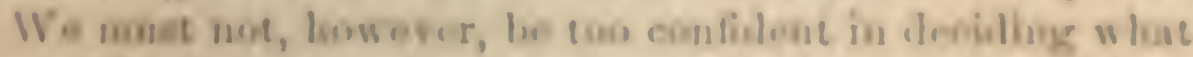
modifiestions are of service to cach being: wo wonld ro-

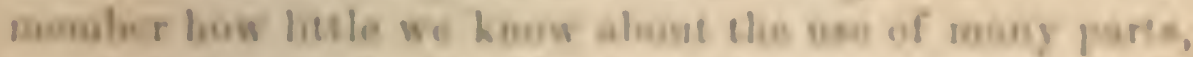
or what chasces in the blood of theres mas enve to bit

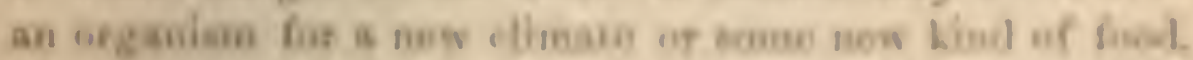
Nor mut we formet tlie principle of somelation, by which, 
as Isidore Geoflioy has shown in the case of man, many strange deviations of structure are tied together. Independently of correlation, a change in one part often leads, through the increased or decreased use of other parts, to other clianges of a quite muexpected nature. It is also well to reflect on such facts, as the wonderful growth of galls on plants caused by the poison of an insect, and on the remarkable changes of color in the plumage of parrots when fed on certain fishes, or inoculated with the poison of toads; ${ }^{80}$ for we can thus see that the fluids of the system, if altered for some special purpose, might induce other strange changes. We should especially bear in mind that modifications acquired and continually used during past ages for some useful purpose would probably become firmly fixed and might be long inherited.

'Thus a very large yet undefined extension may safely be giren to the direct and indirect results of natural selection; but I now admit, after reading the essay by Nügeli on plants, and the remarks by varions authors with respect to animals, more especially those recently made by Prof. Broca, that in the earlier editions of my 'Origin of Specics' I probably attributed too much to the action of natural selection or the survival of the fittest. I have altered the fifth edition of the Origin so as to confine my remarks to adaptive changes of structure. I had not formerly sufficiently considered the existence of many structures which appear to be, as far as we can judge, neither beneficial nor injurious; and this I believe to be one of the greatest oversights as yet detected in my work. I may be permitted to say; as some excuse, that I had two distinct objects in view, firstly, to show that species had not been separately created, and secondly, that natural selection had been the chief argent of cliange, though largely

w 'The Yariation of Auimals and Plants under Domestication,' vol. ii. pp. 280, 282. 
aidcel by the inherited eflects of habit, and sliefuly by the direct action of the surromding conditions. Devertheless I was uot able to anul the intluence of my former belief, then willely prevalent, that each species lad becu purfusely creatcd; aud this led to my tacitly assuming that every detail of structure, excepting rudiments, was of some special, though murecognized, service. Any one with this assumption in his miml wouhl uaturally extent the action of uatural selection, either during past or present tince, too far. Sunce of those who andmit the principle of crulntion, hat reject natural seloction, scem to forgot, when criticising my look, lhat I hasl the abowe two ol)jects in view; hence if I lase erred in giving to natural relection great power, which I am far from aluniliug, or in having oxaggerated its powct, which is in itself protrable, I have at least, as I hoper, done good service in ailling (o) overthrow the dogma of separate creations.

That all organic beings, inclueling man, prescme many modifieations of structure which are of no sersice to them al prosent, nor have lech formerl! is, as I can now see, probable. We huow not what proiluces the ummberless hight dilliremes between the indivielush of eah species,

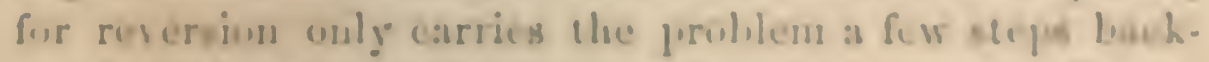
ward; hut ach peonliarity must hase hat its own ellicin me

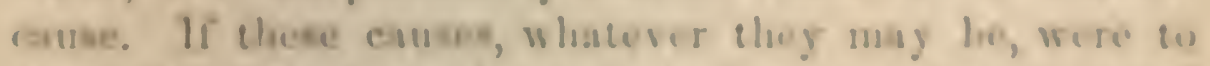
ace more wiformly abd nurge tionlly during a lengllesod

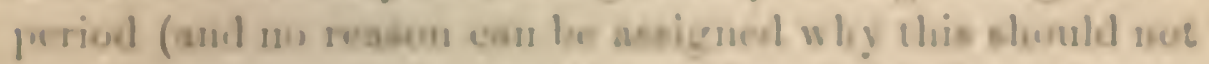
condetimes ocour), the reste would probably be not more

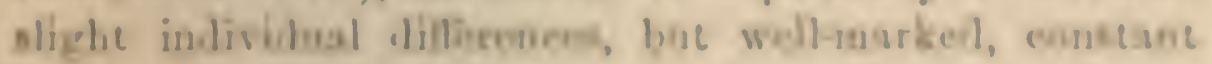
madifleations. Mordiliationt which are in no way bece-

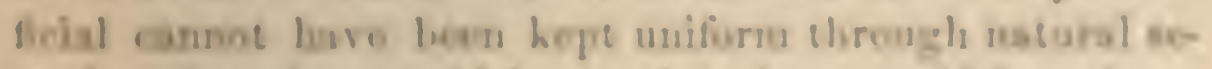

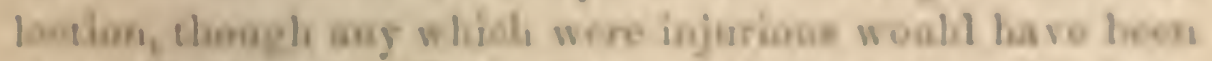

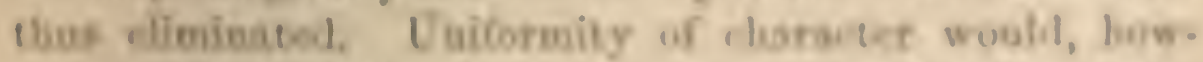

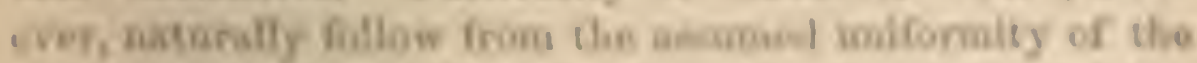

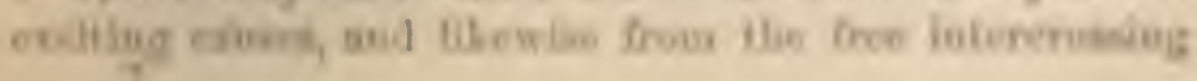


of many individuals. The same organisn might acquire in this manuer during successive periods successive modifieations, and these would be transmitted in a nearly uniform state as long as the exciting causes remained the sime and there was free intererossing. With respect to the exciting causes we cau only say, as when speaking of so-called spontaneous variations, that they relate much more closely to the constifntion of the rarying organism, than to the nature of the conditions to which it has been suljected.

Conchusion.-In this chapter we have secu that as man at the present day is liable, like every other animal, to multiform individual differences or slight rariations, so no doubt were the carly progenitors of man; the variatious being then as now induced by the same general causes, and groverned by the sane general and complex laws. As all animals tend to multiply beyond their means of subsistence, so it must have been with the progenitors of man; and this will inevitably have led to a straggle for existence and to nuttural selection. This latter process will have been greatly aided by the inherited eflects of the increased use of parts; these two processes incessantly reacting on each other. It appears, also, as we shall lereafter see, that rarious unimportant characters hare been acquired by man through sexual selection. An unexplained residumn of chauge, perhaps a large one, must be left to the assuned uniform action of those unknown ageneies, which occasionally induce strongly-marked and abrupt deviations of structure in our domestic productions.

Judging from the habits of savages and of the greater number of the Quadrumana, primeval men, and eren the ape-like progenitors of man, probably lived in socicty. With strictly social animals, natural selection sometimes acts indirectly on the individnal, through the preservation 
of variations which are bencficial ouly to the comanusts. A community including a large number of weltendowed indiviluals increased in number and is sictorions ons other and less well-emlowcd conumusities; althounh rats scparate meuber may gain no adrantage over the other members of the sauc community. With asureiated itnsecty many remarkable structures, which are of litele or us servise to the indivilual or its own oftopring, snels as the polleneollecting apparatus, or the king of the worh. $r$. lece, or the creat jaws of soldier-outs, have boon thus ac. quired. With the higher eocial asiasale, I am ant serare that ang viructure las beeu modifiod solely for tho good of the community, thonsh emue are of soeomlars sers ine to it. For instance, the horns of ruminante aud the gront canime teeth of halieous appear to bave boon acyuirol by the malce as weapous for serual ntrife, lut they am anel in ilefened of the lond or troop. In rogard to cortains ucatal fucultios the (atv, as we niall see in the following eleaperr, is wholly diferent; for these fumbies have bees

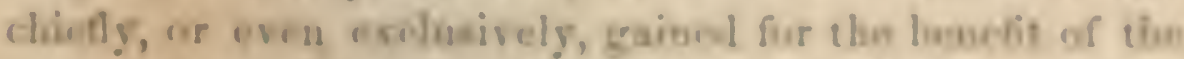

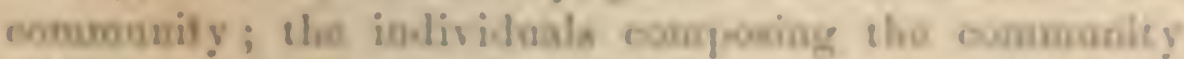
being at the sae time indincelly berefiter.

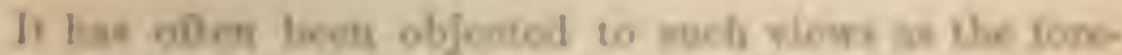

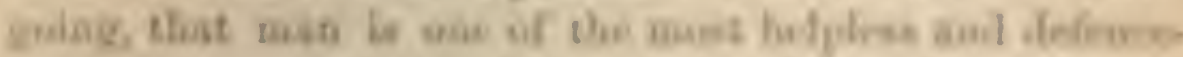

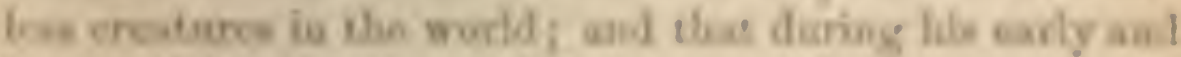

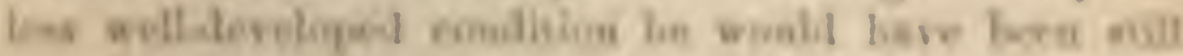

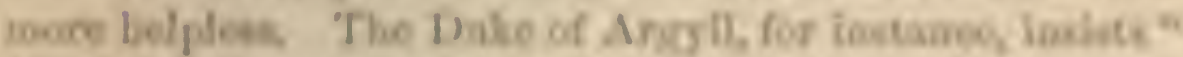

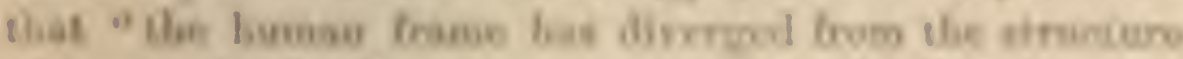

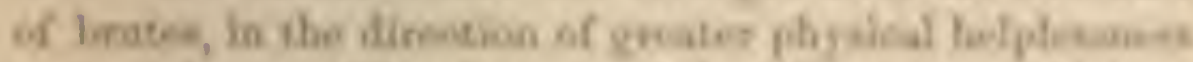

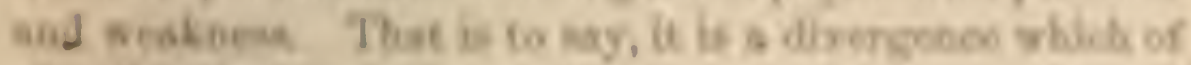

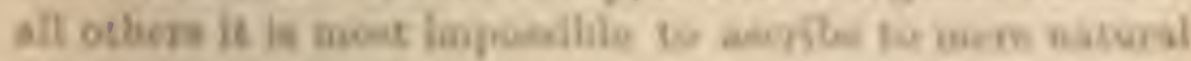

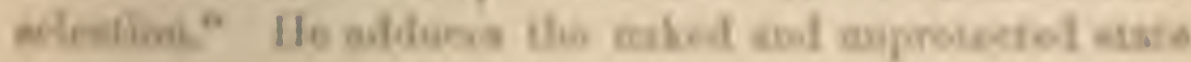


of the body, the absence of great teeth or claws for defence, the little strength of man, his small speed in running, and his slight power of smell, by which to discover finod or to aroid danger. 'To these deficiencies there miglit have been added the still more serious loss of the power of quickly climbing trees, so as to escape from enemics. Seeing that the unclothed Fuecrimus can cxist under their wretched climate, the loss of hair would not have been a great injury to primeral man, if he iuhabited a warm comtry. When we compare defenceless man with the apes, many of which are provided with formidalble canine teeth, we must remember that these in their fullydereloped condition are possessed by the males alone, being chiefly used by them for fighting with their rivals; yet the females, which are not thus providerl, are alble to survive.

In regard to bodily size or strength, we do not know whether man is deseended from some comparatively small species, like the chimpanze, or from one as powerful as the grorilla; and, therefore, we camot say whether man has become larger and strouger, or smaller and weaher, in comparison with his progenitors. We should, however, bear in mind that an amimal possessing great size, strength, and ferocity, and which, like the gorillat, conld d.fend itself from all cuemies, would probably, though not necessarily, have failed to become social; and this would most effectually have checked the acquirement hy man of lis higher mental qualities, such as sympathy and the love of his fellow-creatures. Ifence it might have becn an immense advantage to man to have sprung from some comparatively weak creat ure.

The slight corporeal strengtls of man, his little specid, his want of natural weapons, cte, are more than comterbalanced, firstly hy his intellectual powers, thengh which le has, while still remaining in a barbarous state, furmed 


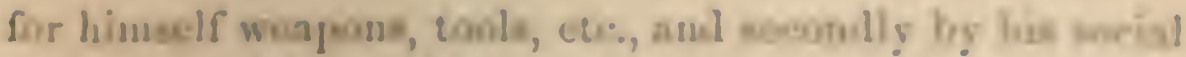
qualitien which leal biu to givo sid to bie follow-men and lo roceise it in returu. No cotatry in the wosli aboumis in a greater dogree wills dangerous beanta shaa Southora Afries; un country jreseats more fearful phytiod lard. thige than the Arctic regions; yet one of the puniest raops.

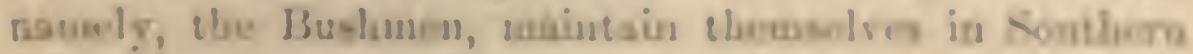
Africa, an do tho dworfed lappaimsax in the Irotic

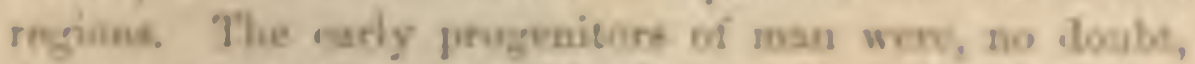
inforior is intellect, and probably in social dieprosibion, is the lewret esisting eavages; but is is quese conocirable thas they mlghe have exised, or escu flowrishel, if, while

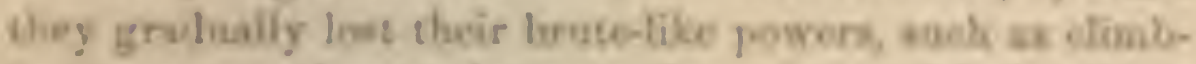

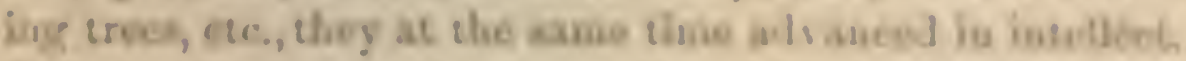
lint prating that the procenifor of rosu were far mom

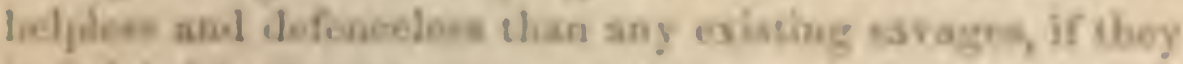

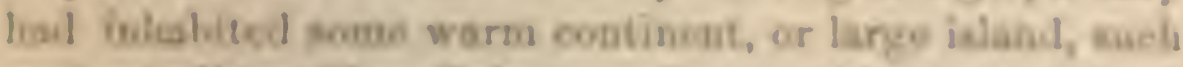

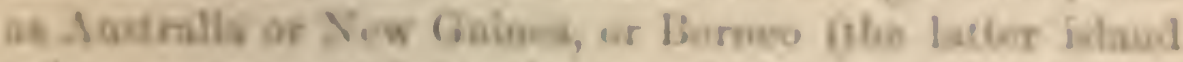
beves wev tenontel by the oraugl, they wondd nos lave

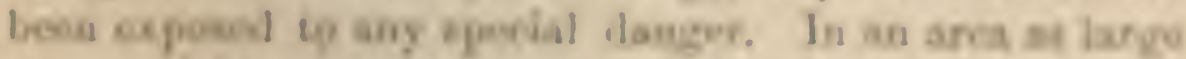

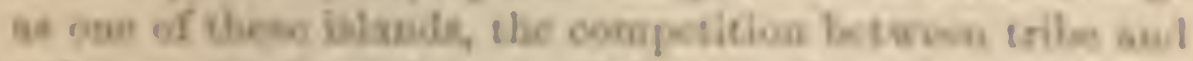

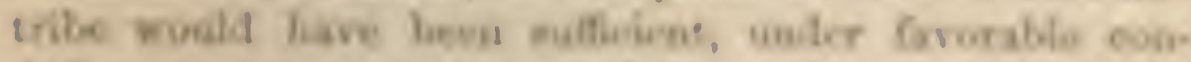
IDiems, to lam ninol mas, through the carrisal of the

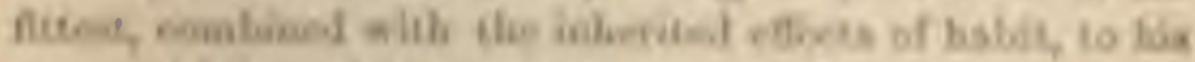

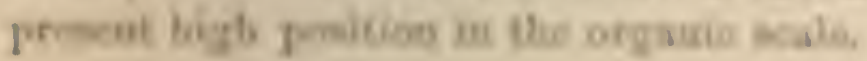




\section{CIIAP'T'E V.}

ON THE DEVEIOPALNT OF THE INTELLYCTUAT AND MORA. FACUITISS DURING PRIMEVAL AND CIVILIZED TIMLS.

The Advaneement of the Intellectual l'owers through Nutural Selection._Iuportance of Imitation. - Social and Moral Fueultics.-Cheir Dovelopnncent within the Linnits of the same Tribc.- Natural Selection as affeeting Civilized Nations. - Evidence that Civilized Nations were onee barbarous.

THE subjects to be discussed in this chapter are of the highest interest, but are treated by me in a most imperfect and fragmentary mamner. Mr. Wallace, in an admirable paper before referred to, ${ }^{2}$ argues that man, after he had partially acquired those intellectual and moral faculties which distinguish him from the lower animals, would hare been but little liable to have had his bodily structure modified through natural selection or any other means. For man is enabled through his mental factities "to keep with an unchanged body in harmony with the changing miverse." II has great power of adapting his habits to new conditions of life. He invents weapons, tools, and various stratagems, by which he procures food and defends himself. When he migrates into a colder climate he uses clothes, builds sheds, and makes fires; and, by the aid of fire, cooks food otherwise indigestible. He aids his follow-men in many ways, and anticipates future erents.

'Anthropological Review,' May, 1864, p. clviii. 
Even at a remote period he practiced some suldivisiun of l:abor.

The lower animals, on the other hamd, must have their bodily structure modified in order 10 survire under grently-changen conditions. They must he rondercd stronger, if accyine more cfective tecth or chaws, in oreler to defeut themactres from new enenies; or they must be reduecel in size so as to sicape detection and danger. When they migrate into a coller climate they must heome clother with thicker fur, or have thoir constitutions alterod. If they fuil to be thus moditical, they will cease to exine

'The easc, Lowerer, is widely diflerent, as Mr. Wallace has with justice insisted, in relation to the intellectual and moral focultics of matu. These faculties are rariatle; and we hase crery reason to belicve that the rarintions temel to he inherited. Therefore, if they were furmerly of high inportanee to primeval man and to his ape-like progeniers, they woukl have been perfected or sulvanced itrongh natural selection. Of the high inportaned of the intellectual fuculties there can be no doubt, for man mainIf owe to them his preminent position in the woeld. We can see that, in the nuleat btate of society, the inelirideale who were the nest sagreious, who iasvutrd and

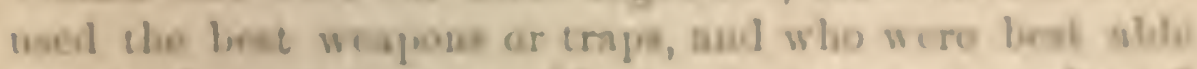
60 defond thenem lres, would rear the grotest number of

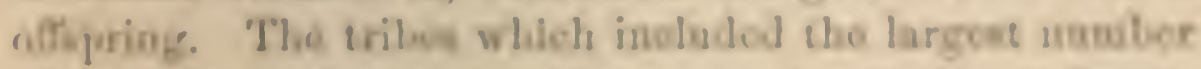
of men thes adowed would iserease in punber seid sup. plant other tribes. Nembere depend primaxily on stie

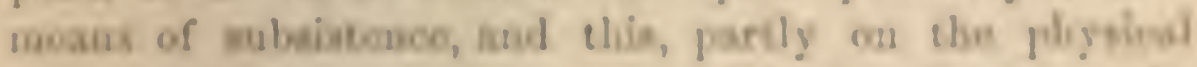
mature of the country, but in a imucls ligher degree on the

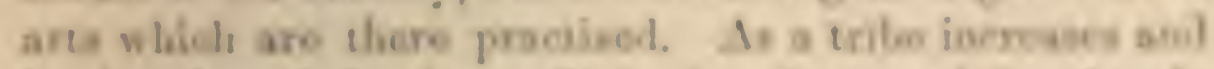

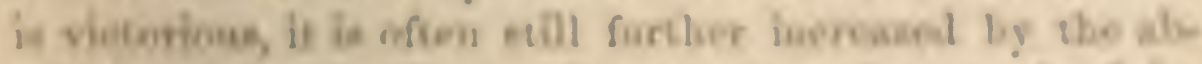

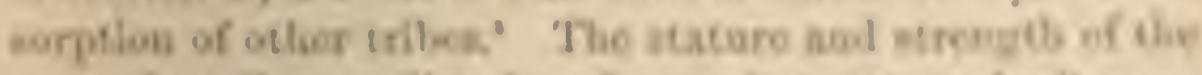
men of a inbe ure likes ise of sume im jartane for the nos

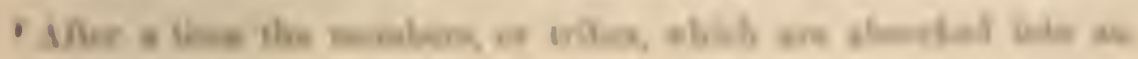


cess, and these depend in part on the nature and amount of the food which can be obtained. In Europe the men of the Bronze period were supplanted by a more powerful and, judging from their sword-handles, larger-handed race; but their success was probably due in a much higher degree to their superiority in the arts.

All that we know about savages, or may iufer from their traditions and from old monuments, the history of which is quite forgotten by the present inhabitants, shows that from the remotest times successful tribes have supplanted other tribes. Relies of extinct or forgotten tribes have been discovered throughout the crvilized regions of the earth, on the wild plains of America, and on the isolated islands in the Pacific Ocean. At the present day civilized nations are everywhere supplanting barbarous nations, excepting where the climate opposes a deadly barrier; and they succeed mainly, thongh not exclusively, through their arts, which are the products of the intellect. It is, therefore, highly probable that with mankind the intellectual fatculties have been gradually perfected through uatural selection; and this conclusion is suflicient for our purpose. Undoubtedly it would have been very interesting to have traced the derelopment of each separate fiaculty from the state in which it exists in the lower animals to that in which it exists in man; but neither my ability nor knowledge permits the attempt.

It deserves notice that as soon as the progenitors of man became social (and this probably occurred at a very early period), the advancement of the intellectual faculties will have been aided and modified in an important manner, of which we see only traces in the lower animals, namely, through the principle of imitation, together with reason other tribe assume, as Mr. Maine remarks ('Ancient Law,' 1S61, p. 131), that they are the co-lesecndants of the same ancestors.

${ }^{3}$ Morlot, 'Soc. Vaud. Sc. Nat.' 1S60, p. 291 
aml (expericnce. Apes are much given to imitation, as are the lowest savages; and the simple favet, previnusly referred to, that after a time no animal can lee cauchit in the same place by the same sort of trap', shows plat auinuls learn by expericnce, and initate cach obluer's coucion. Nuw, if some one man in a tribe, more sagacious than the others, inrented a wew suare or weapun, or oilier means of attack or lefuce, the plaines scef-interst, without the

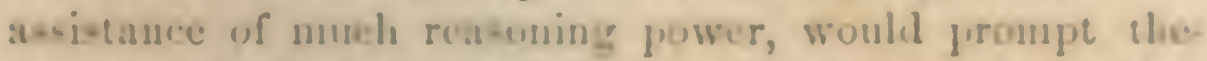
wher members to imitate him; and all would thes protit. The lasbitual procetice of esch now art umet lihewioe is some slighie degrees strungthen the intwlers. If the ses incution were an impurtant one, the tribe would incrase in number, spread, and supjlint oqher tribos. In a trilue thus remlered more numerous there would alwars bo a rather better clatuce of the hirti of other superior aul in.

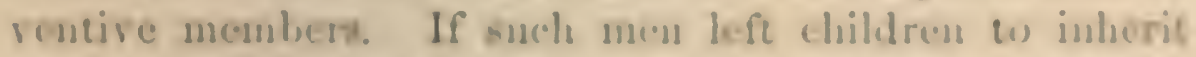
their mental superionity, the chence of tbe birts of will

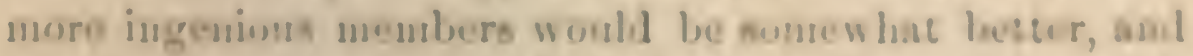
in a rory emall tribe decidedly looter. Liven if thoy lea un chiliten, the trilse would sill inelu le their blous-

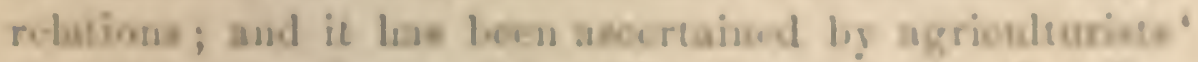

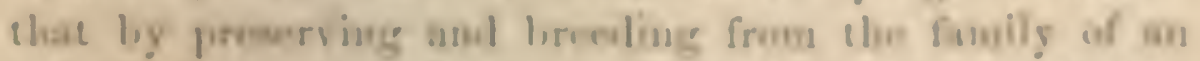

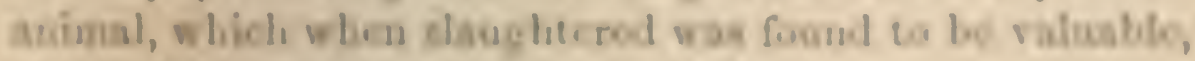

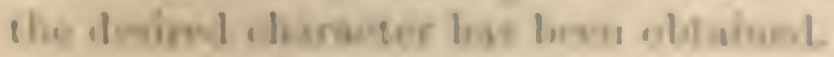

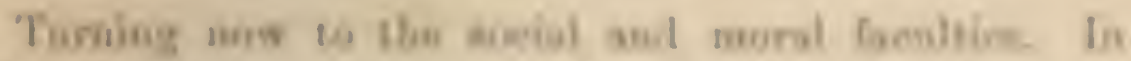
onder that joimeval men, or the apellike progentions of

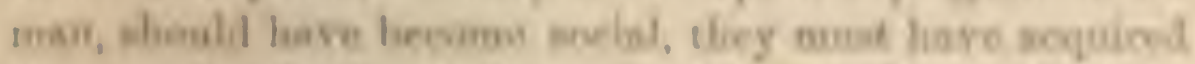

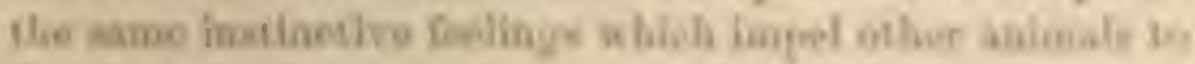

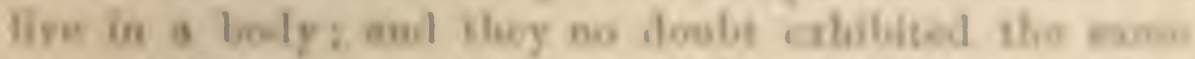

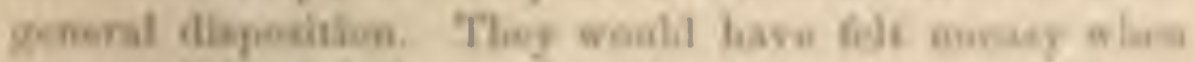

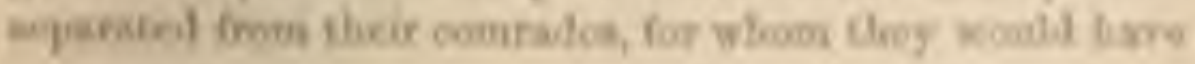

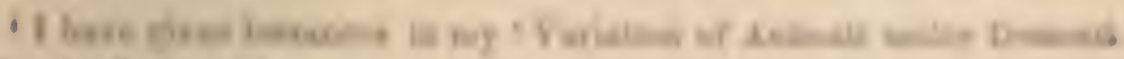
minsind a in ik. 
felt some digree of love; they would have warned each other of damger, and have given mutual aid in attack or defence. All this implies some degree of sympathy, fidelity, and courage. Such social qualities, the paramount importance of which to the lower animals is disputed by no one, were no doulut acquired by the progenitors of man in a similar mamer, namely, through natural selection, aided by inherited habit. When two tribes of primeval man, living in the same country, came into competition, if the one tribe included (other circumstances being equal) a greater number of courageous, sympathetic, and fitithful members, who were always ready to warn each other of danger, to aid and defend each other, this tribe would withont doubt suceed best and conquer the other: Let it be borne in mind low all-important, in the neverceasing wars of savages, fidelity and courage must be. The alvantage which disciplined soldiers lave over undisciplined hordes follows chiefly from the confidence which each man feels in his comrales. Obedience, as Mr. Baggehot has well shown, is of the highest value, for any form of goremment is better than none. Selfish and contentious people will not cohere, and without coherence nothing can be effected. A tribe possessing the above qualities in a high degree would spread and be victorious over other tribes; but in the course of time it would, judging from all past listory, be in its turn overcome by some other and still more highly-endowed tribe. Thus the social and moral qualities would tend slowly to adrance and be diffused throughout the world.

But it may be asked, How within the limits of the sane tribe dicl a large number of members first becone cmrlowed with these social and moral qualities, and how was the standard of excellence raised? It is extremely

S fiec a remarkable scries of articles on Physies and Politics in the 'Fortnightly Review, Nov. 1867; April 1, 1868; July 1, 1869. 
doubeful whother the oft-pring of the more syuspathetie and bencrolent parenta, or of those which were the mont fithful to their comralles, would be rearcel in greater number than the children of selfish and treacherous pareuts of the same tribe. He who was realy to saeritios him - lif, as many a savage has heen, rather than betray his comrade, would often leare no oftspring to inherit his uroble uature. The brarest men, who were al wars williag (1) come to the frout in war, and who frecly risked thoir lives for others, woull on an average perisl in larger mum. her tban otlue morn. 'Therefure it seoms sarely poseible (haring in miml that we are not hrespeahing of one tribe being victorious over another) that the unulues of unengiftel with such, rirtued, or that thestasdund of their ercelleuce, combl be increascal through natural selection, that is, by the survival of the fiterst.

Althomgli the ciromuetanoos which leal io au inervane in the number of men thas endewed within the same trile are too complex to be clearly followed out, we csu trant emat of the probible stepa. In the tint place, an tho rod-

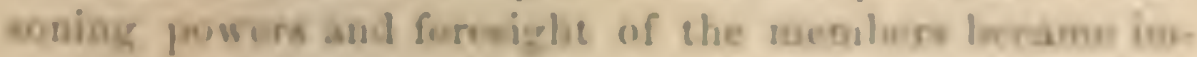
proved, esb man wohld woon learo from exporience tbae.

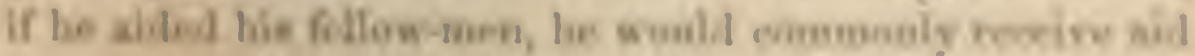

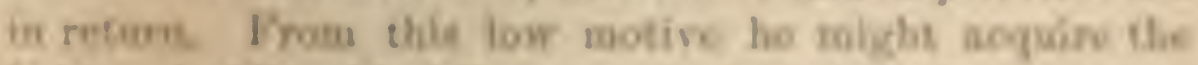

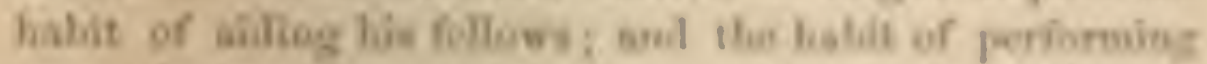

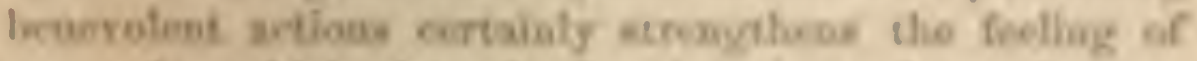

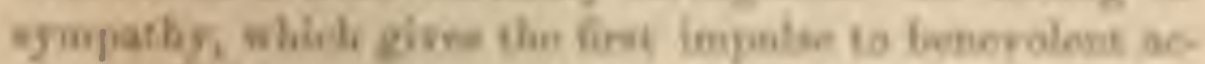

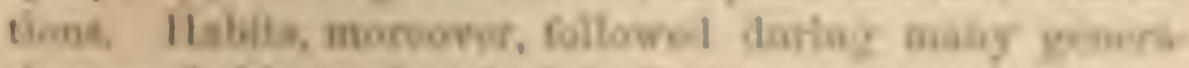
tions peribalily tend to for inheriled.

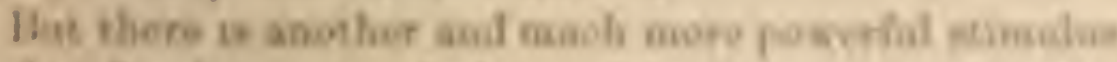

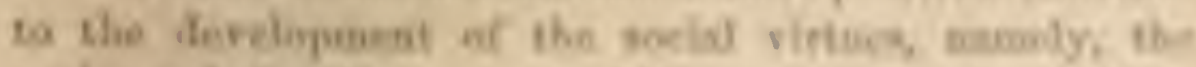

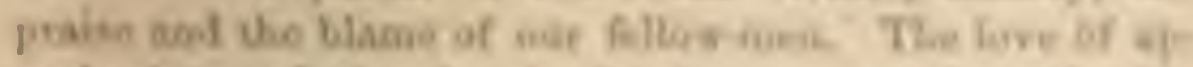

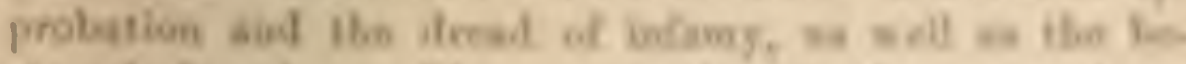

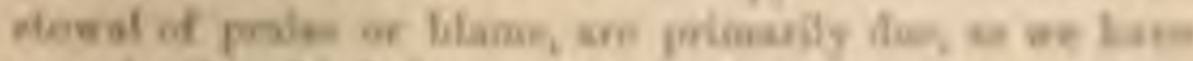

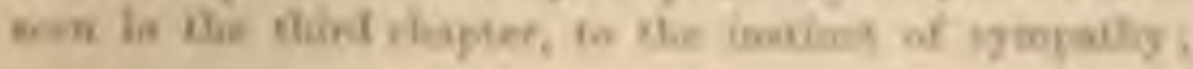


and this instiuct no doubt was originally acquired, like all the other social instincts, through natural selection. At how carly a period the progenitors of man, in the course of their derelopment, became capable of feeling and being impelled by the praise or blame of their fellow-creatures, we cannot, of course, say. But it appears that even dogs appreciate encouragement, praise, and blame. 'Tlie rudest savages feel the sentiment of glory, as they clearly slow by preserving the trophies of their prowess, by their habit of excessive boasting, and even by the extreme care which they take of their personal appearance and decorations; for unless they regarded the opinion of their comrades, such habits would be senseless.

They certainly feel shame at the breach of some of their lesser rules; but low far they experience remorse is doubtful. I was at first surprised that I could not recollect any recorded instances of this feeling in savages; and Sir J. Lubbock ${ }^{\circ}$ states that he knows of none. But if we banish from our minds all cases giren in novels and plays and in death-bed confessions made to priests, I doubt whether many of us have actually wituessed remorse; though we may liave often seen shame and contrition for smaller offences. Remorse is a deeply-hidlen feeling. It is incredible that a savage, who will sacrifice his life rather than betray his tribe, or one who will deliver himself up as a prisoner rather than break his parole, ${ }^{7}$ would not feel remorse in his inmost soul, though lie mighlit conceal it, if he hat failed in a duty which he held sacred.

We may therefore conclude that primeval man, at a very remote period, would have been influeneed by the praise and blame of his fellows. It is obvious, that the nembers of the same tribe would approve of conduct

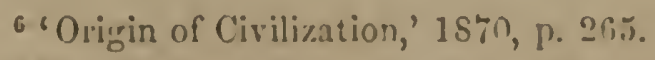

'Mr. Wallace gives cases in his 'Contributions to the Theory of Natural Sulection,' 1870, p 351. 
which appeared to them to be for the gencral grood, and would reprobate that which appeared evil. To do gevel unto others-to do unto others as ye would they should do unto you-is the foundation-stone of morality. It is, therefore, hardly possible to exaggerate the importamec during rude times of the love of praise and the lread of blame. A man who was not impelled by any decp, insinctive feclims, to sacrifice his life for the grooul of otlers, yet was roused to such actions lyg a sense of glory, would by his cxample excite the same wish for glory in other men, and would sircugthen byeserise the uoble feling of almiration. He might thus do far more gool to his tribe than by lecgetting off-pring with a tenteney to inherit his owu high character.

With increased expericnee amb reason, man percives the more remote consequences of his actions, and the stifregarding virtues, such as temperance, chastity, cte., which during early times are, as we hate hefore secm, ueferly disregareded, come to be highly estecmed or esen held sacered. I need not, howerer, repeat what I hare mail on this heal in the third chapue lohimately a higlu!-compluce ecutiment, laving its first arigin in ibo eocial intincts, largely goided by the aplrutation of un f.llow-suen, roled ly rosem, ealfincerot, and in later limes by dop religions foeliags, rontirno-1 by instraction

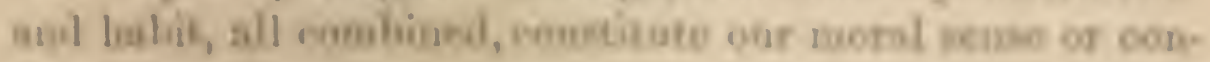
wienee.

If mues but be Sorzoties that, abbongli a Wgh stand.

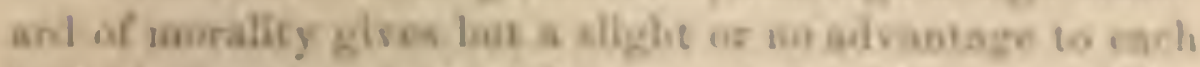

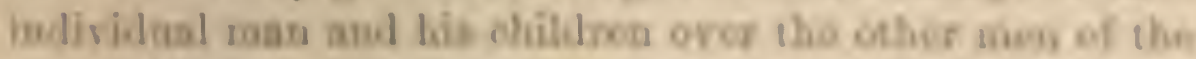
some triloc, yet that an a-Irsocement in the stantand of

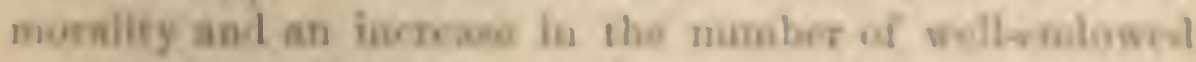

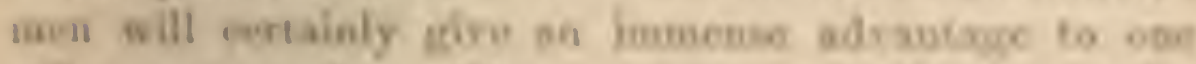

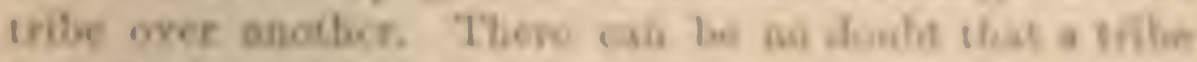

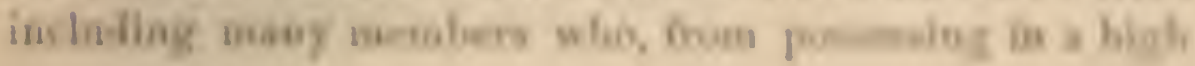


degree the spirit of patriotism, fidelity, obedience, courage, and sympathy, were always realy to give aid to each other and to sacrifice themselses for the common good, would be victorious over most other tribes; and this would be natural selection. At all times throughout the world tribes have supplanted other tribes; and as morality is one element in their success, the standard of morality and the number of well-endowed men will this everywhere tend to rise and increase.

It is, howerer, rery difficult to form any judgment why one particular tribe and not another has been suceessful and has risen in the scale of civilization. Many sayages are in the same condition as when first discovered several centuries ago. As Mr. Bagehot has remarked, we are apt to look at progress as the normal rule in lumnan society; but history refutes this. 'The ancients did not even entertain the idea; nor do tho Oriental nations at the present day. According to another high authority, Mr. Maine," "the greatest part of mankind has never shown a particle of desire that its civil institutions should be improved." Progress secms to depend on many concurrent furorable conditions, fir too complex to be followed out. But it has often been remarked, that a cool climate from leading to industry and the various ants has been highly farorable, or even indispensable for this end. The Esquimaux, pressed by hard necessity, have succeeded in many ingenious inventions, but their climate has been too serere for continued progress. Nomadic habits, whether over wide plinins, or through the dense forests of the tropiea, or along the shores of the sea, have in every case been highly detrimental. While observing the barbarous inlabitame of Tierra del Fuego, it struck the that the possession of some property, a fixed athode, and the union of many fami-

'Ancient Iaw,' 1861, p. 2!. For Mr. Bagehot's remarks, 'Fort nightly lieview,' April 1, 1965, p. 452. 


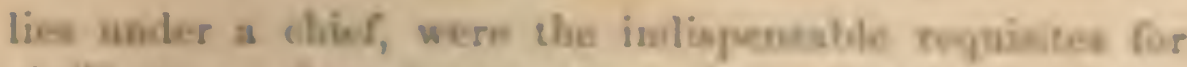

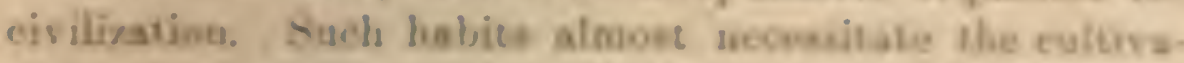

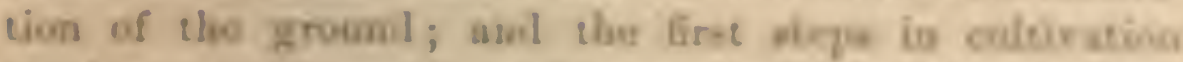

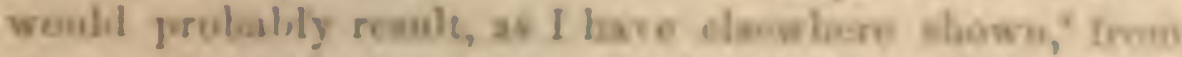

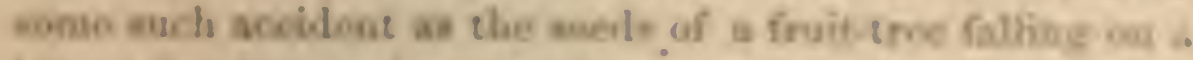
lusp of refume aad prolocing an uramully flom veriety. Thie probtem, howeser, of the linst sirsece of avages

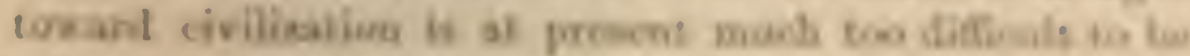
solved.

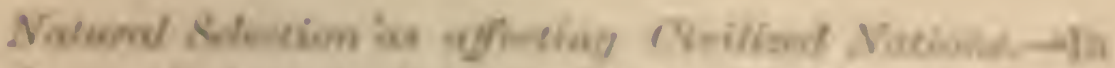

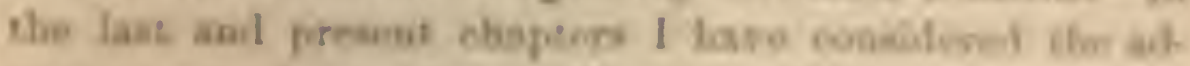

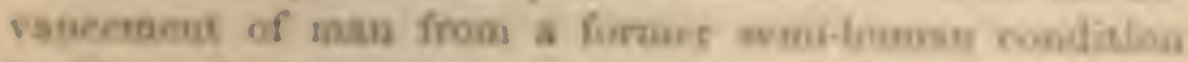

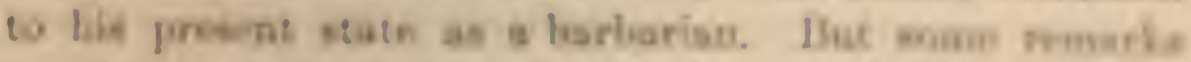

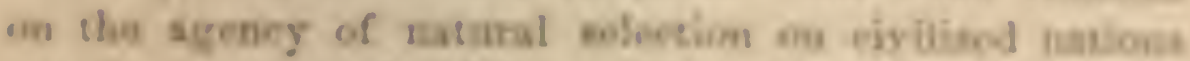

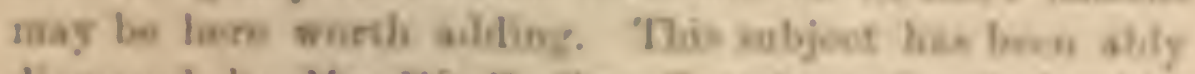

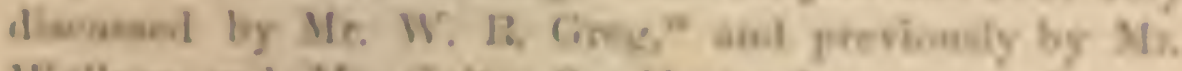

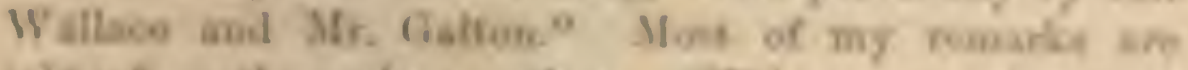

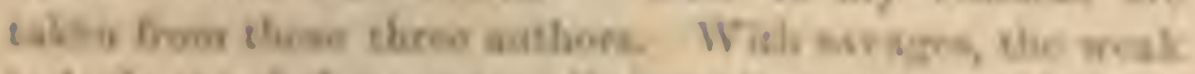

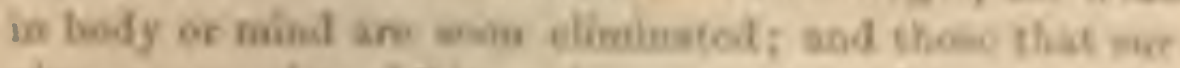

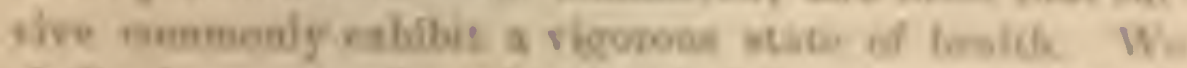

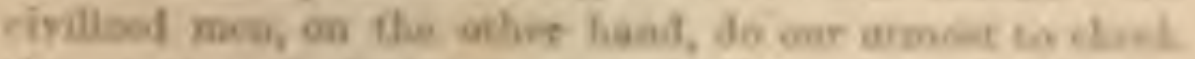

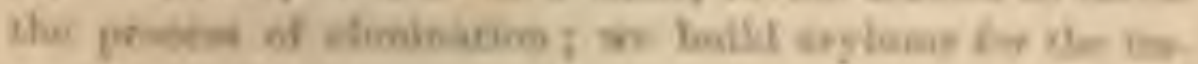

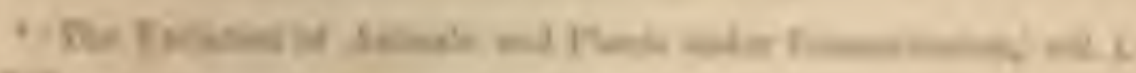
1. $21 \mathrm{r}$

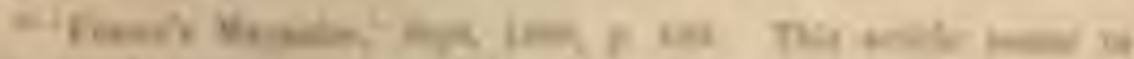

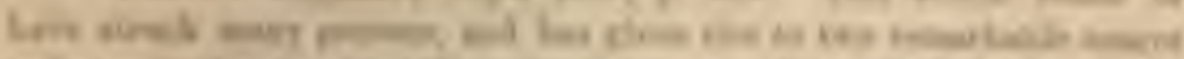

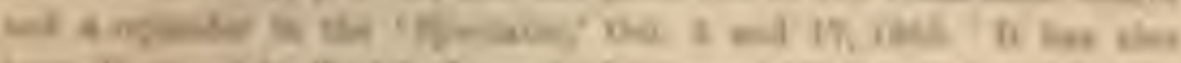

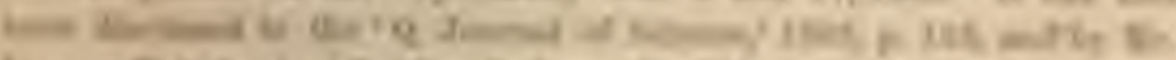

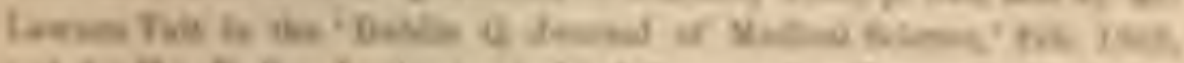

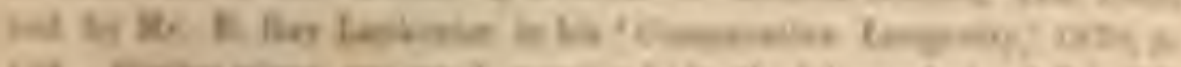

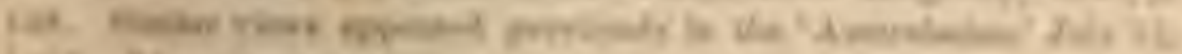

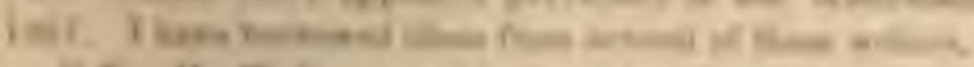

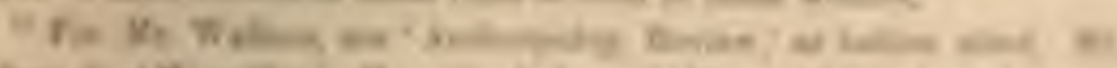

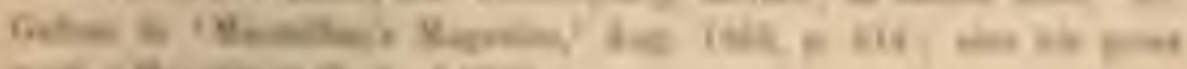

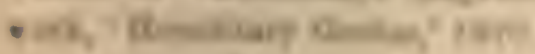


becile, the maincel, and the sick; we institute poor-laws; and our medical nen exert their utmost skill to save the life of every one to the last moment. There is reason to believe that vacciuation has preserved thousands, who from a weak constitution would fornerly have succumbed to small-pox. Thus the weak members of civilized societies propagate their kind. No one who has attended to the breeding of domestic animals will doubt that this unust be lighlyly injurious to the race of man. It is surprising low soon at want of care, or care wrougly directed, lenils to the degeneration of a domestic race; but excepting in the case of man himself, hardly any one is so iguorant as to allow his worst animals to breed.

The aid which we feel impelled to grve to the helplesy is mainly an incidental result of the instinct of sympatly, which was originally acquired as part of the social instincts, but subsequently rendered, in the manner previously indicated, more tender and more widely diffused. Nor could we clieck our sympathy, if so urged by hard reason, without detcrioration in the noblest part of our uature. The surgeon may harden himsolf while performung an operation, for he knows that lie is acting for the good of his patient; but if we were intentionally to neglect the weak and helpless, it could only be for a contingent benefit, with a certain and great present cvil. Hence we must bear without complaining the undoubtedly bad eflects of the weak surviving and propagating their kind; but there appears to be at least one check in steady action, namely the weaker and inferior members of socicty not marrying so freely as the sound; and this check unght be indefinitely incereased, though this is more to be hoped for than expected, by the weak in body or mind refraining from marriage.

In all civilized comtries man accumulates property aud bequeaths it to his children. Sin that the children in 
the came country do nut lig aus mant nare fir in the race for snceses. Rut this is fur from ass unmised ovit; fur witbrut the secomnlation of capitul she ars could sos progrest; and it is chiesly through their power thase the civiliaed raees hare extouded, asud are now everywhere extending, pheir range, en as to take the plaoe of the buwer ruces. Nor dines the moderne aceumblation of wolets iscerfere with the promes of seleciom. When a pelor uman becumes rich, lis childron enter endes or profosions in which there it otrokgle onoggh, to that the able is lnoly

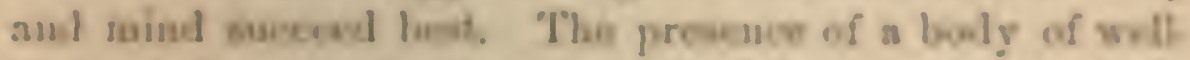
iumeroeted sura, who hare nos to labor for their dally

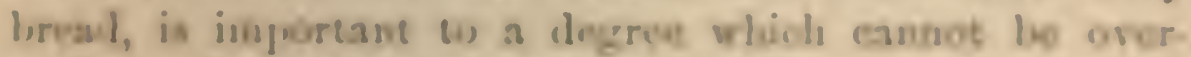

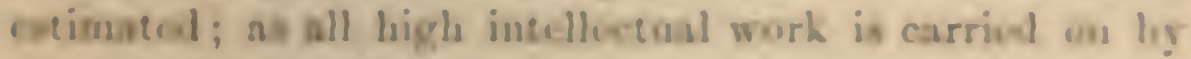
them, and on sueh work material yroeres of ail hivds mainly depouds, not to mention other and highen adsantages. Nin dethbe walth, when very gereat, teade to oob.

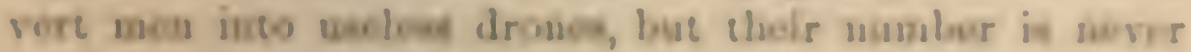
larke; abil nume degren of dimization here oceurs, as we

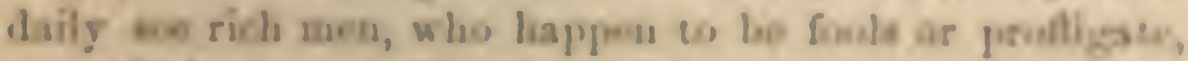
mpandering away all their weslib.

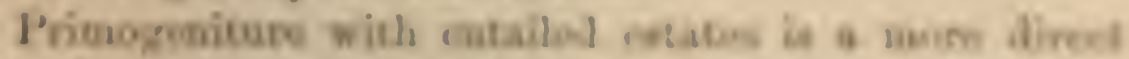
wil, flungly it way formerly hore lecen a great advaotoge in the rreailon of a dominast claks, and any gorememens is better thas anarebs The elitist somd thouceb they

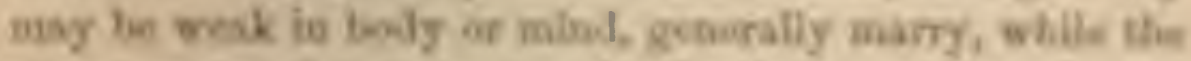

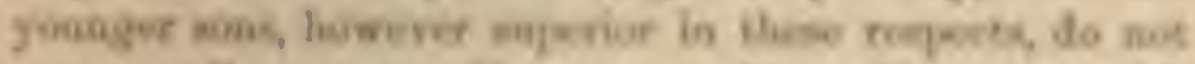

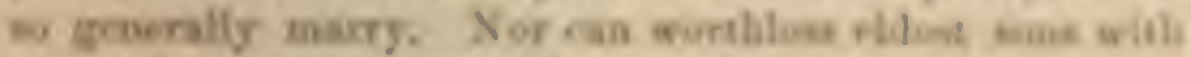

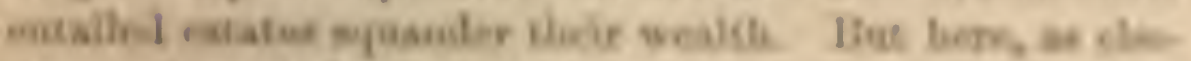

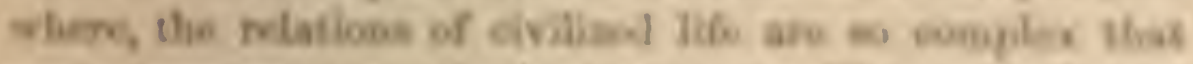

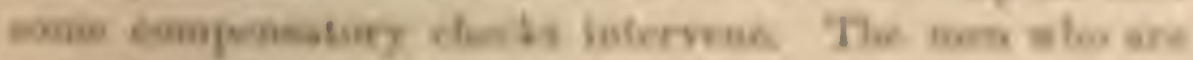

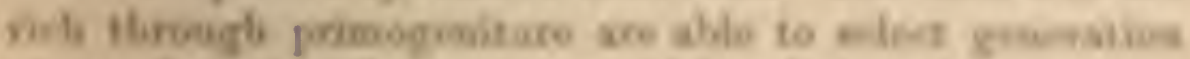

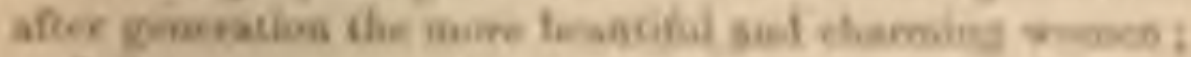

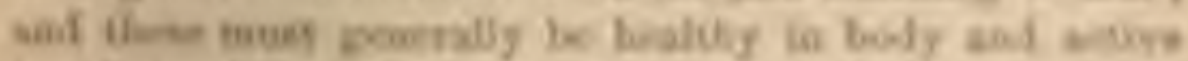

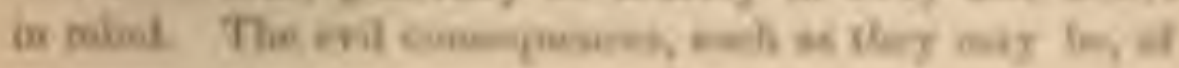


the continned preservation of the same line of descent, withont any selection, are checked by men of rank always wishing to increase their wealth and power; and this they effict by marrying heiresses. But the daughters of parents who have produced single children, are themselves, as Mr. Galton has shown, ${ }^{12}$ apt to be sterile; and thus noble families are continnally cut off in the direct line, and their wealth flows into some side-channel; but unfortunately this channel is not determined by superiority of any kind.

Althongh civilization thus checks in many ways the action of natural selection, it apparently favors, by means of inproved food and the freedom from occasional hardships, the better derelopment of the body. This may be infered from civilized men having been found, wherever compared, to be physically stronger than savages. They appear also to have equal powers of endurance, as has been proved in many adventurous expeditions. Even the great luxury of the rich can be but little detrimental; for the expectation of life of our aristocracy, at all arres and of both sexes, is very little inferior to that of healthy English lives in the lower classes."

We will now look to the intellectual faculties alone. If in each grade of society the members were divided into two equal bodies, the one including the intellectually superior and the other the inferior, there can be little dunbt that the former would succeed best in all occupations and rear a greater number of children. Liven in the lowest walks of life, skill and ability must be of some adrantage, though in many occupations, owing to the great division of labor, a very small one. In'mee in civilizod nations there will be some tendency to an increase both

12 'Herelitary Geniug,' 16i", pp. 13:-14n.

13 See the fifth aud sisth colunus, compiled from good authorities, in the table giren in Jr. L. I. Iauked:er's 'Comparative Lungevity,' 18to, p. $11 \%$ 
in the romber and in the standard of the intellectradly alle. Lut $I$ do nut wish wo aesert that this tondericy may not be more than cotnterbalanced in other wasn, as by the mulipliestion of the reeklese and improsident; has

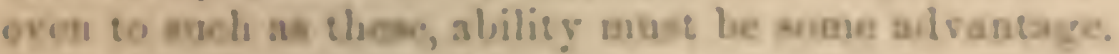

It has anse been abjoctel to riews like the foregoing. that the mont eninent men who have ever lived have telt the offrpring to isherit their gmat iatellees, Mr. Gatton

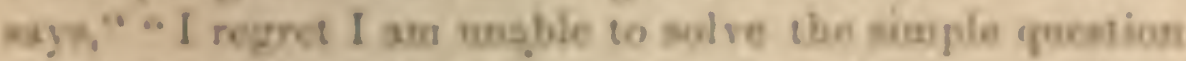
whotler, aind hes fier, mest wod women who are prodigies of genias aro ieferile. I lave, bowerer, showe that mox of cmiacene are by uo mease $\mathrm{a}$." Greas lawgivers, the fovoden of bepelicent religiom, great plitesophers ased dimoveren in scienos, aid the progress of mankind in a fur bigher degree by their works than by teasieg a menemas yrogeng. In the case of corporval nersetares, it is the seloction of the sliphely betteremelowed sad tho

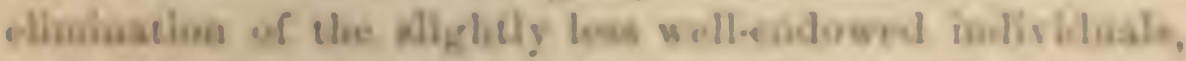
and bus the presorration of strosigf -morhol and nere

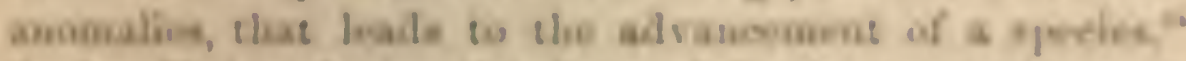
$\checkmark$ it will bo with the intellertusl faendeies, namely, fnow the monewlat soure able men in each grade of weirty

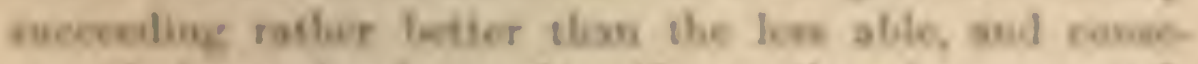

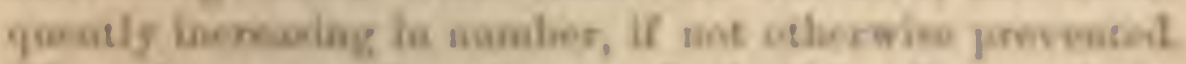

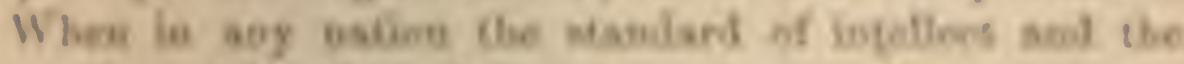

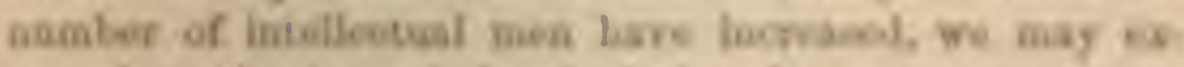

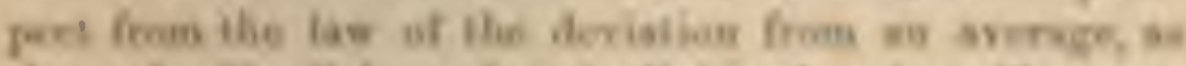

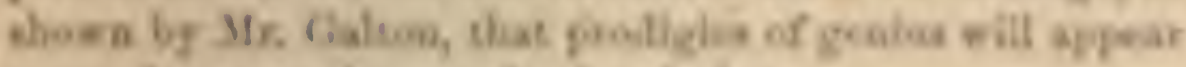

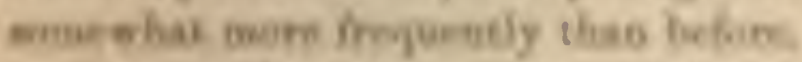

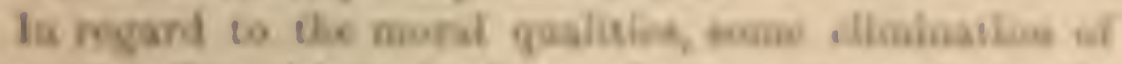

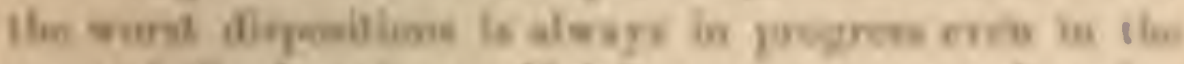

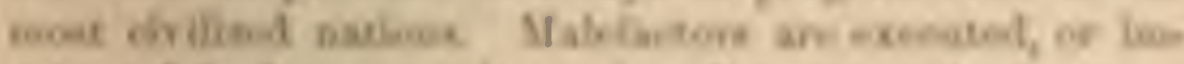

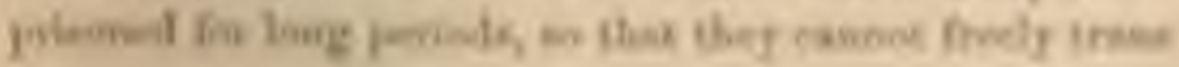


mit their bal gualities. Melancloolie and iusane perons are confined, or commit suicide. Violent and quarrelsome uren often cone to a bloody end. Restless men who will not follow any steady occupation-and this relic of barbarism is a great cleck to cirilization "-cmigrate to newly-sutlod countriea, where they prove useful pionecrs. Intemperance is so highly destructive, that the expecta. tion of life of the intemperate, at the age, for instance, of thirty, is only 13.8 years; while for the rural laborers of Einglund at the sane age it is 40.59 years. ${ }^{17}$ Prolligate women bear few children, and profligate men rarely mary; ; both sufter from discase. In the breeding of domentic animals, the elimination of those indiriduals, thongh fow in number, which are in any marked manner inferior, is by no means an mimportant clement toward success. 'This especially holds good with injurions characters which tend to reappear through reversion, such as blackness in sheep; and with mankind some of the worst dispositions which occasionally without any assignable cause make their appearance in families, may perhaps be reversions to a savage state, from which we are not removel by very many generations. 'This riew seems indeed recognized in the conmon expressiou that such meu are the black sheep of the family.

With cirilized natious, as far as an adrauced standaril of morality, and an increased number of fairly wellendowed men are concerued, natural selection apparently effects but little; though the fundanental social iustincts were originally thus gained. But I have already said enough, while treating of the lower races, on the causes

"Illenditary Gonius,' 1870, p. 31\%.

31. Itay Lauketer, 'Compurative Iongervits,' 18\%, p. 11s. Tho table of the iutempernse is from Neion'a 'Vital Statitties.' In regarl to profligacs, tee Dr. Harr, "Influence of Marriese on Mtortality," 'Mat Assoc. fur the Promotion of Social Science, 1558. 


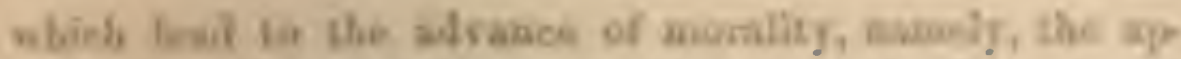

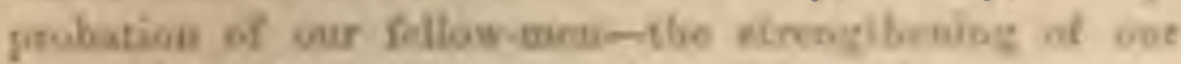

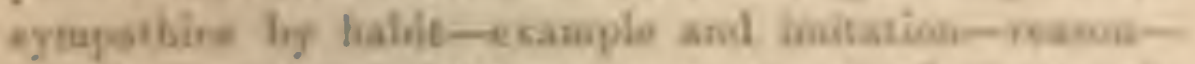

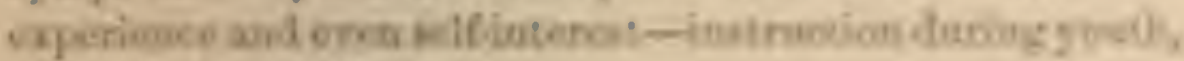
and riliglous fielioss.

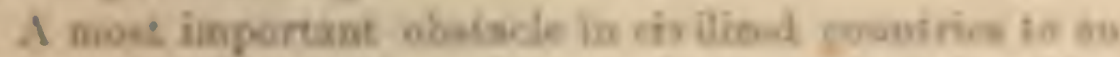

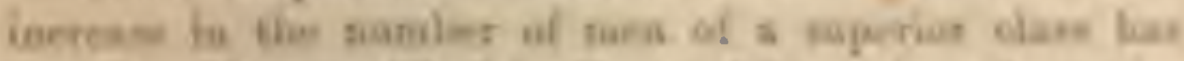
bon otrong if urgad by Mr. Greg aod Mr. Gallov," namely,

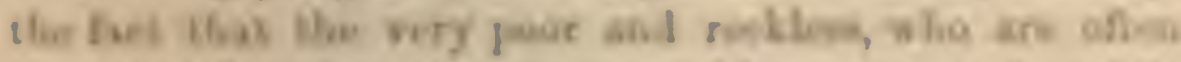
degralat by vire, stmose ioranibly marry eady, wlale

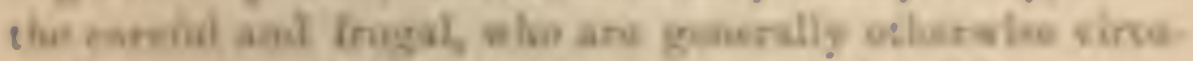
wos, warry toee io life, to that tiey tosy be shle to nap

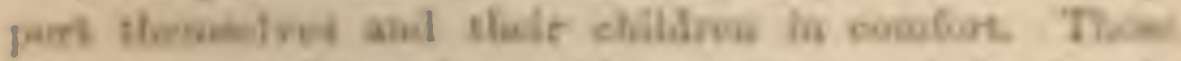
who marry eady projuco wiable a giver pribel not asly

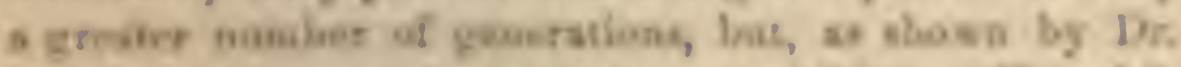

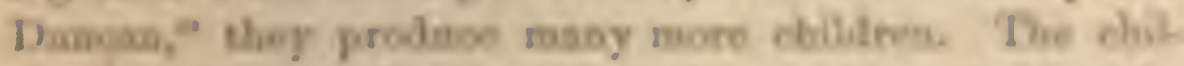

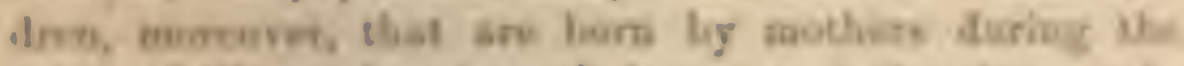

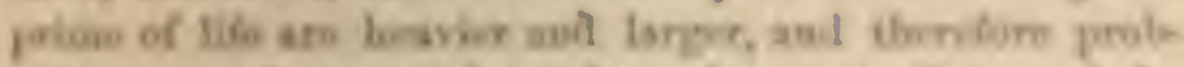

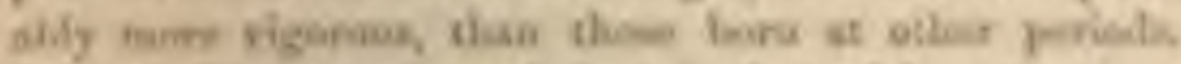

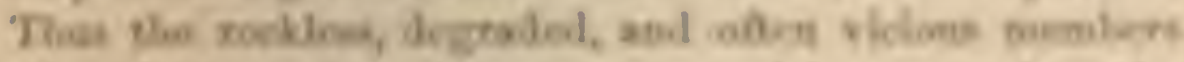

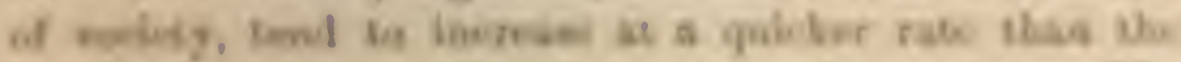

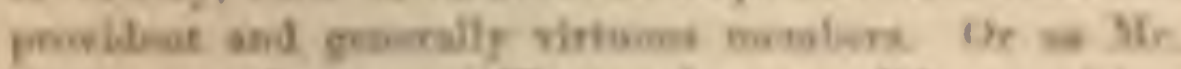

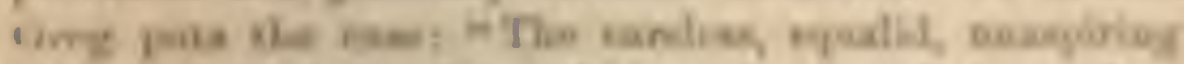

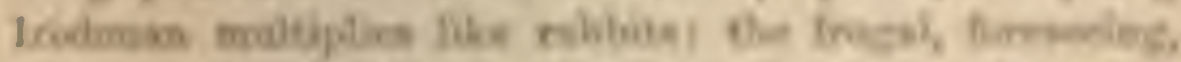

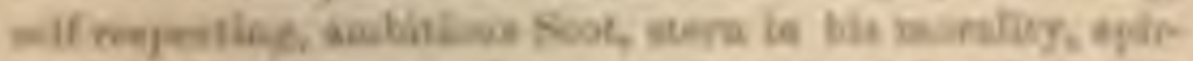

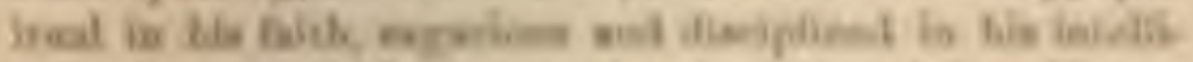

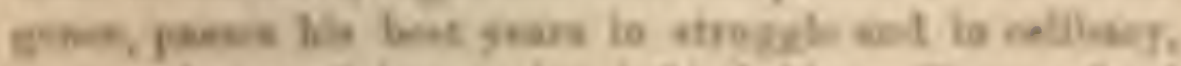

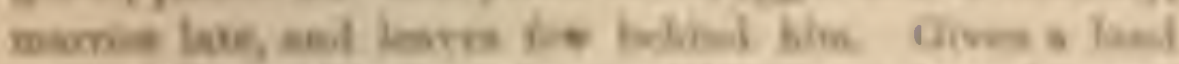

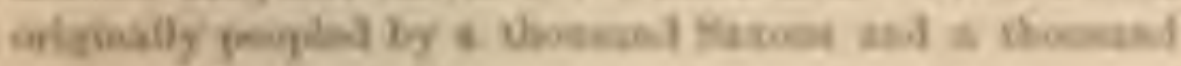

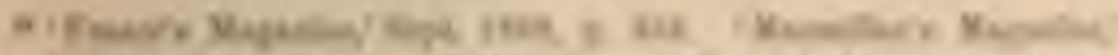

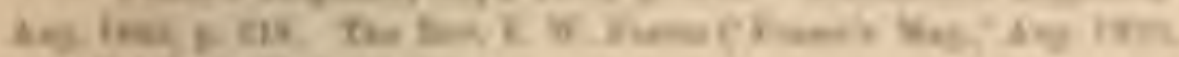

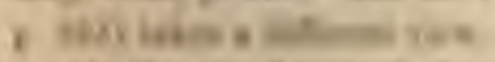

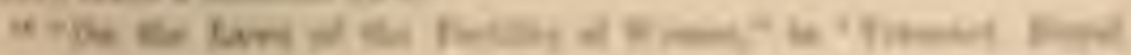

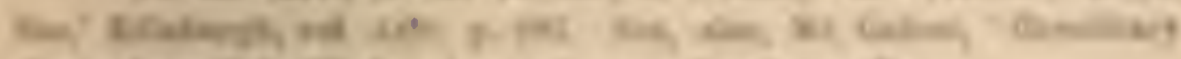

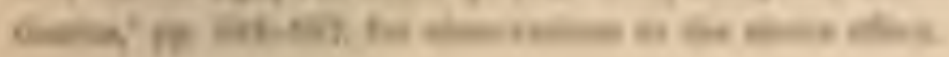


Cilt-and in as dozen gucrations fivenixthe of the popt. lation would be Celes, lout fivenistles of the fropperty, of the power, of the intellet, wonly belong to the enesixth of Sarous that romained. In the eterual 'atriggle for exiefence,' it would he the inferior anil lese fororeal race that had prevailed-and prevaileal by rirtue not of ite good qualitice but of its fauls."

There are, howerer, some cheche to this duwuward tendency. We have seen that the intemperate knfier from a high rate of mortality, and the extromely frotligate leave few off-pring. The poorest classes crowd into towne, and it has been proved by Dr. Stark from the statistica of thu years in Scotland," that at all agow the denth-rate is higher in towns than in rural districts, "and during the first fire years of life the town deatli-rate is almoet ex. actly donble that of the rural districts." As these returus include both the rich and the poor, no doubt more than donble the number of lieths would be reynisite to ketp up the number of the very poor inhabitans in the townt, relatirely to thoee in the country. With women, marringe at too early an age is highly injurious; for it hase lesen found in France that "twice as many wires unler twenty die in the year, as died out of the same number of the unnarried." The mortality, also, of husbands under twenty is "ercosirely high," " but what the cause of this may be seems donbeful. Iasty, if the men who prudently dulay marrying until they can bring up their fumilies in comfurt, were to solect, as they often do, wo. men in the prime of life, the rate of increase in the better clans woudd be only slighely lesected.

It was cetalilished from an cuormons body of etacietion,

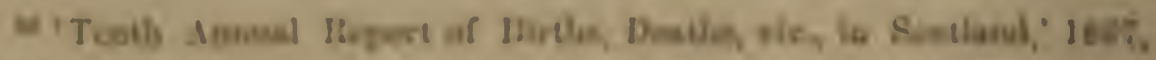
p. asis.

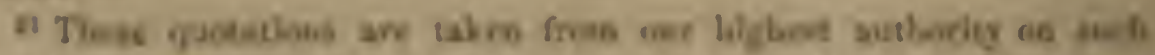

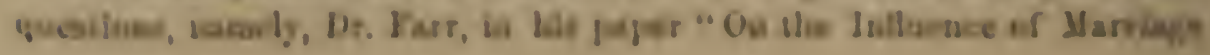




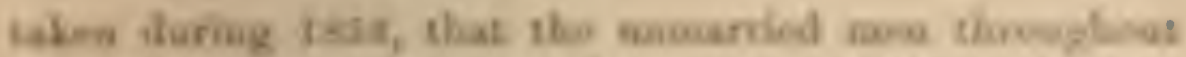

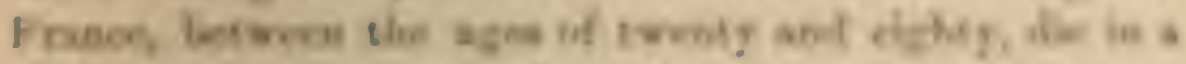

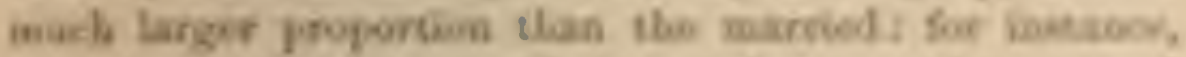

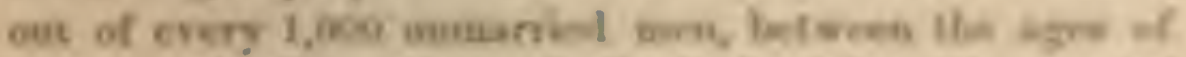

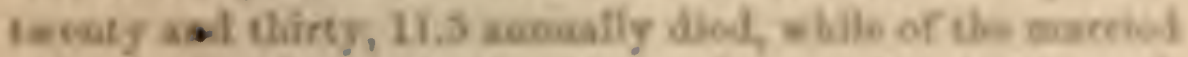

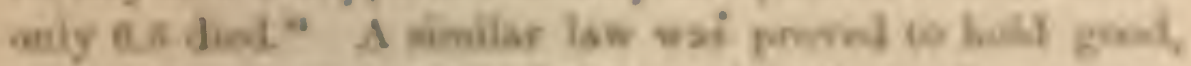

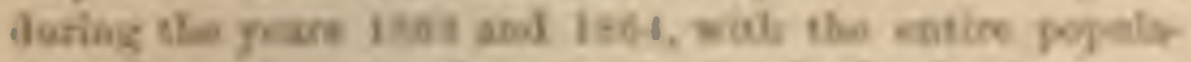

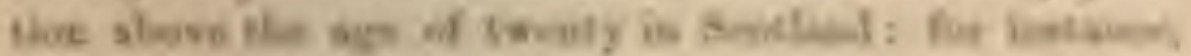

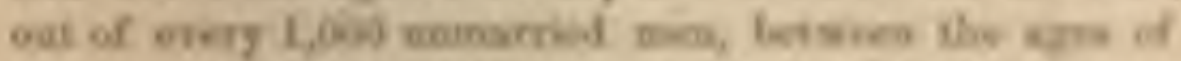

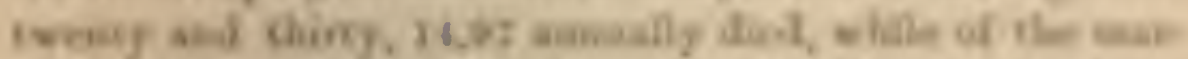

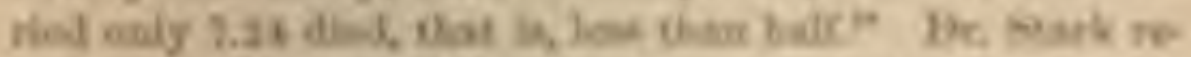

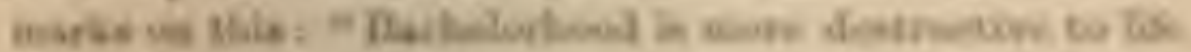

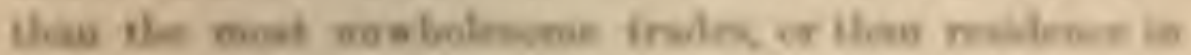

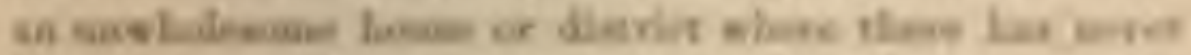

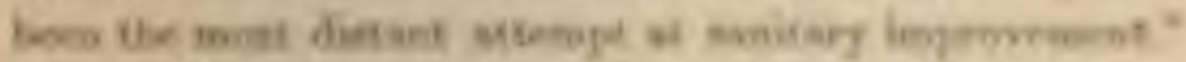

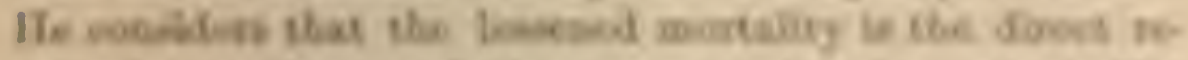

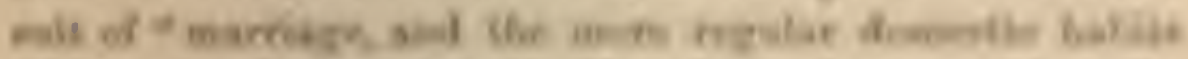

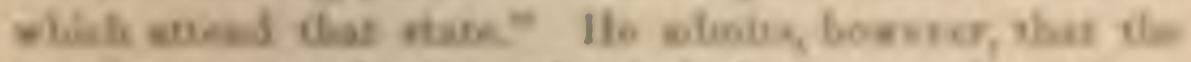

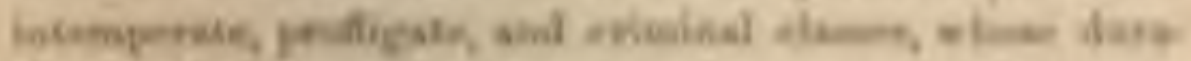

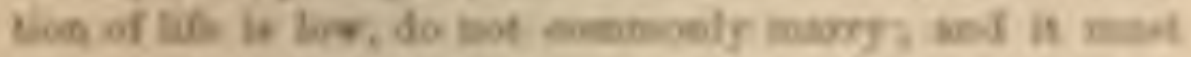

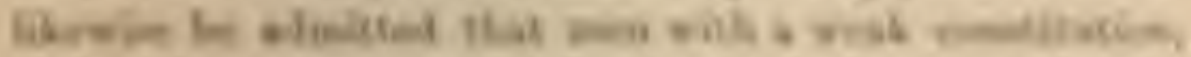

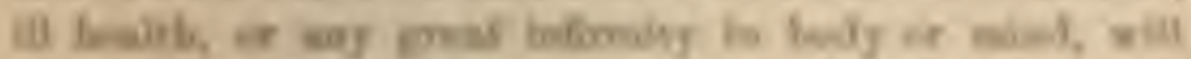

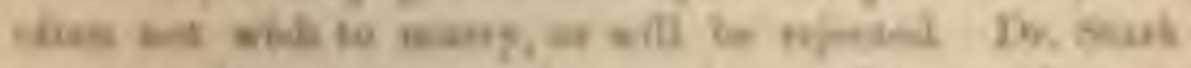

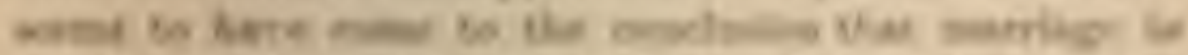

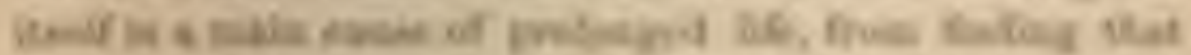

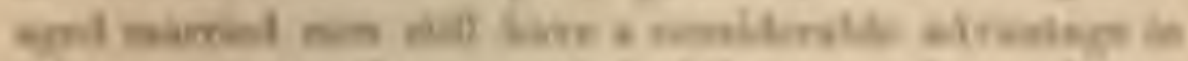

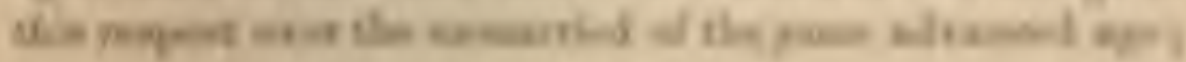

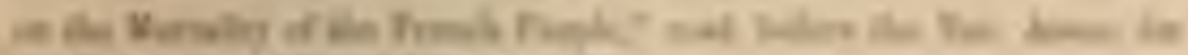

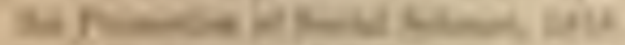

no- her.

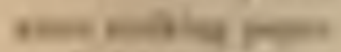

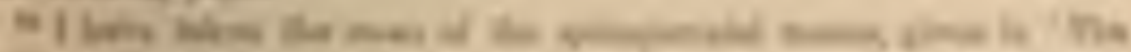

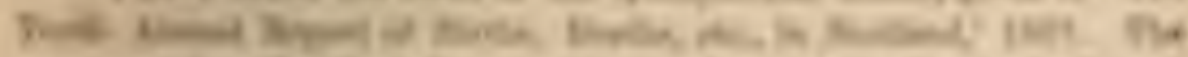

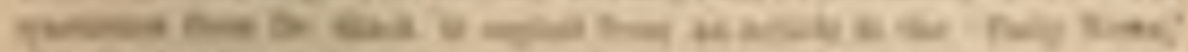

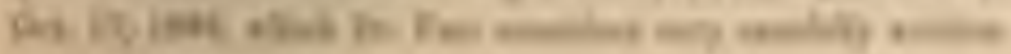


but erery one must have known instances of nen, who with weak health during youth did not marry, and got hatro Amrived to old age, though remaining weak and therefore always with a lessened chance of life. There is anoth(11 remarkable cirenmstance which secms to support 1)r. Stark's conchusion, nancly, that widows and widlowers in linance suffier in comparison with the married a rery heavy rate of mortality; but Dr. Farr attributes this to the porerty and evil habits consequent on the disruption of the family, and to grief. On the whole we may conchule with 1)r. Farr that the lesece mortality of married than of unmarrica men, which secus to be a general law, "is mainly lue to the constant rimination of imperfect types, and to the skilful selection of the finest individuals out of cach successive gencration;" the solection relating only to the marriage state, and acting on all corporeal, intcllectual, and moral qualities. We may, therefore, infer that somnd and grood men who ont of prudence remain for a time unmarricel do not suffere a high rate of mortality.

If the various eliecks specified in the two last paragraphs, and perhaps others as yet unknown, do not prevent the reckless, the vicions, and otherwise inferior members of society from increasing at a quicker rate than the better class of men, the untion will retrograde, as has occured too often in the listory of the world. We must renember that progress is no iuvariable rule. It is most difficult to say why one civilized nation rises, becomes more powerful, and spreads more widely, than another; or why the same nation progresses more at one time than at another. We can only say that it depends on an increase in the actual number of the population, on the number of the men endowed with ligh intcllectual and moral facultics, as well as on their standard of excellence. Corporeal structure, except so far as vigor of body leads to vigor of mind, appears to lia ve little influence. It has been urged by several writers that as high in. 
L llectual powon are adrantagenas is a ration, the oft

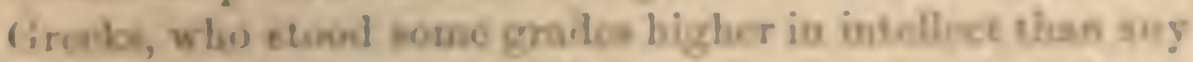

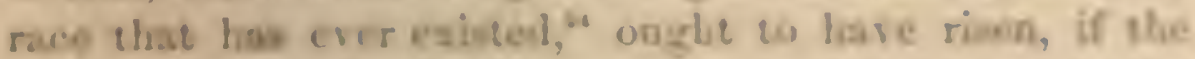
power of patural ectepeion were real, will ligbur in the neale, increased in number, sail veeted the whate of Kr. ropte. If re we have the tacit anousption, no ofter made with respect to corporeal strontures, that there is nome in-

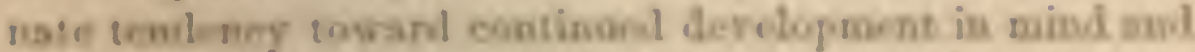
hody. Liat doviopoese of all kizids dejebile fas sesny

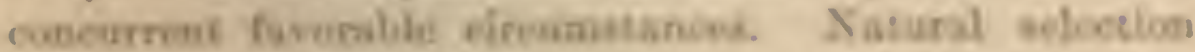

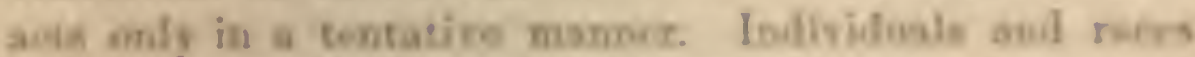

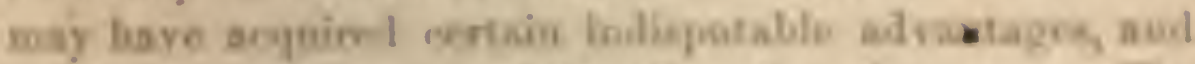

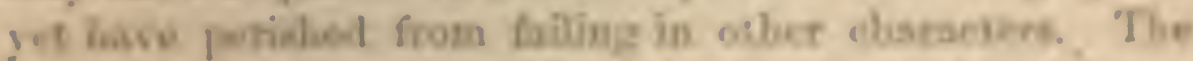

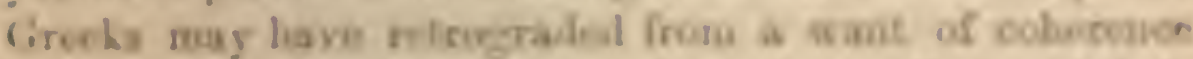
hewien the mang cmall etabs, from the malt eien of their whole cousery, iman the peartion of slisury, or from ex. treme wosualley; for they did sot tocoumb ansil "ther: were cuerrated and corrapt io the wey nore," w "The

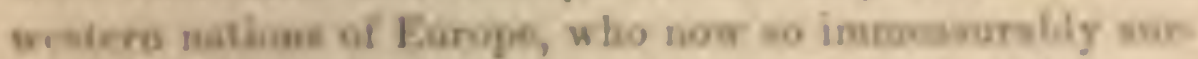
jand thir former nsyage jrogesifors and stand at the wasewit of cisiliestion, owe litte or none of thoir hajerionty th

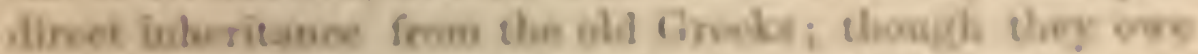

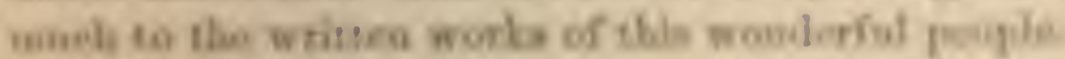

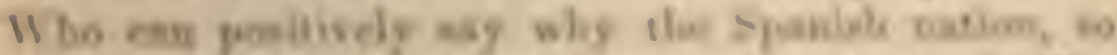

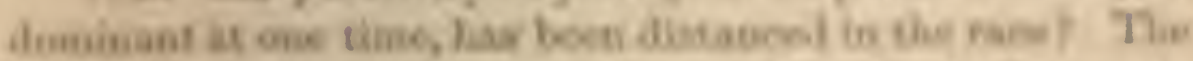

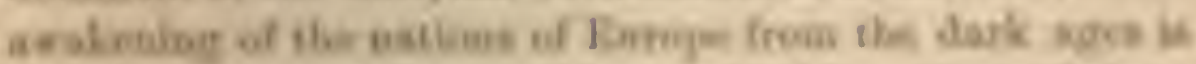

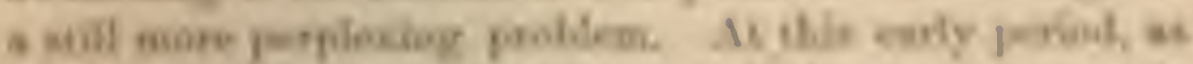

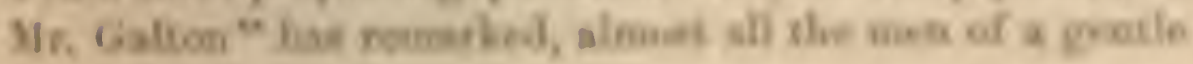

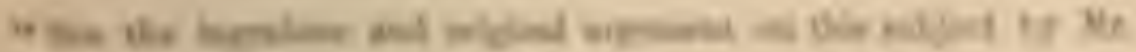

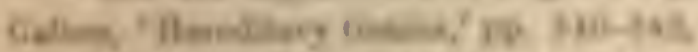

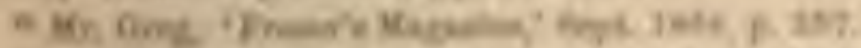

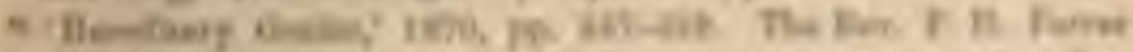

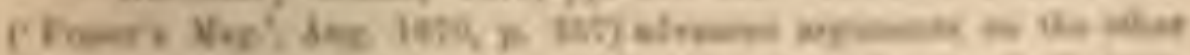

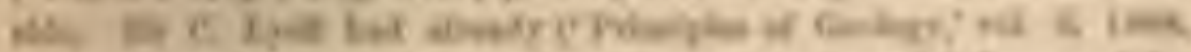

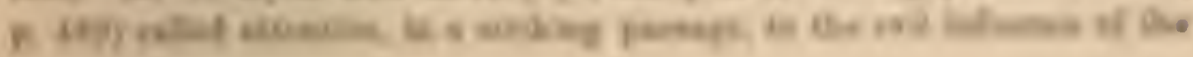


usture, these grires to metitation or culture of the mist, had no refuge esepet in the boban of the Clureh whioh demanded celibacy ; and this could hardly fail to hare had a deteriorating influence on meh sucenesise generation. During this sane periol the Iloly Inquisition selooted with estrome care the frome and boldex men in order to burn or imprison then. In Spain slane some of the lxest menthose who doubted and questioned, and withont doubling there can be no progres-were elimiuated during throe centurics at the rate of a thousaud a year. The evil which the Catholic Chureh has thus cellected, thongh no doubs comterbalancel to a certain, perhaps large expent in collex ways, is incalculable; noverthcless, linrope has juragressed on an unparalleled rate.

The remarkable suceess of the linglish as colonista orer other liuropean nations, which is well illustrated by comparing the progres of the Canadians of linglish and French certraction, has becu ascribed to their "dariug and persistent cuergy;" but who can say how the linglish gained their cuergy? "There is apparently mueh truth iu the belice that the womlerfil progress of the United States, as well as the characerer of the people, are the resule of uatural selection; the more unergetic, restless, and conragoous men from all ports of Furope laviug cmigrated during the last ten or twelre generationy to that great country, and haviug there succeded best." Looking to the distant future, I do not think that the Per. Mr. Tinoke takes an exagrerated view when lwe exss: " ".ll other sering of erents-ax that which resuled in the culture of inind in Groce, atel that which roulted in the enpire of

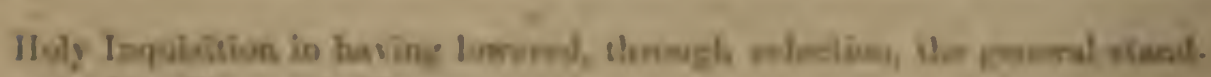

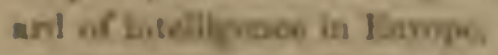

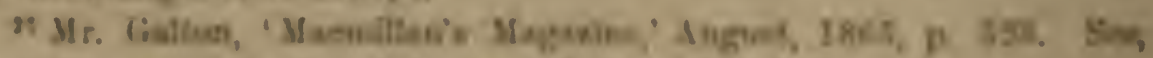

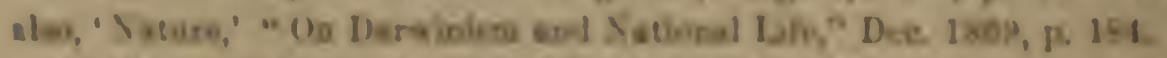

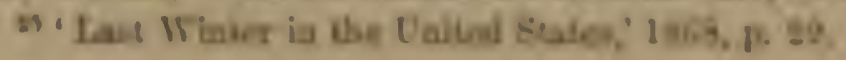




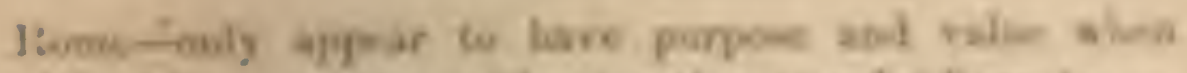

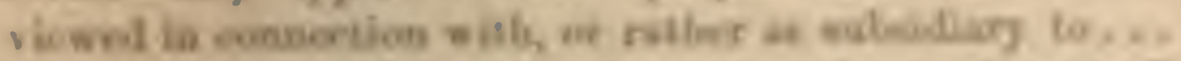

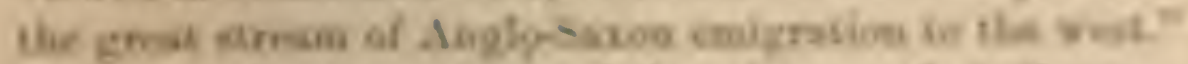

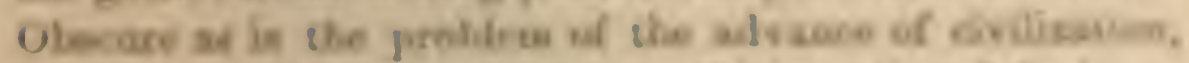

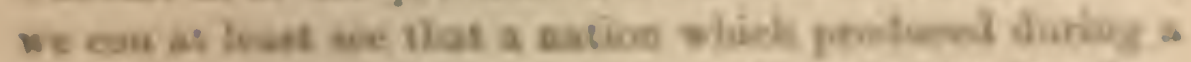

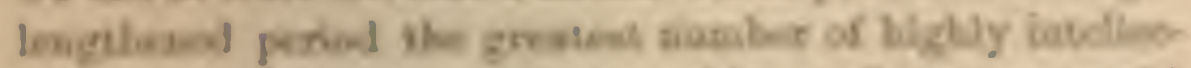

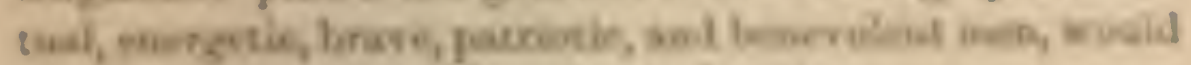
geonslly prevall ince tes favored nasioos.

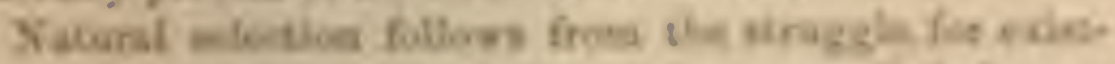

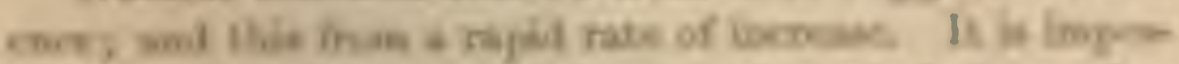

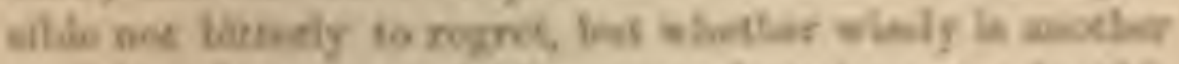

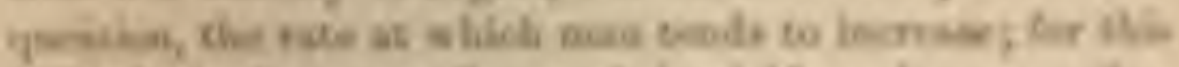

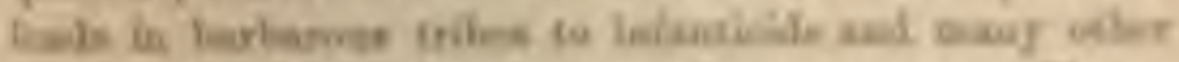

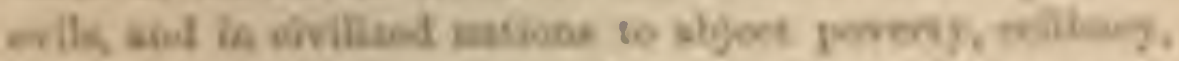

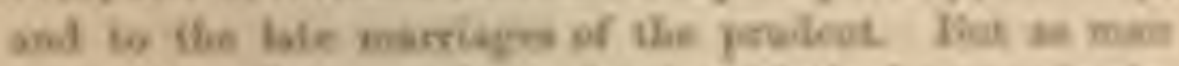

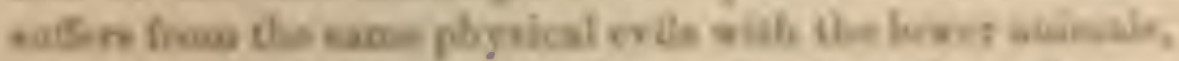

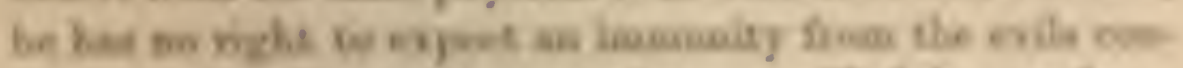

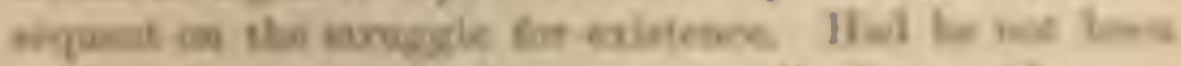

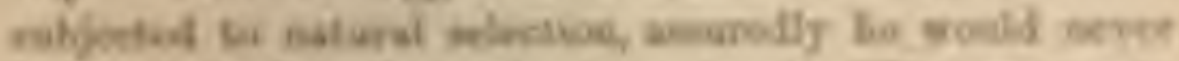

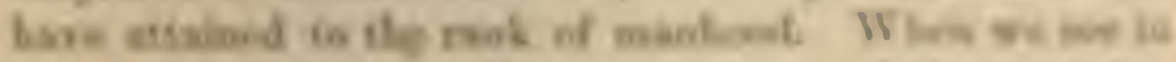

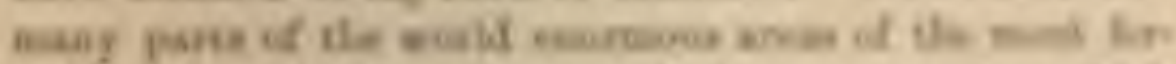

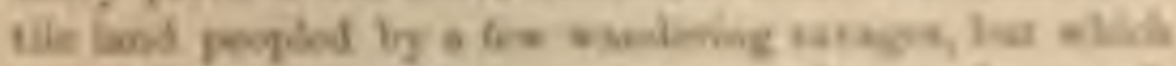

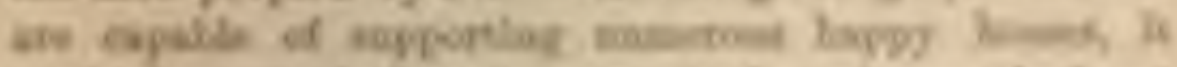

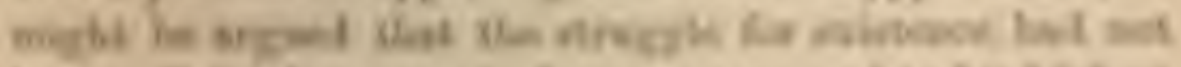

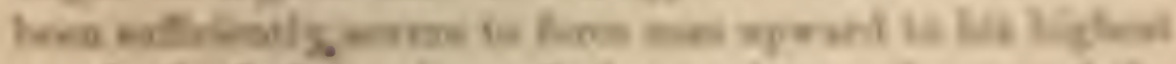

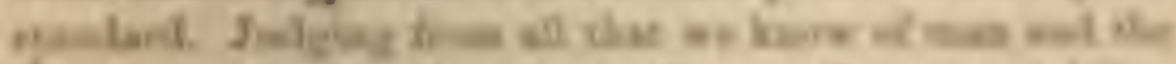

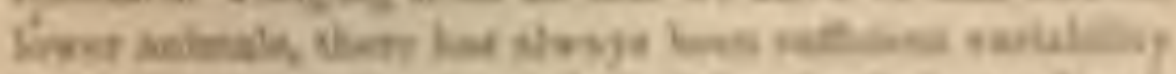

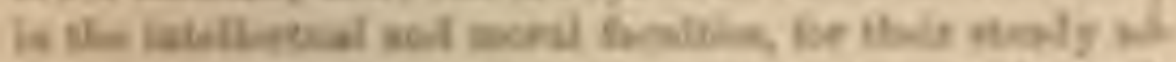

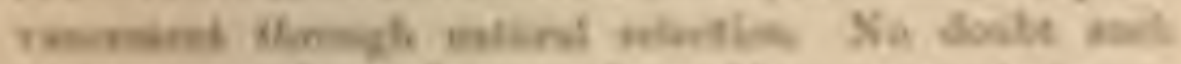

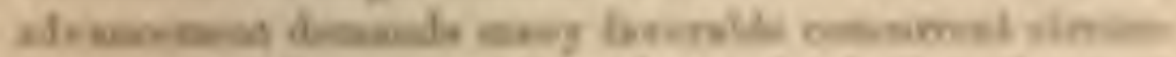

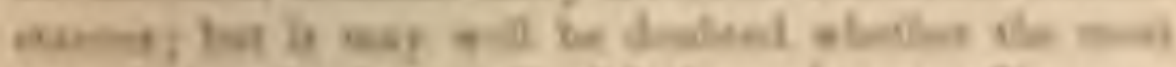

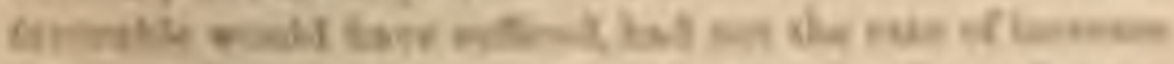

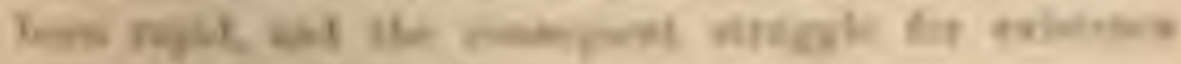

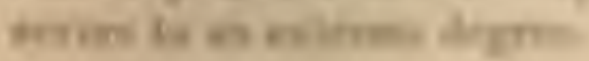


On the ceidence that all civilized mations tedie once liabarous. - As we hare had to comsider the steps by wheh some semi-human creat ure has been gralually raticel to the rank of man in lis unost perfect state, the present subject cammot be quite passed orer. Fut it has becm trated in so full and admirable a mamer by sir J. labl). bock, Mr. 'Tylor, Mr. M'Lemuan, and others, that I need here give only the bricfest summary of their results. The arguments recently advanced by the Duke of Aregll ${ }^{30}$ and formerly by Arelibishop Whatcly, in faror of the belicf that man came into the world as a civilized being and that all savages lave since undergone degradation, secu to me weak in comparison with those alvanced on the other side. Many nations, no doubt, have fallen away in civilization, and some may have lapsed into ntter barbarisu, though on this latter head I bave not met with any evidence. 'The Fuegians were probably compelled hy other conquering hordes to settle in their inlospitable country, and they may lave become in consequence somewhat more degraded; but it would be difficult to prove that they have fallen much below the botocudos who inhahit the finest parts of Brazil.

The evidence that all civilized nations are the descendants of barbarians, consists, on the one side, of cleal traces of their former low condition in still-existing customs, beliefs, language, etc.; and, on the other side, of proofs that savages are independently alble to raise thensclves a few steps in the scale of civilization, and have actually thus risen. The evidence on the first heal is extremely curious, but camot be here given: I refer to such cases as that, for instance, of the art of cummeration, which, as Mr. 'Tylor clearly shows by the words still used

so 'On the Origin of Civilization,' 'I'roc. Ettunological Soc.' Nor. 26, $186 \%$.

so 'P'rincral Man,' isce? 
in eusme plasen, originatud in contring the fongots, fine of

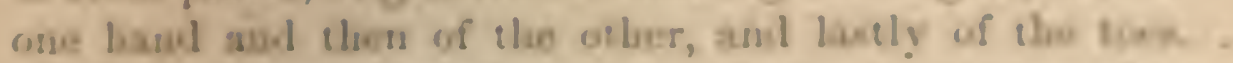
We lisve traeses of llis in our own decimal ngrtem, and io the loman unmeds, which after reacling to the samber V., clange intos VI., ete., whes the other had wo douin

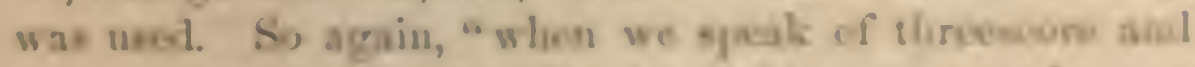

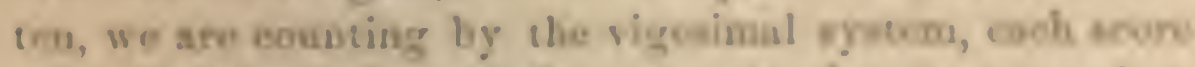

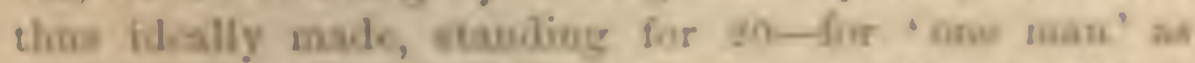
a Meriess ic Carib would pat it." " Acoondiog to a large

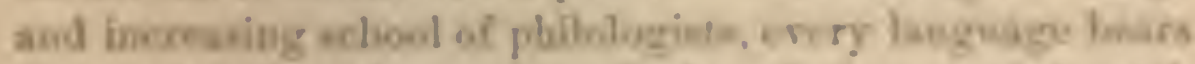

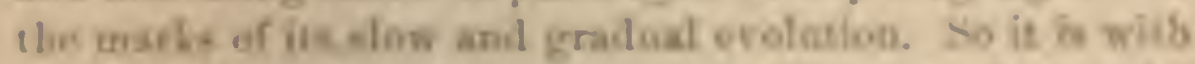
the ans of wtiving, an lecters bre ruliesenes of pinsorial reprevetalions. It is havilly poesible to rad Mr. Y'Lell.

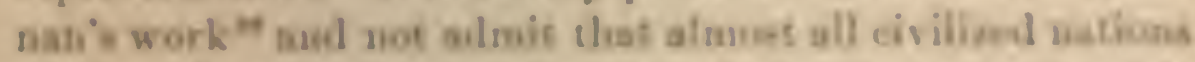
sill resin wrme tracie of nich rode la bite as tho foreible aptare of wives. What ancirat uaviuts, as the sasne auchor

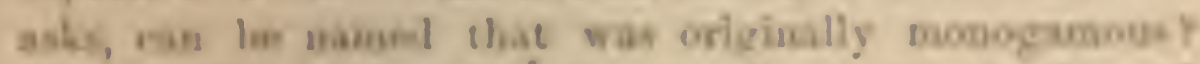
The primitive idea of jestice, as shewn loy the las of

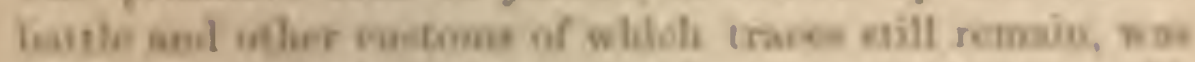

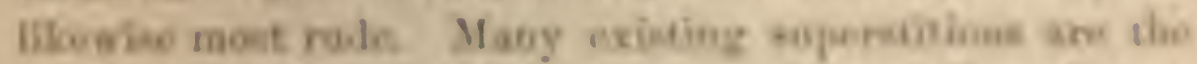

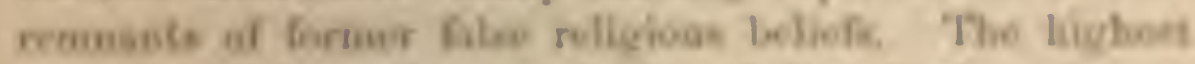

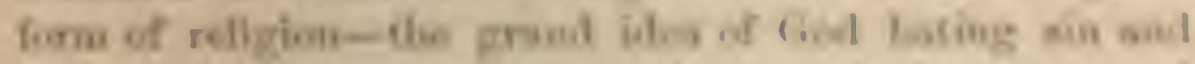

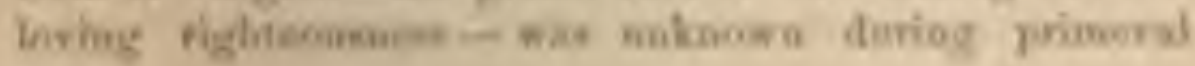
enones

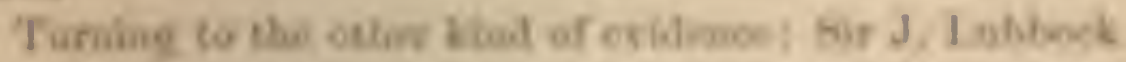

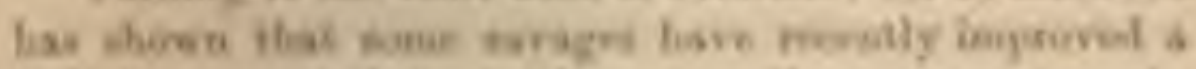

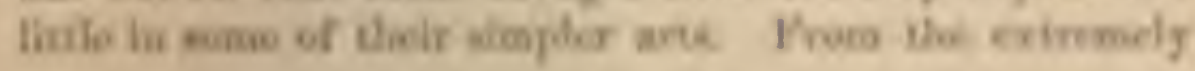

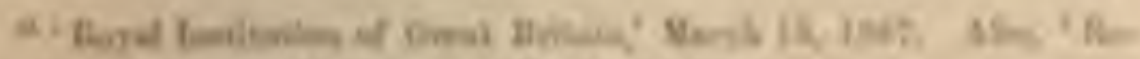

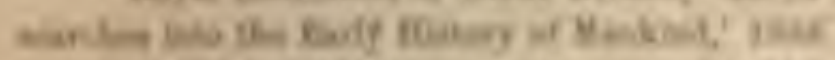

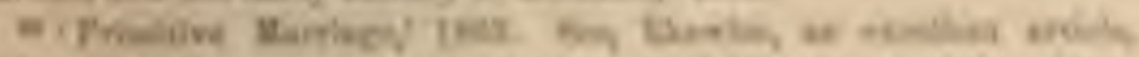

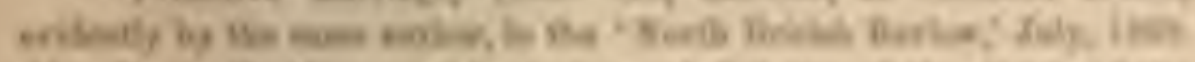

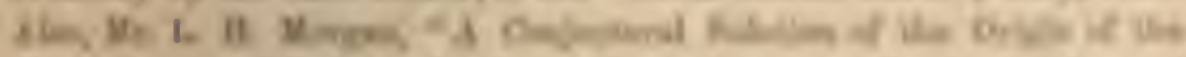

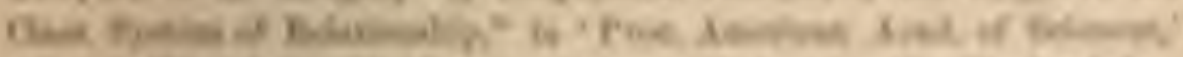

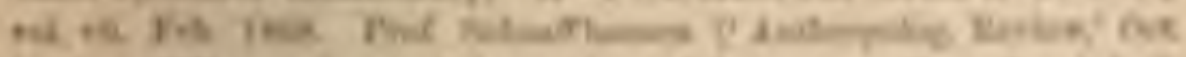

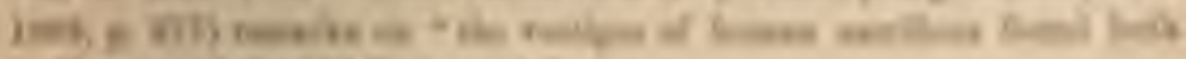
is II. 
curious account which he gives of the weapons, tools, and arts, nsed or practised by savages in various parts of the world, it camot be doubted that these have nearly all been independent discoveries, excepting perhaps the art of making fire. ${ }^{33}$ 'The Australian boomerang is a good instance of one such independent discovery. The Tahiti:ns when first visited had advaneed in many respects beyond the inbabitants of most of the other Polynesian islands. There are no just grounds for the belief that the high culture of the native Peruvians and Mexicans was derived from any foreign source; ${ }^{34}$ many native plants were there cultivated, and a few native animals domesticated. We should bear in mind that a wandering crew from some semi-civilized land, if washed to the shores of Ameriea, wonld not, judging from the small influence of most missionaries, have produced any marked effect on the natives, unless they had already become somewhat advanced. Looking to a very remote period in the history of the world, we find, to use Sir J. Lnbbock's well-known terms, a paleolithic and neolithic period; and no one will pretend that the art of grinding rough flint tools was a borrowed one. In all parts of Eirrope, as farr east as Grece, in P'alestine, India, Japan, New Zealand, and Africa, including Egypt, flint tools have been discovered in abund:ance; and of their use the existing inlabitants retain no tradition. There is also indirect evidence of their former use by the Chinese and ancient Jews. Hence there can hardly be a doubt that the inhabitants of these many countries, which include nearly the whole civilized world, were once in a barbarons condition. 'To believe that man was aboriginally civilized and then suffered utter degradation in so many

${ }^{23}$ Sir J. Lubbock, 'Irehistoric Times,' 2d edit. 1S69, chaps. $x v$. and xri. ci passim.

st Dr. I. Ifitler has male some good remarks to this effect in the Iicise der Nurara : Anthropolog. Theil,' Abtheil. iii. 1868, s. 127. 
regious, is to take a pitiably low viow of human nature. It is apparestly a truer and more checrful riew that prunres has been much more general than retrogre-ion; that man has risen, though by sluw and interrupted stoph, from a lowly condition to the highest standard as yet attaincel ly him in knowlelge, morals, and religion. 


\section{II A P T ER VI.}

ON TIIE AFFIXITLS AXII GI:EALOGY OI MAX.

Position of Man in the Animal Seriea. - The Natural Syntem genealogicul. - Aclaptive Clanracters of Slight Vulue.-Varions snall Points of ReRemblance between Man and the Quadrumanno-liank of Mas in tho Nintural Sratem.-Birthplace and Antiquiky of Man.-Abence of Fossil Connecting-links.-Iower Stages in the Genealogge of Mnn, at inferred, firtly from his Aflinitics and sccondly fron his Structure.Larly Androge mous Condition of the Vertebrata.-Conclusion.

Frr:x if it be granted that the difference between man and his noarest allies is as great in corporeal structure as fome naturalists maintain, and although we must grant that the difference between them is immone in mental power, yet the facts giren in the previous chapters doclare, as it appears to me, in the planest mamer, that man is deseculed from some lower form, notwithstanding that connecting-links have not hitherto been discovered.

Man is liable to numerous, slight, and diversified variations, which are induced by the sume general causes, are governed and transmitied in accordance with the same general laws, as in the lower animals. Man tends to multiply at so rapid a rate that his ofl-pring are uecescarily exposed to a strugerle for existence, and consequently to natural selection. He has given rise to many races, some of which are so diflirent that they have often been ranked by uaturalists as distinct species. His body is constructed on the same lomological plan as that of other mammals, 


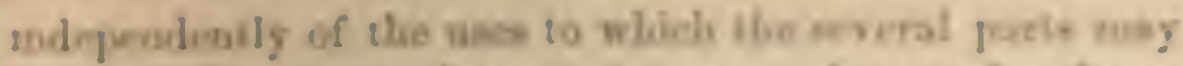
In gat. Ile pases throngh the ame phane of cobryo.

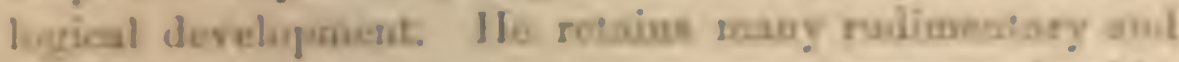
usbes stracture, which so duabe were owe avriocable. Gararters corationally make their reaptraranos is lim. which we liave escry ravas on liclieve were pasenew by bis rarly prugeaitum. If the origio of wose bal bem wholly difforas frods tlat of all whier asimals, these sarious aprearaores wadh le mure carpey decptione; bue

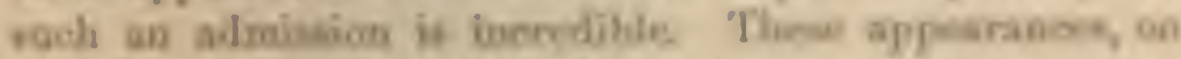
the other hani, are intellivibley at have to a turge exeore,

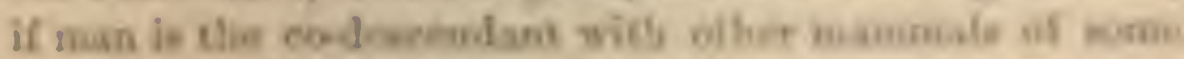
noknows and Jevres furth.

Some nataralises, frow ledeg decply fupereest wat.

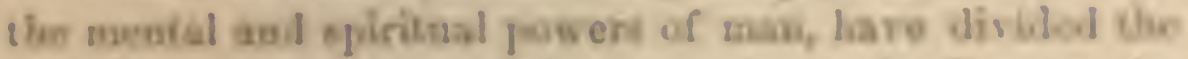
whole orpanie wortd into deree Liugoloms, tbe Hemen, the

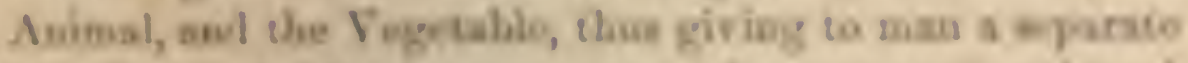

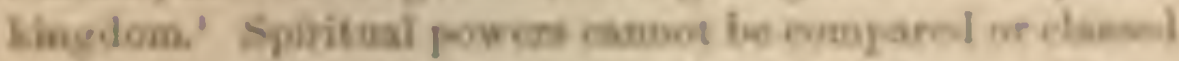
Iry ibe valursllat; lut be reay endesver to show, as 1 harre

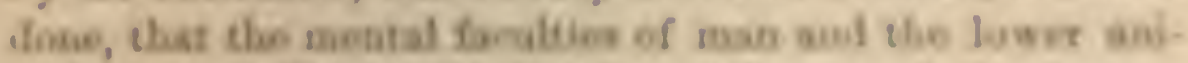

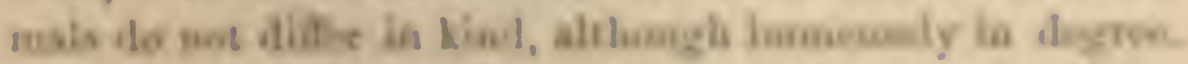

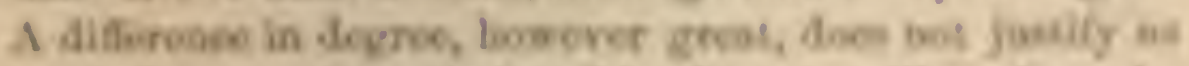

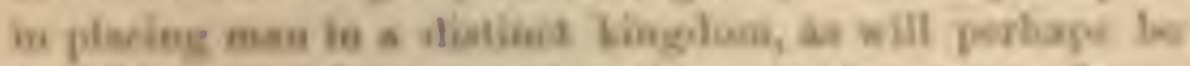

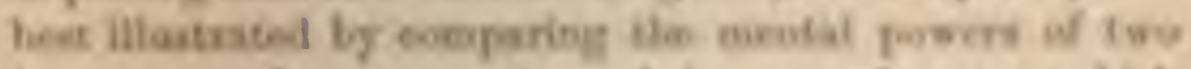

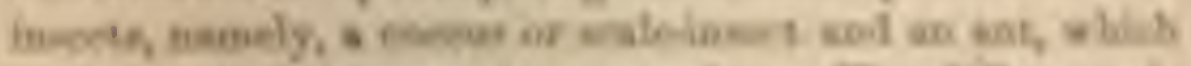

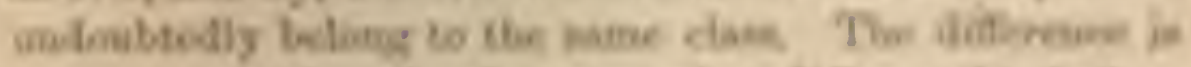

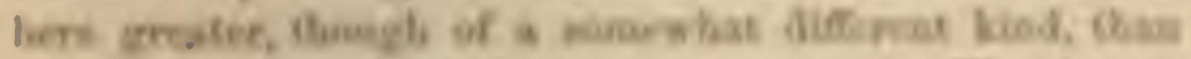

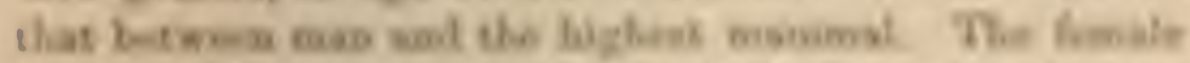

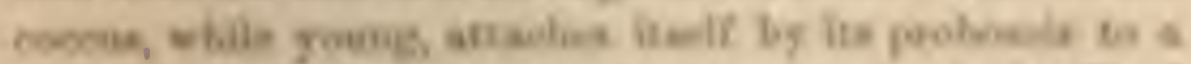

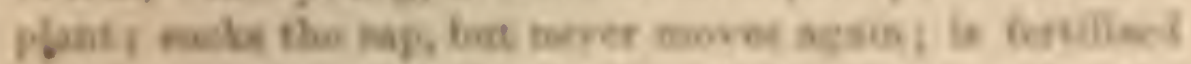

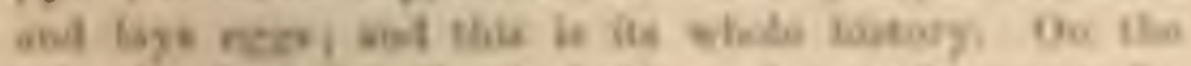

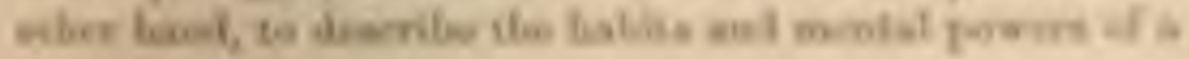

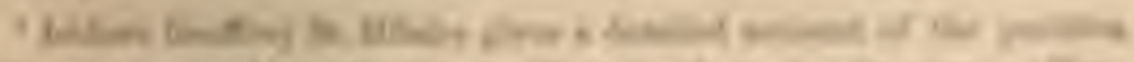

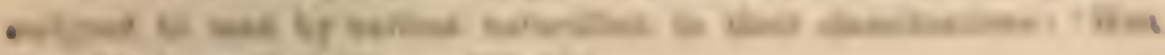

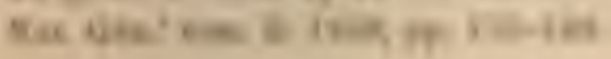


female ant, would require, as Pierre Iuber has shown, a large volume; I may, however, briefly specify a few points. Ants communicate information to each other, and sereral unite for the sane work, or games of play. 'Tliey recognize their fellow-ants after months of absence. They build great edifices, keep them clean, close the doors in the evening, and post scutries. They make roads, and eren tunnels under rivers. They collect food for the community, and when an object, too large for entrance, is bronglit to the nest, they enlarge the door, and afterward build it up again." They go out to battle in regular bands, and freely sacrifice their lives for the common weal. They emigrate in accordance with a preconcerted plan. They capture slaves. They keep Aphides as milch-cows. Thry move the eggs of their aphides, as well as their own eggs and cocoons, into warm parts of the nest, in order that they may be quickly hatched; and endless similar facts conld be given. On the whole, the difference in mental power between an ant and a cocens is immense; yet no one has ever dreamed of placing them in distinct classes, much less in distinct kingdoms. No doubt this interval is bridged over by the intermediate mental powers of many others insects; and this is not the ease with man and the higher apes. But we have erery reason to believe that breaks in the series are simply the result of many forms lıaving become extinct.

Prof. Owen, relying chiefly on the structure of thebrain, has divided the mammalian series into four sub) elasses. One of these he devotes to man; in another lic places both the marsupials and the monotremata ; so that he makes man as distinct from all other mammals as are these two latter groups conjoined. This view has not been aceepted, as far as I am aware, by any natinalist

sce the very interesting article, "L'Instinct chez les Insects," by 1. George Poucliet, 'Luvue des Deux Mondes,' Feb. 1870, p. 6\$2. 


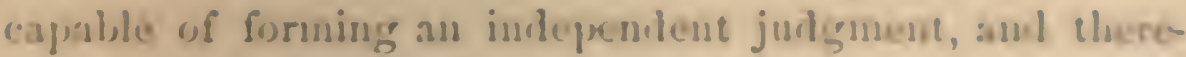
fore need not here be further comidered.

We can understand why a ciascifiontion foumed an any single cliaracter or organ-eren an organ so wonderfully complex aud iuportaut as the brain-or ou the lizh development of the mental faculties, is almose sure to prove unsatisfactory. 'This principle has indecd been triewith hymenopterout insects; bue when thes clansod by their habies or iustines, the arrangenent prosnel thor. ruglily artificial.' Claseifications may, of course, be hased ind any claracter whaterer, ax on size, celor, or the ole ment iuhabited; but unturalise have loug felt a profound couviction that there is a untural syntem. This syetem, it in now gouerally admitted, usust be, as fur as powible, gesuealogieal in arrangenent-that is, the co-slesendants of the rame form mus be hept togethor in one group, wop arate frum the somlescenlauts of ans other form; lant if the paran forme are rolatid, wo will be their desongdunte, and tie $\mathrm{twh}$ gremiga togreber will form a larger group.

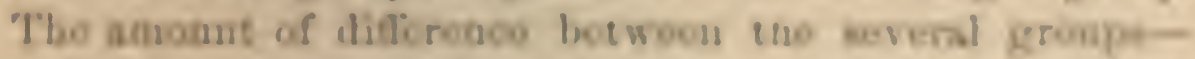
that is, the supusut of mudifiration which encls bar andert

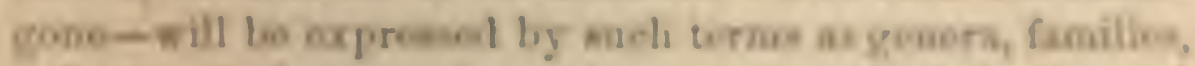

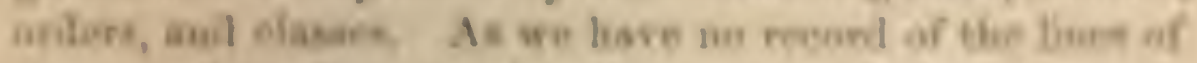

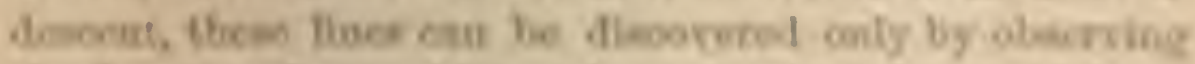

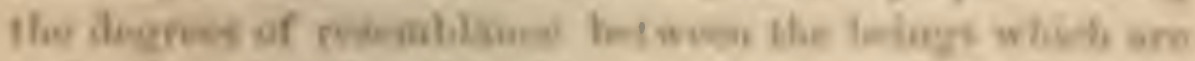

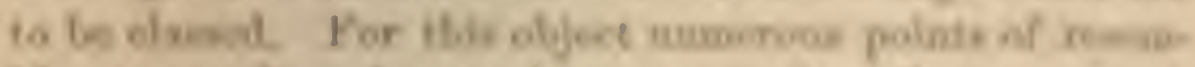

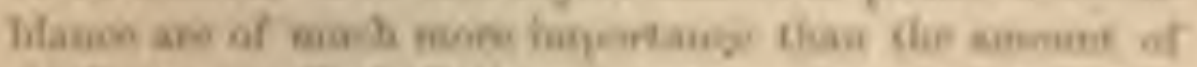

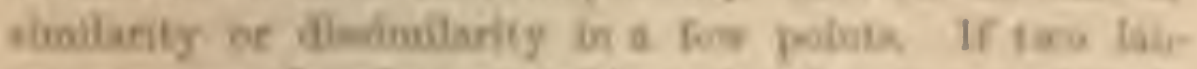

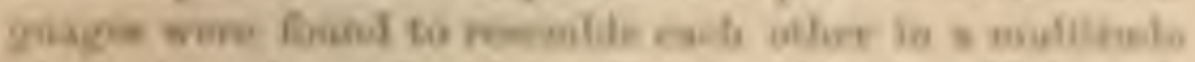

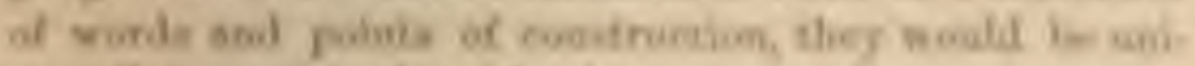

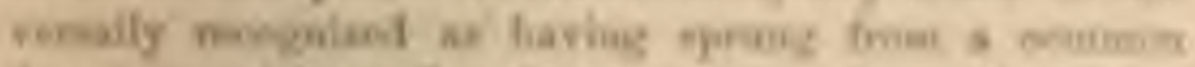

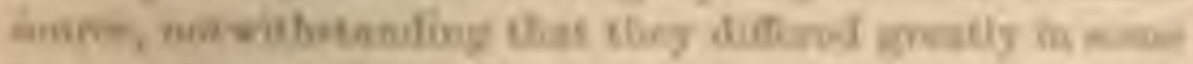

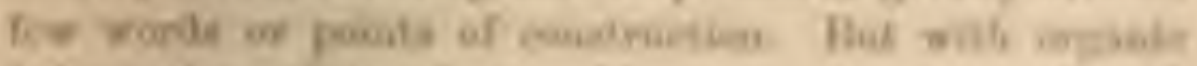

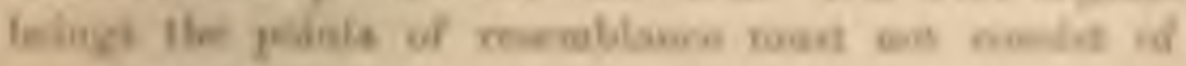


adaptations to similar haljits of life: two animals may, for instance, have had their whole frames modified for living in the water, and yet they will not be brought any nearer to each other in the natural system. Hence we can sec how it is that resemblances in unimportant structures, in useless and rudimentary organs, and in parts not as yet fully developed or functionally active, are by far the most serviceable for classification; for they can hardly be due to adaptations within a late period; and thus they reveal the old lines of descent or of true aflinity.

We can further see why a great amount of modification in some one character ought not to lead us to separate widely any two organisms. A part which already differs much from the same part in other allied forms has already, according to the theory of crolution, varied much; consequently it would (as long as the organism remained exposed to the same exciting conditions) be liable to further variations of the same kind; and these, if beneficial, would be preserved, and thus continually augmented. In many cases the continued development of a part, for instance, of the beak of a bird, or the tecth of a mammal, would not be advantageous to the species for gaining its food, or for any other object; but with man we can see no definite limit, as far as advantage is concerned, to the continued development of the brain and mental faculties. Therefore in determining the position of man in the natural or genealogical system, the extreme development of his brain onght not to outweigh a multitude of resemblances in other less important or quite unimportant points.

The greater number of naturalists who have taken into consideration the whole structure of man, including his mental faculties, have followed Blumenbach and Cuvier, and have placed man in a separate Order, under the title of the Bimana, and therefore on an equality with the 
Orilers of the Quadrunama, Caruisora, etc. Piecutly many of our best naturalists have recurred to the virw first propounded by Linnous, so remarkable for his sagacity, and have placed man in the same Oriler with the (Quadrumana, under the title of the Primates. The justice of this conclusion will be admitted if, in the first place, we bear in mind the remarks just mate on the compara. tively small inportance for classification of the great development of the brain in man; bearing, also, in mint that the strongly-marked differences between the skulls of man and the Quadrumana (lately insinted upon ly Bischotl; Acby, and othere) apparently follow from their dif. fertuty-dereloped brains. In the second place, we must renember that nearly all the other and more important differences between man and the Quadrumana are manifistly adaptive in their nature, and relate chiefly to the erect position of man; such as the structure of his hand, foot, and petris, the curvature of his spine, and the pro eition of his head. The funily of neals offirs a goon illustration of the kmall importance of adaptire claracters fur clanification. Thee auimals differ from all other Car. nirora in the form of thrir bodica and in the ntructure of their limbs, far more than doen man from the bigher apos: yot in every sytem, from that of Curier to the mont re-

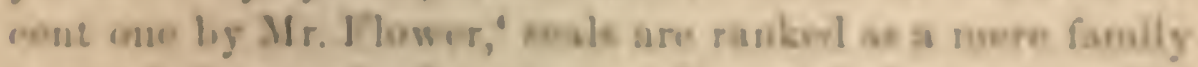
is the Order of the Carnivora. If man tand not bow his

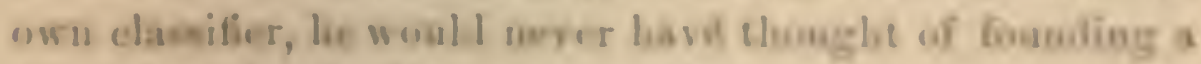
eqparate order for his own reopetion.

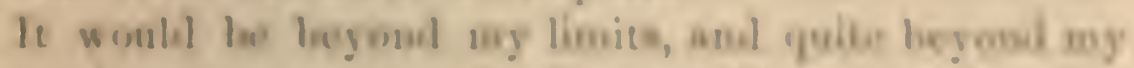

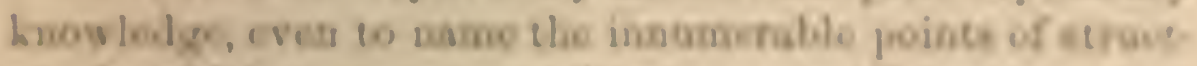

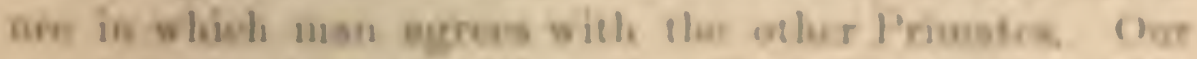

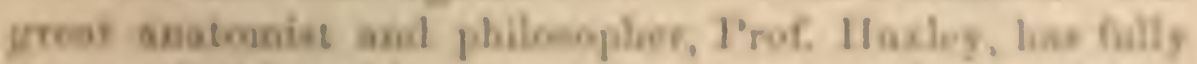

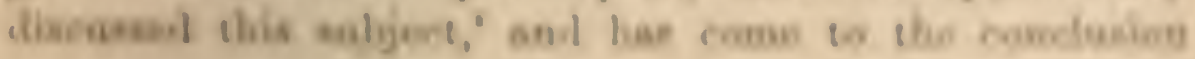

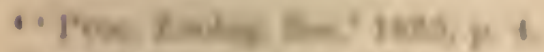

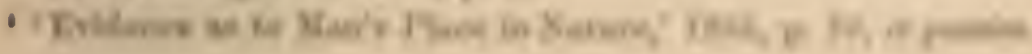


that man in all parts of his organization differs less from the ligher apes, than these do from the lower members of the same group. Consequently there "is no justifieation for placing man in a distinet order."

In an early part of this volume I brought forwari various facts, showing how closely man agrees in eonstitution with the higher mammals; and this agreement, no doubt, depends on our elose similarity in minute structure and chemical composition. I gave, as instances, our liability to the same diseases, and to the attacks of allied parasites; our tastes in common for the same stimulants, and the similar effects thus produeed, as well as by various drugs; and other such facts.

As small unimportant points of resemblance between man and the higher apes are not eommonly noticed in systematic works, and as, when numerous, they clearly reveal our relationship, I will specify a few such points. The relative positions of the features are manifestly the same in man and the Quadrumana; and the various emotions are displayed by nearly similar movements of the muscles and skin, chiefly above the eycbrows and round the mouth. Some few expressions are, indeed, almost the same, as in the weeping of eertain kinds of monkeys, and in the laughing noise made by others, during which the corners of the mouth are drawr backward, and the lower eyelids wrinkled. The external ears are curiously alike. In man the nose is much more prominent than in most monkeys; but we may trace the commeneement of an aquiline curvature in the nose of the Hoolock Gibbon; and this in the Semnopithecus nasica is carried to a ridiculous extreme.

The faces of many monkeys are ornamented with beards, whiskers, or mustaches. The hair on the head grows to a great length in some species of Semnopithecus $;^{\circ}$ and in the Bonnet monkey (Macacus radiatus) it 'B Isid. Gcoffroy, 'Hist. Nat. Gén.' tom. ii. 1859, p. 217 
radiates from a point on the crown, with a parting down the middle, as in man. It is commonly said that the forehead gives to man his noble and intellectual appearance; but the thick hair on the head of the Bonnet monkey terminates abruptly downward, and is succecded by such short and fue hair, or down, that at a little distance the forchead, with the cxecption of the cychrows, appears quite naked. It has been erromeusly asserted that 'yebrows are not prescnt in any monkey. In the species just named the degree of nakedness of the forcheal diflers in diflerent individushs, aml Eschricht states ${ }^{7}$ that in our children the limit betweri the hatry scalp and the naked forehcad is sometimes not well defincel so that here we secm to have a trifling case of leversion to a prosenitor, in whom the forehead lad not as yet become yuite nahed.

It is well known that the hatir ou our arms temls to comverge from atove and below to a point at the dluw. 'This curious arrangement, so mblike that in must of the lower mammals, is common to the gorilla, chimpanze, orang, some species of IIylobates, and even to some fow Aunerican monkeys. But in Mylobates agilis the hair on the formarm is directed dowmard or cowarel the wriet in the ordinary manner; and in $/ 1$. lur it is mesty crem, with only a rery slight forwarl inclinuten; so that in this latter specoios it is in a transitimnt state. It can hardly he donbteal that witl uset manmals the thickmos of the latir and itw dircetion on the back is alapted on throw sefl tue rain; even the trousverae haira ou the form ling of a dog may ocrue for this and when he is coiled up selen. Alr. Wallace renuark that the convergenee of the hir towarel the ellinw on the arma of the arasg (u linese

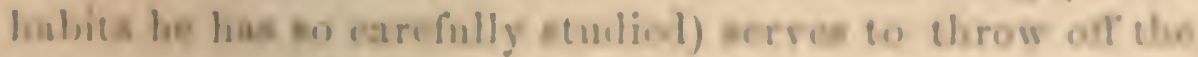
min, when, as it the outurn of this animal, the unue are

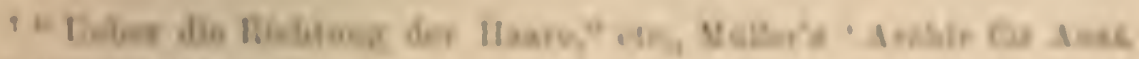

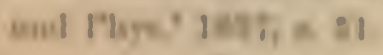


bent, with the hands clasped round a branch or orer its own head. We should, however, bear in mind that the attitude of an animal may perhaps be in part determined by the direction of the hair; and not the direction of the hair by the attitude. If the above explanation is corret in the case of the orang, the hair on our forearms ofliers a curious record of our former state; for no one supposes that it is now of any use in throwing oft the rain, nor in our present erect condition is it properly directed for this purpose.

It would, however, be rash to trust too much to the principle of adaptation in regard to the direction of the hair in man or his carly progenitor's; for it is impossible to study the fignes given by Eschricht of the arrangement of the hair on the human fatus (this being the same as in the adult) and not agree with this excellent observer that other and more complex canses have intervened. The points of convergence secin to stand in some relation to those points in the embryo which are last closed in during development. There appears, also, to exist some relation between the arrangement of the hair on the limbs, and the course of the medullary arteries."

It must not be supposed that the resemblances between man and certain apes in the above and many other points-such as in having a naked forchead, long tresses on the head, etc.-are all necessarily the result of mbroken inheritance from a common progenitor thus characterized, or of subsequent reversion. Many of these resemblances are more probably due to analogous variation, which follows, as I have elscwhere attempted to show;

- On the hair in Hylobates, sec 'Nat. Hist. of Mammals,' by C. L. Martin, 1841, p. 41\%. Also, Isid. Geofroy on the Americau monkeys and other kinds, 'Ilist. Nist. Géno' rol. ii. 1859, pp. 216, 243. Fischricht, ibic. R. 46, 55, 61. Owen, 'Anat. of Vertebrates,' vol. iii. p. 619. Wallace, 'Contributions to the Theory of Natural Selection,' 1850, p. 34.

' 'Origin of Species,' Eth edit. 1868, p. 121. 'The Variation of Animals and Plants under Donnestication,' vol ii. 1888 , p. 348. 
from co-descended organisms having a similar constitation and having been acted on by similar causes inducing variability. With respect to the similar direction of the hair on the forearms of man and certain monkeys, as this character is common to almost all the anthropomorphons apes, it may probably be attributed to inheritume; bet not cortainly so, as somo rery distinct Amcrican monkers are thus characterized. The same remark is applicable to the tailles condition of man; for the tail is absent in all the anthropenorphous apes. Neverticless thit claracter camot with cortainty be attributed to inheritance, as the tail, though not absent, is rudinentary in several other Old World and in some New World specios, and is guite alsent in several specios lechonging to the allied group of lemurs.

Ahlongh, a we have now mon, man has no juat right to form a epparate Oriter for his own rencpetina, he may perlange claim a distina Sub-oriles or Family. Prot. Ifus. ley, in his late work, "dirides the Primates into three Subirilece: namely, the Antlropilise with man slone, the

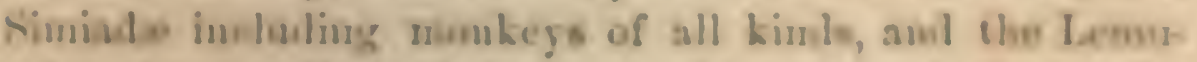
rida witb tho dirersibel goum of letwars. As far as dif.

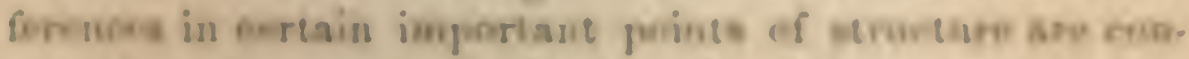
cernod, man may no doubt riebly elaim tho raok of a Sulwotider; aus this rabk is tho low, if we kook chiefly un

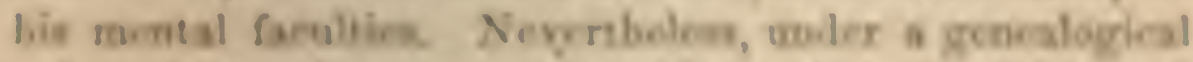

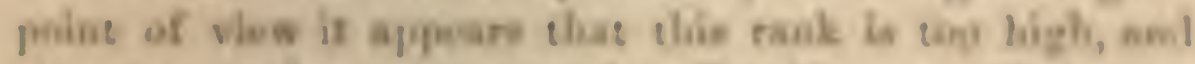
that man ought to fomi merely a Yamily, of poedbly ovon

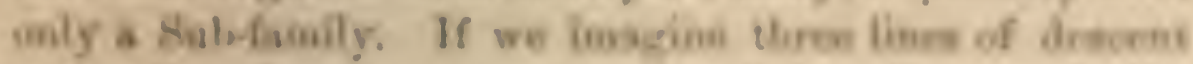
prosecelteg from a common sourcs, it is groite conesivalio

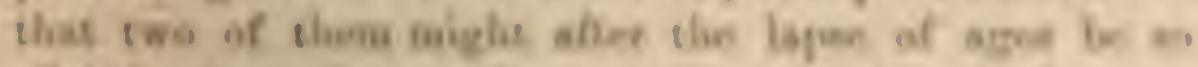

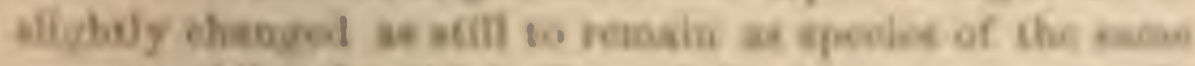

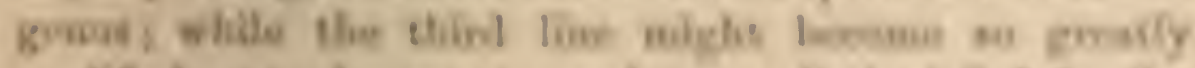

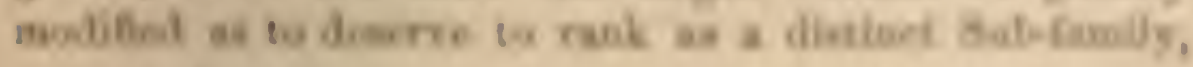

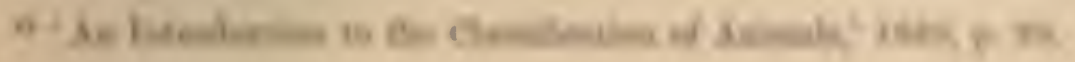


Family, or even Order. But in this case it is almost certain that the third line would still retain throngh inheritance numerous suall points of resemblance with the other two lines. Here, then, would oceur the difficulty, at present insoluble, how much weight we ought to assign in our classifications to strongly-marked diflerences in some few points-that is, to the amount of modification undergone; and how much to close rescmblance in numerous unimportant points, as indieating the lines of descent or genealogy. The former alternative is the most obvious, and perhaps the safest, though the latter appears the most correct as giving a truly natural classificition.

'To form a judgment on this lead, with reference to man we must glance at the classification of the Simiada. 'This family is divided by almost all naturalists into the Catarhine group, or Old World monkeys, all of which are characterized (as their nane expresses) by the peculiar structure of their nostrils and by having four premolars in each jaw; and into the Platyrhine group or New World monkeys (including two very distinct sub-groups), all of which are characterized by differently-constructed nostrils and by having six premolars in each jaw. Some other small differences might be mentioned. Now man unqques. tionably belongs in his dentition, in the structure of his nostrils, and some other respects, to the Catarline or Ohl World division; nor does he resemble the Platyrhines more closely than the Catarhines in any characters, excepting in a few of not much inportance and apparently of an ad:sptive nature. 'Therefore it would be against all probability to suppose that sone ancient New World species laad varied, and bal thus produced a man-like creature with all the distinctive characters proper to the Old World division; losing at the same time all its own distinctive characters. There ean consequently hardly be a doubt that man is an oflshoot from the Old World sim. 


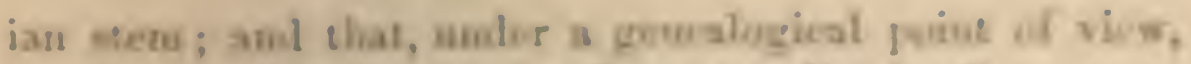
be most be clased wich the Cacorline diviono."

'The suthrupounorphous spee, raenely the gorills, chim. parze, arang, and by biates, are keparated at a distibet

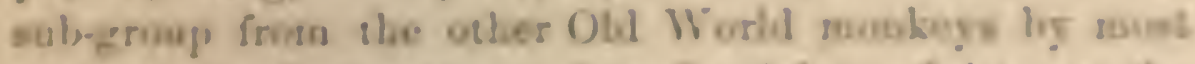
satumisis. I am awase that Comeiolet, relging on she strueture of the hrain, loce not almit the ecieteser of this

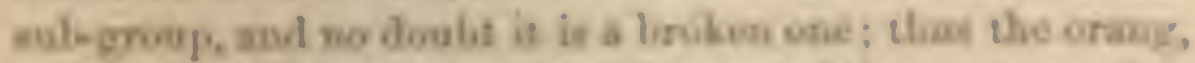

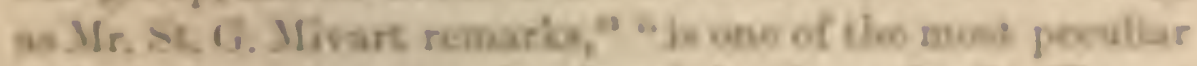

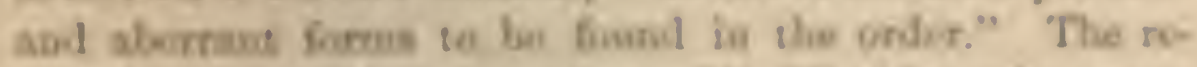

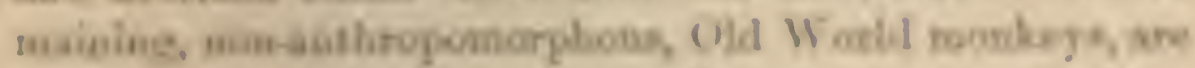

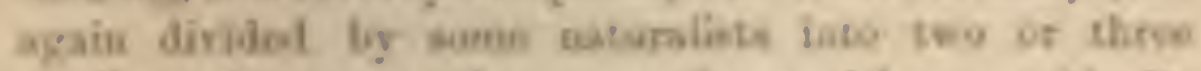

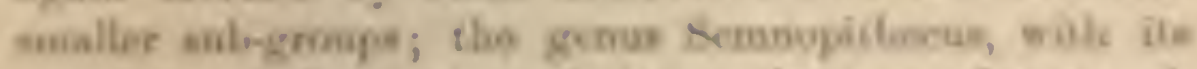

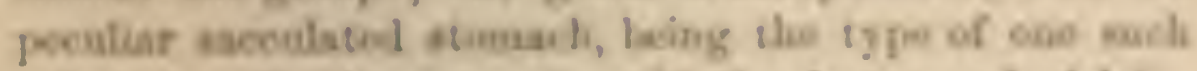

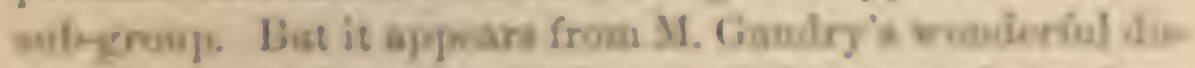
coverise is Attion, that durtege the Minswe próned a form erispal there, whin counered Arronojistercus and Mirs-

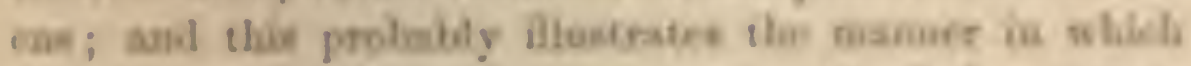

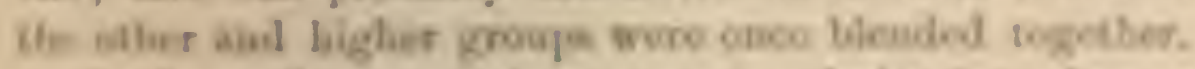

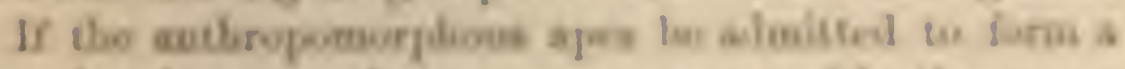

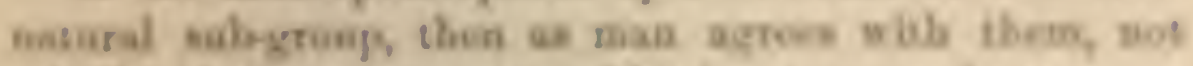

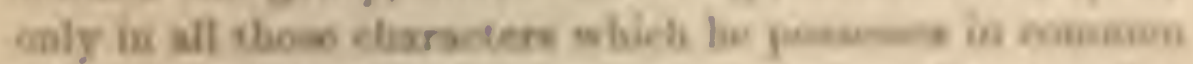

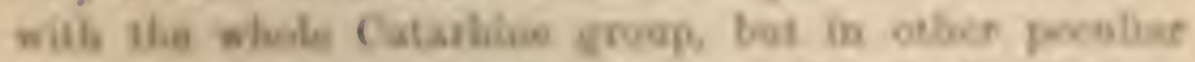

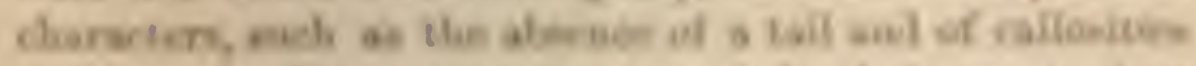

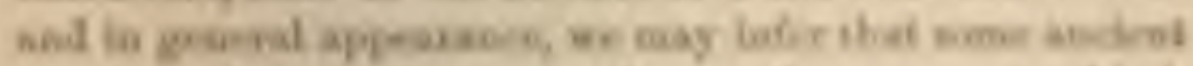

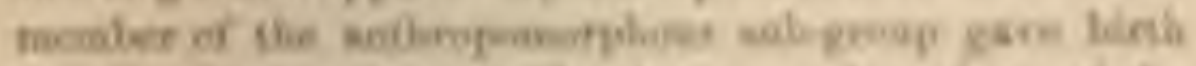

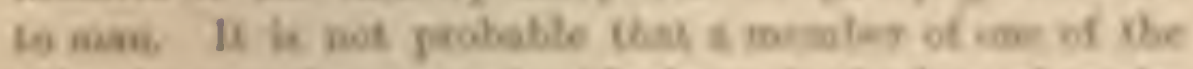

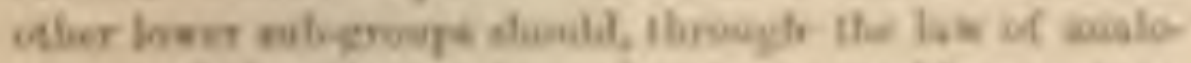

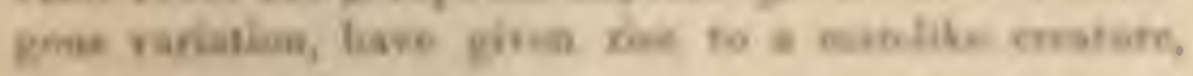

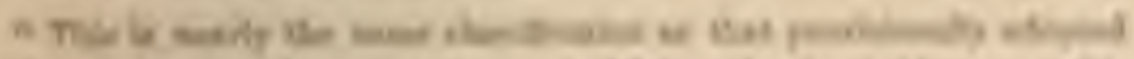

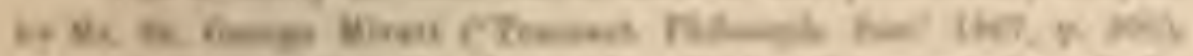

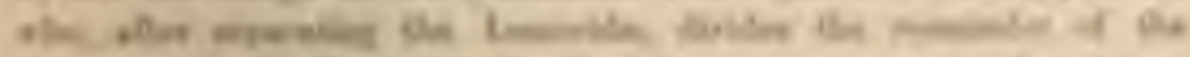

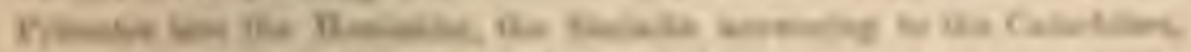

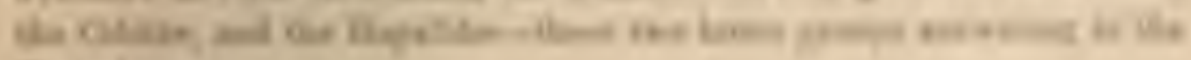
namiles.

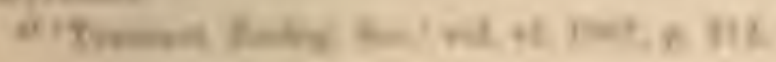


resembling the higher anthropomorphous apes in so many respects. No doubt man, in comparison with most of his allies, has undergone an extraordinary amount of modification, chicfly in consequence of his greatly-dercloped brain and erect position; nevertheless, we should bear in mind that he "is but one of sereral exceptional forms of Primates." "

Every naturalist, who believes in the principle of evolution, will grant that the two main divisions of the Simiade, namely the Catarhine and Platyrhine monkeys, with their sub-groups, have all proceeded from some one extremely ancient progenitor. The early descendants of this progenitor, before they had diverged to any considerable extent from each other, would still have formed a single natural group; but some of the species or incipient genera would have already begun to indicate by their diverging characters the future distinctive marks of the Catarhine and Platyrhine divisions. Hence the members of this supposed ancient group would not have been so uniform in their dentition or in the structure of their nostrils, as are the existing Catarhine monkeys in one way and the Platyrhines in another way, but would have resembled in this respect the allied Lemuridio which differ greatly from each other in the form of their muzzles, " and to an extraordinary degree in their dentition.

The Catarhine and Platyrhine monkeys agree in a multitude of characters, as is shown by their unquestionably belonging to one and the same order. The many characters which they possess in common can lardly bave been independently acquired by so many distinct species; so that these characters must have been inherited. But an ancient form which possessed many characters

${ }^{13}$ Mr. St. G. Mivart, 'Trancact. I'hil. Soc.' 186 i, p. 41 n.

"Messrs. Murie and Mivart on the Lemuroiden, 'Trausact. Zoulog. Soc.' rol. vii. 1869, p. 5 . 
coumon to the Catarlsue aud Platgrluse monkeys, an I wherh in an insermediate condition, ans some fo werlapes distiset from those now present in eiller groug, would undoubtedly hase been ranked, if secu hy a naturalise, as an ape or monhey. And as man under a genealogiest proint of view belongs to the Catarlusuc or Old Worts stoek, we must conelule, liowerer much the conelseioss uay revele our prile, that our arly progendions woald lave lecer properly thas desigusted." Jint we must no: full iuto the error of sapposing that the early jomgesitur of the whole Simian stork, inclading man, wat identical with,

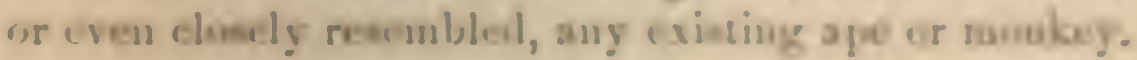

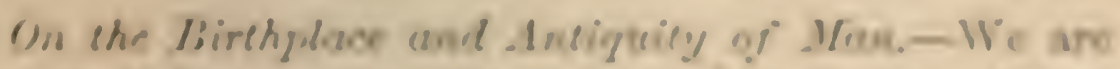
saturally led (1) infuire where whe she hirelypluev of suas at that anpe of deccut when our progenitors divergod

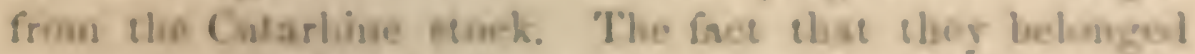
to this stock dearly shows that thoy intiabited the Otd

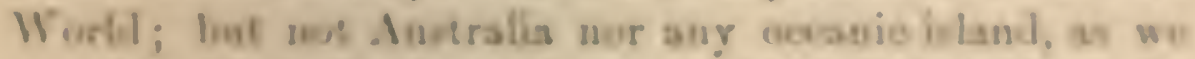
mas infer from tho laws of geogrophiosal diatribation. In eanli terat region of the world the living mameste am clowly rolated fo the eçtiset spovios of the same region.

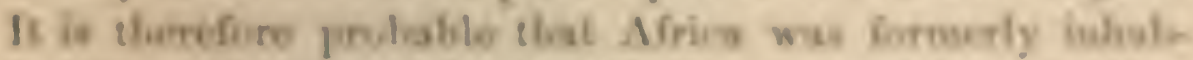

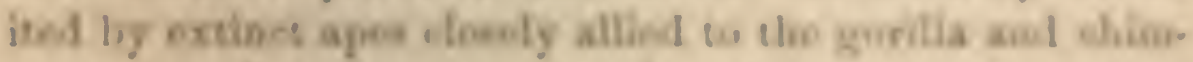

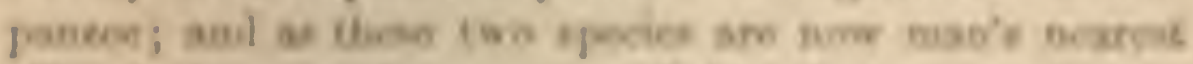
aDlea, it He menewlose more probable that voe, rady jor Eeniton lired or tbe Ahrou Contiums tbas elocobore.

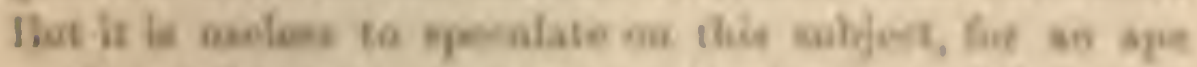

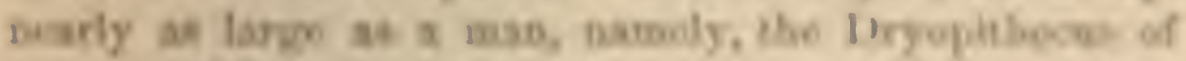

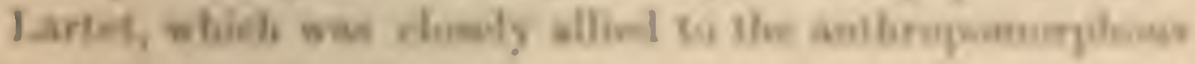

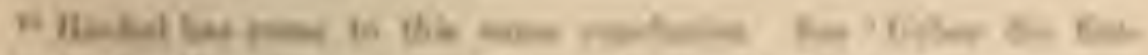

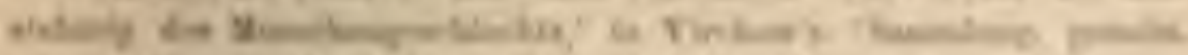

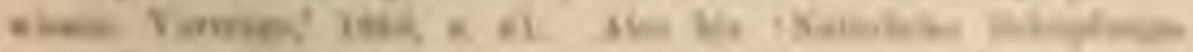

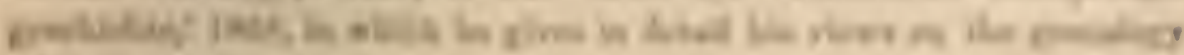
of ese 
Hylobates, existed in Europe during the Upper Miocene period; and since so remote a period the earth has certainly undergone many great revolutions, and there has becoln anple time for migration on the largest scalle.

At the period and place, whenever and wherever it maty have been, when man first lost his hairy covering, he probably inhabited a hot country; and this wonld have heen favorable for a frugiferons diet, on which, judging from analogy, he subsisted. We are far from knowing how long ago it was when man first diverged fiom the Cat:arhine stock; but this may have occured at an epoch as remote as the Eocene period; for the higher apes had diverged from the lower apes as carly as the Upper Miocene period, as shown by the existence of the Dryopithecus. We are also quite ignorant at how rapid a rate orgranisms, whether high or low in the scale, may under farorable circumstances be modified: we know, however, that some have retained the same form during an enormous lapse of tine. From what we see going on under domestication, we leam that within the same period some of the co-descendants of the same species may be not at all changed, some a little, and some greatly changed. Thus it may have been with man, who has undergone at great amount of modification in certain characters in conparison with the higher apes.

The great break in the organic chain between man and his nearest allies, which camnot be bridged over by any extinct or living species, has often been advanced as as grave objection to the belief that man is descended from sone lower form; but this objection will not appear of much werght to those who, convinced by genersl reasons, believe in the general principle of erolution. Breaks incessantly oceur in all parts of the series, sone being wide, sharp, and defined, others less so in various degrees; as between the oramg and its nearest allies-between the 
Tar-ins and the wher Jasuridx-intwen the dephant sml in a mure striking manuer botwoen the Ornichertign. olnas or Felielna, and other mammals. Rat all these

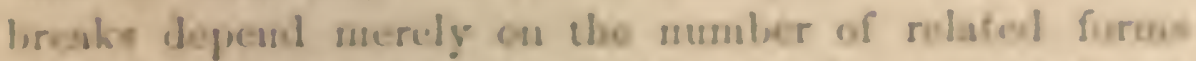
whioh have become alimet. At sinae future ju rionl, bot very distant as measured ho centurice, the civilized races of man will almoat cortainl orerminate and replace tirnoglonut the world the savage races. At tbe eamur line the anthropoinorphont ay"es, as l'rue. Ac bsaffisasou lise remarked," will se shobt bo escerninated. The frock will then be retolerel wiler, for it will botervem

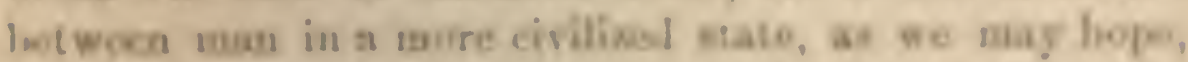

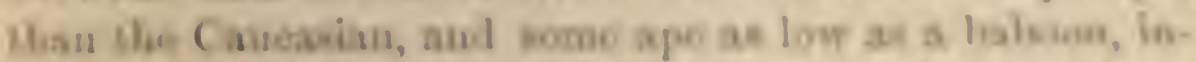

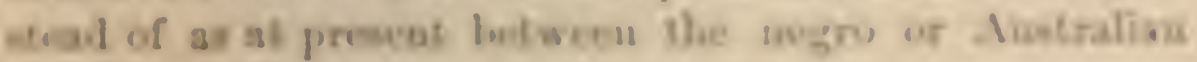
sud the gerills.

Witk roppest to the absence uf hasil remains, worving

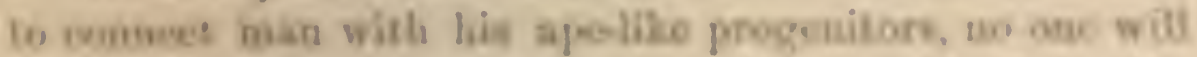

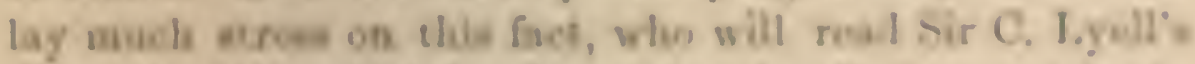

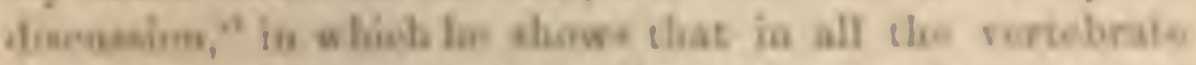
olases the dincopory of foeil rowoms bas hero su ex-

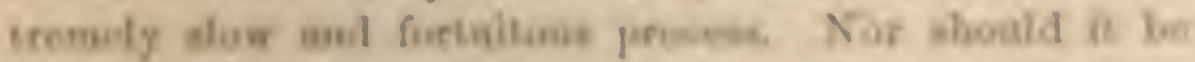

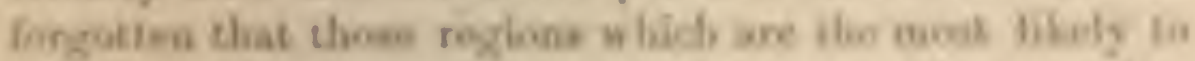

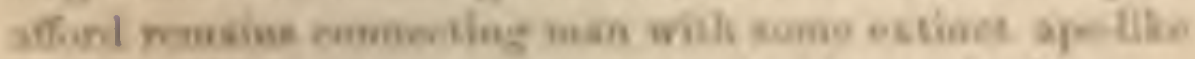

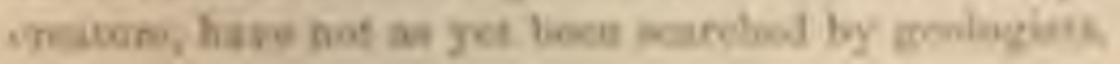

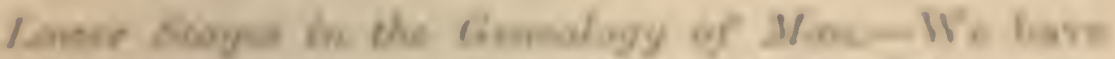

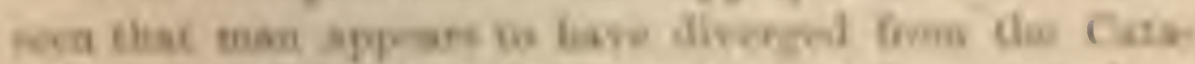

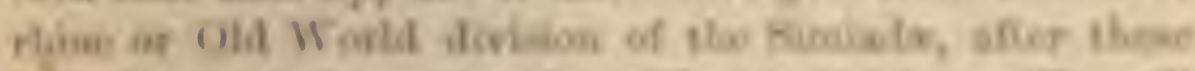
hat diverged fous der Soe Wochl afrisian We will

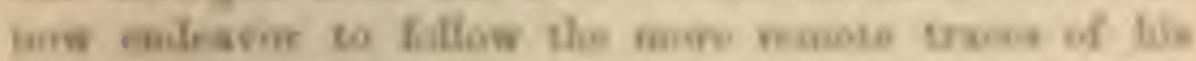

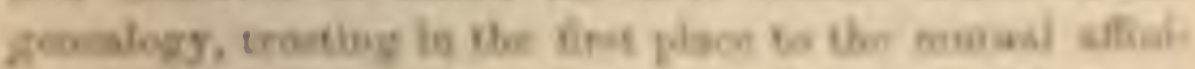

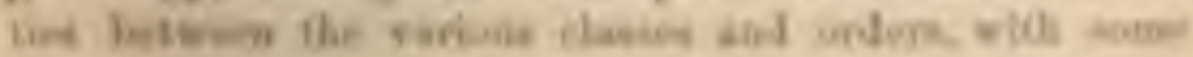

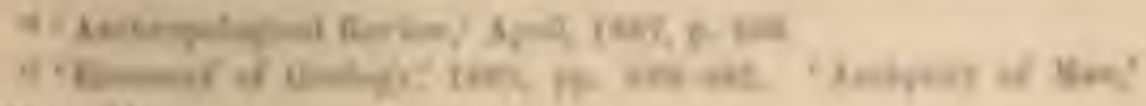


slight aid from the periods, as far as ascertained, of their successive appearance on the earth. The Lemuridie stand below and close to the Simiada, constituting a very distinct family of the Primates, or, according to Itackel, a distinct Order. 'This group is diversified and broken to an extraordinary degree, and includes many aberrant forms. It has, therefore, probably suffered much extinction. Most of the remnants survive on islands, namely, in Madagascar and in the islands of the Malayan archipelago, where they have not been exposed to such severe competition as they would have been on well-stocked continents. This group likewise presents many gradations, leading, as Huxley remarks, "insensibly from the crown and summit of the animal creation down to creatures from which there is but a step, as it seems, to the lowest, smallest, and least intelligent of the placental mammalia." From these various considerations it is probable that the Simiade were originally developed from the progenitors of the existing Lcmuride; and these in their turn from forms standing very low in the mammalian series.

Tho Marsupials stand in many important characters below the placental mammals. 'They appeared at an earlier geological period, and their range was formerly much more extensive than what it now is. Hence the Placentata are generally supposed to have been derived from the Implacentata or Marsupials; not, however, from forms closely like the existing Marsupials, but from their early progenitors. The Alonotremata are plainly allied to the Marsupials; forming a third and still lower.division in the great mammalian series. They are represented at the present day solely by the Ornithorliynchus and Echidua; and these two forms may be safely considered as relies of a much larger group which have been preserved in Australia through some fitrorable concurrence of circumstances. 18 'Jan's Place in Nature,' p. 105. 
The Monotremata are emiuculy iuteresting, as iu serceral important points of structure they lead toward the clas of reptiles

In attrupting to trace the guncalory of the Manmalia, and therefore of man, lower down in the series, we become imvolvel in greater and greater obscurity. He who wislses to sec what ingenuity and knowledge can cflect, may com-ult Prof. Hächel's works." I will coneont myself with a fuw gencral rumarka. Fvery evolutionist will almit that the five great vertebrate classes, mamcly, mammals, birls, reptiles, amphibians, and fislocs, are all descended from sume one prototspe; for they lase umoh in common, expecially duriug their embryonic state. $A$ sthe clases of fi-lecs is the mone lowly organized and appeared before the others, we may concluele thas all the members of the vertubrate kingelom are derived from some fimlslike animal, less lighly organized than any as yei fouml in the loweet huown formations. The belief that animals as divince as a moukey or clophant and a liummimg-lirel, a wuake, fron, aml tim, che, cuuld all have sprung from the eame parute, will appear moutrow es thome who hare not attended to the reecut progres of untural lisenry. Jor this belief implics tho former a.

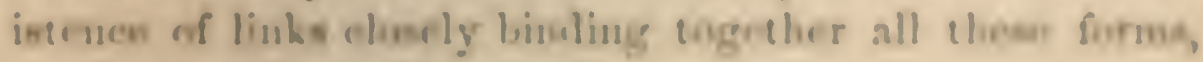
unw to ueverly smliho.

Nerertlefess, it is ceriain tbat prospe of asimale bare erieted, or do now exist, whinh erve in ommome umre or

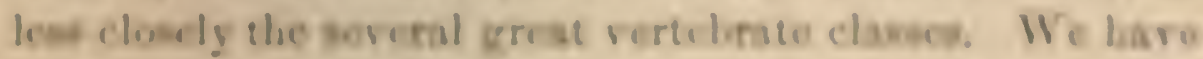

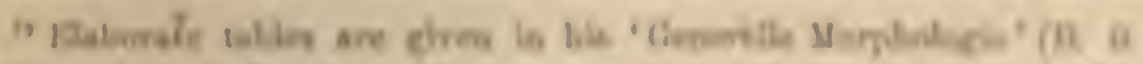

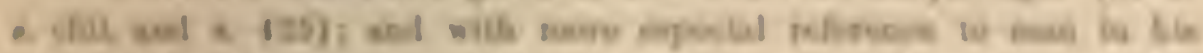

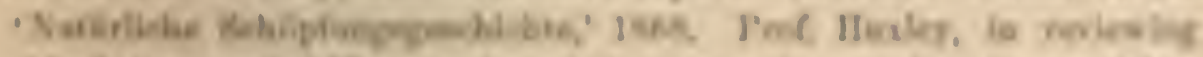

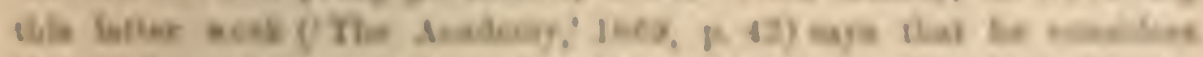

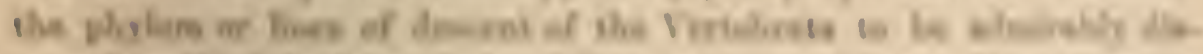

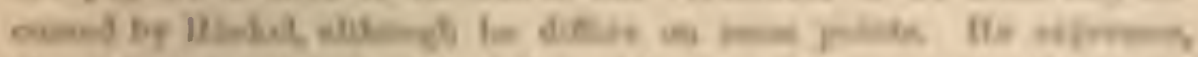

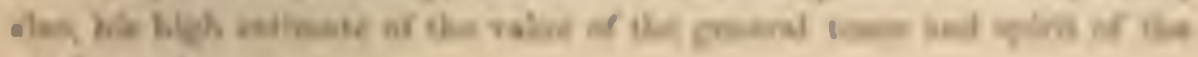
mistenes. 
seen that the Ornithorhynchus graduates toward reptiles; and Prof. Huxley has made the rematiable discorery, confirmed by Mr. Cope and others, that the old Dinosaurians are intermediate in many important respects between certain reptiles and certain birds-the latter consisting of the ostrich-tribe (itself evilently a widely-diftused rem. nant of a larerer group) and of the Archeopteryx, that strange Secondary bird having a long tail like that of the lizard. Again, according to Prof. Owen, ${ }^{20}$ the Ichthyosaurians-great sea-lizards furnished with paddles-present many aflinities with fishes, or rather, according to Ifuxley, with anphibians. This latter class (including in its highest division frogs and toads) is plainly allied to the Ganoid fishes. These latter fishes swarmed during the enrlier geological periods, and were constructed ou what is called a highly-rencralized type, that is, they presented diversified affinities with other gronps of organisms. The amplibians and fishes are also so closely united by the Lepilosiren, that naturalists long disputed in which of these two classes it ought to be placed. The Lepidosiren and some few Ganoid fishes have been preserved from utter extinction by inhabiting our rivers, which are harbors of refuge, bearing the same relation to the great waters of the ocenn that islands bear to continents.

Lastly, one single member of the immense and dirersified class of fishes, namely, the lancelet or amphioxus, is so different fiom all other fishes, that Hïckel maintains that it ought to form a distinct class in the vertebrate kingilom. This fish is remarkable for its negative characters; it can hardly be said to possess a brain, vertebral columm, or heart, etc.; so that it was classed by the older naturalists among the worms. Many years ago Prof. Groodsir perceived that the lancelet. presented some affinities with the Ascilians, which are invertebrate, hermaphro20 'Palicontologg:' 1S60, p. 199. 


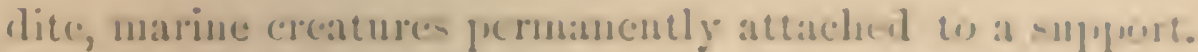
'They hardly appear like animals, and combiot of as simple, tongh, leathery sack, with two small projecting oriliem. They belong to the Molluscoidat of Muxley-a lower divisiun of the great hineglon of the Mollusea; but they hase recently lecen placed hy some natulali-ts amonge the Vermes or worms. Their larvae somewhat resemble talproles inslapee, and hase the powor of swimming freely about. simb obersations lately mate ly M. Kiowa-

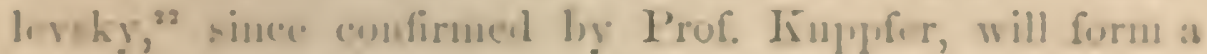
diecovery of estrumplinary interest, if still further ax. icouler, as I hear from .I. Kumalevshy in Niplos loo lus sriw efficeded. The diacosery is that the larras of . I. ciclians are relatcl to the Vurtebrata, in their namber of levelopunent, in the relatise position of the nerrons as. tem, and in pustensing a structure clusely lihe the chorls tersolis of vertobrate animals. It thus appears, if we

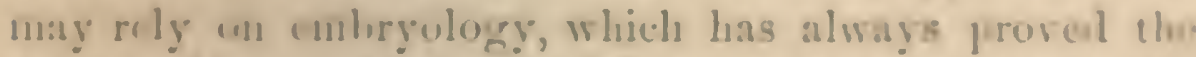
anfet guide in classifieation, that we have at liet gainod

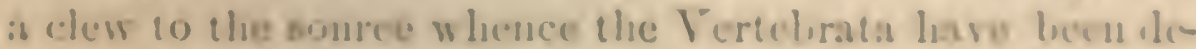

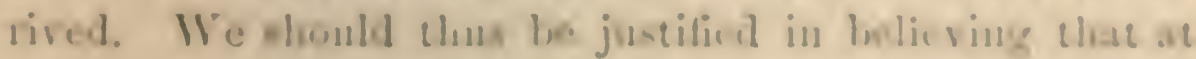

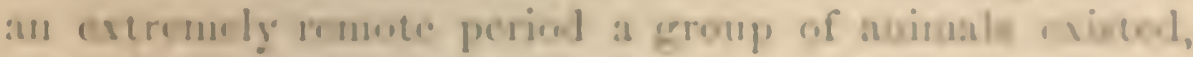

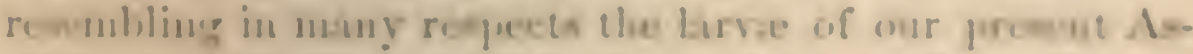
cilinus, which diverged into two grest brothelice-the one

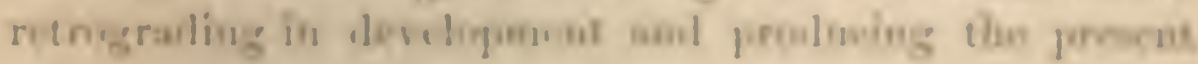

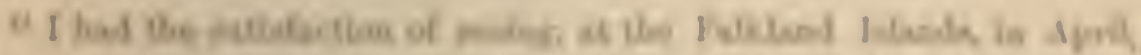

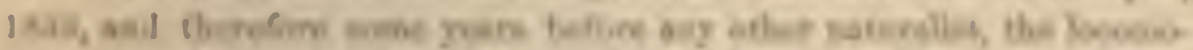

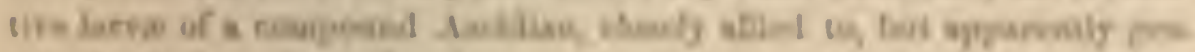

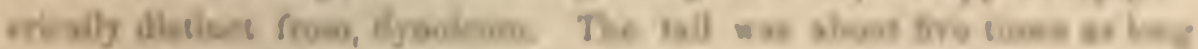

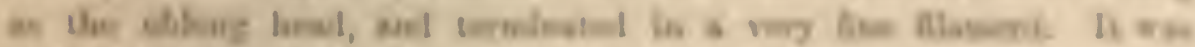

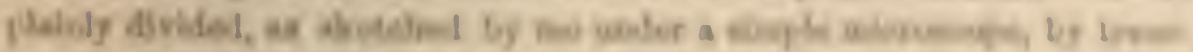

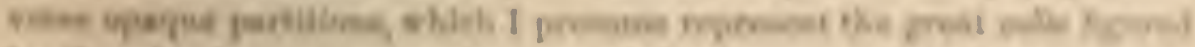

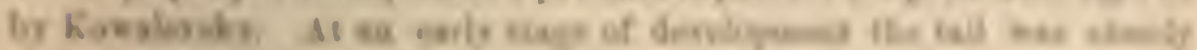

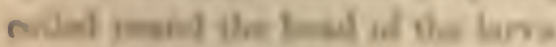

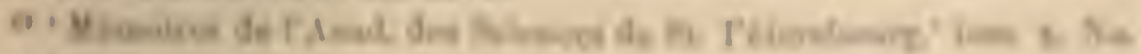
Is. 1 mese 
class of Ascidians, the other rising to the crow'u and summit of the animal kingdom by griving birth to the Vertebrata.

We lave thus far endeavored rudely to trace the genealogy of the Vertebrata by the aid of their mutual affinities. We will now look to man as he exists; and we shall, I think, be able partially to restore during successive periods, but not in due order of time, the structure of our early progenitors. This can be effected by means of the rudiments which man still retains, by the characters which oceasionally make their appearance in him through reversion, and by the aid of the principles of morpholngy and embryology. The various facts, to which I shall here allude, have been given in the previous chapters. The carly progenitors of man were no doubt once corered with hair, both sexes having beards; their ears were pointed and capable of movement; and their bodies were provided with a tail, having the proper muscles. Their limbs and bodies were also acted on by many muscles which now only occasionally reappear, but are normally present in the Qnadrumana. 'The great artery and nerve of the humerus ran through a supra-condyloid foramen. At this or some earlier period, the intestine gave forth a much langer diverticulum or cecum than that now existing. The foot, juiging from the condition of the great-toe in the foctus, was then prehensile; and our progenitors, no doubt, were arboreal in their habits, frequenting some warm, forest-clad land. The males were provided with great canine teeth, which served them as formidable weapons.

At a much earlier period the uterus was double; the excreta were roided through a cloaca; and the eye was protected by a third cyclid or nictitating membrane. At a still earlier period the progenitors of man must havo becu aquatic in their habits; for morphology plainly tells us that our lungs consist of a modified swim-bladder, which 
once served as a float. 'The clefts on the neck in the cubluryo of man slow where the branchis once existed. It aljont this period the true kidueys wcre replaced by the corpor. wolltiana. 'The heart existed as a simple pulsating resel; and the chorda dorsalis took the place of a verecural oot. umu. These carly predeceseors of man, thus seen in the dim receses of time, must lave been as lowly organimed as the lancelet or amphious, or even still more luwly or. gauized.

There is one other point deserving a fuller notice. It has loug hesu known that in the rertebrate hinglous otse bes bears rudinenes of various accessory parts, appertaia. ing to the rejproductire sptetem, which properly helong w the opposite ee $x$; and it las mow heen ascertaised that as

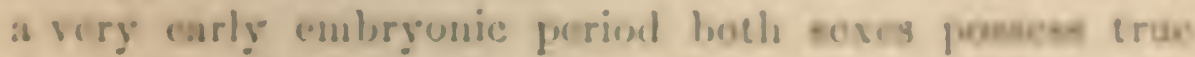
male and female glanila. Hence kome estremely romow progenitor of the whole vertelirate hisgelom appears to

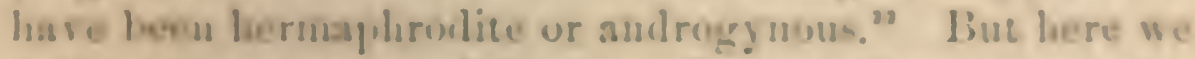
meonuter a siugulur diflieulty. In the msnumalinu dass

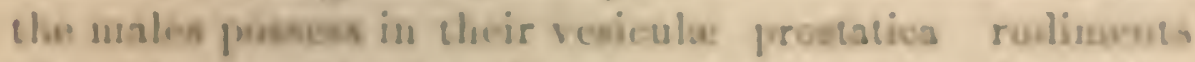
of a uterus with the adjacene pesage; they bear ales

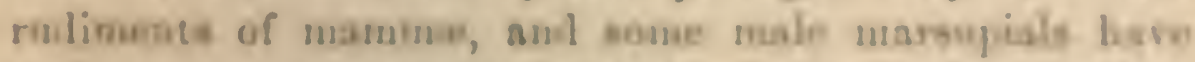
rulimenet of a marempial eack." Oeler analogous facen

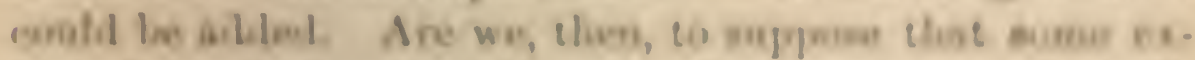

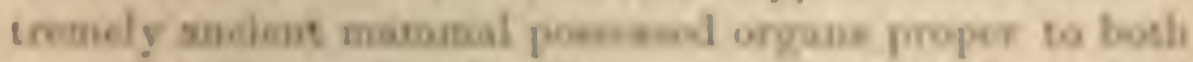

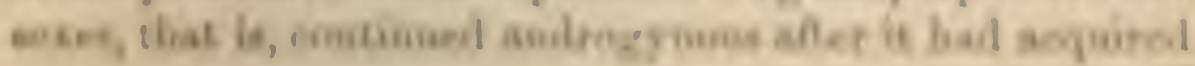

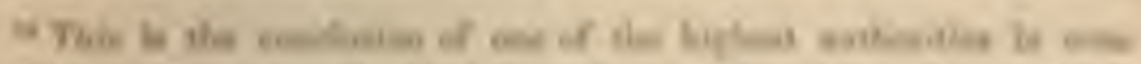

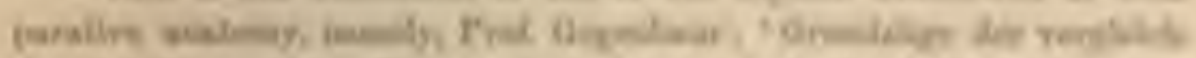

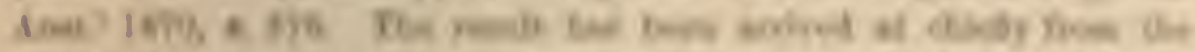

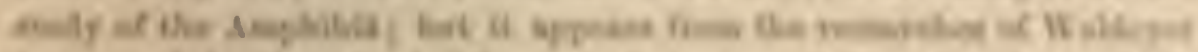

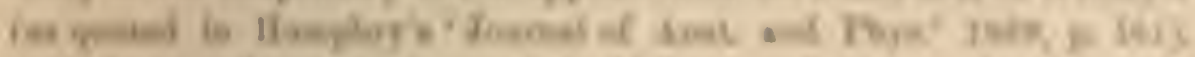

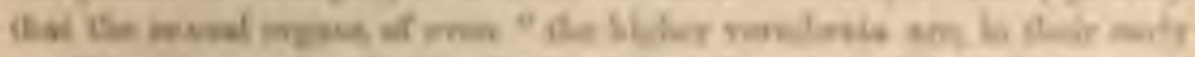

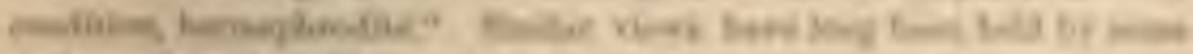

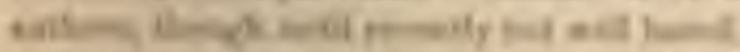

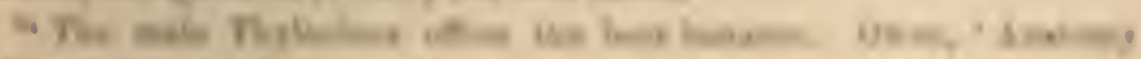

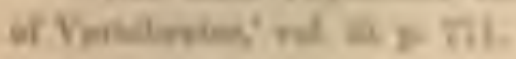


the elict distinctions of its proper class, and therefore after it had diverged from the lower classes of the vertebrate lingdom? 'This seems inprobable in the highest degree; for, had this been the case, we might have expected that some few menbers of the two lower classes, namely fishes and amplibians, would still have remained androgynons. We must, on the contrary, believe that when the five vertebrate classes diverged from their common progenitor the sexes had already become separated. To account, howerer, for male manmals possessing rudiments of the accessory female organs, and for female mammals possessing rudiments of the masculine organs, we need not suppose that their early progenitors were still androgynous after they had assuned their chief mammalian characters. It is quite possible that, as the one sex gradually acquired the accessory organs proper to it, some of the successive steps or modifieations were transmitted to the opposite sex. When we treat of sexual selection, we shall meet with innumerable instances of this form of transmission-as in the case of the spurs, plumes, and brilliant colors, acquired by male birds for battle or ornament, and transferred to the females in an imperfect or rndimentary condition.

The possession by male mammals of fuuctionally imperfect mammary organs is, in some respects, especially eurious. The Monotremata have the proper milk-secreting grlands with orifices, but no nipples; and, as these animals stand at the very base of the manmalian series, it is probable that the progenitors of the elass possesser, in like manner, the milk-seceting glands, but no nipples. 'This conclusion is supported by what is known of their

23 Serranus is well known often to be in an hermaphrodite condition ; lut Dr. Günther informs me that he is convinced that this is not its nol:mal state. Descent from an ancient androgsnous prototype would, however, unturally faror and explain, to a certain extent, the recurrence of this condition in these fislies. 
masuct of levelopment f fur Profesor Turner informs am, on the atuthority of Külliher aud Lauger, that in the om. bryo the manuary glands can loe distuctly traced before the sipples are in the least viville; and it should be horme in mind that the derelopment of sucecesire parts in the indivilual gencrally seenus to reprecent and aceord with the derclopment of sucesesive beings in the same lise of decent. The Marupials ditio frums the Monotremata lig puasosiug uipleles; so that thene crgass we re probally fire acquircil by the Mareupials after the had dirrged from, and risu alore, the Monotremata, and were then trans. sirted to the flacenta! usmmals. No ono vill soppose that after the Marmupiale lad approximately saxpuirel their present siruceture, and therefore at a raiber late perion in the development of the mammalian series, any of iis members still remaind androgryoms. We sem, ther. fure, compelled to recur to the foregoing riew, and to com. chude the the nipples we re firke developed in the fomales of some rery early marrupial form, and were tben, in accurlance with a common law of inleriensuce, trausfursel in a functionally imperfect condition to the males.

Neverthelose, a euspirion lan sametiones cromed smy mind that long nfer the progenitors of the whole mani-

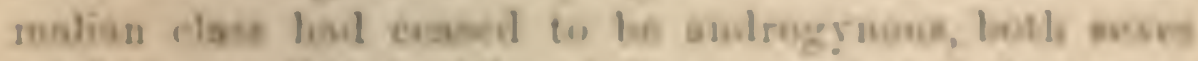
might have giveled mllk and thue nouriobod their pouas:

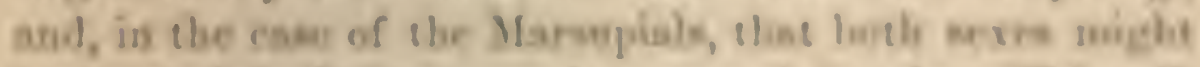
have carriel their formg in marsopial racks. 'This will not spear uterly birncdible, if we mflese that the wales

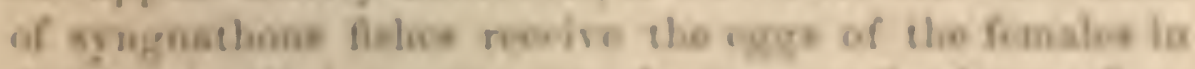

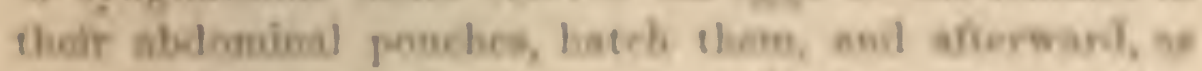

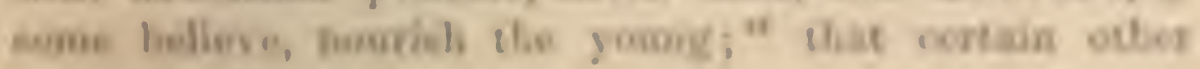

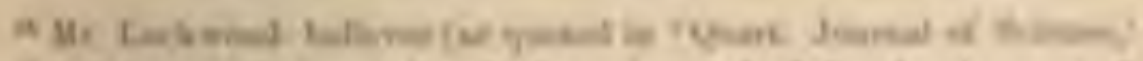

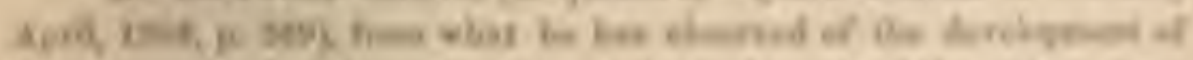

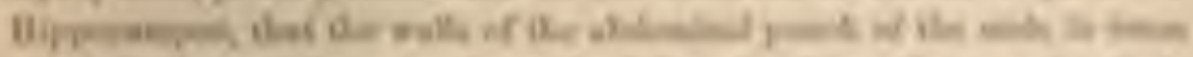

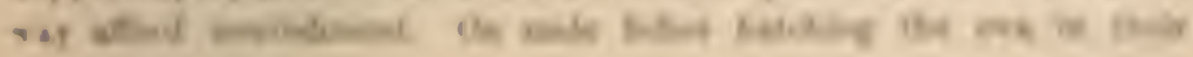


male fishes lateh the eggs within their mouths or branchial cavities; that certain male toads take the chaplets of eggs from the females and wind them round their own thighs, keeping them there until the tadpoles are born; that certain male birds undertake the whole duty of incubation, and that male pigeons, as well as the females, feed their nestlings with a secretion from their erops. But the above suspicion first oecurred to me from the mammary glauds in male mammals being dereloped so much more perfectly than the rudiments of those other accessory reproductive parts, which are found in the one sex though proper to the other. The mammary glands and nipples, as they cxist in male mammals, can indecd lardly be called rudimentary; they are simply not fully developed and not functionally active. They are sympathetically affected under the influence of certain diseases, like the same organs in the female. At birth they often secrete a few drops of milk; and they have been known occasionally in man and other mammals to become well developed, and to yield a f:ir supply of milk. Now if we suppose that during a former prolonged period male inammals aided the females in nursing their offispring, and that afterward from some cause, as from a smaller number of young being produced, the males ceased giving this aid, disuse of the organs during maturity would lead to their becoming inactive; and from two well-known principles of inheritance this state of inactivity would probably be transmitted to the males at the corresponding age of maturity. But at all earlier ages these organs would be left unaffected, so that they would be equally well dereloperd in the young of both sexes.

mouths, sce a rery interesting paper by I'rof. Wyman, in 'Proc. Boston Soc. of Nat. Hist.' Sept. 15, 1857; also Prof. Turner, in 'Journal of Anat. and I'hys.' Nor. 1, 1566, p. 7S. Dr. Günther has likewise described similar cascs. 
Conclusion.-The best dedinition of alsancusene or progress in the organic scale ever giren, is that hy lon barr; and this rets on the amoust of difterentiation and specialization of the several parts of the same being, when arrived, as I should be inclincel in all, at maturity. Now as organisus have breome flowly alapeel by mean of natural selection for diversifed lines of life, their yarts will hare becounc, from tho adrantage gained lig the disision of pliysiolocical hbor, moro and more difliremiatod aud epecialized fur vorious fusclious. The sane part aypeart ofen to have bea molified firte for one purpees, and then long afforwarl for bowe other sud youte distines purpoes; asul thus all the phrte are renderod more amd usore complex. Bne asch orgasion will beill retain ibu geteral type of structure of the progenitor from whinh ie was aboriciually derived. In accordance with this view it sicus, if we turu to gecologional evidence, that orgation. tion on the whole bas ledranod throughout the world lig

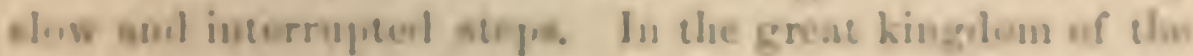

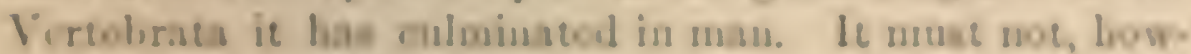
ever, be suppoad flist groups of orzanic lwings ars al. wask cupplastud and diexppear as acon so they hase

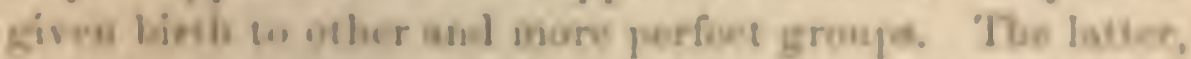

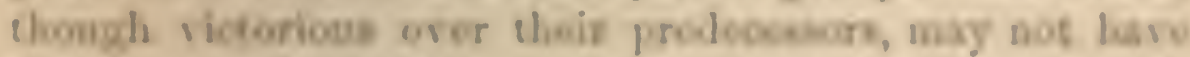

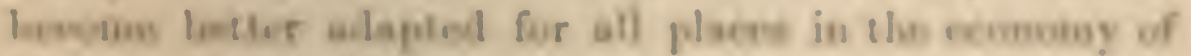
Nature. Soros old forms appor io hare survivel from ins labliking frotected sites, where they liswe not leces ex.

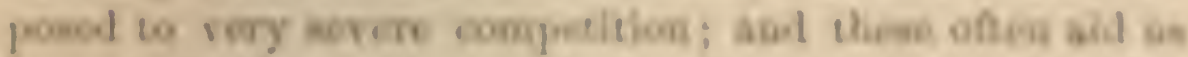

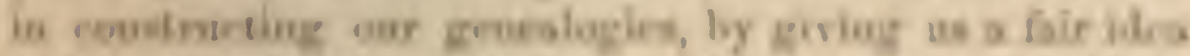
of fumer and lose populations. Jot we mast not fall inde

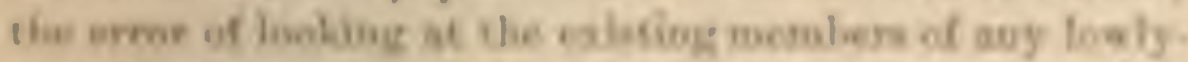

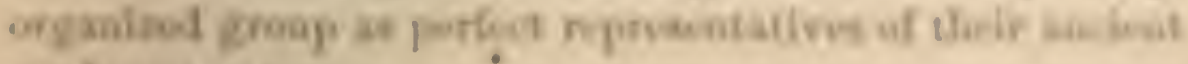
predrernaters

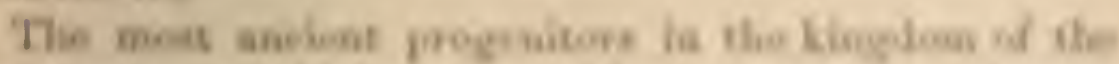

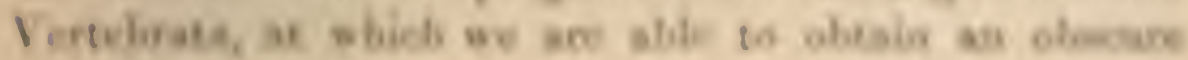


glanee, apparently consisted of a group of marine animals, ${ }^{27}$ resembling the larva of existing $A$ scidians. 'These animals probably gave rise to a group of fishes, as lowly organized as the lancelet; and from these the Ganoids, and other fishes like the Lepidosiren, must have been developed. From such fish a rery small advance would carry us on to the amphibians. We have seen that birds and reptiles were once intimately connected together; and the Monotremata now, in a sliglit degree, connect mammals with reptiles. But no one can at present say by what line of descent the three higher and related classes, namely, mammals, birds, and reptiles, were derived firom either of the two lower vertebrate classes, namely amphibians and fishes. In the class of mammals the steps are not dificult to conceive which led from the ancient Monotremata to the ancient Marsupials; and from these to the early progenitors of the placental mammals. W6 may thus ascend to the Lemuridie; and the interval is not wide from these to the Simiadie. The Simiadie then branched off into two great stems, the New World and Old World monkeys; and from the latter, at a remote

${ }^{27}$ All vital functions tend to run their course in fixed and recurrent periods, and with tidal animals the periods would probably be lunar; for such animals must hare been left dry or corered deep with water-supplied with copious food or stinted-during endless generations, at regular lunar intervals. If, then, the vertebrata are descended from an animal allied to the existing tidal $A$ seidians, the mysterious fact that, with tho higher and now terrestrial Vertebrata, not to mention other classes, many normal and abnormal rital processes run their course according to hunar periods, is rendered intelligible. A recurrent period, if approximately of the right duration, when once gained, would not, as far as we ean julge, be liable to be changed; consequently it might be thus transmitted luring almost any number of geuerations. This conclusion, if it could lie proved souml, would be currous; fur te shoukd then see that the period of gestation in each mammal, and the hatching of each bird's erggs, and many other vital processes, still betrayed the prinordial birthplaco of these animals. 
period, Man, the wouler and glory of the Unisere, proceederl.

Thus we have given to man a pedigree of prodigions length, but not, it may be said, of noble quality. The world, it has often been remarked, appears as if it had leug been preparing for the advent of man; and this, in one senae is strictly true, for he owes his birth to a long line of progenitore. If any single link in this chain has never existed, man would not have been exactly what he now is. Unlcas we wilfully close our eyes, we may, withs our firescut knowledge, approximately reognize our parentage; nor noed we feel ashamed of it. 'The most ham. be organism is something mucls higher than the inurganio lust under our feet; and no one with an umbiased nind ean study any living cresture, howerer humble, without being struck with entlusiann at its unarvellows neructure and propertios. 


\section{A T'ER VII.}

ON THE MALE OF MAY.

The Nature and Value of Speoific Characters. - Application to the Races of Man.-Arguments in favor of, and opposed to, ranking tho Soealled Races of Man as Distinet Species. - Sub-species.-Monngenist and Podrgenists. - Convergence of Chnracter.-Numerous Points of Resemblance in I3ody and MLind between tho most Distinct Races of Man.-Tho State of Man when he first spread ofer tho Earth.-Each Raco not descended from $n$ Singlo Pair.-The Extinction of Races.The Formation of Races. - Tho Eiflects of Crossing.-Slight Influenco of tho Dircet Action of the Conditions of Life. -Slight or no Influenco of Natural Selcetion.-Scxual Selcetion.

Ir is not my intention liere to describe the several socalled races of men; but to inquire what is the value of the differences between them under a classificatory point of view, and how they have originated. In determining whether two or more allied forms ought to be ranked as species or varictics, naturalists are practically guided by the following considerations: namely, the amount of difference between them, and whether such differences relate to few or many points of structure, and whether they are of pliysiological importance; but more especially whether they are constant. Constancy of character is what is chiefly ralued and sought for by naturalists. Whenever it can be shown, or rendered probable, that the forms in question have remained distinct for a loug period, this becomes an argument of much weiglit in favor of treating them as species. Even a slight degree of sterility lutween 
any two forms when firni crosed, or in their offipring, is generally considered as a decisive est of their speritic distuctness; and their contuned pensistunce without blending within the same area, is usually accrpted as suflicient evidence, cither of some degree of musual steril. ity, or in the case of animals of some ropugnasee to mutual joiring.

Indepulently of lelending from intererossing, the emmplute alsence, in a well-iurestigateul region, uf saries tirs linking logethor any two doselsallied forms, is probubly the unot important of all the criteriout of this

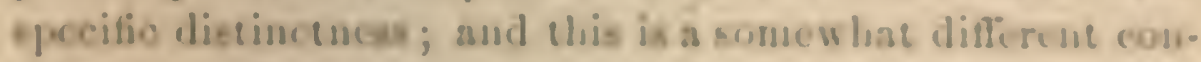
sileration frum uere comtaney of claracter, for two forms may bo lighly varialde and yet me yiplel inter. uncliate rarictios. (ieographieal distribution in oftus us. conecionely and somcrimes consociously lrought into plas; so that forme living in two wielelsotparated areas, in

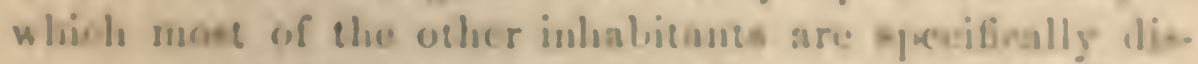
tinct, are tlemeclses usublly looked at an dietisce; hat in

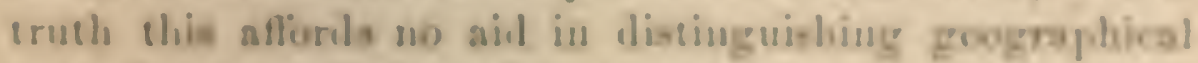
rares from so-called good or true species.

Now lot us spply these prortal! salmiecod prinetples to the rasece of man, viewing hims in she susme vilie as a

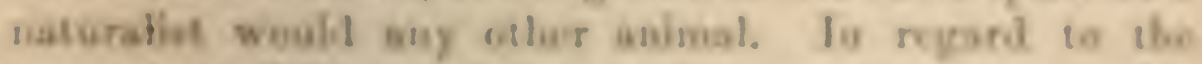

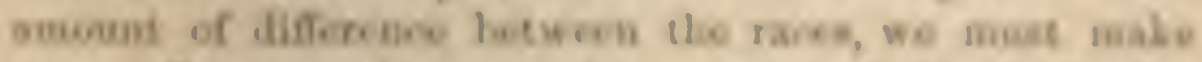
wome allowahre fir per sice pasers of dincrimivados pained by ibe bong lable of olecrving ourelsex. Io ladia,

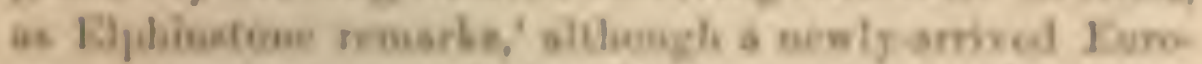
pon canbot at fines Aistingoleh the sarioue native toess,

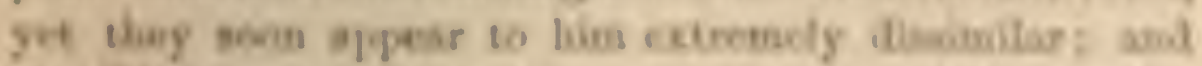
the Ithdoes canoot at fies porveive sey diffirum le

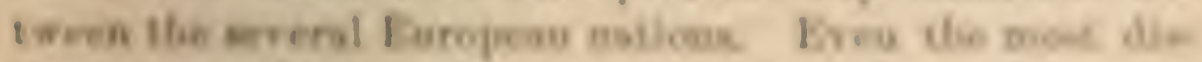

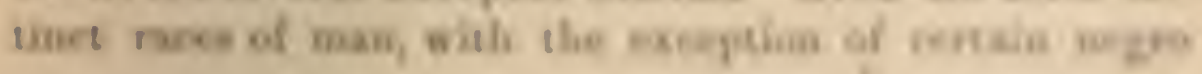

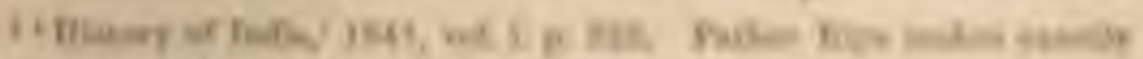

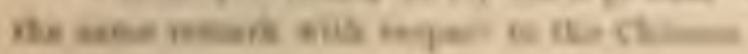


tribes, are much more like each other in form than would at first be supposed. 'This is well shown by the French photographs in the Collection Anthropologique du Muséum of the men belonging to various races, the greater number of which, as many persons to whom $I$ have shown them have remarked, might pass for Europeans. Nevertheless, these men if seen alive would undoubtedly appear very distinct, so that we are clearly much influenced in our judgment by the mere color of the skin and hair, by slight differences in the features, and by expression.

There is, however, no doubt that the various races, when carefully compared and measured, differ much from each other-as in the texture of the hair, the relative proportions of all parts of the borly, the capacity of the lungs, the form and capacity of the skull, and even in the convolutions of the brain. ${ }^{3}$ But it would be an endless task to specify the numeróus points of structural difference. The races differ also in constitution, in acclinatization, and in liability to certain diseases. 'Their mental characteristics are likewise very distinct; chiefly' as it would appear in their emotional, but partly in their intellectual, faculties. Every one who has had the opportunity of comparison, must have been struck with the contrast between the taciturn, even morose, aborigines of. South America and the light-hearted, talkative negroes. There is a nearly similar contrast between the Malays and the Papuans, who live under the same physical conditions,

$2 \Lambda$ rast number of measurements of Whites, Blacks, and Indians, are given in the 'Inrestigations in the Military and Anthropolog. Statistics of American Soldiers,' by B. A. Gould, 1869, pp. 298-358; on the capacity of the lungs, p. 471. See also the numerous and raluable tables, by Dr. Weisbach, from the obserrations of Dr. Scherzer and Dr. Schwarz, in the 'Reise der Norara: Anthropolog. Theil,' 1867.

${ }^{3}$ Sec, for instance, Mr. Mars!all's account of the brain of a Bushwoman, in 'Phil. Transact.' 1861, p. 519.

4 Wallace, 'The Malay Archipelago,' vol. ii. 1869, p. 178. 
and are separated from cach otler ouly by a uarrow space of sen.

We will first consider the arguments which may be arlvancerl in favor of classing the races of man as dietiuet species, and then those on the other sile. If a maturali-t, who had never before seen such beings, were to compare a Negro, Hottentot, Australian, or Mongolian, he woulil at once perceive that they diflered in a multitude of characters, some of slight and some of considerable inportance. On inguiry lo would fud that they were alappeol of live umler widely-alifleront climates, amel that they differed somewhat in hodily constitution and mental dismo sition. If he were then told that humberls of similar specimens conld be brought from the same comutrie, he would assuredly declare that they were as goml species as many to which he had been in the lablit of aflisiug sperific names. This conclusion would be greatly strementiencul as poous as he had ascertained that these forms habl all ro tabuel the same characeter for many centuries; aud elate uegroes, apparouly idemtionl with existing uegroes, houl lived at lease 4,000 yearo ngon. He would ulso hear from

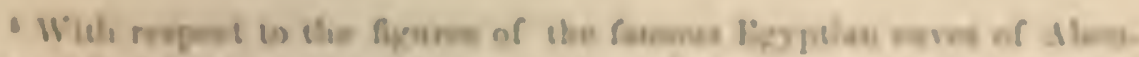

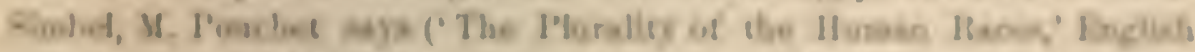

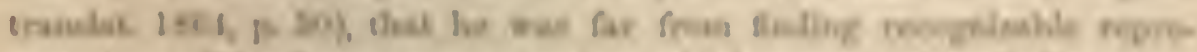

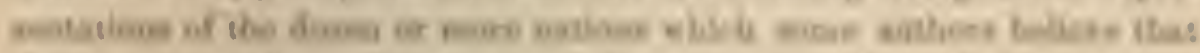

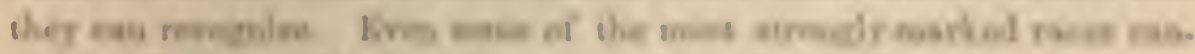

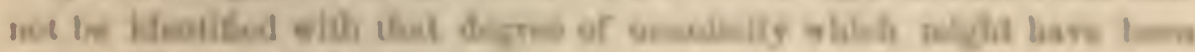

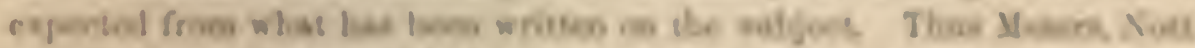

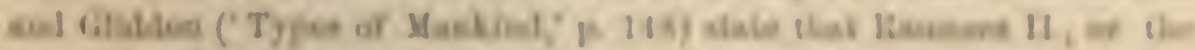

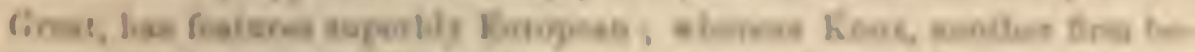

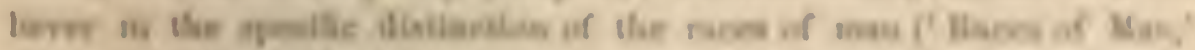

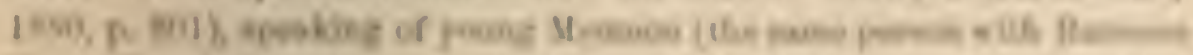

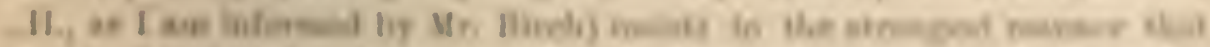

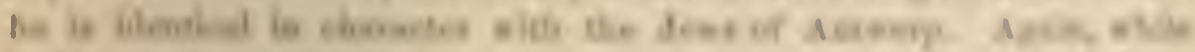

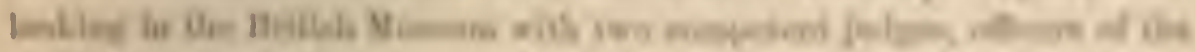

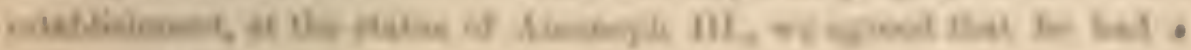


an excellent observer, Dr. Lund, that the human skulls found in the caves of Brazil, entombed with many extinct mammals, belonged to the same type as that now prevailing throughont the American Continent.

Our naturalist would then, perhaps, turn to geographical distribution, and he would probably declare that forms diffuring not only in appearance, but fitted for the hottest and dampest or driest countries, as well as for the Aretic regions, must be distinct species. He might appeal to the finct that no one species in the group next to man, namely, the Quadrumana, can resist a low temperature or any considerable change of elimate; and that those species which come nearest to man have never been reared to maturity, even under the temperate climate of Europe. He would be deeply impressed with the fact, tirst noticed by $A$ gassi\%, ${ }^{7}$ that the different races of man are distributed over the world in the same zoological provinces, as those inhabited by undoubtedly distinct speeies and genera of mammals. This is manifestly the case with the Australian, Mongolian, and Negro races of man; in a less well-marked manner with the Hottentots ; but plainly with the Papuans and Malays, who are separated, as Mr. Wallace has shown, by nearly the same line which divides the great Malayan and Australian zoologieal provinces. The al)origines of America range throughout the continent; and this at first appears opposed to the above rule, for most of the productions of the Southern and Northern halves differ widely; yet some few living forms, as the opossum,

strongly necro cast of features; but Mesers. Nott and Gliddon (ibid. $p$. 116, fig. 53) describe him as "a hybrid, but not of negro intermisture."

- As quoted by Nott and Giliddon, 'Types of Mankind,' 185.4, p. 43?. They give also corroborative evidence; but C. Vogt thinks that the sub. ject requires further investigation.

7 "Diversity of Oritrin of the IIuman liaces," in tlac "Christian Ezaminer,' July, 1850 . 
runge from the one into the other, as did formerly nome of the gigantic Filentata. The Esquiunaux, like other Arctic animals, extend round the whole polar regions. It should be observed that the mammalian forms which is. liabit the several zoologrical prosinces, do not diflir frum cosch other in the same degree; fo that it can hardly le comsilered as an anomaly that the Vegro ditters more, and the American mush lese, from the other races of man than do the mammals of the mune continents from those of the other provinces. Mau, it may be alled, lows mot appear to lave aloriginally iuhabie.el any oveanic is lasol; aul in this respect lue resombles the other members of his (.). lass.

In determining whether the varieties of the same hind of domestiv animal should be rankeel as specilieally dilinct, that is, whether suy of them are deseomled from distince wild specion, every uaturalise would hy muels

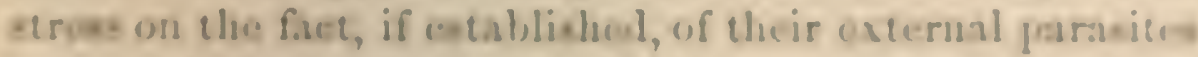
being specilieall! distinet. All the more aros would be lahl ou this fome, as it wombl be an exocprional ose, for 1

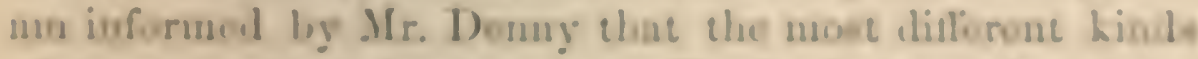

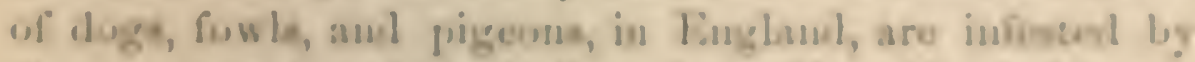
the nue opecios of P'eliculi or liee. Now Mr. A. Murray

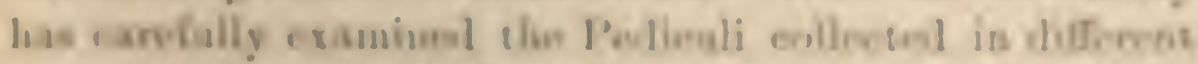

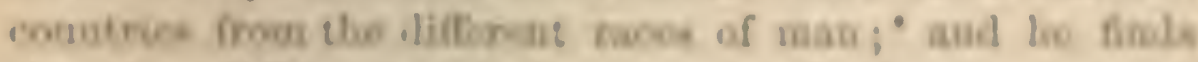

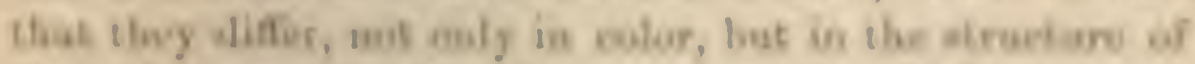

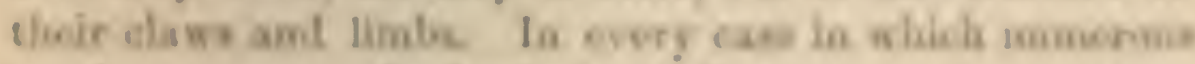

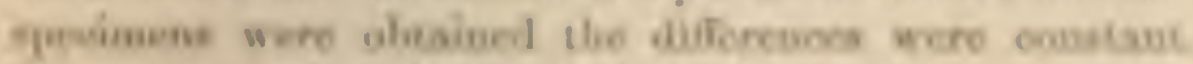

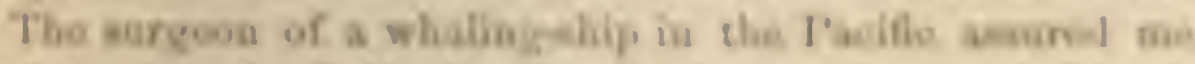

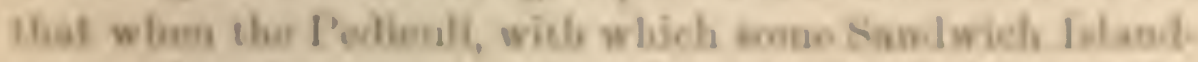

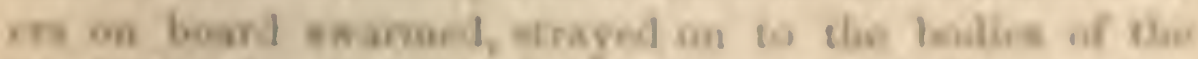

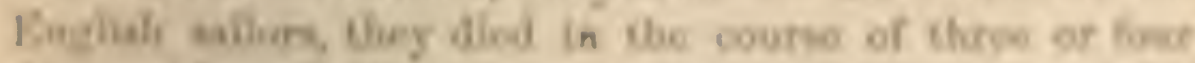

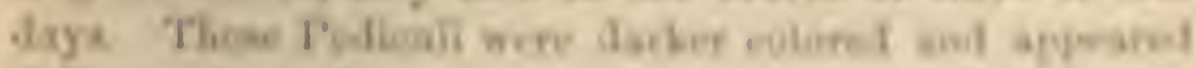

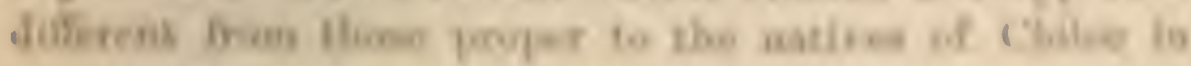

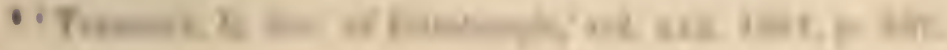


Soutl America, of which he gave me specimens. These, again, appeared larger and much softer than European lice. Mr. Murray procured four kinds from Africa, namely from the Negroes of the Eastern and Western coasts, from the Hottentots and Caffres; two kinds from the natives of Australia; two from North, and two from South America. In these latter cases it may be presumed that the Pediculi came from natives inlıabiting different districts. With insects slight structural differences, if constint, are generally esteemed of specific value: and the fact of the races of man being infested by parasites, which appear to be specifically distinct, might fairly be urged as an argument that the races themselves oughe to be classed as distinct species.

Our supposed naturalist, having proceeded thus far in his investigation, would next inquire whether the races of men, when crossed, were in any degree sterile. Me miglit consult the work ${ }^{\circ}$ of a cautious and plrilosophical ob)server, Prof. Broca; and in this lie would find good evidence that some races were quite fertile together; but evidence of an opposite nature in regard to other races. Thus it has been asserted that the native women of Australia and Tasmania rarcly produce children to European men; the evidence, however, on this head has now been shown to be almost ralucless. The half-castes are killed by the pure blacks; and an account lias lately been published of eleven half-caste youths murdered and burnt at the same time, whose remains were found by the police."

' On the l'henomena of IItbridity in the Cienus IIomo,' Eng. translation, 1864.

${ }^{10}$ See the interesting letter by M(r. T. A. Murray, in the 'Anthropolng. Review,' April, 18ris, p. liii. In this letter Count Strzelecki's statement, that Australian women who have borne clildren to a white man are afterward sicrile with their own race, is disproved. If. A. de Qua. trefages bas also collected ('Rerue des Cours Scientifiques,' March, 1863, 
Again, it has often hecu sid that when mulattoes intrrmarry they produee few children; on the other hasu, 1)r. bacluman of Clarleson" posidively aseerts that he has huown mulateo families which lase iuternarried for ses. cral generations, and have continucel on an arerage as fertile as either pure whites or pure lilacks. Inquiries formerly male by sir C. Tyell on this subject led him, as lac informs use, to the sance conclusion. In the Uuitcl

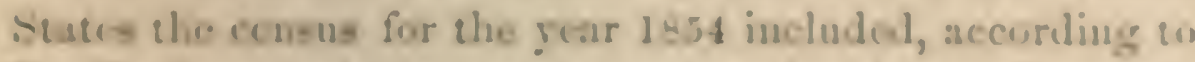

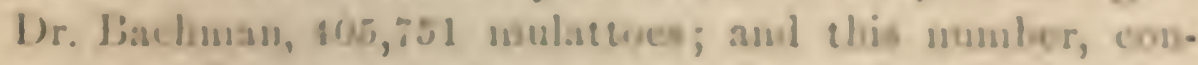

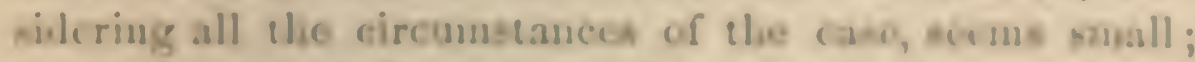
but it uay pargly he accousted for hy the degnuded and anoumlous postion of the class, and lig the prosligaeg of the wusten. A certain asount of aborption of mulations iulo uogroes mukt always be in jrogress; aud this would

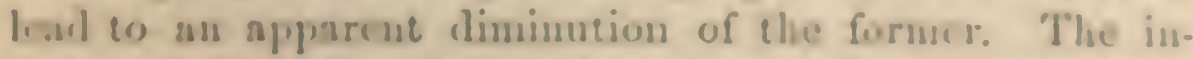

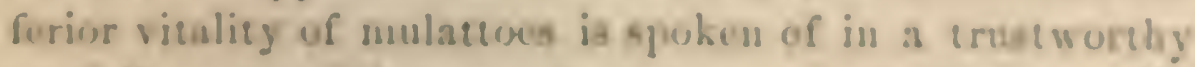
work" as a well-huown plonomenon; bue thit is a dif.

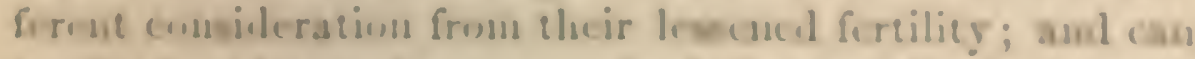

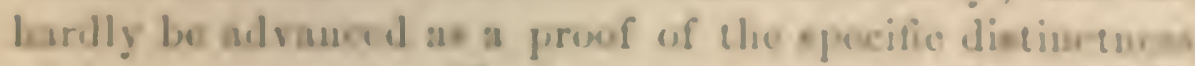
of the parrat raws. No foulit both suimal snd regetable

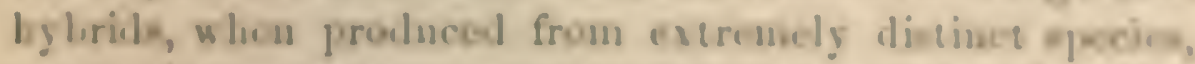
are linble 20 preseature death; list the parente of umblat.

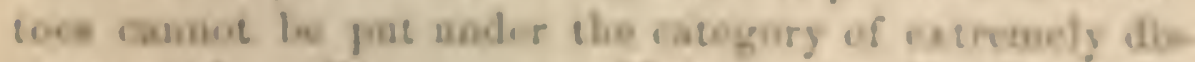

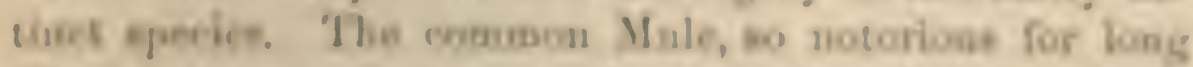

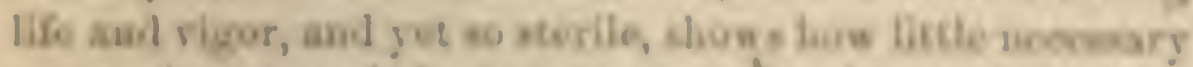
comoction tlare is in ligbrids becween lemencel forillicy

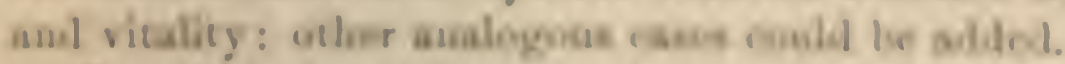

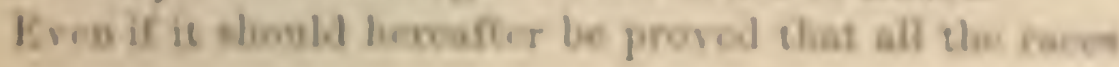

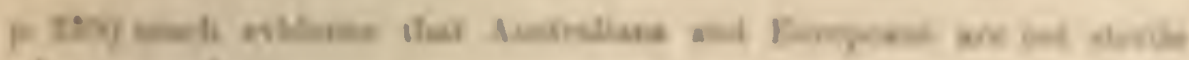

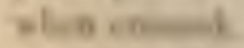

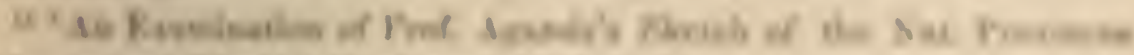

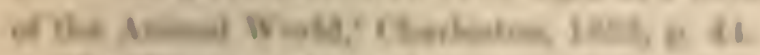

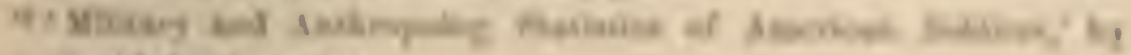

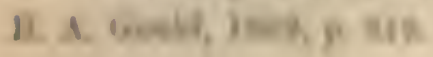


of men were perfectly fertile together, he who was inclined from other reasons to rank them as distinct species, might with justice argue that fertility and sterility are not safe criterions of specific distinctness. We know that these qualities are easily affected by changed conditions of life or by close inter-brecling, and that they are governed by highly complex laws, for instance that of the unequal fertility of reciprocal crosses between the same two species. With forms which must be ranked as undoubted species, a perfect series exists from those which are absolutely sterile when crossed, to those which are almost or quite furtile. The degrees of sterility do not coincide strictly with the degrees of diflerence in exterual strueture or habits of life. Man in many respects may be compared with those animals which have long been domesticated, and a linge body of evidence can be alvanced in fitvor of the Pallasian doetrine, ${ }^{19}$ that domestication tends to climimate

13 'T'lue Variation of Aumals and Plants under Domestication,' rol. ii. 1. 109. I inaly here remind the reader that the sterility of species when crossed is not a specially-acyuired quality; but, like the incapacity of certain trees to be grafted together, is incidental on other acquirel diffirences. The nature of these ditierenees is unknown, but they delate more especially to the reproductire system, and much less to external structure or to ordinary dillerences in constitution. Onc important element in the sterility of crossed species apparently lies in one or both Lariug been long habituated to fixed conditions; for we know that changed conditions bare special infuence on the reproductire system, and we have gool reason to believe (as before remarked) that the fluctuating conditions of donestication tend to climinate that sterility which is so feneral with species in a natural state when crossed. It has ckewhere been shown by me (ibid. vol. ii. 1). 185, and 'Origin of Species,' 6th ellit. p. 31\%) that the sterility of erossed species has not been acquired through uatural selection: we can see that when two forms have aliendy been reudered very sterile, it is scarcely po-sible that their sterility should bo aunguented by the preservation or surviral of the more and more sterilo iulividuals; for us the sterility increases fewer and fewer oftzpriun will be produced from which to breed, aud at last ouly single iudiriduals will be producel, at the rarest intervals, But there is even a higher 
the sterility which is so general a result of the croesing of species in a sate of nature. Frum these sureral comsial. cratou, it may be justly urged that the perfect feribies of the intererusserl races of man, if establishent, would uot absulutely prectude us frum rankiug thom as distines species.

Inde pendenty of fertilit5, the characer of the ufts jring from a crose has anuedius bess thought to aflord eridence whether the parent-firme ought to be rauhed as Fpecies or varictice; lat after carfully atulying tho evidonoe, I hase colue in the cuselusion that uo general rule uf this kitol

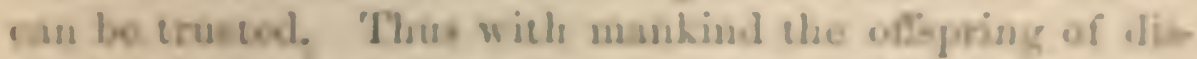

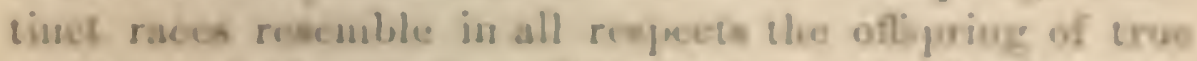
Fpeies and of rarieties. This is show 11 , for instanen, lig

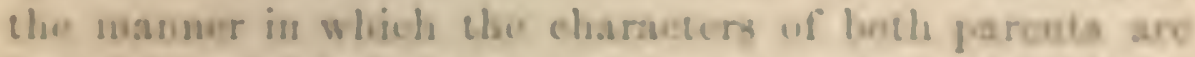
blended, and l,y one form alworbige suother through re prafol croens. In this latter case the jrogers! botb of

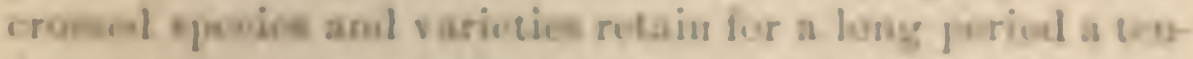
lesey to revert to thoir attonson, eppocially to that one

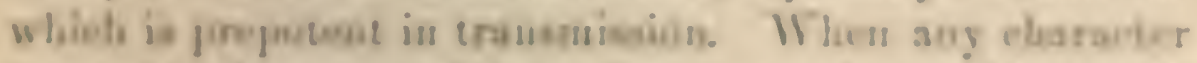
bas enddinly spjeard in an race or specisa as the mends

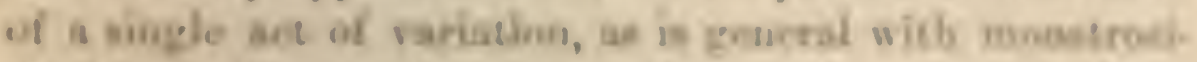

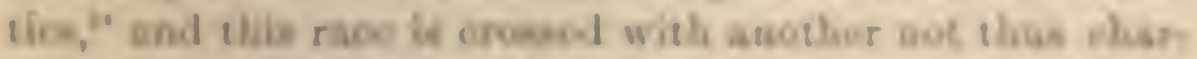

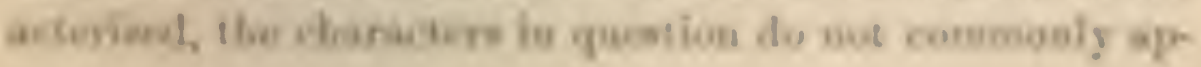

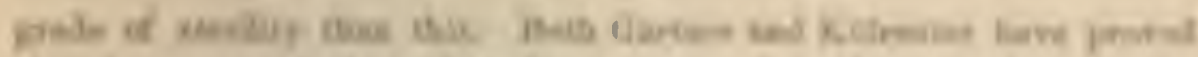

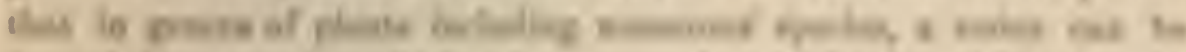

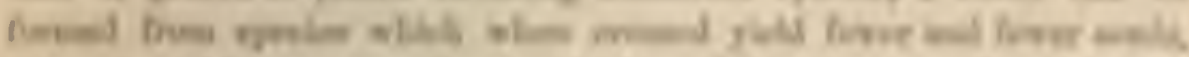

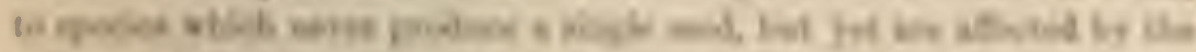

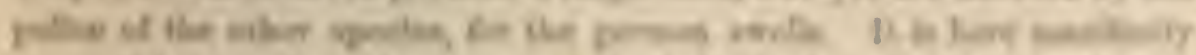

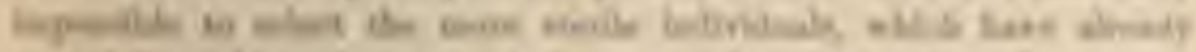

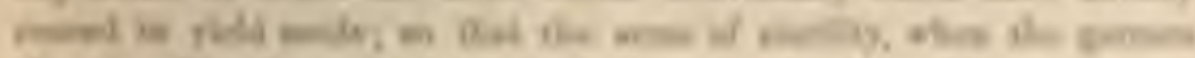

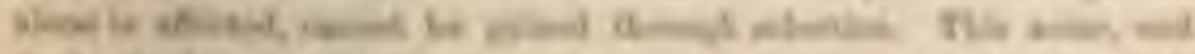

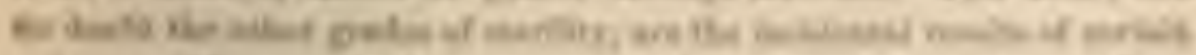

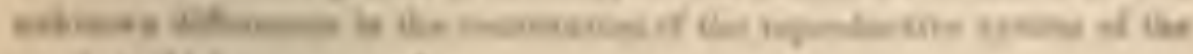
portan sllit an moned

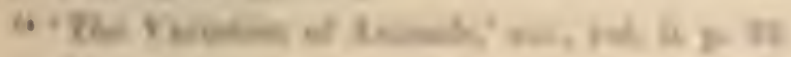


pear in a blended condition in the young, but are trans. mitted to them either perfectly dereloped or not at all. As with the crossed races of man cases of this hind rarely or never oceur, this may be used as an argument aganint the view suggested by some ethnologists, namely, that cortain characters, for instance the blachuess of the negro, first appeared as a sudden variation or sport. Had this occurred, it is probable that mulattoes would often have been born either completely black or completely white.

We have now seen that a naturalist might feel himself fully justified in ranking the races of man as distinet species; for he has found that they are distinguished by many differences in structure and constitution, some being of inportance. These differences have, also, remained nearly constant for very long periods of time. He will have been in some degree influenced by the enormous range of man, which is a great amomaly in the class of mammals, if mankind be riewed as a single species. Ife will have been :truck with the distribution of the sereral so-called races, in accordance with that of other undubtedly distinct species of mammals. Finally, he miglit urge that the mutual fertility of all the races has uot yet been fully proved; and even if proved would not be an absolute proof of their specific identity.

On the other side of the question, if our supposed naturalist were to inquire whether the forms of man kept distinct like ordinary species, when mingled together in large numbers in the same country, he would immediately discorer that this was by no means the case. In Brazil ho would behold an immense mongrel population of Negroes and Portuguese; in Chiloe and uther parts of South America he would behold the whole population consisting of Indians and spaniards blended in various degrees." In

16 Mr. de Quatrofages has given ('Anturogoleg. Review,' Jan. 16is?, 
masy parts of the ame continest be would mort wish

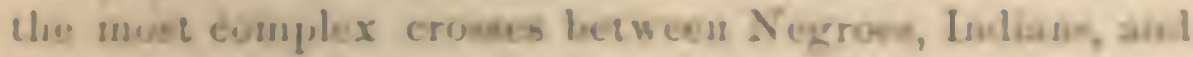

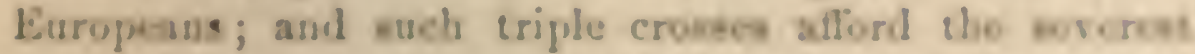
sest, judging fross the regetulile kinglums, of the suatmal fertility of the parent-forms. In one island of the l'acitic he would find a suall pogularioss of wisgled l'olsursian and fougliah blood; asol is the Viri Arolipgelagos a jerpe. lasion of Peolynesians and Nezribat croasod in all degroes.

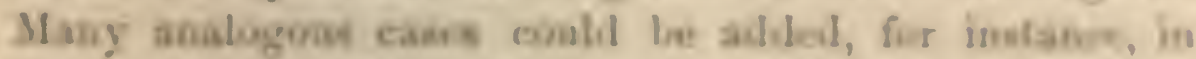

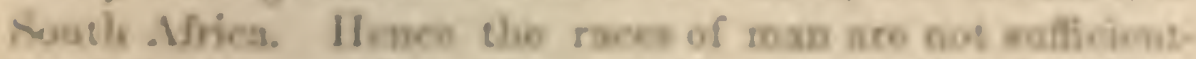

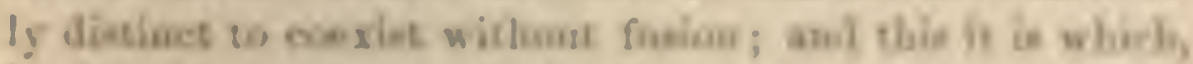

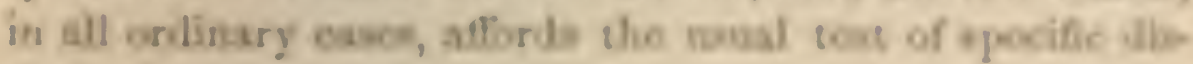
linctmess.

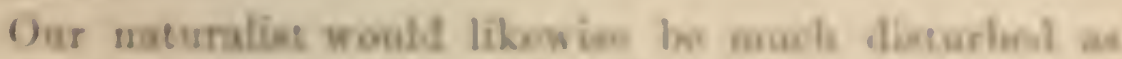

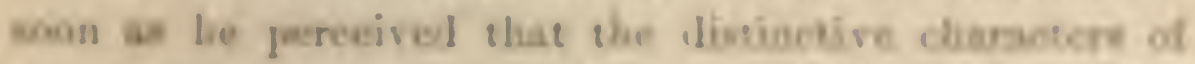
every race of mass wore liehly sarlable. This serikes

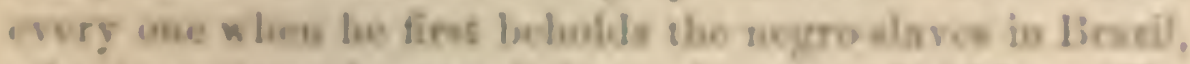
who lave beca ingertel froun all parta of Afrise. The

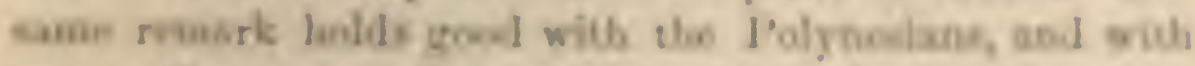

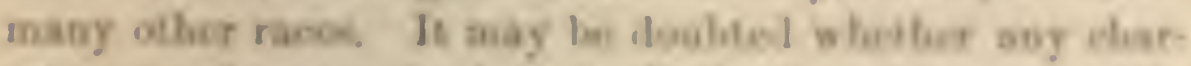

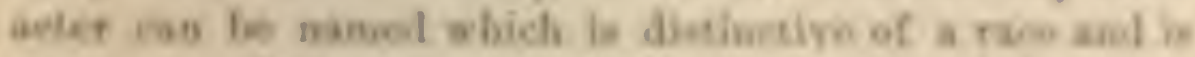

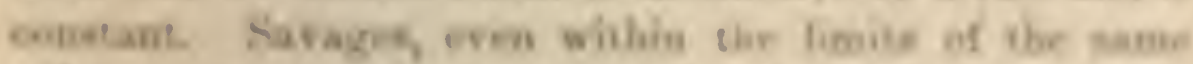

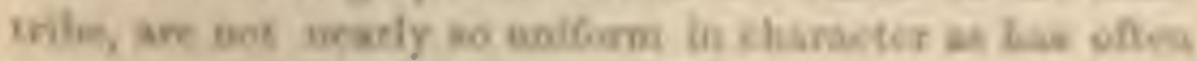

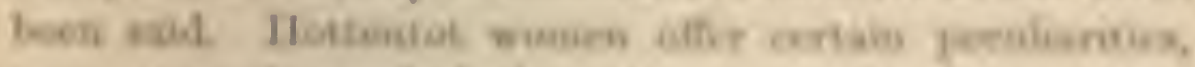

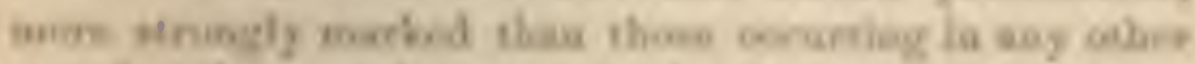

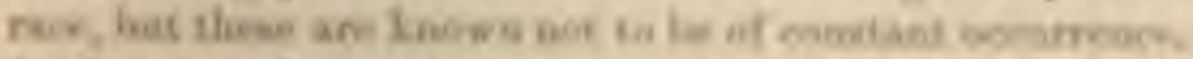

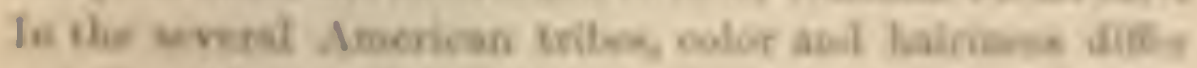

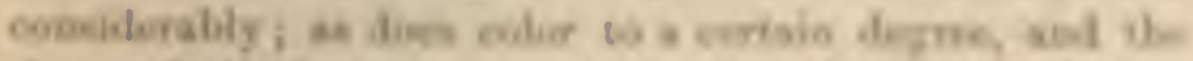

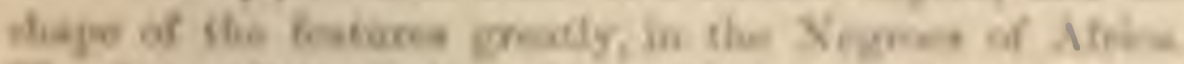

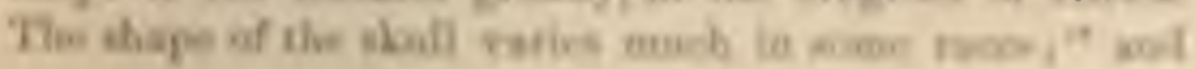

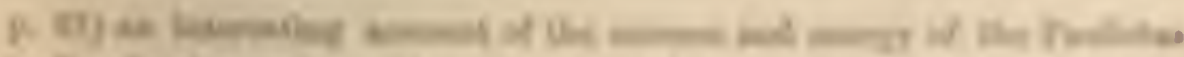

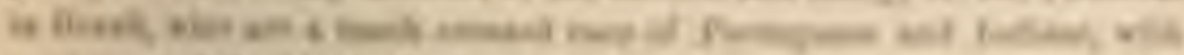

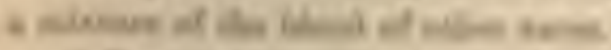

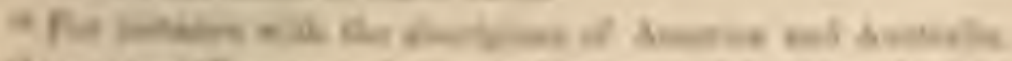

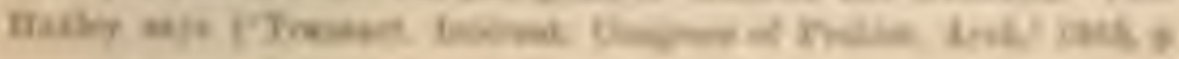


to it is with every other chanacter. Now all naturalists have learned, by dearly-bought experience, how rash it is to attempt to define species by the aid of inconstant characters.

But the most weighty of all the arguments against treating the races of man as distinct species, is that they graduate into each other, independently in many cases, as fin as we can julge, of their having intererossed. Min has been studied more carefully than any other organic being, and yet there is the greatest possible diversity among capable judges whether he should be classed as at single species or race, or as two (Virey), as three (Jacquinot), as four (Kint), five (Blumenbach), six (Buflun), sev'n (Hunter), eight (Agassi\%), eleren (Pickering), fifteen (Bory St. Vincent), sixteen (Desmoulins), twenty-two (Morton), sixty (Crawfurd), or as sixty-three, according to Burke. ${ }^{37}$ This diversity of judgment does not prove that the races ought not to be ranked as species, but it shows that they graduate into cach other, and that it is hardly possible to discover clear distinctive characters between them.

Every naturalist who has had the misfortune to undertake the description of a group of highly-varying organisms, has encountered eases (I speak after experience) preciscly like that of man; and if of a cantious disposition, he will end by uniting all the forms which graduate into each other as a single species; for he will say to himself that he has no right to give numes to objects which he cannot define. Cases of this kind oceur in the Order which includes man, nanely, in certain grencra of monkeys;

105) that the skulls of many Sonth Gecmans and swiss are "as short and ns broal as those of the Tartars," ete.

17 Sec a good discussion on this sulject in Waitz, "Introduct, to $\mathrm{An}$. thropology, Fug. translat. 1863, pp. 195-208, 227. I liave taken some of the aljore statements from II. Tuttle's 'Origin and Antifuity of Physicad Mlan,' Boston, 1866, p. $3 \tilde{\text { ú. }}$ 
while in olfer gencra, as in Cercofitheeus, mest of the species can be determincd with cortainty. In the American genus C'ebus, the various forms are rasberl log some naturalists as species, by otlers as mere geographieal races. Now, if numcrous specimens of Cebus were collected from all garts of soutl Ameriea, and thuse forms which at present appear os bo specifically distuct, were found to groduate into cach other by dowe stepe, they would be rasked liy nose naturalius an mere variegies or roces; and thus the grester sumber of maturaliets lowe

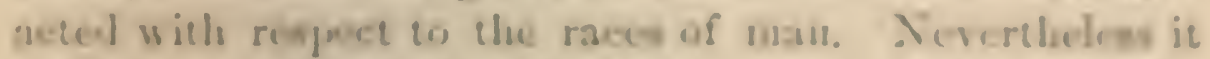
most be confised that ilure are forms, at leat in the vegrable kinglom," which wo conmot arvid naning as provio, but which are couneotol together, inde pearlinely of intererosing, lig numberless goulatious.

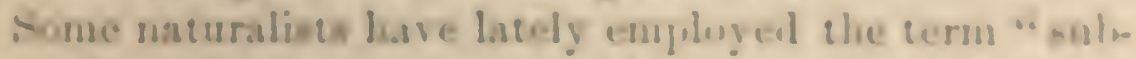
"perics" on desiguaer forms which pomene ming of the

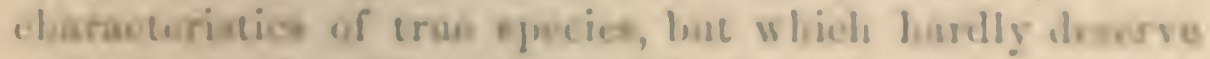
en ligha rank. Now, if we retloot on tho wriglity argouewe, alowe given, finr raining the raees of thats to the Jignisy of epocies, and the insuporable difticalsies on the

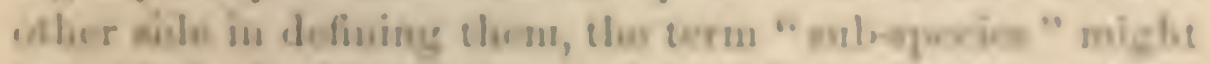

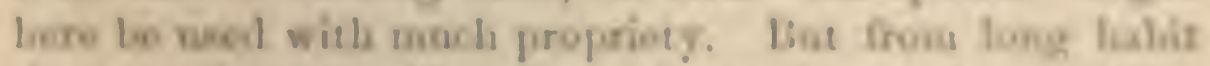

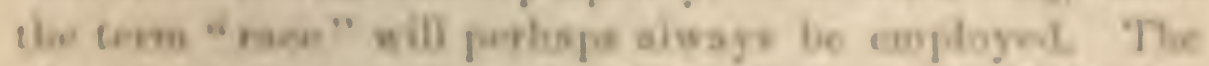
- hotce of teoms id only to fus important as ie is helhy do-

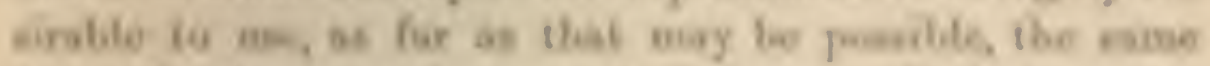

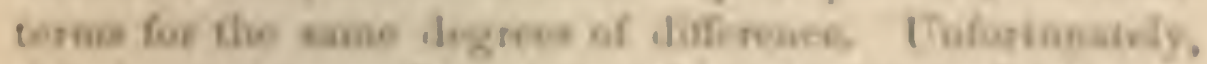

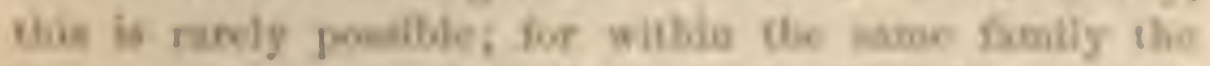

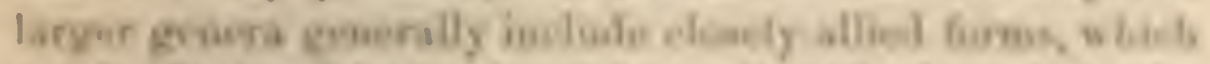

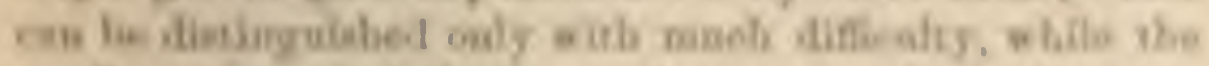

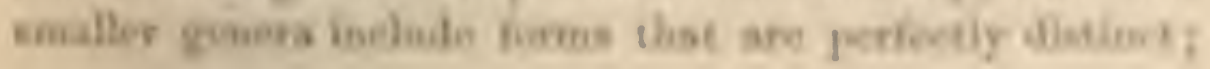

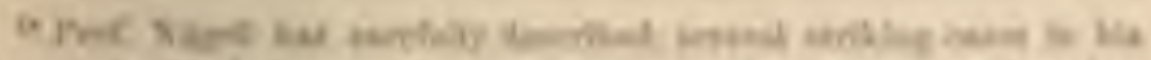

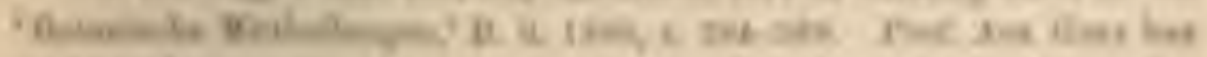

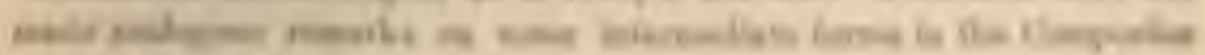

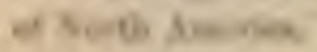


yet all must equally be ranked as species. So again the species within the same large genus by no means resemble each other to the same degree: on the contrary, in most cases some of them can be arranged in little groups round other species, like satellites round planets. ${ }^{19}$

The question whether mankind consists of one or several species has of late years been much agitated by anthropologists, who are divided into two schools of monogenists and polygenists. Those who do not admit the principle of evolution, must look at species either as separate creations or as in some manner distinct entities; and they must decide what forms to rank as species by the analogy of other organic beings which are commonly thus received. But it is a hopeless endeavor to decide this point on sound grounds, until some definition of the term "species" is generally accepted; and the definition must not include an element which cannot possibly be ascertained, such as an act of creation. We might as well attempt without any definition to decide whether a certain number of houses should be called a village, or town, or city. We have a practical illustration of the difficulty in the never-ending doubts whether many closely-allied mammals, birds, insects, and plants, which represent each other in North America and Europe, should be ranked species or geographical races; and so it is with the productions of many islands situated at some little distance from the nearest continent.

Those naturalists, on the other hand, who admit the principle of evolution, and this is now admitted by the greater number of rising men, will feel no doubt that all the races of man are descended from a single primitive stock; whether or not they think fit to designate them as distinct species, for the sake of expressing their amount 19 ' Origin of Species,' 5th edit. p. 68. 
of difference. ${ }^{20}$ With our domestic aninals the question whether the various races have arisen from one or more species is different. Although all such races, as well as all the natural species within the same genus, have undoubtedly sprung from the same primitive stock, yet it is a fit sulject for discussion, whether, for instance, all the domestic races of the dog have acquired their present differences since some one species was first domesticated and bred by man; or whether they owe some of their characters to imheritance fiom distiuct svecies, which hat already been modified in a state of nature. With mankiud $n$ such question can arise, for he cannot be said to have been domesticated at any particular period.

When the races of man diverged at an extremely res. mote epoch from their common progenitor, they will have difiered but little from ench other, and been few in num. ber; consequently they will then, as far as thcir distingruishing characters are concerued, have had less claim to rank as distinct species, than the existing so-called races. Nevertheless such early races would perhaps have been rambed by some naturalists as distinct specoles, an arhitrary is the term, if their diflerences, althongh ertremely slight, had becon more constant than at fresemt, and had noe graduated into cach othur.

It is, howerer, pmible, lhomgh lin firm probshlie, that the early progenitors of man might at lirst hase diverged much in characeter, until they became more unlike

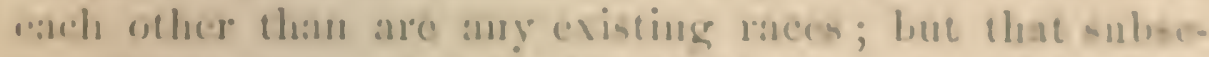

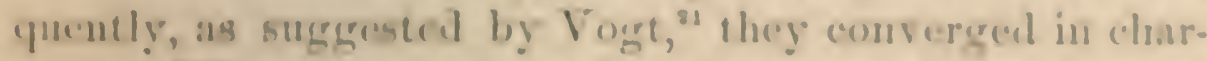
acter. When man selecets fur the samo ohjece the of: fpring of two distimet specios, he sumetimes imlones, as fir ay geural appearaneo is concernod, a cousielerable 1.. 1876.

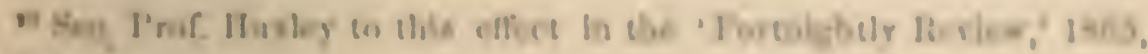

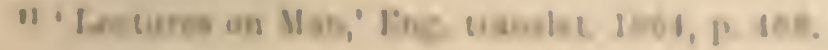


amount of convergence. 'This is the calse, as shown by Von Nathusius, ${ }^{22}$ with the improved breeds of pigs, which are descended from two distinct species; and in a less well-marked manner with the improved breeds of cattle. $\Lambda$ great anatomist, Gratiolet, maintains that the anthropomorphous apes do not form a natural sub-group; but that the orang is a highly-developed gibbon or semnopithecus; the chimpanzee a highly-dereloped macacus; and the gorilla a highly-developed mandrill. If this conclusion, which rests almost exclusively on brain-characters, be admitted, we should have a case of convergence at least in external characters, for the anthropomorphous apes are certainly more like each other in many points than they are to other apes. All analogical resemblances, as of a whale to a fish, may indeed be said to be cases of convergence; but this term has never been applied to superficial and adaptive resemblances. It would be extremely rash in most cases to attribute to convergence close similarity in many points of structure in beings which had once been widely different. The form of a crystal is determined solely by the molecular forees, and it is not surprising that dissimilar substances should sometimes assume the same form; but with organic beings we should bear in mind that the form of each depends on an infinitude of complex relations, namely, on the variations which have arisen, these being due to causes firr too intricate to be followed out-on the nature of the variations which have been preserved, and this depends on the surrounding physical conditions, and in a still higher degree on the surrounding organisms with which each has come into competition-and lastly, on inheritance (in itself a fluctuating element) from innumerable progenitors, all of

22 'Dic Racen des Schweines,' 1860, s. 46. 'Torstudien für Geschichte, etc., Schwcineschädel,' 1864, 6. 104. W'ith respect to cattle, see M. de Quatrefages, 'Unité de l'Espèce Humaine,' 1861, p. 119. 
which have had their forms deternined through equally complex relations. It appears utterly iucredible that two organisms, if differing in a marked manner, should ever afterward converge so closely as to lead to a near apr proach to identity throughlout their whole organization. In the case of the convergent pigs above referred to, evidence of their descent from two primitive stocks is still plisinly retained, according to Von Nathusius, in certain hones of their skulls. If the races of man were descented, as supposed by some naturalists, from two or more distinct species, which had diflered as much, or nearly as much, from each other, as the orang diflins from the gorillat, it cau hardly le doubted that marked diflerences in the structure of certain bones wuthl still have been dis. coverable in man as he now erists.

Athough the eristing races of mau difler in many reeprects, as in color, hair, shape of shull, proportions of the body, ate, yet if their whele organization be taken into conbileration they are fomml to resemble each other clenely in a multitule of points. Many of these prines are of ei) mimportant or of so singular a nature, that it is ax. tromely injrobable that thers should hase bon independently acenuirud by ahoriginally distinet kperias or roces. The sume romarh holls fond in ith egual or preater fores witl repreat to the memerous poists of mental similarity bet werot the most dietinct races of man. The Amerissis

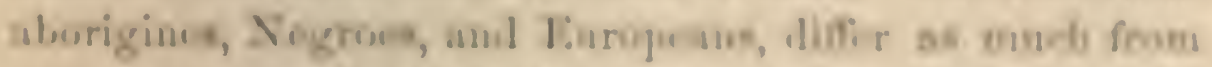

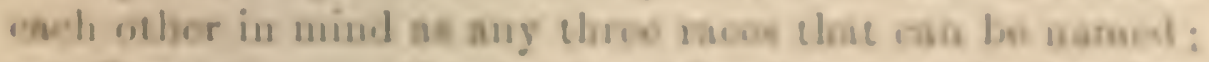
got I was incesmunty strurk, while living wish the the-

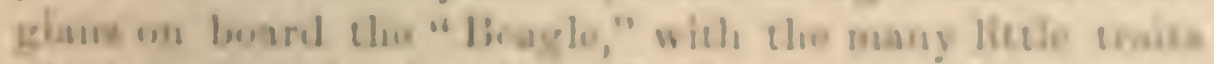
of chanamer, sliowiug low sinular their minds were to

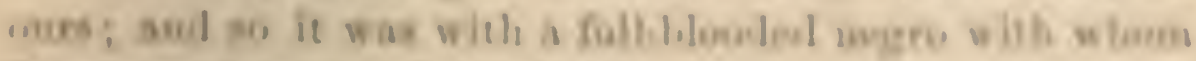

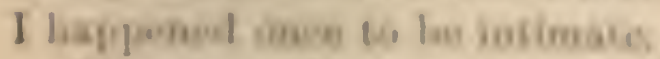

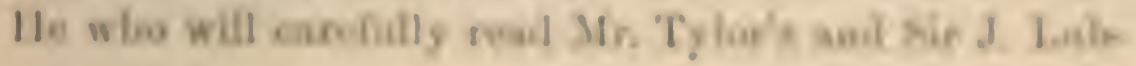


bock's interesting works ${ }^{23}$ can hardly fail to be deeply im. pressed with the close similiarity between the men of all races in tastes, dispositions, and habits. This is shown by the pleasure which they all take in dancing, rude music, acting, painting, tattooing, and otherwise decorating them selves-in their mutual comprehension of gesture-language -and, as I shall be able to show in a future essay, by the same expression in their features, and by the same inarticulate cries, when they are excited by rarious emotions. This similarity, or rather identity, is striking, when contrasted with the different expressions which may be observed in distinct species of monkeys. There is good evidence that the art of shooting with bows and arrows has not been handed down from any common progenitor of mankind, yet the stone arrow-heads, brought from the most distant parts of the world and manufactured at the most remote periods, are, as Nilsson has shown, ${ }^{24}$ almost identical; and this fact can only be accounted for by the various races laving similar inventive or mental powers. 'The same observation has been made by archæologists ${ }^{25}$ with respect to certain widely-prevalent ornaments, such as rigzags, ete. ; and with respect to various simple beliefs and customs, such as the burying of the dear under megalithic structures. I remember observing in South America, ${ }^{20}$ that there, as in so many other parts of the world, man has generally chosen the summits of lofty hills, on which to throw up piles of stones, either for the salke of recording some remarkable event, or for burying his dead.

23 'T'ylor's 'Litrly Mistory of Mankind,' 1865; for the evidence with repect to gesture-language, see p. 54. Lubbock's 'Prehisturic 'l'mes,' id edit. 1869.

24 'The Primitive Inhabitants of Scandinavia,' Jing. translat. edited hy Sir J. Lubbock, 1868, p. 101.

${ }^{25}$ Hodder M. Westropm, on Cromlechs, etc., 'Journal of Ethmolergical Soc.' as given in 'Scientific Opinion,' June 2, 1869, p. 3.

26 'Journal of Rescarches: Voyage of thic "Beagle," p. 46. 
Now, when uaturalists observe a close agrecunent in numerous small details of habits, tastea, and dispositionr, between two or more donestic races, or betwcen nearlyallied natural forms, they use this fact as an argument that all ase descended from a common progcuitor who was thus condowed; and coneequently that all shouh be classed under the sanne species. The same argument nay be applied with much furce to the races of man.

As it is improbable that the mumerous and unimportant points of resenblance between the several races of man in bodily structure and mental faculties (I do not here refir to similar customs) should all have lece-inde pendemely acpuired, they must have been inherited from progenitors who were thus characteri\%cl. We thus gaiu some ineight into the carly state of man, hefore he had spreal sep) by menp over the face of the earth. The sprealing of nan to regious widcly-separated by the sea, no doubt, preceled aug comsideable amount of disergence of character in the several races; for otherwise we should somecimes met with the same race in dintinct continents; and this is uever the case. Sir J. Iubluck, affes cumpuring the are now praceiced ly sarages in all parts of the world, cpecities throe which suan could not lase huewn, when be

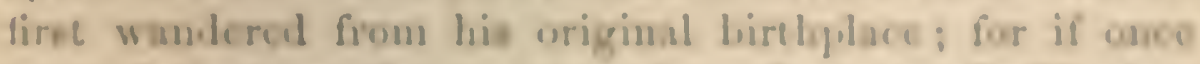
lesmeul they would urser have hero furguten." Ho thas

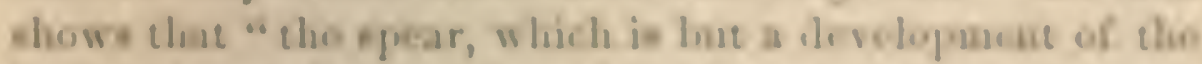
huifepoint, snd the club, wheh is but a long bansmer, am

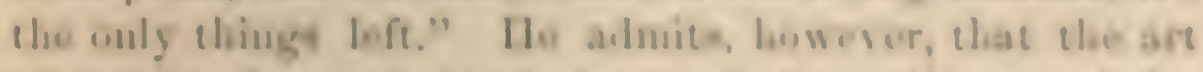

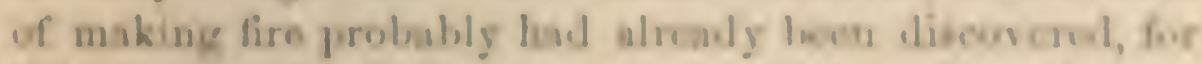

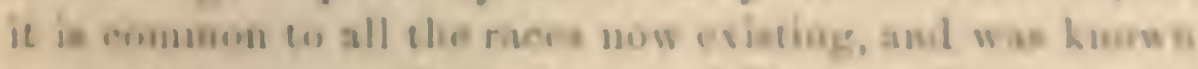

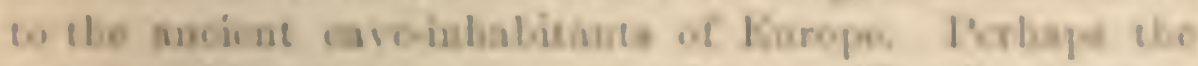

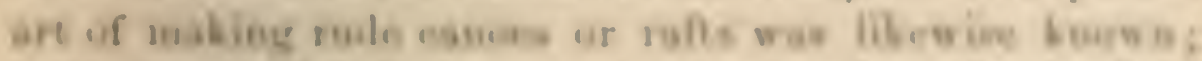

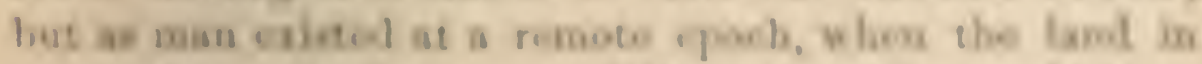

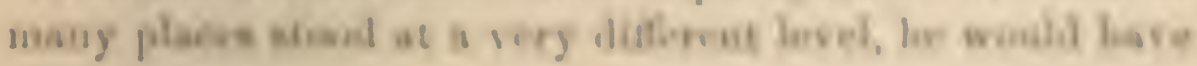

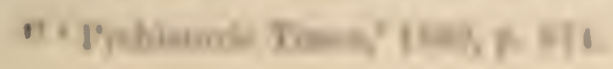


been able, without the aid of canoes, to have spread widely. Sir J. Lubbock further remarks how improbable it is that our earliest ancestors could have "counted as high as ten, considering that so many races now in existence cannot get beyond four." Nevertheless, at this early period, the intellectual and social faculties of man could hardly have been inferior in any extreme degree to those now possessed by the lowest savages; otherwise primeval man could not have been so eminently successful in the struggle for life, as proved by his early and wide diffusion.

From the fundamental differenees between certain languages, some philologists have inferred that when min first became widely diffused he was not a speaking aniinal; but it maly be suspected that languages, far less perfect than any now spoken, aided by gestures, might have been used, and yet have left no traces on subsequent and more highly-developed tongues. Without the use of some linguage, howerer imperfect, it appears doubtful whether man's intellect could have risen to the standard implied by his dominant position at an early period.

Whether primeral man, when he possessed very few arts of the rudest kind, and when his power of language was extremely imperfect, would have deserved to be called man, must depend on the definition which we employ. In a series of forms graduating insensibly from some ape-like creature to man as he now exists, it would be impossible to fix on any definite point when the term "man" ought to be used. But this is a matter of very little importance. So again it is almost a matter of indifference whether the so-called races of man are thus designated, or are ranked as species or sulb-species; but the latter term appears the most appropriate. Finally, wo may conclude that when the principles of evolution are generally accepted, as they surely will be before long, the 
dispute between the monogenists and the polygenists will die a silent and unobserved death.

One other question ouglit not to be passed over without notice, namely, whether, as is sometimes assumed, cacls sub-specics or race of man lass splumg from a single pair of progenitors. Witl our domertic animals a new race can realily be formed from a siugle par possessiug some now character, or coven from a siugle iudividual thus characterizch, by carcefully mateling the varyiug ofl-priug; but most of our races liave becu forment, not intemenally fiom a selected pair, but uneonsciumsly hy ile preservation of many indiriduals which laste varicel, lowerer slighly, in some useful or desired manmer. If in one commtry stronger and heavier horses, and in another country lightor and flectcr lorses, were lablhitually preferred, we maty feel sure that two distinct sub-brecels would, in the coume of tiue, he produced, withoue auy particulat pars or iuli-

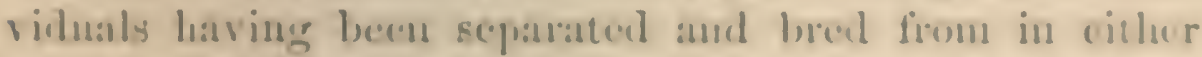
coumery. Mauy races have been thus lormed, and throir manuer of fiormation is closely analengus w ith that of uatural specica. We know, also, thate the liorses which liare

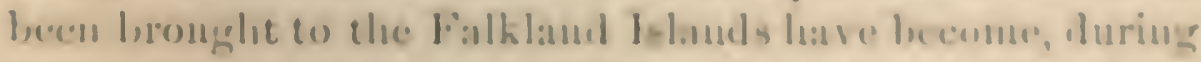
sucecenive generations, smaller amd woaker, while those

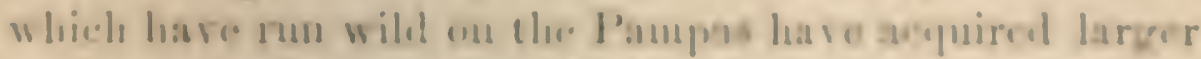

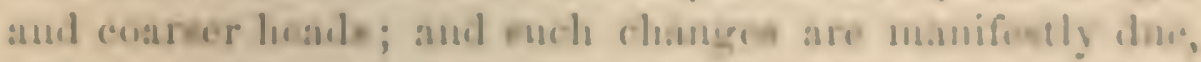
mot to aug oue par, bue to all the individuals bariug heon

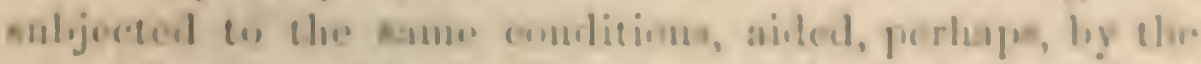

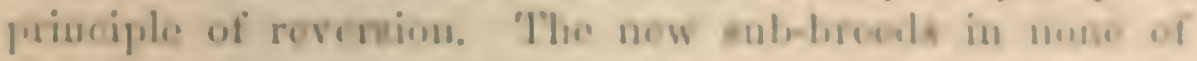

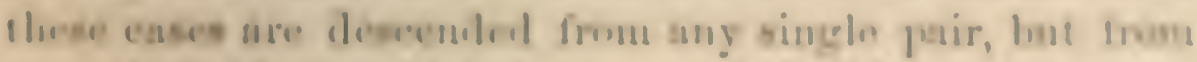

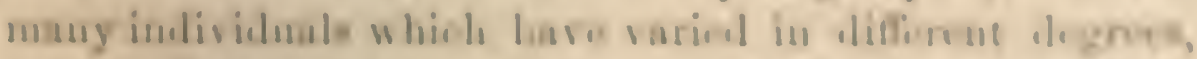

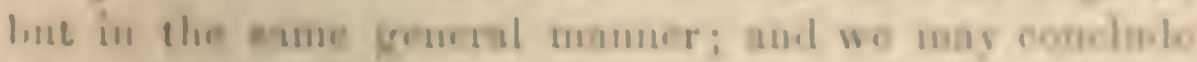

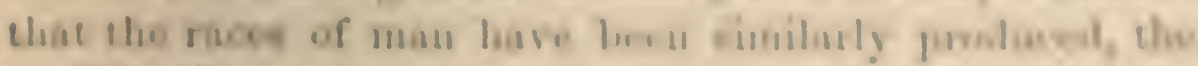

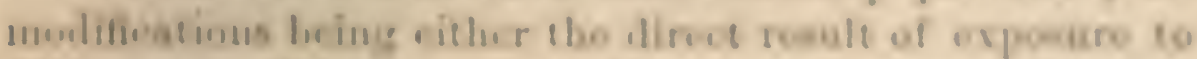

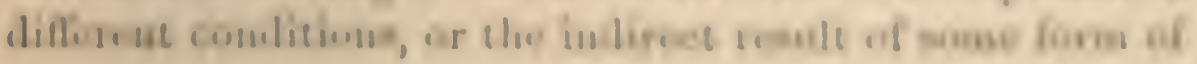


selection. But to this latter subject we shall presently return.

On the Extinction of the Races of Man.-The partial and complete extinction of many races and sub-races of man are historically known events. Humboldt saw in South America a parrot which was the sole living creature that could speak the language of a lost tribe. Ancient monuments and stone implements found in all parts of the world, of which no tradition is preserved by the present inlabitants, indicate much extinction. Some small and broken tribes, remnants of former races, still survive in isolated and generally mountainous districts. In Europe the ancient races were all, according to Schaaffhausen, ${ }^{29}$ "lower in the scale than the rudest living savages;" they must therefore have differed, to a certain extent, from any existing race. The remains described by Prof. Broca ${ }^{20}$ from Les Eyzies, though they unfortunately appear to have belonged to a single family, indicate a race with a most singular combination of low or simious and high characteristics, and is "entirely different from any other race, ancient or modern, that we have ever heard of." It liflered, therefore, fiom the quaternary race of the caverns of Belgium.

Unfavorable physical conditions appear to have had but little effect in the extinction of races. ${ }^{30}$ Man has long lived in the extreme regions of the North, with no wood wherewith to make his canoes or other implements, and with blubber alone for burning and giving him warmth, but more especially for melting the snow. In the South-

sy 'T'unslation in 'Anthropolorgical lieview;' Oct. 1868, p. 431.

:9 'I'ransact. Intermat. Cougress of Prehistoric Arch.' 1868, pp. 172175. Sece also Hroca (trauslation) in 'Authropological Review, Oct. 1868, p. 410 .

3) Lr. Gerlaud, 'Leber das Aussterben der Naturvölker,' 1868, s. 82 
cru cxtrenity of America the Fuegians survive witlout the protection of clothes, or of any builhng worthy to be called a horel. In South Africa the aborigines wauder over the inost arid plains, where daugerous beasts abound. Man can withstand the deadly influence of the 'Terai at the foot of the Himalaya, and the pestilemtial shores of tropical Africa.

Extinction follows chichly from the competition of tribe with tribe, and race with race. Varius checks are always in action, as specified in a forner chapter, which serve to kecl down the uumbers of each sarage tribe-such as periodical faminea, the wandering of the parents and the cunsequent deaths of infauts, prolonged suckling, the stealing of women, wars, accidents, sickuces, licentiousuns, en pecially infanticide, and, perhaps, lesened ferrility frum as nutritious food, and many hardships. If from any rause any one of these chechs is lessoned, even in a slighe slogree, the tribe thus forored will temel to increase; am whon one of $t$ wo aljoining tribes becomes more mum rous and powerful than the other, the contest is som sctelod by war, slanglier, camuladisu, flavery, and alsarplim. Jiven whon a weaker tribe is

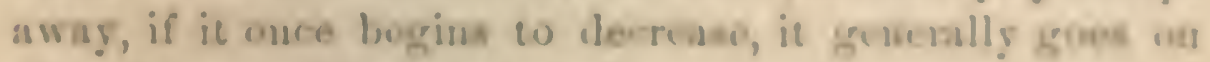
decrewing until it in entinet."

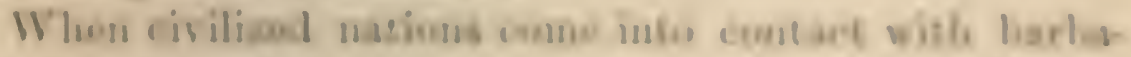

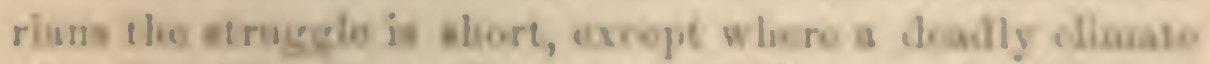
girse its aid to the satise rave. (I) the cusces wbieb lod

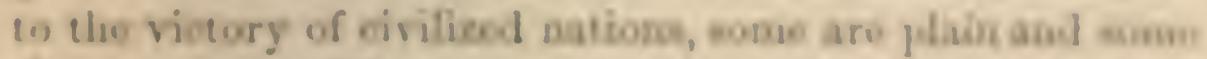

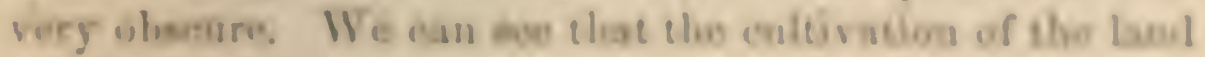
will bo fitul in mang wask to kavages, for tlivy saumet, of will not, hangen thrir lublita. New diesance and viocs are

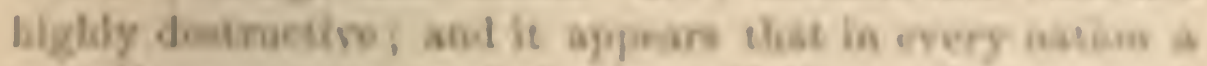

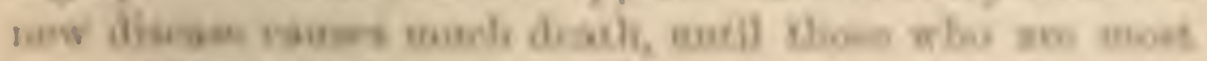

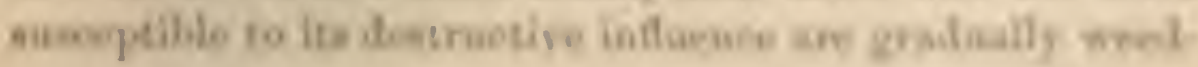

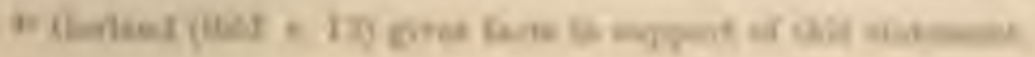


ed out; ${ }^{32}$ and so it may be with the evil eflects from spirituous liquors, as well as with the unconquerably strong taste for them shown by so many savagres. It further appears, mysterious as is the fact, that the first meeting of distinct and separated people grenerates disease. ${ }^{33}$ Mr. Sproat, who in Vancouver Island elosely attended to the subject of extinction, believes that changed habits of life, which always follow from the advent of Europeans, induces much ill-health. He lays, also, great stress on so trifling a cause as that the natives become "bewildered and dull by the new life around them; they lose the motives for exertion, and get no new ones in their place." "s4

'The grade of civilization seems a most important clement in the success of nations which come in competition. A few centuries ago Europe feared the inroads of Eastern barbarians; now, any sucl fear would be ridiculous. It is a more curious fact that savages did not formerly waste away, as Mr. Bagehot has remarked, before the classical nations, as they now do before modern civilized nations; had they done so, the old moralists would have nused over the event; but there is no lament in any writer of that period over the perishing barburitus.

Although the gradual decrease and final extinction of the races of man is an obsenre problem, we ean see that it depends on many eauses, diflering in different places and at different times. It is the same difficult problem as that presented by the extinction of one of the higher ani-

${ }^{32}$ Sec renarks to this eflect in Sir II. Holland's 'Medical Notes and Reflections,' 1839, p. 380.

${ }^{83}$ I have collected ('Journal of Rescarches, Voyage of the "Beargle," " p. 435) a good many cases bearing on this subject: sec also Carland, ibid.s. 8. Poeplyigg speaks of the "breath of civilization as poisonous to savages."

3s Sproat, 'Secnes and Studies of Sarage Life,' 1868, p. 294.

${ }^{35}$ Bagehot, "Physies and Polities," 'Fortnighlıly Reriew;' A pril 1, 1868, p. 455. 
mals-of the fossil horse, for instauce, which cli-appearel fion South Ancrica, soon afterwarl to be replacel, with. in the same dintricts, ly coumtless troops of the spani-h dur-e. The New-Zealander secuss conbcious of this paral. folism, for lie compares his future fate with that of the native rat almost exterminated by the kisropean rat. 'The differalty, thoughts great to our imsaginatiou, amsl real. Iy great if we wish to ascertain the precise causes, ought unt to be so to cur reasuls, as long as we heep steadily in mind that the increqse of each species and each race is

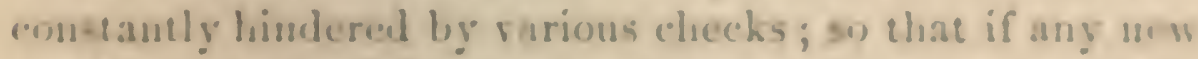
check, or cause of drstruction, orca a slighte one, he surper. alded, the race will surrly decrease in uussluer; ansl as it has evergwhere beew olenerved that savbeges are subels op posed to :asy changere of hishics, ly which mease injurious

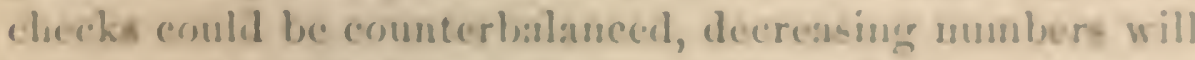
cooner or lator lead to cxtincetion; the cul, in most cass. being promply decermined ly the inrouls of inereasing and eonqueriug tribes.

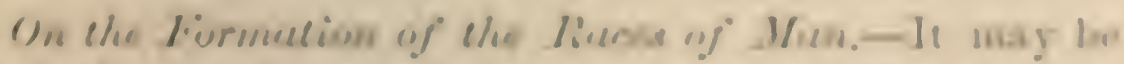
premised that when we lisud the nasue rare, though broben "1p inte disinet tribes, rasuging wor a great arra, as uver

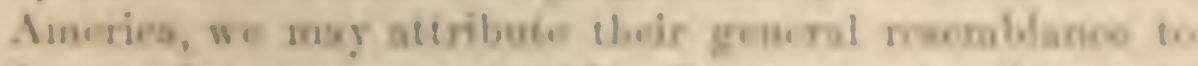

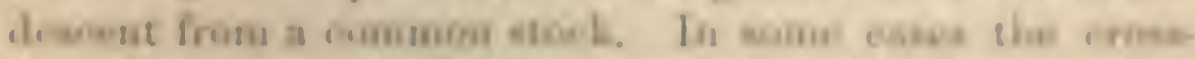

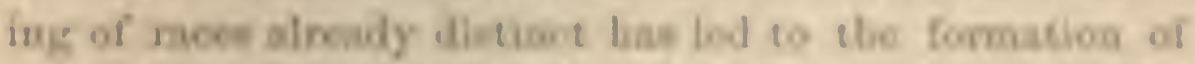

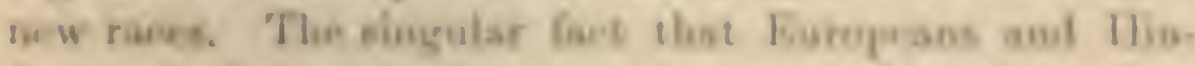
doos, w bo boloog to the eame Argan ntook and vpeak a

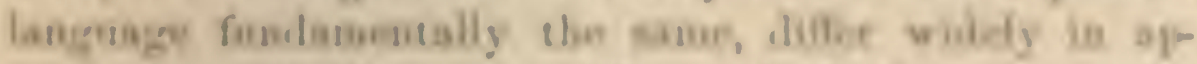
pearance, while Jumpeans differ bet Jiesle from Jewn, who

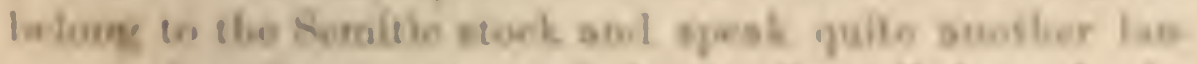
guage, low been actomatrol for by liroca" thermple the

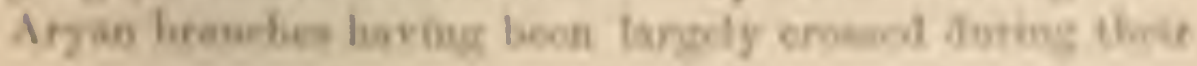


wide diftusion by various indigenous tribes. When two races in close contact cross, the first result is a heterogeneous mixture: thus Mr. Hunter, in describing the Sautali or hill-tribes of India, says that hundreds of impercep)tible gradations may be traced "from the black, squat tribes of the mountains to the tall olive-colored Bramin, vith his intellectual brow, calm eyes, and high but narrow head; "so that it is necessary in courts of justice to ask the witnesses whether they are Santalis or IIindoos." Whether a heterogeneous people, such as the iuhabitants of some of the Polynesian islands, formed by the crossing of two distinct races, with few or no pure members left, would ever become lomogencous, is not known from direct evidence. But, as with our domesticated animals, a crossed breed can certainly, in the course of a few generations, be fixed and made uniform by careful selection," we may infer that the free and prolonged intererossing luring many gencrations of a heterogencous mixture would supply the place of selection, and overcome any tendency to reversion, so that a crossed race would ultimately become lomogeneous, though it might not partake in an equal degree of the characters of the two parent-races.

Of all the diflerences between the races of man, the color of the slin is the most conspicuous and one of the best marked. Differences of this kind, it was formerly thought, could be accounted for by long exposure under diflerent climates; but Pallas first showed that this view is not tenable, and he has been followed by almost all anthropologists." 'The view has been rejected chiefly be-

3: 'The Aunals of Rural Bengal,' 1868, p. 131.

33 'The Variation of Animals and Plants under Domestication,' rol. เi. p. 95.

39 I'allas, 'Act. Acal. St. Petersburg,' 17s0, part ii. p. 69. IIe was fullorred by lindulphi, in his 'Bertrüge zur Anthropologie,' 1812. An 
rause the dietribution of the varionsly-coloreal races, moet of whom must have loug inhabited their preacut lomes, does not coincide with corresponding differences of cli. mate. Weight must also be given to such cases as that of the Dutch families, who, as we hear on creclleut anthority," have not undergone the least change of color, after reaiding for three centuries in sonth Afriea. The uniform appearance in various parts of the world of gypties and Jewn, though the uniformity of the huter has heen somwhat exapecratcd," is likewise an argument on the same sille. A very damp or a rery dry amospliene las becu supposed to be more intlusutial in modifying the color of the shin than ruere larat; bue as Dotrbigur in Sonth Amrerica, and Livingatouc in Africa, arrived at disunetrically opposite conclusions with respect to daupues and drynea, any conclusion on this heal must be consid. - rul as very doubliful."

Vurious fact, which I have deewhere giren, forove that the colur of the skin and hair is sometiuts norro latol in a surpriving mamer with a complete immunity frum the action of certain ingetable poisons and frous the ultseds of certain parasites. Hettee is ocentrol $6 \mathrm{me}$.

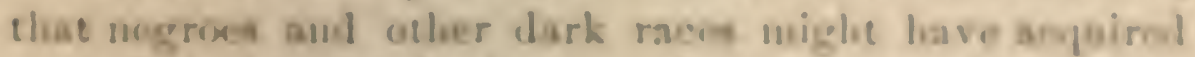

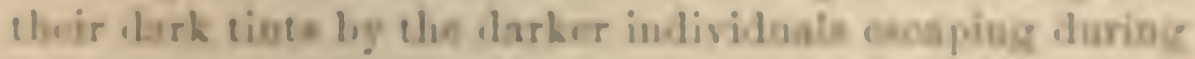
a long we rise of gourations frum the deally fufweruse of the minemas of thair wative collutrica.

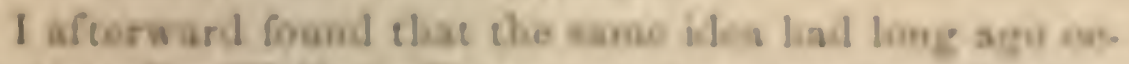
currol to Wr. Welle," Thast neproes, abel eron mulateos.

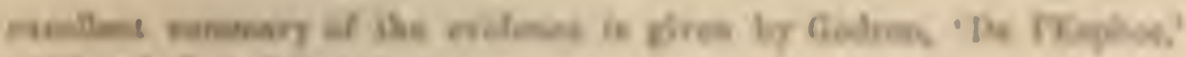
lese wa a is tie, eti.

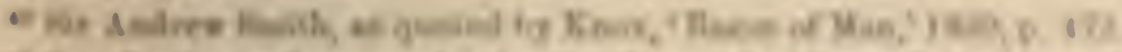

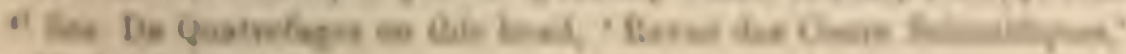
Oe. 17, laes, $\alpha$ :at.

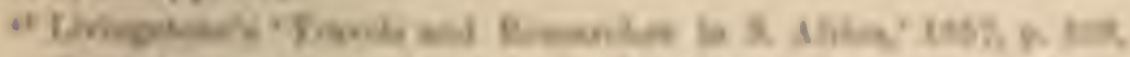

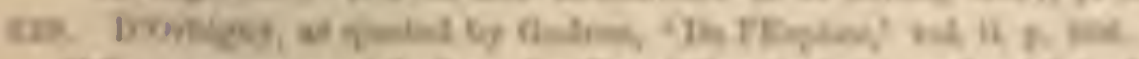

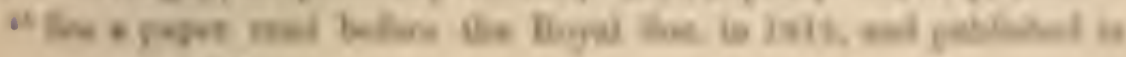


are almost completely exempt from the yellow fever, which is so destructive in tropical America, has long been kuown." They likewise escape to a large extent the fatal intermittent fevers that prevail along, at least, 2,600 miles of the shores of Africa, and which amually cause onc-fifth of the white settlers to die, and another fifth to return lome invalided." 'This immunity in the negro seems to be partly inherent, depending on some unknown peculiarity of constitution, and partly the result of acclimatization. Pouchet" states that the negro regiments, borrowed from the Viceroy of Egypt for the Mexican War, which had been recruited near the Soudan, escaped the yellow fever almost equally well with the negroes originally brought from various parts of Africa, aud accustomed to the climate of the West Iudies. 'That acclimatization plays a part is shown by the many cases in which uegroes, after having resided for some time in a coller climate, have become to a certain extent liable to tropical fevers." The nature of the climate under which the white races have long resided, likewise has some influence on them; for, during the fearful epidemic of ycllow fever in Demerara during 183\%, Dr. Blair found that the death-rate of the iumigrants was proportional to the latitude of the country whence they had come. With the negro the immunity, as far as it is the result of acclimatization, implies

his Essars in 1818. I have given an account of Dr. Wells's views in the Ilistorical Sketch (p. xri.) to my 'Origin of Species.' Tarious cases of color correlated with constitutional peculiarities are giren in my ' Variation of Animals under Domestication,' rol, ii. pp. 227, 335.

4t See, for instance, Nott and Gliddon, 'Types of Mankind,' p. 68.

4s Major Tulloch, in a paper read before the Statistical Society, April 20, 1810, and giren in the 'Athenteum,' 1840, p. 353.

46 'The Plurality of the IIuman Iace' (translat.), 186., p. 60.

47 Quatrefages, 'Lnité de l'Espèce II unaine,' 1861, p. 205. Waitz, 'Introduct. to Authropologg,' translat. vol. i. 1563, p. 121. Livingstono gires analugous cases in his 'Travels.' 
exposure during a prodigious length of time; fur the ahorigines of tropical America, who have resiled there from time immenorial, are not exempt from yellow ferer; asd the Rev. B. 'Tristram states that there are districts iu Northern Africa which the native inhabitants are cunpelled aunually to leave, though the negrors cau remain with safuty.

That the imumity of the negro is in any degree cor. related with the color of his thin is a mere conjecture: it may be correlntel with some dillerenee in his blowh, uervoun symem, or other iesues. Nescrtueles, from the folets abore alluded to, and frum sarue cumeerion apjar. encly existing between complexion and a teudeuey wo con. sumplion, the conjecture secuned to une rot improbalite. Contergueuty I endearored, with bue licte nucess," w

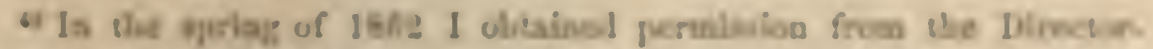

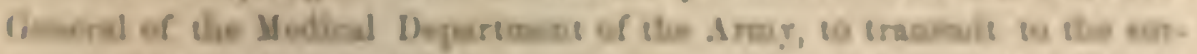

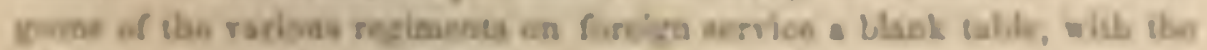

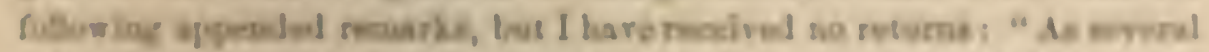

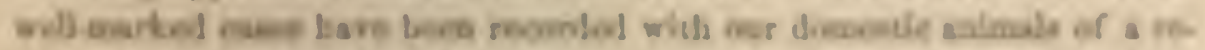

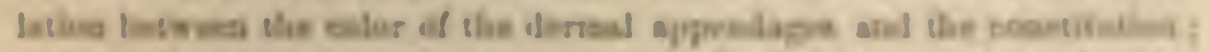

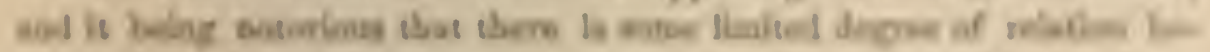

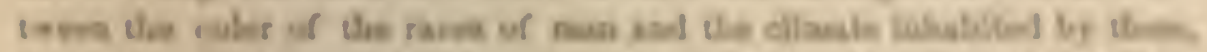

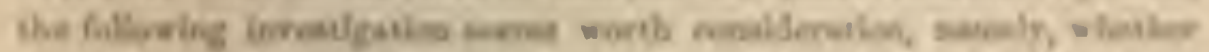

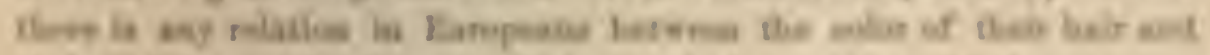

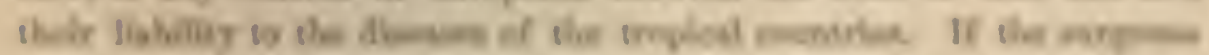

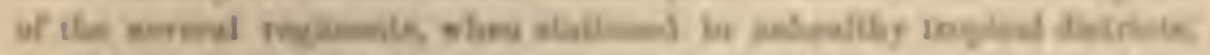

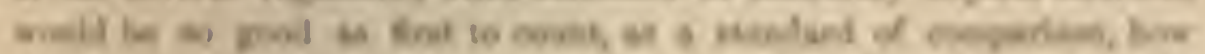

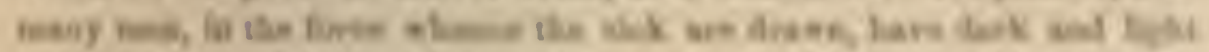

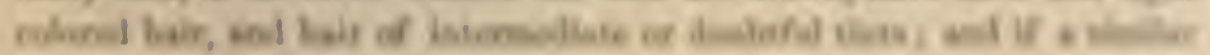

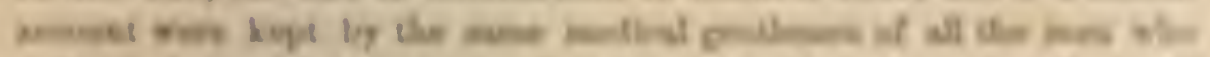

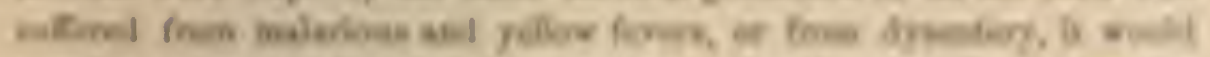

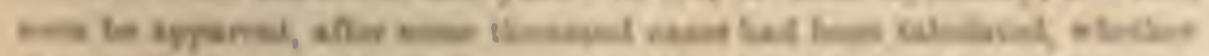

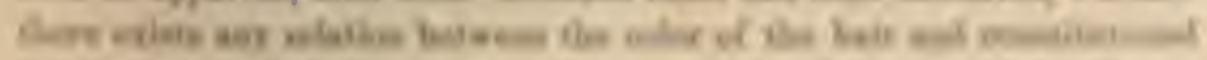

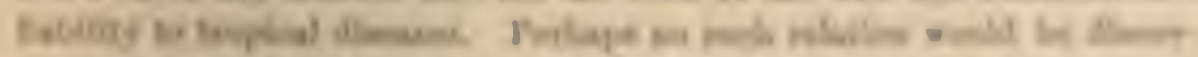

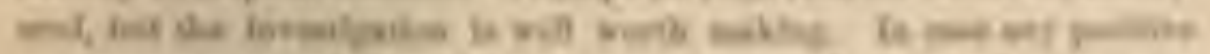

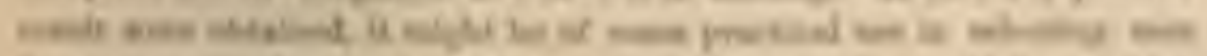

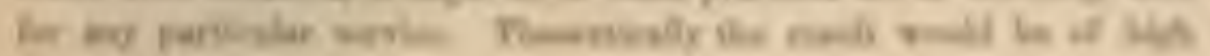


ascertain how far it held good. The late Dr. Daniell, who hand long lived on the West Coast of Africa, told me that he did not believe in any such relation. He was limself musually fair, and had withstood the climate in a wonderful manner. When he first arrived as a boy nut the coast, an old and experienced negro chief predicted from his anpearance that this would prove the ease. Di: Nicholson, of Antigna, after having attended to this subject, wrote to me that he did not think that dark-colored Europeans escaped the yellow fever better than those that were lightit-colored. Mr. J. M. IIarris altogether denies" that Europeans with dark hair withstand a hot climate better than other men; on the contrary, experience has tanght him, in making a selection of men for service on the coast of $\Delta$ frica, to choose those with red hair. As far, therefore, as these slight iudications serve, there seems no foundation for the hypothesis, which has been accepted by several writers, that the color of the black races may have resnlted from darker and darker individuals having survired in greater numbers, during their exposure to the fever-grenerating miasmas of their native countries.

Although with our present knowledge we cannot account for the strongly-marked differences in color between the races of man, either through correlation with constitutional peculiarities, or through the direct action of elimate; yet we must not quite ignore the latter agency, for there is good reason to believe that some inherited cffect is thus produced. ${ }^{20}$

interest, as indicating one menns by which a race of men inblubiting from a remote period an unhenthy tropical climate, might have hecotne darkcolored hy the better preservation of dark-haired or dark-complerioned individuals during a long succession of generations."

49 'Anthropological Review,' Jan. 1866, p. xxi.

so Ser, for instance, Quatrefages ('Revue des Cours Scientifiques,' Oct. 10,1868, p. 724$)$ on the effects of resildence in Abytsinia and Arabia, and other aualogous cases. Dr. Rolle (Der Mensch, scine Ahbtammung, 
We have socu in use third chuper tlat the conditions

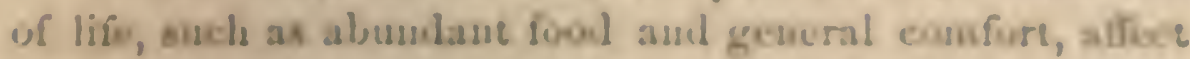
in a diroet mauner the derelogment of the botily frome, the effects being iransmitsed. Through the esmbined inAluence of climate and clasuged lubiu of life, Ioropean setslers in the Linited states undergo, an it geverally ad. mited, a slighe lut extmordinarily rapid cliauge of apr purasese. There is, alom, a consilerable hudy of evilears flowing that in tho foncliern Statre the bouke-slare of the thinl goneration presut s markedly digrent apper anee froth the field tavo."

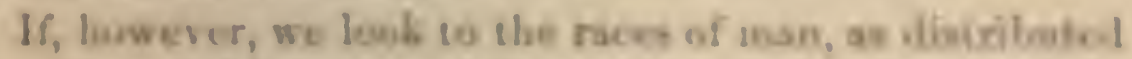
oser the world, we axuse infer that their chararterieties

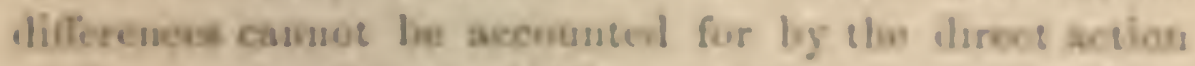
ot diforat conditione of life, erou after espoesere en them fur an cournabu jerion of time. The berguimanx firo ox. dusirely on animal fool; they are closhed is thirk for, und sere expesed to intense nolil sed to jrolowged dark. swer; get they do not diffir in ang controme degne frus

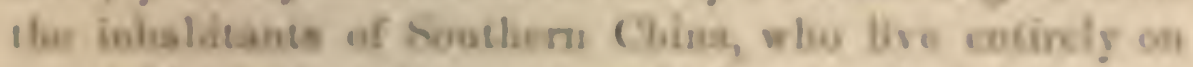

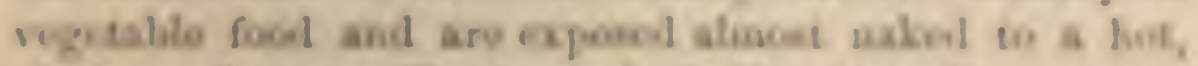

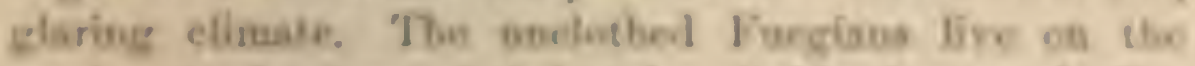
merise prodections of their mhorplesble slowes she the

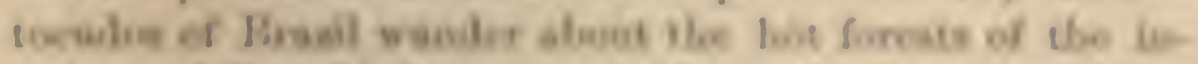

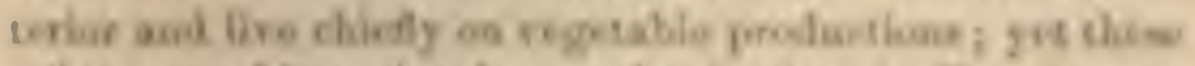

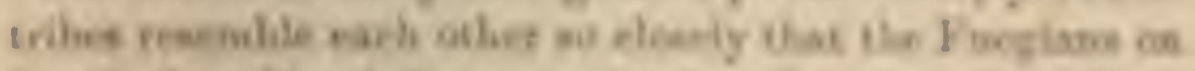

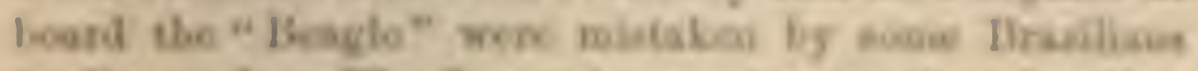

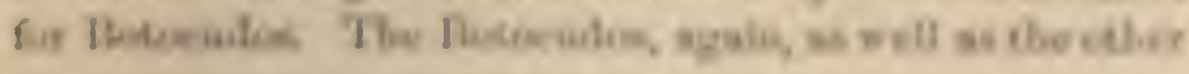

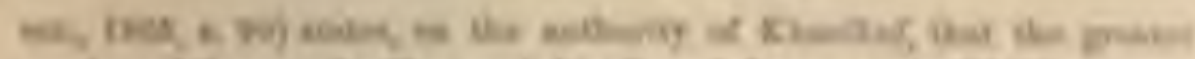

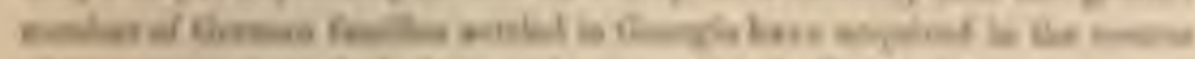

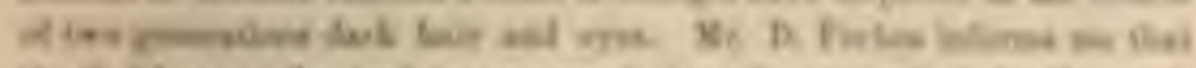

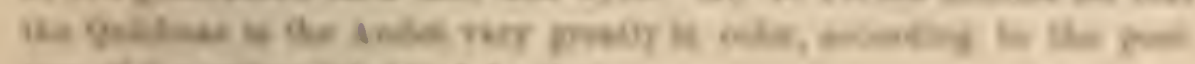

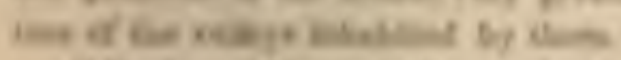

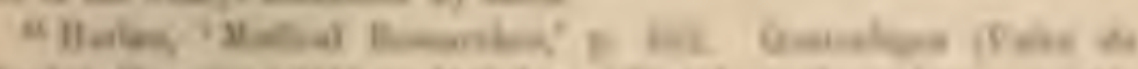

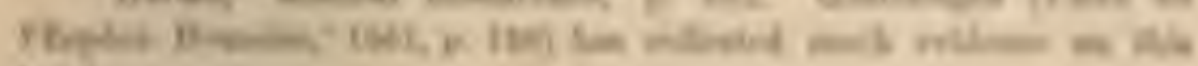
low. 
inhabitants of tropical America, are wholly different from the Negroes who inhabit the oppowite khores of the Al. lantic, are exposed to a nearly similar climate, and follow nearly the eame habita of life.

For can the differences between the races of man be acconnted for, except to a quite insignificant degree, by the inherited effects of the increased or decreased une of parts. Mon who hahitually lise in canoes may hare their legs somewhat stunted; those who inhabit lofty regions have their cliests enlarged; and those who constantly uas certain sense-organs have the carities in which they are lodged somewlint increased in size, and their features consequently a litte uodified. With cirilized nations, tles reduced size of the jaws from lessened use, the habitual play of diflerent muscles serving to express diflirent emotions, and the increased size of the brain from greater incellectual activity, have together produed a considerable eflect on their general appearance, in comparison with sarages." It is also possible that increased bodily atature, with no corresponding increase in the size of the lorain, may hare given to some races (judging from the prerivusly adduced cases of the rabbits) an clongated skull of the dolichoceplaalic type.

Insty, the litcle-understood principle of corretation will almost cortainly have come into action, as in the case of great unscular development and etrongl r-projecting supra-orbital ridges. It is not improbable that the texture of the hair, which diffirs unch in the diffireut raees, may atand in some hind of correlation with the nouoture of the skin; for the culor of the hair and skin are certainly correlated, as is its color and terture with the Mandaus."

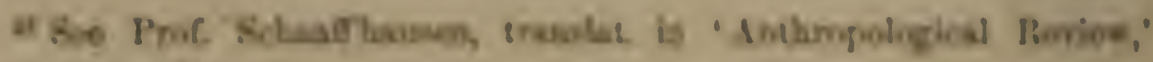
OCL IKes, g ILD.

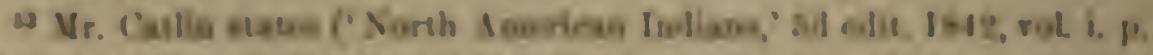

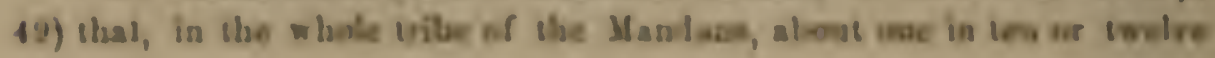


Toe eotor of the duin and the olor coulesed by is ane bib-

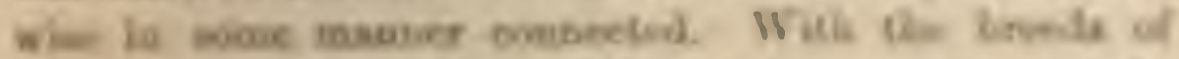

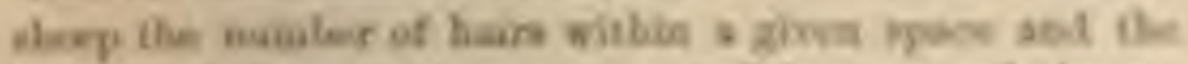

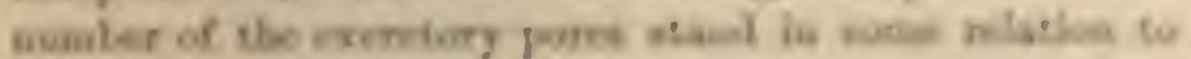
cels uher." If we way jod ge frum the sosherr of ons

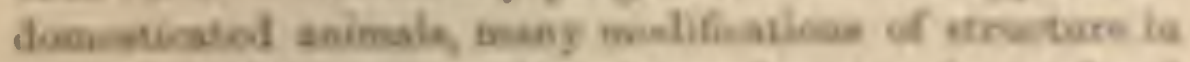

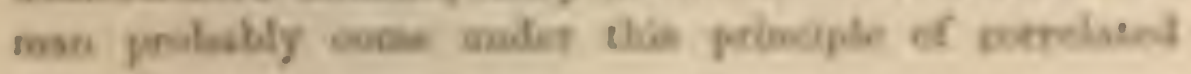
growith.

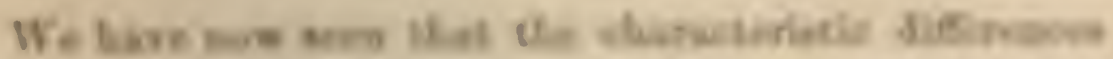

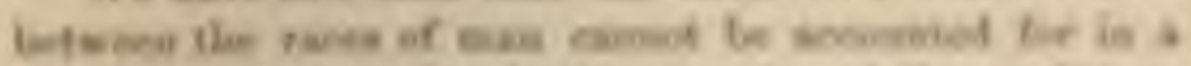

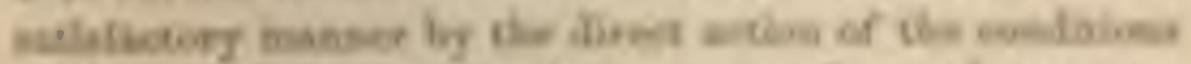

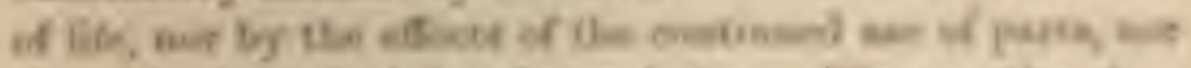

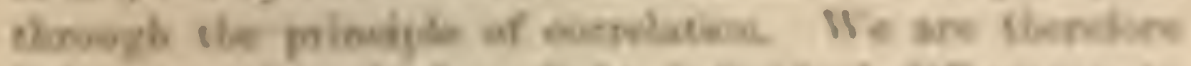

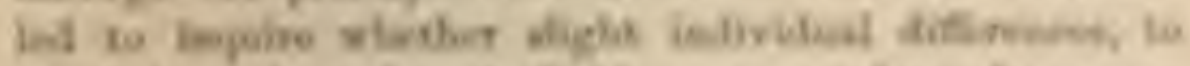

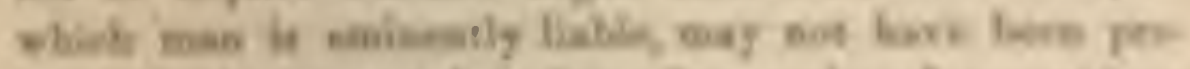

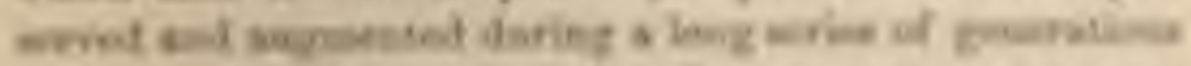

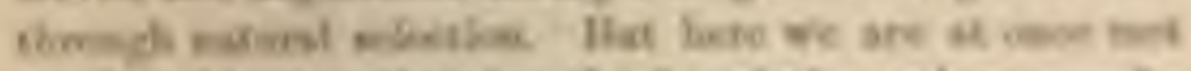

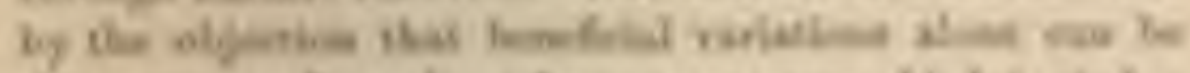

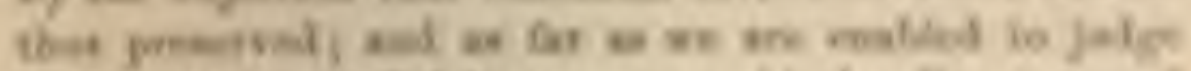

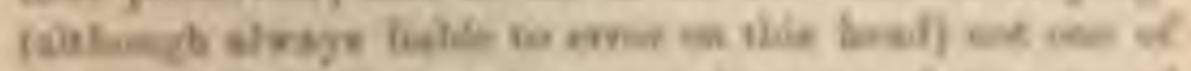

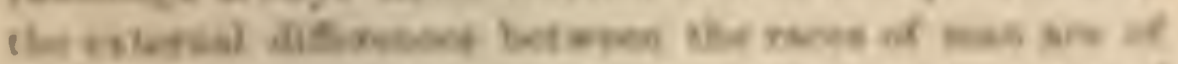
wey dines a porial mnke lo blas. The ieodlectsal and

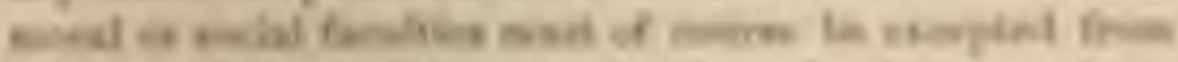

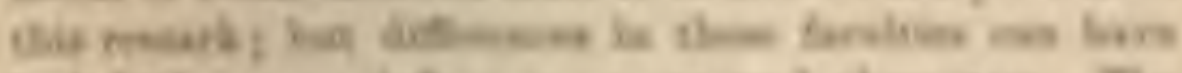

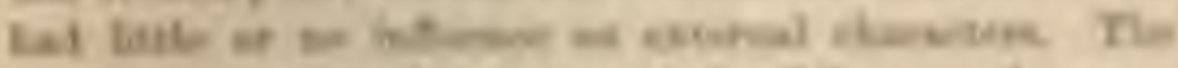

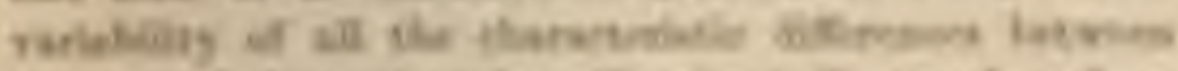

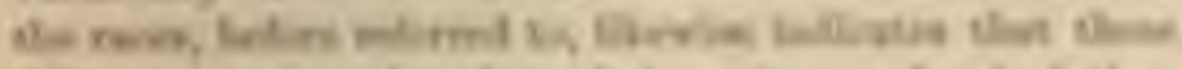

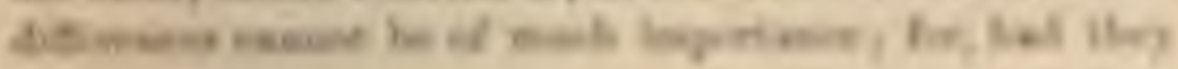

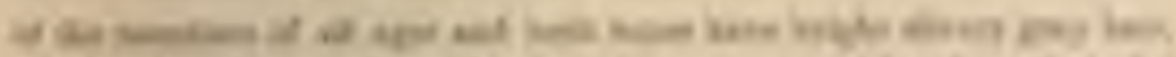

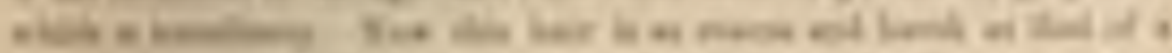

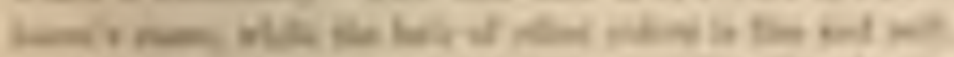

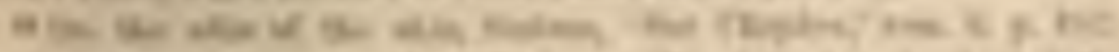

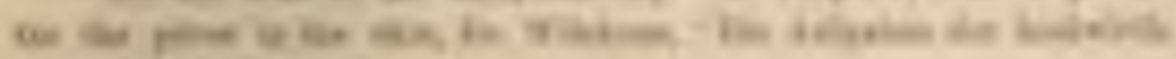
Cination * i 
been important, they wouk long ago have been either fixed and preserved, or eliminated. In this respect man resembles those forms, ealled by naturalists protean or polymorphic, which have remained extremely variable, owing, as it seems, to their variations being of an indifferent nature, and eonsequently to then having escaped the action of natural selection.

We have thus far been baffled in all our attempts to account for the differences between the raees of man; but there remains one important agency, namely, Sexual Selection, which appears to have acted as powerfully on man as on many other animals. I do not intend to assert that sexual seleetion will account for all the difterences between the races. An unexplained residum is left, about which we can in our ignorance only say that, as individuals are continually born with, for instance, heads a little rounder or narrower, and with noses a little longer or shorter, such slight differences might become fixed and uniform, if the unknown agencies which induced them were to act in a more constant mamer, aided by long-continued intercrossing. Such modifications come under the provisional class, alluded to in our fourth ehapter, which for the want of a better term have been called spontaneous variations. Nor do I pretend that the effects of sexual selection ean be indicated with scientifie precision; but it can be shown that it would be an inexplicable fact if man had not been modified by this agency, which has acted so powerfully on innumerable animals, both high and low in the seale. It ean further be shown that the diflerences between the races of man, as in color, hairiuess, form of features, ete., are of the nature which it might have been expected would have been acted on by sexual selection. But in order to treat this subjeet in at fitting manner, I have found it necessary to pass the whole animal kingilom in review; I have therefore de. 
votol to it the second Part of this work. At the clote I shall return to man, and, after attempting to show bow far he has been modified through sexual sclection, will give a brief summary of the chapters in this First Parh 

I'ARI II.

SEAUAL SELECTION. 



\title{
SEXUAT, SELECTION.
}

\section{('II I I'T I:I: VIII.}

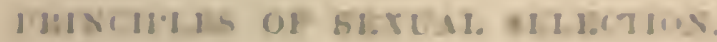

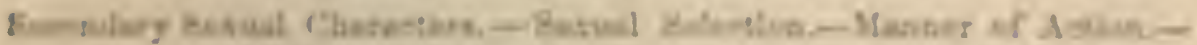

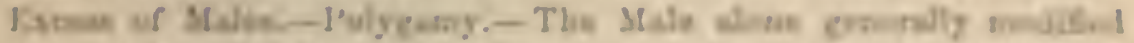

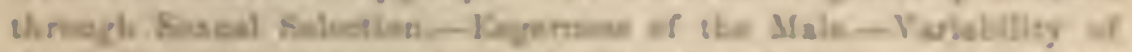

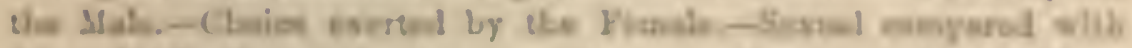

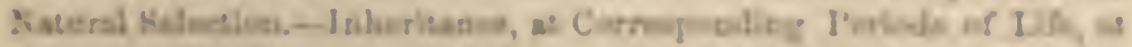

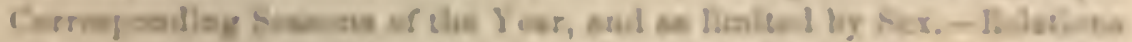

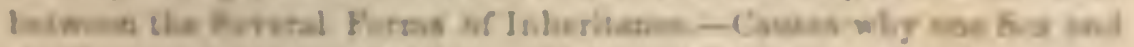

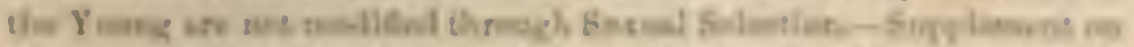

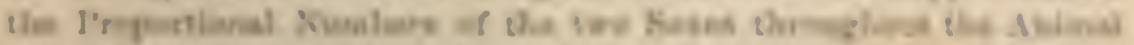

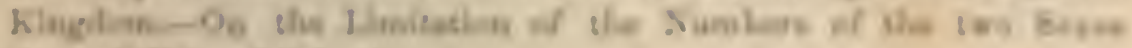
Dirsugh Noweral Whetion.

Wim animals whim haw thir sexes moroted, the

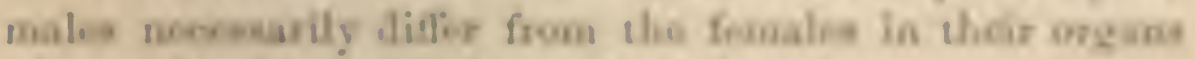

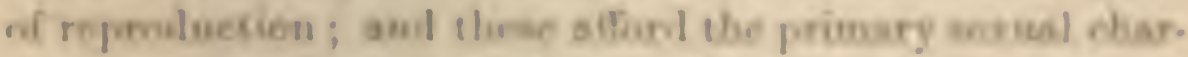
aeterse. liak the soxus oftor difir in what llonter has

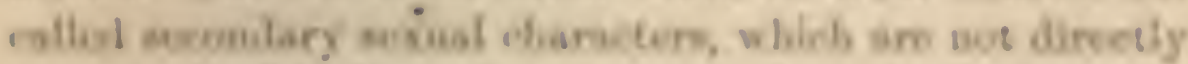
comourest silit the ent of reprofuceber; for inatanos, in

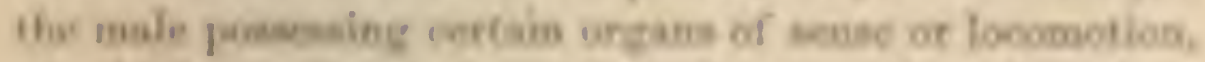
of which the fomale id quite desticinte, or in baving them

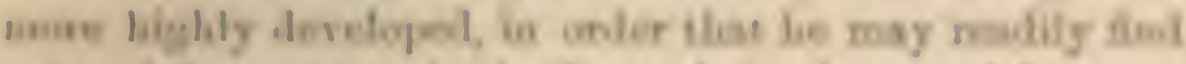
or mab lox; or ayain, in des male having opecial onema

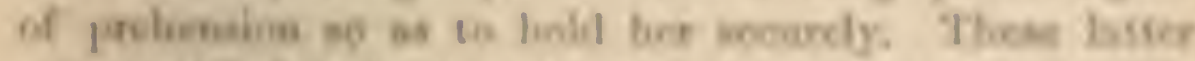

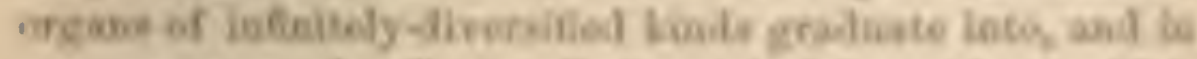

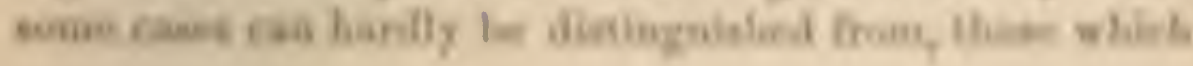


are commonly ranked as primary, such as the complex appendages at the apex of the abdomen in male insects. Unless indeed we confine the term "primary" to the reproductive glands, it is scarcely possible to decide, as far as the organs of prehension are concerned, which ought to be called primary and which secondary.

The female often differs from the male in having organs for the nourishment or protection of her young, as the mammary glands of mammals, and the abdominal sacks of the marsupials. The male, also, in some few cases differs from the female in possessing anilogons organs, as the receptacles for the ova possessed by the males of certain fishes, and those temporarily developed in certain male frogs. Female bees have a special apparatus for collecting and carrying pollen, and their ovipositor is modified into a sting for the defence of their larva and the community. In the females of many iusects the ovipositor is modified in the most complex manner for the safe placing of the eggs. Numerous similar cases conld be given, but they do not here concern us. There are, however, other sexual differences quite disconnected with the primary organs with which we are more especially concerned-such as the greater size, strength, and pugnacity of the male, his weapons of offence or means of defence against rivals, his gaudy coloring and various ornaments, his power of song, and other such cliaracters.

Besides the foregoing primary and secondary sexual diflerences, the male and female sometimes differ in structures comnected with different habits of life, and not at all, or only indirectly, related to the reproductive functions. Thus the females of certain flies (Culicida and Tabanide) are blood-suckers, while the males live on flowers and have tlreir mouths destitute of mandibles.' 'The males

'Westwood, 'עcdern Class, of Insecta,' rol. ii. 1810, p. 541. In 
aloue of certaiu moths and of sume orustaceans (e. F, "Taurin) have imperfect, clowed mouthe, and camot foed. The complemental males of certain Cirripeles lise like triphytic plants cither on the female or hermaghrodite form, and are desitute of a mouth aud preleusile limb. In theac cawa it it the male which has becn modified and lass luat certain important organs, w lisels the other unetubern of the same group postcas. In ocher cases it is the

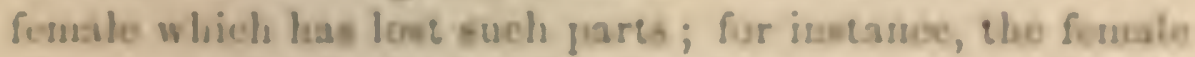
glowwors is dectirste of wisge, as are masy female motle, sone of whiels never leave tbeir cucous. Masy formale paravitio crustacexsu have lom their natatory has. In soure wereil-Inctes (Curculionide) there is a great diflirence betweon the male and fesnate in the lenglis of the restrum or strout; ' bue the meaning of this, and of many analogous difli ronow, is not at all anderswow. Difi-rences of struetere Intwech the two icxes in relation so difforeat babite of life are sunerally continel to then

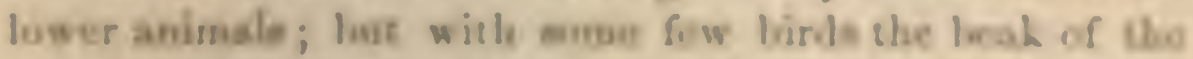
sable difin from thot of the fomale. So donbt in sust, lut apparvatly nut in all thoe eave, the diffirences aco indirectly coanseted with tho propagatiou of elve speint slias a female whidy lias to smovish a roeltitede of owa will require room food than ibe male, and ounesymenty

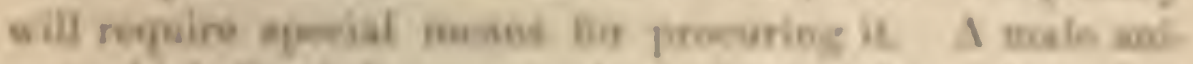

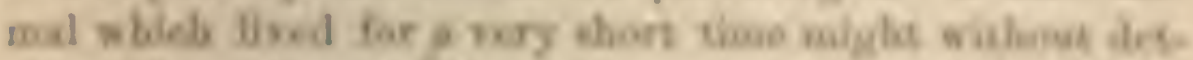

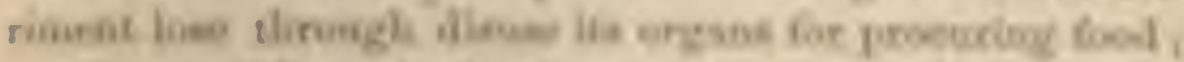

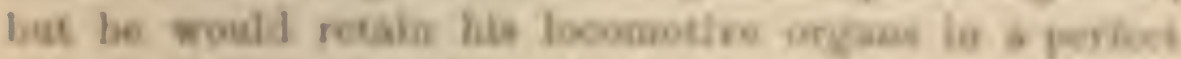

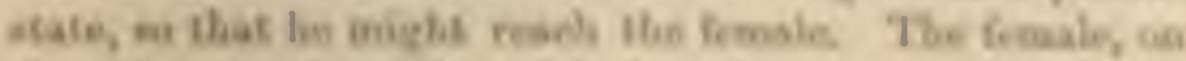

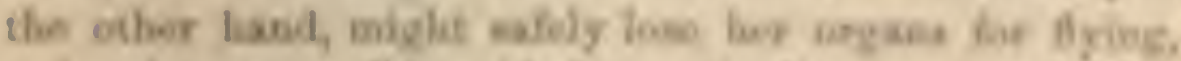

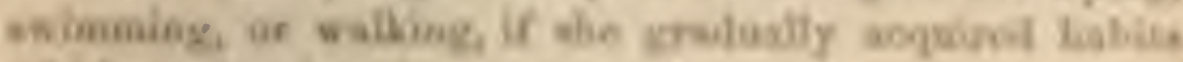
which rebiend ruck powere new les.

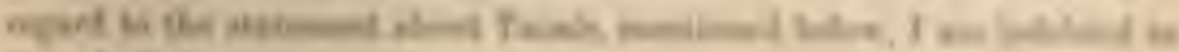
Jiar Yiales.

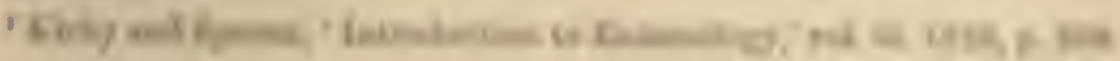


We are, however, here concerned only with that kind of selection which I have called sexual selection. This depends on the advantage which certain individuals have over other individnals of the same sex and species, in exclusive relation to reproduction. When the two sexes differ in structure in relation to different habits of life, as in the cases above mentioned, they have no doubt been modified through natural selection, accompanied by inheritance limited to one and the same sex. So, again, the primary sexual organs, and those for nomishing or protecting the young, come under this same head; for those individnals which generated or nonrished their offspring best, wonld leave, cateris paribus, the greatest number to inherit their superiority; while those which generated or nourished their offspring badly, would leave but few to inherit their weaker powers. As the male has to search for the female, he requires for this purpose organs of sense ant locomotion, but if these organs are necessary for the other purposes of life, as is generally the case, they will have been developed through natural selection. When the male has found the female he sometimes absolutely requires prehensile organs to hold her; thus Dr. Wallice informs me that the males of certain moths camnot unite with the females if their tarsi or feet are broken. The males of many oceanic crustaceans have their legs and antenne modified in an extraordinary manner for the prehension of the female; hence we may snspect that owing to these animals being washed about by the waves of the open sea, they absolutely require these organs in order to propagate their kind, and if so their development will have been the result of ordinary or natural selection.

When the two sexes follow exactly the same habits of life, and the male has more highly-dereloped sense or locomotive organs than the fomale, it may be that these in their perfected state are indispensable to the male for 
fiuliug the fernale; lut in the vat majority of cusen, ther erve unly to give oue male an adrautago over sobther, for the less wellendowed males, if time were allowed shem, would suceed in pairing with the females; and the? would in all other repects, jucl ging from the serueture of the fomale, le equally well adapect for the ir ordinary lasbits of life. In such casps sexusd seleetion smust have come into action, for the malia hare aeguired their pres. ent etrueture, not frosu lwing lecter fited to sursive in the seruggle for eaintenes, lut from having gained an asl.

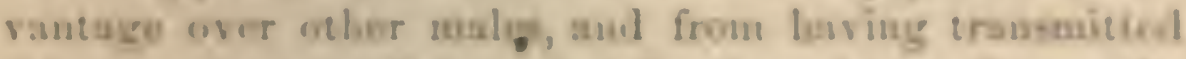
this alvantage en their unde offipring sloce. It was the importase of this dictiartion w bich led me 20 drsipwase this form of seloction at sexual nolection. So, ngais, if the chicf service reulerel (1) the male log bis grebmude ongans is to prevent the ecoape of the female hefore the arrisal of other usales, or when atsaliod lig them, these angans will have boon perfocted throngli eosul eulection, that is, hy the alsuntage aequired loy crrtain unles orer their

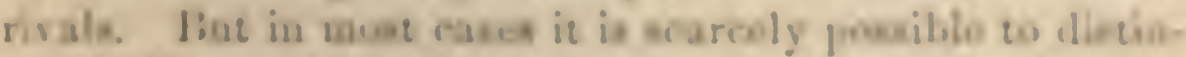

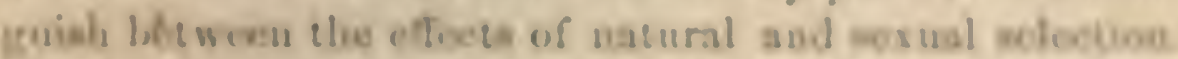

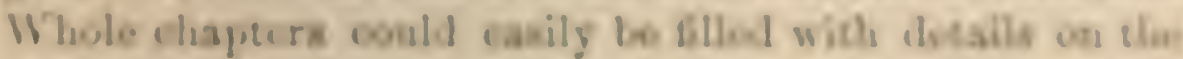

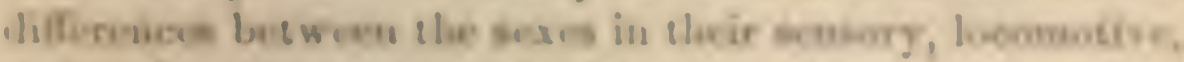
asd pceluensile organs. $\Lambda$, howeres, thes otrocsures are unt unore incurvetiong thas uthent alapted for doe antuary

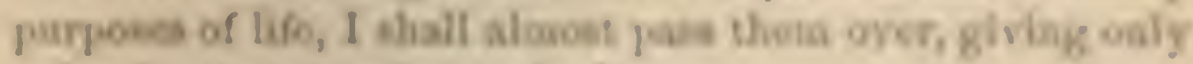

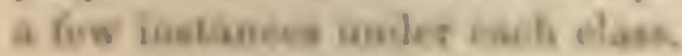

There are inany ocher etruesures and batincte whib th

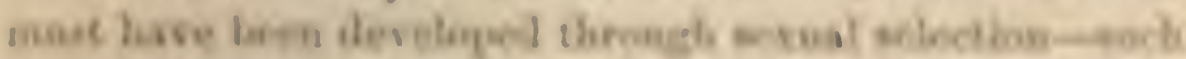

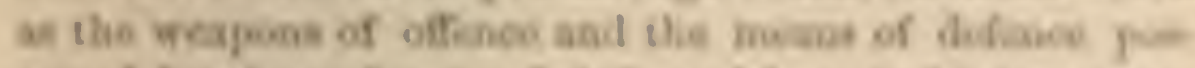

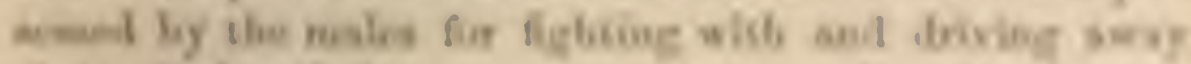

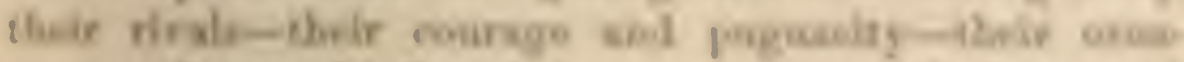

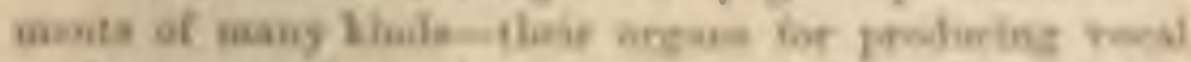

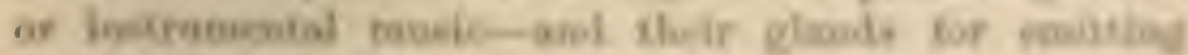

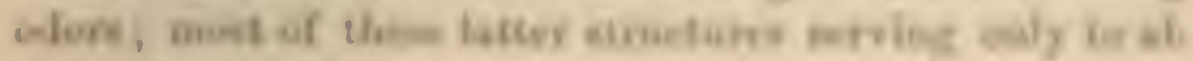


lure or excite the female. That these characters are the result of sexual and not of ordinary selection is clear, as unarmed, unornamented, or unattractive males would succeed equally well in the battle for life and in leaving a numerous progeny, if better-endowed males were not present. We may infer that this would be the case, for the females, which are unarmed and unornamented, are able to survive and procreate their kind. Secondary sexual characters of the kind just referred to, will be fully discussed in the following chapters, as they are in many respects interesting, but more especially as they depend on the will, choice, and rivalry of the individuals of either sex. When we behold two males fighting for the possession of the female; or several male birds displaying their grorgeous plumage, and performing the strangest antics before an assembled body of females, we cannot doubt that, though led by instinct, they know what they are about, and consciously exert their mental and bodily powers.

In the same mamer as man can improre the breed of his game-cocks by the selection of those birds which are victorious in the cockpit, so it appears that the strongest and most vigorous males, or those provided with the best weapons, have prevailed under Nature, and have led to the improvement of the natural breed or species. 'Through repeated deadly contests, a slight degree of variability, if it led to some advantage, howerer slight, would suffice for the work of sexual selection; and it is certain that secondary sexual characters are eminently variable. In the same manner as man can give beauty, according to his standard of taste, to his male poultry-can give to the Sebright bantam a new and elegant plumage, an erect and peculiar carriage-so it appears that in a state of nature female birds, by having long selected the more attractire males, have added to their beauty. No doubt this int- 
plies powers of di-crimination am tante on the part of the female which will at first appear cxtremely improbable; but I hope hereafter to show that this is not the case.

From our igmorance on several points, the precise manner in which sexual selection acts is to a certain extent uncertain. Nevertheles if those naturalists who alrcady belices in the mutability of species, will road the following chapters, they will, I thisk, agree with me that sexual selection hat played an iuportaut part in the historg of the organie worlil. It is certain tlate with almom all animals there is a atruggelo between the males fur the poescesion of the female. This fact is oo motorious that it would be 8 s. perfluoun to give insances. Hence the foualos, mujposing that their mental capacity sufliced for the esertion of a ehoice, could select one out of seriral uales. Fur in uemetous cases it uppears as if it lad beu specially arranged that there bloubl to a struggle between maing wables. 'Tlsus witle migratury lirds, the males gencrally arrive be. fore the frubles at elueir place of lireding, fo that mang

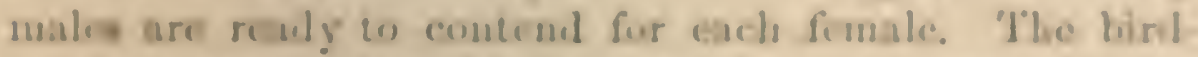

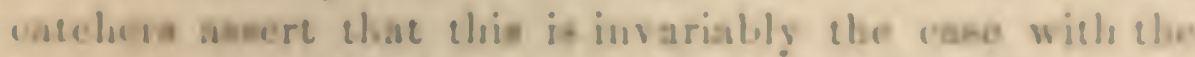

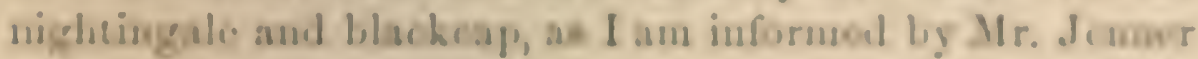
Wir, who eunfirms the nuteunent wils rovpeet to the lab tor sponios.

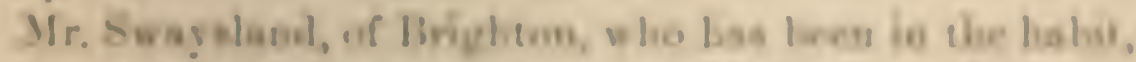
-luring the last forty Jare, of atclíng our migratory

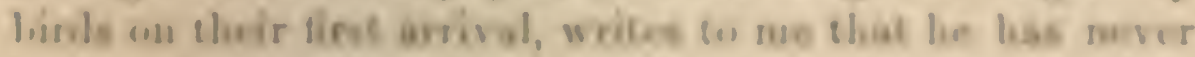
knowu the fomales of ang epocies to arrivo lefore theis

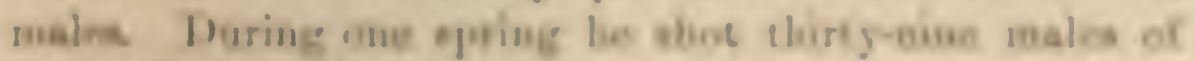
liay's wagtail (liwdycer lodii) before he axw a single for

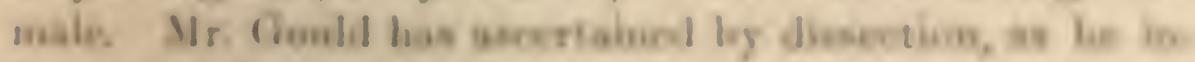

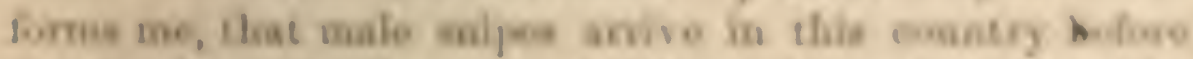
the fromates. In thas ease of fish, at then periol whes then

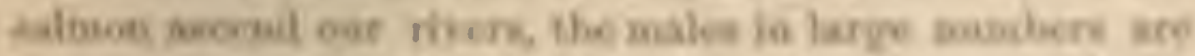

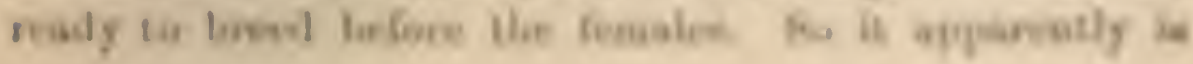


with frogs and toads. Throughont the great class of insects the males almost always emerge from the pupal state before the other sex, so that they generally swarm for a time before any females can be seen." The canse of this difference between the males and females in their periods of arrival and maturity is sufficiently obvious. Those males which anmally first migrated into any country, or which in the spring were first ready to breed, or were the most eager, would leave the largest number of offspring ; and these would tend to inherit similar instincts and constitntions. On the whole, there can be no doubt that with almost all animals, in which the sexes are separate, there is a const:mtly recurrent struggle between the maless for the possession of the females.

Onr difficulty in regard to sexual selection lies in understanding how it is that the males which eonquer other males, or those which prove the most attractive to the females, leave a greater number of offspring to inherit their superiority than the beaten and less attractive males. Unless this result followed, the characters which gave to certain males an advantage over others, conld not be perfeeted and angmented through sexual selection. Whon the sexes exist in exactly equal numbers, the worst-endowed males will ultinately fird fomales (excepting where polygamy prevails), and leave as many ofispring, equally well fitted for their general habits of life, as the best-endowed niales. From various facts and considerations, I formerly inferred that with most animals, in which secondary

8 Even with those of plants in which the sexes are separate, the male llowers are generally mature hefore the femule. Many hermaphrodite plantsmre, ns first shown by C. K. Sprengel, dichoganous; that is, their Inale and female organs are not ready at the same time, so that they cannot be self-fertilized. Now with such plants the pollen is generally mature in the same flower before the stigma, though there are soine excep. tional species in which the fenale organs are mature before the male. 
sexual characters were woll dereloped, the males consiblers.

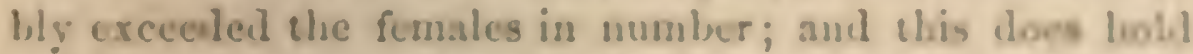
good is some fow casea. If the males were to the fanales as two to one, or as three 10 two, or ereas in a sussurbat lower ratio, the whole aftair would be niagple: for the het. ter-armed or more attractive msales wotsh leave the lar. Let umsber of ofi-prisg. Jiut after isvestigatiug, as far as possible, the uumerical proportious of the sexes, I do nort believe that auy great issequality in ususher comssouls rists. In moet cams sexual scleotion nppore to have hean eflective in the followiug mamer:

Joe we tahe any rpocios, a bird for ismasec, asd di.

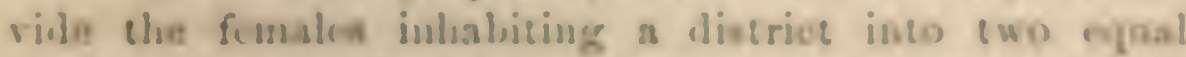
hodies: the one cominsing of the more vigorons sad bee. terountisted individusts, and the other of the hes sigas-

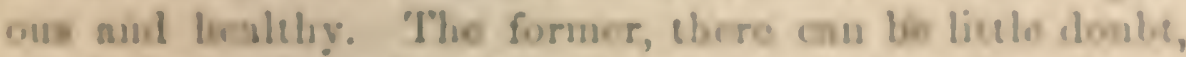

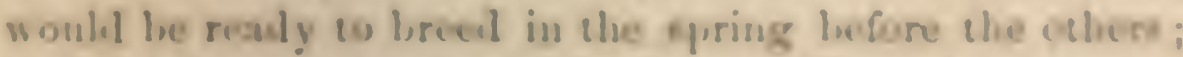
and this is the optuion of Mr. Jomer Wier, who has during wany sears cofefuftr attembel to the habies of liots. There an aloo be no doubt that the most riporous,

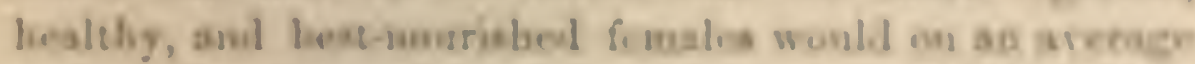
mocosd in rexring the largent smuler of offrpringe. The

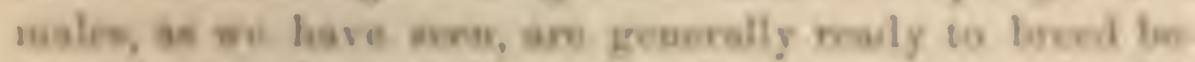
fore the fonales; of the malea the strongest, asd sish wase sperien then hest areusl, drive ansy din wesker males; and the formor would tlex nolte with die mone

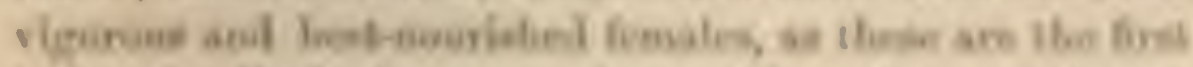
to broed. Hach voorous pairs would torely rax a lacger

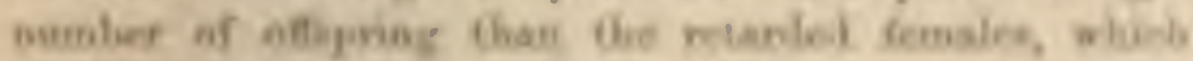

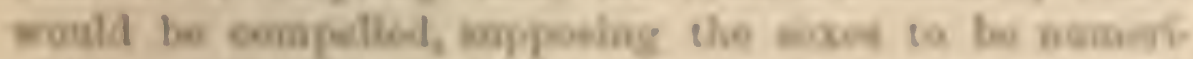

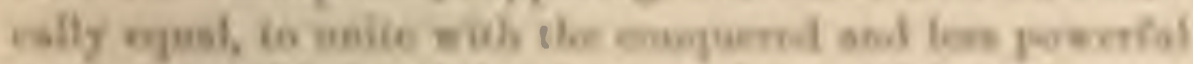

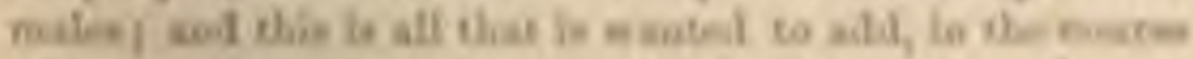

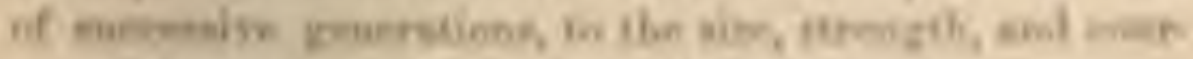

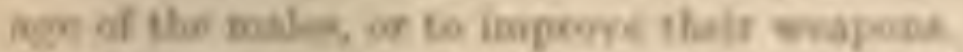

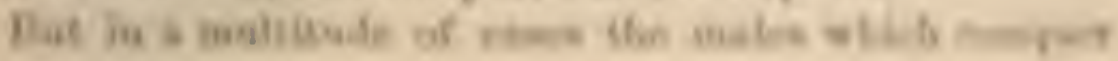


other males do not obtain possession of the females, independently of choice on the part of the latter. The courtship of animals is by no means so simple and short an aflair as might be thought. The females are most exeited by, or prefer pairing with, the more ornamented males, or those which are the best songsters, or platy the best anties; but it is obviously probable, as has been actually observed in some cases, that they would at the same time prefer the more vigorous and lively males." Thus the more vigorons females, which are the first to breed, will have the ehoice of many males; and though they may not always seleet the strongest or best armed, they will select those which are vigorous and well armed, and in other respeets the most attractive. Such early pairs would lave the same advantage in rearing offspring on the female side as above explained, and nearly the same advantage on the male side. And this apparently has sufficed during a long course of generations to add not only to the strength and fighting-powers of the males, but likewise to their various ornaments or other attractions.

In the converse and much rarer case of the males selecting particular females, it is plain that those which were the most vigorous and had eonquered others, would have the freest choice; and it is almost eertain that they would select rigorous as well as attractive females. Such pairs would have an advantage in rearing offspring, more especially if the male had the power to defend the female during the pairing-season, as occurs with some of the higher animals, or aided in providing for the young. The same principles would apply if both sexes mutually preferred and selected ecrtain individuals of the opposite sex;

- I have received information, hereafter to be given, to this effect with respect to poultry. Exen with birds, such as pigenne, which pair for life, the female, as I hear from Mr. Jenner Weir, will desert her mate if he is injured or grows wenk. 
supposing that they selected not ouly the more attractive, but likewise the more vigorous indiriduals.

Numerical I'roportion of the Tiro Sesiy.-I hro resuarteol that scxual selection wouhl be a simple athir if the males considerably exceeded in mumber the femules. Hence I was led to iuvestigatce, as fur as I could, the prop portigus between the two soxes of as many amimale as prosible; but the materials are scunty. I will bure give only a brief aburact of the resule, retaining the details for a eupplumentary diteussou, so as not to interfore with the coure of my argunent. Dumeticated subuals alowe alloril the opportunity of ascertaining the proportiosal sumberk at lirels; but so rocords have been vpecially he git fur this purpose. By indirec meass, howercr, I bave col. lectad a convile rable body of statinical dota, from which it appears that with mos of our domesic animale the

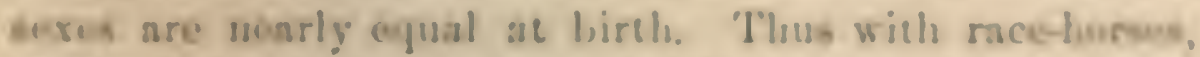

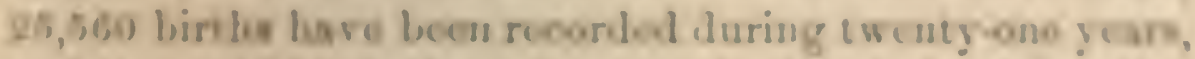

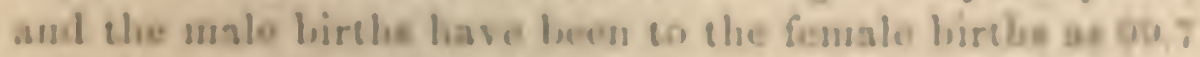
(o) 100 . With gregloonde the inogualitg is grouter thas with any acluer animal, for duriag irelse years, out of 6,A78 lirtls, the male birthe have bencu as 110,1 to 100

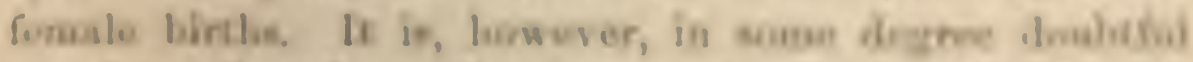
wbether it if eafe to infer that the ame propontionst nome.

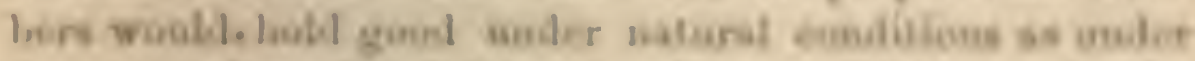

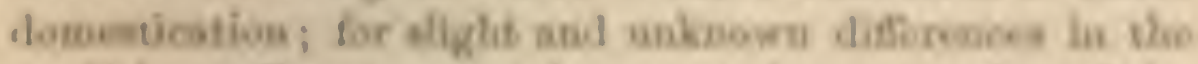

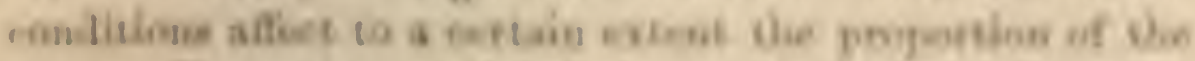

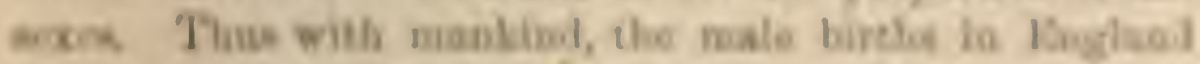

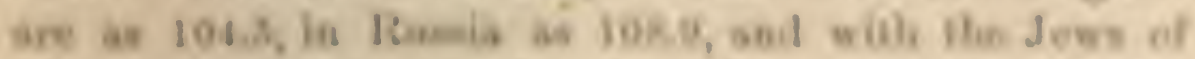

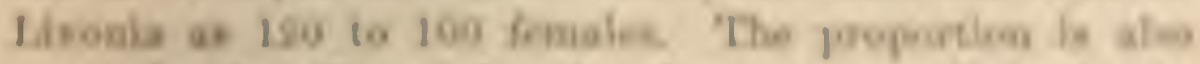

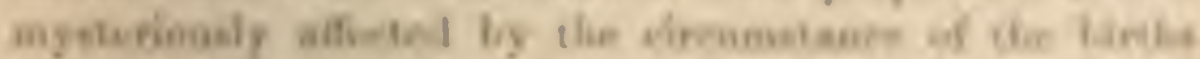

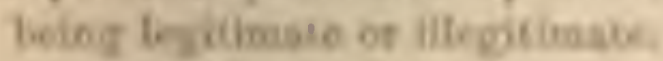

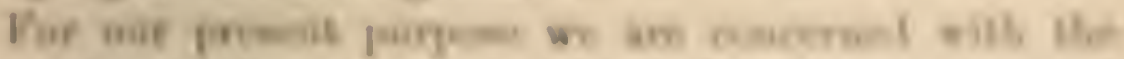

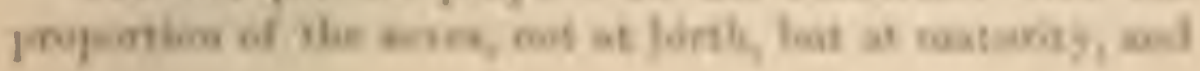


this adds another element of doubt; for it is a well-ascertained fact that with man a considerably linger proportion of males than of females die before or during birth, and during the first few years of infancy. So it almost certainly is with male lambs, and so it may be with the males of other animals. The males of some animals kill each other by fighting; or they drive each other about until they becone greatly emaciated. They must, also, while wandering about in eager search for the females, be often exposed to various dangers. With many kinds of fish the males are much sinaller than the females, and they are believed often to be devoured by the latter or by other fishes. With some birds the females appear to die in larger proportion than the males: they are also liable to be destroyed on their nests, or while in charge of their young. With insects the female larve are often larger than those of the males, and would consequently be more likely to be devoured: in some cases the mature females are less active and less rapid in their morements than the males, and would not be so well able to escape from danger. IIence, with animals in a state of nature, in order to judge of the proportions of the sexes at maturity, we must rely on mere estimation; and this, except perhaps when the inequality is strongly marked, is but little trustworthy. Nevertheless, as far as a judgment can be formed, we may conclude, from the facts griven in the supplement, that the males of some few mammals, of many birds, of some fish and insects, considerably exceed in number the females.

The proportion between the sexes fluctuates slightly during successive years: thus with race-horses, for every 100 females born, the males raried from 107.1 in one year to 92.6 in another year, and with greyhounds from 116.3 to 95.3. But had larger numbers been tabulated thronghout a more extensive area than England, these fluctuations would probably have disappeared; and such as they are, 
they wouhd hardly suflice to lesul under at stite of uatur. to the ceflective action of sersual belevetion. Nevertheles with some fow wild animals, the proporrions secun, as flown in the supplemest, to flusesuate rither during diflic-

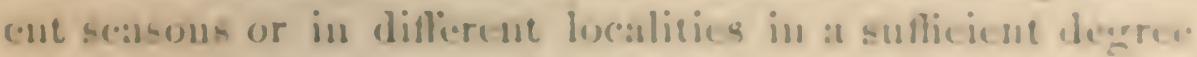
to lead to such action. For ic should be obeersed that any advantage gained during certaiu yeare or iu rerain localities by those males which were ahle to congluer otler males, or were the most attractire to the females, would

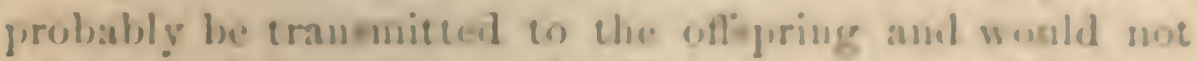
subsequenely be climinated. Duriug the wocecoling maeunt, when frum the cyuality of the seres every male was esergwlere able to procure a female, the etronger or mose actractive uales preriously producul would still lawe a loas as good a chance of liasing ofl-priug as the low beroug or leas ateractire.

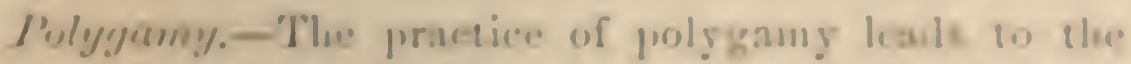
sane results as would follow from au aceubl inc glablity in the sumin $r$ of the seses; for if each mule secures two or more fomales, many males will not be able os pair; smel the later besurolly will le the water or lies assactive

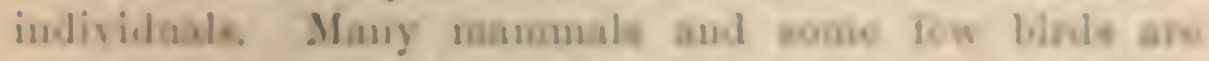

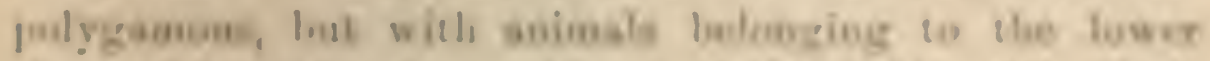

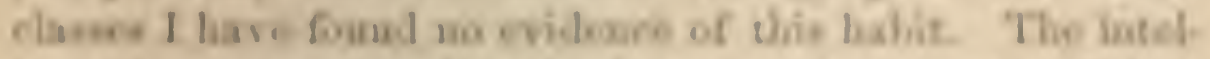

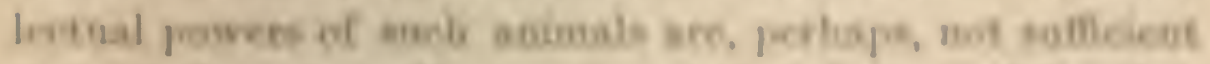

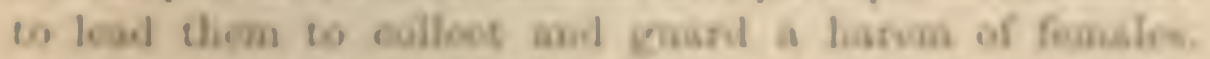

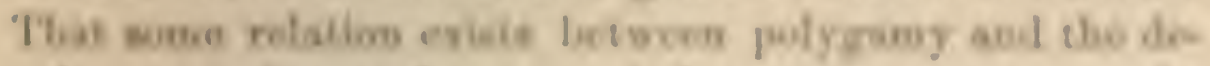

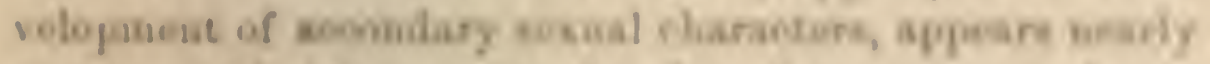
cetsin; and this eupporie the vley that a nuwerical por-

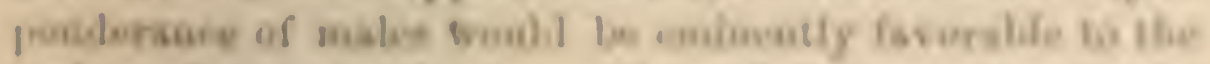

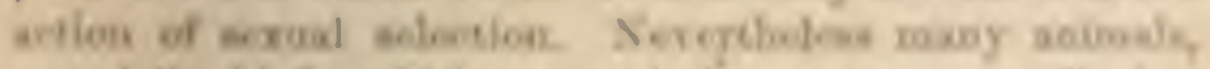

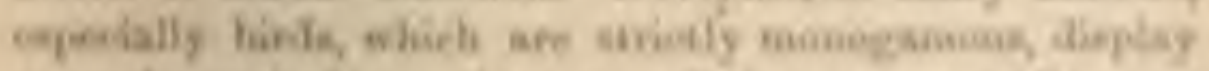

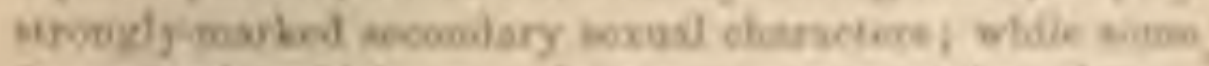

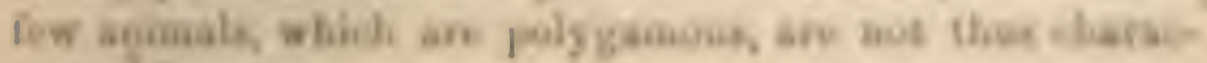
terisol? 
We will first briefly run through the class of mammals, and then turn to birds. The gorilla seems to be a polyganist, and the male difters considerably from the female; so it is with some baboons which live in herds containing twice as many adult females as males. In South Americ:: the Mrycetes curayg presents well-marked sexulal diflepences in color, beard, and rocal organs, and the male generally lives with two or three wires: the male of the Cebus capucinus difters somewhat from the fumale, and appears to be polygamous." Little is known on this head with respect to most other monkeys, but some species are strictly monogamons. The ruminants are eminently poly:samous, and they more frequently present sexual diflierences than almost any other group of mammals, cepecially in their weapons, but likewise in other characters. Most leer, cattle, and shecp, are polygamous; as are most antelopes, though some of the latter are monogamous. Sir Andrew sunith, in speaking of the antelopes of South Africa, says that in herds of about a dozen there was rarely more than one mature male. 'The Asiatic Antilope sceiga appears to be the most inordinate polygamist in the worhl f for Pallas states that the male drives away all rivals, and collects a herd of about a hundred, consisting of females and kids: the female is hornless and has softer hair, but does not otherwise differ much from the male. The horse is polygamous, but, except in his greater size and in the proportions of his.body, diflers but little from

s On the Gorilla, Savage and Wyman, 'Boston Journal of Sat. IIint.' vol. v. 184j-1817, p. 423. On Ornocephalus, Brehm, 'Illust. Thierleben,' 13. i. 1S61, 8. 76. On Mycetea, Rengger, 'Maturgesch. : Sungethiere von l'araguay,' 1830, s. 14, 20. On C'ebus, Brelim, ibid. s. 105.

- Pallas, 'Spicilegia Zoolog., Fasc. xii. 17i7, p. 29. Sir Aulrew Sinith, 'Illustrations of the Zoology of South Africa,' 1849, pl. 29, on the kiobus. Owen, in lis 'Anatony of Yertebrates' (vol. iii. 1868, p. 633), gives a talsle incilcutally showing which species of Antclopes pair and which are gregarious. 
the mare. The wilithour, iu lia great twakt and sume other characters, preasuts well-marhol nextad chanaciens; iu Europe and in India le leads a molicury life, ereegis dur. ing the bredingenason; best at this wown he consorts in Intia with several fenales, as Sir W. K:llioe, who lias had large experionee in observing this amimal, believew: whether this bolits govil in barope is deubuful, ha: is nup

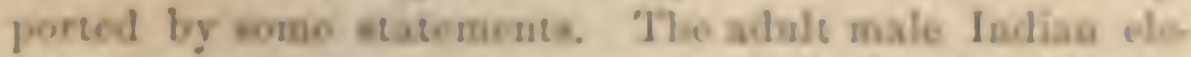

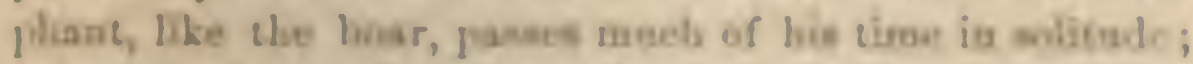
but whon asociatims with octien, "is is rare to find," as

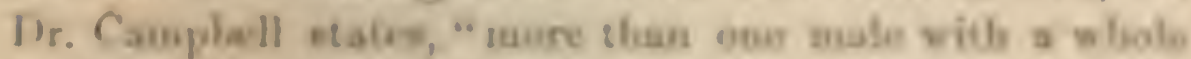

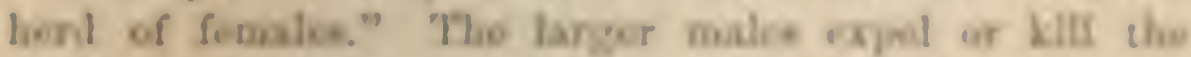
sualler abil weaker ous. The male diliss from toa to

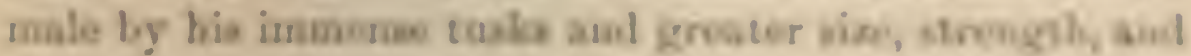

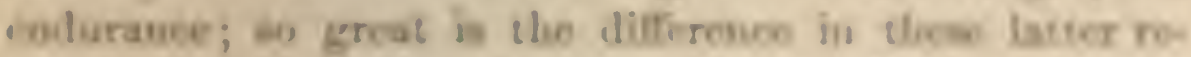

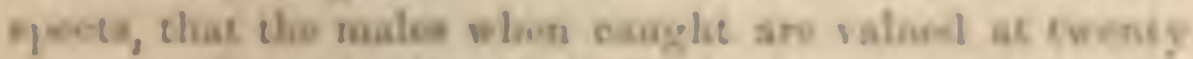

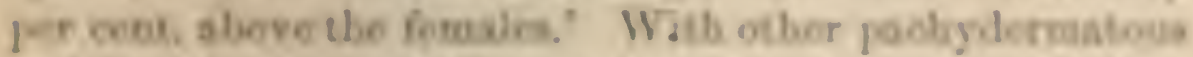

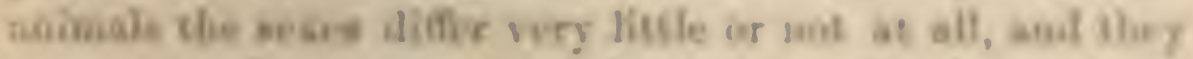

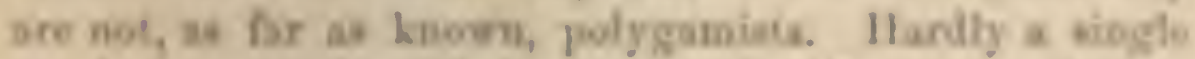

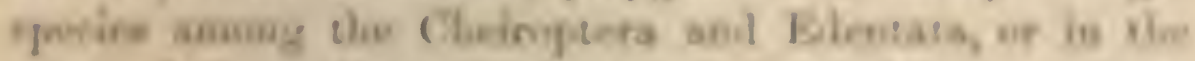
ervat Ordere of the liodents and Inbectinon, prosente

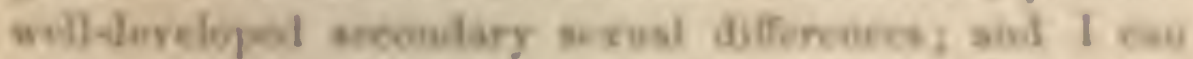

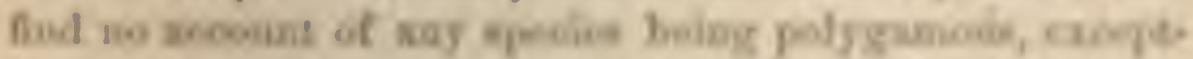

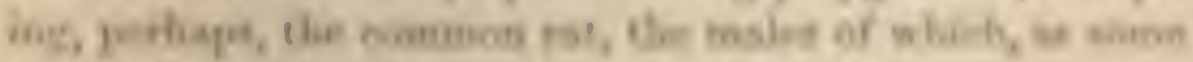
rateatobers afling, leve wh werirst fomalis.

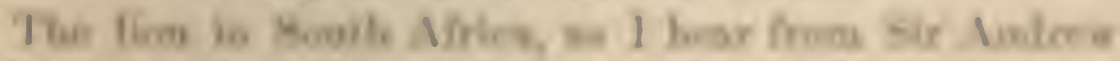

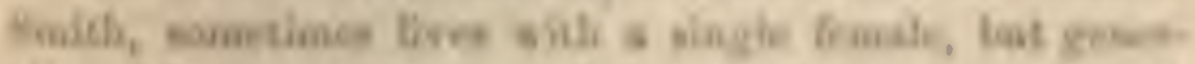

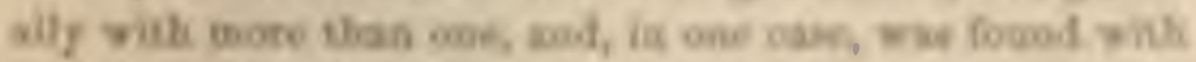

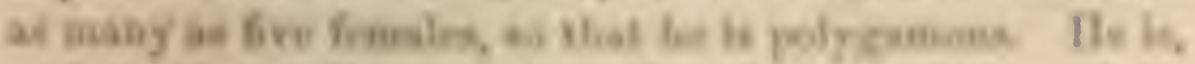

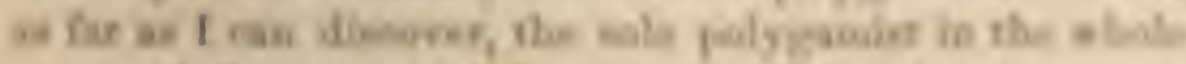

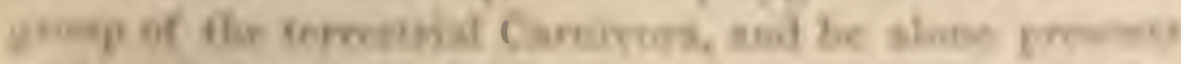

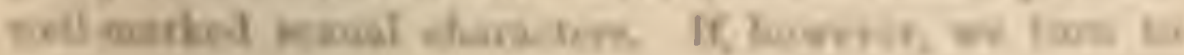

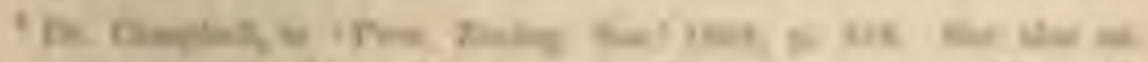

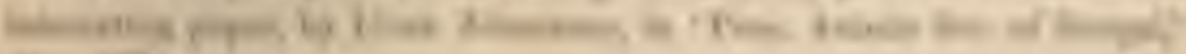
Kays $x$ at 
the marine. Carnivora, the case is widely different; for many species of seals offer, as we shall hereafter see, extraordinary sexual differences, and they are eminently polygamous. Thus the male sea-elephant of the Southern Ocean always possesses, according to Péron, several females, and the sea-lion of Forster is said to be surrounded by from twenty to thirty females. In the North, the male sea-bear of Steller is accompanied by even a greater number of females.

With respect to birds, many species, the sexes of which differ greatly from each other, are certainly monogamous. In Great Britain we see well-marked sexual differences in, for instance, the wild-duck, which pairs with a single female, with the common blackbird, and with the bullfinch, which is said to pair for life. So it is, as I am informed by Mr. Wallace, with the Chatterers or Cotingidre of South America, and numerous other birds. In several groups I have not been able to discover whether the species are polygamous or monogamous. Lesson says that birds of paradise, so remarkable for their sexual differences, are polygamous, but Mr. Wallace doubts whether he had sufficient evidence. Mr. Salvin informs me that he has been led to believe that humming-birds are polygamous. The male widow-bird, remarkable for his caudal plumes, certainly seems to be a polygamist. ${ }^{8}$ I have been assured, by Mr. Jenner Weir and by others, that three starlings not rarely frequent the same nest; but whether this is a case of polygamy or polyandry has not been ascertained.

The Gallinacere present almost as strongly-marked sexual differences as birds of paradise or humming-birds,

8 'The Ibis,' vol. iii. 1861, p. 133, on the Progne Widow-bird. See also on the Vidua axillaris, ibid. vol. ii. 1860, p. 211. On the polygamy of the Capercailzie and Great Bustard, see L. Lloyd, 'Game Birds of Sweden,' 1867, pp. 19, 128. Montagu and Selby speak of the Black Grouse as polygamous, and of the Red Grouse as monogamous. 
and many of the species are, as is well known, polygamous; others being strictly monogamous. What a contrast is presented between the sexes by the polygamous peacock or pheasant, and the monogamous guinea-fowl or partridge! Many similar cases could be given, as in the grouse-tribe, in which the males of the polygamous capercailzie and black-cock differ greatly from the females; while the sexes of the monogamous red grouse and ptarmigan differ very little. Among the Cursores, no great number of species offer strongly-marked sexual differences, except the bustards, and the great bustard (Otis tarda) is said to be polygamous. With the Grallatores, extremely few species differ sexually, but the ruff (Machetes pugnax) affords a strong exception, and this species is believed by Montagu to be a polygamist. Hence it appears that with birds there often exists a close relation between polygamy and the development of stronglymarked sexual differences. On asking Mr. Bartlett, at the Zoological Gardens, who has had such large experience with birds, whether the male tragopan (one of the Gallinacex) was polygamous, I was struck by his answering, "I do not know, but should think so from his splendid colors."

It deserves notice that the instinct of pairing with a single female is easily lost under domestication. The wild-duck is strictly monogamous, the domestic duck highly polygamous. The Rev. W. D. Fox informs me that with some half-tamed wild-ducks, kept on a large pond in his neighborhood, so many mallards were shot by the gamekeeper that only one was left for every seven or eight females; yet unusualiy large broods were reared. The guinea-fowl is strictly monogamous; but Mr. Fox finds that his birds succeed best when he keeps one cock to two or three hens. ${ }^{9}$ Canary-birds pair in a state of na-

9 The Rev. L. S. Dixon, however, speaks positively ('Ornamental 
ture, but the breeders in England successfully put one male to four or five females; nevertheless the first female, as Mr. Fox has been assured, is alone treated as the wife, she and her young ones being fed by him; the others are treated as concubines. I have noticed these cases, as it renders it in some degree probable that monogamous speciès, in a state of nature, might readily become either temporarily or permanently polygamous.

With respect to reptiles and fishes, too little is known of their habits to enable us to speak of their marriagearrangements. The stickle-back (Gasterosteus), however, is said to be a polygamist; ${ }^{10}$ and the male during the breeding-season differs conspicuously from the femalc.

To sum up on the means through which, as far as we can judge, sexual selection has led to the development of secondary sexual characters. It has been shown that the largest number of vigorous offspring will be reared from the pairing of the strongest and best-armed males, which have conquered other males, with the most vigorous and best-nourished females, which are the first to breed in the spring. Such females, if they select the more attractive, and at the same time vigorous, males, will rear a larger number of offspring than the retarded females, which must pair with the less vigorous and less attractive males. So it will be if the more vigorous males select the more attractive and at the same time healthy and vigorous females; and this will especially hold good if the male defends the female, and aids in providing food for the young. The advantage thus gained by the more vigorous pairs in rearing a larger number of offspring has apparently sufficed to render sexual selection efficient. But a large preponderance in number of the males over the females would

Poultry,' 1848, p. 76) about the eggs of the guinea-fowl being infertile when more than one female is kept with the same male.

${ }^{10}$ Nocl Humphress, 'River Gardens,' 1857. 
be still more efficient; whether the preponderance was only occasional and local, or permanent; whether it occurred at birth, or subsequently from the greater destruction of the females; or whether it indirectly followed from the practice of polygamy.

The Male generally more modified than the Female.Throughout the animal kingdom, when the sexes differ from each other in external appearance, it is the male which, with rare exceptions, has been chicfly modified; for the female still remains more like the young of her own species, and more like the other members of the same group. The cause of this seems to lie in the males of almost all animals having stronger passions than the females. Hence it is the males that fight together and sedulously display their charms before the females; and those which are victorious transmit their superiority to their male off'spring. Why the males do not transmit their characters to both sexes will hereafter be considered. That the males of all mammals eagerly pursue the females is notorions to every one. So it is with birds; but many male birds do not so much pursue the female, as display thcir plumage, perform strange antics, and pour forth their song, in her presence. With the few fish which have been observed, the male seems much more cager than the female; and so it is with alligators, and apparently with Batrachians. 'Throughout the enormous cliss of insects, as Kirhy remarks," "the law is, that the male shall seck the female." With spiders and crustaceans, as I hear from two great atuthorities, Mr. Blackwall and Mr. C. Spence Bate, the males are more active and more crmatic in their hahits than the fomales. With inseots and arnstacenins, when the organs of sense or locomotion are press

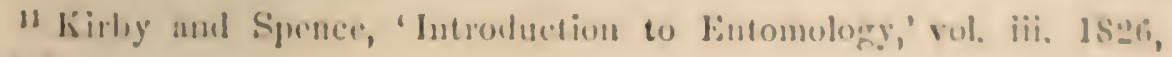
p. 312. 
ent in the one sex and absent in the other, or when, as is frequently the case, they are more highly developed in the one than the other, it is almost invariably the male, as far as I can discover, which retains such organs, or has them most devoloped; and this shows that the male is the more active member in the courtship of the sexes. ${ }^{12}$

The female, on the other hand, with the rarest exception, is less eager than the male. As the illustrious Hunter ${ }^{13}$ long ago observed, she generally "requires to be courted;" she is coy, and may often be seen endeavoring for a long time to escape from the male. Every one who has attended to the habits of animals will be able to call to mind instances of this kind. Judging from various facts, hereafter to be given, and from the results which may fairly be attributed to sexual selection, the female, though comparatively passive, generally exerts some choice and accepts one male in preference to others. Or she may accept, as appearances would sometimes lead us to believe, not the male which is the most attractive to her, but the one which is the least distasteful. The exertion of some choice on the part of the female seems almost as general a law as the eagerness of the male.

We are naturally led to inquire why the male in so many and such widely-distinct classes has been rendered more eager than the female, so that he searcties for her and plays the more active part in courtship. It would be

12 One parasitic Hymenopterous insect (Westwood, 'Modern Class. of Insects,' vol. ii. p. 160) forms an exception to the rule, as the male has rudimentary wings, and never quits the ecll in which it is borm, while the female has well-developed wings. Audouin believes that the females are impregnated by the males which are born in the same cells with them; but it is much more probable that the females visit other cells, and thus avoid close interbreeding. We shall hereafter meet with a few exeeptional cases, in various classes, in which the female, instead of the male, is the secker and woocr.

13' 'Essays and Observations,' edited by Owen, vol. i. 1861, p. 194. 
no advantage and some loss of power if both scres were mutually to search for each other; but why should the inale almost always be the secker? With plants, the ovules after fertilization have to be nourished for a time; hence the pollen is necessarily brought to the female orgrans-being placed on the stigma, through the agency of insects or of the wind, or by the spontaneous movements of the stamens; and with the Algx, etc., by the locomotive power of the antherozooids. With lowly-organized animals permanently affixed to the same spot and haviug their sexes separate, the male element is invariably brought to the female; and we can sce the reason; for the ora, even if detached before being fertilized and not requiring subsequent nourishment or protection, would be, from their larger relative size, less easily transported than the male element. Hence plants ${ }^{14}$ and many of the lower animals are, in this respect, analogous. In the case of animals not affixed to the same spot, but enclosed within a shell with $n$ power of protruding any part of their boties, and in the case of animals having little power of locomotion, the males must trust the fertilizing element to the risk of at least a short transit through the waters of the sea. It would, therefore, be a great alvantage to such aubuals, as their organization becane pere fected, if the males when realy to cutt tho furtilizing ole. ment, were to acquire the habit of approathing the female as closely as possible. 'The males of various howly-organimed animals having thus ahoriginally arepuited the habit of approatsing and secking the fomstes, the same hahie wonld natually be transmitted to their more highlyehevoloped male descendants; and in order that they should

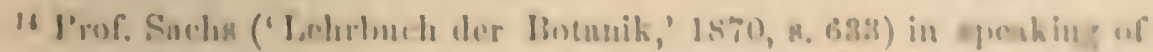

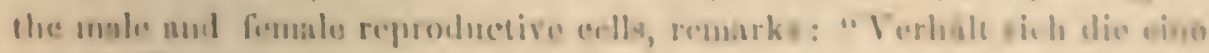

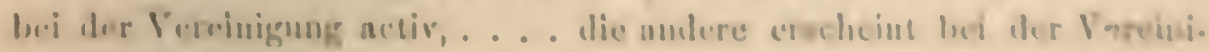

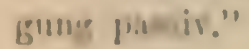


become effieient seekers, they would have to be endowed with strong passious. The acquirement of such passions would naturally follow from the more eager males leaving a larger number of offispring than the less eager.

The great eagerness of the male has thus indirectly led to the much more frequent development of secondary sexual clanacters in the male than in the female. But the development of such characters will have been much aided, if the conclusion at which I arrived, after studying domesticated animals, can be trusted, namely, that the male is more liable to vary than the female. I am aware how difficult it is to verify a conclusion of this kind. Some slight evidence, however, can be gained by comparing the two sexes in mankind, as mau has been more carefully observed than auy other animal. During the Novara Expedition ${ }^{15}$ a vast number of measurements of rarious parts of the body in different races were made, and the men were found in almost every case to present a greater range of variation than the women; but I shall have to recur to this subject in a future chapter. Mr. J. Wrood, ${ }^{16}$ who has carefully attended to the variation of the muscles in man, puts in italies the conclusion that "the wreatest number of abnormalities in each subject is found in the males." IIe had previously remarked that "altogether in 102 subjects the varieties of redundancy were found to be half as many again as in females, contrasting widely with the greater frequency of deficiency in females hefore described." Prof. Macalister likewise remarks ${ }^{17}$

15 'Reise der Norara: Anthropolog. Theil,' 1867, \&. 216-269. The results were calculated by Dr. Weisbach from measurements made by Irs. K. Sclierzer and Scliwarz. On the greater variability of the males of domesticated animals, sce my 'Variation of Animals and l'lants under Iomestication,' rol. ii. 1868, p. T5.

16 'I'roceedingrs loọal Soc.' rol. xri. July, 1868, pp. 51?, 524.

is 'I'roc. Loyal Irish Acadcmy'; rol. x. 1868, p. 123. 
that variations in the muscles "are probably more common in males than feunle.". Certain unscles which are not normally present in mamkind are also more frequenty developed in the male than in the female ser, ahlowerl (xceptions to this rule are said to occur. Dr. Burt Wild. er" has tabulated the caces of 152 individuals with supermumerary digits, of which sij were males, aud 39, or less than half, fomales; the remainiug 27 being of unkuown sex. It should not, hiswerer, in overlooked that wossen would more froquently culearor to conceal a deformisy of this himd than men. Whether the large proportional utumber of deaths of the male offeprisg of man and aplar. ently of elseep', comparal with the fumble oflispring, be

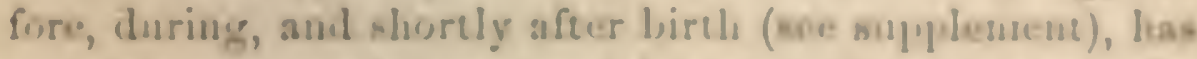
suy relation to as senger temelecy in the organs of the male (1) bary and thus to beeome aluormal iu serueture or function, I will not pretend to conjeceure.

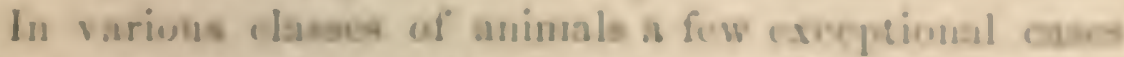
ocenr, in whiols tho fontale inetead of the tusle lises ac-

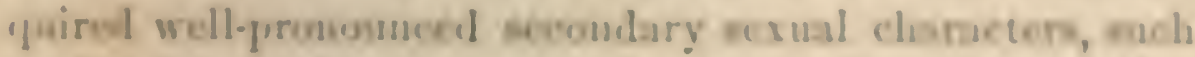

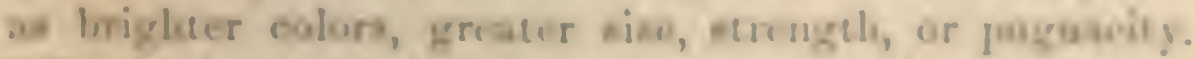

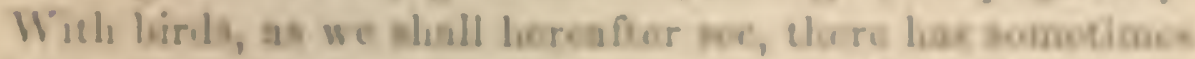

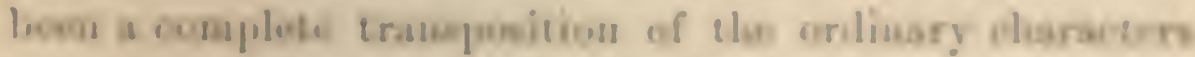

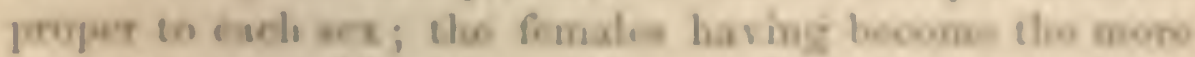

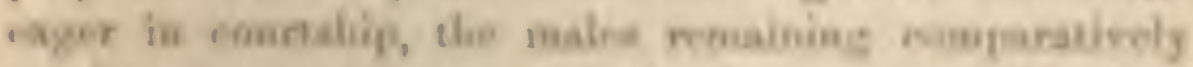
pasive. lat apparontly aloeting, as wo may isfor from

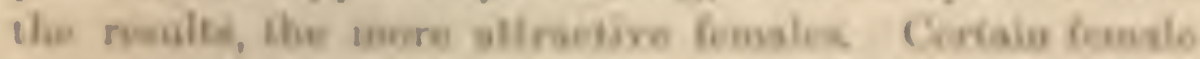
birde lowe drus lewe remtercel more lighly colered or

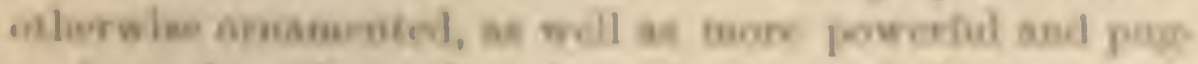

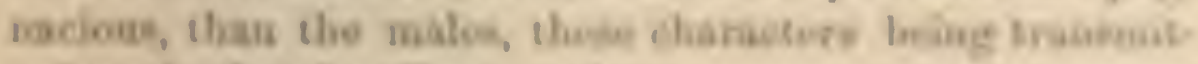

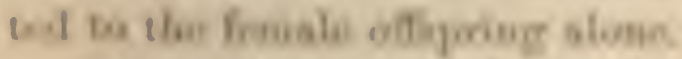

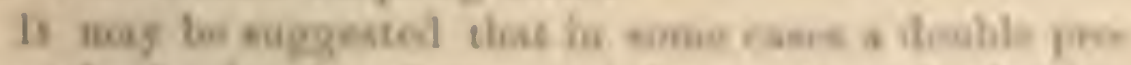

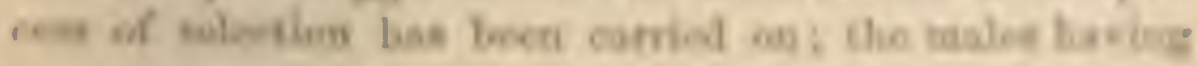


sclected the more attractive females, and the latter the more attractive males. 'This process, however, though it might lead to the modification of both sexes, would not make the one sex different from the other, unless indeed their taste for the beantiful differed; but this is a supposition too improbable in the case of any animal, excepting man, to be worth eonsidering. There are, however, many animals, in which the sexes resemble each other, both being furnished with the same ornaments, which analogy rould lead us to attribute to the ageney of sexual sclection. In such cases it may be suggested with more plausibility, that there has been a double or mutual proeess of sexual sclection; the more vigorous and precocious females having selected the more attractive and vigorous males, the latter having rejected all exeept the more attractive females. But, from what we know of the habits of animals, this riew is hardly probable, the male being gencrally eager to pair with any female. It is more probable that the ormaments common to both sexes were acquired by ore sex, generally the male, and then transmitted to the oflspring of both sexes. If, indeed, during a lengthened period the males of any species were greatly to exceed the females in number, and then during another lengthened period under diflerent conditions the reverso were to occur, a double, but not simultaneons, process of sexual selection might casily be carricd on, by which the two sexes miglt be rendered widely different.

We shall hereafter see that many amimals exist, of which neither sex is brilliantly colored or provided with special ormanents, and yet the members of both sexes or of one alone have probably been modified throngh sexual selection. The absence of bright tints or other ornaments may be the result of variations of the right kind never having oceurred, or of the animals themselves preferring simple colors, such as plain black or white. Obseure 
colurs hise often boen acpuirch through natural eclection for the sake of protection, and tbe sorquiresucut throngh serual selection of compicuous colors, may hase beon rleceked from the danger tlus ineurred. But in otlier casen the males lave probably struggled iogether disring long ages, through lirute force, or by the dieplay of their clarms, or by both meaus combised, and yee no effece will linve bern produed unlese a larger number of af: Fpriug were loft ly the moresureceful males to iulerit the ir superiority, thas lig the lese socconfol males; and

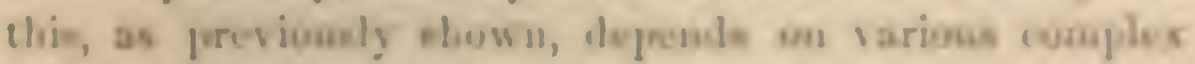
consingencirs.

Sesial melectins aces in a less rigormas smaner than naturil seloction. The later produces its effoote by dhe life or death at all agres of the mure or less swowsofut

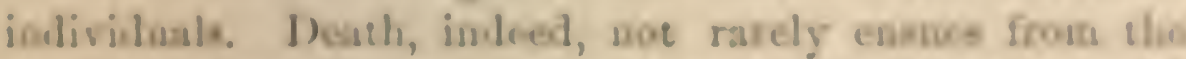
confliets of rival males. Bue proverally the lese sisometul male merily fails to ohtain a fomale, or obtains later in the reason a retarded and les rigorous femsle, or, if yeulygamone, olvains fewer fomales; so that they leave fewer,

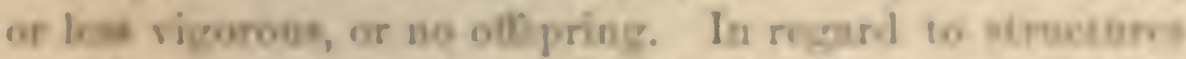

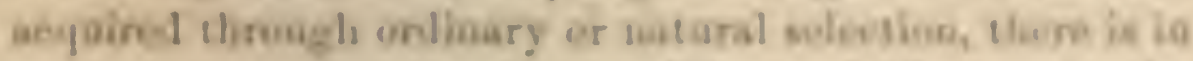

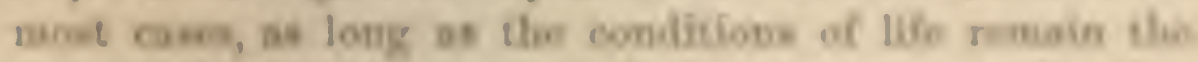

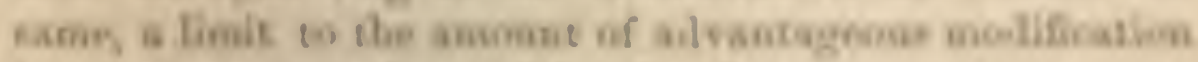

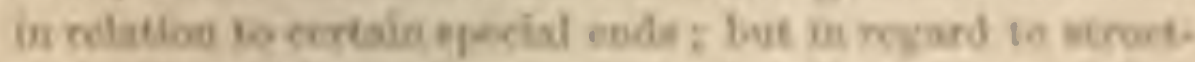

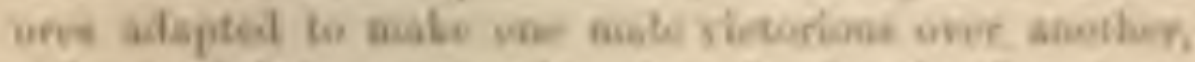

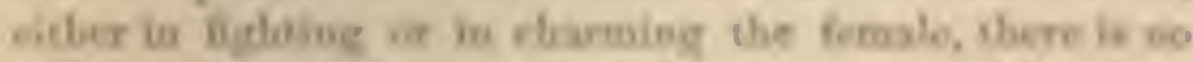

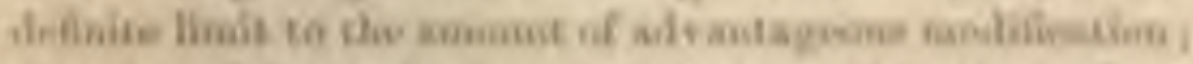
to that $\mathrm{Ne}$ foog as the jeoger varlatiane srike tbe work of

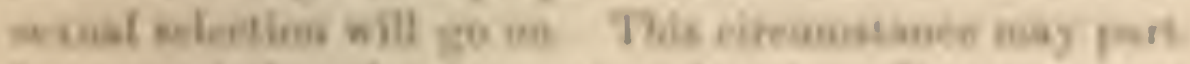

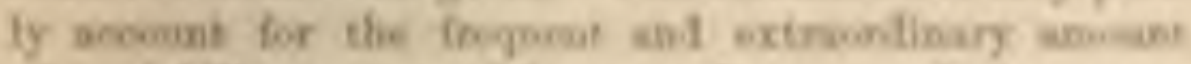

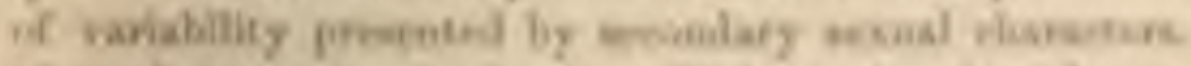

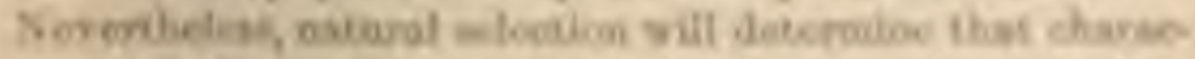

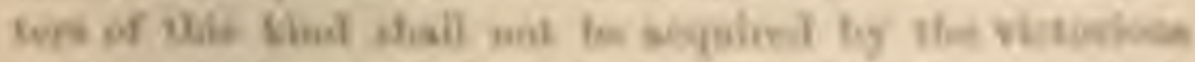

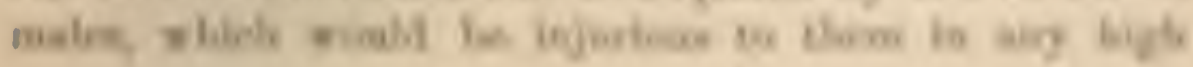


degree, eitler ly expending too nuch of their vital powers, or by exposing them to any great danger. The derelopment, howerer, of certain structures-of the horns, for instance, in certain stags-has been carried to a wonderful extreme; and in some instances to an extreme which, as fin as the general conditions of life are concermed, must be slightly injurious to the male. From this fict we learn that the advantages which favored males have derived from conquering other males in battle or courtship, and thus leaving a mumerous progeny, have been in the long-run greater than those derived from rather more perfect adaptation to the external conditions of life. We shall further see, and this conld never have been anticipated, that the power to clrarm the female lias beew in sone few instances more important than the power to conquer other males in battle.

\section{LAWS OF INHERITANCE.}

In order to understand liow sexual selection has acted, and in the course of ages has produced conspicuous results with many animals of many classes, it is necessary to bear in mind the laws of inheritance, as far as they aro known. Two distinct clements are included under the term "inheritance," nancly, the transmission and the development of characters; but as these generally go together, the distinction is often overlooked. We see this distiuction in those characters which are transmitted through the early years of life, but are developed only at maturity or during old age. We sce the same distinction more clearly with secondary sexual characters, for these ane transmitted through both sexes, though developed in one alone. That they are present in both sexes, is manifest when two species, having strongly-marked scxual characters, are crosed, for each transmits the chinacters 
propur to itsown male aud females tox to the bylirid uff epring of both sexcs. The saine foet is lihewise mantfos?, wben charaeters yroper to the uale aro nevanimalty de relopen in the female whes she grows oll or become diseanel; aul so conversely with the male. Acain, chor. uctern ocobionally apyear, as if trasufe rred from the male (n) the fesuale, as when, in certain lirods of the fow l, sure regularly afyear iu the yotuge and lesilly fonales; line is eruel they aro kimply develoged in the fosole; for in ciery broed cach dezail in the stracture of the num is inaumitced tbrough sle fomale to her male oftepring. Is all samet of revenim, ismeters are taumbind slimugh

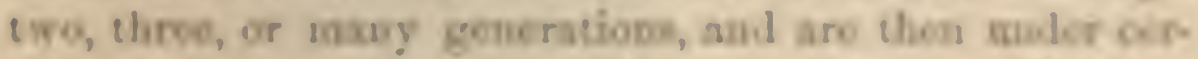

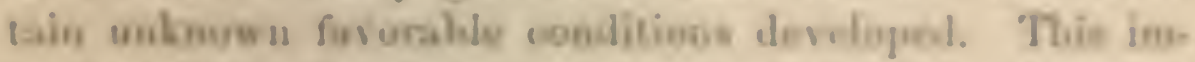
portont dlatiuction between tramsni-sioh and dovelopment

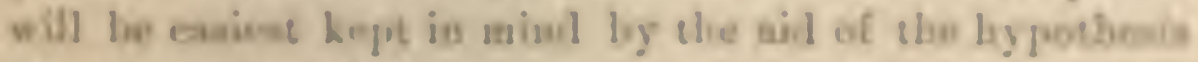
of pasgonesis, whother or not it be accepted as irne. A.

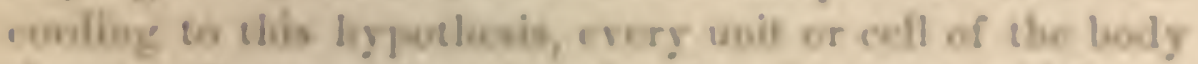
elirows of gomanales or andevelngesl atome, whirh are

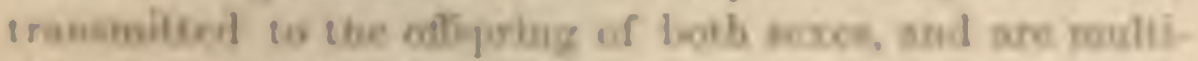

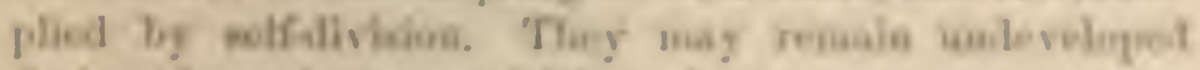

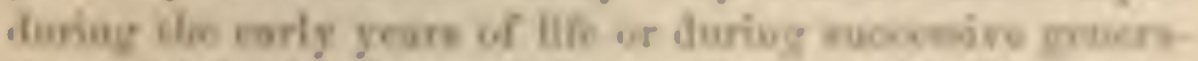

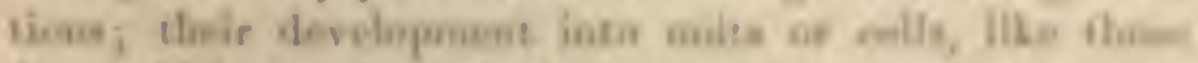

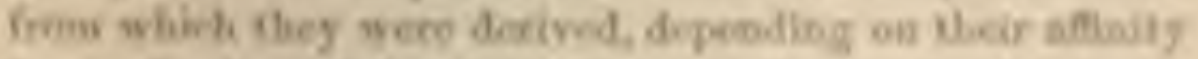

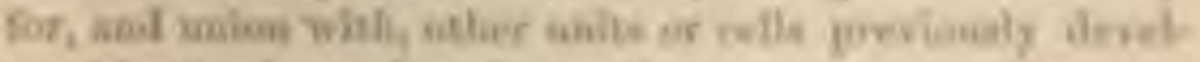

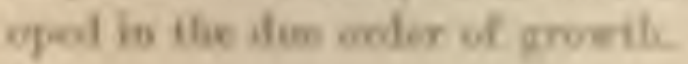

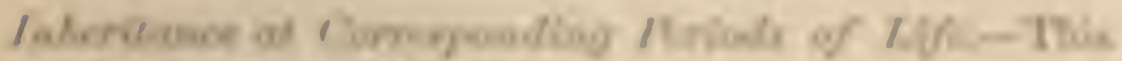

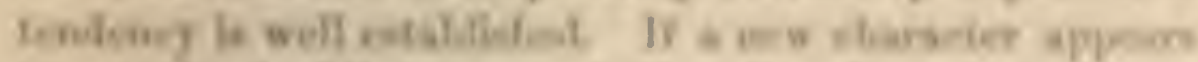

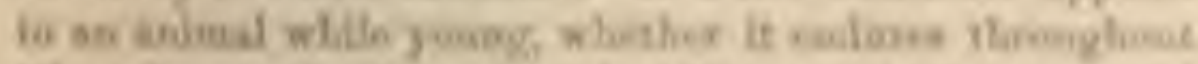

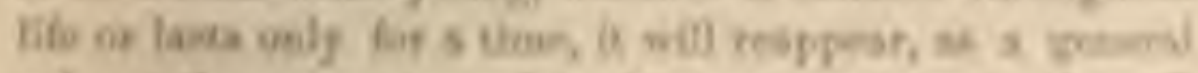

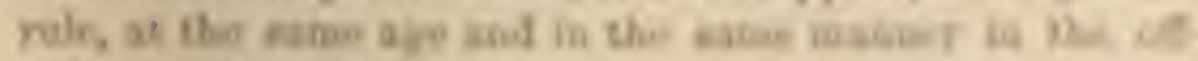

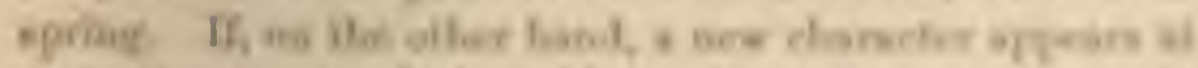

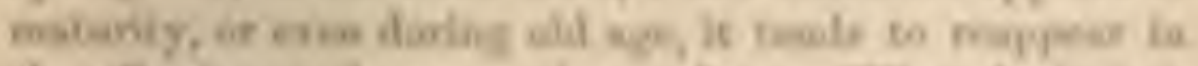

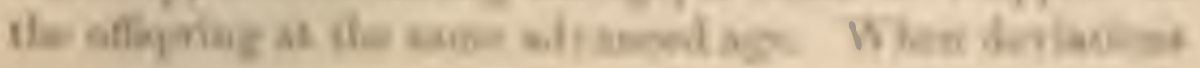


from this rule occur, the transmitted characters much oftener appear before than after the corresponding age. As I have discussed this subject at sufficient length in another work, ${ }^{10}$ I will here merely give two or three instances, for the sake of recalling the subject to the reader's mind. In several breeds of the Fowl, the chickens while coverer with down, in their first true plumage, and in their adult plumage, differ greatly from each other, as well as from their common parent-form, the Gallus bankiva; and these characters are faithfully transmitted by each breed to their offspring at the corresponding period of life. For instance, the chickens of spangled Hamburgs, while covered with down, have a few dark spots on the head and rump, but are not longitudinally striped, as in many other breeds; in their first true plumage, "they are beautifully pencilled." that is, each feather is transversely marked by numerous dark bars; but in their second plumage the feathers all become spangled or tipped with a dark round spot. ${ }^{20}$ Hence in this breed variations have occurred and have been transmitted at three distinct periods of life. The ligeon offers a more remarkable case, because the aboriginal parent-species does not undergo with advancing age any change of plumage, excepting that at maturity the breast becomes more iridescent; yet there are breeds which do not acquire their characteristic colors until they have moulted two, three, or four times; and these modifications of plumage are regularly transmitted.

12 'The Variation of Animals and Plants under Domestication,' vol. ii. 1868, p. 75. In the last chapter but one, the provisional hypothesis of prangenesis, above alluded to, is fully explained.

20 These facts are giren on the high authority of a great breeder, Mr. Tecbay, in Tegetmeicr's 'Poultry Book,' 1868, p. 158. On the characters of chickens of different breeds, and on the breeds of the pigeon, alluded to in the abore paragraph, sec 'Variation of Animals,' etc. rol. i. pp. 160 , 249 ; rol ii. 1. 77. 


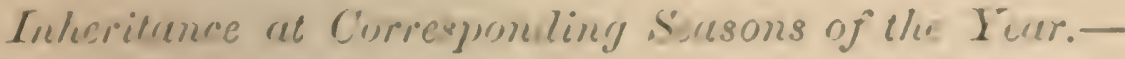
With animals in at state of mature innumerable instances oceur of characters periodically appearing at diflerent scasons. We see this with the lroms of the starg, and with the fur of arctic animals which becomes thick and whice during the winter. Numerous birds acquire bright colors and other diecorations during the brechling-season aloue. I catu throw but litte liglit on this form of inheritance from fote obecrved uncler dumestication. l'allas states "1 that, in Siberia, donestic cattle and horses periodically become lighter-colored during the winter; and I hase observed a similar markrel chamere of color in certain ponies in linglamel. Alehomen I do not know that this tendenoy to an sume a differenty-eolored coat during different seasous of the ycall is transmitted, yet it probably is so, as all shames of color are strongly inherited by the horse. Nor is this furm of inlseritance, as limited by season, more remarhable than inhrepitance as limited l,y age or sex.

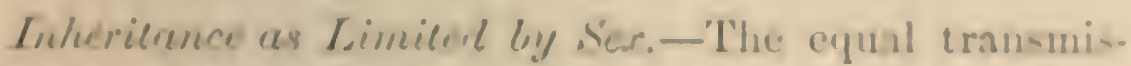
hion of chanacters to hoth seres is the commonest form of inheritance, at least with those animals which do not prenesul atrongly-marheal senwal dillierences, and inderel with uhuy of these. But characers are not rarily transermel esclusisely to that sur, in which they firet appearod. Ample evidenee on this head has heen advanod in $13 y$ work on Varintion muler Dometikation; bat a few in-

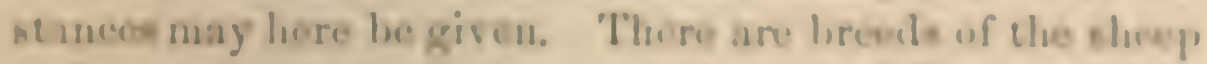
and grme, in which thes lourus of the male dilier groully in shise from those of the femule; but theso diflimeoses, an

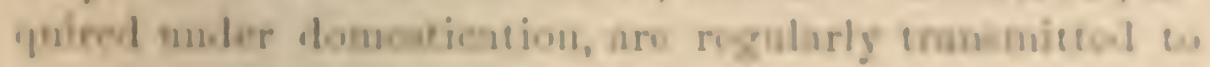

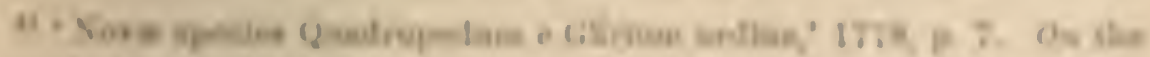

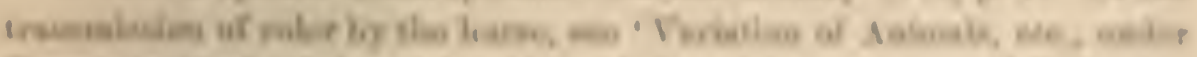

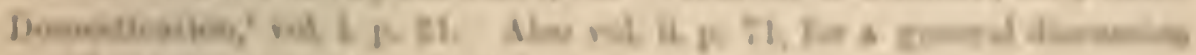

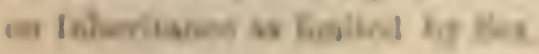


the same sex. With tortoise-shell cats the females alone, as a general rule, are thus colored, the males being rustyrecl. With most breeds of the fowl, the characters proper to each sex are transmitted to the same sex alone. So gencral is this form of transmission that it is an anomaly when we see in certain breeds variations transmitted equally to both sexes. There are also certain sub-breeds of the fowl in which the males can hardly be distinguished from each other, while the females differ considerably in color. With the pigeon the sexes of the parent-species do not differ in any external character; nevertheless in certain domesticated breeds the male is differently colored from the female. ${ }^{23}$ The wattle in the English Carrier-pigeon and the crop in the Pouter are more highly developed in the male than in the female; and although these characters have been gained through long-continued selection by man, the difference between the two sexes is wholly due to the form of inheritance which has prevailed; for it has arisen, not from, but rather in opposition to, the wishes of the breeder.

Most of our domestic races have been formed by the accumulation of many slight variations; and as some of the successive steps have been transmitted to one sex alone, and some to both sexes, we find in the different breeds of the same species all gradations between great sexual dissimilarity and complete similarity. Instances liave already been given with the breeds of the fowl and pigeon; and under Nature analogous cases are of frequent occurrence. With animals under domestication, but whether under Nature I will not venture to say, one sex may lose characters proper to it, and may thus come to resemble to a certain extent the opposite sex; for instance, the males of some breeds of the fowl have lost

${ }^{22}$ Dr. Chapuis, 'Le Pigeon Voyageur Belge,' 1865, p. 87. Boitard et Corbic, 'Les Pigeons de Volic̀re,' etc., 1S24, p. 173. 
their masculine plumes and hackles. On the other hand, the differences between the sexes may be increased under domestication, as with merino shecp, in which the ewe's have lost their horns. Again, characters proper to one sex nay suddenly appear in the other sex; as with those sub-breeds of the fowl in which the hens while young acquire spurs; or, as in certain Polish sul--breeds, in which the females, as there is reason to belicre, originally acquired a crest, and subsequently transferred it to the males. All these eases are intelligille on the hypothesis of pangenesis; for they depend on the gemmules of ecrtain units of the body, although present in both sexes, becoming through the influence of donestication domant in the one sex; or, if naturally dormant, becoming dereloped.

There is one difficult question which it will be consenicut to defer to a future chapter; nanely, whether a chasracter, at first developed in both sexes, ean be rendered through selection linited in its derelopment to one sex alune. If for instance, a breeder observed that some of his pigeons (in which species characters are usually transfirred in an equal degree to both sexes) ranied into pale hlue; could he by long-continued selection make a breet, in which the males alone slonuld be of this tint while the females remained unchanged? I will here only saly that this, though perhap's not imposilile, would be extrencly diflicult; for the natural result of breding from the palel, hue males wonld be to change his whole stock, inchuding loth sexes, into this tint. If, loweser, varintions of the desired tiut appeared, which wore from tho tirst liminel in their development to the male sex, the re would not he the least difliculty in making a breal characterized hy the

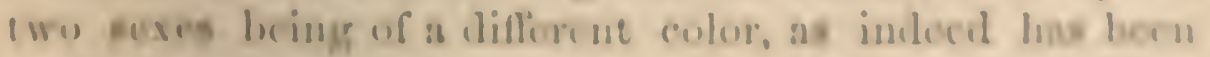

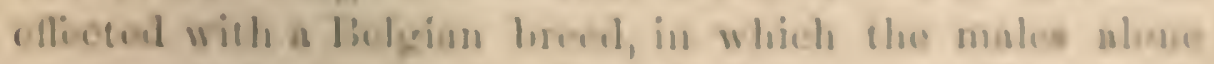

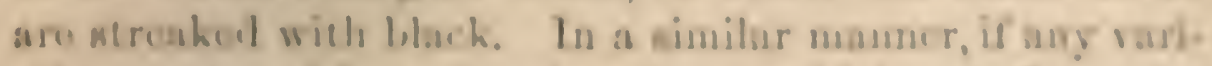

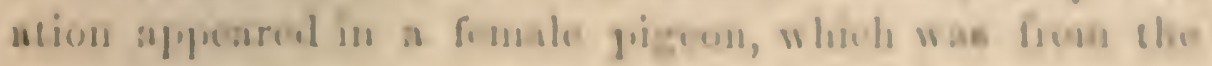


first sexually limited in its development, it would be easy to make a breed with the females alone thus characterized; but if the variation was not thus originally limited, the process would be extremely difficult, perhaps impossible.

On the Relation between the period of Development of a Character and its transmission to one sex or to both sexes. - Why certain characters should be inherited by both sexes, and other characters by one sex alone, namely, by that sex in which the character first appeared, is in most cases quite unknown. We cannot even conjecture why with eertain sub-breeds of the pigeon, black strix, though transmitted through the female, should be developed in the male alone, while every other character is equally transferred to both sexes. Why, again, with cats, the tortoise-shell color should, with rare exceptions, be developed in the female alone. The very same characters, such as deficient or supernumerary digits, color-blindness, etc., may with mankind be inherited by the males alone of one family, and in another family by the females alone, though in both cases transmitted through the opposite as well as the same sex. ${ }^{23}$ Although we are thus ignorant, two rules often hold good, namely, that variatious which first appear in either sex at a late period of life, tend to be developed in the same sex alone; while variations which first appear early in life in either sex tend to be developed in both sexes. I am, however, far from supposing that this is the sole determining cause. $\Lambda$ s I have not elsewhere discussed this subject, and as it has an important bearing on sexual selection, I must here enter into lengthy and somewhat intricate details.

It is in itself probable that any character appearing at

23 References are given in my" 'Variation of Animals under Domsstication,' vol. ii. 1). 72. 
an carly age would tend to be inlerited equally by both sexes, for the sexes do not difler much in constitution, before the power of reproduction is gained. On the other hand, after this power has been gained and the sexes liave come to differ in constitution, the gemmules (if I mis agrain use the language of paugenesis) which are cast oft from each varying part in the one sex would be much more likely to possess the proper attinities for uniting with the tissucs of the same sex, and thus becoming dereloped, than with those of the opposite sex.

I was first led to infer that a reiation of this hind exists, from the fact that whenever and in whatever mamer the adult male has come to difler from the adult female, lic diflirs in the same manner from the youmg of beth sexes. The generality of this fuct is quite remarkable: it holds gool with almost all mammals, biris, amphibiane, aud fishes; also with many crustaceans, spilers, and some frw iuscets, namcly, certain orthoptern and libellulae. In all these cases the variations, throngh the accumulation of which the male acquired his proper masenline characters, must have oceurreal at a somewliat late perion of life; otherwise the yomng males wombl have heen similarly -haracterized; amel conformably with our rule, they are transmited (n) and dewhloped in the alule males alome. When, on tlue other hamel, the mhle male clesely resem.

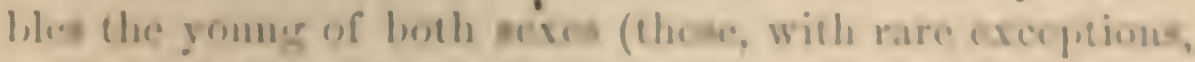

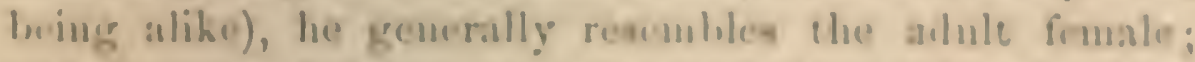
and in most of thase cases the rarintions through wheh

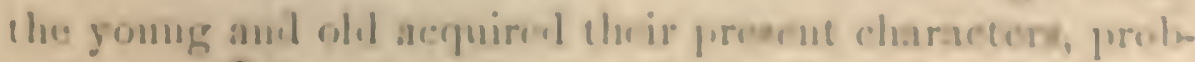
aloly ocourrid in conformits wiels our rulv during smath. line chere is lowe room for dembe, as ehancturs are some

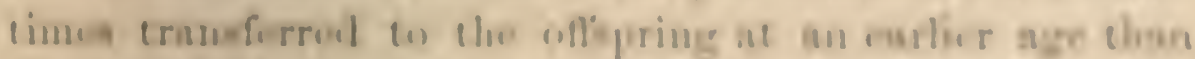
that at which thes lint appourod in the paresta, so that

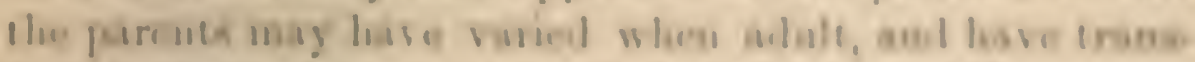
f.rred tbeir deancters to their oflipolag whilo yameg. 
There are, moreorer, many anmals, in which the two sexes doscly resemble each other, and yet both difter from their young; and here the charnoters of the adults must have been acquired late in life; nevertheless, these cliaracters in apparent contradiction to our rule, are transferred to both sexes. We must not, howerer, overlook the possibility or even probability of suecessive variations of the sane nature somctimes occurring, under exposure to similar conditions, simultaucously in both sexes at a rather late period of life; and in this case the rariations would be transferred to the oflipring of both sexes at a corresponding late age; and there would be no real contradiction to our rule of the variations which occur linte in life being trimsferred exclusircly to the sex in which they first appeared. This latter mle scems to hold true more generally than the second rule, namely, that variations which occur in either sex early in life tend to be transferred to both sexes. As it was obviously impossible even to estimate in how large a number of cases throughout the animal kingdom these two propositions hold good, it occurred to me to investigate some striking or crncial instances, and to rely on the result.

An excellent case for investigation is afforded by the Deer Fauily. In all the species, excepting one, the horus are developed in the male alone, though certainly transmitted through the female, and capable of occasional abnormal development in her. In the reindeer, on the other hand, the female is provided with horns; so that in this species, the horns ought, accordiug to our rule, to appear early in life, long before the two sexes hat arrived at maturity aud had come to differ much in constitution. In all the other species of deer the horns ought to appear later in life, leading to their development in that sex alone, in which they first appeared in the progenitor of the whole family. Now, in seren species, belonging to 


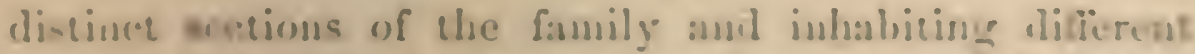
regions, in which the stags alone bear horus, I tiud that the horns first appear at periols varying from nime mouths after birth in the rocbuck to th or twelve more montbs is the stags of the six other larger species." But with the reindece the case is widely diflierut, fur as I hear from P'rof. Nibsou, who kinlly male speciul inquiries fur me in Iaphan, the horns appear in the roumg animals within four ur fire werks after birth, and at the kanse line in both sexes. So that here se have a strocture, des lopo-1 at a most unusually early age in one species of thes fumily, and common to buth wexes in this once species.

la several hishe of autelopes the undes aloue are pro bided wilh horm, while in the greater unubor lwots eose

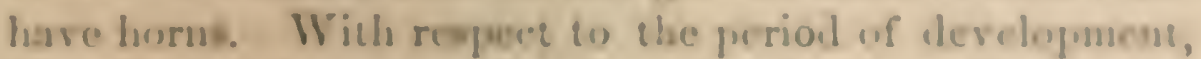
Mr. Lilgels informs me that there lisal nt obe time in the \%oolengiral (iardeut a young hoodon (An!. strgainoroa). in whieh species the males aluse are horsed, aud sbe young of a closelyallicd ppocirs, riz, the cland (AnL. urome), in which both hoces are hormed. Now in strice coiformity with our rule, in the poung male hoodoo, altheugh arriced at the age of to suouthe, the burms were rowarkably emall conviderisg the kize ultimately attabmel

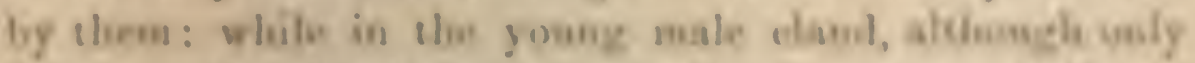

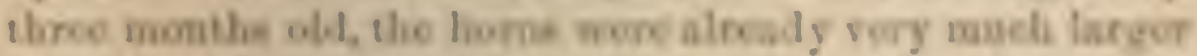

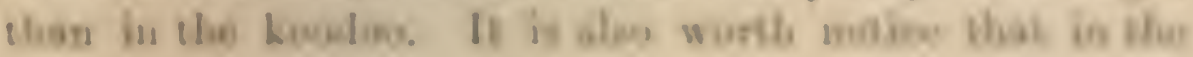

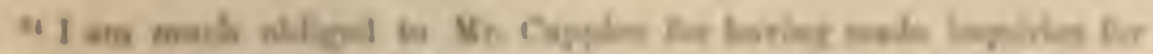

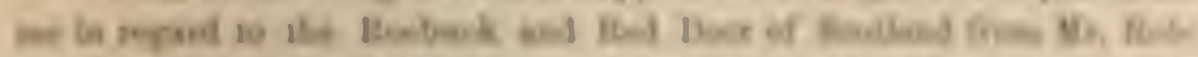

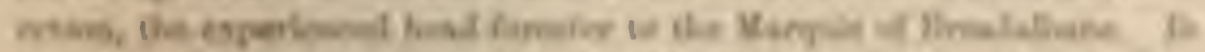

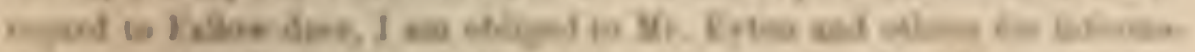

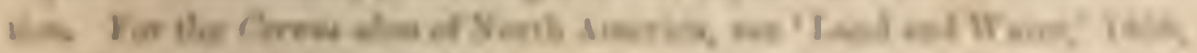

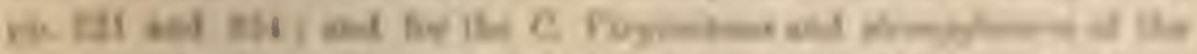

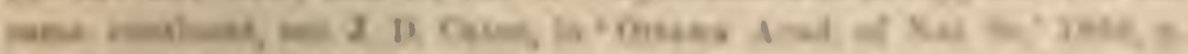

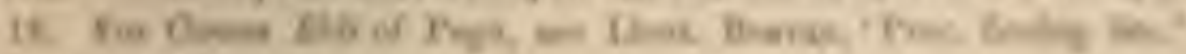
1W1, o 5ak. 
prong-horned antelope, ${ }^{28}$ in which species the horns, thongh present in both sexes, are almost rudimentary in the female, they do not appenr until about five or six months after birth. With sheep, goats, and cattle, in which the horus are well developed in both sexes, though not quite "qual in size, they can be felt, or even scen, at birth, or soon afterward. ${ }^{20}$ Our rule, however, fails in regard to some breels of sheep, for instance, merinos, in which the rams alone are horned; for I cannot find on inquiry, ${ }^{27}$ that the horns are developed later in life in this breed than in ordinary sheep in which both sexes are horned. But with domesticated slieep the presence or absence of horus is not a firmly-fixed character; a certain proportion of the merino ewes bearing small horns, and some of the rams being hornless; while with ordinary sheep hornless ewes are occasionally produced.

In most of the species of the splenclid family of the l'heasants, the males differ conspicuously from the females, and they acquire their ornaments at a rather late period of life. The cared pheasant (Crossoptilon auritum), however, offers a remarkable exception, for both sexes possess

25 Antilocapre Americana. Owen, 'Anatomy of Tertebrates,' vol. iii. p. 627.

${ }^{26}$ I have been assured that the horns of the sheep in North Wales can always be felt, and are sometines eren an inch in length, at hirth. With cattle Youatt says ('Cattle,' 1834, p. 25t) that the prominence of the frontal bone penetrates the cutis at birth, and that the horns matter is soon formed orer it.

:I I am greatly indebted to Prof. Victor Carus for hasing made inquiries for me, from the highest authorities, with respect to the inerino sheep of Saxony. On the Guinca const of Africa there is a breed of sheep in which, as with merinos, the rams alone hear horns; and Mr. Winwood Reade informs ne that in the one case obecrved, a young ram born on February loth first showed horns on March Gth, so that in this mstance the development of the homs occurred at a later period of life, conformably with our rule, than in the Welsh sheep, in which both serey are Lomed. 
the fune caulal plumes, the large ear-tufts and the crimson velvet about the head; and I fisd on inguiry in elue \%oological Cardeas that all these characters, in acenrdance with our rulc, appear very early in life. The alule male can, however, be distinguished from the adult fomale by oue character, namely, by the presence of spurs; and conformably with our rule, these do not begin (n) be developed, at I am astured by Mr. Bartlet, before the age of six months, and cren at this age, can hardly be dislingriphed in the two sexes." "lice male and fomale T'acoek differ equspicuously from each other in aluoes coery part of their plumage, except in the elegant lead. erest, which is common to both seses; and this is dereloped very early in life, long hefore the weture orma. montk which are confinesl to the male. The wilil duek uflin an analogous case, for the lecatiful groen speculum on the wings is common to luth secres, thongh dulles am nomewbat smaller in the female, and it is developed arly in life, while the curbal tril-fiesthers and ether ornaments proculiar to the malo aro developed later." bicwora each

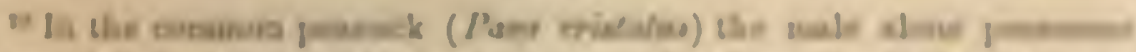

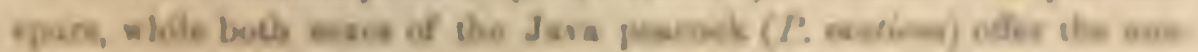

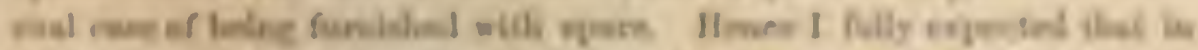

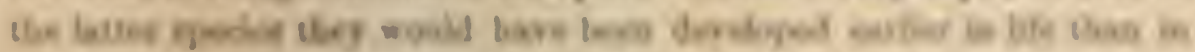

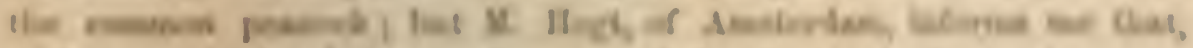

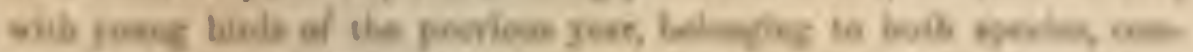

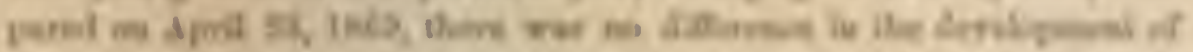

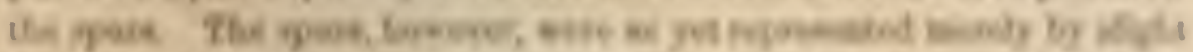

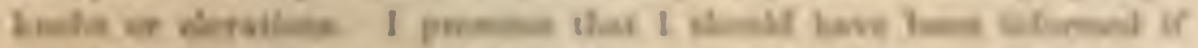

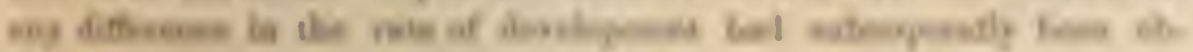
wrred.

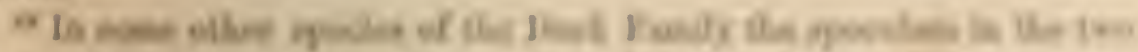

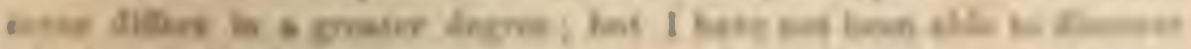

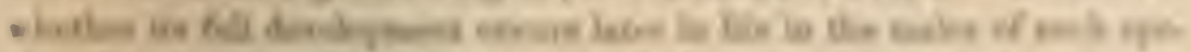

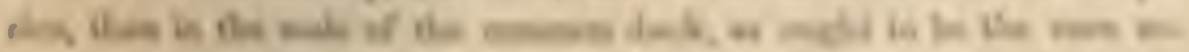

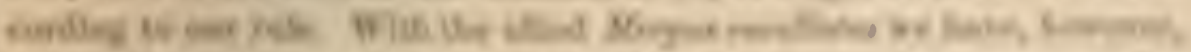

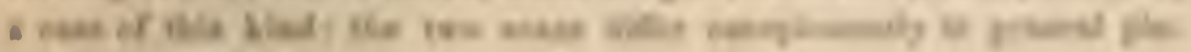


extreme cases of close sexnal resemblance and wide dissimilarity, as those of the Crossoptilon and peacock, many intermediate ones could be given, in which the characters follow in their order of development our two rules.

As most insects emerge from their pupal state in a mature condition, it is doubtful whether the period of atevelopment determines the tramsference of their characters to one or both sexes. But we do not know that the colored scales, for instance, in two species of butterflies, in one of which the sexes ditfer in color, while in the other they are alike, are developed at the same relative age in the cocoon. Nor do we know whether all the scales are simultaneously dereloped on the wings of the same species of buttertly, in which certinin colored marks are confined to one sex, while other marks are common to both sexes. $A$ difference of this kind in the period of development is not so improbable as it may at first appear; for, with the Orthoptera, which assume their adult state, not hy a single metamorphosis, but by a succession of moults, the young males of some species at first resemble the females, and acquire their distinctive masculine characters only during a later moult. Strictly analogous cases occur during the successive moults of certain male crustaceans.

We have as yet only considered the transference of characters, relatively to their period of derelopment, with species in a natural state; we will now turn to donesticated animals; first touching on monstrosities and diseases. The presence of supernumerary digits, and the

mage, and to a consilerable degree in the speculum, which is pure white in the male and grayish-white in the female. Now the young males at first resenble, in all respects, the female, and have a grayish-white specuhun, but this becomes pure white at an earlier age than that at which the adult male accunires his other more strongly-marked sexual differ. ences in plumage: see Audubon, 'Ornithologrical Bingraplyy' rol. iii. $1835, \mathrm{pr} .219,250$. 
absence of certain plablanges, muat be decermincel at aus early cmbryonic period-elie tenlenoy to profuse blecding is at least congenital, as is probably color-blimblues-yet theee peculiaritics, and otler sinilar ones, are ofteu limitol in their transmiesion to one sex; so that the rule that characters which are developed at an carly period tend to be transmitced to both sexces, here wholly fuils. But this rule, as before rouarked, does not appear to be nearly an geuerally true as the converse propesition, uamely, that clasacters which ajpear late in life in one sex are iransnitted excluribuly to the same sex. From the face of the above abmormal peculiarities beoming attaclod to one sex, long before the sexual functions are aetive, we may infer that there nust be a difference of nome hind betwen the gexes at an extremely early age. With respect to kexually-limitcel discases, we know too litule of the prerionl at which they originate, to draw ang fair conclusion. lious, howerer, scems of fall unler our rule; fur it is generally causul ly intemprance afer early pouth, and is

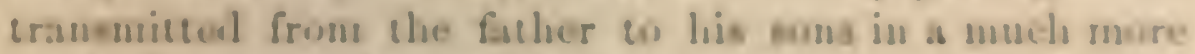
uarkod usauer tban to lis daugliters.

In the varions domestic Lreals of slyepp, gush, abul ostele, the mules diftior from their repposion females in

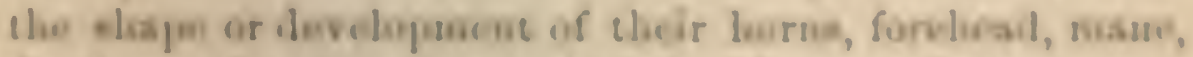

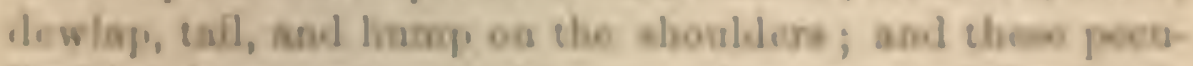

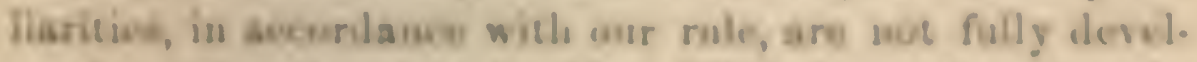
ojed nutil rasber lase in lifes. Whele doge, the euse do

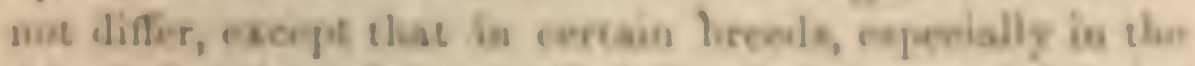
Footcli der r-liound, the male if muob larger and heavor

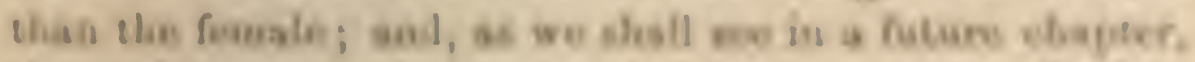

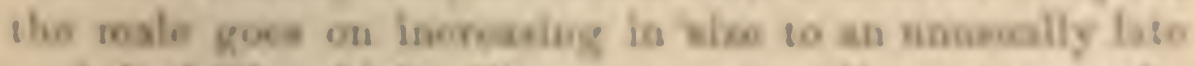

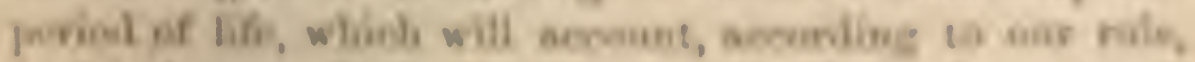

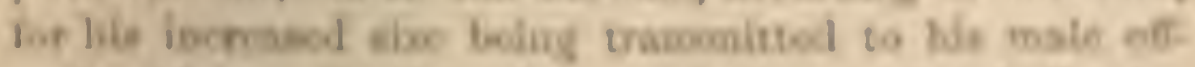

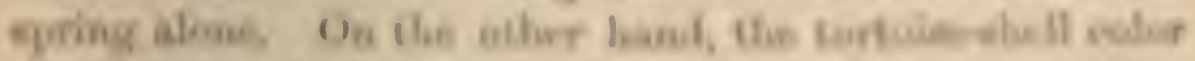

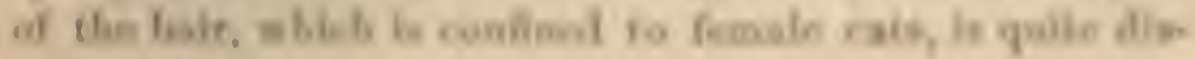


tinct at birth, and this case violates our rulc. There is a breed of pigcons in which the males alone are streaked with black, and the streaks can be detected even in the nestlings; but they become more conspicuous at cach successive moult, so that this case partly opposes and partly supports the rule. With the English Carricr and Pouter pigeon the full development of the wattlc and the crop occurs rather late in life, and these characters, conformably with our rule, are transmitted in full perfection to the males alone. The following cases perhaps come within the class previously alluded to, in which the two sexes have varied in the same manncr at a rather late period of life, and have conscquently transferred their new charactcrs to both sexcs at a corresponding late period; and if so, such cases are not opposed to our rule. Thus there are sub-brceds of the pigcon, described by Ncumeister, ${ }^{30}$ both sexes of which change color after moulting twice or thrice, as does likewise the Almond Tumbler; nevertheless these changes, though occurring rathcr late in life, arc common to both scxes. Onc variety of the Canary-bird, namcly, the London Prize, offers a nearly analogous casc.

With the brecds of the Fowl the inheritance of various characters by one sex or by both sexes secms generally determined by the period at which such characters are developed. Thus, in all the many brecds in which the adult male differs grcatly in color from the female and from the adult malc parent-species, he differs from the young male, so that the newly-acquired charactcrs must have appeared at a rather late period of life. On the other hand, with most of the breeds in which the two sexes resemble each other, the young arc colored in nearly the same manner as their parents, and this renders it proba-

80 'Das Ganze der Taubenzucht,' 1837, s. 21, 24. For the case of the 6treaked pigeons, sec Dr. Chapuis, 'Le Pigeon Voyagcur Belge,' 1865, p. 87 
ble that their colors first appeared early in life. We have instances of this fict in all black and white breeds, in which the young and old of both sexes are alike; nor can it be maintained that there is something peculiar in is back or white flunage, leading to its transference to both sexes; for the males alone of many uatural species are either black or white, the females being very diflerently colored. With the so-called Cuckoo sub-breeds of the fowl, in which the feathers are transversely pencilled with dark stripes, both sexes and the chickens are colored in uerly the same manner. The laced phumage of the Sebright bantan is the same in both sexes, and in the chickens the feathers are tipped with black, which makes a near approach to lacing. Spangled Hamburge, however, offer a partial exception, for the two sexes, though not quite alike, resemble each other more closely than do the sexes of the aboriginal parent-species, yet they acquire their characteristic plumage late in life, for the chichens are distinctly pencilled. Turning to other characters besides color: the males alone of the will parent-species and of most domentic breeds possess at fairly well-durelopied comb, but in the young of the spanish fowl it is largely deseloped at a very early age, and apparenty in comsefunce of this it if of untenal size su the alult females. In the Gane breots puguneity is descloped at a wonler. fully carly nge, of which curious prowen could be gison; and this character is transmitted to both seses, sis that the hen, from their extrome pugnecity, are now goverally exhilited in equarate peus. With the Polists breeds the houy protulsorance of the skull which supjerta the cret is phrtially dercloped crea before the chiehins aro hatohod.

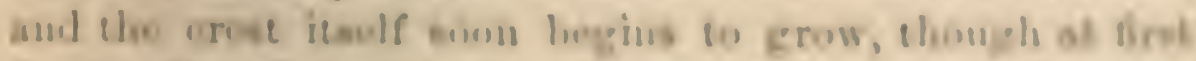

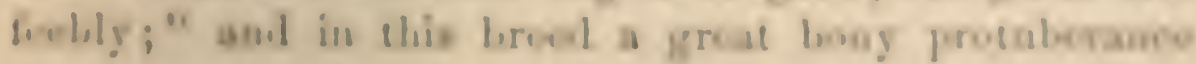

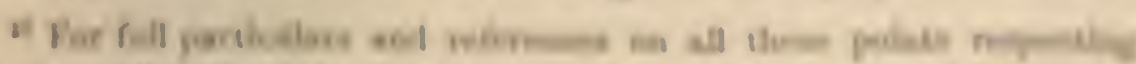

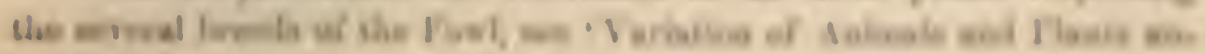


and an immense crest characterize the adults of both sexes.

Finally, from what we have now seen of the relation which exists in many natural species and domesticated races, between the period of the development of their characters and the manner of their transmission-for example, the striking fact of the carly growth of the horus in the reindeer, in which both sexes have horns, in comparison with their much later growth in the other species in which the male alone bears horns-we may conclude that one cause, though not the sole cause, of characters being exclusively inherited by one sex, is their development at a late age. And secondly, that one, though apparently a less efficient, cause of characters being inherited by both sexes is their development at an early age, while the sexes differ but little in constitution. It appears, however, that some difference must exist between the sexes even during an early embryonic period, for characters developed at this age not rarely become attached to one sex.

Summary and concluding remarlis. - From the foregoing discussion on the various laws of inheritance, we learn that characters often or even generally tend to become developed in the same sex, at the same age, and periodically at the same season of the year, in which they first appeared in the parents. But these laws, from unknown causes, are very liable to change. Ifence the successive steps in the modification of a species might readily be transmitted in different ways; some of the steps being transmitted to one sex, and some to both; some to the offispring at one age, and some at all agres. Not only are der Domestication,' rol. i. pp. 250, 25f. In regrarl to the higher anitnals, the sexual differences which have arisen under dounestication are described in the same work under the head of each species. 
the laws of inheritance extremely complex, but so are the canses which induce and govern variability. The raria. tions thus cauced are preserved and accumulated by sexual ackertion, which is in itseif an extremely complex aftair, depending, as it does, on ardor in lose, courage, and ilue rivalry of the males, and on the powers of perception, taste, and will, of the female. Sexual belection will abo be dominated ly uatural selection for the gencral welfore of the speeies. Hence the manner in which the undividu. als of cither sex or of both sexes are allected through sexual belection camot fail to be complex in the hielsest degrees.

When sariations occur late in lifo in one ses, and are transuitted to the same sex at the same age, the wher aex and the youne are necessarily left umbodified. When they oceur late in life, hut are transmiteel to buils sexes at the kame age, the young alonce are left unmodified. tariations, howerer, may oceur at any period of life in oncener or in both, and lie trunsmittel to both sers at all ageos, and then all the indiribuals of the speceics will be similarly modified. Jn the follow ing chapers it will lue secol thit all theoe cases freyuently oecur uniler nature.

sesual selection en nesor ace on any animal while sutug, before the age for reproduction las arrion. Finm the gruat cagerseses of the male it has generally aeted on this are sud not on tbe fromales. The males bave thas lie-

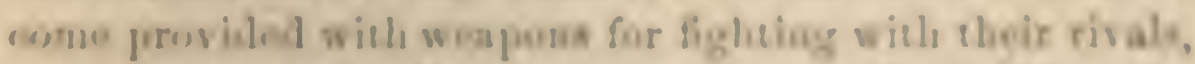
or will orrous for liteortiog and ecourely bolding die

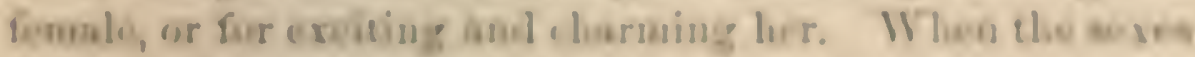
teflin in thow rewpets, it is alec, as wo lave sonn, an es

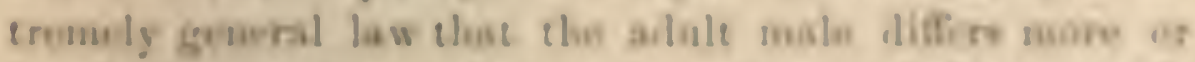
leas form the goung males and we may ounclude frow the

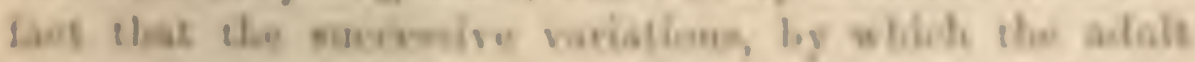

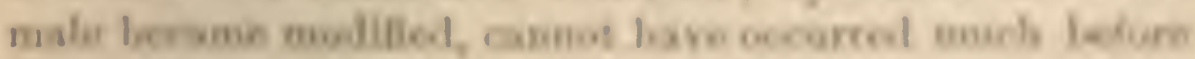

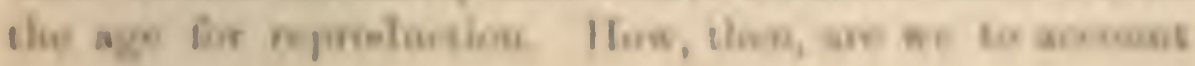


for this general and remarkable coincidence between the period of variability and that of sexual selection-principles which are quite independent of each other? I think we can see the cause: it is not that the males have never varied at an early age, but that such variations have commonly been lost, while those occurring at a later agre have been preserved.

All animals produce more offspring than can survive to maturity; and we have every reason to believe that death falls heavily on the weak and incxpericuced young. If, then, a certain proportion of the offspring were to vary at birth or soon afterward, in some manner which at this age was of no service to them, the chance of the preservation of such variations would be small. We have good evidence under domestication how soon variations of all kinds are lost, if not selected. But variations which occurred at or near maturity, and which were of immediate service to cither sex, would probably be preserved; as would similar variations occurring at an carlier period in any individuals which happened to survive. As this principle has an inportant bearing on sexual selection, it may le advisable to give an imaginary illustration. We will take a pair of animals, weither very fertile nor the reverse, and assume that after arriving at maturity they live on an average for five years, producing each year five young. They would thus produce 25 offepring; and it would not, I think, be an unfair estimate to assune that 18 or 20 out of the 25 would perish before maturity, while still young and inexperienced; the remaining seven or five sufficing to keep up the stock of mature individuals. If so, we can see that variations which occurred during youth, for instimee, in brightness, and which were not of the least service to the young, would run a grood chance of being utterly lost. While similar variations, which occurring at or near maturity in the comparatively few individuals 
Nurviving to this ace", and which immeliately gave an alvantage to curtain males, by rendering them more aterae. rive to the femalea, would be likely to be preacred. Do loubt some of the variations in brightues which ocenrrul at an earlier age would by chance be preserved, and crentually give to the male the sane alrantage as thöse which appeared later; and this will account for the young males commonly partaking to a certain extent (as may ine ubetred with many bircls) of the bright colors of their adult unale parents. If only a few of the succesire variations in briglitues were to weenr at a late age, the alule male would be only a little brighter than the young male; amul wueh cowen are common.

In this illustration I have assumed that the gotase saried in a manuer which was of urs sersice to elsem; hue many charactern proper to the alule male would be actually injuriona (u) the youmg-os bright colors from making tbrn com*ficuons, or horns of large size from expending mach vital furce. Suld variations in the soung wonld

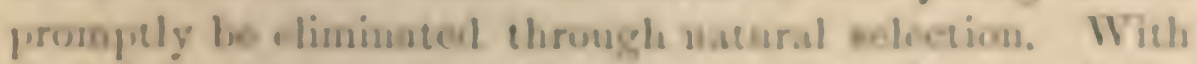

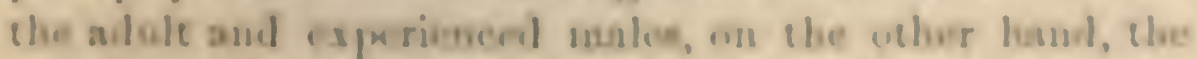
alvantage thus deriod in their riblry with other maloo

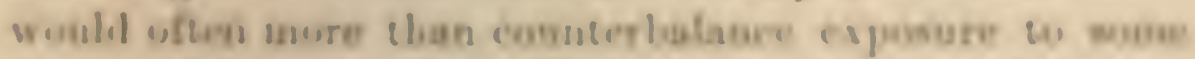
degree of danger. Tlins wo en anderntand how it is that

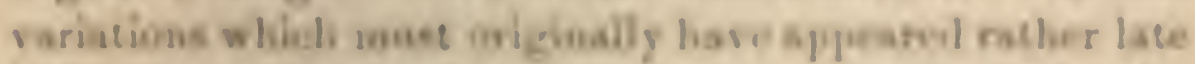
in life lave alone of in elief pan been pesacrod for the desclopmeat of mocuelary mesual elame tres; aed the ro

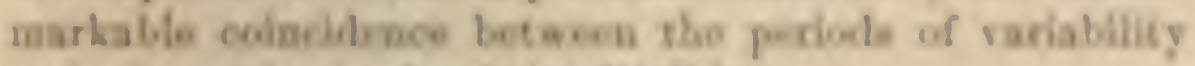

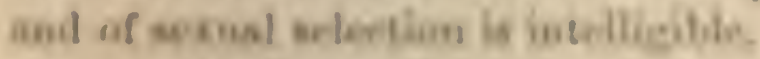

A variatlone eldel, pive to the male kn adraseago in

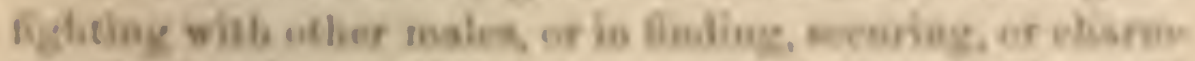

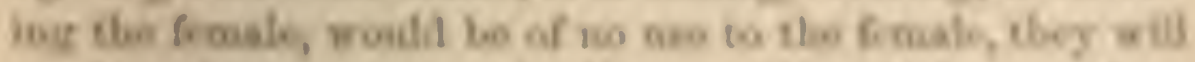

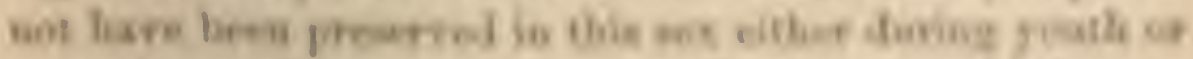

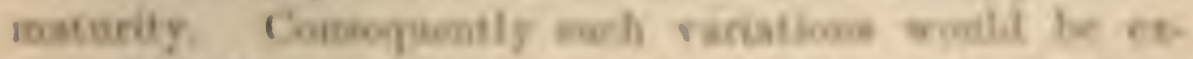

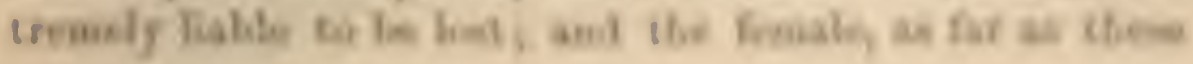


characters are concenced, would be left numodilied, execpting in so far as she may have received them by transference from the male. No donbt if the female raried and transferred serviceable characters to her male offspring, these would be favored throngh sexual selection; and then both sexes would thus far be modified in the same manner. Jut I shall hereafter have to recur to these more intricate contingencies.

In the following chapters, I shall treat of the secondary sexual characters in animals of all classes, and shall eudearor in each case to apply the principles explained in the present chapter. The lowest classes will detain us for a rery short time, but the higher animals, especially birds, must be treated at considerable length. It should be horne in mind that, for reasons already assigned, I intend to give only a few illustrative instances of the innumerable structwes by the aid of which the male finds the female, or, when found, holds her. On the other hand, all structures and instincts by whicls the male conquers other males, and by which he allures or cxcites the female, will be fully discussed, as these are in many ways the most interesting.

\section{Supplement on the moportional numbers of the the seres in animals belonging to various classcs.}

As no one, as far as I can discover, has paid attention to the relative numbers of the two sexes thronghout the animal kingdom, I will here give such materials as I have been able to collect, although they are extremely imperfect. They consist in only a few instances of actual cnumeration, and the mumbers are not very large. As the proportions are known with certainty on a large scale in the case of man alone, I will first give them, as a standard of comparicon. 


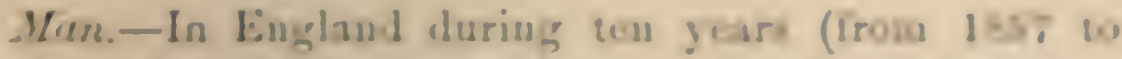
1ki,e) 715,120 children on an ammal average hose boin born alive, in the proportion of 104.5 males to 100 fe unales. But in 1857 the male birshat threughour England were aA 105.2, and 1 Aes as 104.0 (o) 100 . Jooking oo separate dintriets, in buekinglıanshire (whure on as arer. age 5,000 chiliron are amually bors) the mon propor. tion of male to fanales tirtis, daring the whole priml of the above ton goan, wos at 102.9 to 100 ; while his North

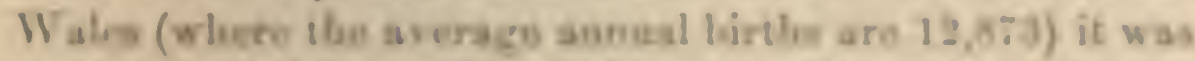
as high as 100.2 to 100 . 'Thking a neill swatler clintrine,

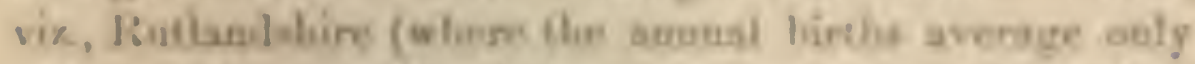
$7.99)$, in 1006 the tnale birchs more at 111,6 , and in 1862 at $9 \% .0$ wh 109 ; lut esen in this small lielried the avroge of

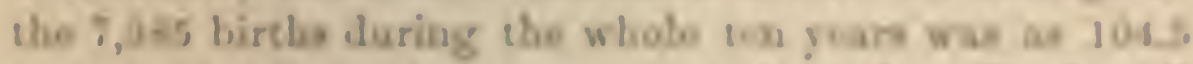

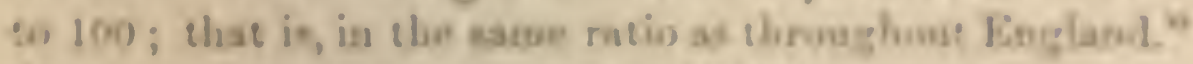
'The proportiost are acmetimes slightly discarbed by cone Known raeses; thes I'rof. Jaye states thas " in sume di= cricte of Sorkay there hase beos-duries a decomial periol

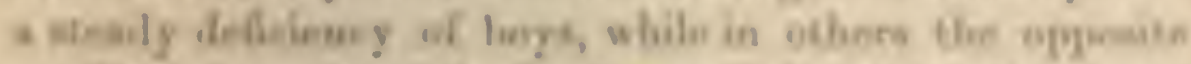
condition hat exioted," In Franco dariog fore Moor yoan

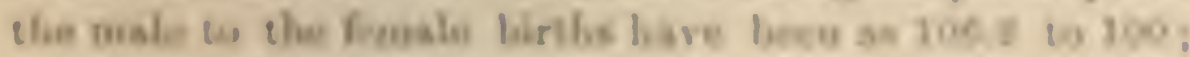
bas darbale the period it bas oscurred firs climes is one de.

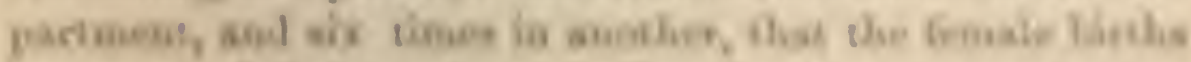

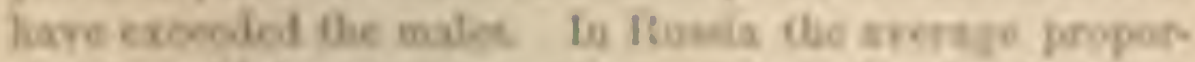

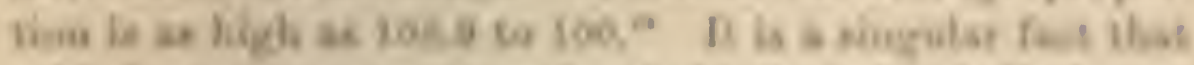

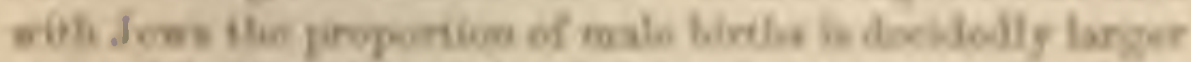

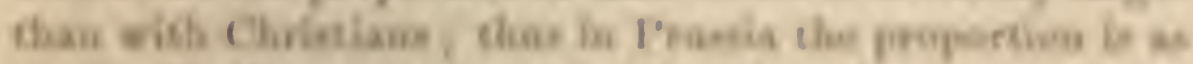

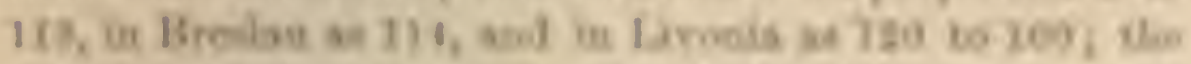

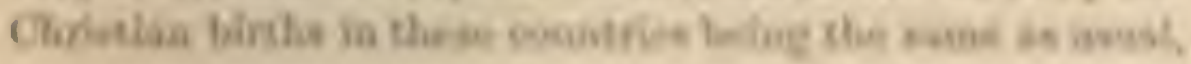

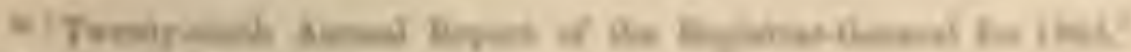

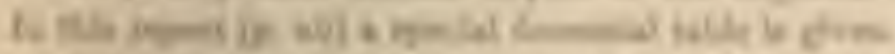

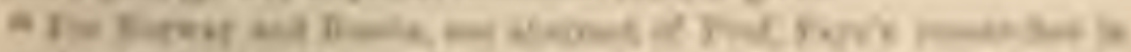

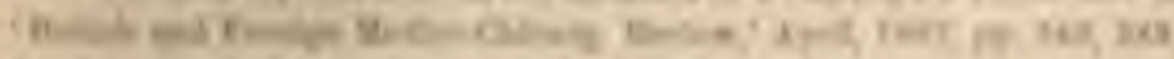

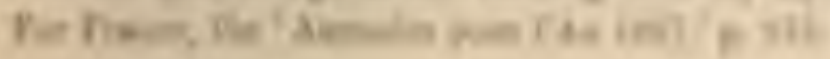


for instance, in Livonia as 104 to $1000^{\prime \prime}$ It is a still more singular fact that in different, nations, under diflerent conditions and climates, in Naples, Prussia, Westphalia, France, and England, the excess of male over female births is less when they are illegitimate than when legitimatc."

In various parts of Europe, according to Prof. Faye and other authors, "a still greater preponderance of males -would be met with, if death struck both sexes in equal proportion in the womb and during birth. But the fact is that, for every 100 still-born females, we hare in sevcral countries from 134.6 to 144.9 still-born males." Moreover during the first four or five years of life more male children die than females; for exanple, in England, during the first year, 126 boys die for erery 100 girls - a proportion which in France is still more unf:vorable." 30 As a consequence of this excess in the death-rate of male children, and of the exposure of men when adult to various dingers, and of their tendency to emigrate, the females in all old-settled comtries, where statistical records have been kept," are foumd to preponderate considerably over the males.

अ In regard to the Jers, see 31. Thurr, 'La Iooi de l'roduction dew Sexes,' 1s63, p. 25.

es Ibabbage, 'Edinburgh Jumrnal of Science,' 1829 , rol. i. p. 89 ; al=o I. s0, on still-horn children. On illegrtinate chillren in Fugland, ace ' lieport of Rearistrar-General for 1866,' p. xr.

26 'Mritih and Foreign Medico-Chirurg. leview, April, 1867, p. 313. Dr. Stark al o rcmarks ("Tenth Anuual Report of Birth, I)eaths, cle., in Scotlan?,' 1867, p. xxviii.) that "these cxamples may sulfice to show that, at aluost every stage of life, the maleg in Scotlam have a greater liability to death aud a higher death-rate than the fernales. The fact, however, of this peculiarity leing most strongly dereloped at that infantile period of life when the dresa, fool, and feneral irentucnt of both sexes are alike, scen:s to prove that the higlier male death-rate is an impreasu, uatural, aud conctitutional peculiarity due to gex nlone."

s: With the sarage Guarangs of Paragnay, according to the accurate 
It has often bees expposed that the relative ages of the parcuta determine the sex of the nfirping; and Prof. Leuckar" "has adranced what he contiders ongleient evidence, with respect to man and certain donnetieated abimals, to show that this is ouc imprortant facter in the renult. So, again, the period of inspreguation has bous thought to be the cficient catse; but recent obtervations disoonntenane thit belief. Again, with mankiad polyg.

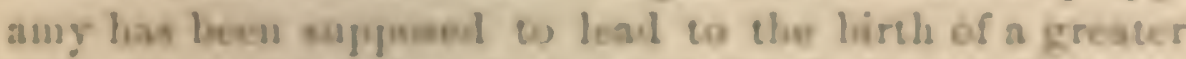
proportion of firale infants; but 1)r. J. Caupbeti" are

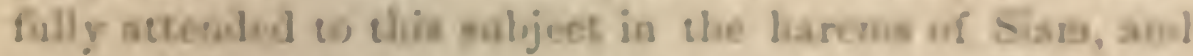
lis conclede that the proportion of malo to frmato birclis

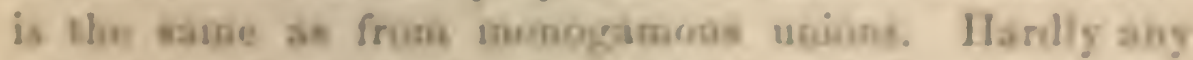
onirast has been rendend to bighly polygamoas as oor linglieh mee-hosins, and we thall ifnumellately weo that their male and female offerritg ane atmost exacty cqual is unsuler.

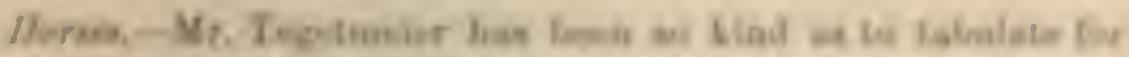

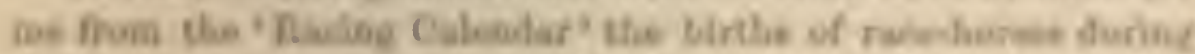

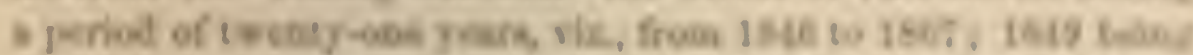

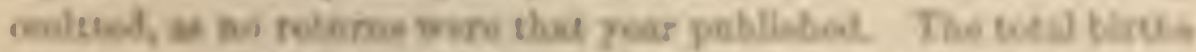

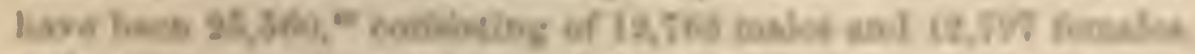

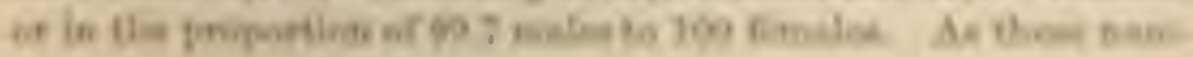

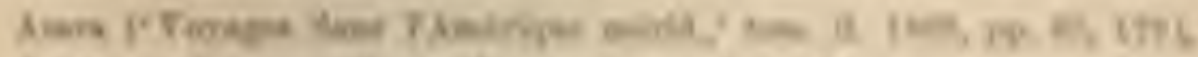

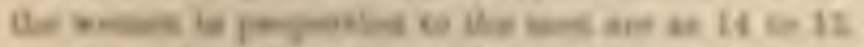

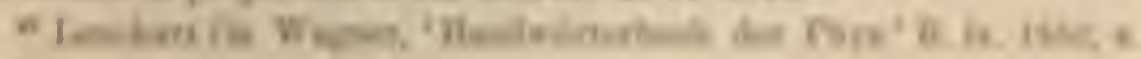
7215

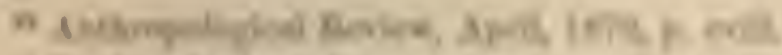

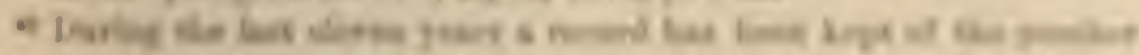

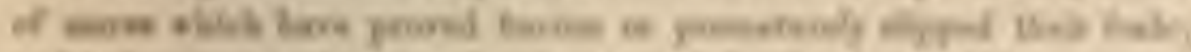

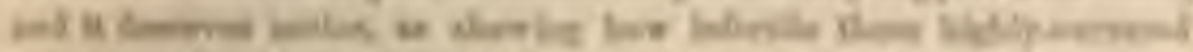

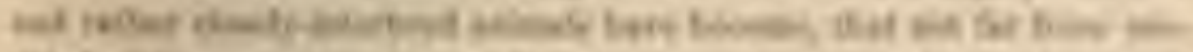

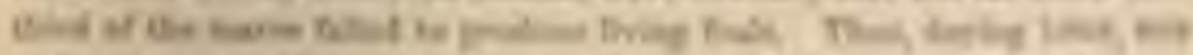

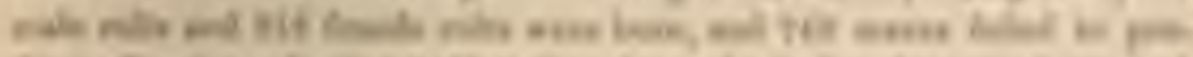

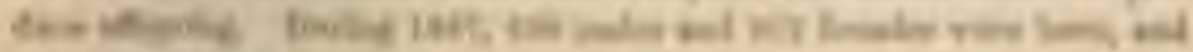
$8+1$ ines bind 
bers aro tolcrably large, and as they aro drawn frou all parts of finglund, during scrernl ycars, wo may with uuch contidenco conclude that with the domestic horse, or at least with tho raceliurse, tho two soxes are produced in almost cqual numbers. The fluctuations in tho proportions during successivo ycars aro closely liko thoso which occur with mankind, when a small and thivly. populated area is considered: thus in 1850 tho malo lorses wero us 107.1, and in 1867 as only 92.6 to 100 females. In tho tabulited returns the proportions vary in cycles, fur tho males execcled tho females duriug six successive years; and tho funalcs excected tho males during two periods each of fuur years: this, howorer, may bo accidental; at lcast I can detect nothing of tho kind with man in the decennial tablo in the Recristrar's Report fur 1566. I may add that certain mares, and this holds food with certain cows and with women, teud to produce more of ono scx than of tho other; Mr. Wright, of Yeldersley Honse, informs mo that one of his Arab mares, thongh put seren times to diflirent horses, produeed scren fillies.

Dogs.-During a period of twelve years, frous 1857 to 1868 , the births of a large number of groyhounds, throughout England, havo been sent to tho 'Field' newspaper'; and $I$ an again indebted to Mr. Tegetmeier for carefully tabulating tho results. The recorded births have been 6,578 , consisting of 3,605 malcs and 3,273 fennales, that is, in the proportion of 110.1 males to 100 females. 'T'he grentest fluctuations occursed in 186t, when the proportion was as 95.8 malcs, and in 1867 , as 116.3 unales to 100 feunules. 'The aboro averago proportion of 110.1 to 100 is probahly nearly correct in the case of tho greyhound, but whether it would hold with other domesticated breods is in some derreo doubinl. Mr. Cupples has inquired from sereral great breeders of dose, and finds that all without exception believe that females are produced in excess; ho suggests that this belief may have arisen from fimales bcing less valued ant the conseñuent disapr pointment producing a stronger impression on the mind.

Shecp. - The sexes of sheep are not ascertained ly agriculturists until scieral months after birth, at tho period when the males are castratcd; so that tho fullowing returns do not gire the proportions at birth. Morcoicr, I find that screral great breclers in Scotland, who annually raise some thousand shecp, are firmly 


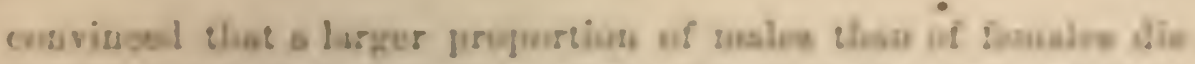

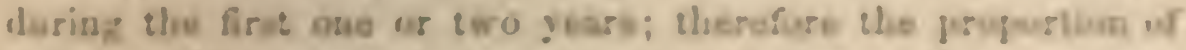

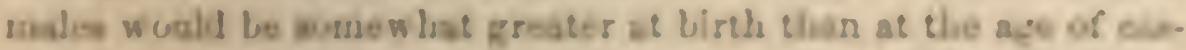

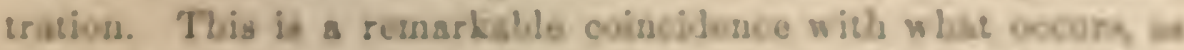
we hese ncon, will rosnkind, asd both cans probally depobd on

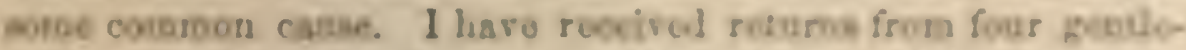

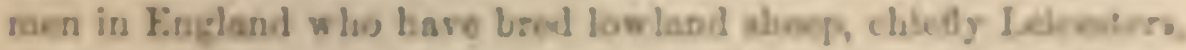

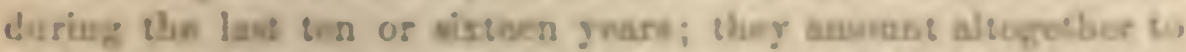

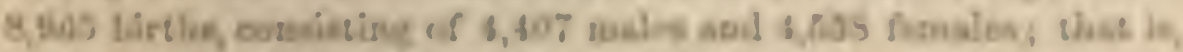

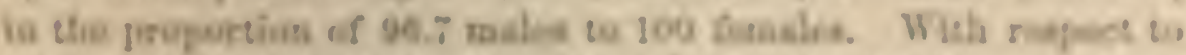

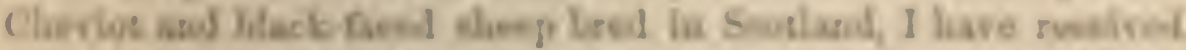

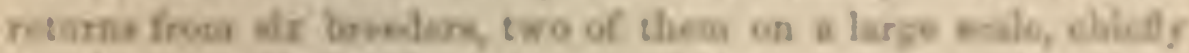

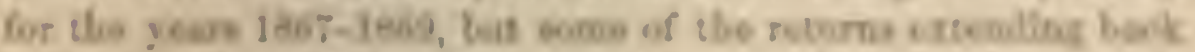

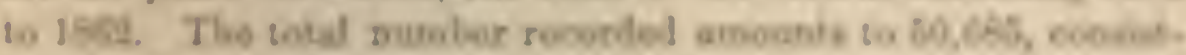

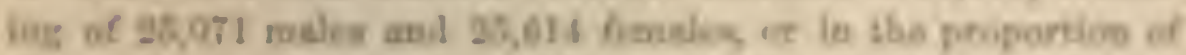

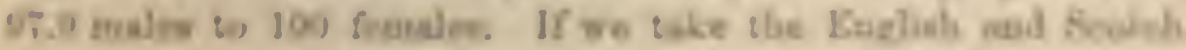

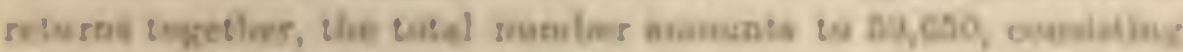

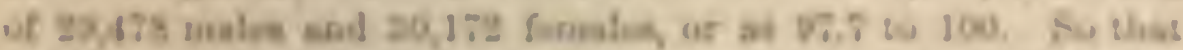

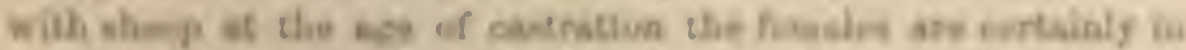

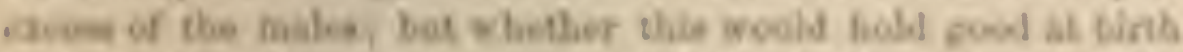

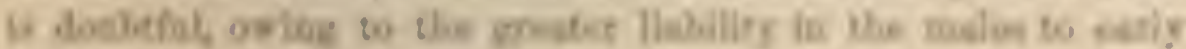
Aesth $\cdot$

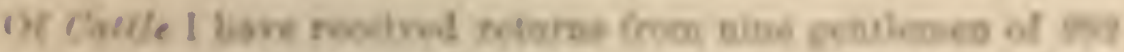

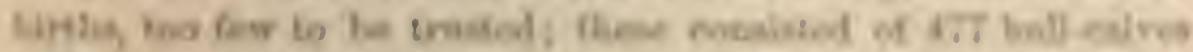

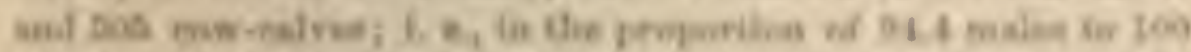
fivates. The Res. W. D. Jos umonise ree thae la Joot wat ad at

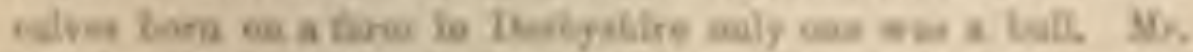

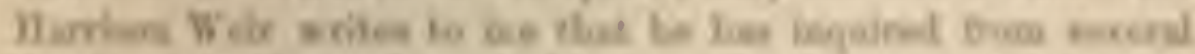

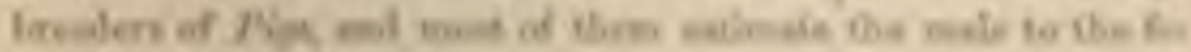

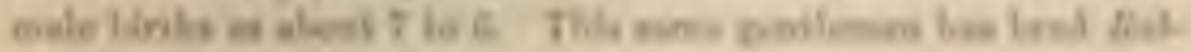

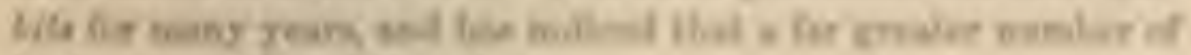

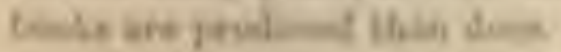

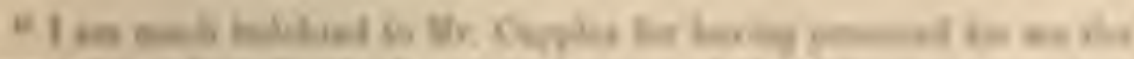

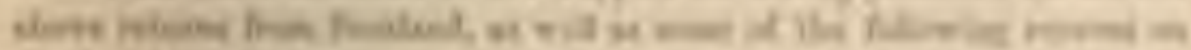

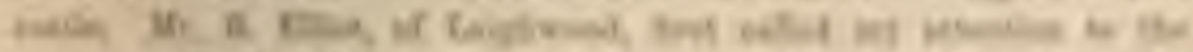

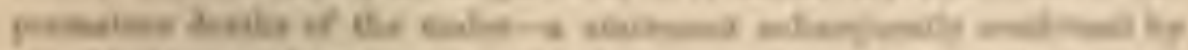

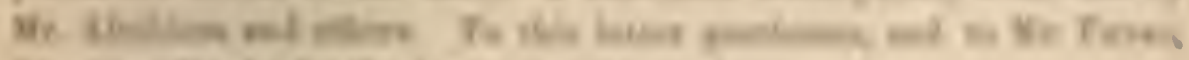

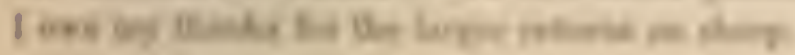


Of Inammalia in a state of nature I have been able to learn very littlo. In regard to tho common rat, I bavo received conflicting statements. Mr. R. Filliot, of Laighwood, informs mo that a rat-catcher assured him that ho had always found tho males in great exeess, eren with the young in tho nest. In consequenco of this, Mr. Elliot himself subsequently exanined somo hundred old ones, and found the statement true. Mr. F. Buckland lias bred a largo number of white rats, and ho also belieres that tho males greatly exceed tho females. In regard to Moles, it is said that "tho males are much more numerous than the females;" 42 and as tho eatehing of these animals is a special oceupation, tho statement may perhaps be trusted. Sir $\Lambda$. Smith, in describing an antelope of South $\Lambda$ friea ${ }^{\text {s }}$ (Kobus ellipsiprymnus), remarks, that in the herds of this and other speeies, tho males are fow in number compared with tho females: the natives belicre that they aro born in this proportion; others believe that the younger males aro expelled from tho herds, and Sir $\Lambda$. Smith says, that though he has himself never seen herds eonsisting of young males alone, others aflirm that this does oceur. It appears probable that the young males, when expelled from the lierd, would bo likely to fall a prey to the many beasts of prey of the country.

\section{BIRDS.}

With respect to the Fowl, I hare reccived only ono account, namely, that out of 1,001 eliekens of a highly-bred stoek of Cochins, reared during eight years by Mr. Streteh, 487 proved males and 514 females: i. e., as 94.7 to 100 . In regard to domestic pigcons thero is good evideneo that the males aro produced in excess, or that their lires aro longer; for these birds invariably pair, and single males, as Mr. Tegetmeicr informs me, can alway bo purchased cheaper than females. Usually the two birds reared from the two eggs laid in the same nest eonsist of a male and female; but Mr. Harrison Weir, who has been so large a breeder, says that he lias often bred two cocks from the samo nest, and seldom two hens; moreover, the lien is grenerally the weaker of the two, and more liable to perish.

42 Bell, 'Ilistory of British Quadrupeds,' p. 100.

43 'Illustrations of the Zoology of South Africa,' 1849, pl. 29. 
With renpect to birds in a sinte of noture, Mr. Ciould and others" aro convineed that the males are generally the nuro numerous; and as the young males of many species rusemblo tho fenalea, tho latter would naturally appear to be the ino-t nunesous. Iarge numbers of plieasants aro reared by Mr. Baker, of J.eadenhall, from ecregs laid by wild birds, and ho informs Mr. Jeaner Weir that four or firo males to one fermalo are generally jro- duced. An experienced ouserver remarks" that in Scandiuavia tho bruods of the cajpercailzie aud black-cock contain moro males than feruales; and that with tho Dal-ripa (a kind of ptaruipin) more mules thas females attend the leks or places of courtship; but this latter circumetance is nccounted fur ly somo obturrers ly a grenter number of hen-birls being killed by rormin. lirom various furts gisen by Whito of Selbourne, "it seems clear that the males of tho part ridgre must bo in considerable excest in tho south of Fonglanl; nnl I havo been assured that this is the caso in Scubhand. Mr. Weir, on inquiring from tho denlers who receive at certuin smanons largo numbers of rull's (Machetes pugnar), was tuld that the males aro much tho most numerons. This samo uaturalitt hăs alo inņuired for mo from tho bird-cntelsers, who annuallg cutch an noniehing number of various small species ulive for the Jondon market, und lo was unhesitatingly answerod by an old and truetwortly man, that with the cliallinch the males aro in

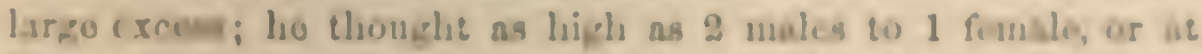

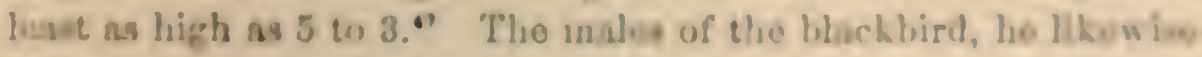
unistainel, wero by fur tho moe numerots, whether caugbs by tragat or lig nutling at night. Theso nententuln map apparestly

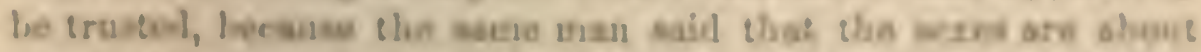

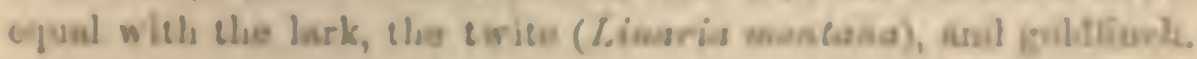

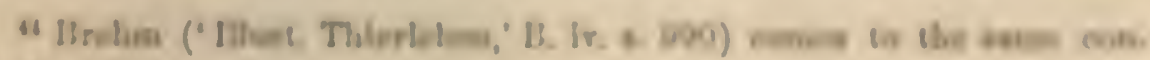
Cluctose.

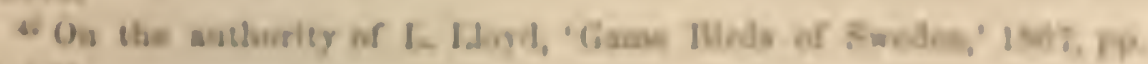
13,132

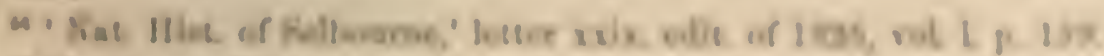

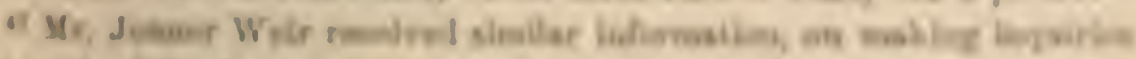

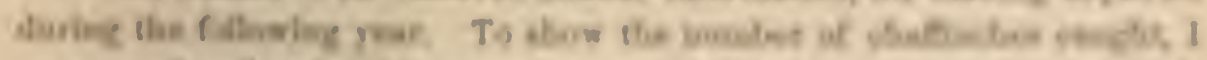

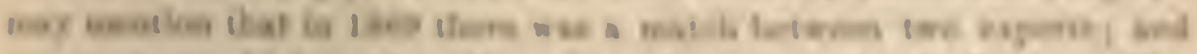

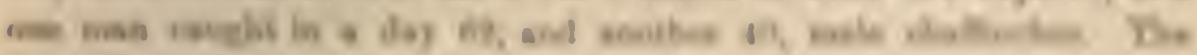

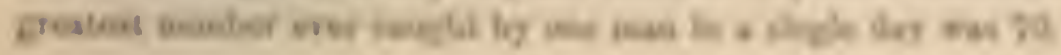


On the other liand, he is ecrtain that with the common linnet, the females preponderate greatly, but unequally during diflerent years; during some years he has found the females to the males as four to one. It should, howerer, be borne in mind, that the chicf season for catching birds does not begin till September, so that with some species partial migrations may lave begun, and tho flocks at this period often consist of hens alone. Mr. Salvin paid particular attention to the sexes of the humming-birds in Central America, and he is convinced that with most of the species the males aro in excess; thus, one year ho procured 204 specimens belonging to ten species, and these consisted of $166 \mathrm{males}$ and of 38 females. With two other species the females wero in excess: but the proportions apparently rary either during different seasons or in different localities; for on one occasion the males of Campylopterus hemileucurus were to the females as fire to two, and on anotheroccasion ${ }^{48}$ in exactly the reversed ratio. $\Lambda$ s bearing on this latter point, I may add that Mr. Powys found in Corfu and Epirus the sexes of the ehaftinch keeping apart, and "tho fomales by fur the most numerous;" while in Palestine Mr. Tristram found "the male flocks appearing greatly to exceed the female in number." 49 So again with tho Quiscalus major, MIr. G. Taylor "soys that in Florida there were "very few females in proportion to the miales," while in IIonduras the proportion was the other way, the species there having the cliaracter of a polygamist.

\section{FISII.}

With fish the proportional numbers of the sexes can be aseertained only by catching them in the adult or nearly adult state; and there are many difficultics in arriving at any just conclusion. ${ }^{b 1}$ Infertile females might readily bo mistaken for males, as Dr. Günther has remarked to mo in regard to trout. With some species

48 'Ibis,' rol. ii. p. 260, as quoted in Gould's 'Trochilide,' 1861, p. 52. For the foregoing proportions, I am indebted to Mr. Salvin for a table of his results.

49 'Ibis,' 1860 , p. 137 ; and 1867 , p. 369

so 'Ibis,' 1862, p. 137.

${ }^{51}$ Lcuckart quotes Bloclı (Wagner, 'Handwörterbuch der Pl.ys.' B. ir. 1853, s. 755$)$, that with fish there are twiee as many males as females. 
the males are believed to die soon after fertilizing the orit. With many species the males are of much smaller size than the fermales, so that a large number of males would excape from the same net by which the females wero caught. M. Carbonnier, ${ }^{2}$ who has copecially attended to the natural history of the pike (Frox luciux) states that many males, owing to their sunall size, are devoured by the larger femnles; and he belieres that the males of almost all fish aro exposed from the samo cause to grenter danger than tho fomales. Neverthcles, in the few cases in which the proportional munbers have been actually observed, the males tupear to he largely in caxcess. Thus, Mr. I. IBuiat, the superintendent of the Sicmontfich experiments, savs that in 1865 , ont of 70 salmon first landed for the purpose of obtaining the ora, upward of 60 were males. In 1865 lac again "calls uttention to the a ast disproportion of the males to the funales. Wo had at tho ontset ne leist ten males to ono fomale." Anterward sufficient fumales for whtaining ova wero procured. He adis, "From the great proportion of the males, they are constantly fighting and tearing ench wher on tho spawning-beds." ts This disproportion, no donlu, can be accomted for in part, lout whether wholly is sery doubciol, by the males ancending the rivers before the fumales. Mr. F. linchland romarks in recrard to trout, that "it is a curious fact that the males preponderato rery largely in number orer the fomales. It ineariably happens that when the first rush of tish is mule to the net, there will be st lenst serem or vight males to one finalo found captive. I cannot ynite accomut for this; cither tho malea aro moro numerous thun tho fomules, or tho buter ank enfity by concealunent rather thun tlight." He then mils thent, Is

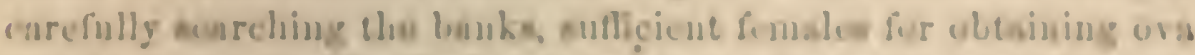

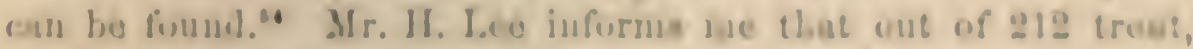

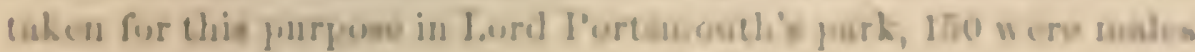
and 6e formalos.

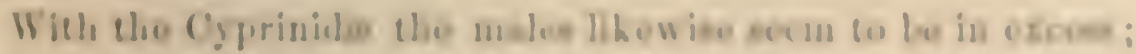

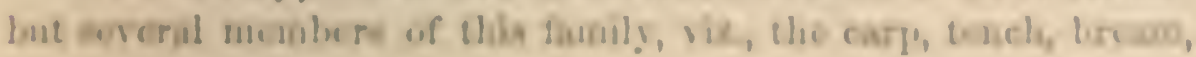

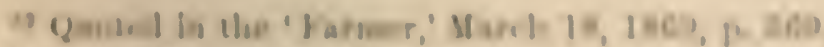

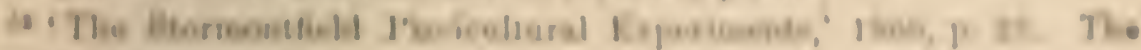

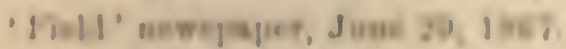

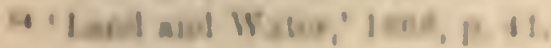


and minnow, appear regularly to follow the practice, rave in tho animal kinglom, of polyandry; for tho female while spawning is always attended by two males, one on each side, and in tho caso of tho bream by three or four males. This fact is so well known, that it is always recommended to stock a pond with two malo tenches to one female, or at least with threo males to two funales. With tho minnow, an excellent observer states that on tho spawning-beds the males aro ton times as numerous as the females; when a female comes among the males, "sho is immediately pressed closely by a malo on each sido; and when thoy havo been in that situation for a time, are superseded by other two males." bs

\section{INSECTS.}

In this class, the Lepidoptera alone afford the means of julging of tho proportional numbers of the sexes; fur they have been collected with special caro by many good observers, and havo been largely bred from tho egrg or caterpillar state. I had hoped that some breeders of silk-moths might have kept an exact record, but after writing to France and Italy, and consulting rarions treatises, I cannot find that this has crer been done. Tho general opinion appears to be that tho sexes are nearly equal, but in Italy, as I hear from Prof. Canestrini, many breeders aro convinced that the females aro produced in excess. Tho same naturalist, howerer, informs me, that in the two yearly broods of tho Ailantus silk-moth (Bombyx cynthia), tho males greatly preponderato in tho first, while in tho second the two sexes aro nearly equal, or the females rather in excess.

In regard to Butterfies in a state of nature, severnl observers havo been much struck by tho apparently enormous preponderance of the males. ${ }^{68}$ Thus Mr. Bates, ${ }^{87}$ in speaking of the species,

${ }^{65}$ Yarrell, 'Ilist. British Fishes,' vol, i. 1836, p. 307; on the Cyprinus arpio, p. 331 ; on the Tinea vulgaris, p. 331 ; on the Alramis Lrama, p. 336. See, for the minnow (Ieuciscus phoxinus), 'Loudon's Mag. of Nat. Ilist.' rol. v. 1832, p. 692.

B6 Leuckart quotes Meinecke (Wagner, 'Handwörterbuch der Phys.' B. iv. 1853, s. 775) that with Butterflies the males are three or four times as numerous as the fernales.

57 'The Naturalist on the Amazons,' rul. ii. 1863, pp. 228, 317. 
no less than about a liundred in number, which inlabit tho Upper Amazong, says that the males aro much moro numerous than the fenalea, even in the proportion of a hundred to one. In Corth Aucrica, Edwards, who had great experience, entiuates in the genus Papilio tho males 80 the femules as four to one; and Mr. Wialsh, who informed ne of this statement, kass that with I'. turnus this is certainly tho case. In South Airios. Mr. P. Trinnen foumd the unules in excess in rinchech sprecies; ${ }^{20}$ und in ono of these, which swarms in open finces, he entimated the number of males as fing to ono female. With another siee. cien, in whioh the mnley aro munerous in certuin lecalities, be collected Jurimg meven years only firo fomates. In the iatsnd of Bourbon, M. Mallinad states that the males of ons species of Papilio aro twenty times as numerous at tho femalea." Mr. Irimen infurms tue that as far as he lass himodf noen, or hear! from others it is raro for the fenuales of any buttersty 20 exomi in sumber tho males; but this is perlispan tho case with threo Sotuth African vpecies. Mr. Wallace es siated that the furabes of Ornithoplera crosus, in the Malsy nrohipeloso, are are commoss

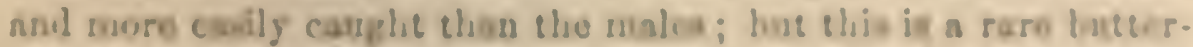
Aly. I may lere add, thet in II! forythra, a gesurs of toatles,

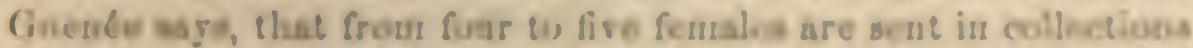
from Intia fur uno malu.

Wher this miljeet of the propurtiunal somblerk of the asus

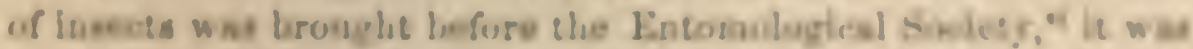

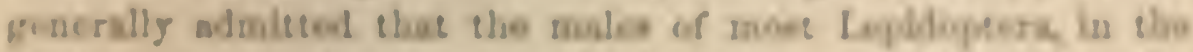

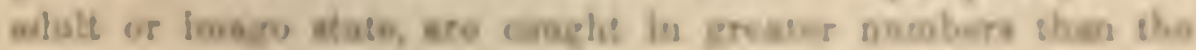

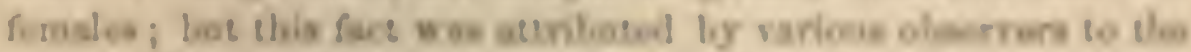

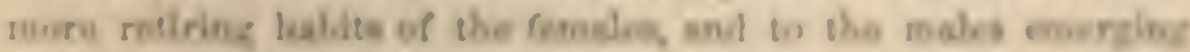

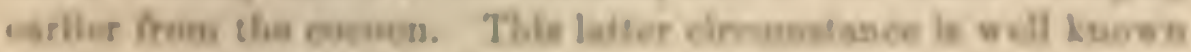

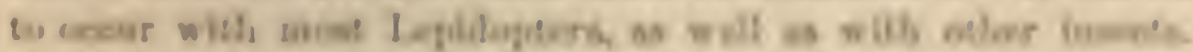

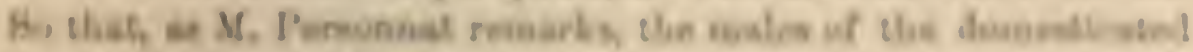

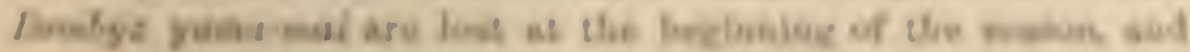

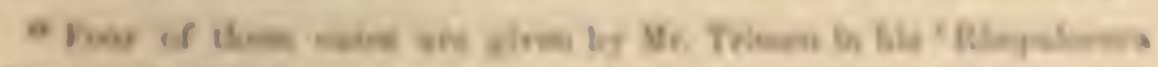
Amer A asorsia: 330

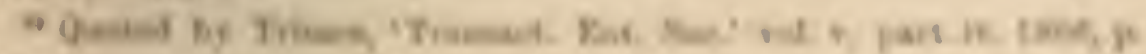

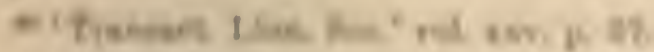

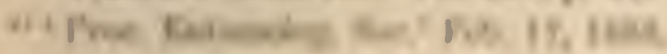


the feinales at the end, from the want of mates. ${ }^{62}$ I cannot, however, persuade myself that these causes suftice to explain the great excess of males in the cases, above given, of butterties which are extremely common in their nativo countries. Mr. Stainton, who has paid such close attention during many years to tho smaller noths, informs me that when he collected them in the inago state, ho thought that tho males wero ten times as numerous as the females, but that, since lio lias reared then on a large scalo from tho caterpillar state, ho is convineed that the females aro tho most numerous. Several entomologists concur in this view. Mr. Doubleday, howerer, and some others, take an opposite view, and are convinced that they haro reared from tho egg and caterpillar states a larger proportion of males than of females.

Besides the more active habits of the males, their earlier emergence from the cocoon, and their frequenting in some cases more open stations, other causes may bo assigned for an apparent or real difference in the proportional numbers of the sexes of Lepidoptern, when captured in the imago state, and when reared from the egr or caterpillar state. It is believed by many breeders in Italy, as I hear from Prof. Canestrini, that the female caterpillar of tho silk-moth suffers more from the recent discaso than tho male; and Dr. Staudinger informs mo that in rearing I.epidoptera more females die in the cocoon than males. With many species the femalo caterpillar is larger than the male, and a collector would naturally choose the finest specimens, and thus unintentionally collect a larger number of females. Threo collectors havo told mo that this was their practice; but Dr. Wallace is sure that most collectors take all the specimens which they can find of tho rarer kinds, which alone are worth the trouble of rearing. Birds, when surrounded ly caterpillars, would prolally devour the largest; and Prof. Canestrini informs me that in Italy some breeders believe, though on insufficient evideuce, that in the first brood of the Ailantus silk-moth, the wasps destroy a larger number of the female than of the male caterpillars. Dr. Wallace further remarks that female caterpillars, from being larger than the males, reciuire more time for their development,

${ }^{62}$ Quoted by Dr. Wallace in 'Proc. Eint. Soc.' 3d serica, vol. r. 156,7, p. $18 \%$. 
and consume more foul and moisture; arsl thrs tlieg wonll the exponeal during a longer time to danger from ielutudamons, birds. 120, and in tirues of scarcity wouhl perieh in greater numbers. Herce it appears quito posible that, is a state of nature. fewer fomble I.cpiloptera may reach maturity than males; an! for our meceial olject wo are concerned with tho numbers at maturit. when tho sexes are rendy tu proparate their kind.

The unsmer in which the males of certain umulws couneresate

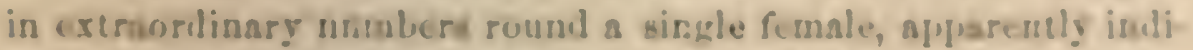
cates a great excess of nales, thongh this fact mas purlags ba

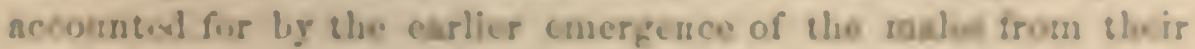

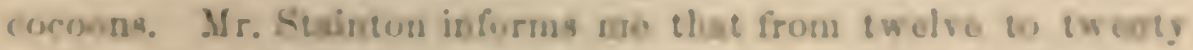
unalea may often be wen conpregated romml a forale Elackian

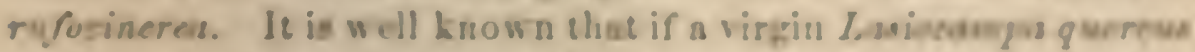

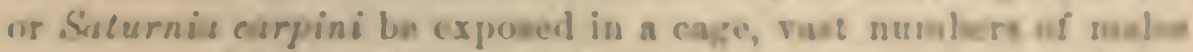
collect rousul ler, amd if confrued in a room will even couno dow n tho chimney to hor. Mr. Dumblelay helieven that he has men

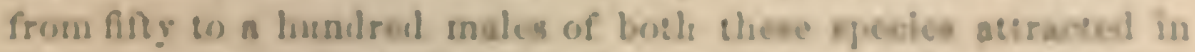
the rourno of a winglo deg lis a female under coutincerone. Mr.

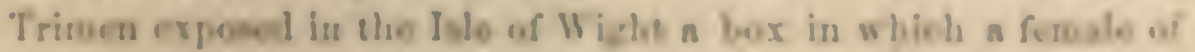

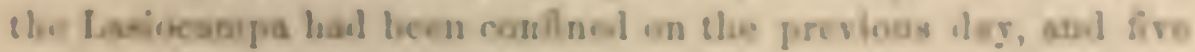

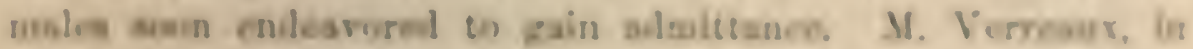

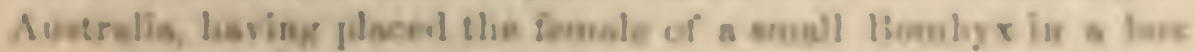

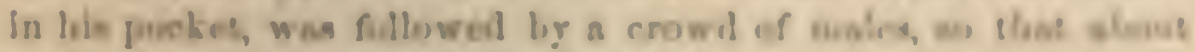
swo hurulrual entered the huse with han."

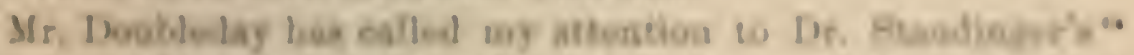

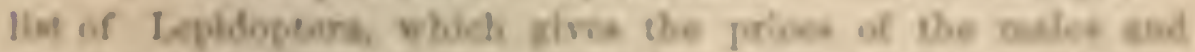

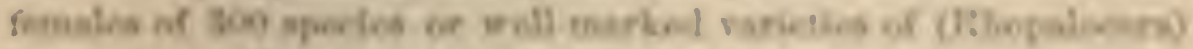

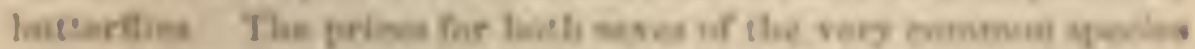

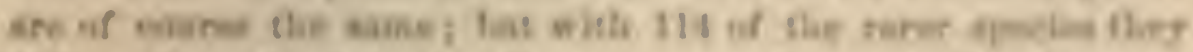

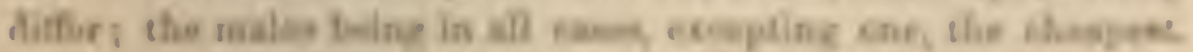

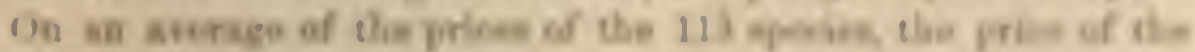

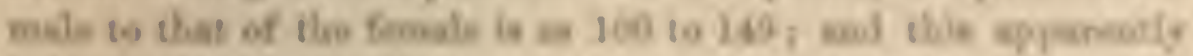

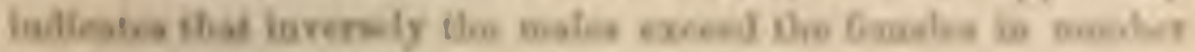

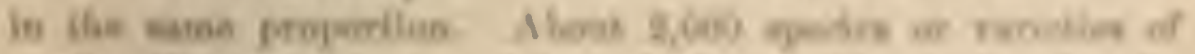

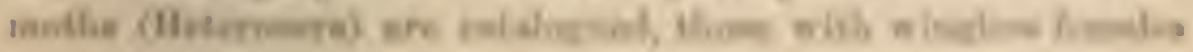

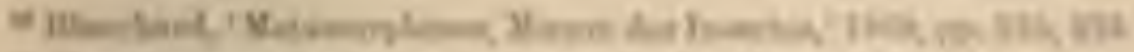

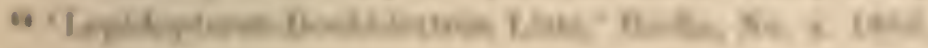


bcing lwre excluded on account of the diflerence in halits of the two sexes: of these 2,000 species, 141 differ in price according to sex, the males of 130 being chenper, and the males of only 11 being dearer than tho females. The average price of tho males of the 130 species, to that of the females, is as 100 to 143 . With respect to the butterflies in this priced list, Mr. Donbleday thinks (and no man in England has had more experience) that thero is nothing in the habits of the species which can account for tho difference in the prices of the two sexes, and that it can be accounted for only by an excess in the numbers of tho males. But I am bound to add that Dr. Staudinger himself, as ho informs me, is of a different opinion. Ho thinks that tho less active halits of the females and the earlier emergence of the males will account for his collectors securing a larger number of inales than of females, and consequently for the lower prices of the former. With respect to specimens reared from the caterpillar-state, Dr. Staudinger believes, as proviously stated, that a greater number of females than of males dio under confinement in the cocoons. IIe adds that with certain species ono sex scems to preponderato ofer the other during certain years.

Of direct observations on the sexes of Icpidoptera, reared either from eggs or caterpillars, I have received only the fow following cases:

The Rer. J. IIelling, os of Exeter, reared, during 1SG9, imagos of 73

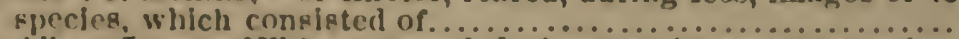

Mr. Aibert Jones, of Fitham, reared, during ises, imago of 9 species,

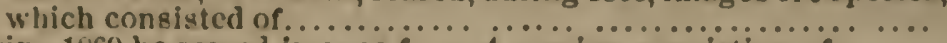

Jurint 1899 he reared imagng froin 4 specirs, consieting of........ 111 112

Mr. Buckler, of Emsworth, Hauts, during 1869, reared Imagos from it species, consisting of............................. $180 \quad 169$

Dr. Waltace, of Colchester, reared from une brood of Boinhyx

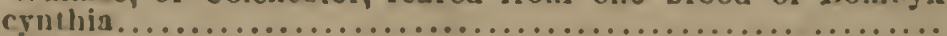

Dr. Wallace raiked, from cocoons of Hombyx ieruyl sent from

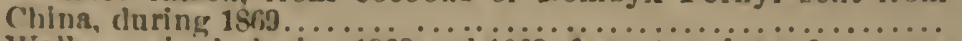

Dr. Wallace rafsed, during 1 sis and 1 seg, from two jots of cocouns of Jombyx yama-mai.

Nales. Fermalea.

Total

So that in these eight lots of cocoons and erges, males wero prodnced in excess. Taken together, tho proportion of males is

65 This naturalist has been so kiml as to send me some results from former years, in which the fenales seemed to preponderate; but so many of the figures were estimates, that I found it impossible to tabulate them 
as 122.7 to 100 females. But the numbers are liarlly larfe enougli to be truitwortly.

On tho whole, from the above various suarces of eridenee. all pointing to the sane direction, I infer that, with most fyecics of Lopicloptero, the males in the imann state fonerally crceed the icmules in number, whatever the proportions may be at their firs: encegence from the erpg.

With reference to the otlue Orders of insects, I havo been allo to collect very littlo reliablo information. With the stapbeetlo (Lueanus cereun) "tlic males apprear in to mucli moro vumerous than the females;" but when, as Corbelitas remarked durine 196\%, an uunwal aumber of them bectles ap pervel in wno part of Germang, the formales appunred to excued the snales as six to on.. With ono of the Filateridm, the males are nid to te much more numeroms thun the fomalos, and " eno or throv aro

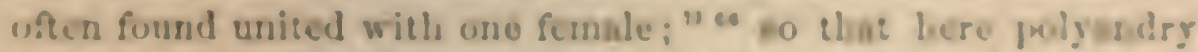

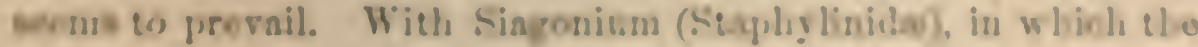
males aro furnished with longna. "the fermales am far more

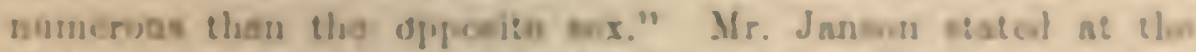

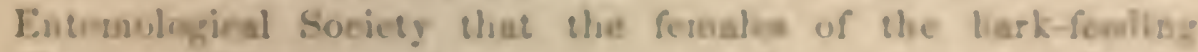

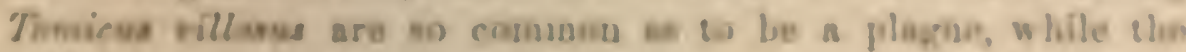

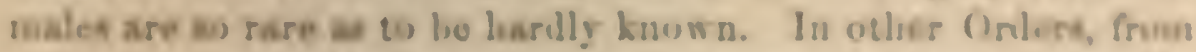

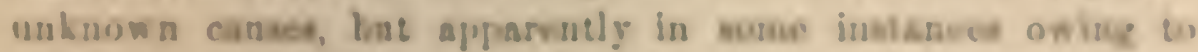

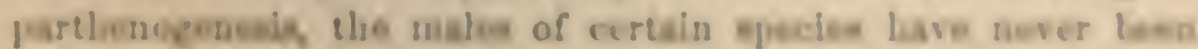

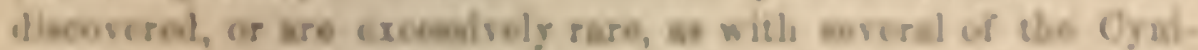

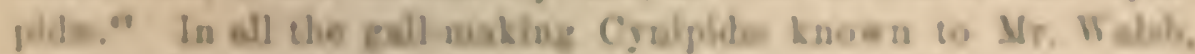

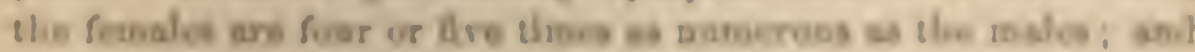

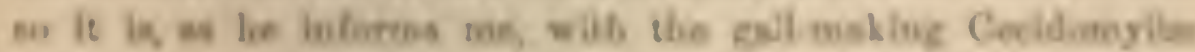

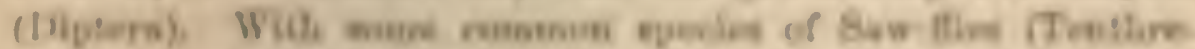

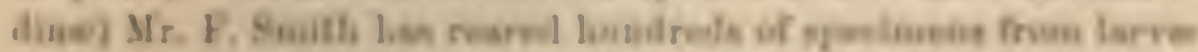

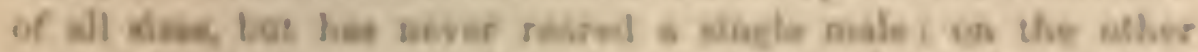

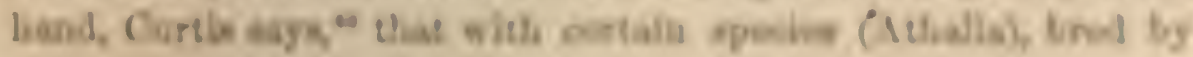

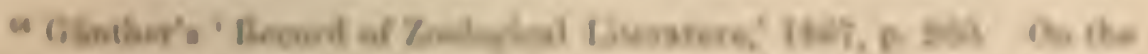

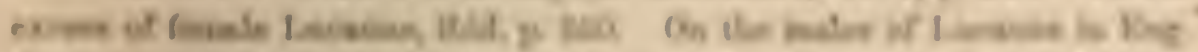

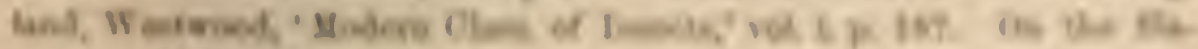
peras, thel. if ita.

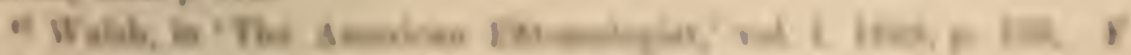

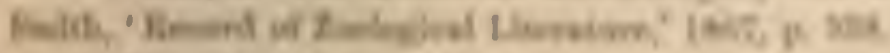

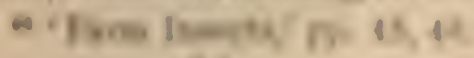


him, the males to tho females were as six to one; whilo exactly the reverso occurred with tho mature insects of the smo species canght in the fields. With the Neuroptern, Mr. Walsh stutes that in many, but by no means in all, the species of the Odonatous groups (Ephemerina), there is a great overplus of males; in the fenus Hetierina, also, the maley aro generally at least four tines as uumerous as the females. In cortain species in tho genus Gomplus tho males aro equally.numerous, whilo in two other species the fernales aro twice or thrice as numerous as the males. In some European species of Psocus thousmuls of females may bo collected without a single male, while with other species of the samo genus both sexes are common. ${ }^{\circ}$ In England, Mr. MacIachlan has captured hundreds of the female Apatania mulicuris, but has never seen the male; and of Borcus hycmalis only four or fivo males havo been hero seen. ${ }^{70}$ With most of these species (excepting, as I have henrd, with the Tenthredina), thero is no reason to suppose that the females aro subject to parthenogenosis; and thus we see how ignorant we are on the canses of tho apparent discrepancy in the fupportional numbers of tho two sexes.

In the other Classes of the Articulata I havo been able to colrect still less information. . With Spiders, Mr. Blackwall, who has earefully attended to this class during many years, writes to mo that tho males, from their moro erratic habits, aro noro commonly seen, and thereforo appear to bo tho more numerous. This is actually tho enso with a few species; but ho mentions several species in sis genera, in which tho females appear to bo much wore numerous than tho males." Tho small size of tho males in comparison with the females, which is sometimes earried to an extremo degree, and their widely-different appearance, may account in some instauces for their rarity in collections."

* 'Observations on N. American Neuroptera,' hy II. Hagau and B. D. Walsh, 'Proc. Eut. Soc. Philalelphia,' Oct. 1563, pl'. 168, 223, 239.

io 'Proc. Kint. Soc. London,' Feb. 17, 1868.

it Another great authority in this class, P'rof. Thorull of t'psala (' On European Spiders,' 1869-'70, part i. p. 20.5) speaks as if f(male spiders were generally eomunuer than the unales.

is See, on this suhject, Mr. Pickard.Chmbrilger, n' quoted in 'Quar. terly Jourual of Science,' 1 S68, 1) 1:8. 
Simme of the lower Criatacesins are able to propagate thels kisd an xually, and this will account for the extrezte rartig of

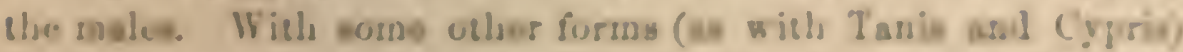
thero is reatron to beliore, as liritz Muller irsforns sac, tha: the

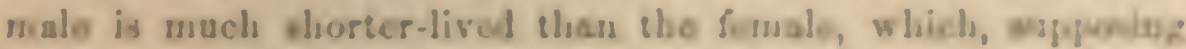
the two nexes to be at first egnal in number, weald explain the marcity of the males. On the ethe band, this sasno noturatim:

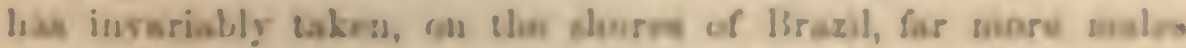

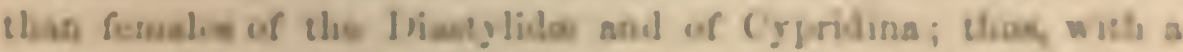

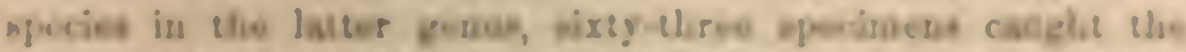

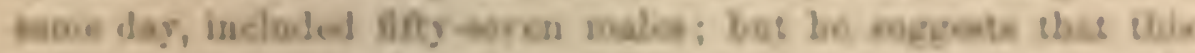

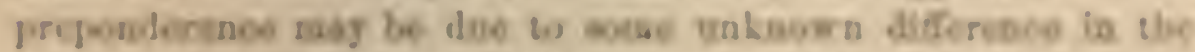

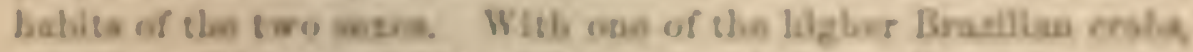

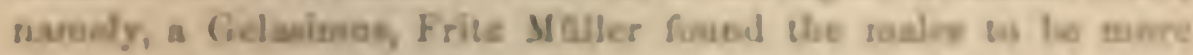

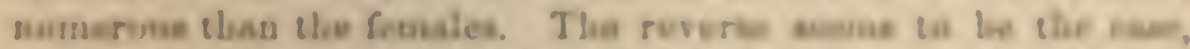
aenuriliar to the large experivuce of Mr. C. Spence Bate, with anx

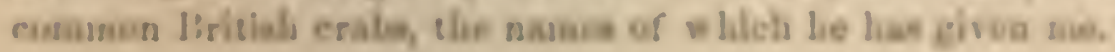

On the Pood of Sistumal delesion to rogulate the jom

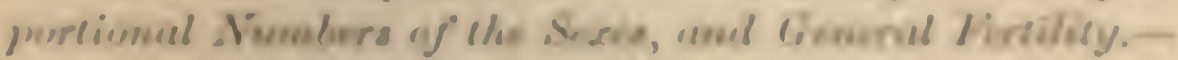
In wome poenilior cans, an excese in tlie number of ose nes oure the uther mighe le a great alvasutuge ws species. at with the eterile females of mocial insect, or with those

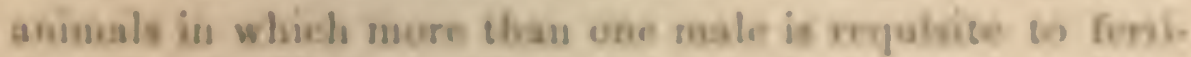
ties the fistale, as with certais cirrigedes and porkaje

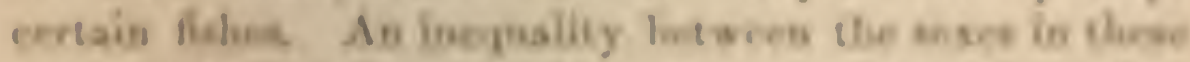
cases soleht lave been acyaiced throogh nataral wlection.

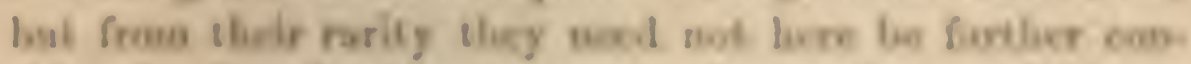

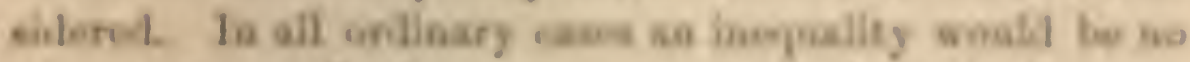

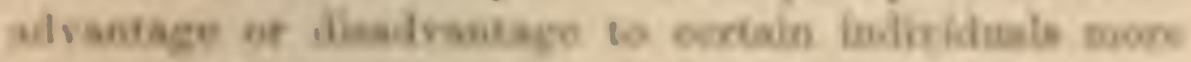

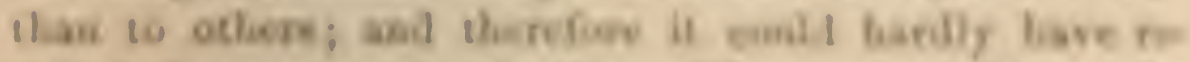

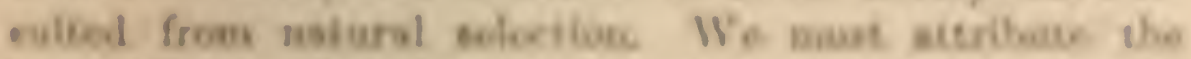

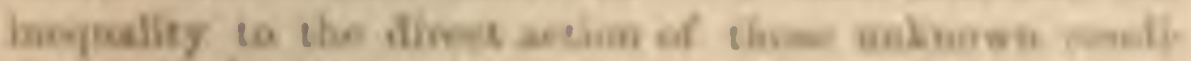

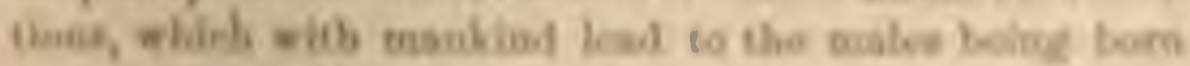

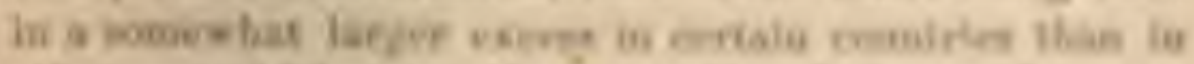

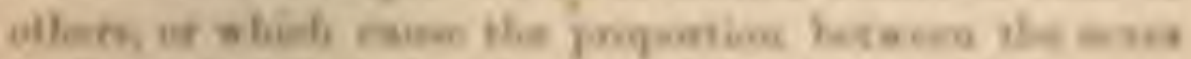

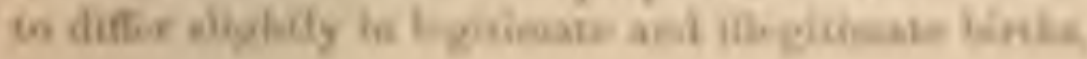


Let us now take the case of a species producing, from the unknown causes just alluded to, an excess of one sex -we will say of males-these being superfluous and useless, or nearly useless. Could the sexes be eqnalized through natural selection? We may feel sure, from all characters being variable, that certain pairs would prodnce a somewhat less excess of males orer females than other pairs. The former, supposing the actual nimber of the oflspring to remain constant, would necessarily produce more females, and would therefore be more productive. On the doctrine of chances a greater number of the offspring of the more productive pairs would survive; and these would inlierit a tendency to procreate fewer males and more females. Thus a tendeney toward equalization of the sexes would be brought about. But our supposed species would by this process be rendered, as just remarked, more productive; and this would in many eases be far from an advantage; for, whenever the limit to the numbers which exist depends, not on destruction by enemies, but on the amount of food, increased fertility will lead to severer competition and to most of the survivors being badly fed. In this case, if the sexes were equalized by an increase in the number of the females, a simultaneous decrease in the total number of the offipring would be beneficial, or eren necessary, for the existenee of the species; and this, I believe, could be efficted throngh natural selection in the manuer hereafter to be described. The same train of reasoning is applicable in the above, as well as in the following case, if we assume that females instead of males are produced in excess, for such females from not uniting with males would be superfluous and useless. So it would be with polygamous species, if we assume the excess of females to be inordinately great.

An excess of either sex, we will again say of the males, could, however, apparently be eliminated through nat nual 
sclection in another and indirect manner, wanely, ly au actual diminution of the inales, without any increase of the fernales, and consequently without any increase in the productiveness of the species. From the variability of all characters, we may feel assured that some pairs, inhabic. ing auy locality, would produce a rather smaller excess of superfuous males, but an equal number of productive females. When the oftspring from the more and the less mable-productive parents were all mingled together, none would have any direct adrautage over the others; but those that produced few superfluous males would have ouse grease indirece alvautage, namely, that their ora or cobryos would probably be larger and fime, or their young lecter untured in the womb and afterwarl. Wie sec this principle illustrated with plants; is those which bear a valt number of secel produce small ones; while thowe which bear comparatively fow seeds, often prosluce large once well-necked with mutrment for the use of the

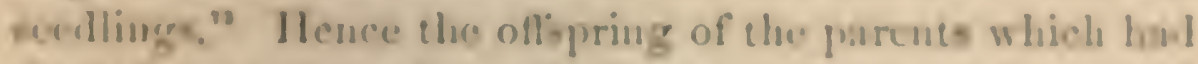
wased leset force in produciug kufuerfluous suales wothd he the turot likely to survire, and wouhd inherit the kame tendoueg not to produce superfluous nales, while retaining their full fertility in the production of fomales. So it would be with the convene pase of the finaleser. Any slightit exces, howerer, of vicher eor conld handly be

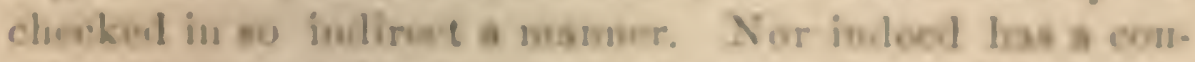

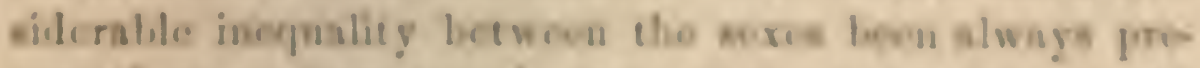

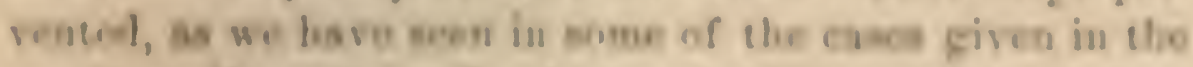

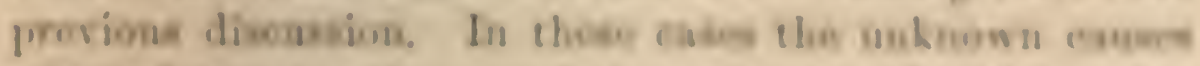
whet determine the mes of the embers, and whin nobr

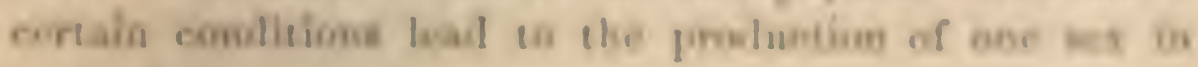

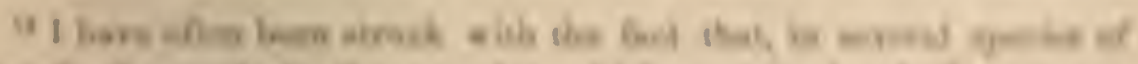

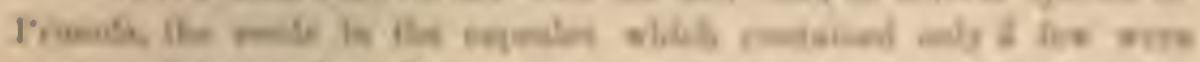

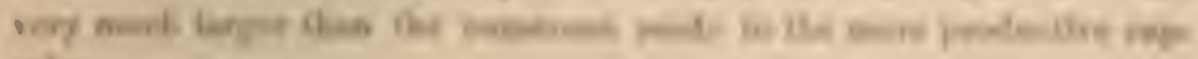
cole. 
cxecss over the other, have not been mastered by the surrival of those varieties which were subjected to the least waste of organized matter and force by the production of superfluous individuals of either sex. Nevertheless we may conclude that natural selection will always tend, though sometimes inefliciently, to equalize the relatire numbers of the two sexes.

Having said this much on the equalization of the sexes, it may be well to add a few remarks on the regulation throngh natural selection of the ordinary fertility of species. Mr. Herbert Spencer has shown in an able discussion " that with all organisms a ratio exists between what he calls individuation and genesis; whence it follows that beings which consume much matter or force in their growth, complicated structure, or activity, or which produee ora and embryos of large size, or which expend nunch energy in nurturing their young, cannot be so productive as beings of an opposite nature. Mr. Spencer funther shows that minor diflurences in fertility will be regulated through natural selection. Thus the fertility of each species will tend to increase, from the more fertile fairs producing a larger number of offspring, and these from their mere number will have the best chance of snlviving, and will transmit their tendency to greater fertility. The only check to a continued augmentation of fertility in each organism seems to be either the expenditure of more power and the greater risks run by the parents that produce a more numerous progeny, or the contingency of very numerous eggs and young being produced of smaller size, or less vigorous, or subsequently not so well nurtured. To strike a balance in any case between the disad vantages which follow from the production of a mmorous progeny, and the adrantages (such as tho

is 'Principles of Biulogg,' rol. ii. 1867, chans. ii.-xi. 
escape of at least some individuals from rarious daugers) is quite leyond our power of judgunent.

When an organisu has once been remdered-extremel: fertile, low its fertility cau be reduced through natural felection is not so clear as low this capascity wan first asyuired. Yet it is obvious that if individuals of a species, from a decrease of their natural encuice, were habicuall? reared iu larger numbers ihas could be supported, all the mombers would suffer. Nevertheles the oftepring from the leas fertile parcats would hare no direct aslvantage wrer lwe ofl-pring from the more fertile parents, whon all were mingled sogether in the same dietrice. Ill the indiviluals would mutully teul wo tarve each onber. "Tho oflepring indevel of else lowe fortile porenes would lie under come great diesdrantage, for, from the simple fact of leimg

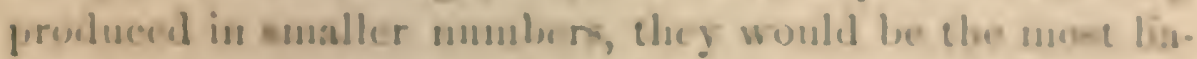
he to extermisacion. Indirecty, howeror, they would purtabe of oncegrest sulvasuge; for, usuler tho suppoed comblition of arere compecition, when all wore preseal for

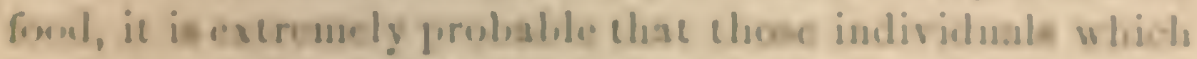

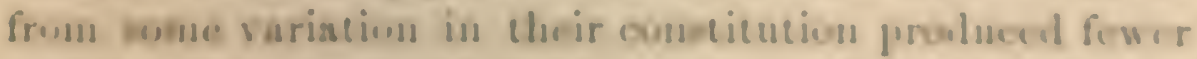
eges or soung. would probluce thom of grouser sise or bigur; aud the mblula ruaral frum awo egen or joung wentul manifosty have the bes elased of tarriving, and

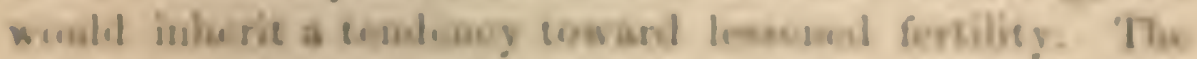

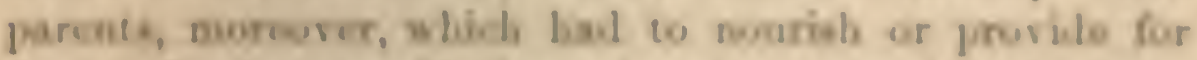

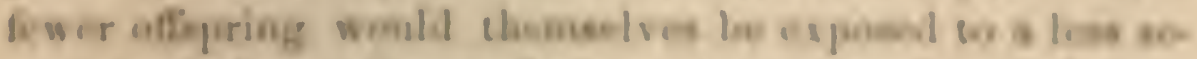

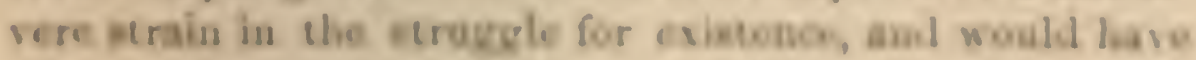

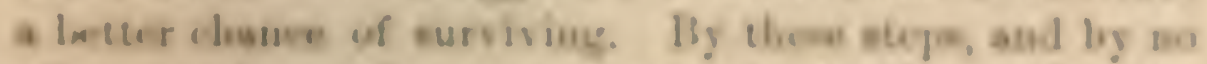
others as for as I cato coe, uasural eclection, ender the

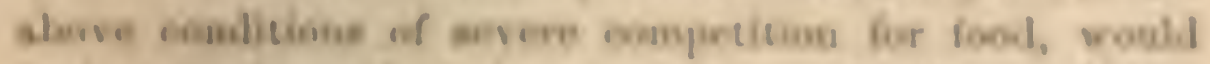

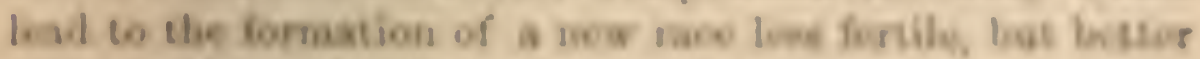

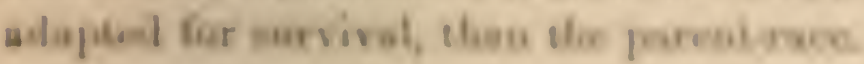




\section{CH A P TER IX.}

SECONDARY SEXUAL CIIARACTFRS IN THE LOWER CIASSLS OF THE ANIMAL KINGDOM.

Theso Characters absent in the Lowest Classcs.-Brilliant Colors.-Mollusca.-Annelids.-Crustacea, Secondary Scxual Characters strongly developed; Dimorphișm; Color; Characters not acquired before Maturity.-Spiders, Sexual Colors of; Stridulation by tho Malcs.Myriapoda.

Is the lowest classes the two sexes are not rarely united in the same individual, and therefore secondary sexual characters cannot be developed. In many cases in which the two sexes are separate, both are permanently attached to some support, and the one cammot search or struggle for the other. Moreover, it is almost certain that these animals bave too imperfect senses and much too low mental powers to feel mutual rivalry, or to appreciate each other's beauty or other attractions.

Hence in these classes, such as the Protozoa, Colenterata, Echinodermata, Scolecida, true secondary sexual characters do not occur; and this fact agrees with the belief that such characters in the higher classes have been acquired through sexual selection, which depends on the will, desires, and choice, of either sex. Nevertheless soine few apparent exceptious occur; thus, as I hear from Dr. Bairl, the males of certain Entozoa, or internal parasitic worms, difier slightly in color from the females; but we 
have no reason to suppose that such differences have been angmented through sexual selection.

Many of the lower animals, whether hermaplirodites or with the sexes separate, are ormanented with the most brilliant tints, or are shated and striped in an clegant manuer. This is the case with many corals and sea-ancmonces (Actini:e), with some jelly-fish (Medusat, Porpita, cte.), with some Planaria, Asciliane, numerous Star-fi-hes, Echini, ctce; hut we may conclude, from the reasous al. reasly indicated, namedy, the union of the two sexes in mome of these animals, the permanemty aftixul comblicion of ophers, and the low uncutal fowers of all, that such colure do not serre as a sexual attraction, and have not beon acyuired through sexual selection. With the higher andmals the case is very different; for with them when one sex is much more brillianty or econspicanu-ly colored than the other, and there is no diflerence in the habits of the two seres which will aceount for this difliresece, we lase reason (1) believe in the influemere of sexual selecrion; and shis bedief is stromegly conlirmed when the more ormament-

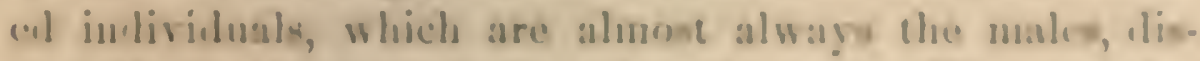
play their attractions before the wher nor. We mag ales

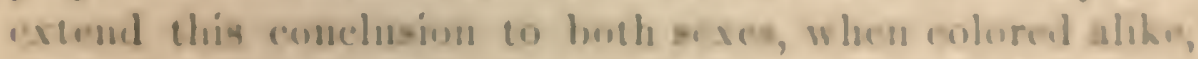
if their colork are plainly amblogeus to thoed of ome we alous in certain olfur species of the natue gromp.

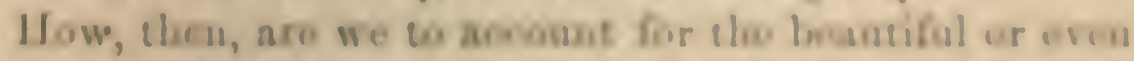

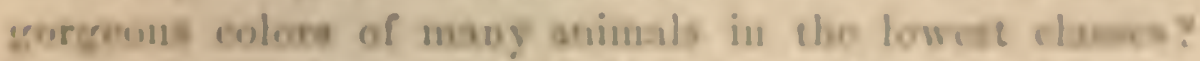

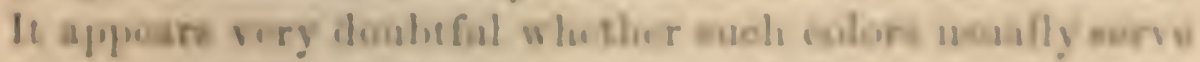
as a protection; lut we are criremely lisblo to err in ro

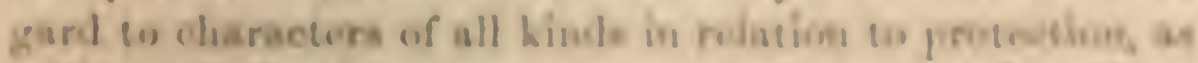
will be nelmitted by every one who has road Mr. Wal.

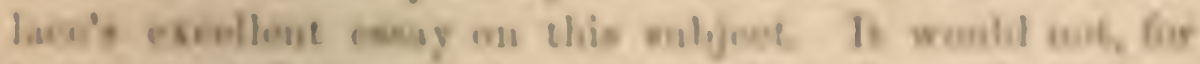
instauce, at firse oceur to ang one that sle perfoct trans.

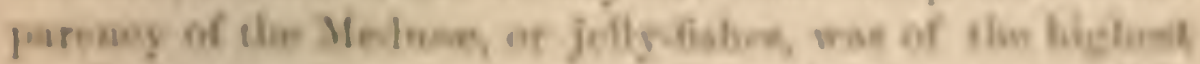

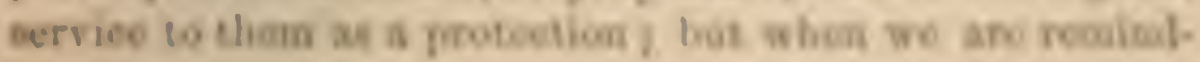


ed by Häckel that not only the medusa but many floating mollusca, crustaceans, and even small oceanic fishes partake of this same glass-like strueture, we can hardly loubt that they thus escape the notice of pelagic birds and ether enemies.

Notwithstanding our ignorance how far color in many eases serves as a protection, the most probable view in regard to the splendid tints of many of the lowest animals seems to be that their colors are the direct result either of the chemical nature or the minute structure of their tissues, independently of any benefit thus derived. Hardly any color is fincr than that of arterial blood; but there is no reason to suppose that the color of the blood is in itself any advantage; and though it adds to the beauty of the maiden's cheek, no one will pretend that it has been acquired for this purpose. So again with many animals, especially the lower ones, the bile is richly eolored; thus the extreme beauty of the Eolidie (naked sea-slugs) is chiefly due, as I am informed by Mr. Hancock, to the biliary glands seen through the translueent integuments; this beauty being probably of no service to these animals. The tints of the decaying leaves in an American forest are described by every one as gorgeous; yet no one supposes that these tints are of the least advantage to the trees. Bearing in mind how many substances closely analogous to natural organic compounds have been recently formed by chemists, and which exhibit the most splendid colors, it would have been a strange fact if substances similarly colored had not often originated, independently of any uscful end being thus gained, in the complex laboratory of living organisms.

The sub-kingdom of the Mollusca.-Throughout this great division (taken in its largest acceptation) of the animal kingdom, secondary sexual characters, such as we 
are here considering, uever, as far as I can discover, oceur. Nor could they be expected in the threc lowest classes, namely, in the Ascidians, Polyzoa, and Brachioporls (constituting the Molluscoida of IIuxley), for most of these animals are permauenty affixed to a support or loave their sexes united in the sane individual. In the Lamellibran. cliata, or bivalve shells, hermaphroditism is not rare. In the next higher class of the Gasteropoda, or marine univalve shells, the sexes are either united or separate. But iu this latter case the males never possens special organs for linding, securiug, or clanrming the females, or for fight. ing with other males. The sule exterual difierence be tween the sexes consists, as I am informed hy Mr. Giwn Jeftreys, in the shell sometimes liftering a litele in form; for instance, the shell of the male periwinkle (fillorine littoren) is narrower and has a more clungated spire than that of the female. But diflerentes of this nature, it may l.e presumed, are directly conneced with the act of repror duefion or with the develepursent of the ora.

The Gisenropodal, thougle capable of locosnotion and furnished with imperfect eges, to not spyeur (o) he as. dowed with anflioint mentil powers for the menthom if the same suc to 8 truggele together in rivalry, and thes 6 arquire encusulary soxual charach rs. Deverth les with the pulmoniforous gasteropoes, or labitmails, the pairins

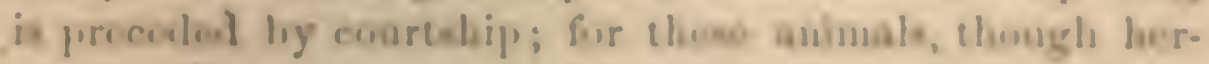

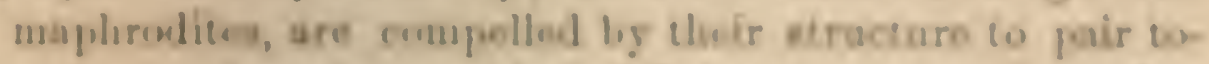

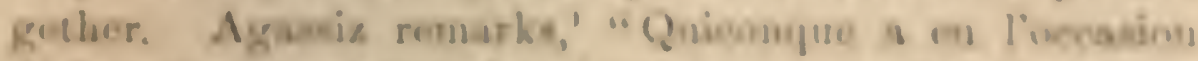

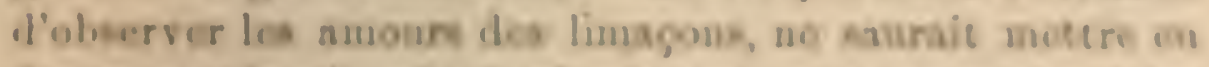

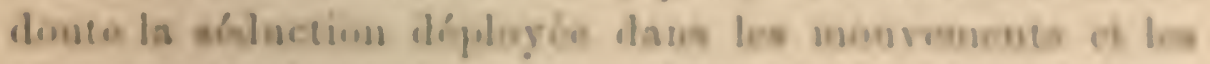

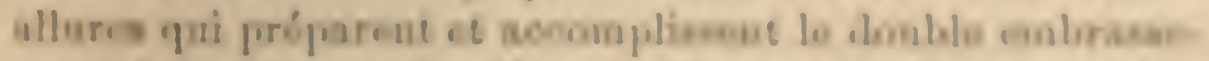

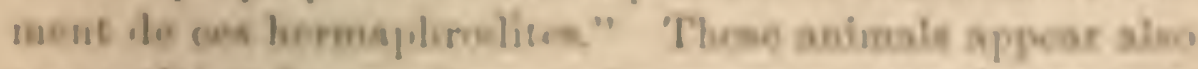

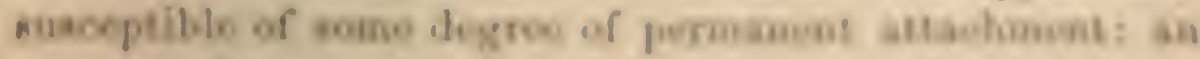

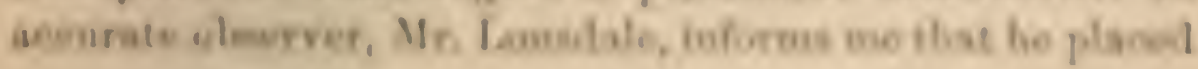

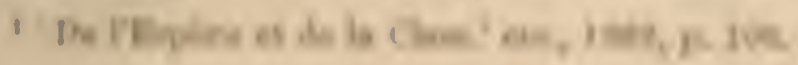


a pair of land-shells (Helix pomatia), one of which was weakly, into a small and ill-provided garden. After a short time the strong and healthy.individual disappeared, and was traced by its track of slime over a wall into an adjoining well-stocked garden. Mr. Lonsdale concluded that it had deserted its sickly mate; but after an absence of twenty-four hours it returned, and apparently communicated the result of its successful exploration, for both then started along the same track and disappeared over the wall.

Even in the highest class of the Mollusca, namely, the Cephalopoda or cuttle-fishes, in which the sexes are separate, secondary sexual characters of the kind which we are here considering do not, as far as I can discover, occur. This is a surprising circumstance, as these animals possess highly-developed sense-organs and have considerable mental powers, as will be admitted by every one who has watched their artful endeavors to escape from an enemy. ${ }^{3}$ Certain Cephalopoda, however, are characterized by one extraordinary sexual character, namely, that the male elcment collects within one of the arms or tentacles, which is then cast off, and, clinging by its sucking-disks to the female, lives for a time an independent life. So completcly does the cast-off arm rescinble a separate animal, that it was described by Cuvier as a parasitic worm under the name of IIectocotyle. But this marvellous structure may be classed as a primary rather than as a secondary sexual character.

Although with the Mollusea sexual selection does not seem to have come into play, yet many univalve and biralve shells, such as volutes, cones, seallops, etc., are beautifully colored and shaped. The colors do not appear in most cases to be of any use as a protection; they are

${ }^{2}$ See, for instance, the account which I have given in my 'Journal of Researches,' 1815, p. 7. 
probably the direct result, as in the lowest classes, of the nature of the tissues; the patterns and the sculpture of the shell depending on its manner of growth. The amount of light seems to a certain extent to be influential; for although, as repeatedly stated by Mr. Giwy Jeflreys, the shells of some species living at a profound depth are brightly colored, yet we generally see the lower surfitces and the parts covered by the mantle less highty colored than the upper and exposed surfaces." In some casces, as with fluells living anoug corals or brightly-tinted se:a-weeds, the bright colors may serre as a protection. But many of the nudibranch mollusea, or sea-shges, are as beatifully colored as any shells, as may be seen in Messrs. Alder and IIancock's magnificent work; and from information kindly given me by Mr. Hancock, it is extremely doubtiul whether these colors usually serse as a protection. With some species this may he the case, as with one which lives on the green leares of algae, and is itaelf bright green. But many l,rightyly-colored, white or otherwisc conkpenoms species, do not sech concealnent; while again ome equally conspicuous species, as well an uther dulleolored hinds, lise under stones sund in darh re censes. So that, with these modilirunch mollusks, colur apparrutly does not atund in any dowe relation to the nature of the placeon which they inlabitit.

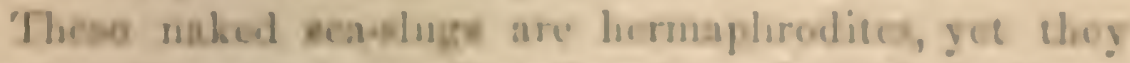
pair togethur, as do bantenaile, mang of which have es-

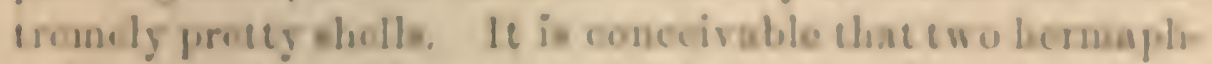
rolites, atcracted by each other's greater beanty, mighe unite and hase oflepring which would fiblerit cheir par ente' grenter lesury. Lint with surd lowl porysolined

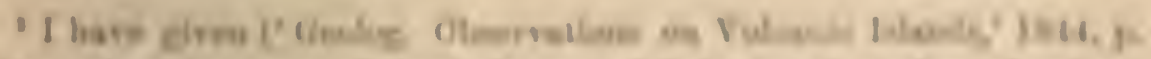

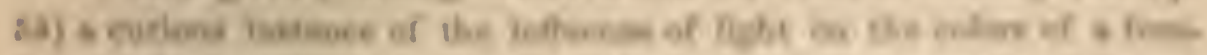

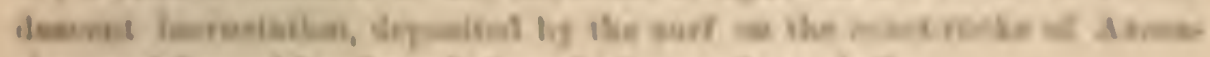

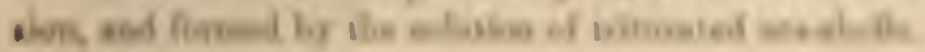


creatures this is extremcly improbable. $N$ or is it at all obvious how the offspring from the more beautiful pairs of hermaphrodites would have any advantage, so as to increase in numbers, over the offspring of the less beautiful, unless indeed vigror and beauty generally coincided. We have not here a number of males becoming mature before the females, and the more beautiful oncs selected by the more vigorous females. If, indeed, brilliant colors were beneficial to an hermaphrodite animal in relation to its general habits of life, the more brightly-tinted individnals would suceed best and would increase in number; but this would be a case of natural and not of sexual selection.

Sub-kingdom of the Vermes or Anmulose: Class, Annelictu (or Sea-10orms). - In this class, although the sexes (when separate) sometimes difter from each other in characters of such importance that they have been placed under distinct genera or eveu families, yet the differenees do not seem of the kind which can be safely attributed to sexual selection. These animals, like those in the preceding classes, apparcntly stand too low in the seale for the individuals of either sex to exert any choice in selecting a partner, or for tlie individuals of the same sex to struggle together in rivalry.

Sub-lingdom of the Arthropoda: Class, Crustarca.In this great class we first meet with undoubted secondary sexual characters, often developed in a remarkable manner. Unfortunately, the habits of crustaceans are very inperfectly known, and we cannot explain the uses of many structures peculiar to one sex. With the lower parasitic species the males are of small size, and they alone are furnished with perfect swimning-legs, autennæ and sense-organs; the females being destitute of these organs, with their bodies often consisting of a mere dis- 
torted mass. But these cestraordinary diflerences betwern the $\imath$ wo sexes are no doubt related to their widely-dinterent habits of life, and consecpuently do not concern us. In various crustaceans, belonging to distinct faurilies, the anterior antema are furnisherl with peculiar threal-like hodies, which are believed to act as smelliner-organs, amd thene are much more numerous in the males than in thê feubales. As the nales, without any unusual development of their olfactory organs, would ahuost certainly be alule sonser or later to fint the femalea, the increased number of the sumelling - threach has probably heen actured tirough soxual selection, by the beter provided males latring been the mose snecessul in finding partuers and in leaving off-pring. Frits. Mnfler has deceribed a no. markable dimorplice specius of 'lausis, in which the male is ropresested by two distinct forms, mever graluating iute cach other. In the ure form the male is furnishod with more mumerums smetling-threats, and in the other form with more poworful' and nore elongated chelse or pincess which serre (1) hold the fentale. Friz Mnller wug.

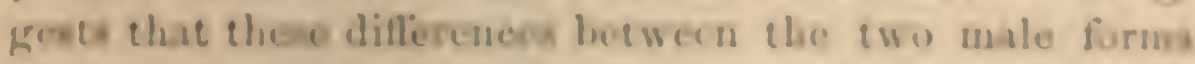

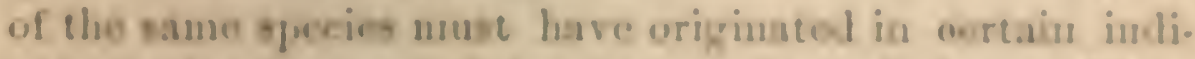
vidule having variel in the munber of the smallows. theals, while otler indirbluale varied in tho shope and

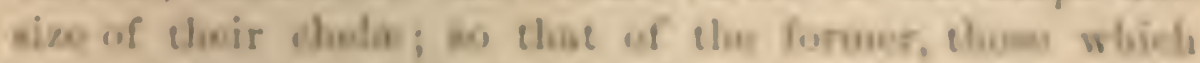
were liest able to find the forale, and of the lateer, thosa

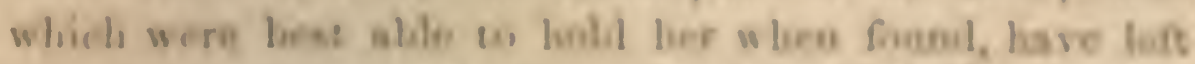
the greater utuber of peogony to isherit their rejuedive alvautuers."

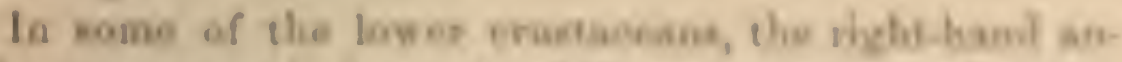

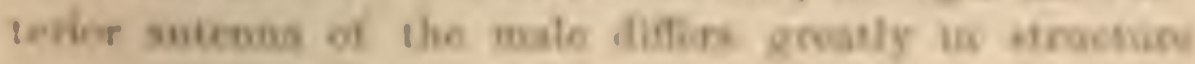

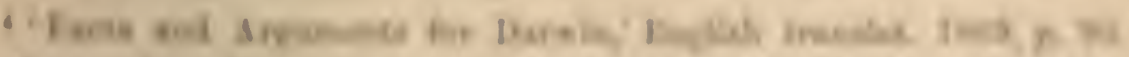

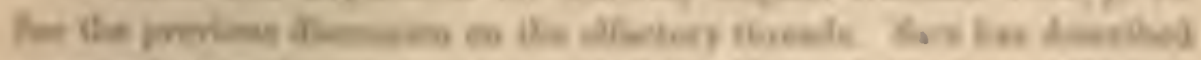

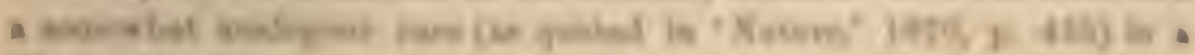

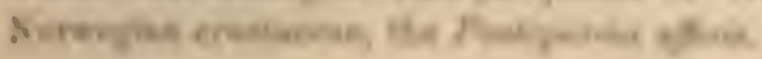


from the left-liand one, the latter resembling in its simple tapering joints the antenna of the fenale. In the male

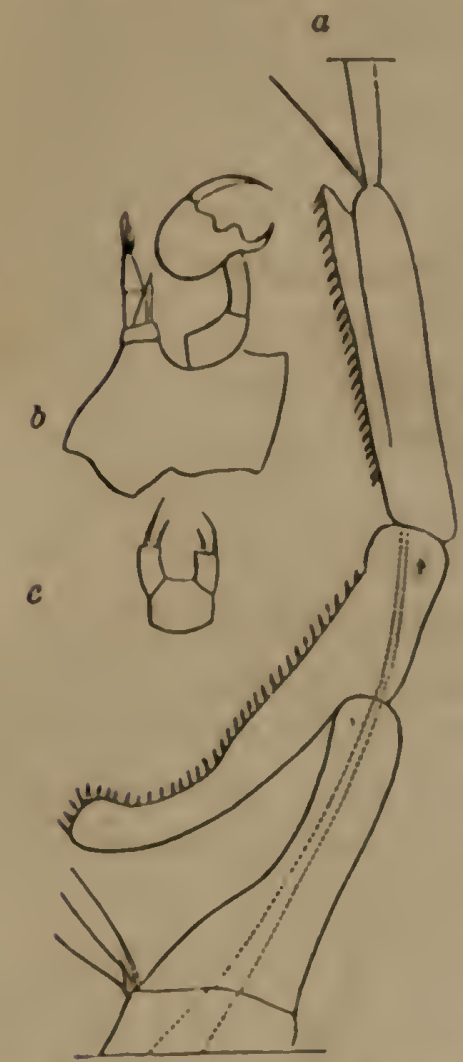

FIG. 3.-Lahidocera Darwini (from Lubbock).

a. Part of right-hand anterior antenna of unale, furming a prehonnile orcan.

6. Posterine mair of the thoracic leers of nuale.

c. Ditto of female.

the modified antemna is either swollen in the midulle or angularly bent, or converted (fig. 3 ) into an clegant, and sometimes wonderfully complex, prehensile organ." It serves, as I hear from Sir J. Lubbock, to hold the female, and for this same purpose one of the two posterior legs (li) on the same sicle of the body is converted into a forecps. In another family tlie inferior or posterior antemie are "curionsly zigzagged" in the males alone.

In the higher crustaceans the anterior legs form a pair of chela or pincers, and these are generally larger in the male than in the fomale. In many species the chela on the opposite sides of the body are of unequal size, the righthand one being, as I am informed hy Mr. D. Spence Bate, generally, though not invarialbly, the largest. This inequality is often much greater in the male than in the female. The two chele also often differ in structure (figs. 4,5 and 6 ), the smaller one resembling those of the fomale. What advantage is gained by their incquality in size

3 See Sir J. Lubhock in 'A muls. and Mag. of Nat. Ilit.' vol. xi. 1853, pls. i. and $x$. ; and rol. xii. (1-53) pl. rii. See also Lublock' in 'Transact. Eint. Sne.' rol. ir. new serics, $1856-16.58$, p. 8. With respect to the zigzagged antenne mentinned below, see Fritz. Müller, 'Facts and $\Delta$ rguments for Darwin,' 1S6?, p. 10, foot-notc. 
on the oppositu silles of the holy, ambly the incquality he ing much greater in the male than in the female; and why,

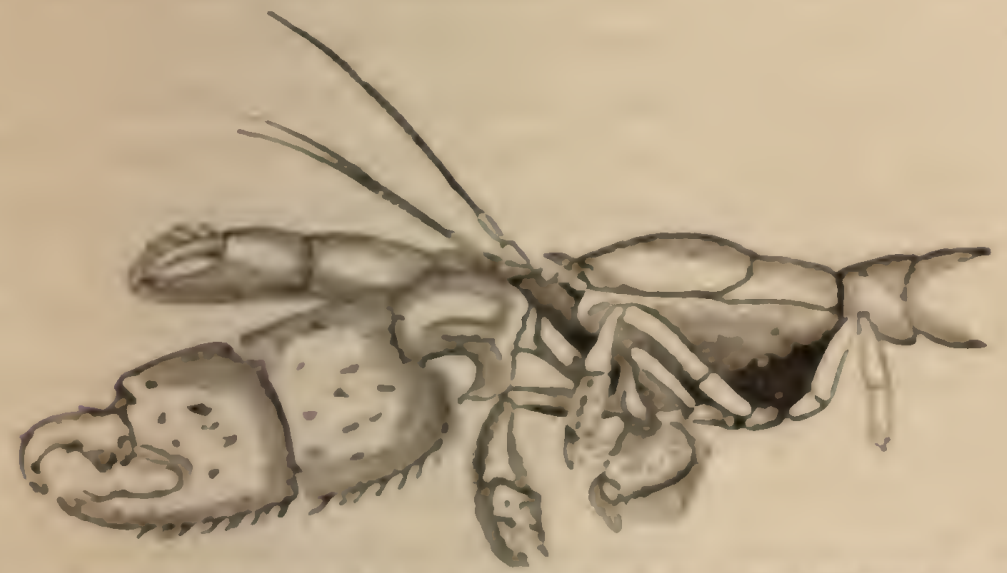

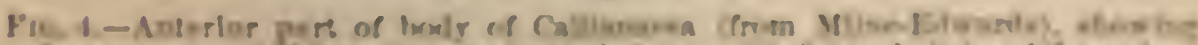

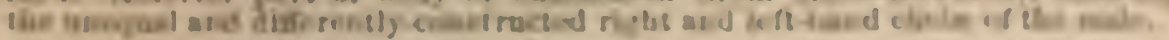

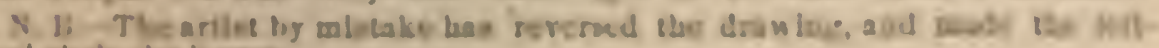
baud clocla the Leghet.

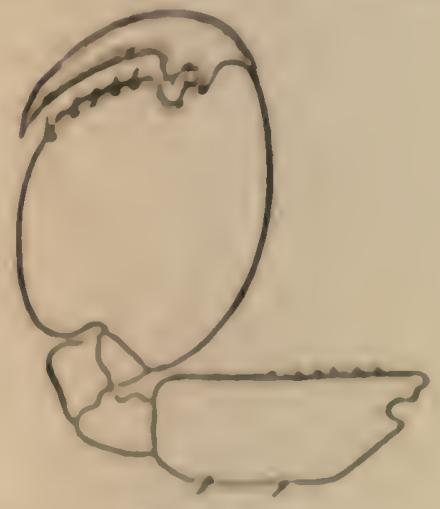

Me 8

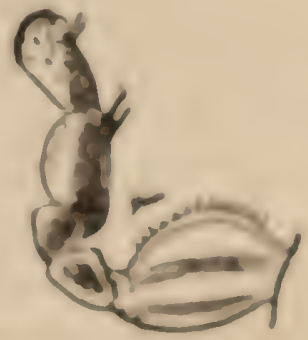

res

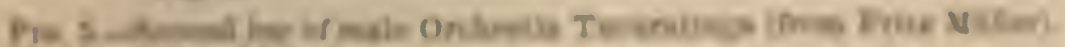

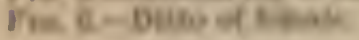

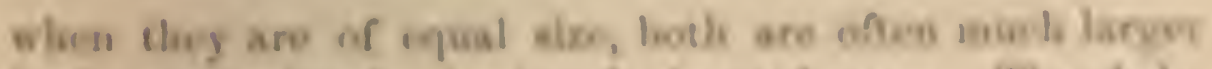

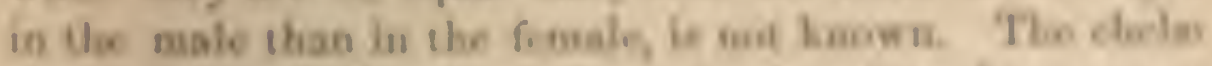

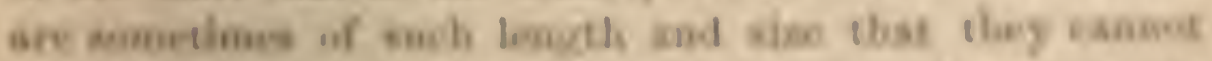

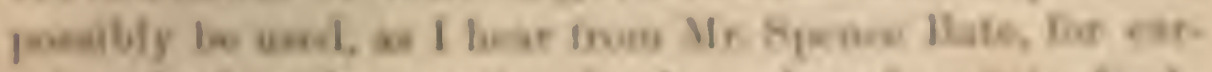

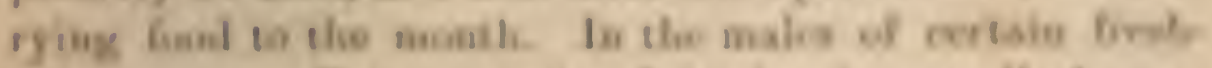
nater prawne (Tolowion) the rigbi log is ansually longer 
than the whole body. ${ }^{\circ}$ It is probable that the great size of one leg with its chelae may aid the male in fighting with his rivals; but this use will not account for their inequality in the female on the opposite sides of the body. In Gelasimus, according to a statement quoted by MilncEdwards, the male and female live in the same burrow, which is worth notice, as showing that they pair, and the male closes the mouth of the burrow with one of its chela, which is enormously developed; so that here it indirectly serves as a means of defence. Their main use, however, probably is to seize and to secure the female, and this in some instances, as with Gammarus, is known to be the case. The sexes, lowever, of the common shore-crab (Carcinus manas), as Mr. Spence Bate informs me, unite directly after. the female has moulted her hard shell, and when she is so soft that she would be injured if seized by the strong pincers of the male; but as she is caught and carried about by the male previously to the act of moulting, she could then be seized with impunity.

Fritz Müller states that certain species of Melita are distinguished from all other amphipods by the females having "the coxal lanellie of the penultimate pair of fect produced into hook-like processes, of which the males lay hold with the hands of the first pair." The development of these hook-like processes probably resulted from those females which were the most securely held during the act of reproduction having left the largest number of offspring. Another Brazilian amphipod (Orchestia Darvoinii, fig. 7 ) is described, by Frit\% Müller, as presenting a case of dimorphism, like that of Tanais; for there are two

${ }^{6}$ See a paper by Mr. C. Spence Bate, with figures, in 'Proc. Zoolog. Soc.' 1868, p. 363 ; and on the nomenelature of the genus, ibid. p. 585 . I am greatly indebted to Mr. Spence Bate for nearly all the abore statoments with respect to the chela of the higher crustaceans.

' 'Ilist. Nat. des Crust.' tom. ii. 1837, p. 50. 
male forms, which differ in the structure of their chela:" As chelat of either shape would certininly have sufficed to liold the female, for both are now used for this purpose, the two male forms probably originated, by some having varied in one mumer and some in another; both forms laving derived certain special but mearly equal advantages, from their diflirently-shaped organs.

It is not krown that male crusaceans fight together for the possession of the females, but this is probable; for with mo-t animals when the male is larger than the female, he seems to have acquired his greater size by las ing conquered duriug many generations other males. Now, Mr. Spence bate informs anc that in most of the crustactan orders, especially in the lighest or the Brachyura, the male is larger than the female; the parasitic genera, however, in which the sexes follow diflerent habits of life, and most of the lintomostraca must be exceptcel. The chelas of many crustaceans are weapous well alapted for fighting. Thus a Devil-crab (Portumes puber) was secu ly a son of Mr. Bate fighting with a Curcinus manas, amel the latter was soon tlrown on its back, and land every limb corn from its bolly. When several suales of a Brazilian (iclisimus, a species furniahed with inmense pincers, were placed cogether hy liriz Muller in a glases roted, they matiased and killed etsch other. Mr. liate pot a large

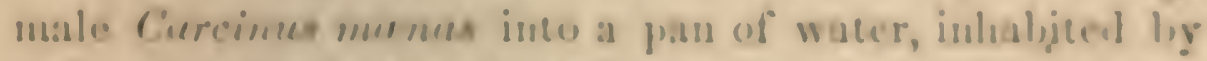
a female pairel with a smbller male; tlo lacter wak moun

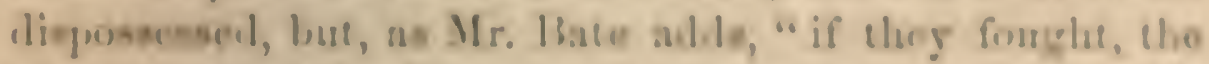

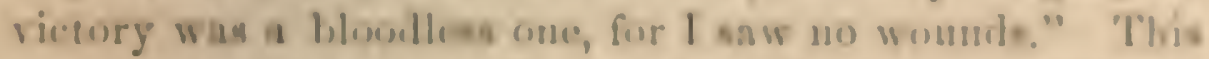
same uaturalit soptaracel a male undekippor (en commos

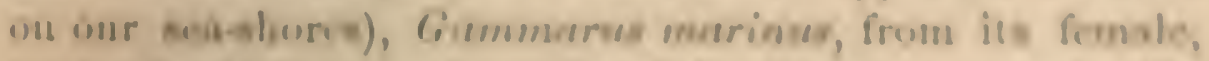
both of which were impriensud in tho mams rement with

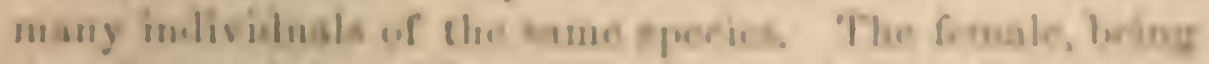

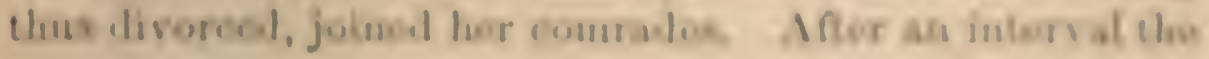

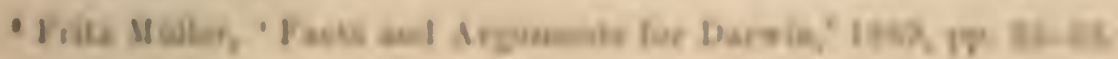


male was again put into tho same vessel and he then, after swimming about for a time, dashed into the crowd, and without any fighting at once took away his wife. 'This
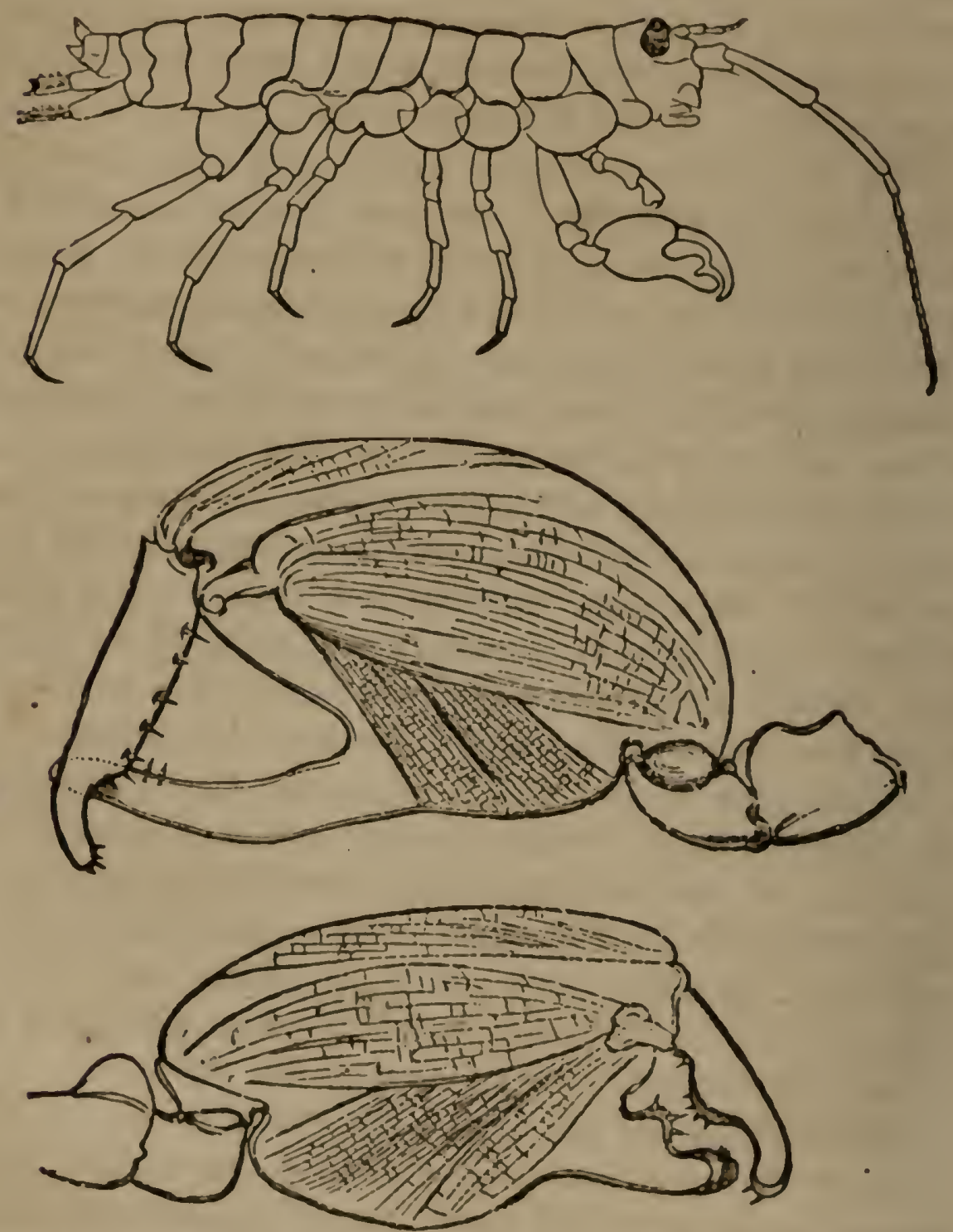

Fig. 7.-Orchestia Darwinil (from Fritz Manler), showing the diffurently-constructed chelse of the two malc forms.

fact shows that in the Amphipola, an oreder low in the scalle, the males and females recoguize each other, and are mutually attached. 
The mental powers of the Crustacea are probably higher than might have been expected. Any one who has tried to catch one of the shore-crabs, so numerous on many tropical coasts, will have perceived how wary and alert they are. There is a large crab (Birgus lutro), found on coral islands, which makes at the bottom of a decep burrow a thick bed of the picked fibres of the cocoa-nut. It feeds on the fallen fruit of this tree by tearing off the husk, fibre by fibre; and it always begins at that end where the three eye-like depressions are situated. It then breaks through one of these eyes by hanmering with its heary front pincers, and, turning round, extracts the albuminous core with its narrow posterior pincers. But these actions are probably instinctive, so that they would be performed as well by a young as by an old animal. The following case, however, can hardly be so convidered: A trustworthy naturalist, Mr. Garelner,' white watching a shorcerab (Gelasimns) making its burrow, threw some sliclls toward the hole. One rolled in, and three other shells remaned within a few inclies of the month. lin about fire minutes the crab lirought out the shell which had fallen in, and carried it ansy to the distance of a foot; it then saw the three other shells lying nesr, and cridently thinhing that they might likewise roll in, carried them to the opot where it hat hisd the linst. It would, I think, be difliente to distingnish this aet from one performed lieg min by the aid of reason.

With respect to colve which on ofton difters in the

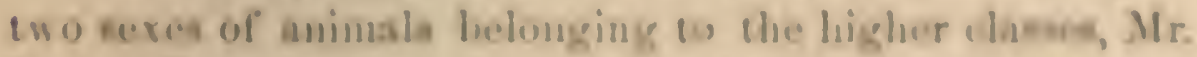
Spence bate doen not know of ang will-ziarked intanos

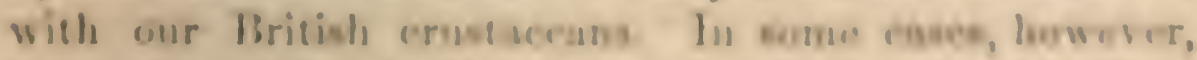
the male and formale differ somen hat in tine, led Str. Liate

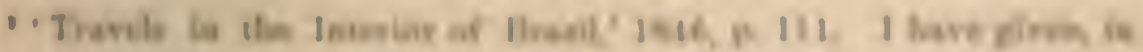

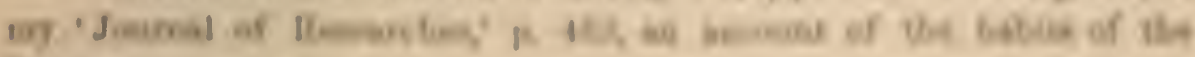
Mirges 
thinks not more than may be accounted for by their different habits of life, such as by the male wandering more about and being thus more exposed to the light. In a curious Bornean crab, which inhabits sponges, Mr. Bate could always distinguish the sexes by the nale not having the epidermis so much rubbed off. Dr. Power tried to distinguish by color the sexes of the speeies which inhabit the Mauritius, but always failed, except with one species of Squilla, proably the S. stylifera, the male of which is described as being "of a beautiful bluish-green," with some of the appendages cherry-red, while the female is clouded with brown and gray, "with the red about her much less vivid than in the male." In this case, we may suspect the agency of sexual selection. With Saphirina (an oceanic genus of Entomostraca, and therefore low in the scale) the males are furnished with minute shields or cell-like bodies, which exhibit beautiful changing colors; these being absent in the females, and in the case of one species in both sexes. ${ }^{11}$ It would, howerer, be extremely rash to conclude that these curious organs serve merely to attract the females. In the female of a Brazilian species of Gelasimus, the whole body, as I am informed by Fritz Müller, is of a nearly uniform grayish-brown. In the male the posterior part of the cephalo-thorax is pure white, with the anterior part of a rich green, shading into dark brown; and it is remarkable that these colors are liable to change in the course of a few minutes-the white becoming dirty-gray or even black, the green "losing much of its brilliancy." The males apparently are much more numerous than the females. It deserves especial notice that they do not acquire their bright colors until they become mature. They differ also from the fe-

10 Mr. Ch. Frascr, in 'Proc. Zoolog. Soc.' 1569, p. 3. I am indebted to Mr. Bate for the statement from Dr. Power.

" Claus, 'Dic freilebenden Copepoden,' 1863, s. ริ. 
males in the larger size of thrir chele. In some species of the genus, probably in all, the sexes pair and inlabie the same burrow. 'They are also, as we have secu, highlyintelligent animals. From the various considerations it seems highly probable that the male in this species has beconc gayly ormamented in orler to attract or excitc the fomale.

It has just been stated that the male Gelasinns doos not acpuire his couspicuous colors until mature and uearly ready to breet. 'This secus the gemeral rule in the whole class with the many remakable diflerences in structure between the two sexes. IVe shall hereafter find the same law prevaling thronghout the great sub-kingdoun of the Vertebrata, and in all cases it is eminently distinctive of characters which have been acquired through sexual selection. Frit\% Maller ${ }^{12}$ gives some striking instances of this law; thus the male sind-hopper (Orchestia) does not accunire his large claspers, which are very ditterently con. structed from those of the female, unt nearly full growu; while young his claspers resemble those of the fomale. 'Thus, again, the male brachyscehs pussesses, like all othe amphipods, a par of posterior antumse; the female, ami] this is a most extraordinary cireumstance, is destitute of them, and so is the mole as lomeg as he remains immoture.

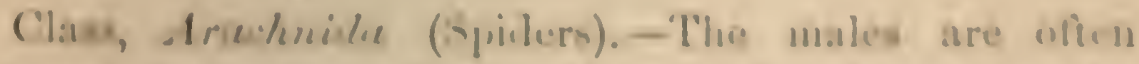

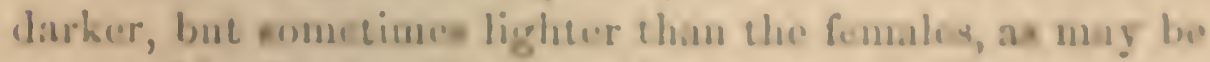

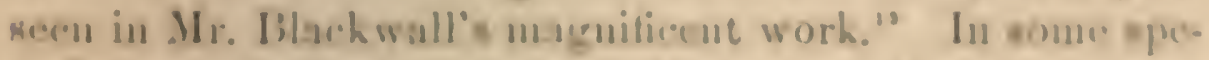

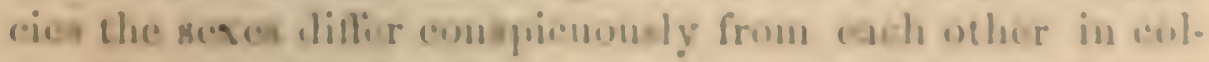

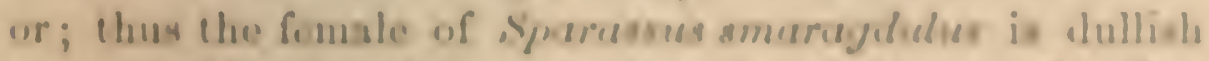
grous, while the alule male has the abilomen of at the sellow, with three longitudinal etripes of tioh rod. In

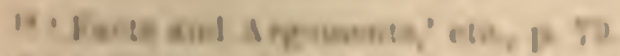

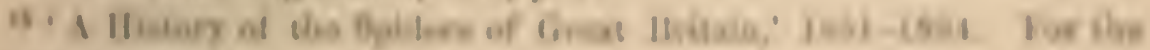

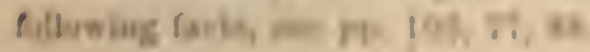


some species of Thomisus the two sexes closely resemble each other; in others they differ much; thus in $T$. citreus the legs and body of the female are pale yellow or green, while the front legs of the unale are redish-brown: in $T$ : floricolens, the legs of the female are pale-green, those of the male being ringed in a conspicuous manmer with various tints. Numerous analogous cases could be given in the genera Epeira, Nephila, Philodromus, Theridion, Linyphia, etc. It is often difficult to say which of the two sexes departs most from the ordinary coloration of the grenus to which the species beloug; but Mr. Blackwall thimks that, as a general rule, it is the male. Both sexes while young, as I am informed by the same author, usually resemble each other; and both often undergo great changes in color during their successive moults before arriving at maturity. In other cases the male alone appears to change color. Thus the male of the above-mentioned brightly-colored Sparassus at first resembles the female and acquires his peculiar tints only when nearly adult. spiders are possessed of acute senses, and exhibit much intelligence. 'The females often.show, as is well known, the strongest aflection for their eggs, which they carry about enveloped in a silken web. On the whole, it appears probable that well-marked differences in color between the sexes lave generally resulted from sexual selection, either on the male or female side. But doubts may be entertained on this head from the extreme variability in color of some species, for instance, of Therilion lineatum, the sexes of which differ when alult; this great variability indicates that their colors have not hecu subjected to any form of selection.

Mr. Blackwall does not remember to have seen the males of any species fighting torgether for the possession of the female. Nor, jullging from analogy, is this probable; for the males are gonerally much smaller than the 
females, hometines to an exiraorilinary degren." Had the males been in the labic of fighting together, they woule, it is probable, lasre gradually aequired greater size amd strength. Mr. Blackwall has nomerimes nees two or more malea on the mane wel, with a nimgle fumale; but their courthip is too todiuns aml prulongen an afiar to be casily olecriel. The male is extremely cantious in making his alvances, as the funale carries her cogmes on a daugeroun pitch. De (ieor saw a male that "in ilic urimet of his proparatery carreses was seized hy the ulijece of lis ate-utiont, aveloped by her in a wels and then ibvoured, a sight whinh, as be alds, filled him with lorror and ismignation." 10

Weiring has made the intersting discosery that the uale of mescral epecies of Therilios" have the pow of of mohing a stribslating sousd (like that made log matry beetlos and wher inmects, but fechler), while the fimalos aro quite unte. 'The apparkes conkines of a serrated ridge

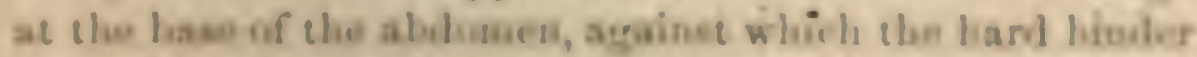

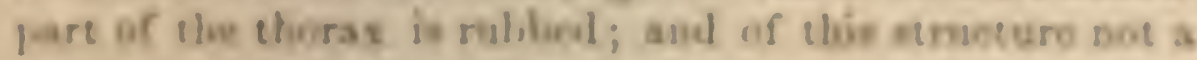

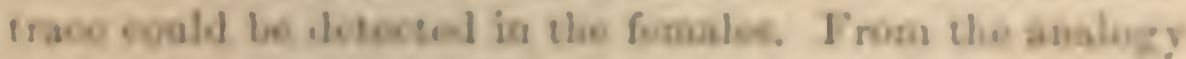
of the Oriboptera ant Ilowupters, to bo drecrited in the

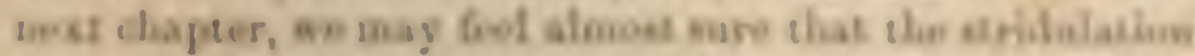
ecres, at Wedring remark, eltier to oll of to-pocite

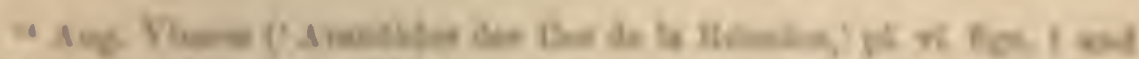
2) pine + pod te

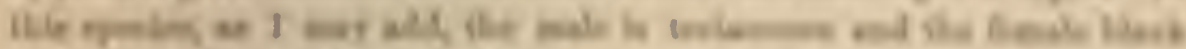

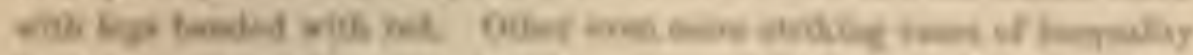

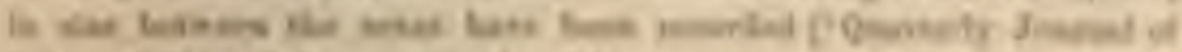

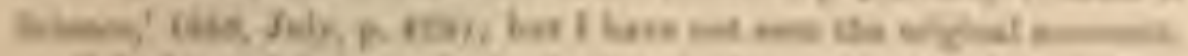

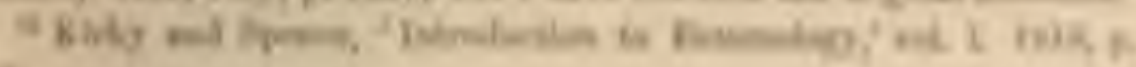
10.

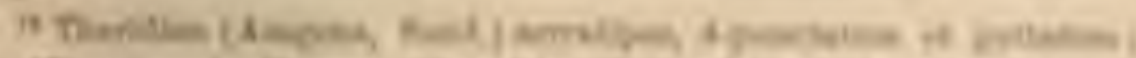

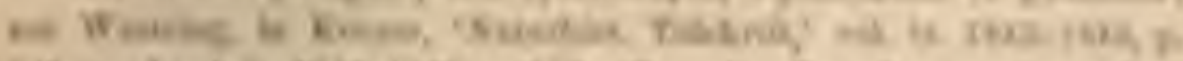

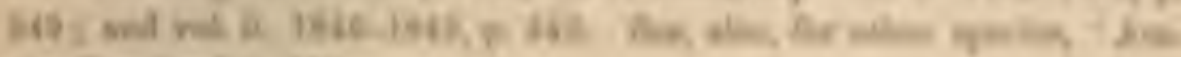

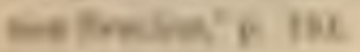


the female; and this is the first case in the ascending scale of the animal kingdom, known to me, of sounds emitted for this purpose.

Class, Mryriapoda.-In neither of the two orders in this class, including the millipedes and centipedes, can I find any well-marked instances of sexual differences such as more particularly concern us. In Glomeris limbata, however, and perhaps in some few other species, the males differ slightly in color from the females; but this Glomeris is a highly-variable species. In the males of the Diplopoda, the legs belonging to one of the anterior segments of the body, or to the posterior segment, are modified into prehensile hooks which serve to secure the female. In some species of Iulus the tarsi of the male are furnished with membranous suckers for the same purpose. It is a much more unusual circumstance, as we shall see when we treat of Insects, that it is the female in Lithobius which is furnished with prethensile appendages at the extremity of the body for holding the male. ${ }^{17}$

18 Walckenaer et P. Gervais, 'Hist. Nat. des Insectes; Aptires, tom iv. 184 i $\mathrm{pl} .17,19,68$. 


\section{ATER X.}

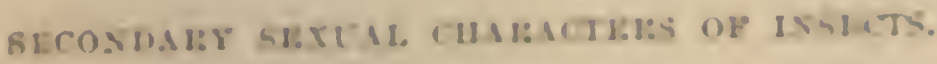

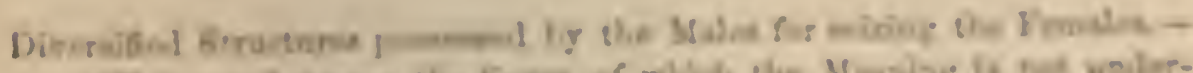

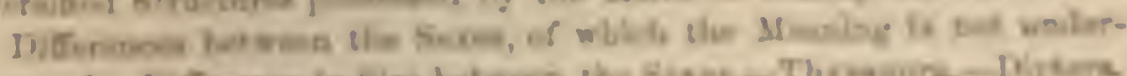

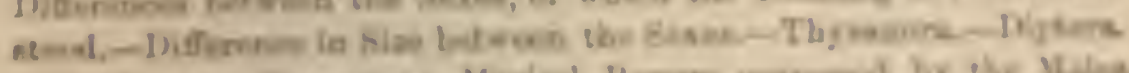

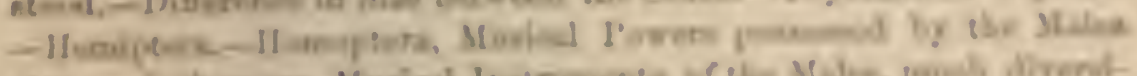

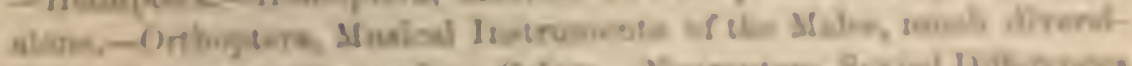

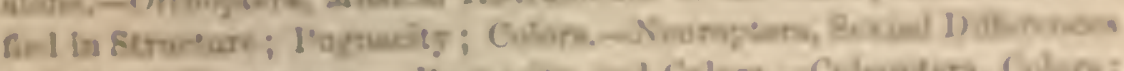

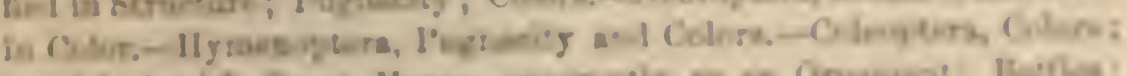

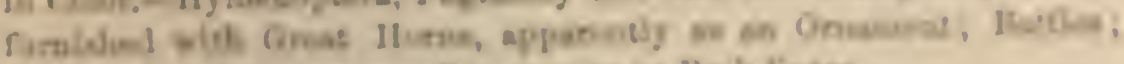

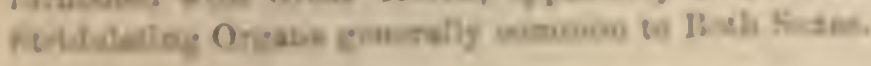

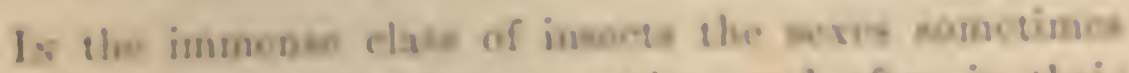
dilfir is their organ for locomotion, and oflen in their

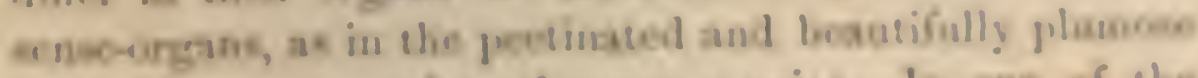
autcusas of the malies of man! quories. Ia obe of the

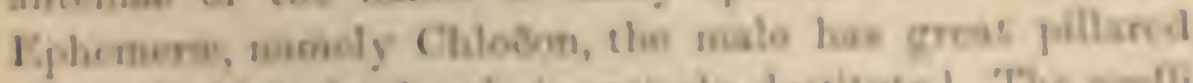

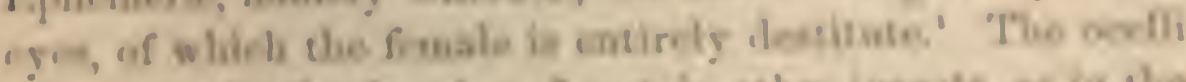

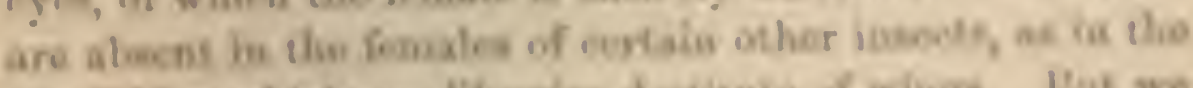

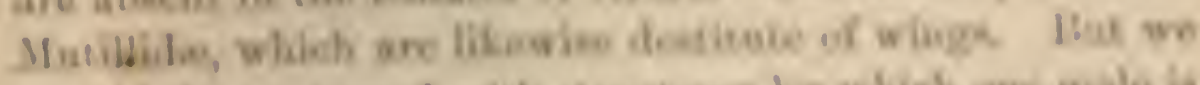

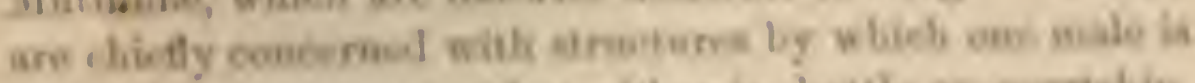

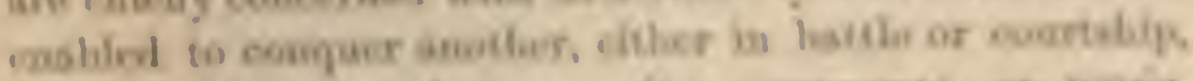

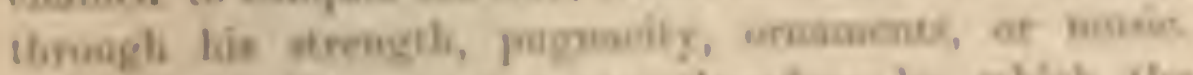

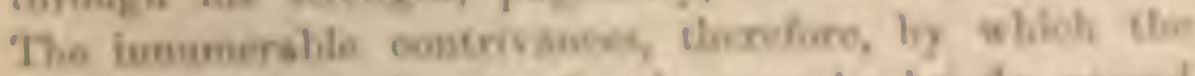

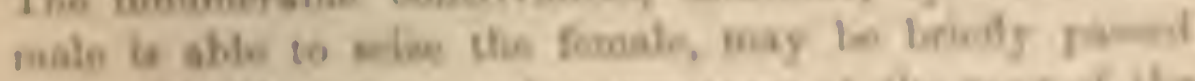

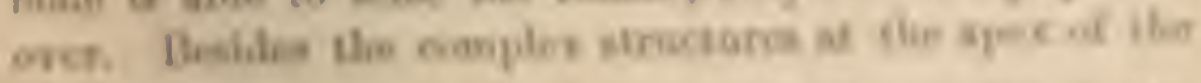

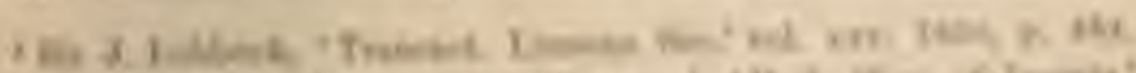

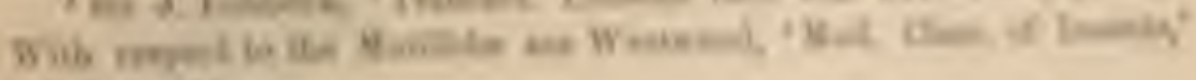
nita a 36 
abdomen, which onght perhaps to be ranked as primary organs, "it is astonishing," as Mr. B. D. Walsh" has remarked, "how many diflerent organs are worked in by Nature, for the seemingly insignificant object of enabling the male to grasp the female firmly." The mandibles or jaws are sometimes used for this purpose; thus the male Corydalis comutus (a neuropterous insect in some degree allied to the Dragon-flies, etc.) has immense curved jaws, many times longer than those of the female; and they are smooth instead of being toothed, by which means he is enabled to seize her without injury. ${ }^{4}$ One of the staggbeetles of North America (Lucanus claphlus) uses his jaws, which are much larger than those of the female, for the same purpose, but probably likewise for fighting. In one of the sand-wasps (Ammophila) the jaws in the two sexes are closely alike, but are used for widely-different purposes; the males, as Prof. Westwood observes, "are exceedingly ardent, seizing their partners round the neck with their sickle-shaped jaws;" while the females use

2 These organs in the male often differ in closely-allied species, and aftord excellent specific characters. Int their inportance under a func. tional point of view, as Mr. R. MacLachlin has remarked to me, has probably been orerrated. It has been sugrgested, that slight differenees in these organs would suffiee to prevent the intererossing of well-narked rarieties or incipient species, and would thus aid in their development. T'lat this can hardly be the case, we may infer from the many recorded cases (see, for instance, Bronn, 'Geschichte der Natur,' 13. ii. \$\$3, s 164 ; and Westwood, 'Transact. Ent. Soc.' rol. iii. 1812, p. 195) of dis. tinet species haring been obserred in union. Mr. MacLachlan informs me (vicle 'Stett. Fnt. Zeitung,' 1867, s. 155) that when several species of P'hryganida, which present strongly-pronouneed differenees of this kind, were confined together by Dr. Aug. Meyer, they coujled, and one pair produced fertile ora.

s 'The Practical Entomologist,' Plitadelphia, vol. ii. May, 1867, p. 88.

4 Mr. Walsh, iljicl. p. 107.

' 'Modern C'lassification of Insects,' vol. ii. 1510, pl. 206, 205. Mr. Walsh, who called my attention to this double use of the jaws, eays that he has repentedly obsersed this fact. 
- llese organ for burrowing in sand-luakt and making their nests.

The tarsi of the front-legs are dilated in many male beceles, or are furnished with broad cushions of lasio; and in many genera of water-beceles they are armed with a roumd flat sucker, so that the male may adtere to the slippery body of the fimale. It is amed urore unnsual ciprumstance that ehe fermales of some water-luceles (Dygtiocus) have eheir elgeras doeply geruesed, and in deilius nulcollet thichly set with hairs, as an aicl to the male. 'The fenalus of sonce otler waterlivelles (Hyolroporus) have their elytra punceurcel for the eame oliject. In the minle of Brulero eribrerius (lic.s), it is the ribia which it dilatod into a hond horny plate, will uiunes nembranema fork, giriuse en it a singularappearance like that of a rielelle? Iu the minles of lenelion (a gumus of
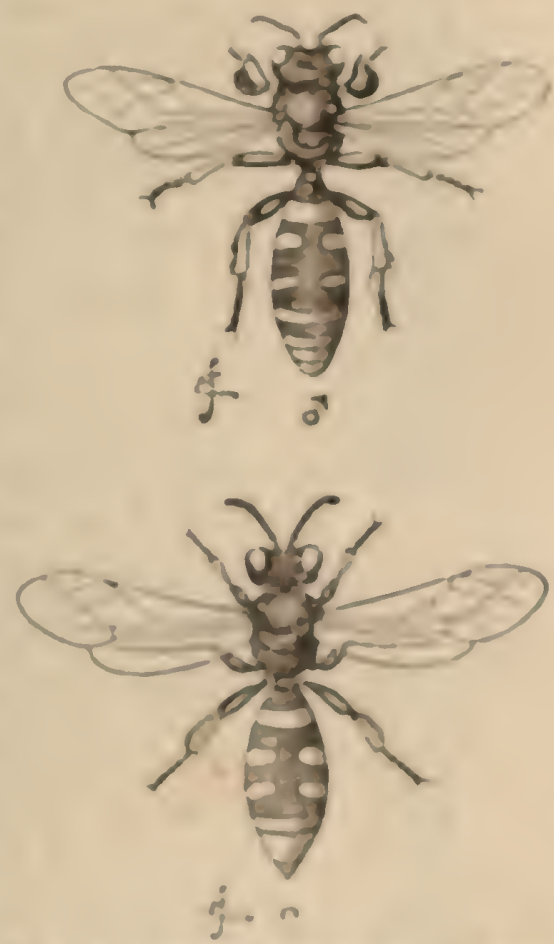

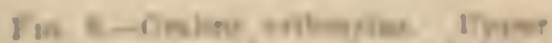

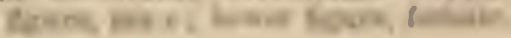
leethe) a fow of the middle joines of the ancennos are lilated and fornisbed on the inferior morfoce will, ensbiens

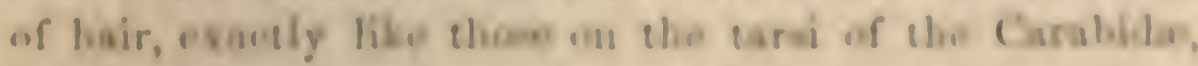

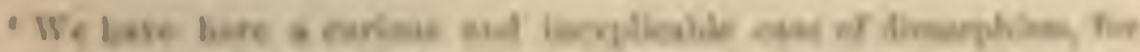

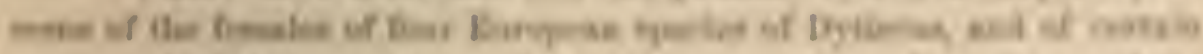

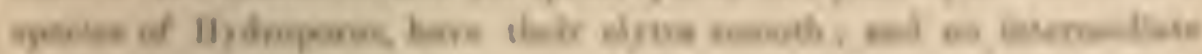

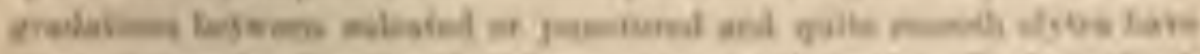

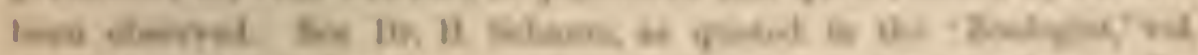

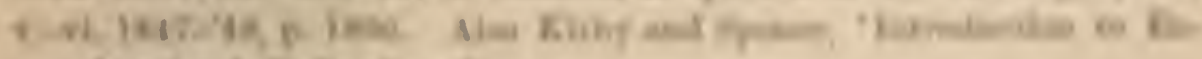

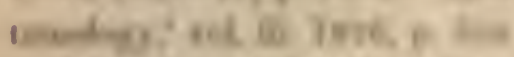

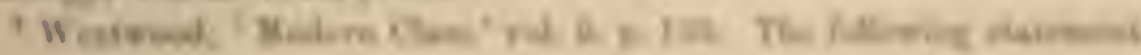


"and obviously for the same cnd." In male dragon-flies, "the appendages at the tip of the tail are modified in an

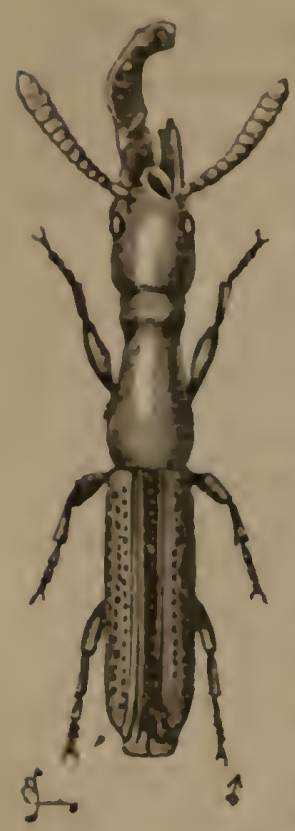
almost infinite variety of curions patterns to enable them to embrace the neck of the female." Lastly, in the males of many insects, the legs are furnished with peculiar spines, knobs, or spurs; or the whole leg is bowed or thickened, but this is by no means invarialbly a sexual character; or one pair, or all three pairs are clongated, sonetines to an extravaugant length. ${ }^{8}$

In all the orders, the sexes of many species present diflerences, of which the meaning is not understood. One curious case is that of a beetle (fig. 9), the male of which lais the left mandible much enlarged; so that the mouth is greatly distorted. In

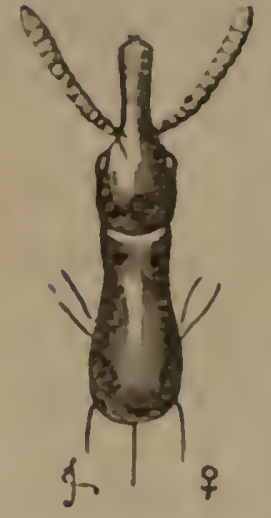

Fica. D. - Taphroderess dishertus (unuch culargedel). linerer lleure. mole: lower 11 sure, female. another Carabidous bectle, the Enrygnathus, we have the unique case, as far as known to Mr. Wollaston, of the head of the fomale being much broader and larger, though in a variable degree, than that of the malc. Any number of such cases could be griven. 'They abound in the Lepidoptera : one of the most extraorlinary is that certain male butterflies have their fore-legs more or less atrophied, with the tibia and tarsi reduced to mere rudimentary knobs. The wings, also, in the two sexes often differ in nenration, ${ }^{10}$ and sonetimes considerably

about Penthe, and others in inverted commas, are taken from Jr. Walsh, 'Pretical Eintomologizt,' Pliladelphia, rol. ii. p. 88.

' Kirby and Spence, 'Introduct.' etc., vol. iii. pp. $332-386$.

'Insicta Maderensia,' 15ii, p. 20.

"H. Doubleday, 'Aumals and Mag. of Nat. Hist.' rol. i. 1818, 1 879. 
in outline, as in the Ariooris quilus, which was shown to me in the Britis Museum by Mr. A. Lutler. The males of certain South American butterties have tufta of lair ou the margins of the wings, and horny excresenses un the di-hs of the pusterior pair." In several briti-h buttertlies, the males alone, as shown by Mr. Wonfor, are in ports eluelicd with peeuliar scales.

The purpose of the luminosity in the somale glow. worm is likewise not understood; for it is rery doubiful whether the prinary ute of the light is to guide the usule to the fensale. It is so surious objoction to this lateo lo-

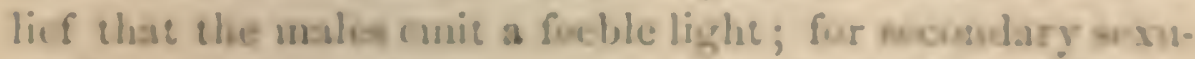
al characters proper to one sex are often dereloped in a slight degree in the other sex. It is a mone raliel uljesion that the larve shine, and in some species brilliantly: Frith Maller informs ase that the mont lunimus insect of hiels be eror belield in Braril was the hrva of nome becte. Bosh seres of ertain Inminoms fpecied of Elater muic lighs.

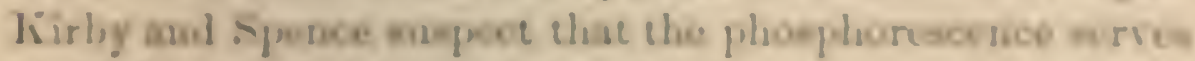
(o) frighten aud irive awny ruesies.

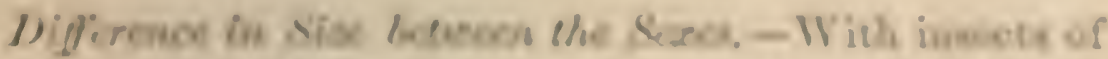

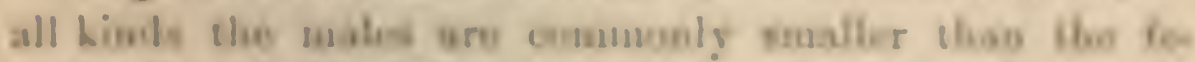

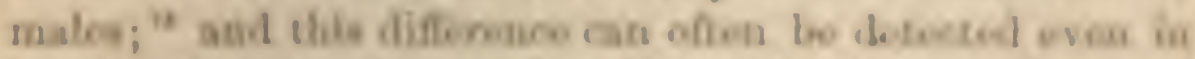

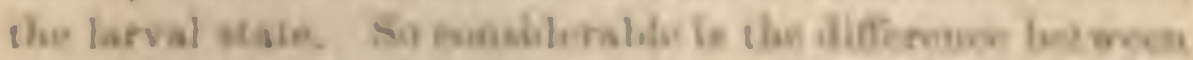

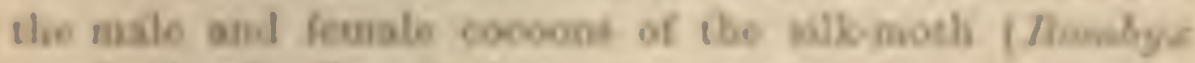

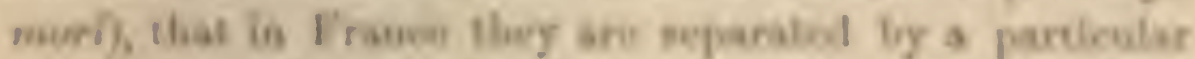

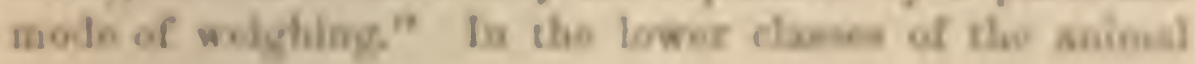

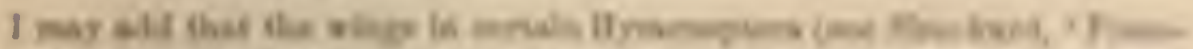

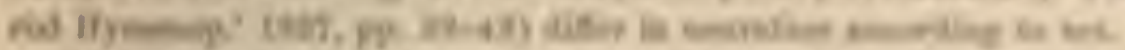

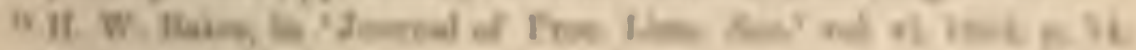

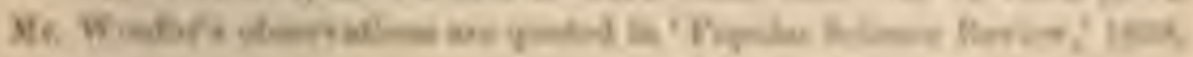
F. 511

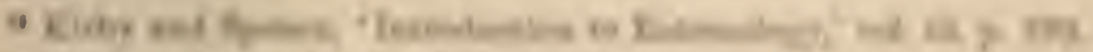

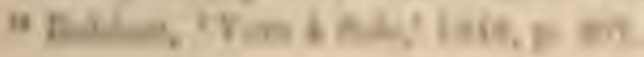


kingdom, the greater size of the females seems generally to depend on their developing an enormous number of ova; and this may to a certain extent hold good with insects. But Dr. Wallace has suggested a much more probable explanation. He finds, after carefully attending to the development of the caterpillars of Bombyx cynthic and yama-mai, and especially of some dwarfed caterpillars reared from a second brood on unnatural food, "that in proportion as the individual moth is finer, so is the timo required for its metamorphosis longer; and for this reason the female, which is the larger and heavier insect, from having to carry her numcrous eggs, will be preceded by the male, which is smaller and has less to mature." "Now, as most insects are short-lired, and as they are exposed to many dangers, it would manifestly be advantageous to the female to be impregnated as soon as possible. This end would be gatined by the males being first matured in large numbers realy for the advent of the females; and this again would naturally follow, as Mr. A. R. Wallace has remarked, ${ }^{18}$ through natural selection; for the smaller males wonld be first matured, and thus would procreate a large number of offipring which wouk inherit the reduced size of their male parents, while the larger males from being matured later would leave fewer offispring.

There are, however, exceptions to the rule of male insects being smaller than the females; and some of these exceptions are intelligible. Size and strength would be an advantage to the males, which fight for the possession of the female; and in these cases the males, as with the stag-beetle (Lucanus), are larger than the females. There are, however, other beetles which are not known to fight together, of which the males exceed the females in size. and the meaning of this fact is not known; but in some

" 'Transact. Fint. Soc.' 3d serica, vol. v. p. 486.

is 'Journal of P'roc. Eut. Soc.' Feb. 4, 1567, p. Ixxi. 
of these cases, as with the huge Dỵnates and Megasoma, We casn at least sece that there would be me meessity for tho males to be smaller than the females, in order to be matured before thesu, for these beetles are not shorelived, and there would be ample time for the paririm of the sesm. Si, ag:iu, male dragon-llies (Libellulida) are sometimes remsibly larger, and never smaller, than the females :" and they do mot, as Mr. Machoolulan believes, gencrally poir with the females, until a weck or fortuight has elopeol, aud until they have assumed their proyer mateuliue colors. But the most curious cane, showing on what conuplex and ratilyoncrlouhed relations fo tritling a charncter as a diflerence in size between the sexes may depend, is that of the aculeate Ilymenoptrat for Mr. F. Sinilh informs me that throughlout asearly the whole of this large group the unales, in aceorlasuee with the gemeral rule, are subller than the females amd eurerge ahout a werk before them; lint anong the Bees, the males of Apis melliples, Anthi-

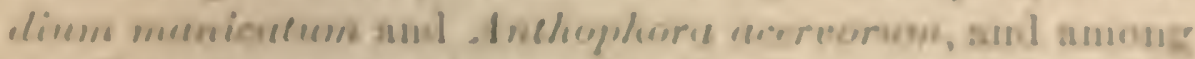

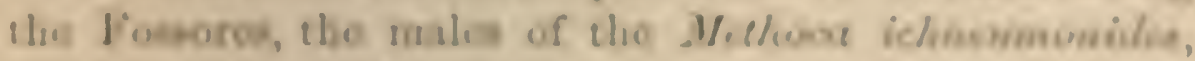
are larger than the foubles. The erplumatoms of this toumaly is that a marriagoslighe is aboolately uncesary

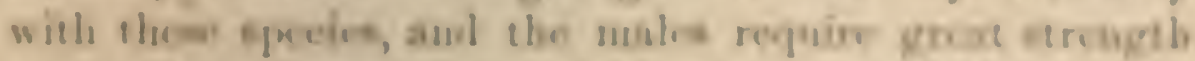
and tize in onder to carry the fomble throght the sic. Io.

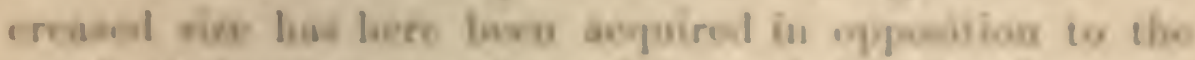

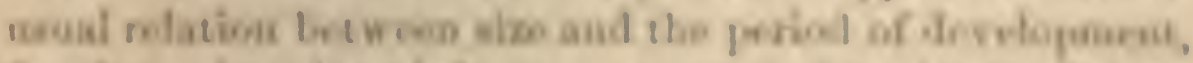

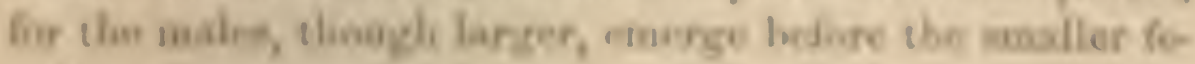
malion.

We will wer mriew the mreral Ondere, whetiug wels

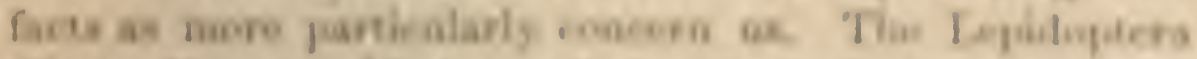

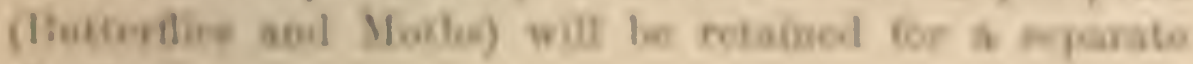
Chapter.

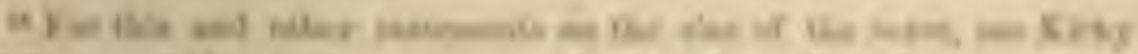

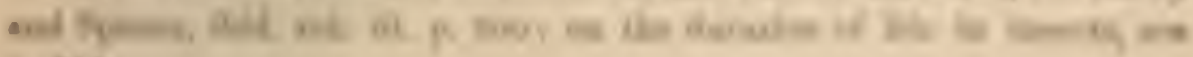
D. 311 
Order, Thysunura.-The nembers of this Order aro lowly organimed for their cliss. 'They are wingless, dullcolored, minute insects, with ugly, almost misshapen hemls and bodics. The sexes lo not ditler; but they ofticr one interesting fact, by showing that the males pay sedulous comrt to their females eren low down in the animal scale. sir J. Lubbock, ${ }^{\prime 7}$ in describing the smynthurus luteus, sitys: "It is very amusing to see these little crestures coquetting togrether. The male, which is much smaller than the female, runs round her, and they butt one another, standing face to face, and moving backward and forwad like two playful lambs. 'Tlun the female pretends to run away and the mule ruus after her will a queer appoarance of :uger, gets in frout and stands facing her again; then se turus coyly round, but he, quicker and more actire, scuttles romil too, and secus to whip her with his antemute; then for a bit they stand foce to fisee, play with their antenu:e, and secm to be all in all to one :mother:"

Oreler, Dipera (Flies).-The scxes dither little in color. 'The greatest dillerence, linown to Mr. F. Walker, is in the gems: lbibio, in which the males are llackish or quite black, and the females obseme brownish orange. The gemu lilaphomyia, discorered ly. Mr. Wallace ${ }^{10}$ in New lininea, is higlily seunarable, as the mules are furnished with homs, of which the female's are quite dentitute. The horus spring from bencit lis the cyos, and curionsly resemble those of stage, being cither hranched or palumated. They equal in length the whole of the borly in one of the spe cies. 'They might be thought to serve for fighting, hut, :4 in one species they are of a beantiful pinh-oblor, elgerl with black, will a pale central stripe, and as these insects have allogether a very clegant appearance, it is perlapes

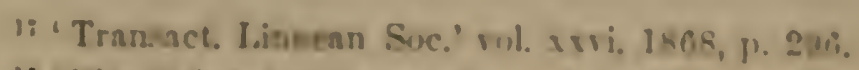

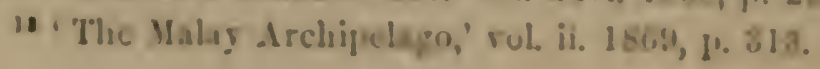


more probable that the luorus serve at urusmons. That the males of tove Dipuers figlut tugcelher is certain; for Prof. Wentwool " has oureral times nom thit with nome epecies of Tipula ar Ilarry-long-lege. Many oluervers helieve that when gnats (Calicida) dance in the air in a boily, alernately rising and falling, the males are cumrtiog

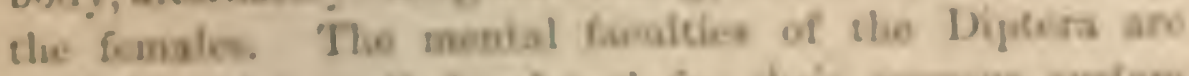

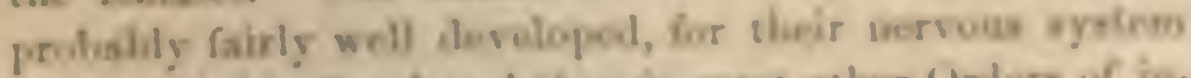

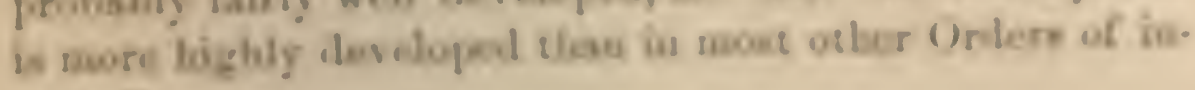
encts."

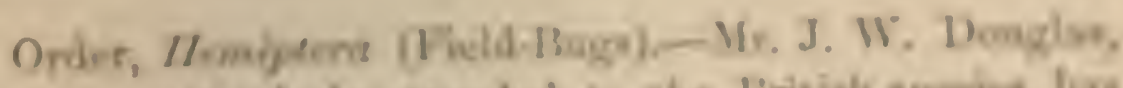

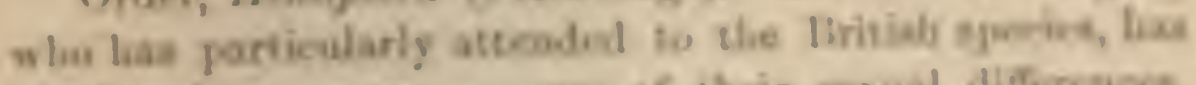

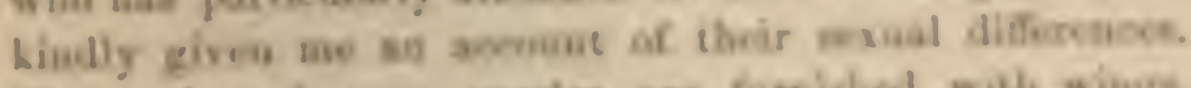

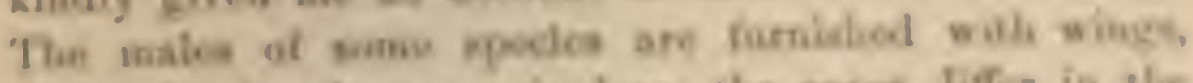

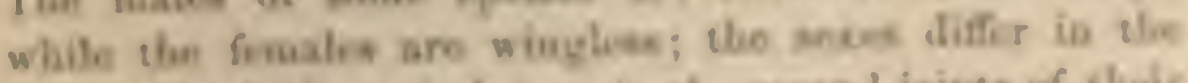

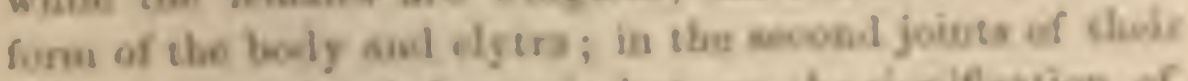

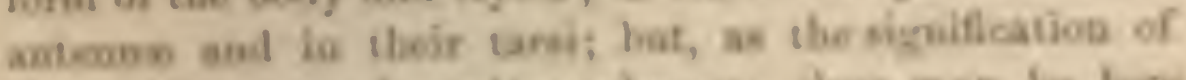

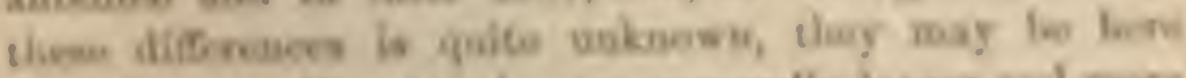

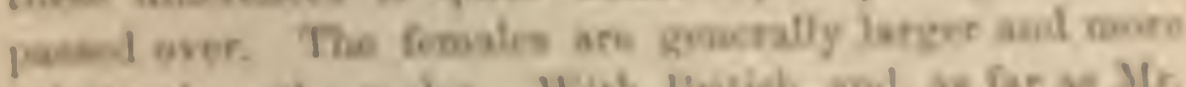
rolubt than the males. Wth lintish, and, an far sa Mr.

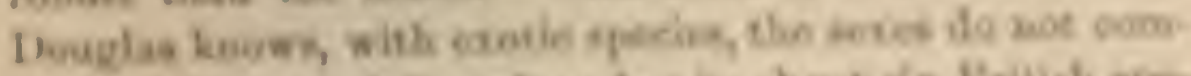

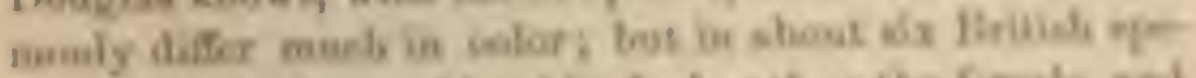

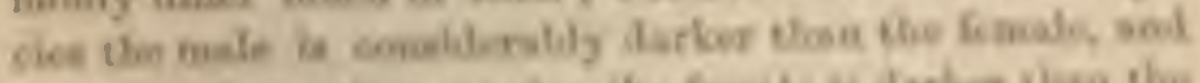

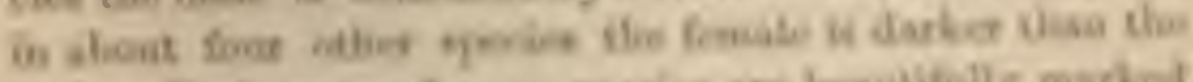

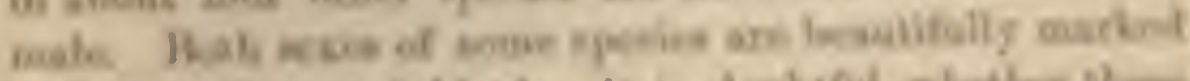

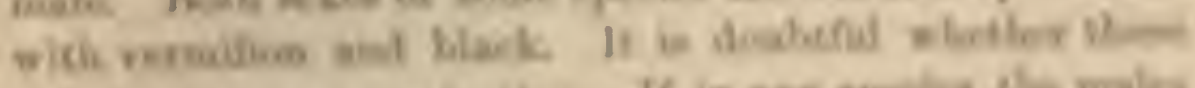

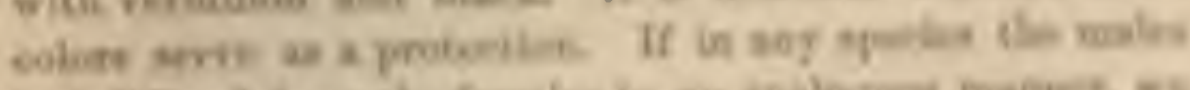

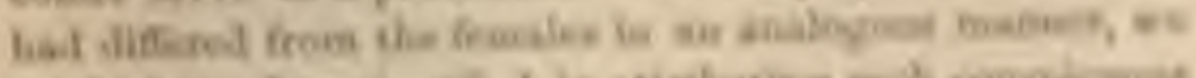

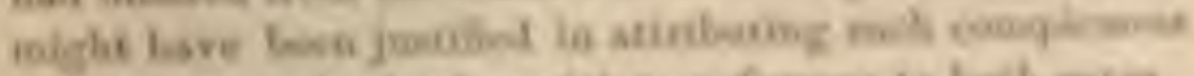

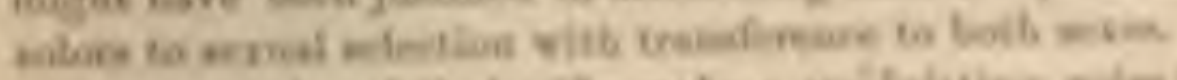

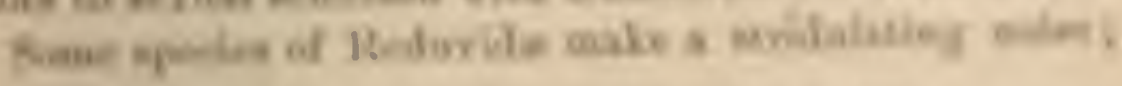

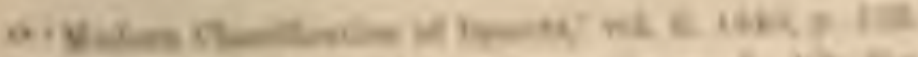

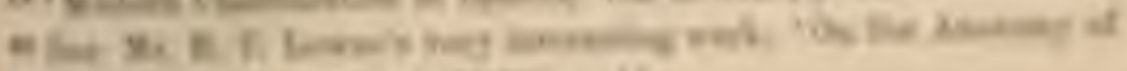

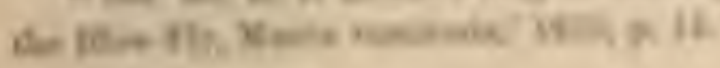


and, in the case of Pirates striclulus, this is said ${ }^{21}$ to he effected by the morement of the neck within the prothoracic cavity. According to Westring, Racluvius prersonatus also stridulates. But I have not been able to leam any particulars about these insects; nor have I any reason to suppose that they differ sexually in this respect.

Urder, Homoptera.-Every one who has wandered in at tropical forest must have been astonished at the din made by the male Cicada. The females are nute; as the Grecian poet Xenarchus says, "Happy the Cicadas live, since they all have roiceless wives." The noise thus male could be plainly heard on board the "Beagle," when anchored at a quarter of a mile from the shore of Brazil; and Captain Hancock says it can be heard at the distance of a mile. 'The Greeks formerly kept, and the Chinese now keep, these insects in cages for the sake of their song, so that it must be pleasing to the ears of some men. ${ }^{32}$ The Cicadida usually sing during the day; while the Fulgoridie appear to be night-songsters. 'The sound, according to Landois, ${ }^{23}$ who has recently studied the subject, is produced by the vibration of the lips of the spiracles, which are set into motion by a current of air emitted from the trachex. It is increased by a wonderfully complex resounding apparatus, consisting of two cavities covered by seales. Hence the sound may truly be called a voice. In the female the musical apparatus is present, but very much less developed than in the male, and is never used for producing sound.

With respect to the object of the music, Dr. Hartman,

21 Westwood, 'Modern Class. of Insecte,' vul. ii. 1) 4 'i3.

22 These particulars are taken from Westwood's 'Modern Class. of Inscets,' rol. ii. 1810, p. 422. Sec, also, on the Fulgoridat, Kirby and Spence, 'Introduct.' rol. ii. p. '411.

93 '\%citsclurift für wissenschaft. Zoolo:'.' 13. xvii. 1867, s. 152-158. 
in spesking of the cienta scpetemecim of the Unitud Statce, says:" "Tlue drums are now (Juse Glh aud ith, 1851) leard in all directions. 'This I believe to be the marital sumuous from the uales. Standing iu thick chestunt-sprouts about as high as my heal, where hundreds were around me, I observed the females comin around the drumming males." He adels: "This scuson (Augu-t, 1868) a dwarf pear-tree in my garden produced about fify larvat of Cic. pruinosa; aud I several times uoticed the fomales to alight near a malo while he was uttering his clanging notes." Fritz. Maller writes to me from Southeru lirazil that he has often lintemed to a um-ical contest between 2 wo or three urales of a Cicada, has ing a particularly loud roice, and seated at a consideralile distance from cavels other. As soon as the firse hat fin. ished lis some, a secoud iumediately lugan; am after be had coucluded, aurotace lregau, and so ou. As thore is an much rivalry between the males, it is probable that the fomales uot ouly discoser them ly the sumbls euitherl, bue that, like feumbe birols, they are excited or allund by the male with the most attractive wiece.

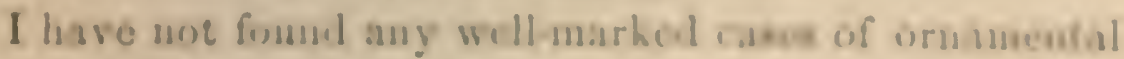

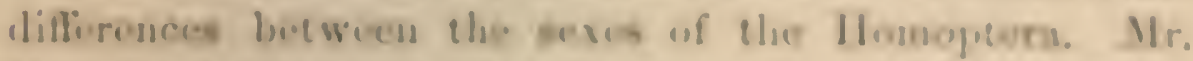

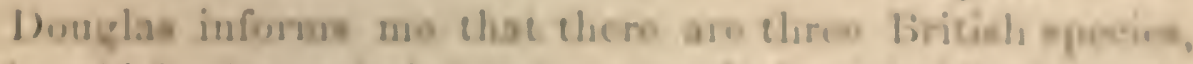

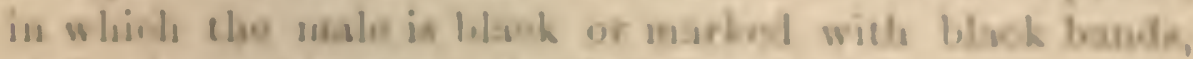

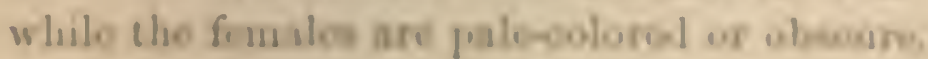

Order, Octeopence- The mbles in the throe micalurial funsilios belungine to this Coler are remarbable for thinde masical powors, usmoly, the Adintils of eriekres. dor

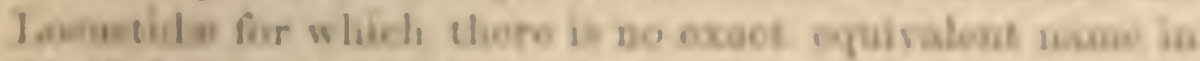

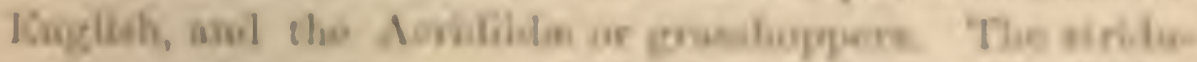

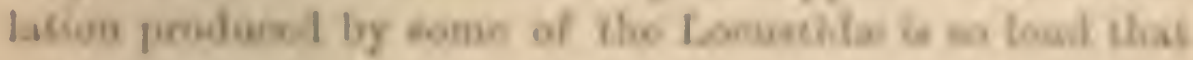

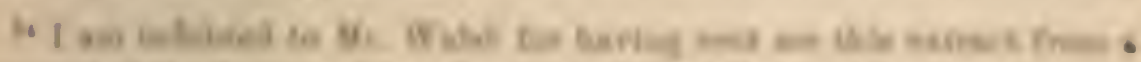

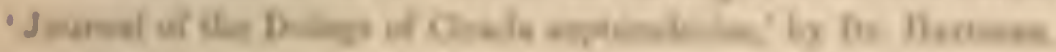


it can be heard dnring the nightit at the distance of a mile; ${ }^{25}$ and that made by certain species is not ummusical even to the human ear, so that the Indians on the Ama\%ons keel) them in wicker cages. All observers agree that the sounds serve either to call or excite the mute females. But it has been noticed ${ }^{20}$ that the male migratory locust of Russia (one of the Acridida), while coupled with the fenale, stridulates from anger or jealousy when approached by another male. 'The house-cricket when surprised at night uses its voice to warn its fellows. ${ }^{27}$ In North America the Kiaty-did (Platyphyllum concavum,

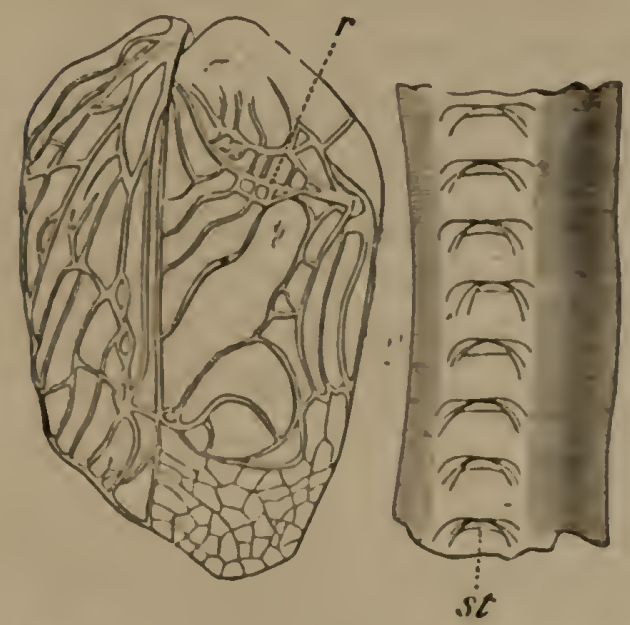

Fig. 10.-Gryllus campestris (from I Landois).

Right-hand figure, under side of part of the wing-nervire, much matrified, showing the teeth, st.

L.ft-hand flgure, upper surface of wingcurer, with the projecting. smooth ne:$v i r e, r$ across which the teeth $(s t)$ are ecriped. until a female approaches, its burrow, and stridulate sueceeded by apronches, when the louder notes are sinceeded by a more subdned tone, while the successful musician caresses with his antemin the mate he has

${ }^{25}$ I. Guilding, 'Transact. Linn. Soc.' rol. xr. p. 154.

${ }^{26} \mathrm{Köppen}$, as quoted in the '\%oological Recordl, for 186 ', p. 460.

$\therefore$ Gilhert White, 'Nat. Hist. of Selborne,' rol. ii. 1525, p. 262.

:s Harris, 'Insects of New England,' 1812, p. 128. 
won." 32 Dr. Feculder was able to excice one of these insects to answer him, ly rubbing on al tile with a quill. In botle sexes a remarkable anditury apparatus lass beeu discovered by Von siebold, sitnated in the front lens."

In the threc Families the sounds are diflerenty prosdnced. In the males of the Arhetielat hoth wingreovers hate the same structure; amb this in the lichl-crichet (Girylles campestris, lig. 10) com-ints, as described by Landuis," of tiom 131 (u) las - harpl, transicrsc ridges ul. tecth (st) on the muler side of une of the ucrures of the wing-eover. 'This toothed ucrume is rapielly scraped

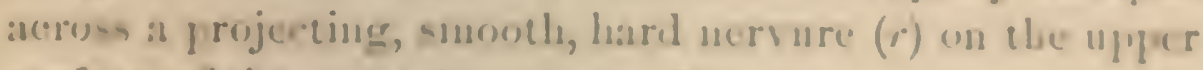
surface of the opposite wing. Fint one wing is rubled wor the wher, amel then the mosenent is revereed. Botls wings are rabed a litule at the fanue time, so as (1) incoesto the resonatuce. In sumbe species the wine-corers of the males are fumithes at the bate witls a talelihe plate." I have here given a druwing (lig. 11) of the teeth on the unter side of the mervure of auother mpecies of liryllus, biz. U. elomentione.

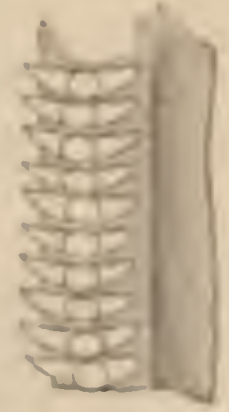

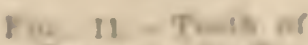

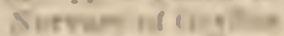

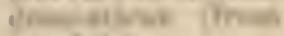
Lombles

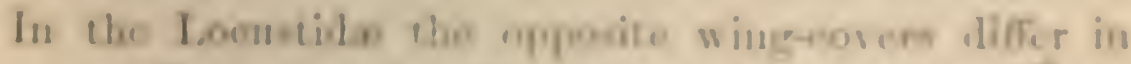

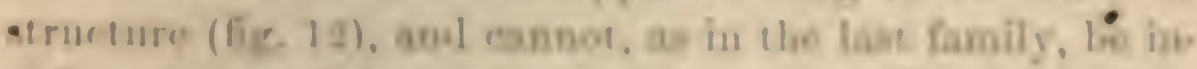

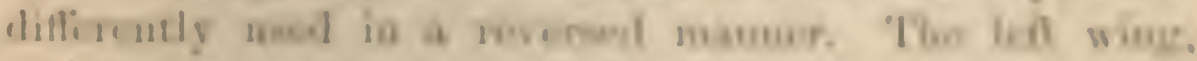
whish oets as the beor of the thalle, lies over the right

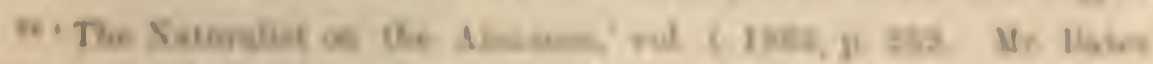

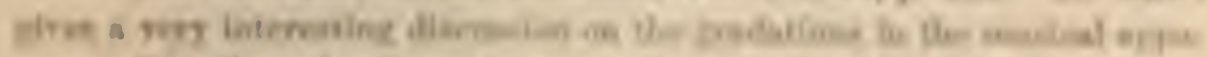

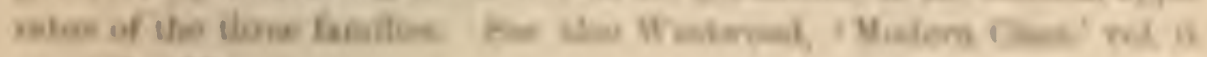
m $11,13 x$

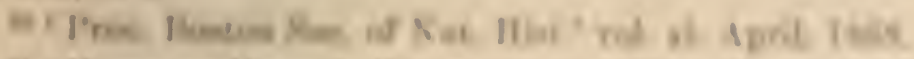

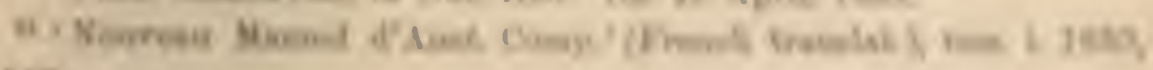
1. $\mathrm{NeT}$.

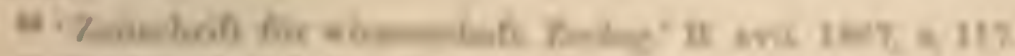

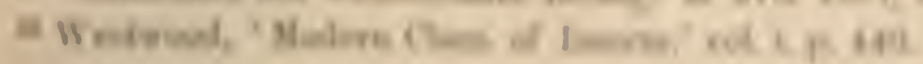


wing which serves as the fiddle itself. One of the nervures $(a)$ on the under surface of the former is finely serrated, and is seraped across the prominent nervures on the upper surlace of the opposite or right wing. In our British Phasgonure viridissime it appeared to me that the serrated nervure is rubbed against the rounded hind corner of the opposite wing, the edge of which is thickened, colored brown, and very sharp. In the right wing, but not in the left, there is a little plate, as transparent as talc, surrounded by nervures, and called the speculum, In Ephippiger vitium, a member of this same family, we have a curious subordinate modification; for the wingcovers are greatly reduced in size, but " the posterior part of the pro-thorax is elevated into a kind of clome orer the

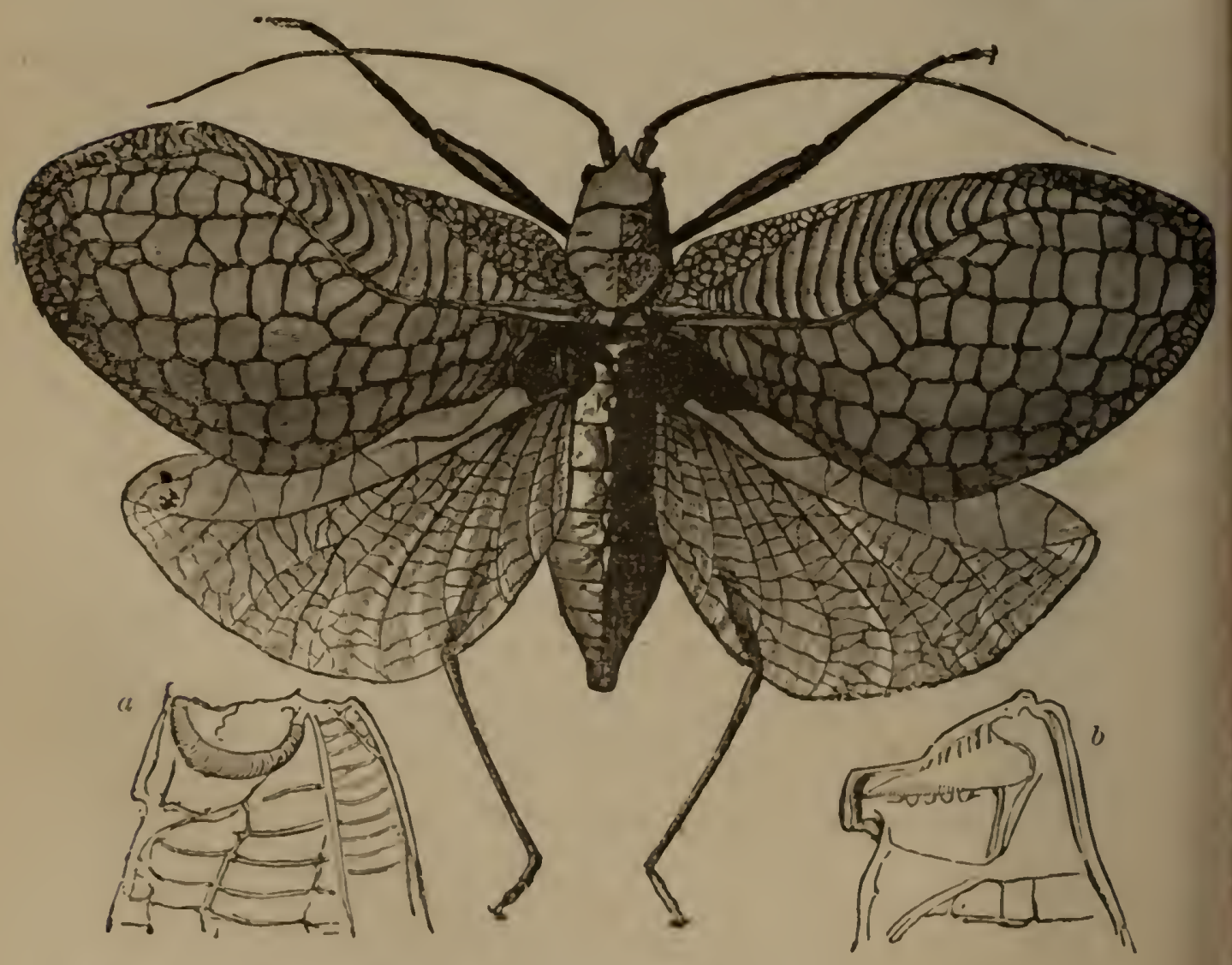

FIG. 12.-(hlorocolus Tauana (from Bates). a. 8. Lobes of oppozitc winc-covers. 
wing-covers, and which has probably the effect of increasing the sound." "st

We thus see that the musical apparatus is more diffir" entiated or specialized in the Locustide, which includes, I believe, the most powerful performers in the Order, than in the Achetidx, in which both wing-covers have the sane structure and the same function. ${ }^{3 s}$ Landois, however, detected in one of the Locustider, nanely, in Decticus, a short and nariow row of small tecth, mere rudinents, on the inferior surface of the right wing-cover, which underlies the other and is never used as the bow. I observed the sane rudimentary structure on the under side of the right wing-cover in Plasgonura viridissima. Hence we may with confidence infer that the Locustidac are descended from a torm, in which, as in the existing tohe tide, both wing-covers had serrated nervues on the under surfoce, and could be indillerently used as the how; hut that in the Lorustilac the two wing-covers gratually be como diflientisted and perfecterl, on the principle of the division of labor, the one to act exclusively as the bow ambl the other as the fidille. By what steps the more simple appiantus in the Achetidas originated, we do noe know, bue it is probsable that the hasal portions of the wingecovert ourlipped cach ocher formerly as at presone, and that the friction of the meroures puoduced a grating wound, as I timl is now the cane with the wingeouers of

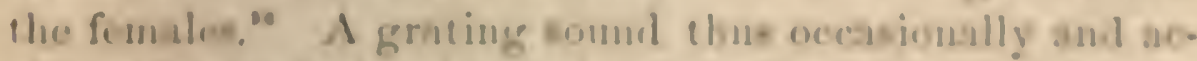

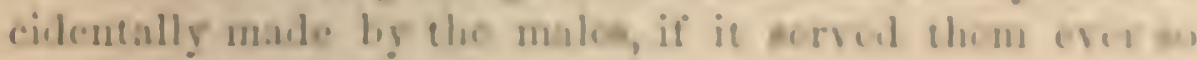

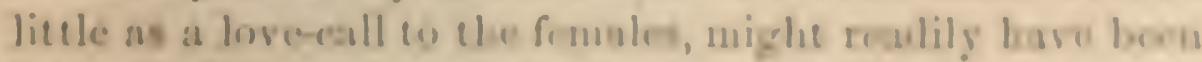
intensifind throngh kesual eolection ly fiering variations in

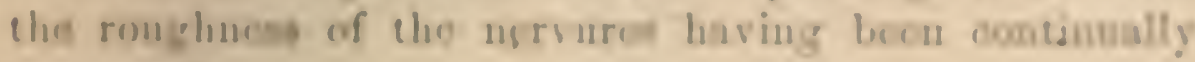
jreosivil.

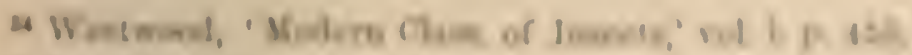

Lambeb, Itid a 171, $17 \mathrm{~K}$

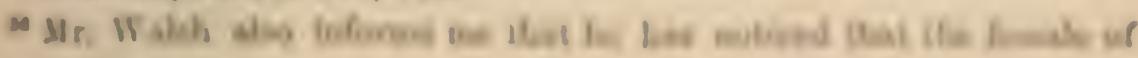


In the last and third Family, namely, the Acridiida or grasshoppers, the stridulation is produced in a very different manner, and is not so shrill, according to Dr. Scudder, as in the preceding Families. The inner surface of the femur (fig. 13, $r^{*}$ ) is furnished with a longitudinal row of minute, elegant, lancet-shaped, elastic teeth, from 85 to 93 in 11 umber; ${ }^{37}$ and these are scraped across the sharp, projecting nervures on the wing-covers, which are thus made to vibrate and resound. Ifarris ${ }^{38}$ says that

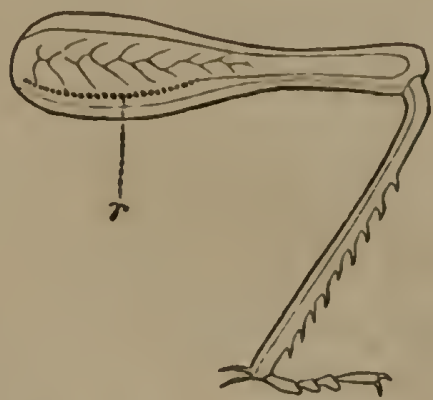

when one of the males begins to play, he first "bends the shink of the hind-leg beneath the thigh, where it is lodged in a furrow designed to receive it, and then draws the leg briskly up and down. IIe does not play both fiddles together, but alternately first upon one and then on the other:" Fid. 13.- Irind-leg of Stenolothrus pratornm: In many species the base the tectl, forming the ridre, the tectlo, forming the ridge, much mag-
nitied (froms Laudois).

lowed out into a great eavity which is believed to act as a resounding-board. In Pneumora (fig. 14), a South African genus belonging to this same family, we meet with a new and remarkable modification: in the males a sinall notched ridge projects obliquely from each side of the abdomen, against which the hind fenora are rubbed. ${ }^{39}$. As the male is furnished with the Plutyphyllum concavum, "when captured, malses a fecble grating noise by shuffling her wing-covers together."

${ }^{37}$ Landois, ibid. s. 113.

38 'Insects of New Englind,' 1842, p. 133.

33 Westwood, 'Modern Classification,' vol. i. p). 162. 
wings, the fomale being wingless, it is remarkable that the thighs are not rubbed in the usual mamer aganims the wing-covers; but this may perhaps be accounted fol ly the unusually small size of the hind-legs. I have not bean able to cxamine the inner surface of the thights, which, jurlging fiom analogy, would be tinely serrated. 'The species of l'nemuora have been nore profunndly modilicel for the sake of stridulation than any other orthequerous insect; for in the male the whole body has been converted

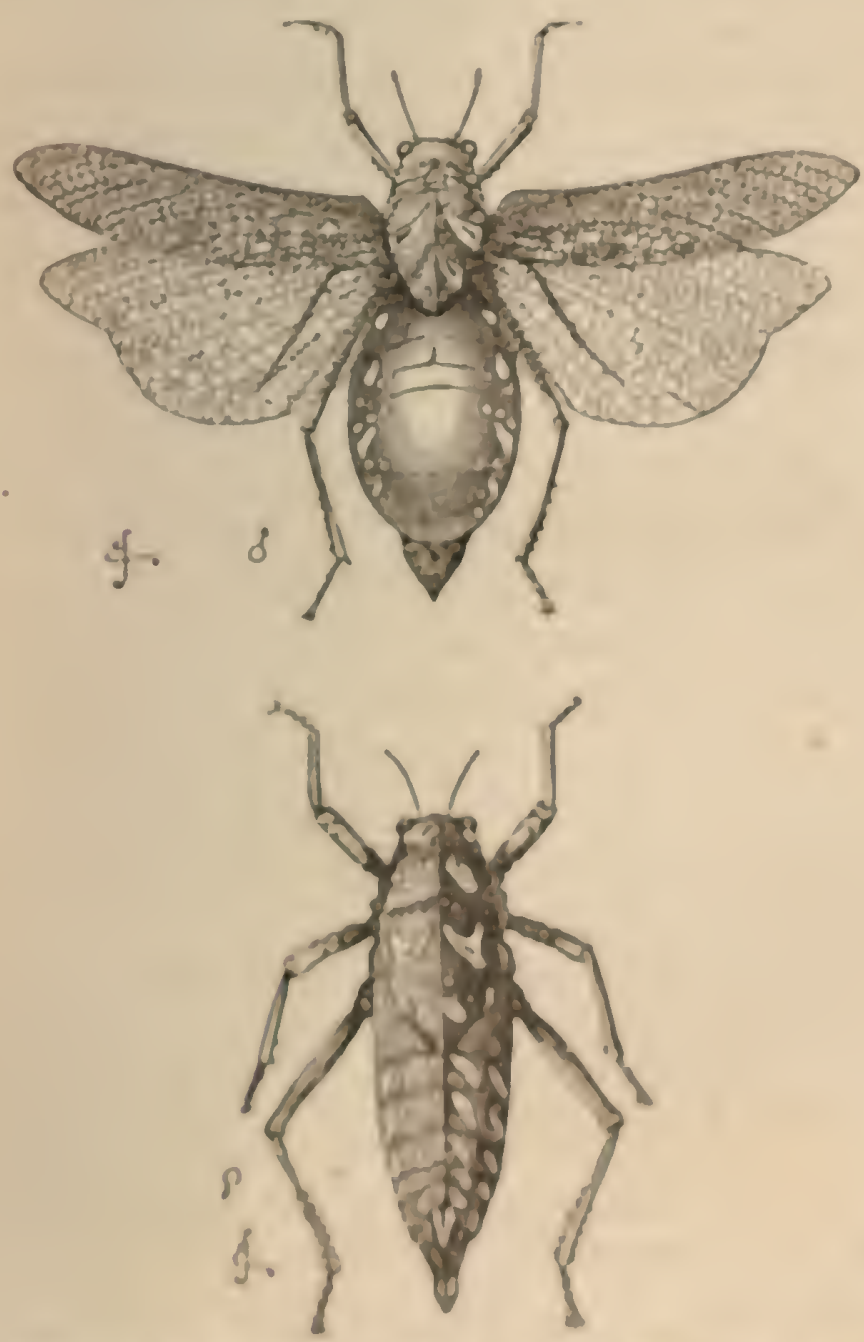


into a musical instrument, being distended with air, like a great pellucid bladder, so as to increase the resonance. Mr. Trimen informs me that at the Cape of Good Hope these insects make a wonderful noise during the night.

There is one exception to the rule that the females in these three Families are destitute of an efficient musical apparatus; for both sexes of Ephippiger (Locustidx) are said ${ }^{40}$ to be thus provided. This case may be compared with that of the reindeer, in which species alone both sexes possess horns. Although the female orthoptera are thus almost invariably mute, yet Landois ${ }^{41}$ found rudiments of the stridulating organs on the femora of the female Acridiidx, and similar rudiments on the under surface of the wing-covers of the female $\Lambda$ chetidx; but he failed to find any rudiments in the females of Decticus, one of the Locusticla. In the Homoptera, the mute females of Cicada have the proper musical apparatus in an undeveloped state; and we shall hereafter meet, in other divisions of the animal kingdom, with innumerable instances of structures proper to the male being present in a rudimentary condition in the female. Such cases appear at first sight to indicate that both sexes were primordially constructed in the same manner, but that certain organs were subsequently lost by the females. It is, however, a more probable view, as previously explained, that the organs in question were acquired by the males and partially transferred to the females.

Landois has observed another interesting fact, namely, that, in the females of the Acridiidx, the stridulating teeth on the femora remain throughout life in the same condition in which they first appear in both sexes during the larval state. In the males, on the other hand, they become fully developed and acquire their perfect structure at

a. Westrood, ibid. rol. i. p. 453.

"Landois, ibid. s. 115, 116, 120, 122. 
the last moult, when the insect is mature and realy to breed.

From the facts now given, we see that the means ly which the males produce their sounds are extremely diversified in the Orthoptera, and are altogether diflirent from those employed by the Homoptera. But throughout the animal kingdom we incessanty fund the same object gained by the most diversified means; this being due to the whole organization nulergoing in the course of anes multifurious changes; and, as part after pant varies, diflierent variations are taken arlvantage of for the same general purpose. The diversification of the means for producing sound, in the threc families of the Orthoptera amel in the IIomoptern, impresses the mind with the ligh intportance of these structures to the males, for the satie of caslling or alluring the females. Tre need feel no surprian at the amount of modification which the Orthoptera hase mulergone in this respect, as we now know, from D)r. scudeler's remarkable discovery," that there has loen more than ample time. This uaturalint has latoly fouml a fossil insect in the Deronian formation of New Frums. wick, which is furnished with "the woll-kur)wn 1 ymp:anum or stribulating apparatus of the male Locustielw." This

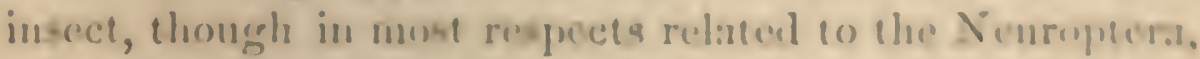
apperars to combet, an is so offen the rase will berg anrient forms, the two ()rilers of the Deuroplera and Ore thoplera which are now generally ranherl as yuite discince.

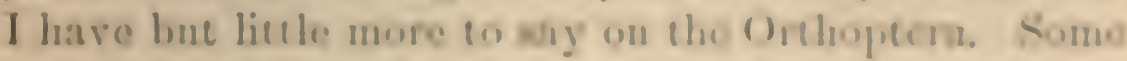
of the species are bry pugenacions: who two male tielle

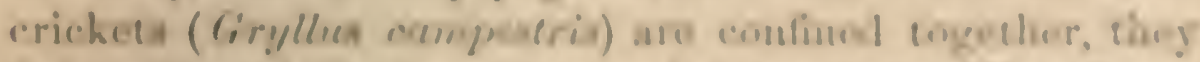

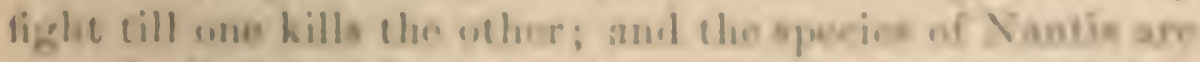

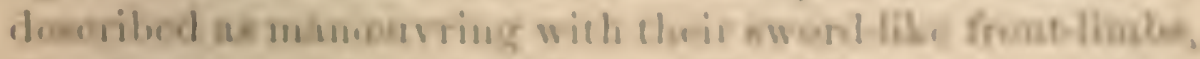

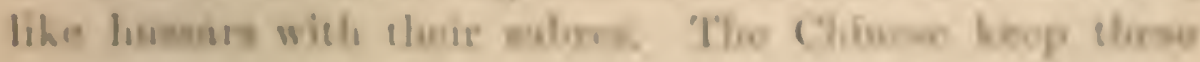

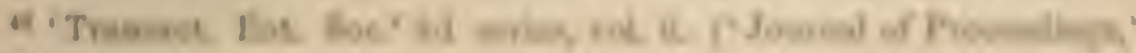
(1) 11,1,
} 
insects in little bamboo cages and match them like gamecocks. $^{43}$ With respect to color, some exotic locusts are beautifully ornamented ; the posterior wings being marked with red, blue, and black; but, as throughout the Order the two sexes rarely differ much in color, it is doubtful whether they owe these bright tints to sexual selection. Conspicuous colors may be of use to these insects as a protection, on the principle to be explained in the next chapter, by giving notice to their enemies that they are unpalatable. Thus it has been observed ${ }^{44}$ that an Indian brightly-colored locust was invariably rejected when offered to birds and lizards. Some eases, however, of sexual differences in color in this Order are known. The male of an American cricket ${ }^{48}$ is described as being as white as ivory, while the female varies from almost white to greenish yellow or dusky. Mr. Walsh informs me that the adult male of Spectrum femoratum (one of the Phasmidx) "is of a shining brownish-yellow color; the adult female being of a dull, opaque, cinereous brown; the young of both sexes being green." Lastly, I may mention that the male of one curious kind of cricket ${ }^{40}$ is furnished with "a long membranous appendage, which falls over the face like a veil;" but whether this serves as an ornament is not known.

Order, Neuroptera.-Little need here be said, except in regard to color. In the Ephemeridx the sexes often differ slightly in their obscure tints ${ }^{47}$ but it is not prob-

${ }^{43}$ Westrood, 'Modern Class. of Insects,' vol. i. p. 427; for crickets, p. 415.

44 Mr. Ch. Horne, in 'Proc. Ent. Soc.' May 3, 1869 , p. xii.

45 The Occanthus nivalis. Inaris, 'Inscets of New Jingland,' 1812, p. 124.

$\$ 6$ Platyblemnus: Westrood, 'Modern Class.' vol. i. p. 447.

47 ]3. D. Walsh, the Pscudo-neuroptera of Illinois, in 'Proc. Ent. Soc. of Philadelphia,' 1862, p. 361. 
able that the males are thus rendered attractive to the females. The Libellulidie or dragon-flies are ormamented with splendid green, blue, ycllow, and vermilion metallic tints; and the sexes often differ. 'Thus, the males of some of the Agrionidx, as Prof. Westwood remarks," "are of a rich blue with black wings, while the females are fine green with colorless wings." But in Agrion Ramburii these colors are exactly reversed in the two sexes. ${ }^{\circ}$ In the extensive North Anerican genus of Hetrerina, the males alone have a beautiful carmine spot at the base of each wing. In Anax junius the basal part of the abdomen in the male is a vivid ultra-marine blue, and in the fenrale grasss-green. In the allied genus Gomplus, on the other land, and in some other genera, the sexes difler but little in color. 'Throughout the animal kingdom, similar' cases of the sexes of closely-allied forms cither differing greatly, or very little, or not at all, are of frequent occurrence. Although with many Libellulida there is so wide a diflirrnce in color between the sexes, it is often diflicult to say which is the unost brilliant; and the ordinary coloration of the two scexes is exactly reversed, as we have just serm, in one species of $\mathbf{A g r i o n}$. It is not probable that their colors in any case have been ganced as a protection. As Mr. Maclachlan, who has closely attendud to this family, Writes to me, dragon-flies-the igrants of the insect-world - are the least liable of any insect to be atacked by birils of oflee enemices. He helieses that their brighe colors ferte as a gromal attraction. It deorses notice, as bearing ou this suhject, that ceretain dragon-tlics appear to be at-

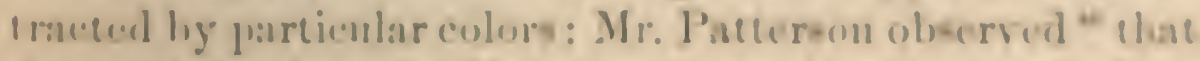
the pperies of Agrionidan, of which the males are hlue,

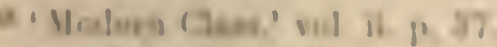

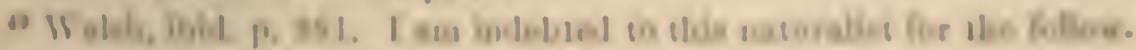

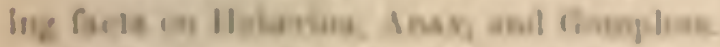

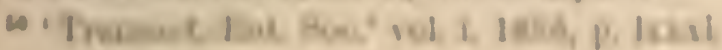


settled in numbers on the blue float of a fishing-line; while two other species were attracted by shining white colors.

It is an interesting fact, first observed by Schelver, that the males, in several genera belonging to two subfamilies, when they first emerge from the pupal state are colored exactly like the females; but that their bodies in a short time assume a conspicuous milky-blue tint, owing to the exudation of a kind of oil, soluble in ether and alco. hol. Mr. MacLachlan believes that in the male of Libellula depressa this change of color does not occur until nearly a fortnight after the metamorphosis, when the sexes are ready to pair.

Certain species of Neurothemis present, according to Brauer, ${ }^{51}$ a curious case of dimorphism, some of the females having their wings netted in the usual manner; while other females have them "very richly netted as in the males of the same species." Brauer "explains the phenomenon on Darwinian principles by the supposition that the close netting of the veins is a secondary sexual character in the males." This latter character is generally developed in the males alone, but being, like every other masculine character, latent in the female, is occasionally. developed in them. We have here an illustration of the manner in which the two sexes of many animals have probably come to resemble each other, namely, by variations first appearing in the males, being preserved in them, and then transmitted to and developed in the females; but in this particular genus a complete transference is occasionally and abruptly effected. Mr. MacLachlan informs me of another case of dimorphism occurring in several species of $\Lambda$ grion in which a certain number of individuals are found of an orange-color, and these are invariably females. This is probably a case of reversion, for in the true Libellulæ, when the sexes differ in color, ${ }^{51}$ See abstract in the 'Zoological Record' for 1867 , p. 450 
the females are always orange or ycllow, so that, supposing Agrion to be descended from some primordial form having the characteristic sexual colors of the typical Libcllulat, it would not be surprising that a tendency to vary in this manner should occur in the females alone.

Although many dragon-ties are such large, powerful, and fierce insects, the males have not been obacred by Mr. MacLachlan to fight together, except, as he helieves, in the casc of some of the smaller species of $A$ grion. In another very distinet group in this Order, namely, in the 'Termites or white ants, hoth sex's at the tine of swarning may be secn running about, "the male after the fomale, sonctimes two chasing one female, and contending with great eagromess who slatl win the prize." os

Oraler, IIymonoplere.-That inimitalble observer M. I:alure, ${ }^{63}$ in decribing the habits of Cerceris, a wasp-like inseet, remarks that "fights frequently ensue between the males for the possestion of some particular fomale, who sits an apparently unconcerned beholder of the strugele for supremacy, and, when the victory is decided, unietly flies away in company with the conqueror." Westrood" saye that the males of one of the saw-flies ('T'meliredinar) "have been found fighting cogethor, with their manditien

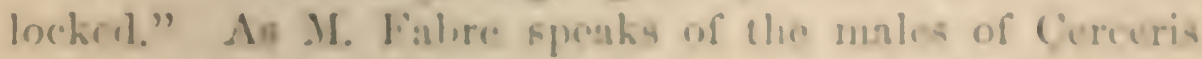
etriving to obtain a partionhe fonale, it may he well to bear in mind that ineces brlonging on this Ordir hase the power of recognizing each ofler after long intersals of time, and are docply attacled. For inetance, Piorelluber. whose aceuracy no ome douhes, eprarated some ante, sasl

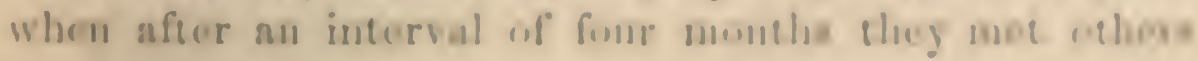

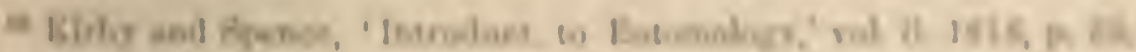

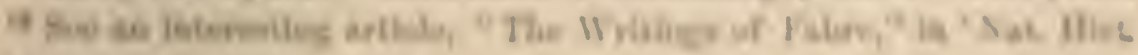
linkwy' Ipol, 1kel, y 122

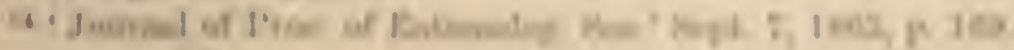
|, 
which had formerly belonged to the same community, they mutually recognized and caressed each other with their antemr. IIad they been strangers they would have fought together. Again, when two communities engage in a battle, the ants on the same side in the general confu. sion sometimes attack each other, but they soon perceive their mistake, and the one ant soothes the other: ${ }^{\circ 8}$

In this order slight differences in color, according to sex, are common, but conspicuous differences are rare except in the family of Bees; yet both sexes of certain groups are so brilliantly colored-for instance, in Chrysis, in which vermilion and metallic greens prevail-that wo are tempted to attribute the result to scxual selection. In the Ychneumonidx, according to Mr. Walsh, ${ }^{\text {io }}$ the males are almost universally ligliter colored than the females. On the other hand, in the Tenthredinida the males are generally darker than the females. In the Siricida the sexes frequently differ: thus the male of Sirex jurenens is banded with orange, while the female is dark purple; but it is difficult to say which sex is the most ornamented. In Tremex columbe the female is much brighter colored than the male. With ants, as I am informed by Mr. F. Smith, the males of several species are black, the females being testaceous. In the family of Bees, especially in the solitary species, as I hear from the same distinguished entomologist, the sexes often differ in color. The males are generally the brightest, and, in Bombus as well as in $\Lambda$ pathus, much more variable in color than the females. In Anthophore retusa the male is of a rich fulvous brown, while the female is quite black: so are the females of several species of Xylocopa, the males being bright yellow. In an Australian bee (Lestis bombylans), the female is of

${ }^{6} \mathrm{P}$ P. Huber, 'Recherches sur les Mceurs des Fourmis,' 1810, pra $150,165$.

"' 'Proc. Eutomolog. Soc. of Philudelphia,' 1866, pp. $28,8,239$. 
an extremely brilliant stecl-bluc, sometimes tinted with vivid green; the male being of a bright brasey color clotherl with rich fulvous puberecence. As in this group the females are proviled with cercellent defensive weapous in their stiugs, it is not probable that they darve come to differ in color fropm the males for the sake of protection.

Mullle fieropora cuits a stridulatiug unise; and ace cording to Gourcan" both seses have this power. He attributes the somnd to the friction of the third and pre ceding abdominal sorgments; and I find that thene snr. fisces are markel with very fine concentric riblges, but so is the projeceing thoracie collar, on which the head articulater ; and this collar, when scratched with the point of

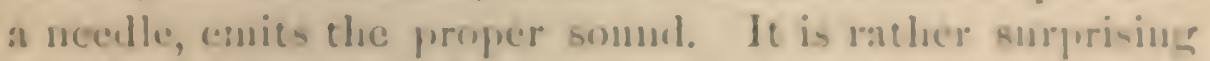
that both sexes should have the powere of strilulutiug as the male is wingerl and the female wingless. It is noworiwas that lices expreses certain cmotions, as of anger, lig the fond of their humming, as do some dipterous inecets; hut I h.1 (1) be in any way connected with the ace of eomrthip.

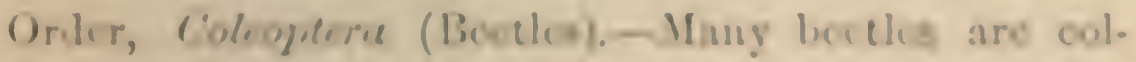

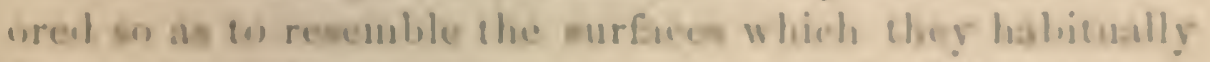

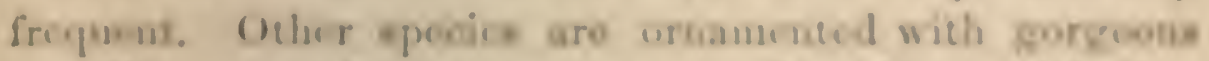

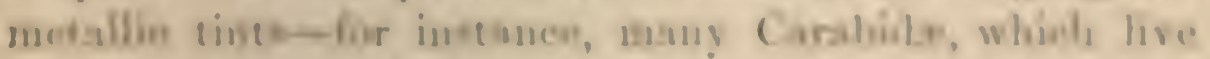
on the gromed and hase the power of defonding then-

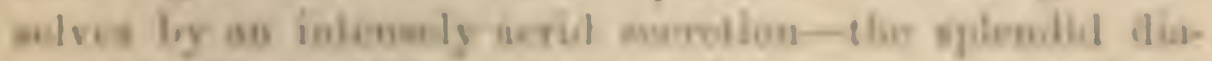

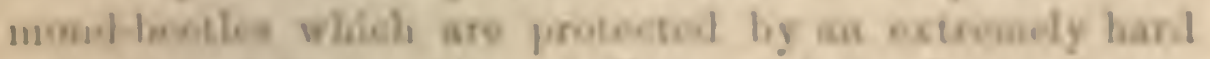

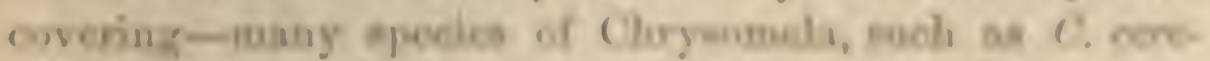

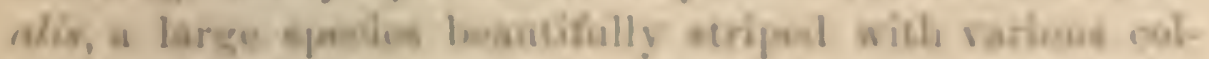
on, amel in firitain confined to the leure sumsoit of stoos.

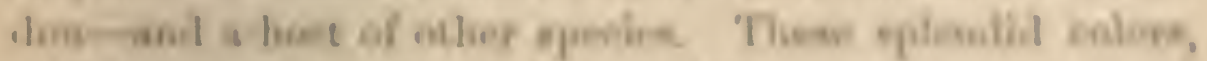

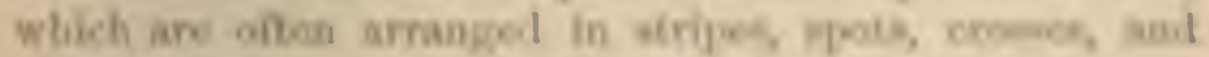

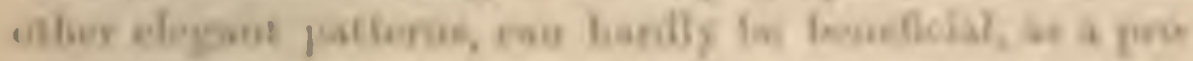

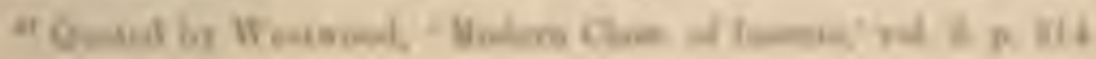


tection, except in the case of some flower-feeding species; and we cannot believe that they are purposeless. Hence the suspicion arises that they serve as a sexual attraction; but we have no evidence on this head, for the sexes rarely differ in color. Blind beetles, which cannot of course behold each other's beauty, never exhibit, as I hear from Mr. Waterhouse, Jr., bright colors, though they often have polished coats: but the explanation of their obscurity may be that blind insects inhabit caves and other obscure stations.

Some Longicorns, however, especially certain Prionidx, offer an exception to the common rule that the sexes of beetles do not differ in color. Most of these insects are large and splendidly colored. The males in the genus Pyrodes, ${ }^{58}$ as I saw in Mr. Bates's collection, are generally redder but rather duller than the females, the latter being colored of a more or less splendid golden green. On the other hand, in one species the male is golden green, the female being richly tinted with red and purple. In the genus Esmeralda the sexes differ so greatly in color that they have been ranked as distinct species: in one species both are of a beautiful shining green, but the male has a

58 Pyrodes pulcherrimus, in which the sexes differ conspicuously, has been described by Mr. Bates in 'Transact. Ent. Soc.' 1869, p. 50. I will specify the few other cases in which $I$ have heard of a difference in color between the sexes of beetles. Kirby and Spence ('Introduct. to Entomology,' vol. iii. p. 301) mention a Cantharis, Meloc, Rhagium, and the Leptura testacea; the male of the latter being testaceous, with a black thorax, and the female of a dull red all over. These two latter bectles belong to the Order of Longicorns. Messrs. R. Trimen and Waterhouse, Jr., inform me of tro Lamellicorns, viz., a Peritrichia and Trichius, the male of the latter being more obscurcly colored than the female. In Tillus elongatus the male is black, and the female always, as it is belicved, of a dark-blue color with a red thorax. The male, also, of Orsodacna xtra, as I hear from Mr. Walsh, is black, the female (the so-called O. ruficollis) having a rufous thoras. 
red thorax. On the whole, as far as I could judge, the females of those Prionida, in which the sexes difler, are colored more richly than the males; and this does not accord with the common rule in regard to color when acquired through sexual selection.
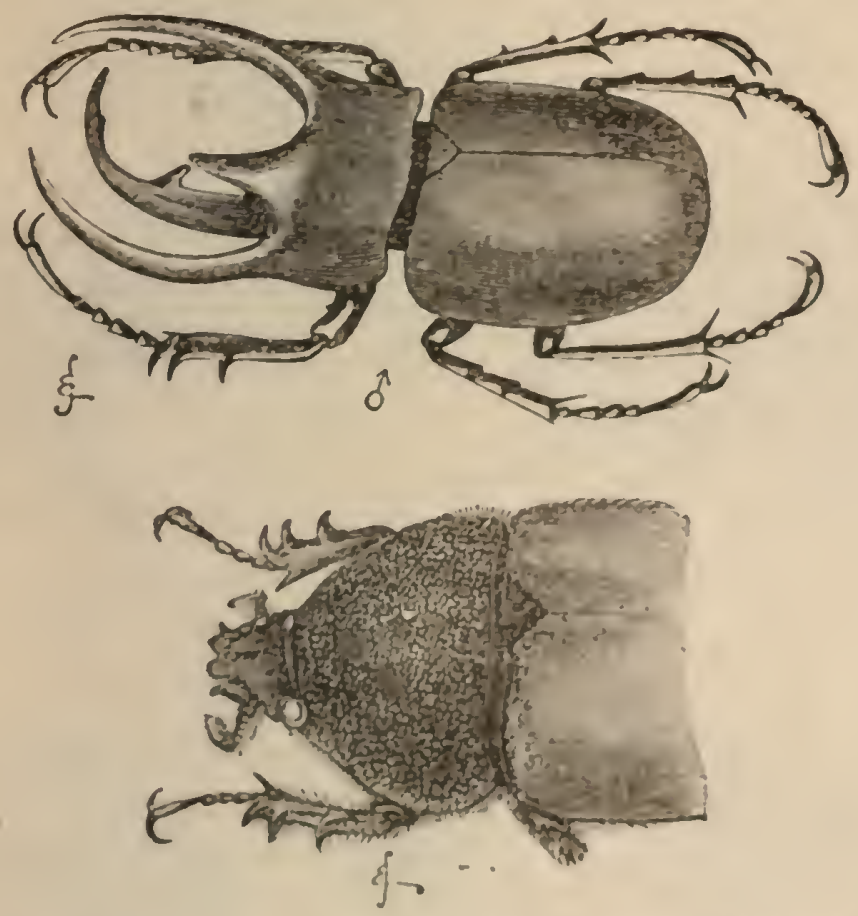

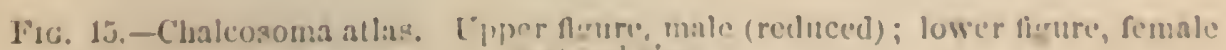
(Iiatlusal siza).

$\Lambda$ most remarkable distinction betweren the sexes of many bectes is presented hy the great horms which rise from the hoad, thorax, or clypens of the males; and in

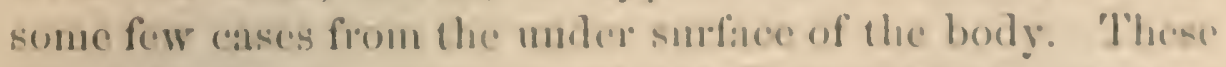
linrus, in the great family of the lamellicorms, rencmble

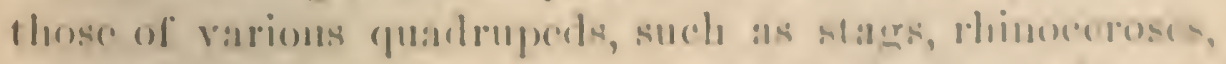

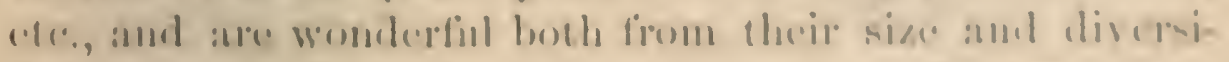

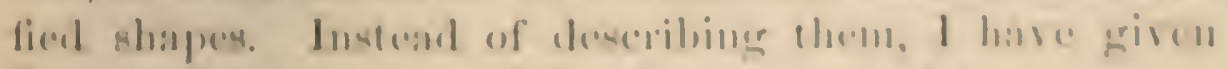

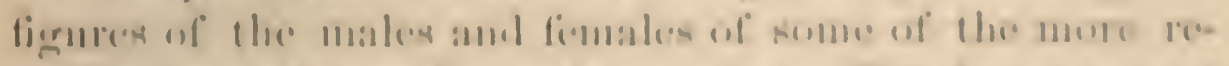

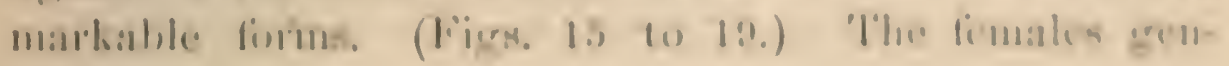



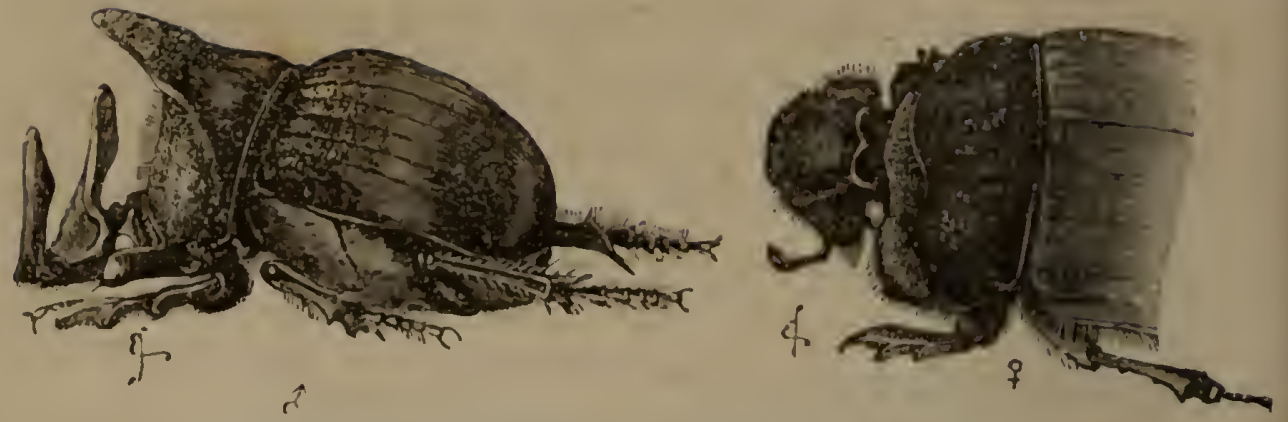

Fra. 16.-Copris isidis. (Loft-hand figures, males.)
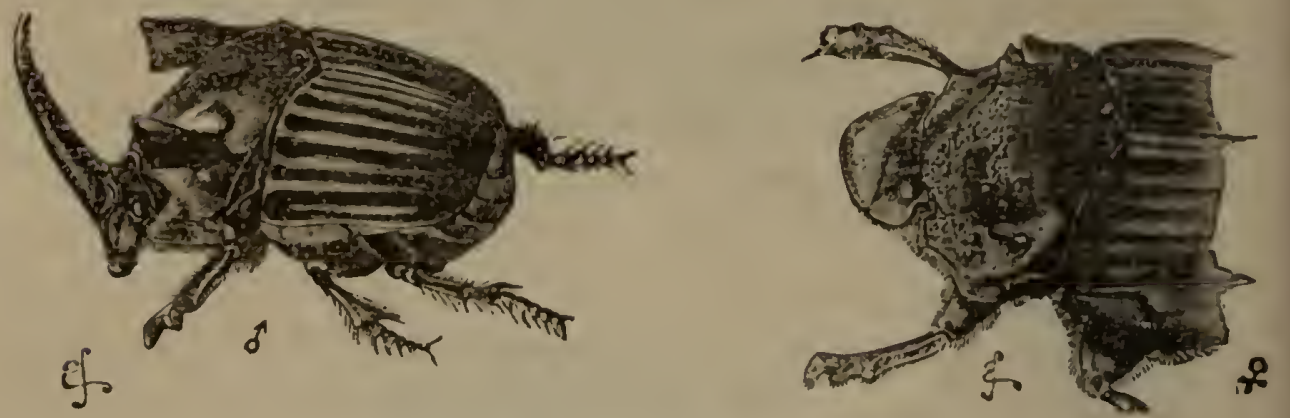

Fra. 17.-Phauxus fiunus.
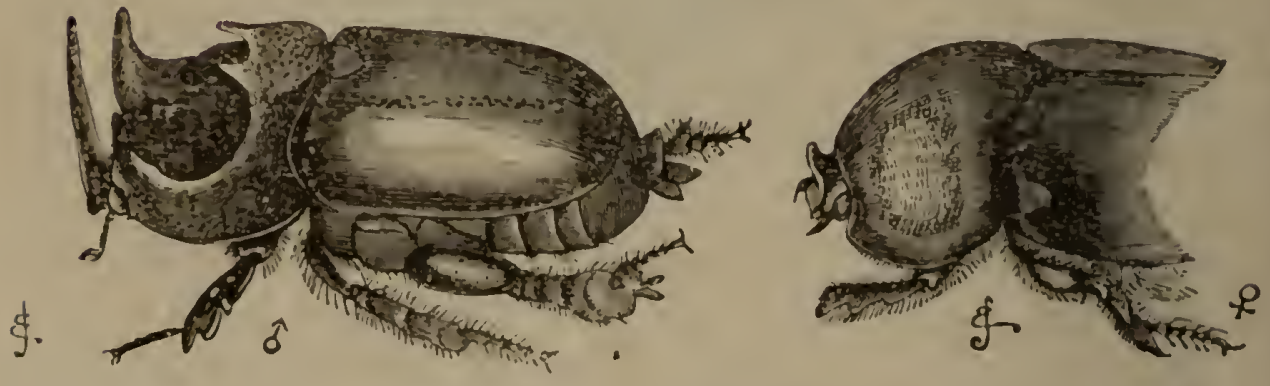

Fra. 18.-Dipclicus cantori.
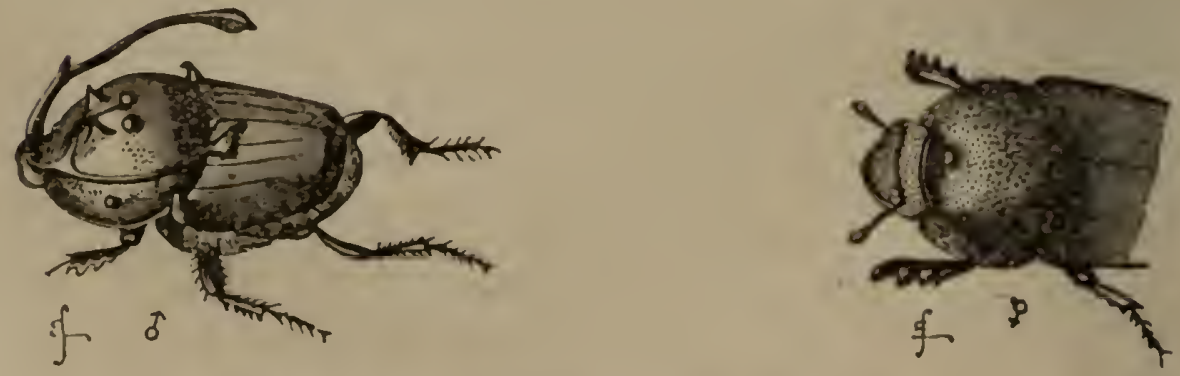

Fig. 19.-Onthophagus rangifer, enlarged. 
crally exhibit rudinents of the horus in the form of small knobs or ridges; but some are destitute of even a ruliment. On the other hand, the horns are nearly as well developed in the female as in the male of Phanous lanrifer; and only a little less well developed in the female's of some other species of the same genus and of Copris. In the several subdivisions of the fimily, the diflerences in structure of the horus do not run parallel, as I am informed by Mr. Bates, with their more inportant and characteristic diflerences; thus, within the same natural section of the genus Onthophagns, there are species which have cither a single cephalic lorn, or two distinct horns.

In almost all cases, the horns are remarkalble from their cocessive variability; so that a graduated serices can be formed, from the most highly-dercloped males to others so degencrate that they can barely be distinguished from the females. Mr. Walsh for fomd that in Plandus carmijex the hurns were thrice as long in some males as in others. Mr. bitces, after examining ahove a humdred

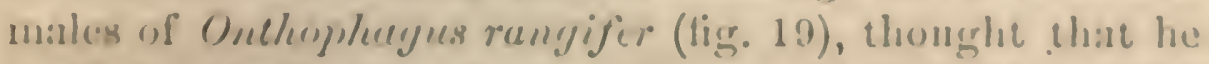
hand at last discovered a species in which the horns did not vary; but further rescanch proved the contrary.

The catratinary size of the horss, and their widelydiflirene seruceure in chosely-stlied forms, indicate that they hase been formesl for sonte imprortant purpose; hue their escessive varialility in the males of the same species

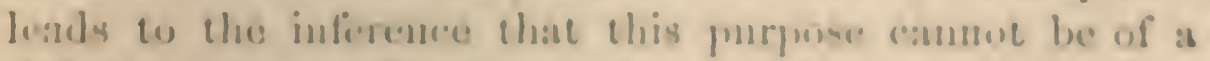
definite nature. The home de not slow maths of trice

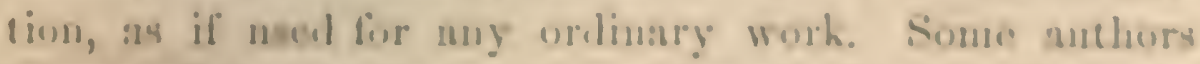

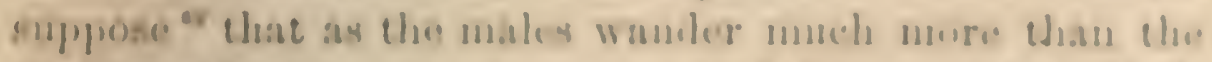

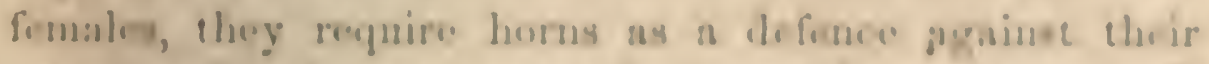

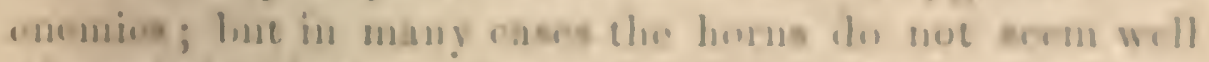

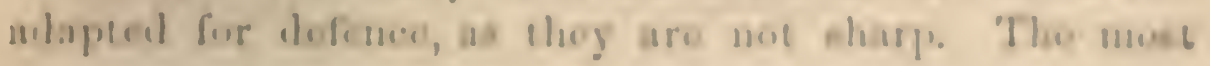

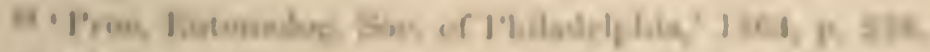

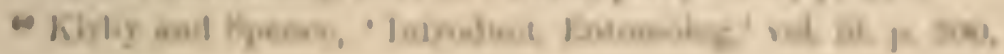


obvious conjecture is that they are used by the males for fighting together; but they have never been observed to fight; nor could Mr. Bates, after a careful examination of numerous species, find any suflicient evidence, in their mutilated or broken condition, of their having been thus used. If the males had been habitual fighters, their size would probably have been increased through sexual sclection, so as to have exceeded that of the female; but Mr. Bates, after comparing the two sexes in above a lnundred species of the Copride, does not find in well-developed individuals any marked difference in this respect. There is, morcover, one beetle, belonging to the same great division of the Lamellicorns, namely, Lethrus, the males of which are known to fight, but they are not provided with horns, though their mandibles are much larger than those of the female.

The conclusion, which best agrees with the fact of the horns having been so immensely yet not fixedly developer-as shown by their extreme rariability in the same species and by their extreme diversity in closely-allied species-is that they have been acquired as ornaments. This view will at first appear extrencly

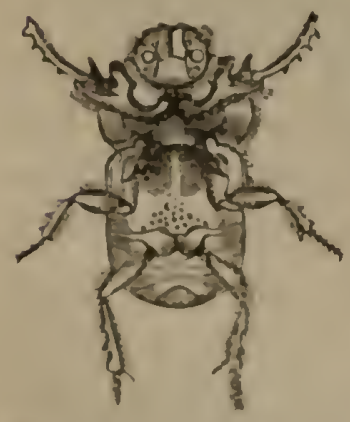

Fin. 20. - Onilis furcifer. male. viowed frum beucitil.

improbable; but we shall hereafter find with many animạls, standing much hightrer in the scale, namely, fishes, anphibians, reptiles, and birds, that various kinds of crests, knobs, horns, and combs, have been developed apparently for this sole purpose.

The males of Onilis furcifer (fig. 20) are furnished with singular projections on their anterior femora, and with a great fork or pair of horus on the lower surfice of the thorax. This situation seems extremely ill-adapted for the display of these projections, and they may be of some real service; 
but no unce can at prosent be asoigued to efrem. It is a

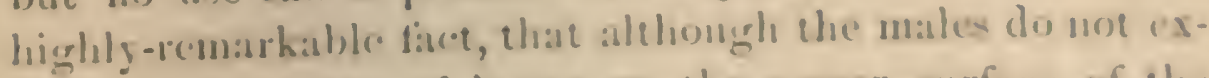
bibit eren a erace of lyorms on the upper surface of the hody, yee in the fentales a ruliment of a -ingle hurn on the

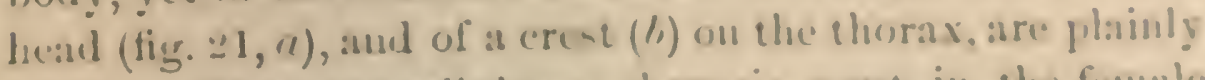
visible. That the slightest thoracic eret in the female
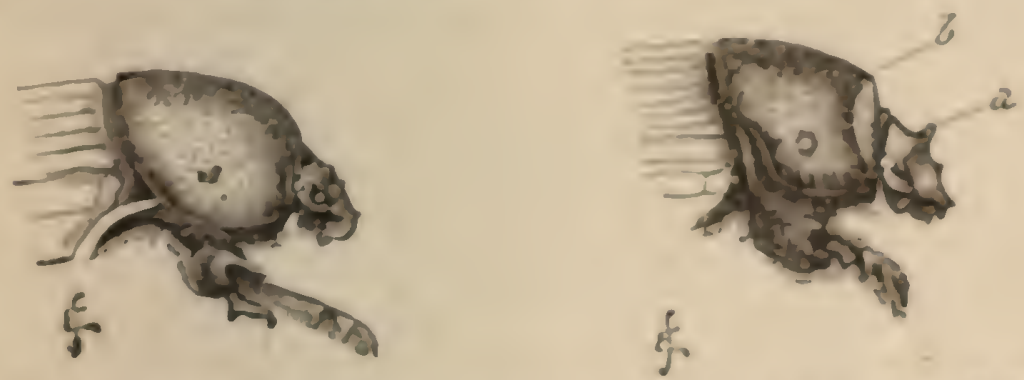

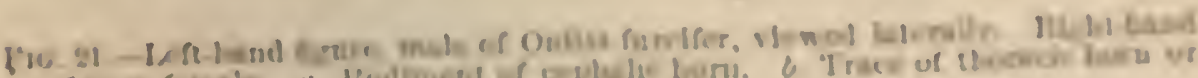

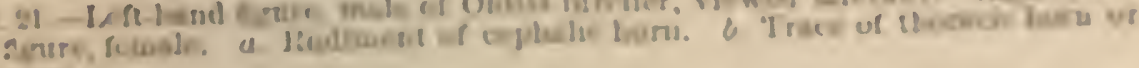
crive.

it at rulimont of a projection proper tis ilue male, though eutirely ab-ent in the nate of this porticular species, is

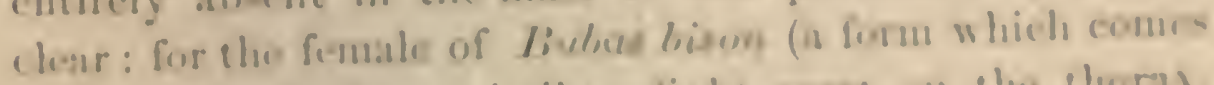

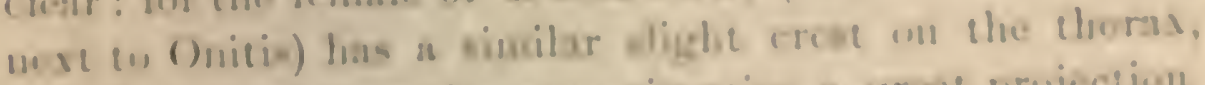

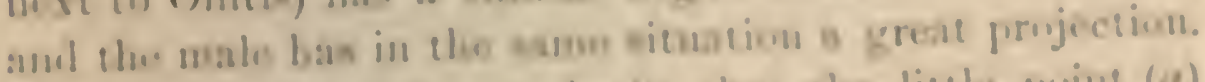
So again there an be un doube that the linte point (a)

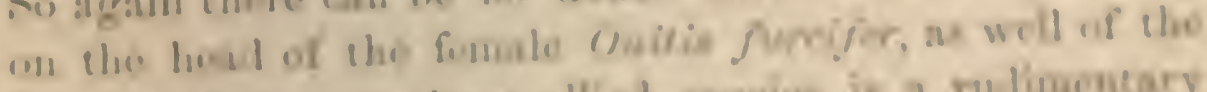

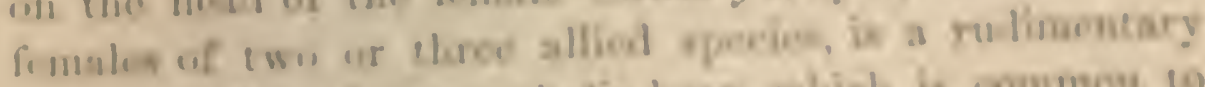

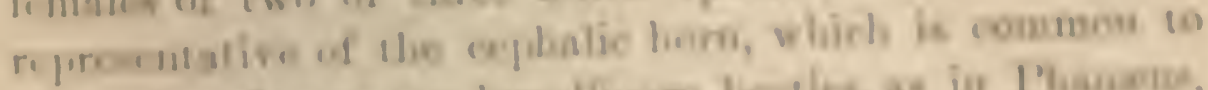

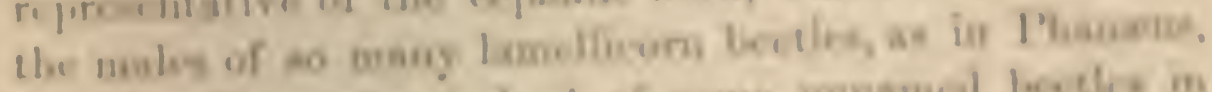

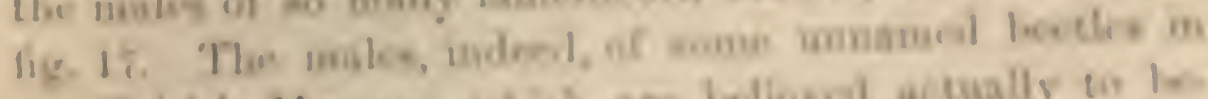

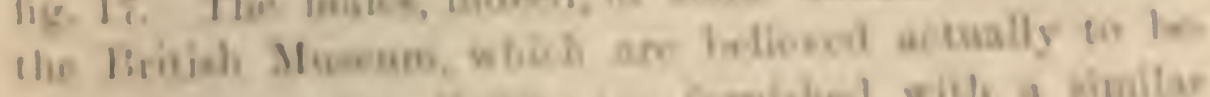

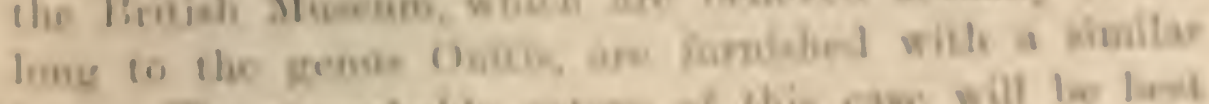

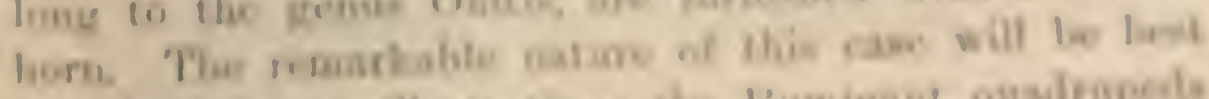

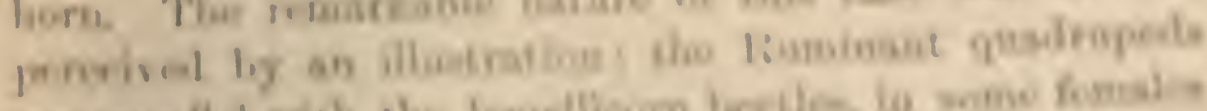

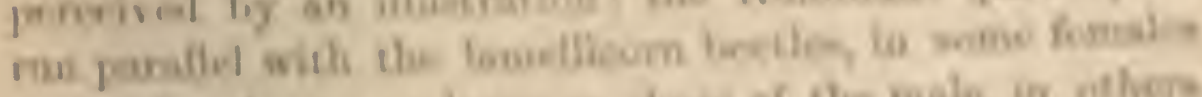

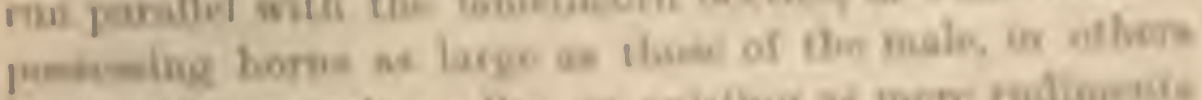

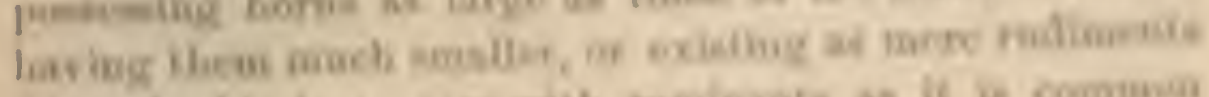

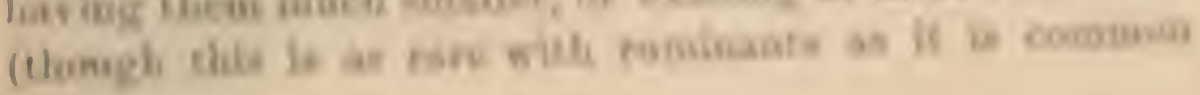


with Lancllicorns), or in having none at all. Now, if a new species of deer or sheep were discovered with the female bearing distinct rudiments of horns, while the head of the inale was absolntely smooth, we should have a calse like that of Onitis furcifer.

In this case the old belief of rudiments laving been created to complete the scheme of Nature is so far fiom holding good, that all ordinary rules are completely broken through. The vicw which seems the most probabe is that some early progenitor of Onitis acquired, like other Lamellicorns, horns on the head and thorax, and then transferred them, in a rudimentary condition, as with so many existing specics, to the female, by whom they have ever since been retained. The subsequent loss of the liorns by the male may have resulted through the principle of compensation from the development of the pro. jections on the lower surface, while the female has nut been thus affected, as she is not furnished with these projections, and consequently has retained the rudiments of the horns on the upper surface. Althongh this view is supported by the case of Bledius immediately to be given, yet the projections on the lower surlace diflier greatly in siructure and derclopment in the males of the sereral species of Onitis, and are eren rudinentary in some; nevertheless the upper surfice in all these species is quite destitute of horns. As sceondary sexual characters are so eminently variable, it is possible that the projections on the lower surface may have been firet aeguired by some pro. genitor of Onitis :md produced their effect throngl com pensation, and then lave been in ecrtain caten almost (i) upletely lost.

All the cases hitherto given rufer to the I.amellicorns, lut the romains of some fers other beetles, belonging to two wilely-distinet groups, namety, the Curculionide and Maphylinider, are furnished with horns-in the former on 
the lower surfuce of the lunly," in the latuer on the apper forface of the beal and thoras. In the staphylboids the horus of the usto in the same spenies are estrouriliatrily sariblele, just an we bave soen with the lasuellicerne. In
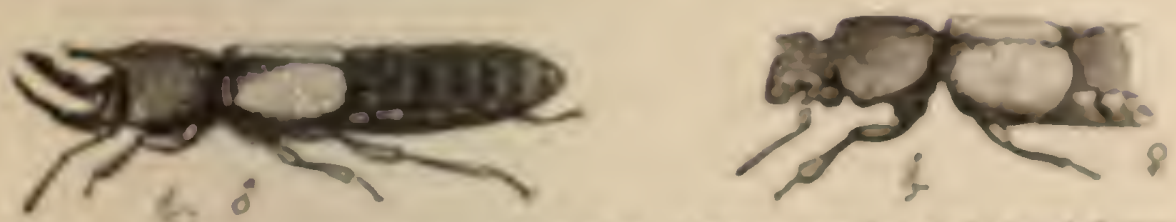

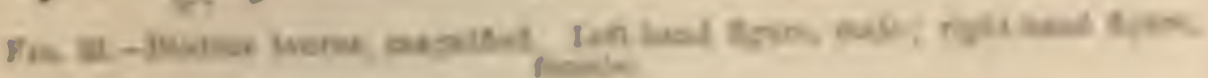

Sixponiem we lase a cses uf dimorphises, for the males

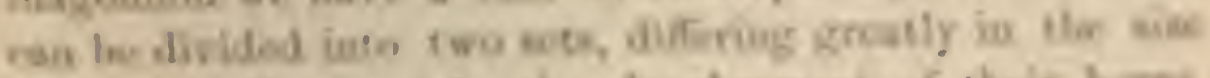
of their bolies, and in the deseloptoens of theie horns.

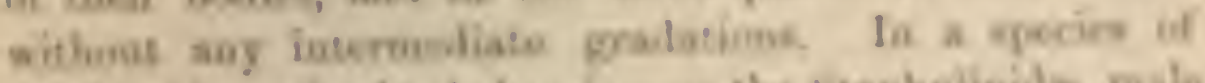

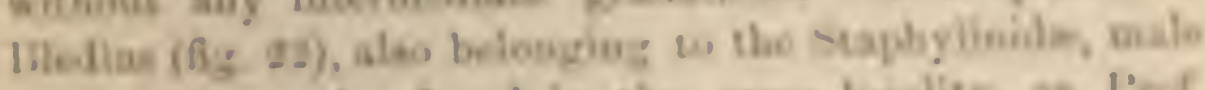

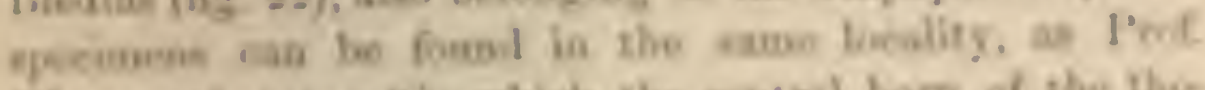

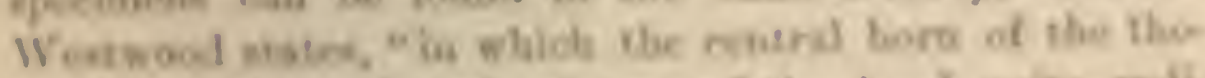

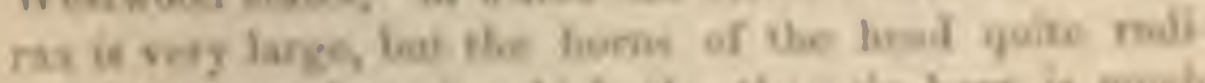

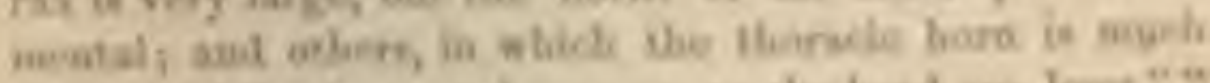

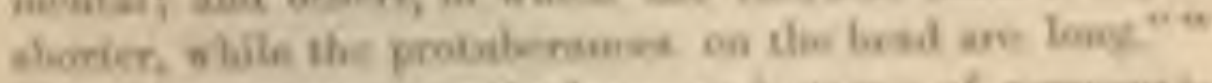

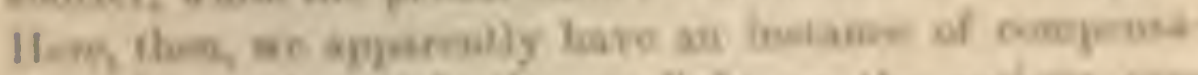

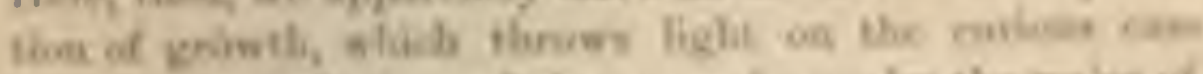

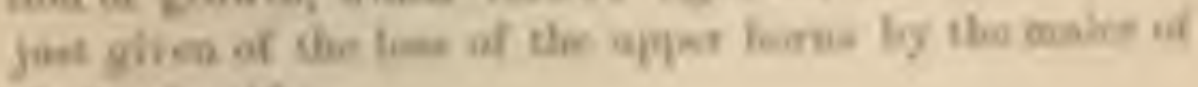
owiti farriph

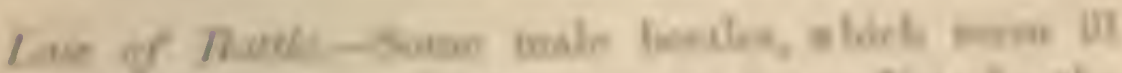

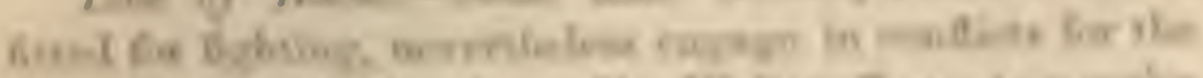

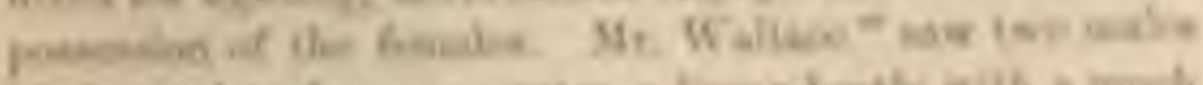

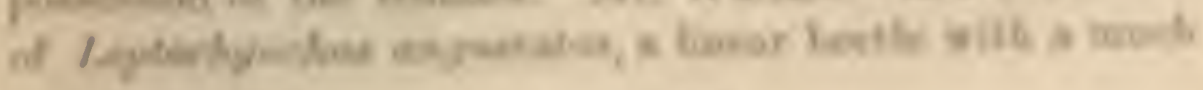

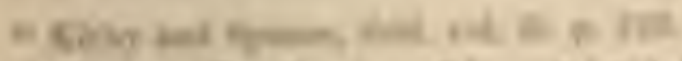

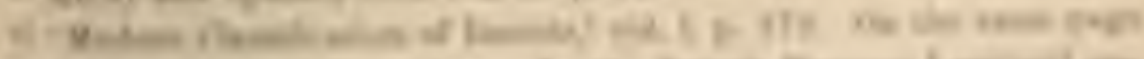

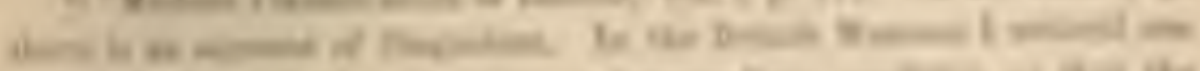

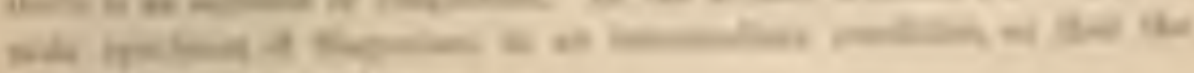

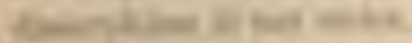

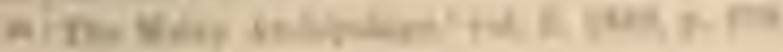


clongatcel rustrun, "fighting for a female, who stood close by husy at her boring. They pushed at each other with their rostra, and clawed and thmped apparently in the greatest rage." The smaller male, howerer, "soon ran away, acknowledging himself vanqui-lied." In some few

- eases the males are well adapted for fighting, by possess. ing great toothed mandibles, much larger than those of the finales. 'This is the case with the common stag-betles (Tocanus cerves), the males of which emerge from tho pupal state abont a week before the other sex, so that several may often be seen pursuing the same female. At this period they engage in fierce conflicts. When Mr. $\Lambda$. II. Davis "enclosed two males with one female in a hor, the larger male severely pinched the sualler one, until he resigned his pretensions. A friend informs me that when a boy he often put the males together to see them fight, and he noticed that they were insch bolder and ficreer than the females, as is well known to be the case with the higler animals. 'The males would scize hold of his finger, if held in fiont, but not so the females. With umy of the Inc:midie, as well as with the abore-mentioned laptorlyyohus, the males are larger and more powerful insects than the females. The two sexes of Fethres aphaloks (une of the Lamellicorns) inhabit the same burrow; and the male has larger mandibles than the female. If, during the breeding-season, a strange male attempts to cuter the burrow, he is attacked the female does not remain pacsive, but closes the mouth of the hurrow, and cn courages her mate by contiunally pushing him on from behind. The action does not ceace until the agerressor is killew or runs away." The ewo seses of anuther lamelli-

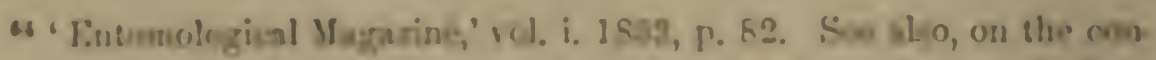

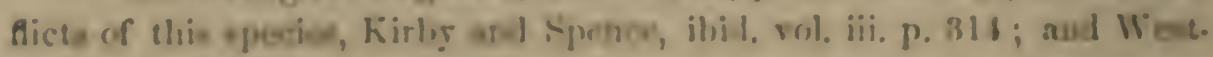
rooul, ilin. wol. i. 1) $18 \%$.

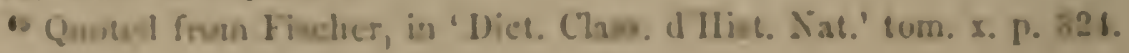




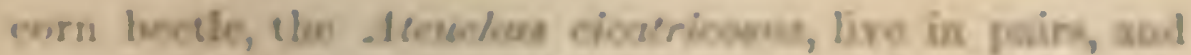

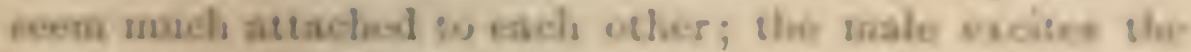
forste to rult the lualts of luve in which the ova are de

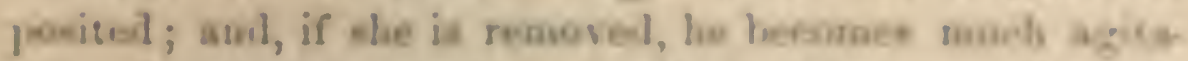
ted. If the male is removed, the fousle cenas all work,

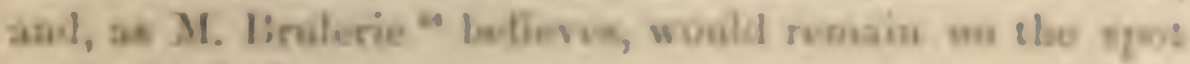
umil the disl.

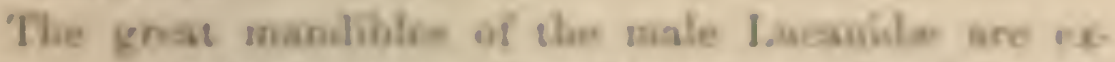

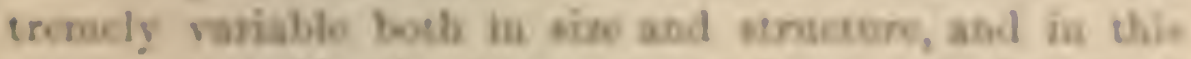

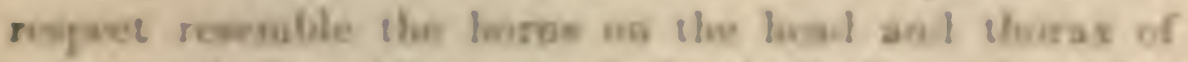
many male Jamedileones and scaphylinidx. A porfect

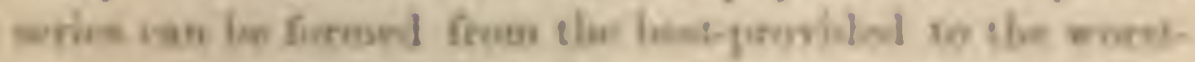
provided or degonorabe males Although ithe mandibles of the cmobum staglexthe, aseil prolably of misuy ot bir

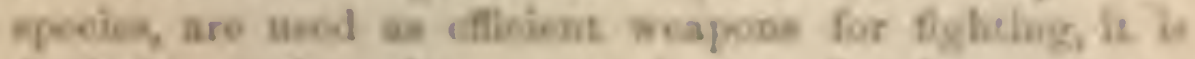

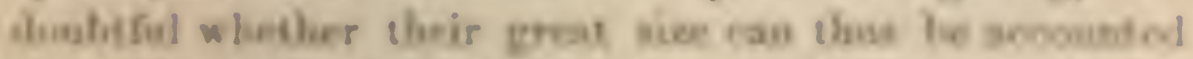
6ot. We bave newe that with the Juconus noghtur of

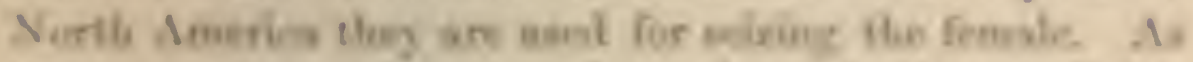

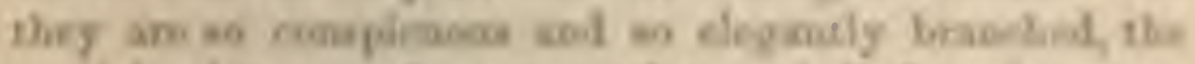

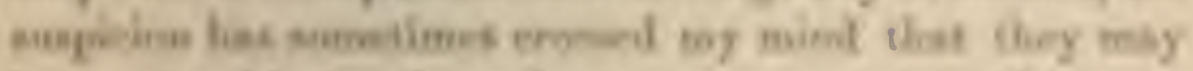
lo exriopable to the males as as ornacosat, in the sane

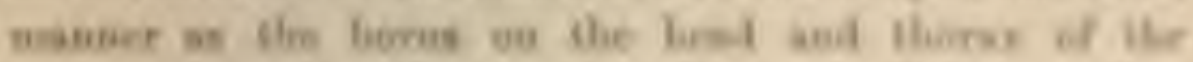

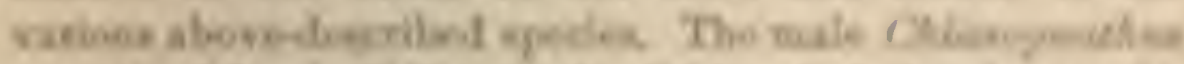

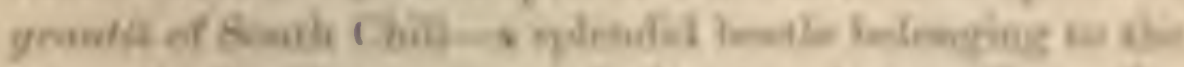

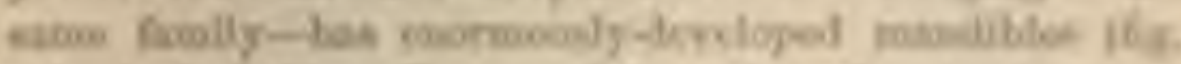

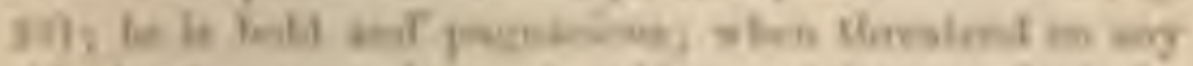

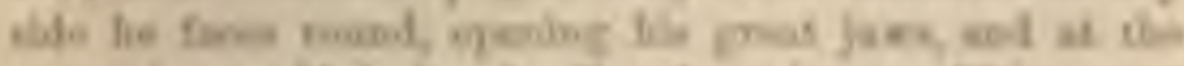

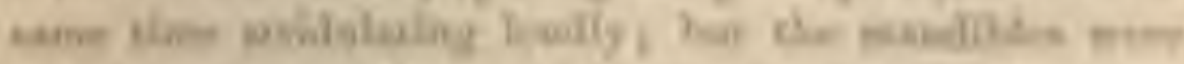

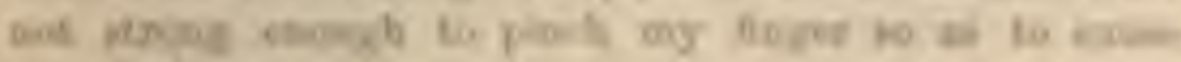
artast pais.

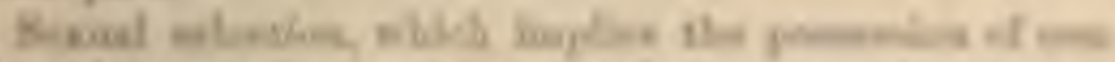

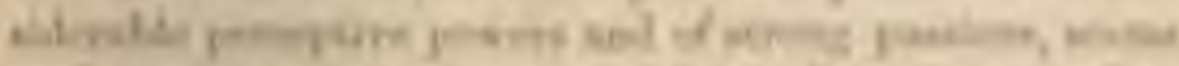

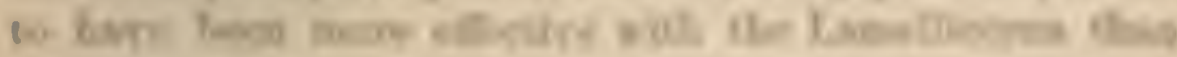

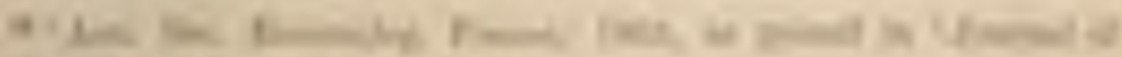

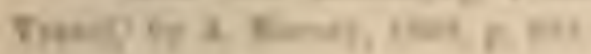


with any other fumily of the Coleoptera or beetles. With
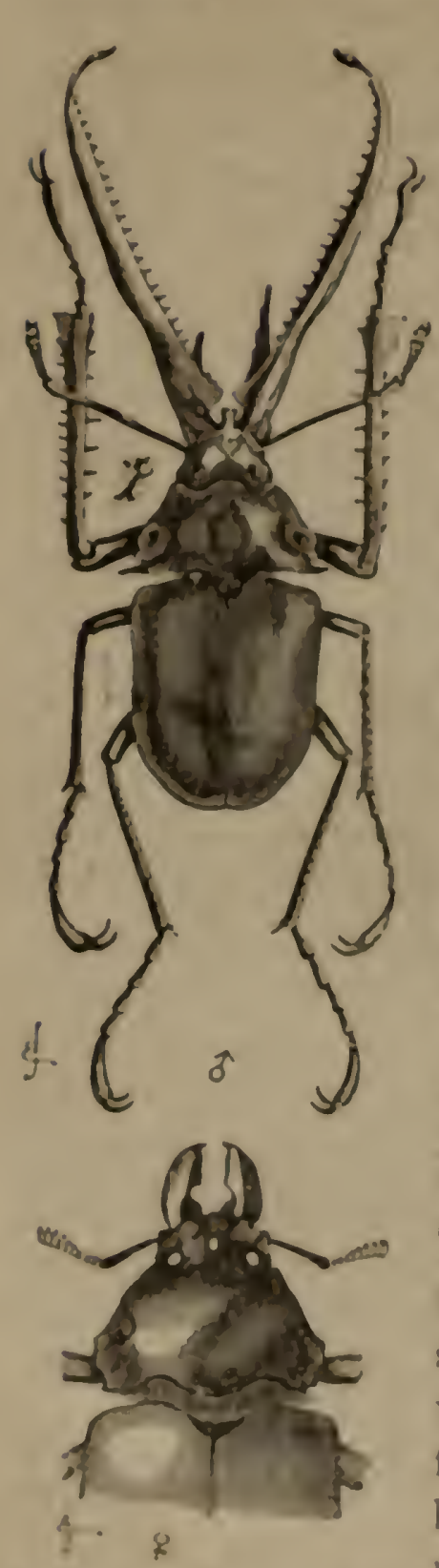

Ius: 23 - Chlomerathus zmnsil, rebral Ipuer Higure, nale; lower thare. fenale. some species the males are proviled with weapons for tighting; sume live in pairs and show mutusl aflection; many have the jowere of strilulating when excited; many are furmished with the most extracodinary horns, apparently for the salic of ormaneme; some which are dimmal in their hal)its are gorgeously colored; and, lastly, several of the largest bectles in the world belong to this family, which was placed by Limneus and Fabricius at the head of the Order of the Colcoptcra. ${ }^{e r}$

Sirictulating organs. - Bectles belongruen to many and widely-distinct fomilices posicess these organs. The somed catu sometimes be heard at the distanee of sereral feet or cren youls, bnt is not contraralile with that produced liy the Orthopted:i. The part which may be called the rave gencrally consists of a ualrow slightly-raised surface, crosterl ly very fine, farallel rilse, somelimes so fince as to camse iridescent colors, and laving a very clegant aplec:almue moler the microscople. In some easses, for imstance, with Typhass, it could lie plaiuly foen that extromoly mi-

s: Woenood, 'Mlablim Ches.' vol. i. p. 1 s.

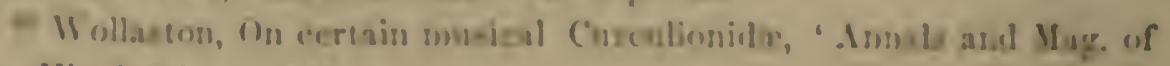
Nat. IIit." vol. vi. 1800, p. 11. 


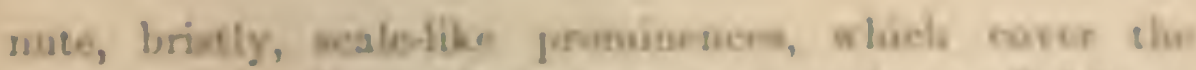

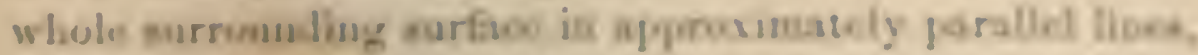

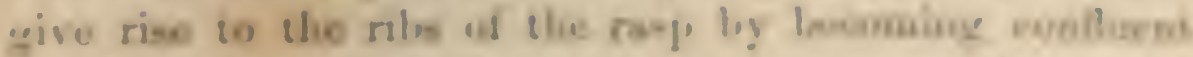

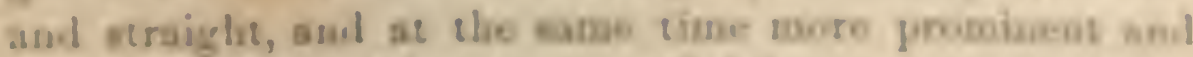

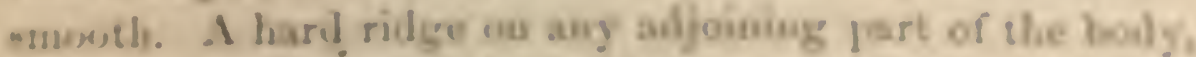

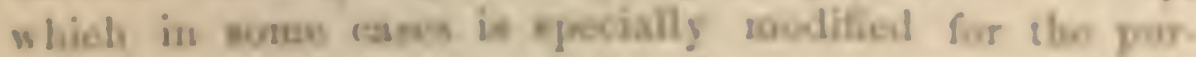

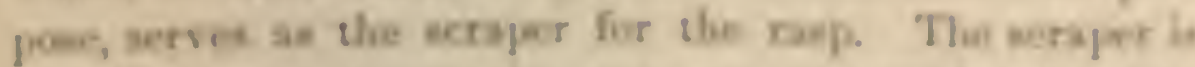

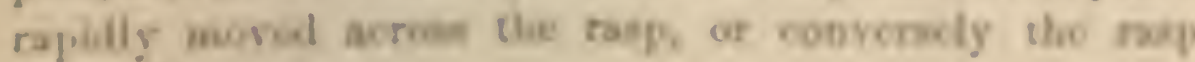
ac ries ilw scroper.

These argant sro kisasod in whlelyalifirewe peatione

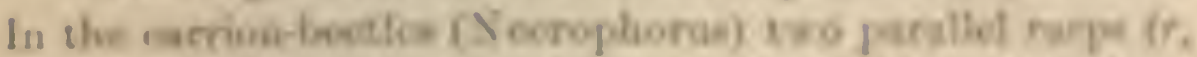
if. 24) ctand on tbe Aonat rurfuee of the fift atslominat
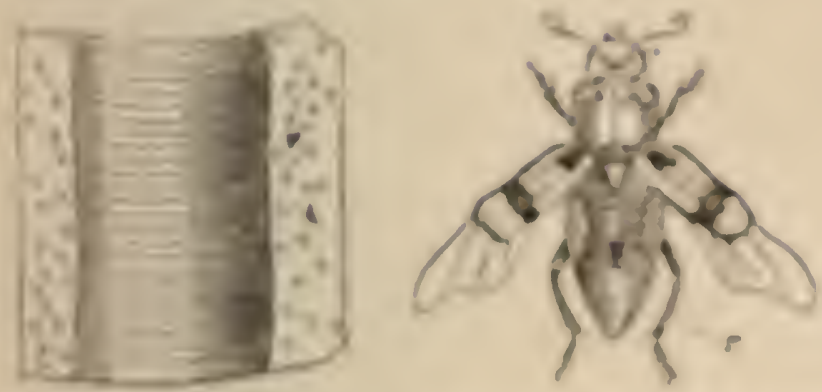

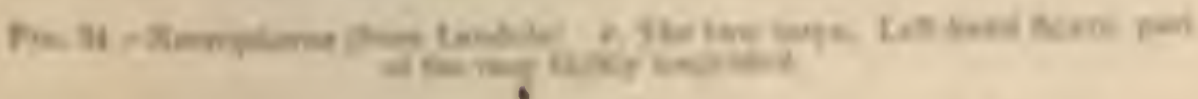

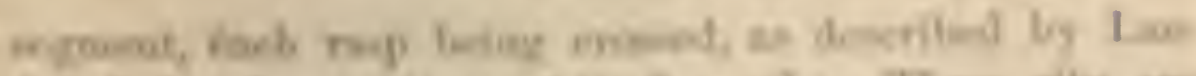

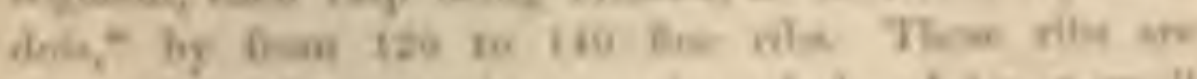

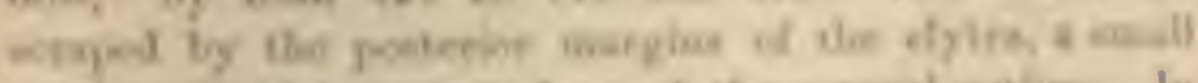

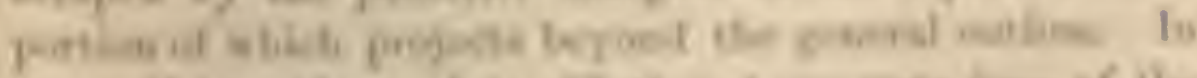

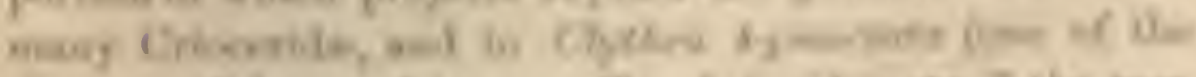

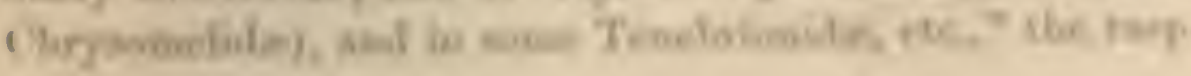

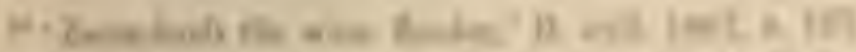

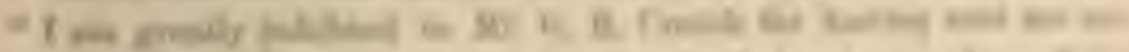

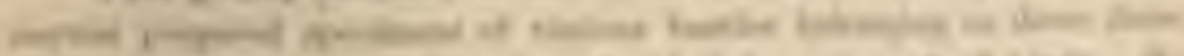

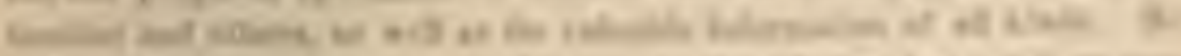

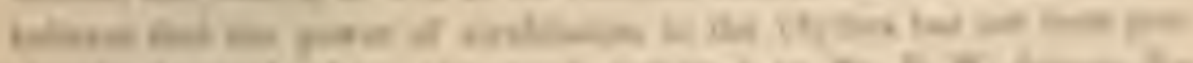

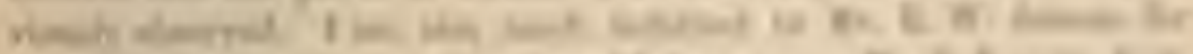

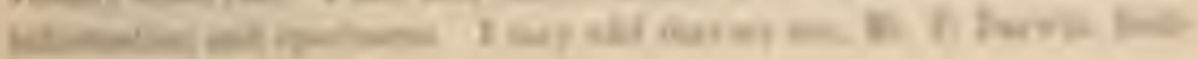


is seated on the dorsal apex of the abdomen, on the pygidium or pro-prgielium, and is scraped as abore by the elytra. In Heterocerus, which belongs to inther fanily, the rasps are placed on the siles of the first abdominal segment, and are scraped by ridges ou the fentora." In cortain Curculionida and Carabidae, ${ }^{72}$ the farts are completely reversed in position, for the rasps are seated on the inferior surface of the elytra, near their apices, or along their outer margins, and the edges of the abdominal senments serve as the scrapers. In Pelobius hermanni (one of Dyticcida or water-bectles) a strong ridge runs parallel and near to the sutural margin of the dytra, and is rrosscd by ribs, coarse in the middle part, but becoming gradually finer at both ends, especially at the upper end; - when this inecet is held under water or in the air, a Etridulating noi-e is produced by scraping the cetreme horny margin of the abdomen against the rasp. In a great mumher of long-horned heetles (Longicornia) the organs are altogrether differently situated, the rasp being on the meso-thorar, which is rubbed against the jorothoras; Landois counted 238 very fine ribs on the rasp of Coramloy.r heros.

Many Lamellicorus have the power of stridulating, aud the organs diffier greatly in pocition. Some specit's stridulate very londly, so that when Mr. F. Smith caught

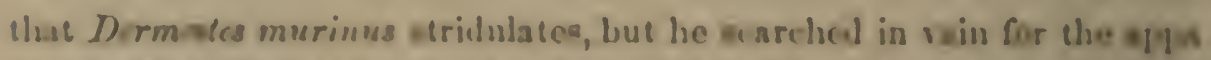

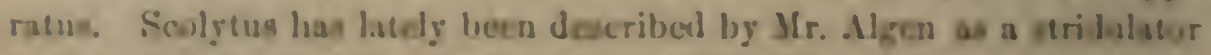
in the 'Folizburgh Monthly Magazine,' 1869, Nor., p. 180.

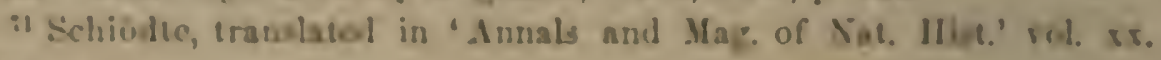
196, , p. 37.

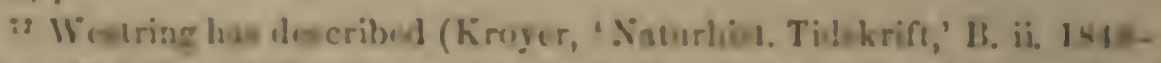

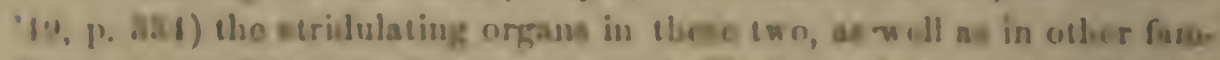

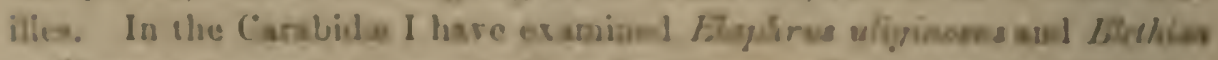

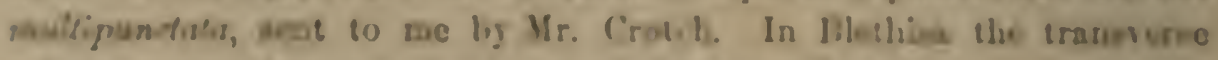

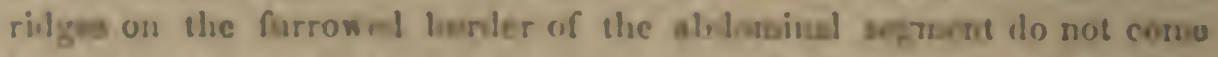

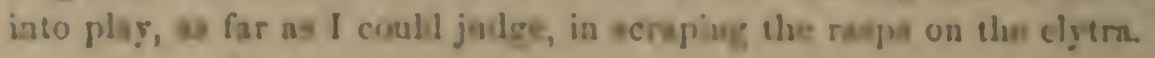




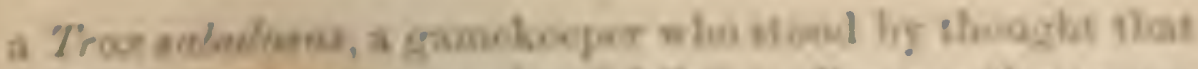

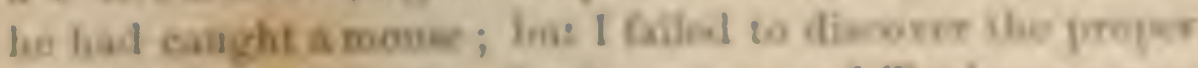

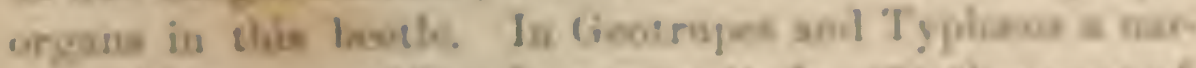

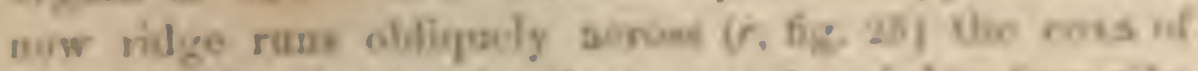

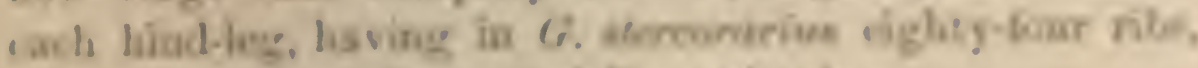
whieh arn acrapod by a / pecially projeoting fart of ome of the alobiminal nogmoese la

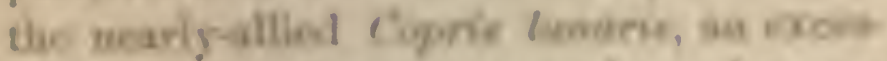
sively narcos fime raty euns slone thie raso.

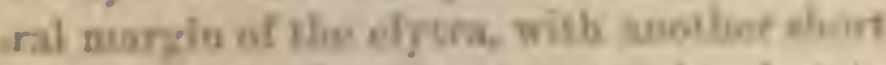
reap war the foed colit margin ; bet in sovelo oeber Coprimi the rawp is watel, se roclieg to Isoonte" on the deosed nurfaces af the abolomice. In Oryeses is is kaveot on

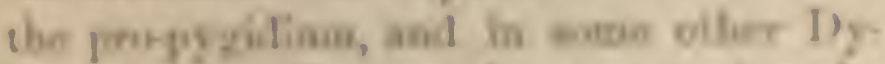

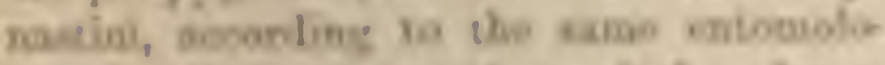
cinc, ua the ander carfare of the elytra.
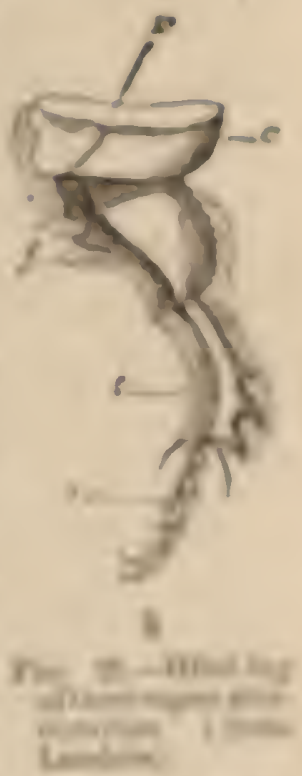

h Dowa y $8=4+$

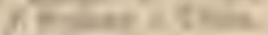

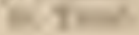
bierases, the parte thos occupgluy the

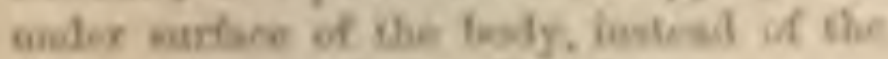
Lavty. Westrue slates that is Omaloptio

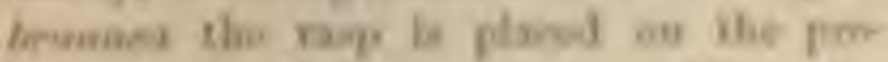
stomoun, and the knaper an tho meta

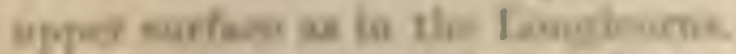

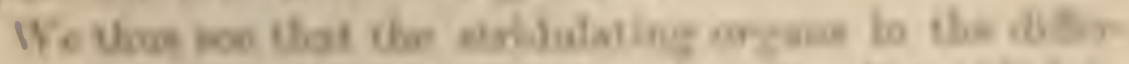

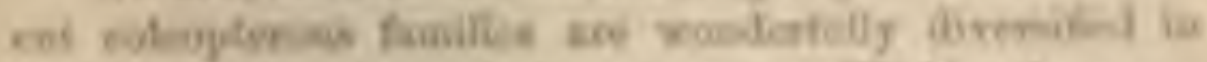

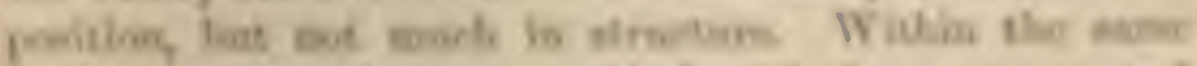

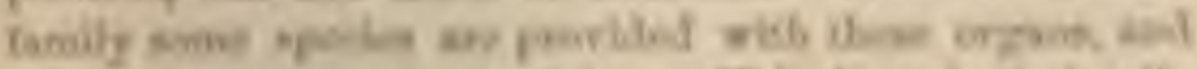

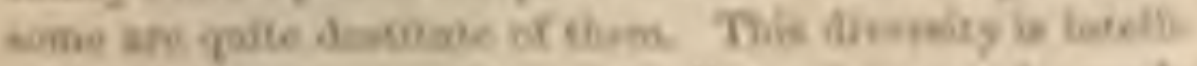

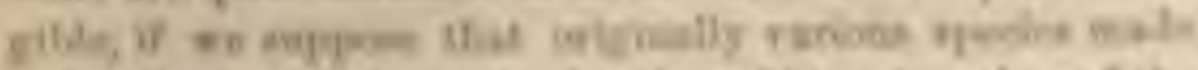

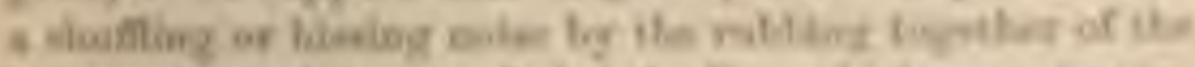

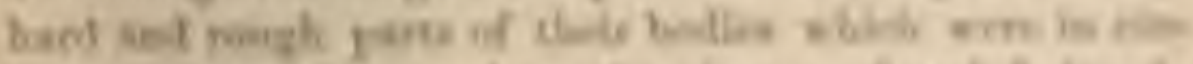

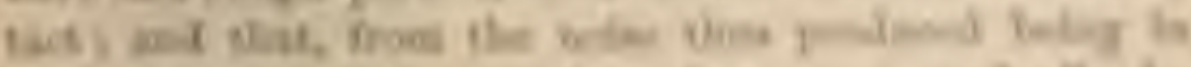

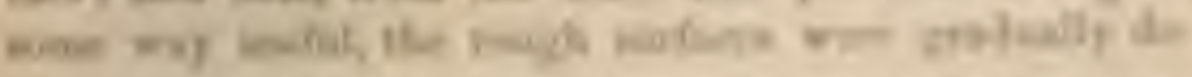

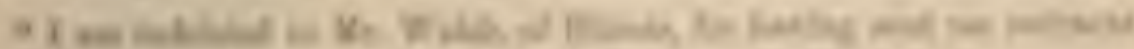

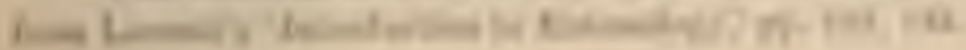


veloperl into regular stridulating organs. Some beetles, as they move, now produce, either intentionally or mintentionally, a shufling noise, without possessing any proper organs for the purpose. Mr. Wallace informs me that the linchirus longimenus (a Lamellicorm, with the anterior legs wonlerfully elongated in the male) "makes, while moving, a low hissing somd by the protrusion and contraction of the abdomen; and when seized it produces a grating sound by rubbing its hind-legs agranst the erlges of the elytra." The hissing somel is clearly due to at narrow rasp rumning along the sutural maregin of calch dytron; and I could likewise make the grating sound by rubbing the slagreened surface of the femur agriust the gramulated margin of the corresponding clytron; lut I could not here detect any proper rasp; nor is it likcly that I could lave overlooked it in so large an insect. After examining Cychrus and reading what Westring has writen in his two papers about this beetle, it seems very donbtul whether it possesses any true rasp, though it has the power of enitting a sombl.

From the amalogy of the Orthoptera and Homoptera, I expected to find that the stridulating organs in the Colcoptera differed according to sex; but Landuis, who has carefully exanimed several species, observed no smeh diflerence; nor did Westring; nor did Mr. G. R. Crotch in preparing the numerous specimens whieh he hat the hindness to send use for examination. Any slight scxual diflerence, however, would be diflicuit to detect, on account of the great vanialility of these organs. 'Thus, in the first pair of the Necrophorus jumator and of the lilobius which I cxamined, the rasp was considerably larerer in the male than in the female; but not so with succecting specimens. In Geotrupes stercorurius the rasp) appeared to me thicker, opaquer, and more prominent in three nales than in the same number of females; conse. 
quenel! m! son, Mr. W. Warwin, is onler io diecover wherher the seres difle red in thoir powrs of stridulasing.

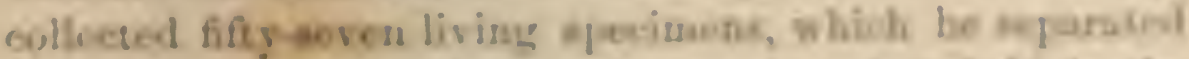
into two luts, acooriliag at sher madr. when fidh hin the

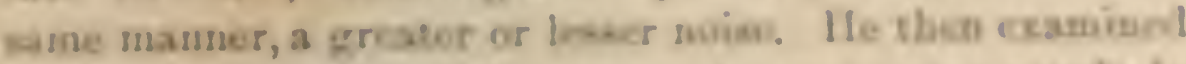

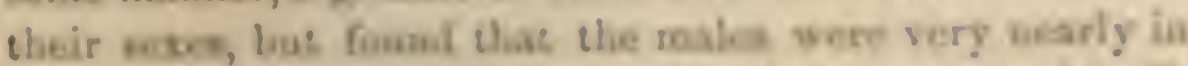

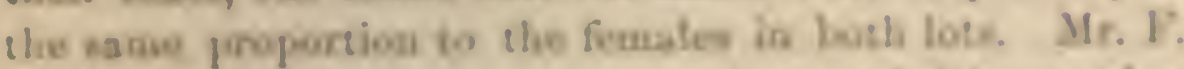

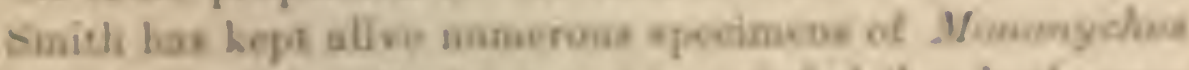

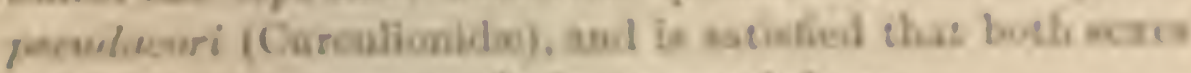
strilulase, mul apyareully in the equal degroc.

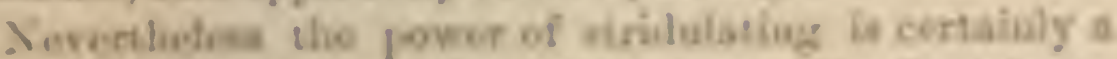

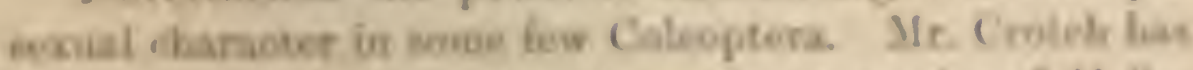

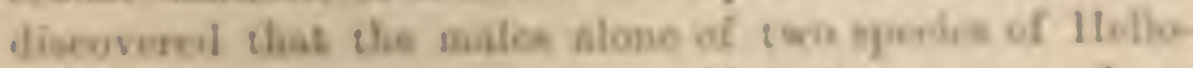

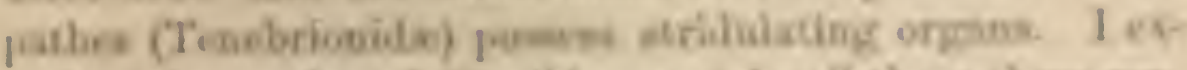

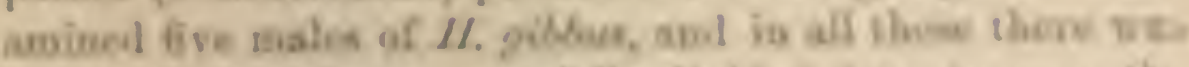
a wollderoloped rotp, parcially divides duto two, os the

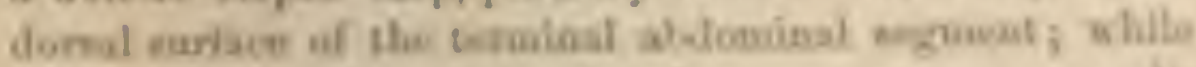

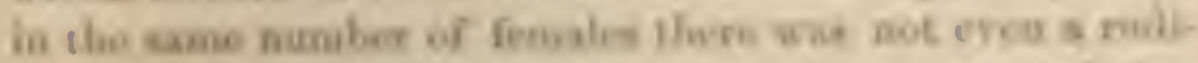

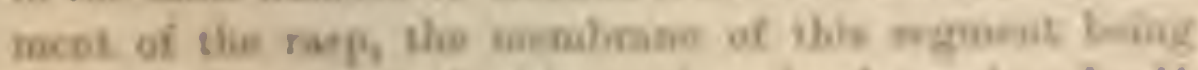

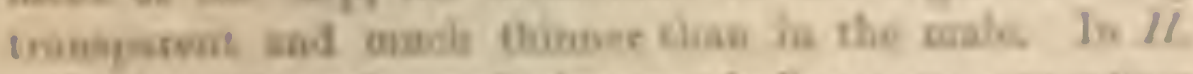

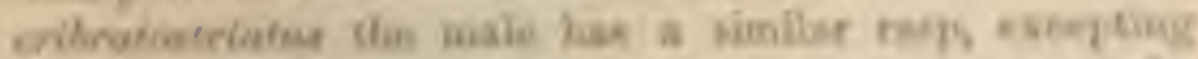

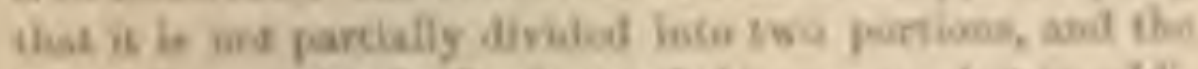

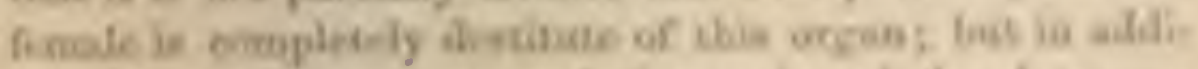

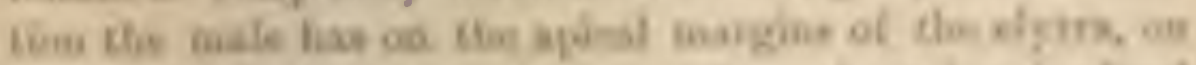

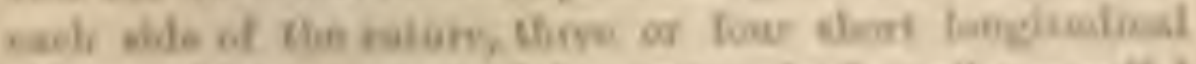

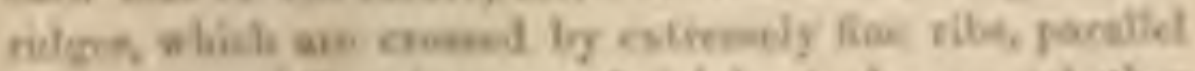

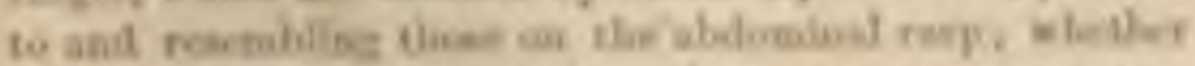

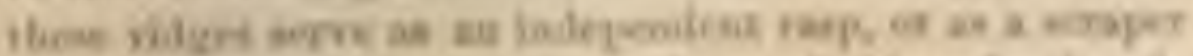

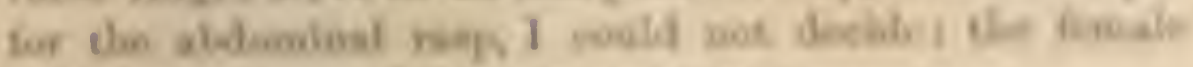

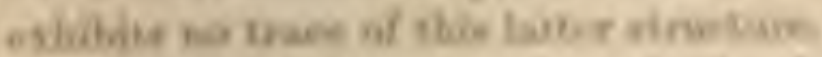

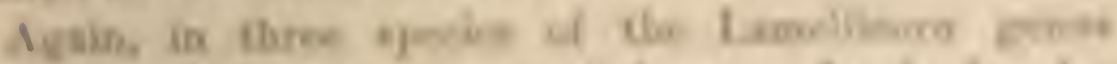

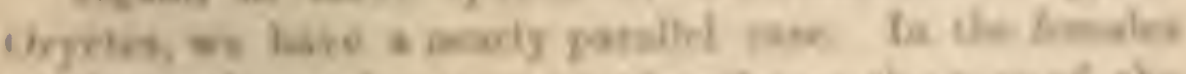

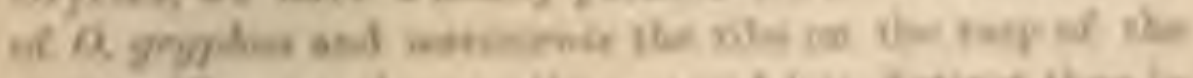

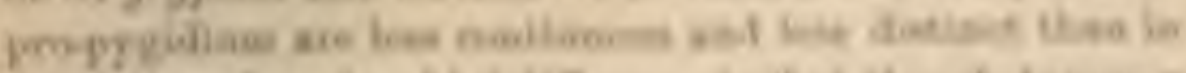

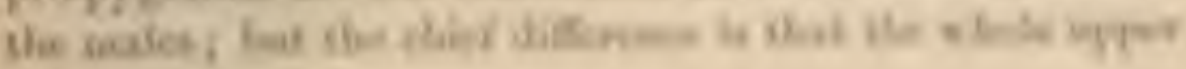


surface of this segment, when hold in the proper light, is secen to be clothed with hairs, which are absent or are represented by excessively fine down in the malce. It should be noticed that, in all Coleopicen, the collective part of the risp is destitute of liairs. In $O$. senceulensis the diflirence between the sexes is more strongly marked, and this is best seen when the proper senment is cleaned and viewed as a tramsparent object. In the female the whole surface is covered with little separate crests, bearing spines; while in the male these crests become, ia proceceling toward the apex, more and more conflucut, regular, and uaked; so that three-fourths of the segment is covered with extremely fine parallel ribs, which are quite alsaut in the female. In the females, however, of all three species of Oryetes, when the abdomen of a softened specimen is pushed backward and forwaril, a slight grating or stridulating sound can be produced.

In the case of the Meliopathes and Oryetes there can hardly be a doubt that the males stridulate in order to call or to cxcite the females; but with most bectles the strilulation apparently serves both sexes as a mutual call. This view is not remlered improbable from beceles strilulating under various emotions; we know that birds use their voices for many purposes besiles singing to their mates. 'The great Chiasognathus stridulates in anger of defiance; many species do the same from distress or forr when held so that they camnot escape: Messrs. Wollaston and Crotch were able, by striking the hollow stoms of trees in the Canary Islamels, to discover the presence of bectles belonging to the genus Acalles by their stribulation. Lastly, the male Atcuchus stridulatus to cncourage the female in her work, and from distros when she is remored." Some naturalists belicre that beetles make this

id Ir. l'. de L liruluric, as yqueted in 'Journal of Trusel,' A. Murnay, rol. i. 1 stik, p. $1: 35$. 
soies to irighton awag their chemies; but I cannot think that the quadeugels aul birils which are ahfe da devour the larger bectlo, with their exirumely lard coata, would he frightenat by no slight a grating sanul. The hellef that the seridslasion wrres at a wordal eall is wopported

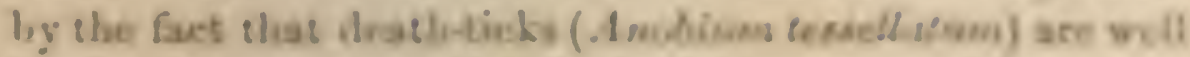

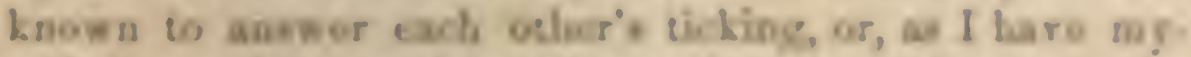

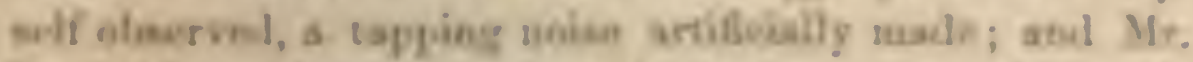
Doublediy informe me that be hat twios of thrive ob arrovl a feruale ticking," an-l in than cuune of ae bour or iwo bas fourd her unfted with a male, and on one wear

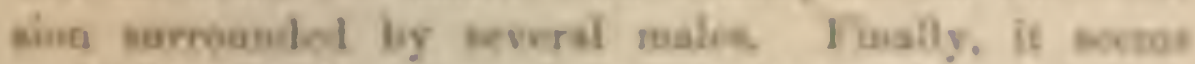
proboble that the swo wexne of masy kinde of bestras were

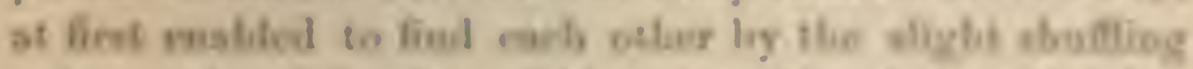
soise produced by the rabbing togother of tze allfuining porte of their hanl hodios; and tlas: as tbe males af

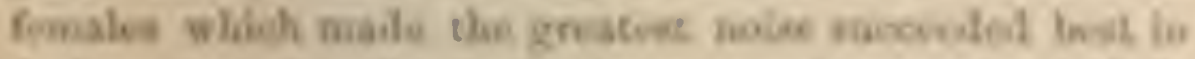

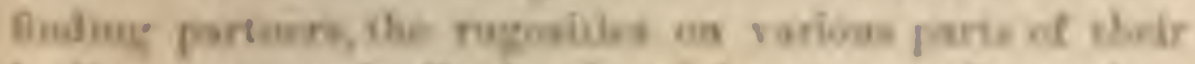

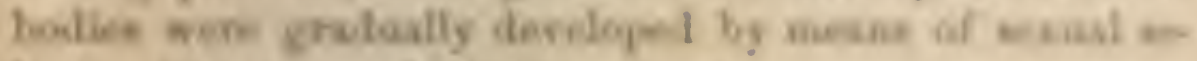

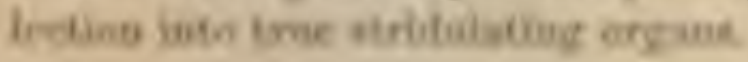

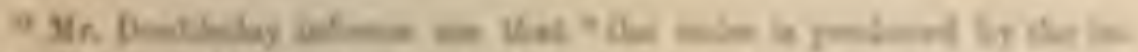

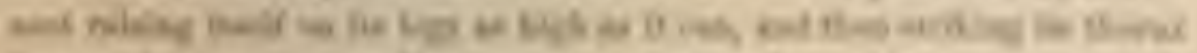

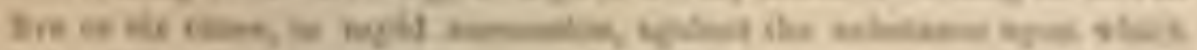

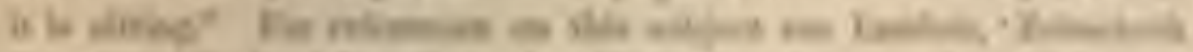

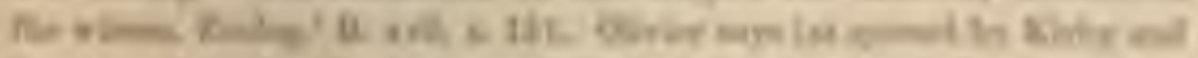

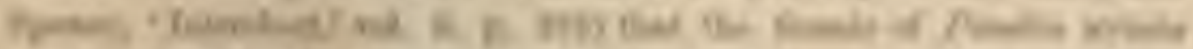

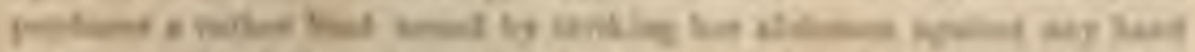

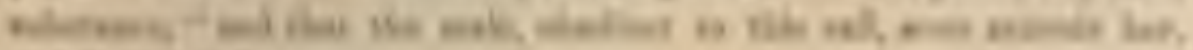
ont Mer po: 


\section{CHAP'TER XI.}

IxSECTS, continued.-ORDI: I.XPIDOPTERA.

Courtship of Butterflies.-Battles.-Tieking Noisc.-Colors common to Both Sexes, or more brilliant in the Males. - lixamples. - Nort due tw the Direet Action of the Conditions of Life.-Colors adnpted for l'rrotection.-Colors of Moths.-Display. - l'erecptive I'nwers of the Leppidoptern.-Variability.-Canses of tho Difference in Color letwen the Males and Females. -Minicry, Female Butterfies more brilliantly colored than the Mnles. - Bright Colors of Caterpillars.-Summary and Coneluding Remarks on tho Secondary Sexual Characters of Insects._Birds and Insects compared.

In this great Order the most interesting point for us is the diflerence in color between the sexes of the same speries, and between the distinct species of the same genus. Nearly the whole of the following chapter will be devoted to this subject; but I will first make a few remarks on one or two other points. Several males may often be secu pursuing and crowding round the same female. Their courtship appears to be a prolonged aftair, for I liave frequently watehed one or more males pirouetting romd a female until I became tired, withont secing the cund of the courtship. Although butterflies are such wcak and fragile creatures, they are pugnacions, and an Emperor butterfly ${ }^{2}$ has been captured with the tips of its wings broken from

'A patura Iris: 'The Fntomologist's Weckly Intelligencer,' 1859, p. 139. For the Bornean Buttertlics, sce C. Collingwood, 'Rambles of a Naturalist,' 1868, p. 183. 
at couflice with amother male. Mr. Collingwond, in spest. ing of the frequent battles butwere the butcerlies of bior. suco, sags, "They whirl rouml each ofloor wit! the greatent rapidity, and appear (1) he incited by the greaten forveit!." One conse is known of a lusterty, muely, the Agrowic jeronie, which wakes a noise like that prodused by a soothed whed pasing under a rgringeratch, and which

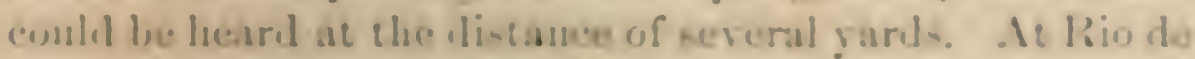
Janciry this sonud was noticed by me, osdy when two

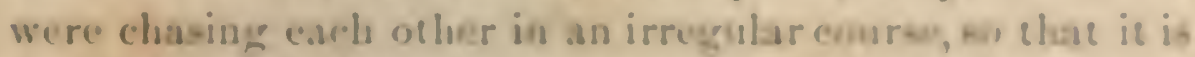
probably sude during the coureship of the nesos; lou I neplocted to atpend to this poimt."

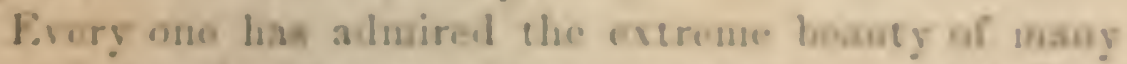
butcertices and of some moths; amd we are led to has, llow has this heasty heon acquirod? Have thir culors am! disersitiol paturns vimply resuled from the direet action

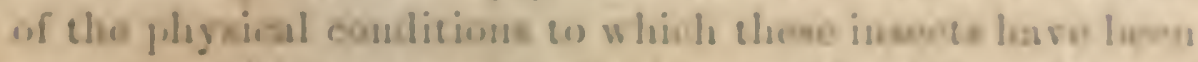
oppocl, whlout ang bonetid being thes dorived? Or

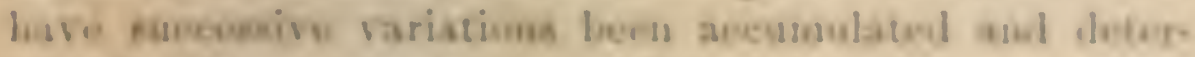

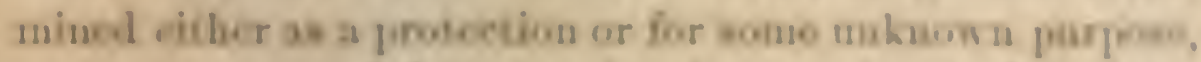

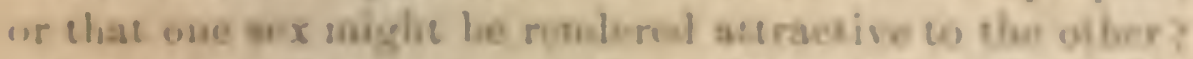
Aod, agrain, rlat is the meaning of the colone bolng wht-

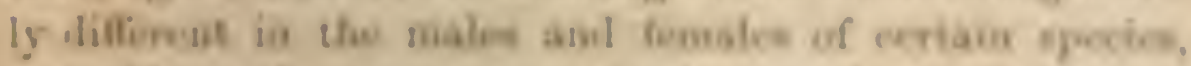

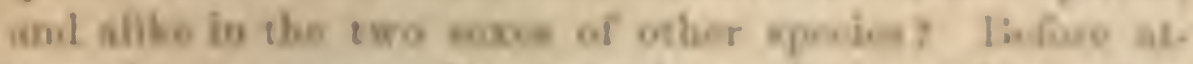
tomptiong in answer these merstions a bnely of facts bana be vivet:

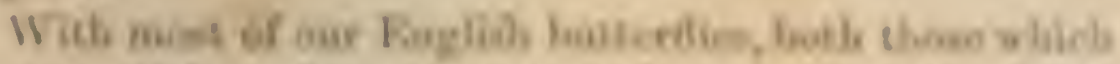
are beastifid, mels os the admiral, proses, and pointed

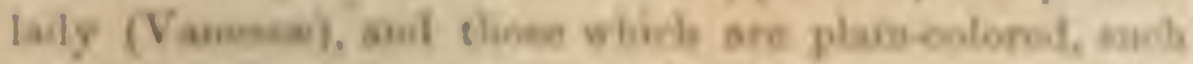

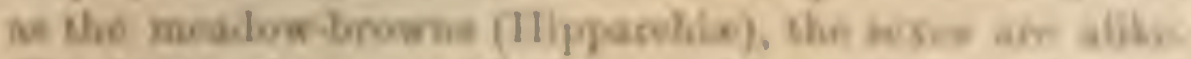

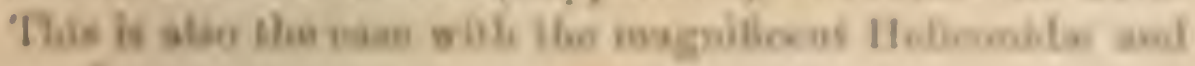

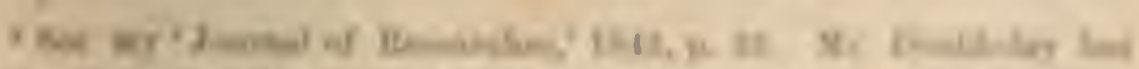

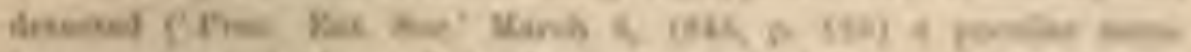

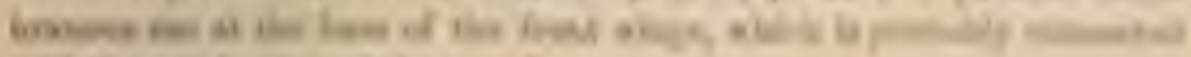

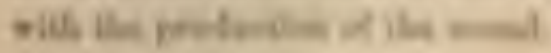


Dunaidse of the tropics. But in cortain other tropical gronps, and with some of onr Finglish butterlies, as the purple enperor, orange-tip, etc. (.Apatura Iris and $A$ thocheris curdemines), the sexes difler cither greatly or slightly in color. No language suftices to describe the splentor of the males of sume tropical species. Fiven within the sane genus wo often find spevies presenting :u extrodinary difference between the sexes, while others have their sexes closcly alike. Thus in the South Ameriean genus Fipiealia, Mr. Bates, to whom I an unch indebted for most of the following facts and for looking orer this whole discuscion, informs me that he knows twelve species, the two sexes of which haunt the same stations (and this is not always the case with buttertlies), and therefore cannot lave been differently aflected ly external conditions.' In nine of these species the males rank anong the most brilliant of all butterflice, and differ so greatly from the comparatively flain temalee that they were formerly placed in distince genera.-The females of these uine species resemble each other in their general type of coloration, and likewise resemble both scxes in several allied genera, fomil in varions parts of the world. Henee, in accordance with the descent-heors, we may infer that these nine species, and probably all the others of the genus, are descended from an ancestral form which wat colored in nearly the same manner. In the tenth species the fomale still retains the same general coloring, but the male resembles her, so that he is colored in a much les gandy and contrasted manner than the males of the previous species. In the eleronth and twolfh species, the fomales lepart from the type of coloring which is nonal with their sex in this geuna, for they are gayly ilecorated in

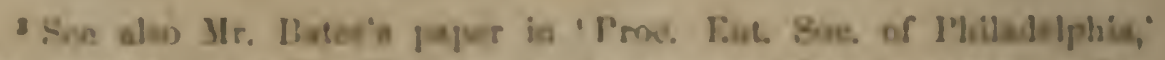

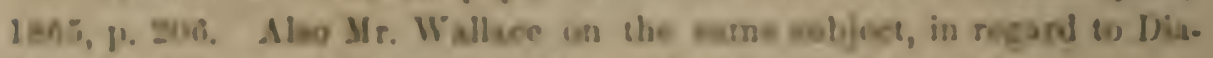

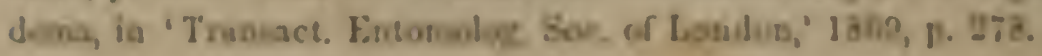




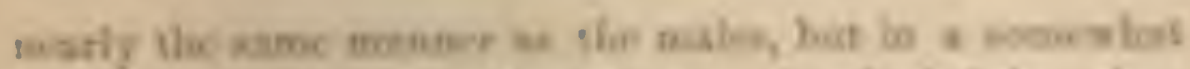

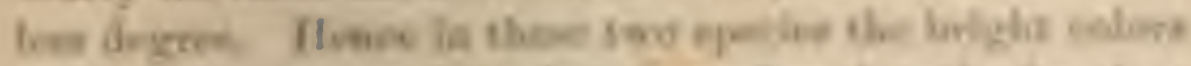

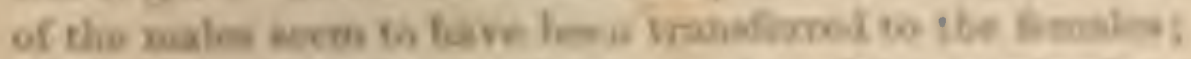

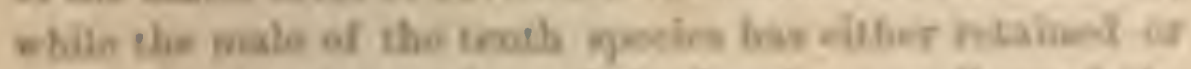

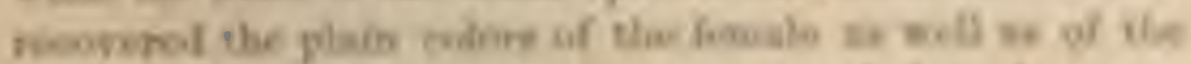

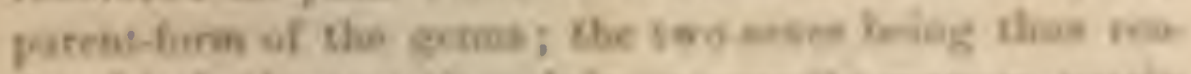

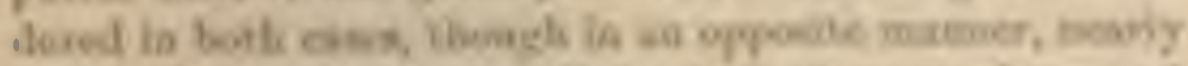

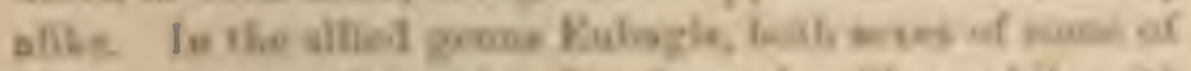

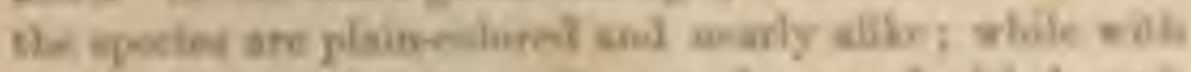

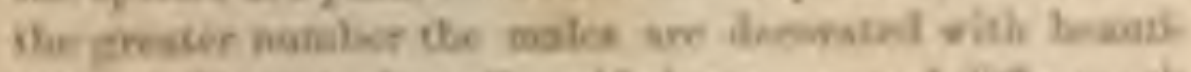

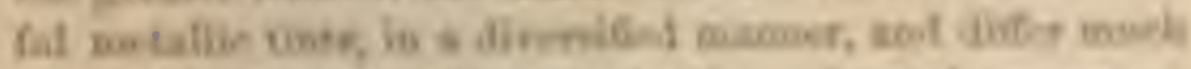

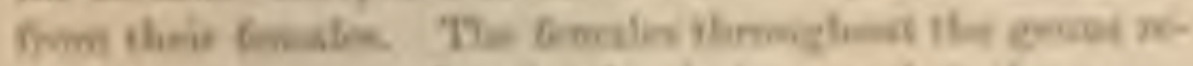

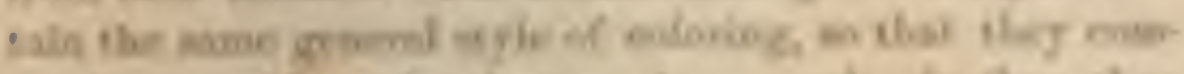

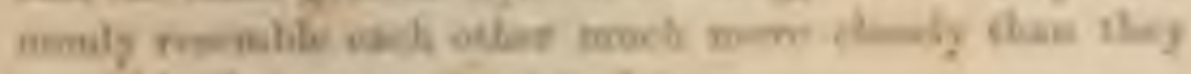

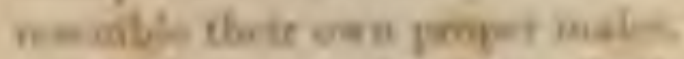

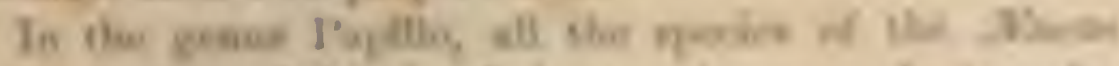

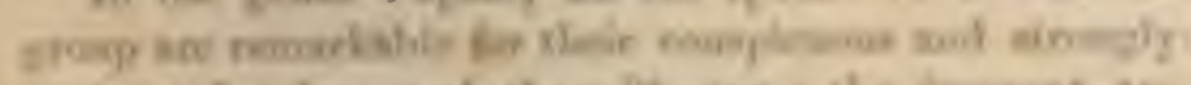

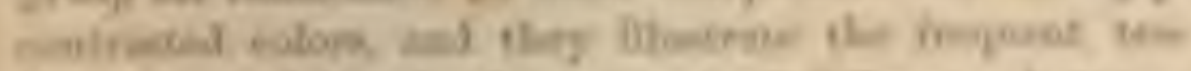

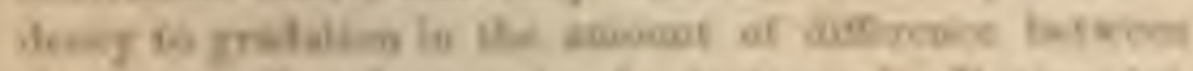

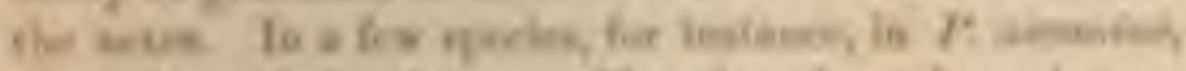

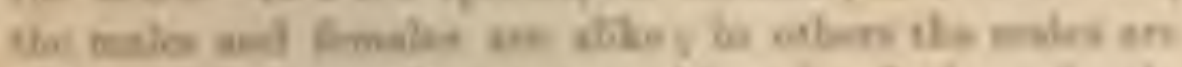

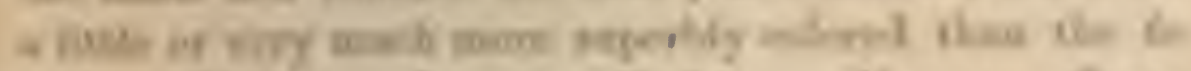

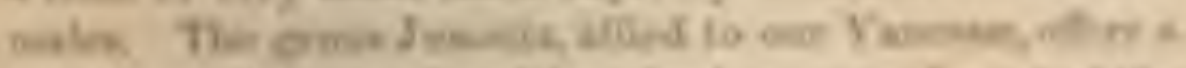

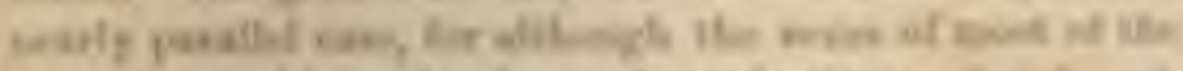

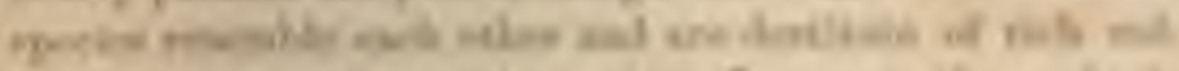

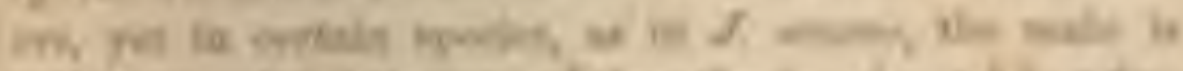

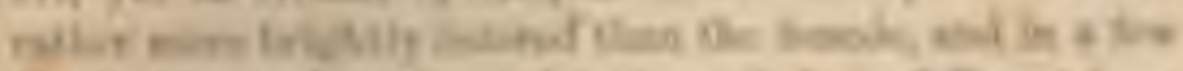

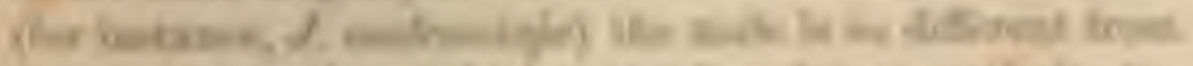

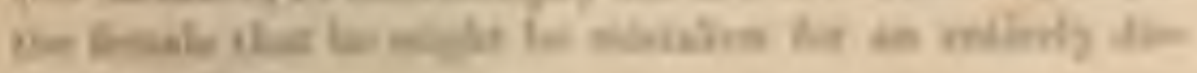
Cinet tpeses.

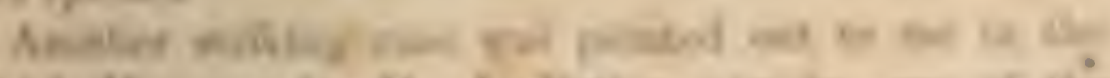

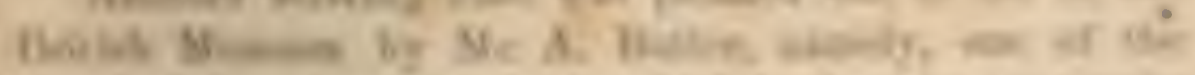

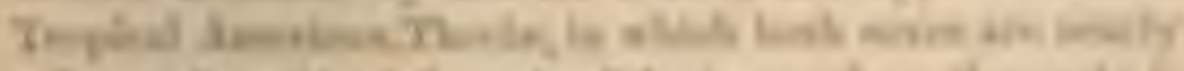

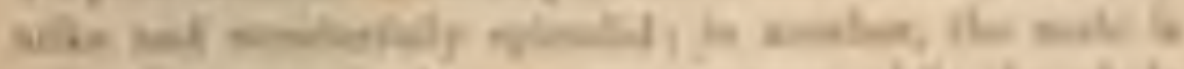
mimila a whe iI 
upper surfice of the female is of a dull uniform brown. Our common little Engrlish blue hutterflies, of the gremus Lyciena, illustrute the various diflerences in color between the sexes, almost as well, thongl not in so striking a manner, as the above exotic gencra. In Lyerma agestis both sexes have wings of a brown color, borlered with small ocellated orange spots, and are consequently alike. In $L_{\text {. }}$ ayon the wings of the male are of a fine blue, bordered with black; while the wings of the female are brown, with a similar border, and closely resemble those of $L$. agestis. Iastly, in I. arion both sexes are of a hlue color and nearly alike, though in the female the ertges of the wings are rather duskier, with the black spots planer; and in a hright-l,he Indian species both sexes are still more closcly alike.

I have given the foresering eases in some divail, in order to show, in the tirst place, that, when the seres of butterflies differ, the male as a general rule is the most hesutiful, and departs most from the usual type of coloring of the group to which the species belongs. Hence in most groups the females of the several species rescomble rach other much more slosely than do the males. In wome exceptional cases, howerer, to which I shall hereafter allude, the females are colored more splondiclly than the males. In the second place, these cosces have bern griven to bring clearly before the mind that, within the sime genus, the two sexes frequently presont every gradation from no difference in color to so great a lifference that it was long before the two were placed ly rutomologrints in the same genus. In the third place, we have secon that, when the soxes nearly resemble ach other, this apparenty may be due cithere to the male having transferred lis colors to the female, or to the male liswing retained, or perliaps recovered, the primordial colors of the grems to which the species heloners. It also desrrves notice that 
in those groups in which the sexes prestut any differenos of colur, the females usually reomble the miles to a oertain extcut, so that, when the males are beausist to an rx. tracrilinary degree, the females almoet inrariably exhilbit sume degree of leanty. From the mumerust cases of gers. datios in the amount of difti resse hetwess the wack, asu from the provalence of the tame grural igpe of ocolontion thronghout the whole of the mase group, we ma! ondescle that tbe canses, whatever tbeg may bo, which bave Jotermined the lurilliast coloriug of the mates aloue of

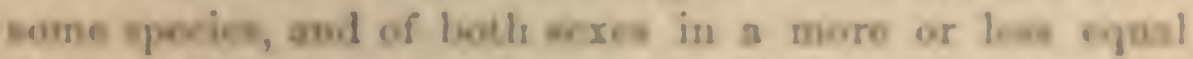
degroo of atlier specirs, have grverally been the same.

At to reany gongoous beterition inlabit the unopies, it has offen been supjuased that they owe their cobn to the sreat hiat and moieture of these zons; hut M/r. liates

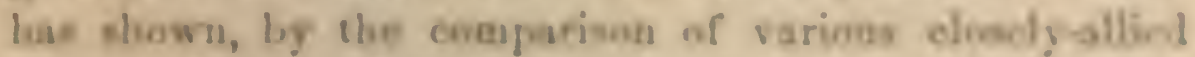

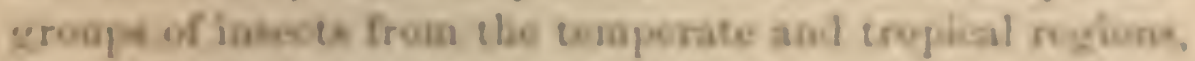
that thie viow mumot lo maimsisod; ase the exileson

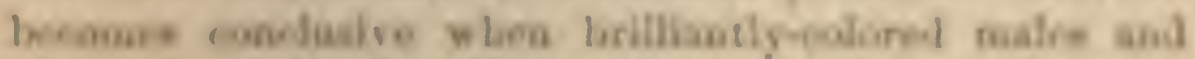

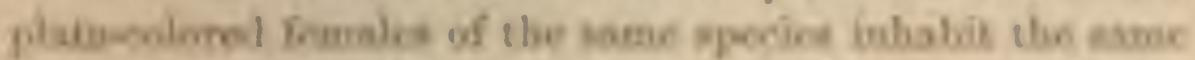
distich fuel in the sane fool, ase follow exartly slie

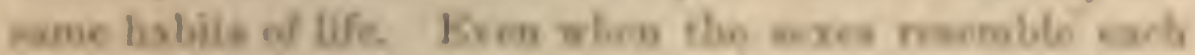

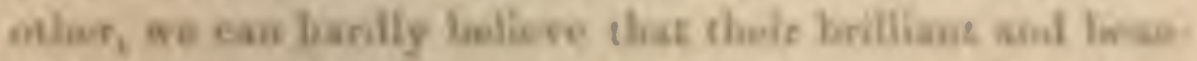

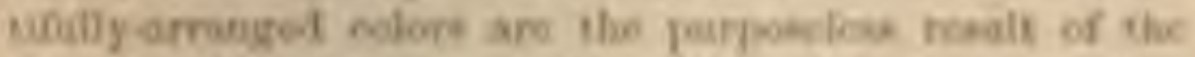

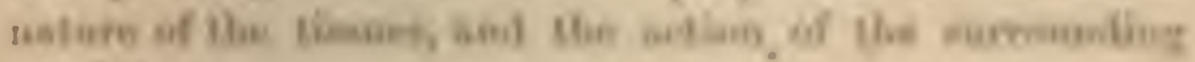
copolitiones

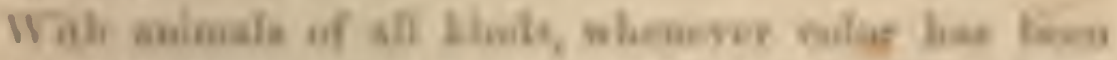
modibal foe toone spesial porpoes, dibe has lecks, as far at

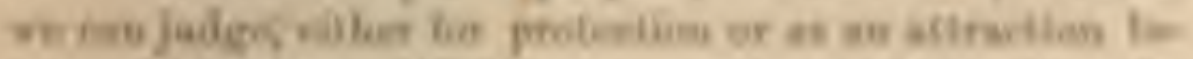

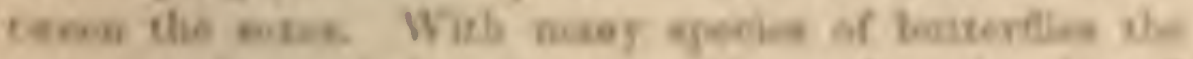

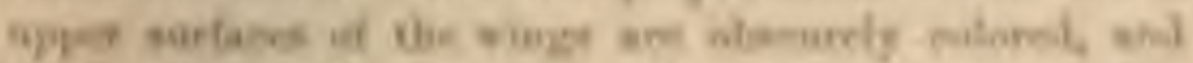

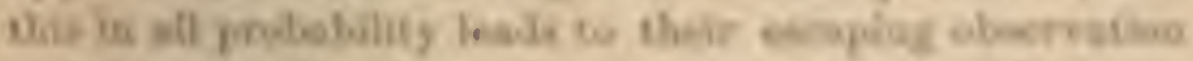

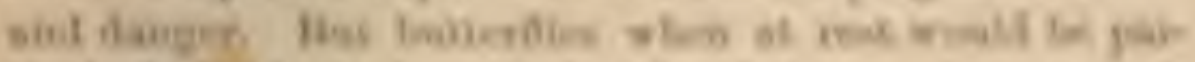

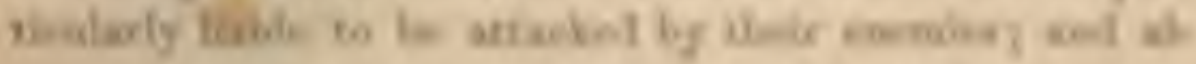

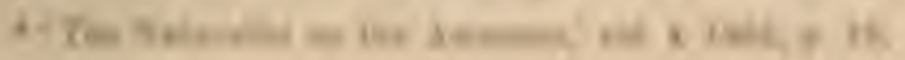


most all the himbla when resting raie their wings rertieally over their backa, wh that the lower sildes alone aro exposed to view. Henoe it is this sile which in many chses is obriously colored so as to imitate the surfares on which these insciets commonly rest. Dr. liüsser, I lecliere, first noticed the similarity of the clesend wings of certain Vancsse and other butterflies to the bark of trees. Many analogous and striking faces coull be girou. The mont interestiug one is that recorded ly. Mr. Wallace of a common Indian and Sumatran butherly (Kallima), which disappears like magric when it sentes in a lusb; fur it hides its hood and antenthe betreen its clused wings, and these, in form, color, and scining, cammot be disinguished from a withered leaf together with the font. killk. In some other coses the lower surfaces of the wings are brilliamly colored, and yet are protectire; thut in Thecla rubi the wings when closcel are of an cuerah green and resemble the young leares of the hramlile, on which this butterly in the spring may ofen be scen seated.

Alliongh the ubscume tints of the upper or unler nurfoce of many buterflies no doube serve to conceal thim, yet we cannot powibly ertemi this viow to the brilliant aul conspicuous colors of many kinds, such as our aluairal and peacock Vane-se, ous white cabbagc-butterflies (Pieris), or the great swallow-tail Papilio which hanus the upen fens-for these butertlion are thus renderod visible to crory lising creature. With thete ppecies louth seres are alike; but in the common brimetone lutterly (Go nejergs rloswinf) the male is of an intense gellow, while

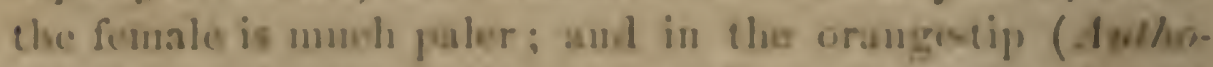
charis curdumine) the bales blone have the loright

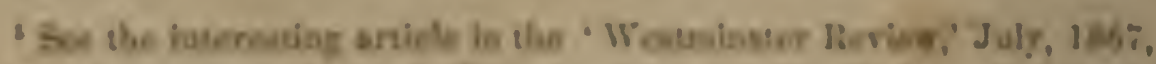

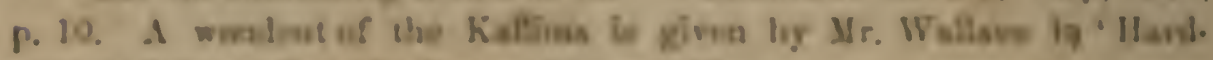

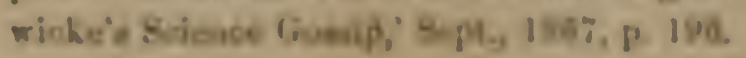




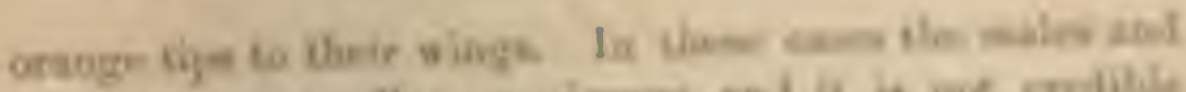

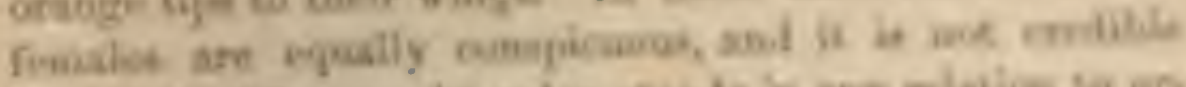

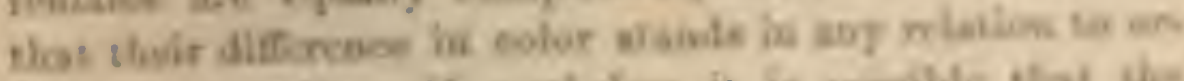
dinary protertion. Neverthelees, is in jemble tlat the

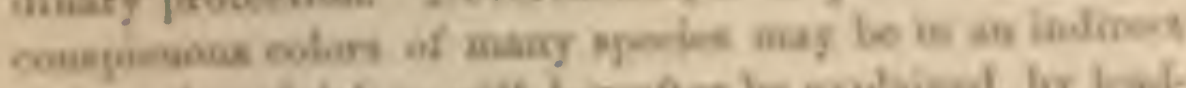

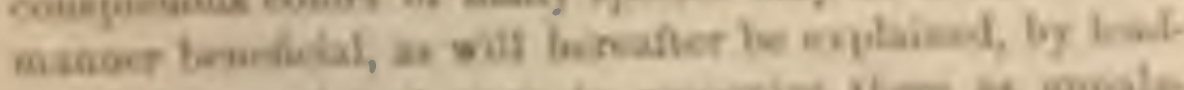

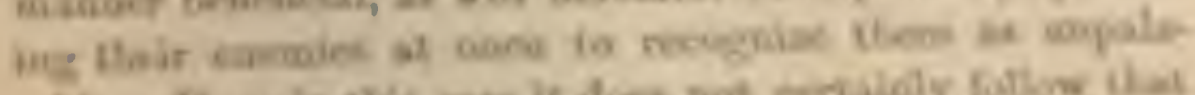

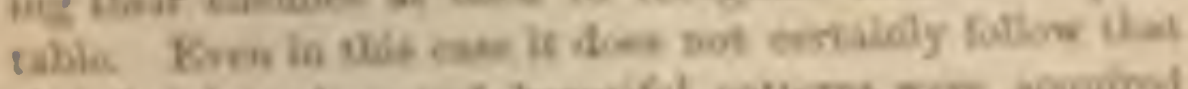

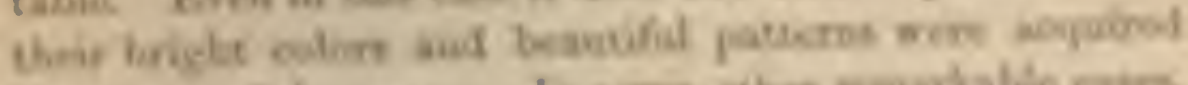

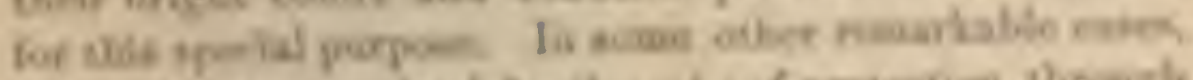

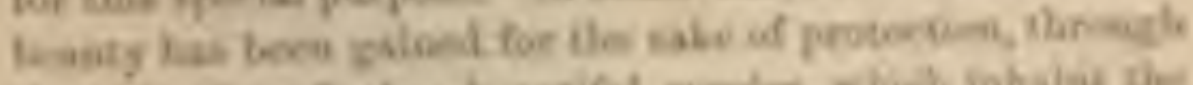

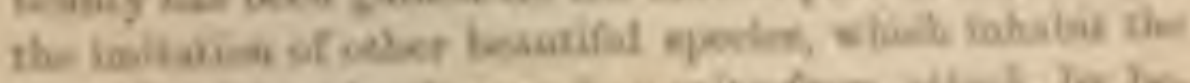

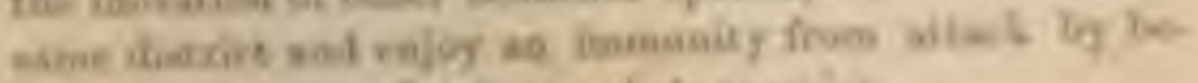

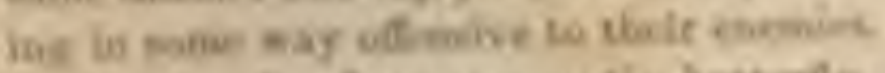

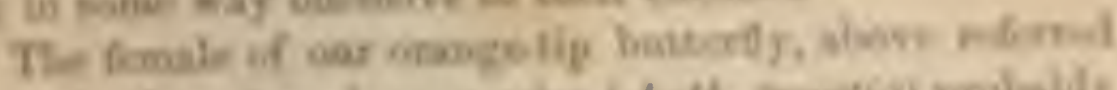

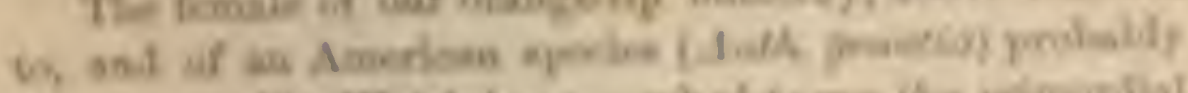

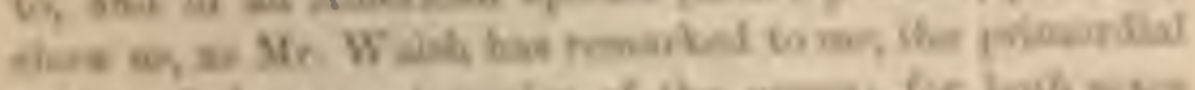

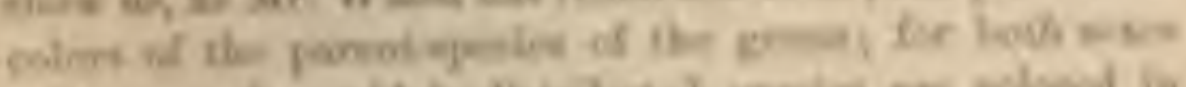

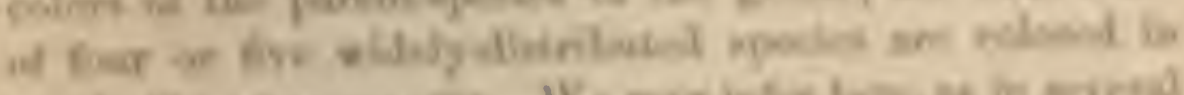

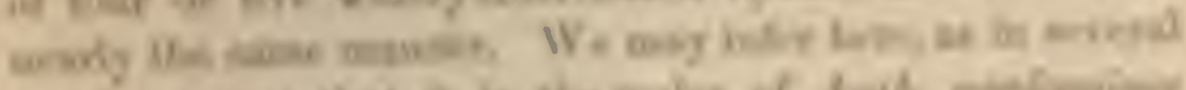

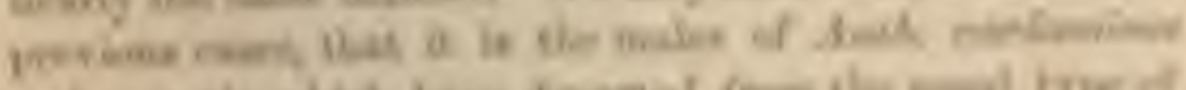

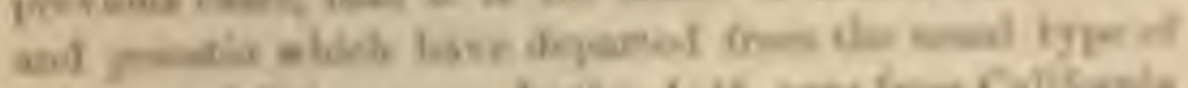

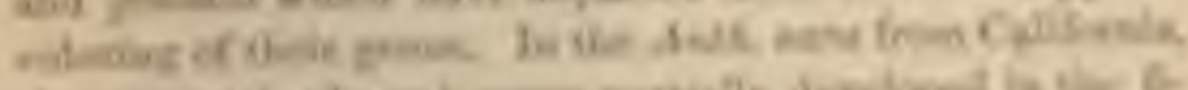

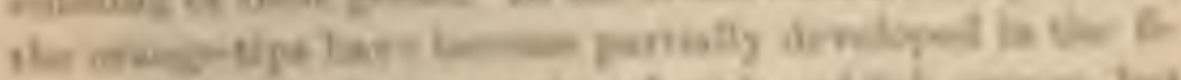

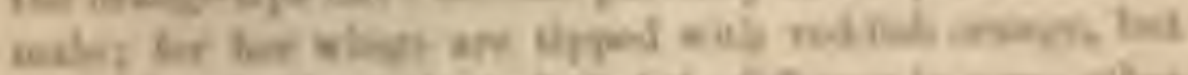

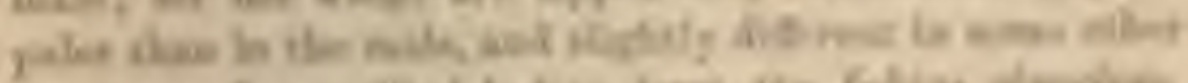

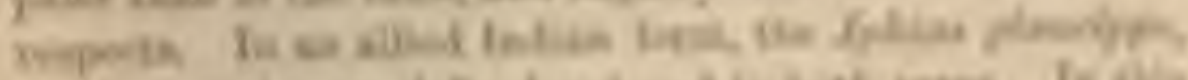

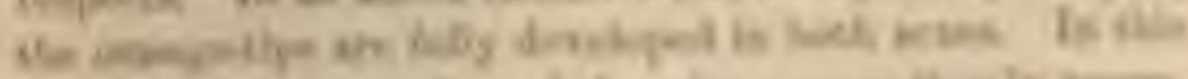

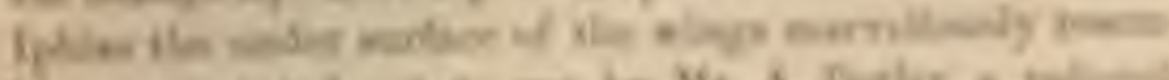

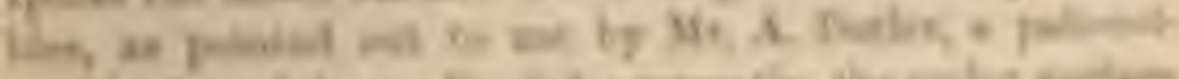

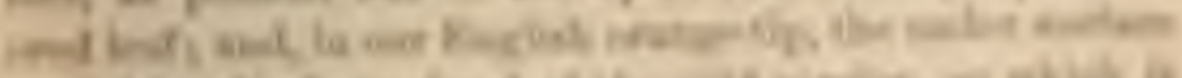

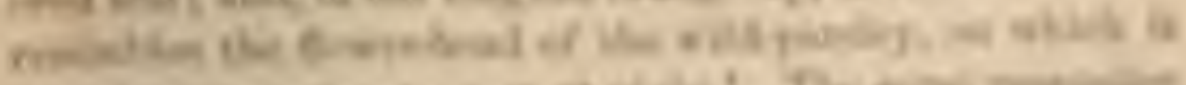

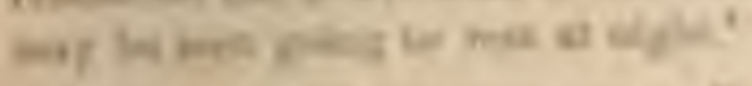

The hasi moves:

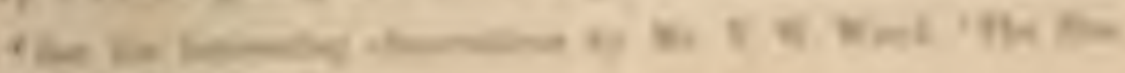

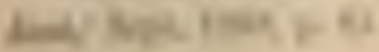


power which compels us to beliere that the lower surfoes hare here been colured for the sake of protecticn, leals us to deny that the wings have been tippeul, copecially when this clanacter is confines to the males, with lightit orange for tle same purponc.

Turving now to Moths: mont of these ret unotionleys with their wings depressed duriug the whole or greater part of the day; and the upper surfuces of their winge are offen sladed and colored in an admirable manme, as Mr. Wallace has remarked, for eacaping detection. With

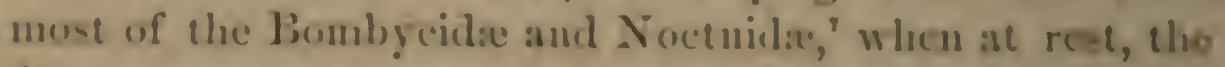
fiom-wings overlap and conceal the hind-wings; so thut the lateer miglu be briglitly colorel without much risk ; and they are thus colored in many species of both funilies. During ile act of thight, motls would often be alle to atcope from their enemies; nevertheless, as the hind-wings we then fully coposed to view, their bright colons muat fenerally have been acquired at the cost of acme litele risk. But the following fact show us how cantions wo onght to be in drawing conclusions on this heorl. The common yellow unler-wings (Triphatna) ofton $\mathrm{H}$ abone during the day or carly erening, and are then conspienoun from the color of their hinel-wings. It would maturally be thouglic that this would be a souree of daugur; bie Mr. J. Jemuer Weir belieses that it atetually eurros thm as a uneaus of escape, for birls strike at these briglallycolored sul fragile surfaces, instead of at the body. Pur instance, Mr. Wir enrued into his ariars a rigurous opecimen of Trifluene gromula, which was iustanty pursued ly a robin; but, the birl's attention lecing canght hy the colored wiugs, the moth was uot copplured until after alout fifty attemple, and muall portions of the winge were rrjeatedly broken off. He tried the same erperi-

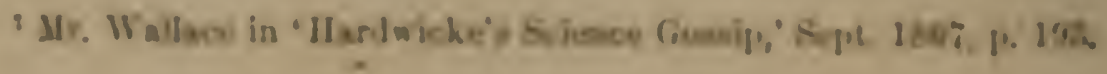




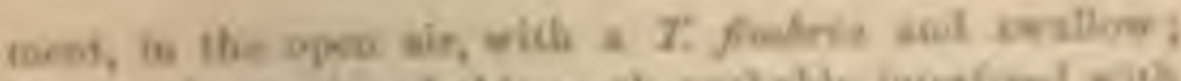

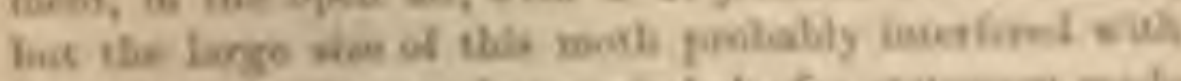

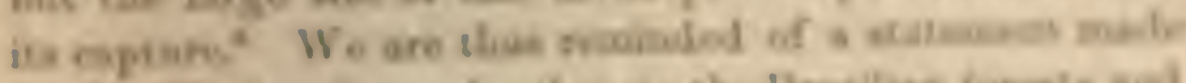

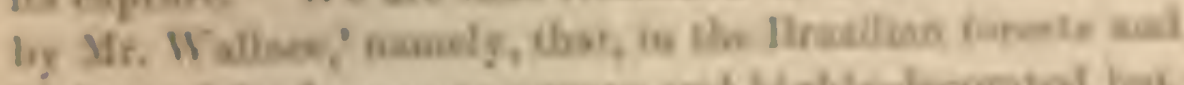

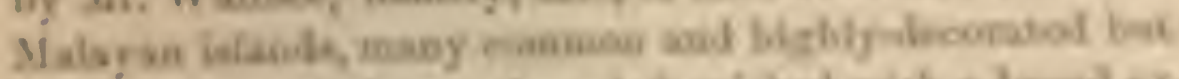

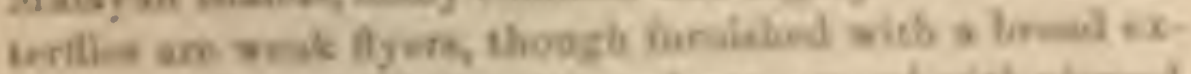

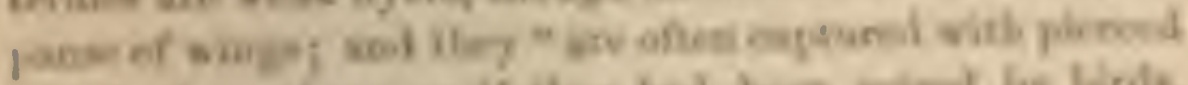

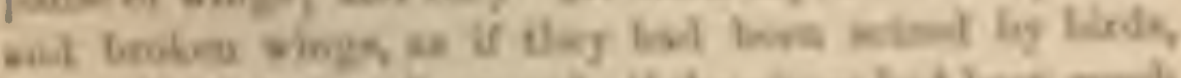

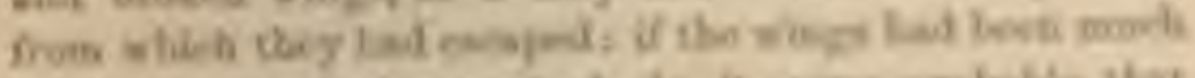

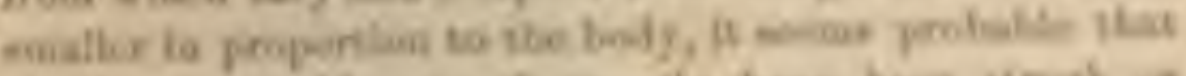

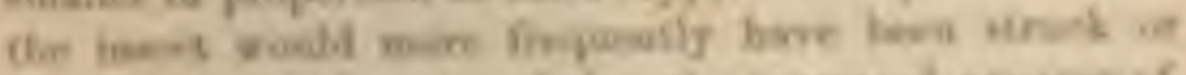

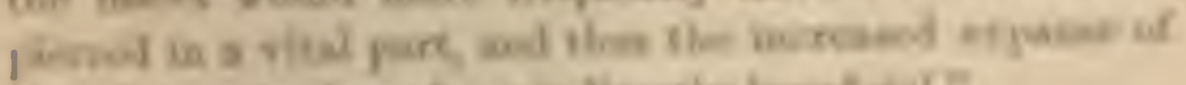

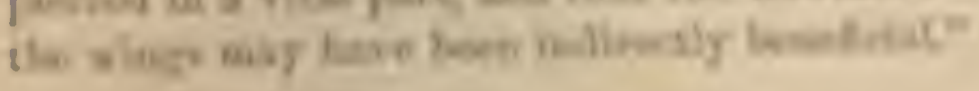

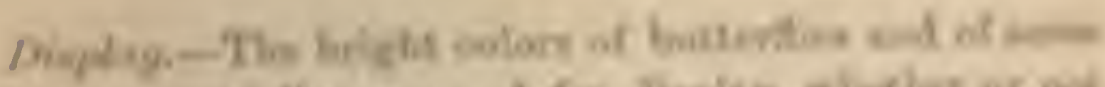

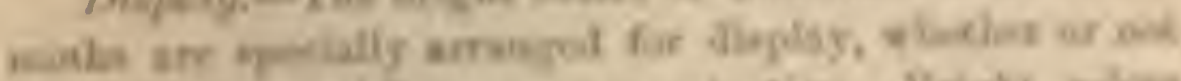

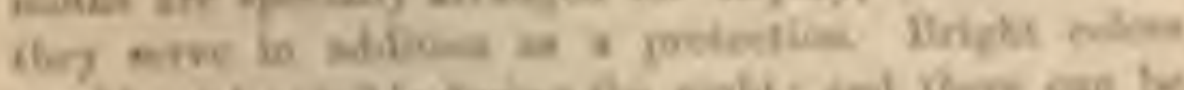

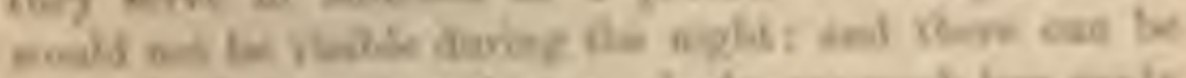

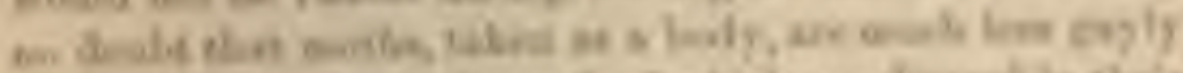

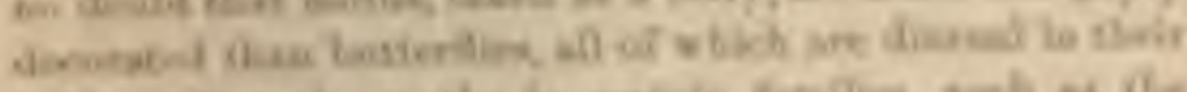

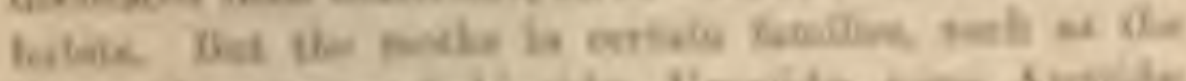

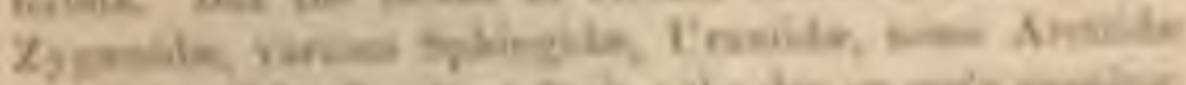

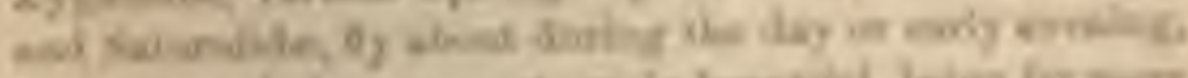

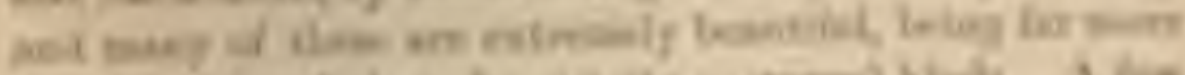

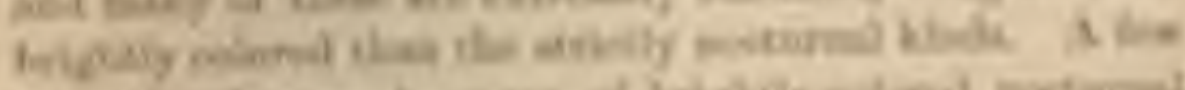

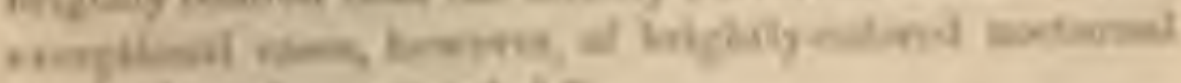

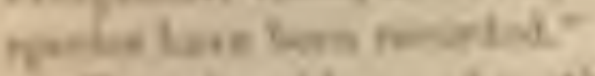

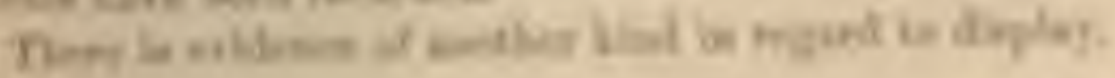

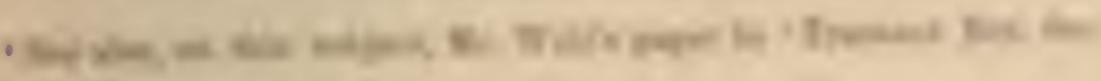
tom $x \mathrm{xh}$

+* o

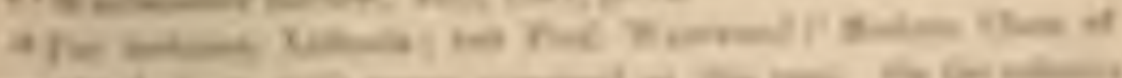

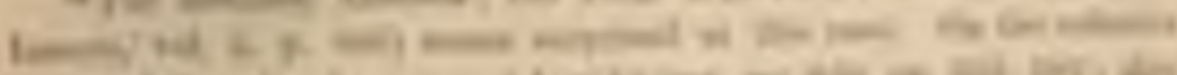

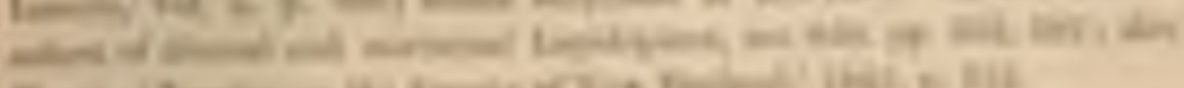

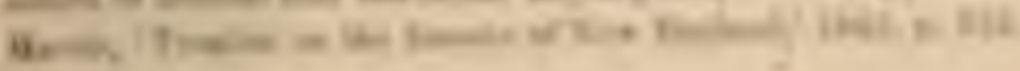


Butfurtlies, as b.fore remarked, elerate their wings when at rest, and while basking in the sumshine often alternately raise and depress them, thus exposing in full view buth surlices; :und, although tle lower surfice is often colureal in :ul obscure manner as a protection, yet in many species it is as highly colored as the npper surfice, and sometimes in a rery different manner. In some tropical species the bwer surfice is even more brilliantly colored than the "pper." In one English fritillary, the Argymnis aglain, the lower surface aloue is ornamented with shining silrer disks. Nerertheless, as a general ruke, the upper surface, which is probably the most fully exposed, is colored more brightly and in a more diversified nituner than the lower. Hence the lower surface generally athorils to entomologints the most useful character for detecting the afthities of the rarious species.

Now if we turn to the enormous gromp of moths, which do not habitually expose to full view the under surfice of their wings, this side is very rarely, as I hear from Mr. stanton, colored more brightly thim the upper side, or "ven with equal brightness. Some execptions to the rulc, cithere real or apparent, must be noticed, as that of Iypolyraspecified by Mr: Wormald.12 Mr. R. Trimen informs mo that, in Gucuece's great work, there moths are figmrerl, in which the moder surface is much the nost brilliant. For instance, in the Australian Gastrophora the upper. surface of the fore-wing is pale grayish-ochreons, while the lower surface is magnificenty ornindented by an ocellus of cobalt-blue, placed in the millst of a black mark, surromuled by or:mge-yellow, and this by bluish-white.

"Sich differences hetween the upper aul luwer surfues of the wingy of several species of Ipapilio ma be seen in the heasiful plates to Mr. Wallace's Jemoir on the l'apilionicle of the Malayan loceion, in 'Trans act. I.inn. Six:' rol. Ixr. prart i. IAti.s.

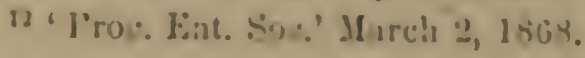


But the habies of then three mothe are noknows; wh that no explanution can be given of their unusual negle of ootoriug. Mr. T'rimen alwe inforsus me that the lower nur-

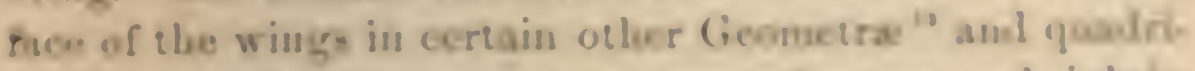
fiel Dineture is cither suore variogated or more lerighel colosod than the upper surfice; bot soue of these opecio

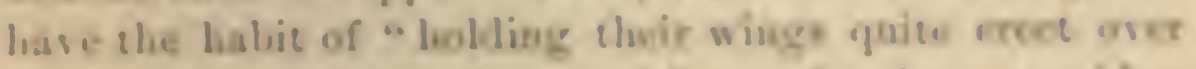
the ir lacks, retaining them in this poation firs a comeiderable tise," and tbus expreioge tu viow the under muchor.

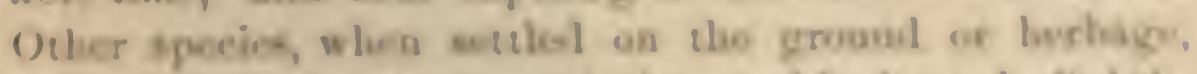
have then babit of sow and that smidenly aml slighel! liftang op sheir wioge. Ilvacs, the lower surbare of the

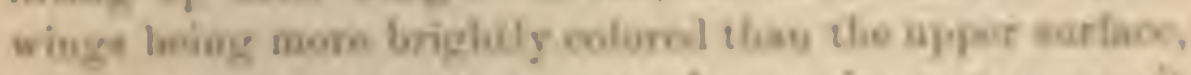

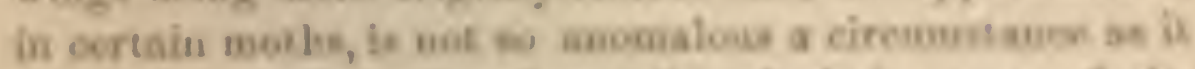

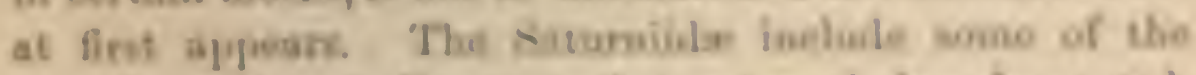

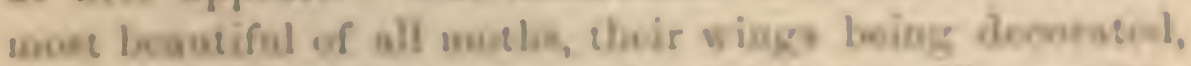

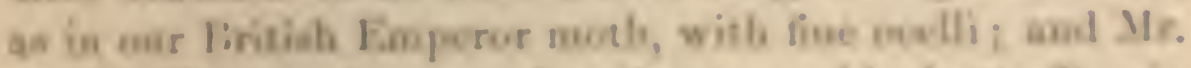

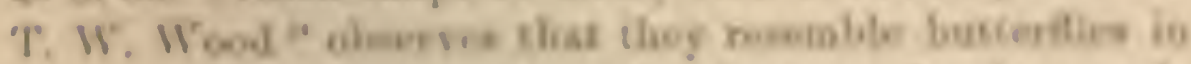

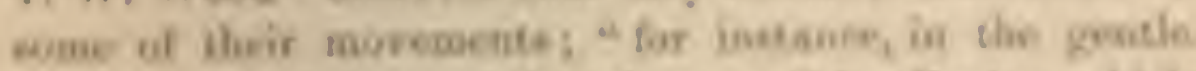
vaske ap aud down of the wings, we if for divpdoy, wbirb

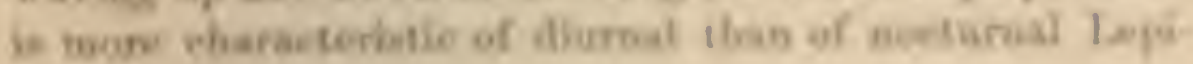
- Hoptera."

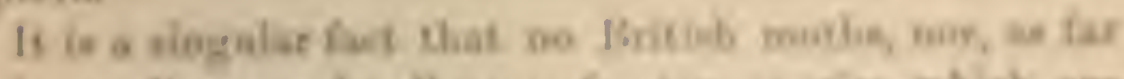
as I can Aheconer, bowby any fireber species, wbich um

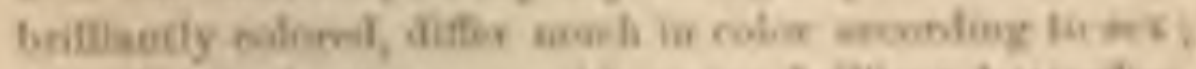

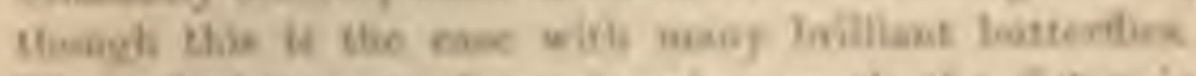

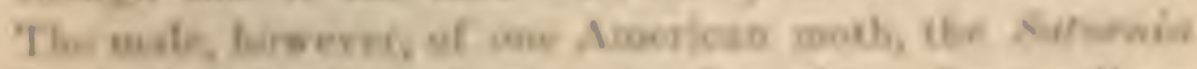

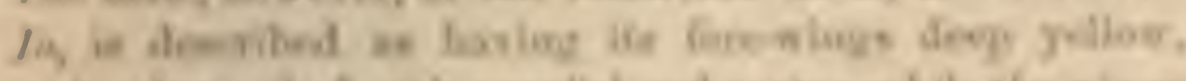

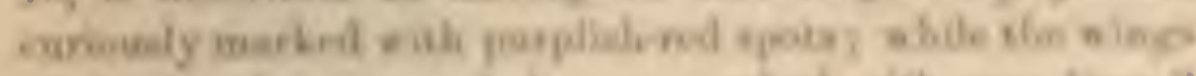

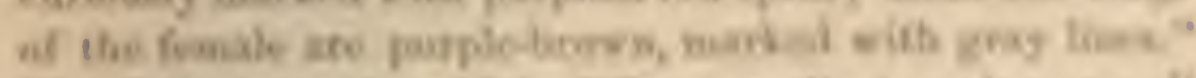

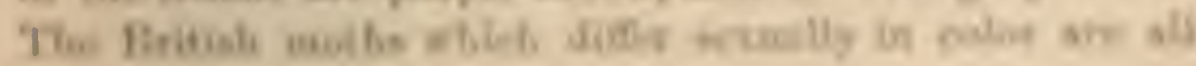

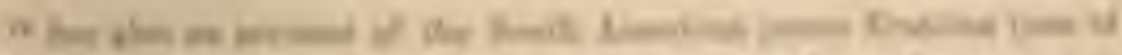

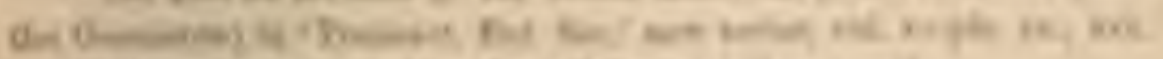

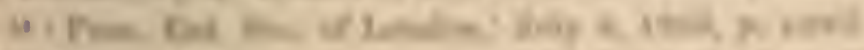

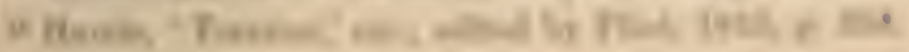


brown, or various tints of dull yellow, or nearly white. In several species the males are much darker than the females, and theae belong to groups which gencrally fly ahout during the afternoon. On the other hand, in many genera, as Mr. Stainton informs me, the males have the hind-wings whiter than those of the ferale- of which fact A:frotis exclumationis ofliers a good instance. The males are thus rendered more conspicnous tham the femalus, while flying abont in the dusk. In the Ghost Moth (1/6pialus humuli) the diflerenee is more strongly marked; the males being white, and the fomales yollow, with darker markings. It is diflicult to conjecture what the meaning can be of these differences between the seres in the shades of darkness or lightness; but we can hardly suppose that they are the result of mere variability with sexually-limited inheritance, independently of any benefit thus derived.

From the forergoing statcusents it is impossible to ad. mit that the brilliant colors of butterflies and of sone fow moths have commonly been acquired for the sake of protection. We have seen that their colors and clegant pattorns are arranged and exlibited as if for display. Hence I an leel to suppose that the females generally prefer, or

"For intetuce, I observe in my eon's calinct that the nube are

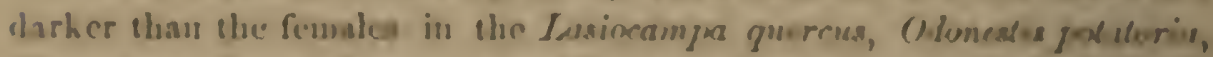
Hyjomeynne dirgar, Dusychira gmalibunda, and Cyenia mendion. In this luter species the difference in color between the two sesen is atrengly marked; nut Wr. Wallace iuforms the that we here lune, an he beliese.

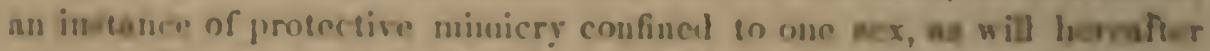
be more fully explained. The white fornate of the Cscria nocsuldes the

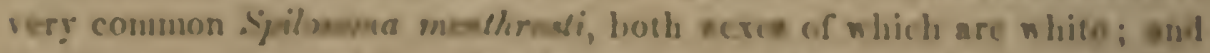
Mr. Siainton ohecried that this latter moth wat rejectet with utter dis-

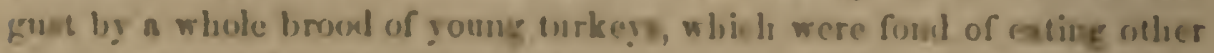

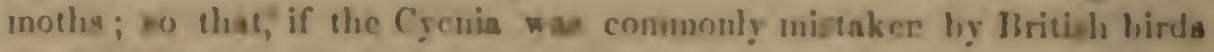
for the spilosoma, it would ecsue being deroured, and its white decp. tire edor woull thus be lighls beneficinl. 
are raost excited by the raose hinilians rasles; fing in any other wopyonition the mates wond.l be monamoated, wh for as we can ace, fir wo purpese. Wr know slise sase and certain lanellioom lectes are capalite of folimp an as.

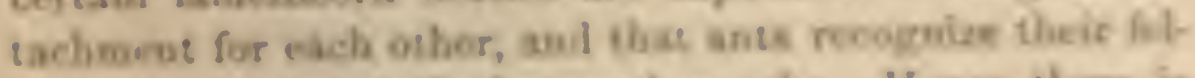

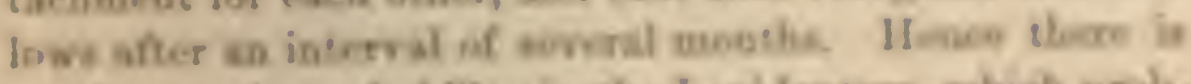

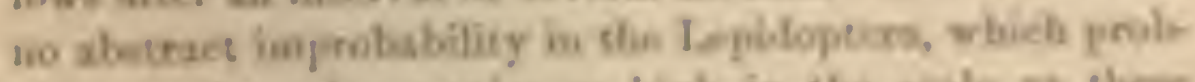

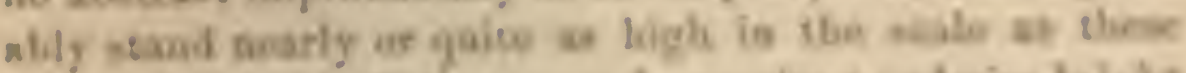

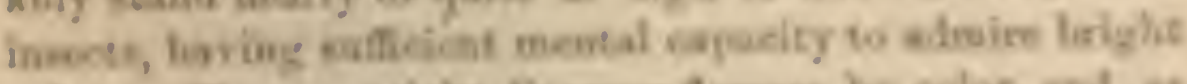

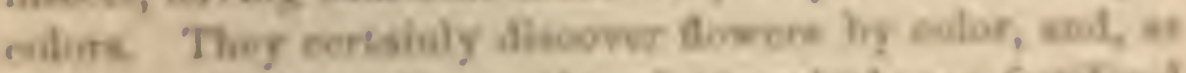

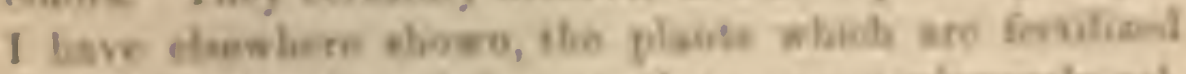
estasivily by tbe winl avrer lave s exemplianody-ool-

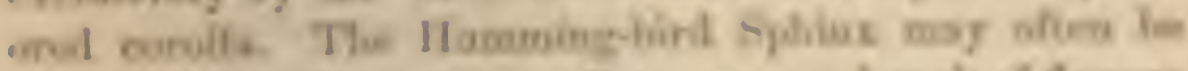

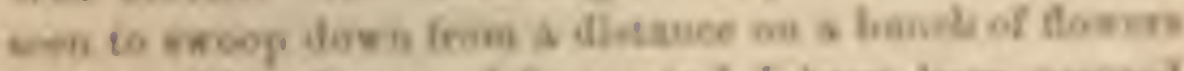
is the miles of proes follase; sind I bave beer sanorvi

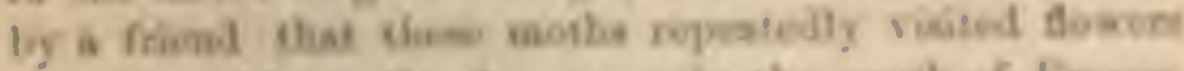
pased un the walte of a mese in the souds of Proess

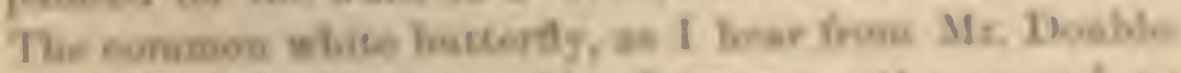

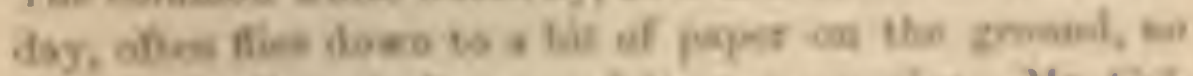

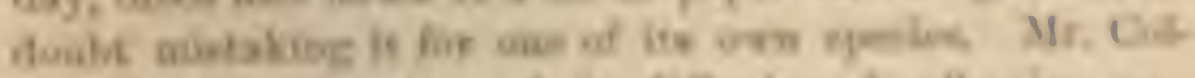

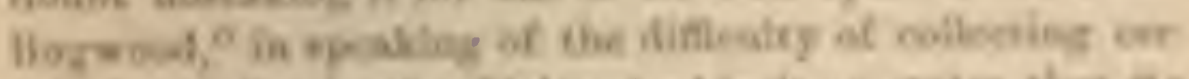

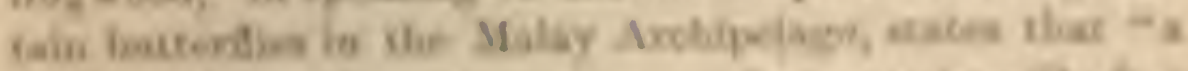

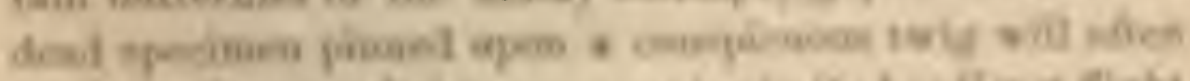

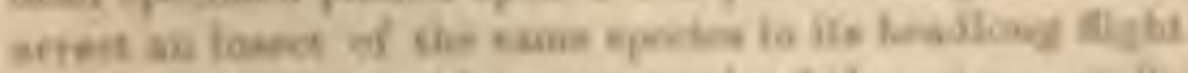

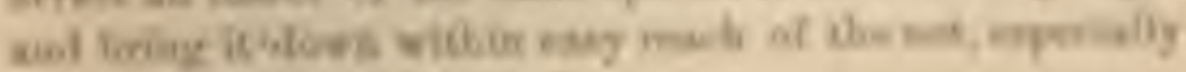

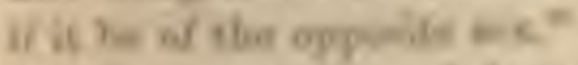

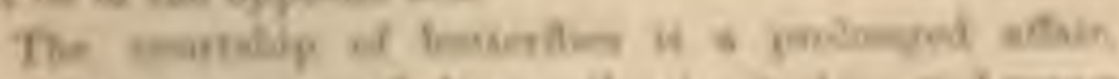

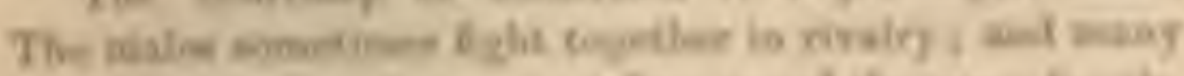

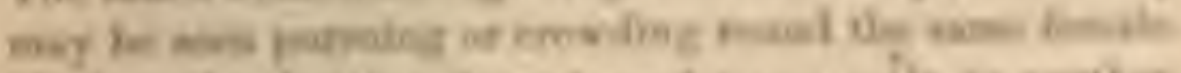

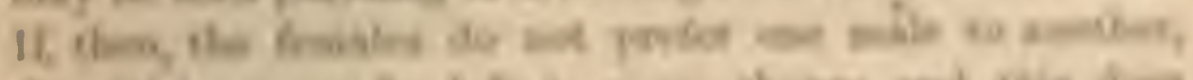

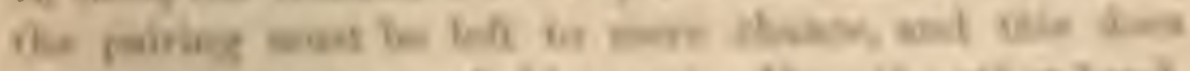

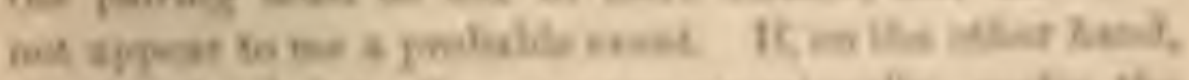

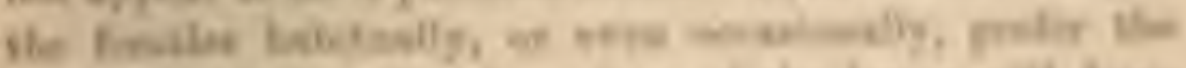

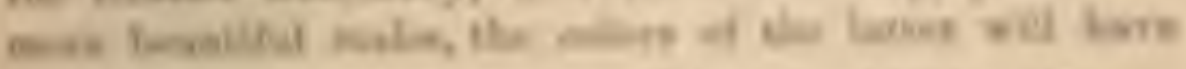


been rendered brighter by degrees, and will have been trimsmitted to both sexes or to one sex, according to which liw of inheritance prevailed. The process of sexmal sclection will have been much ficilitated, if the conchnsions arrived at from various kinds of evidence in the supphement to the ninth chapter can be trusted; namely, that the males of many Lepidoptera, at least in the imago state, greatly exceed in number the females.

Some facts, however, are opposed to the belief that female butterflies prefer the more beautiful males; thus, as I have been assured by several observers, fresh females may frequently be seen paired with battered, faded, or dingy males; but this is a circumstance which conld hard1y fail often to follow from the males emerging from their cocoons earlier than the females. With moths of the fimily of the Bombycidie, the sexes pair immediately after assuming the imago state; for they camot feed, owing to the rulimentary condition of their months. The females, as several entomologists have remarlied to me, lie in an almost torpid state, and appear not to cvince the least choice in regard to their partucrs. This is the case with the common silk-moth (B). mori), as I have been told by some Contincental and English breeders. Dr. Wallace, who has had such immense experience in hreeding $7 B$ ombigx elmthiu, is convinced that the fomales evince no chnice or preference. He has kept above 300 of these moths living together, and has often found the most vigorons females mated with stunted males. The reverse apparently schlom oceurs; for, as lo believes, the more vigenrons makes pass over the weakly females, being attracted by those endowed with mon vitality. Although we have been indirectly indued to beliere that the females of many species lwefer the nore henttiful males, I have no reason to suspect, either with moths or butterflies, that the mates are attracted by the beaty of the females. If 
the more boustiful females lasd heu continsally yroferret, it it alusont certain, froun the colore of butterilios being to frejuently tranksuited (1) one sex alone, that qle foubles would often have been remlered more beatiful that their male partucrk. But this thes not ocetar exeege in a few intunece; and these esu be explainod, as we sladl pros cul! see, in the prineigle of mizhicrs and prosedino.

As sexual selecriou primarily diquads on sariabilit!, a fiw words must bo adiled on this nubject. In reepect to

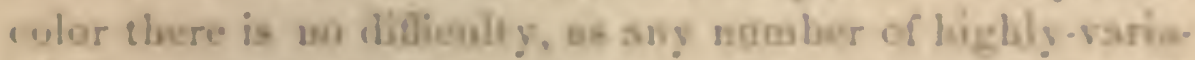
be lepidoptons contd be named. Uae good imotamoe vill

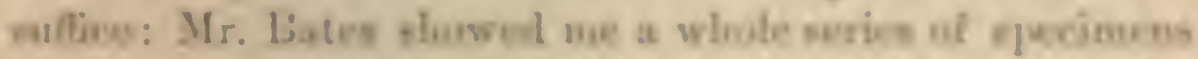
of Jopilio senatrix and chiblroner : in the latter the males saried mueh is the ecent of the fraptitulismamellod greou jaeh on the fore-winge, and in the siav of the o liee wark, as wefl as of the pplevid crimen strijes on tho kimbleimg"; wo that there was a great comerast leswren

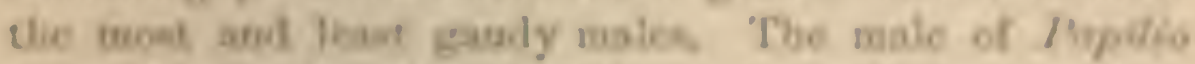

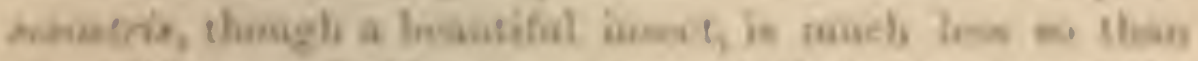

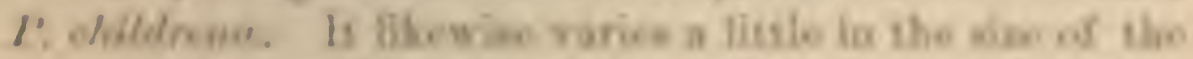

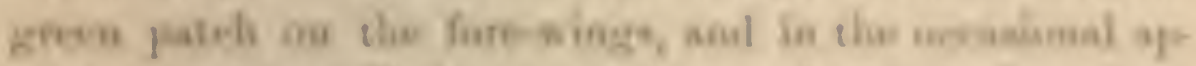

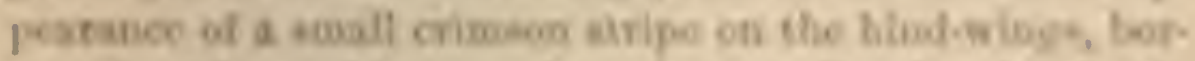

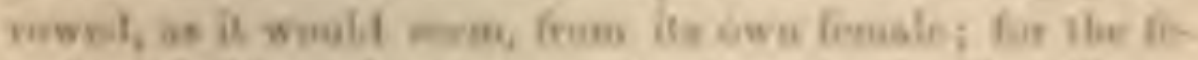

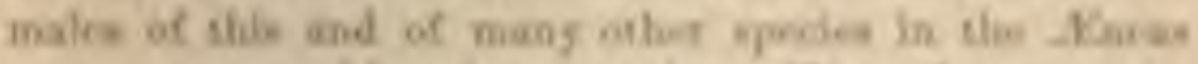

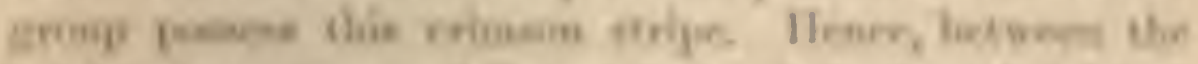

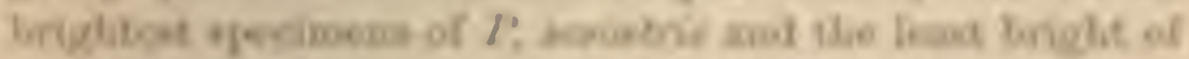

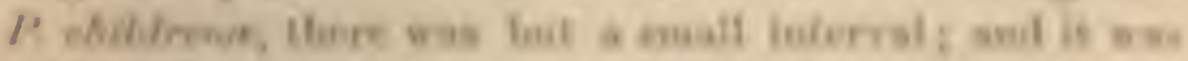

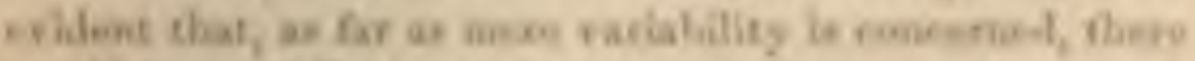

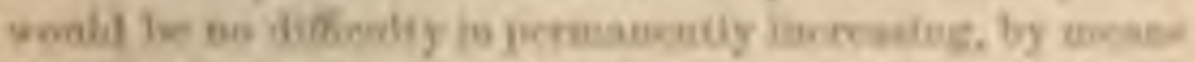

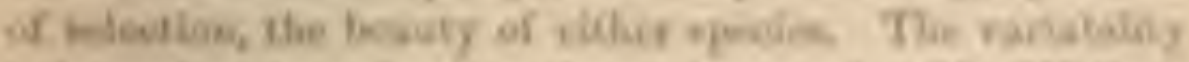

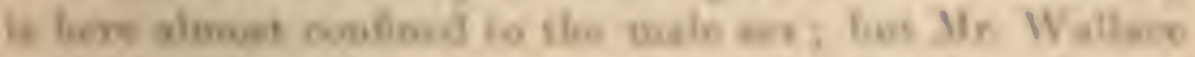

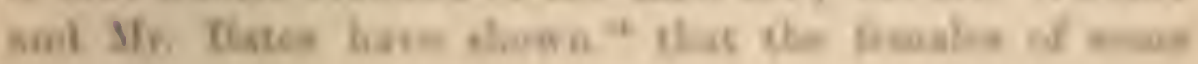

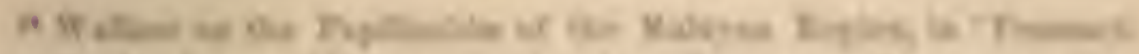

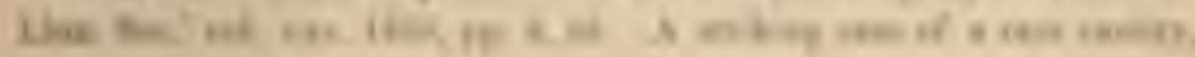


otler species are estromely variable, the males being uearly constant. As I have before mentioned the bhost Moth (Ilepialus humuli) as one of the best instauces in Britain of a diflerence in color between the sexes of motlss, it may be worth adding" that, in the shetlaus Islands, males are frequently found which closely rescusble the females. In a future chapter I shall have occasion to show that the beatiful eye-like spots or ocelli, so common on the wings of many Lepidoptera, are cminently variable.

On the whole, althonga many serions ohjections maly be urged, it secms probable that most of the species of Lepidoptera which are brilliantly colored, owe their colors to scxual selection, excepting in ecrtain cases, prescutly to be memionce, in which conspicnous colors ane bencficial as a protection. Jirom the ardor of the male throughout the auimal kingdom, he is generally willing io acecpt any fomale; and it is the female which usually exerts a choice. Henee, if sexual selection has here acted, the male, when the sexes differ, onght to he the mont brillianty colored; and this undouldedly is the ordinary rule. When the seves are brillianly colored and rescmble each other, the chasacters acyuired by the males appear to hate been ta:manteled to both sexes. But will this explanation of the similarity ant dissinnilanty in eulor between the sexes suftice?

The males and fomales of the same species of butterfly are know * in scroral cases to inhahit diflerent stations, atrietls intrmediste betwean two other well-marked female varieties, is

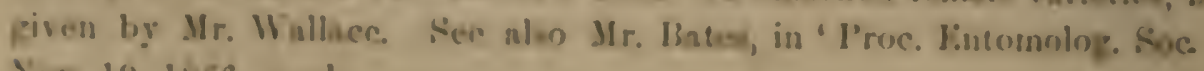
Nirs, 19, IAgh, p. xl.

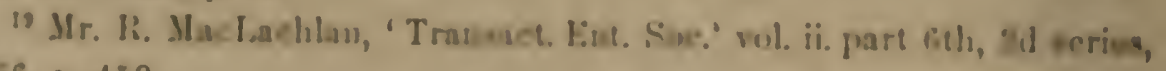
1266, p. tim.

"II. W'. Bate, 'The Nutureliet on the Amazose; vol. ii. I8fi3, p.

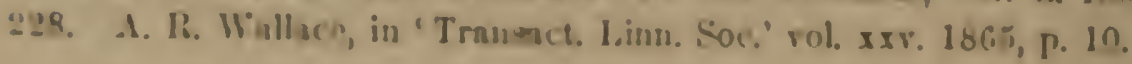


the forwes cousumaly basiog in the sunshise, the fastrs hasating gloomy fomes is is therefore poudble thas different covilibion of life may laxe areel dinectly un the

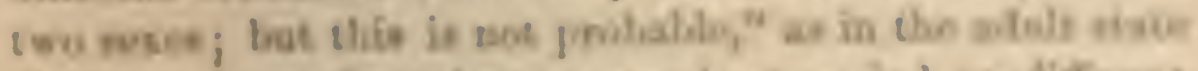
they are espowal desiag a very abort perind to differmat

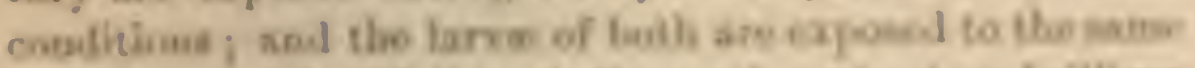

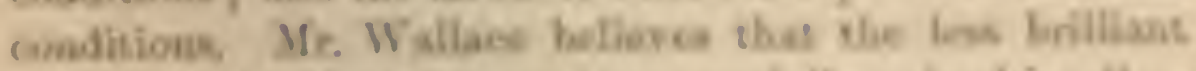
colors of the fomale have boen specially gavoud lo all or almot all cars bor the sake of protection. (1) vlae teme

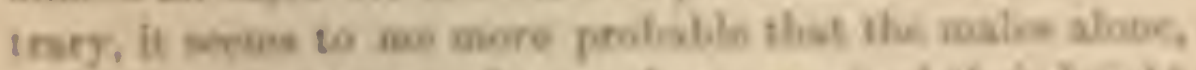
in the laree reajorey of cans, have acyound ther ir lareglat

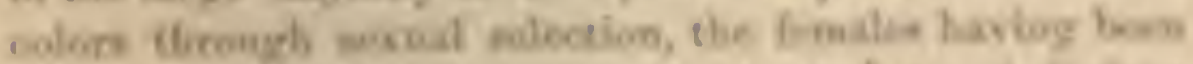

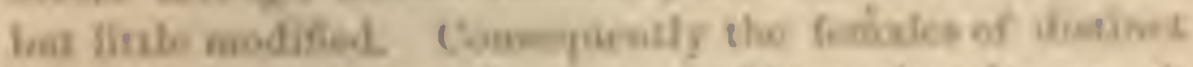

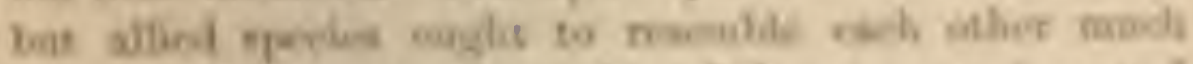

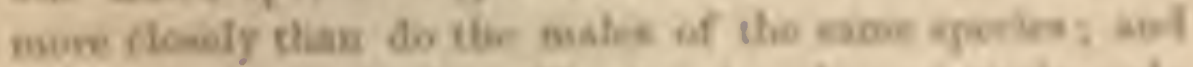

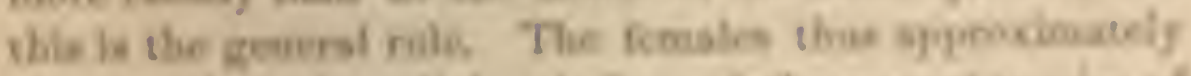

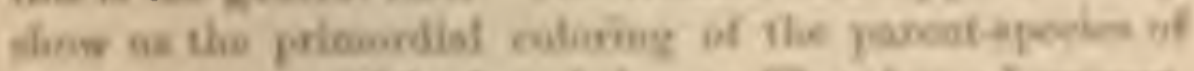

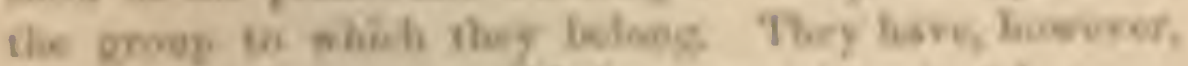

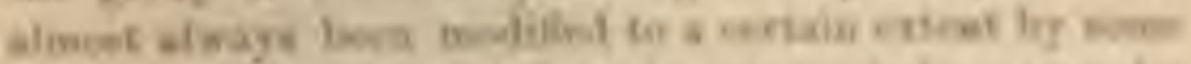

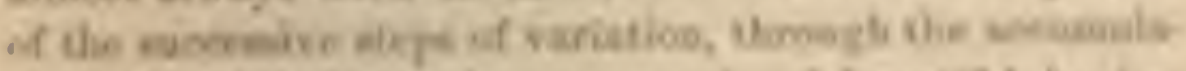

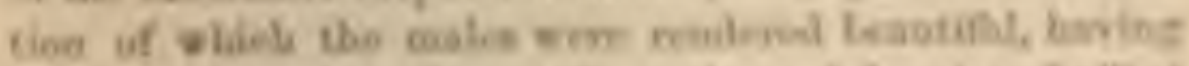

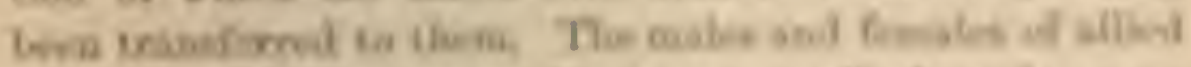

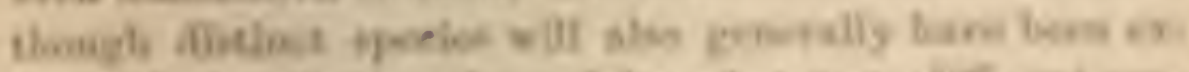

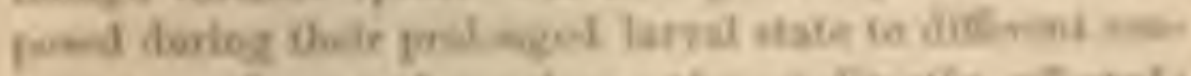

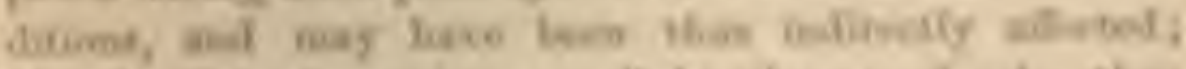

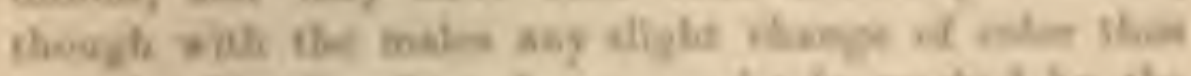

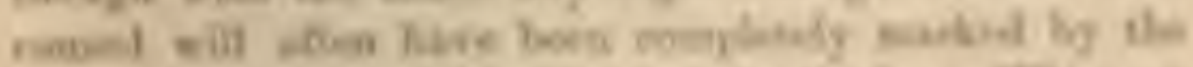

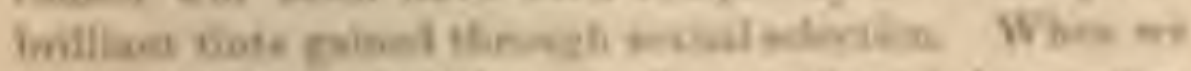

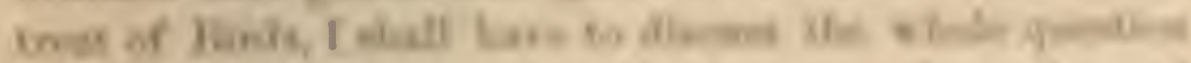

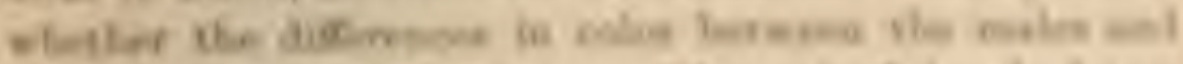

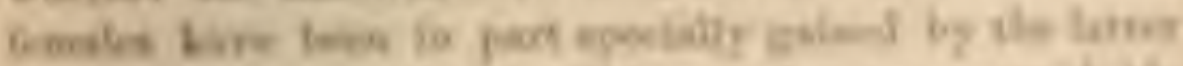

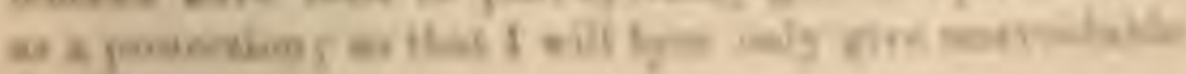
dealls

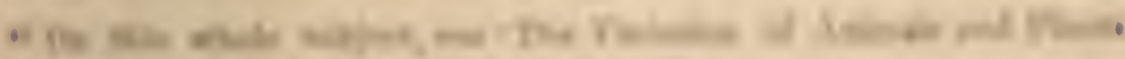

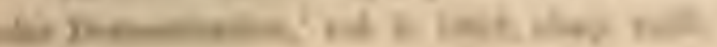


In all cases vihen the more common form of equal inheritance by both sexes has prevailed, the selection of lriglit-colored males would tend to make the fumales bright-colored; and the selection of dull-colored fenales would tend to make the males dull. If both processes were earried on simultaneonsly, they would tend to nentralize each other. As far as I ean see, it would be extremely difficult to change through selection the one form of inheritance into the other. But, by the solection of successive rariations, which were from the first kexually limited in their transmission, there would not be the slightest clifliculty in giving bright colors to the males alone, and at the same time, or subsequently, dull colors to the females alone. In this latter manner female butterflies and moths may, as I fully admit, have been rendered inconspicuns for the salke of protection, and widely diflerene firm their males.

Mr. Wallace ${ }^{22}$ has argned with much foree in fatror of his view that, when the sexes diflier, the female has been specially modified for the sake of protection; and that lats been efficted by one form of inheritance, namely, the transmission of chanacters to both sexes, having been changed throngh the atgeney of natural selection into the other form, namely, transmission to one sex. I was at tims strongly inclined to aceept this view; but, the more I have stmlied the various classes throughout the animal hingdom, the less probable it has appeared. Mr. Wallace urges that both sexes of the Heliconider, Danuider, Acro. cida, ane equally brilliant becanse both are protected from the attacks of birds and other chemies, hy their oflinsive odor; but that in other groupe, which do not possess this immunity, the females lave been rendered

$\because$ A. IR. Wallace, in 'The Iournal of Travel,' vol. i. 186,8, p. א.8. 'Westmineter Review,' July, 186 2 , p. 3\%. See also Mesers. Wallace and Bates in 'Pros. Fnt. Soc.' Nor, 19, 1866, p. xxxir. 


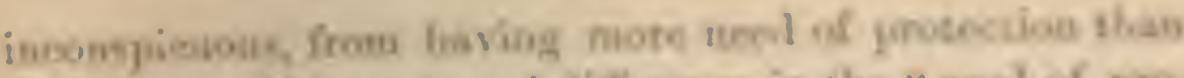

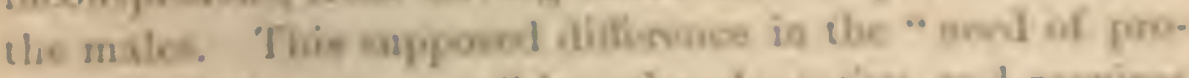
tweivin by the two seses" is rabler decegrive, and rogurest

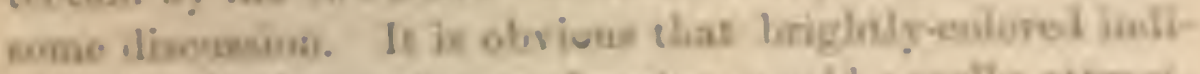

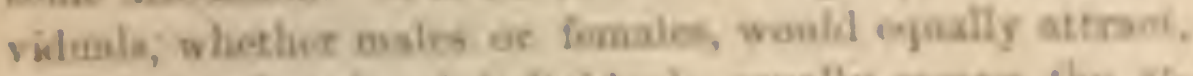

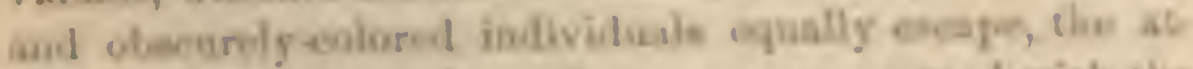

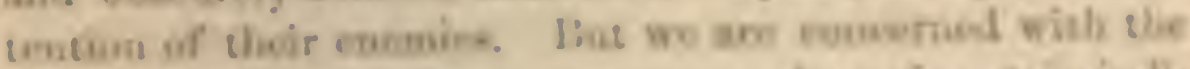

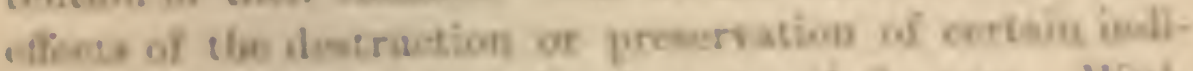
videals, of eithec wx, wh the sharsecter is the rave. Winb

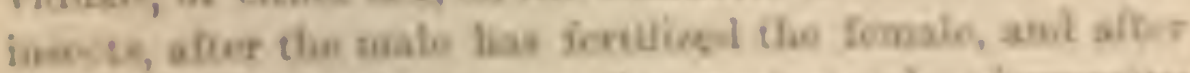

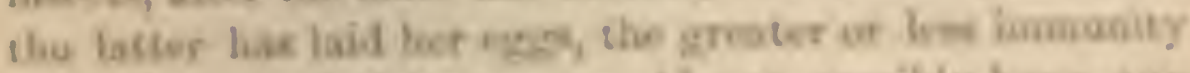

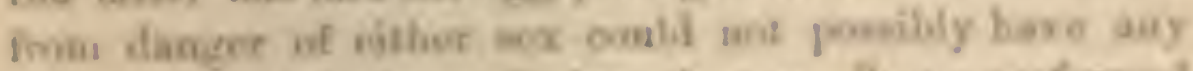

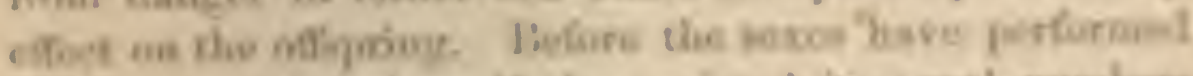

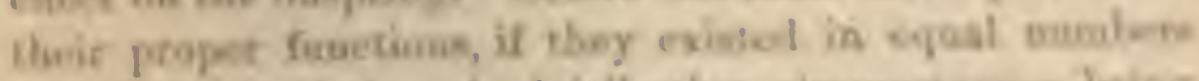
and if Mary seriotly pairol (all other eireumai above being

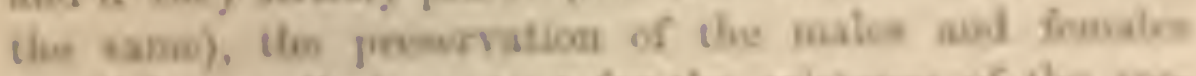

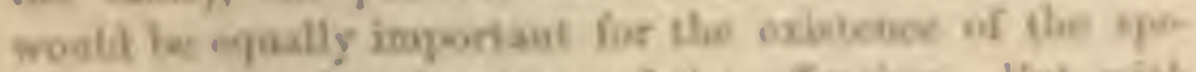

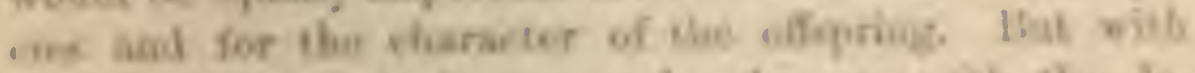

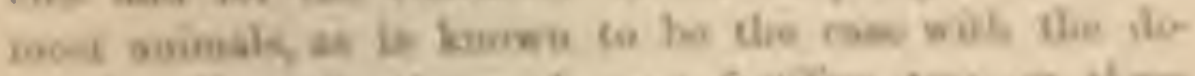

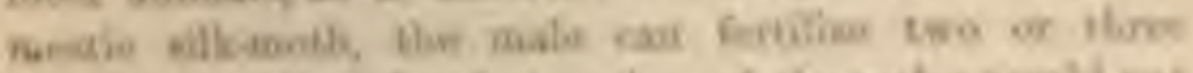

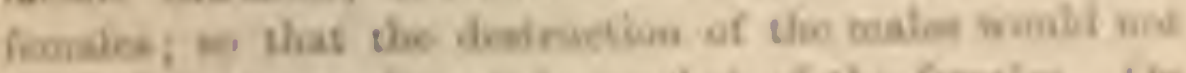

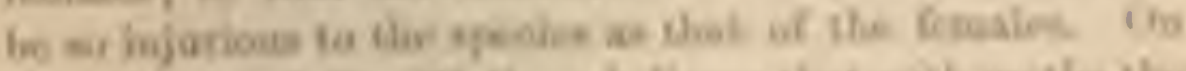

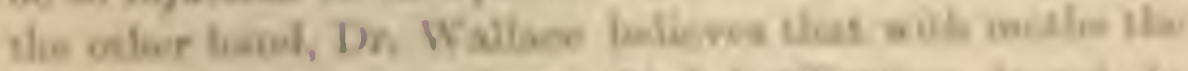

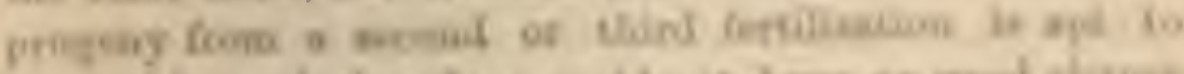

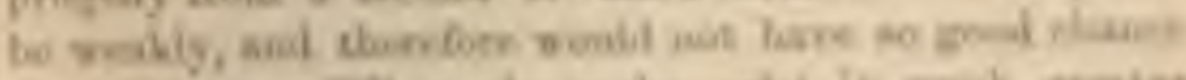

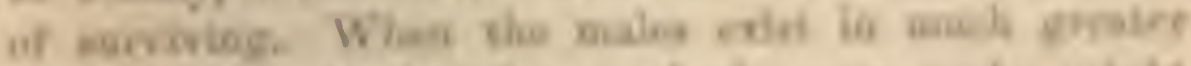

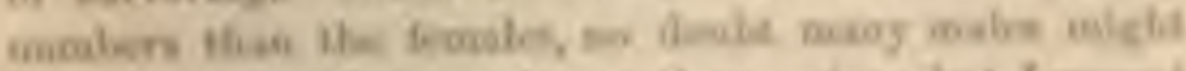

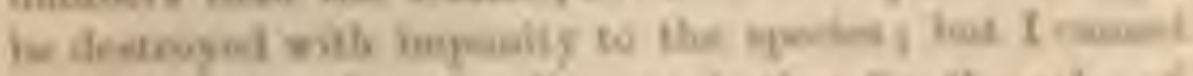

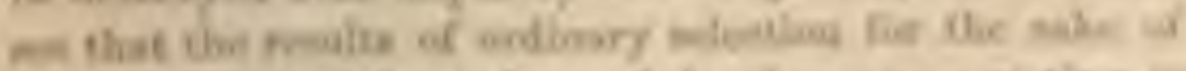

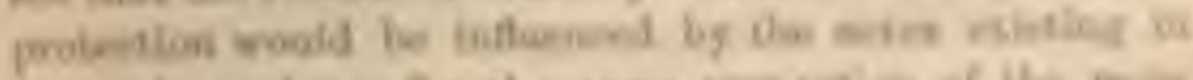

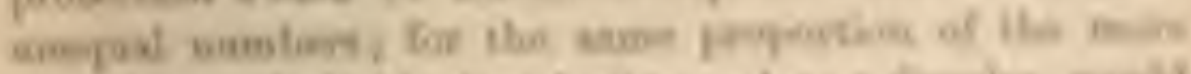

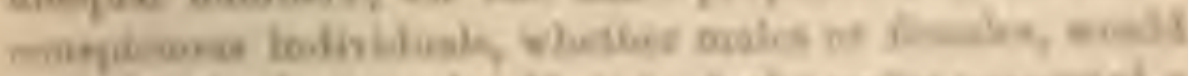

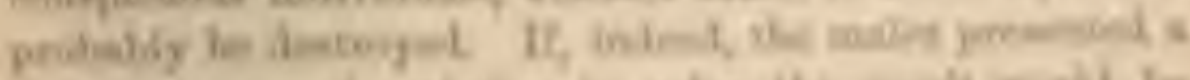

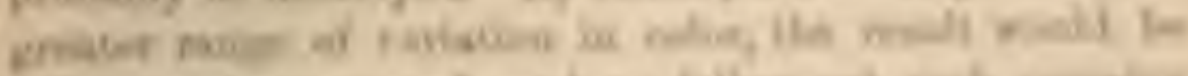

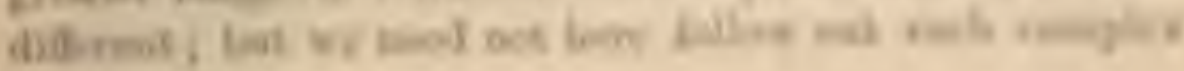


details. On the whole, I camot pereeive that an incquality in the numbers of the two sexes would inthence in auy marked manner the eflects of ordinary selection on the character of the oftopring.

Fimale Lepidoptera require, as Mr. Wallace insists, some days to deposit their fertiliged ova and to search fur a proper place; during this period (while the life of the male was of no importanec) the brighter-colored female's would be exposed to d:mger and would be liable to be destroyed. The duller-colored females, on the other lami, would survive, and thus would influence, it might be thought, in a marlied manner the character of the species -cither of both sexes or of one sex, aceording to which form of inlieritance prevailed. But it must not be forgotten that the males emerge from the cocoon-state sone days before the females, ant during this period, while the unborn females were safe, the brighter-colored males would be exposed to danger; so that ultimately both sexes would probably be cxposed during a nearly equal length of time to danger, and the climination of conspictr ons colors would not be much more eflicetive in the one than the other sex.

It is a more important consideration that fomale ledpidoptera, as Mr. Wallace remarks, and as is known to every collector, are generally slower flyers than the males. Conseqnently the latter, if exposed to greater danger from being conspicnonsly colored, might be able to escipe from their enemies, while the similarly-colored femiles would be deatroyed; and thus the females would have the most influence in modifying the color of their progeng.

There is one other consideration: bright colors, as far as sernal sidection is concerned, are commonly of no service to the females; so that if the latter varied in brightnese, and the variations were sexnally limited in their transmiscion, it would depend on mere chance whether 


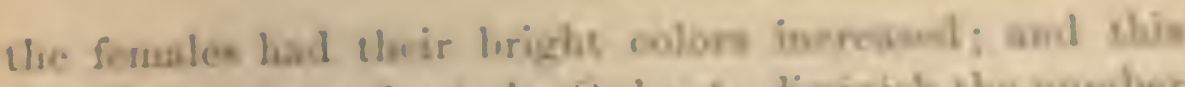
wrabl tesid thronglowe the Undes for diminiwh thes nomber

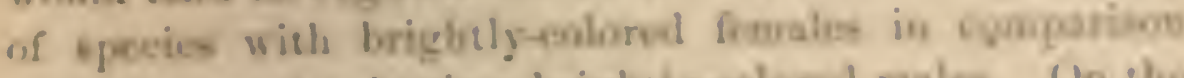
with the epecies bavimg bright!g-oolond males. On the other land, an hright culure are ruppowed to las highls wer. viceralife to the males in their loventrapgles, the hrighier

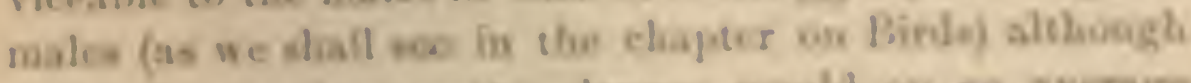
espoed wo raber preater danger, woulh ous an average

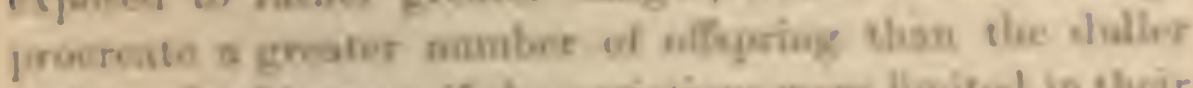

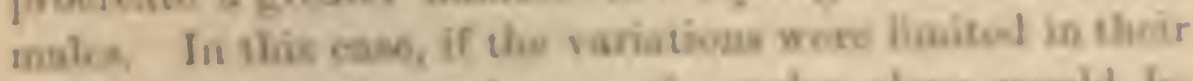

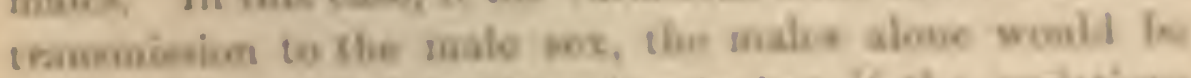

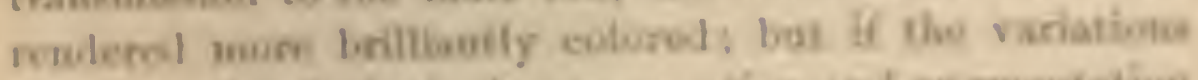

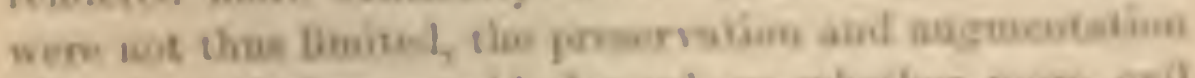

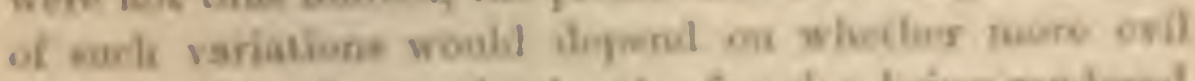

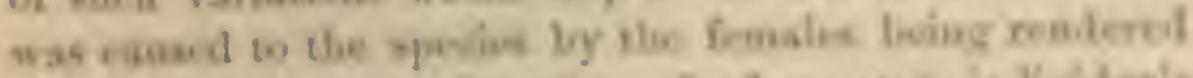

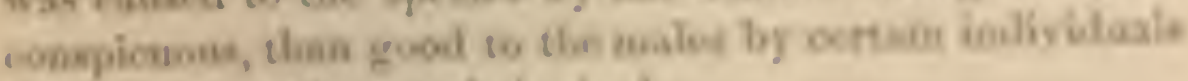
binne nuovesfol oser their rivale

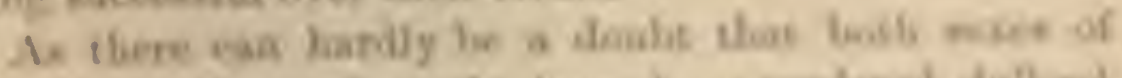

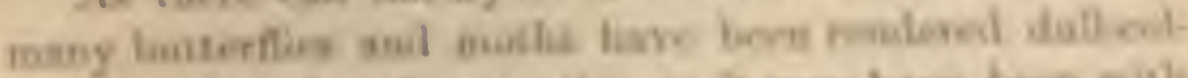

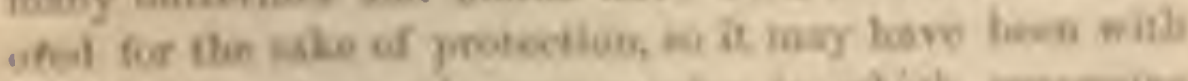

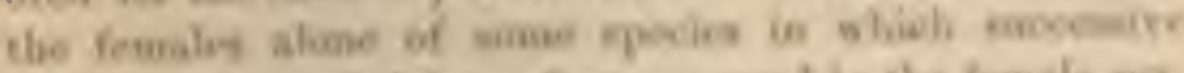

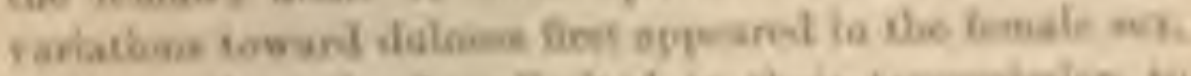

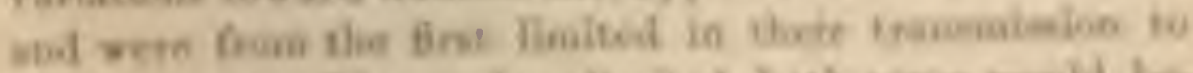

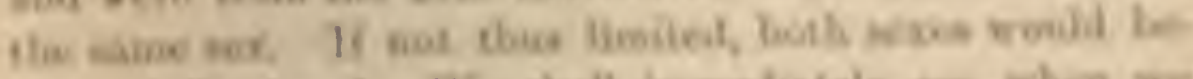

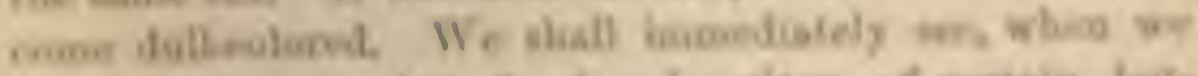

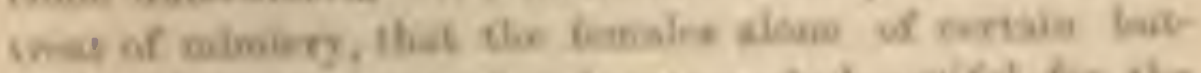

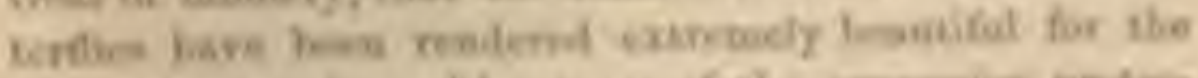

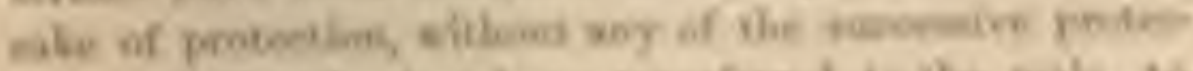

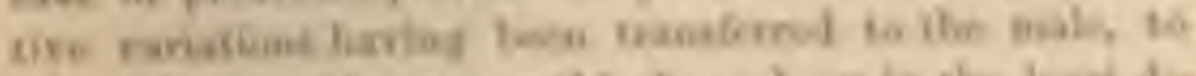

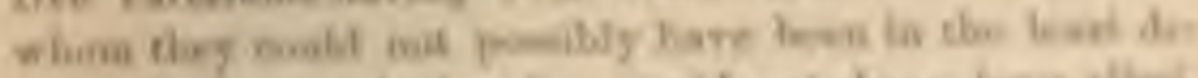

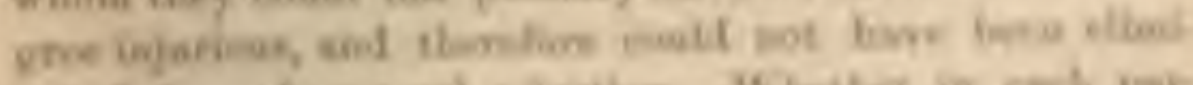

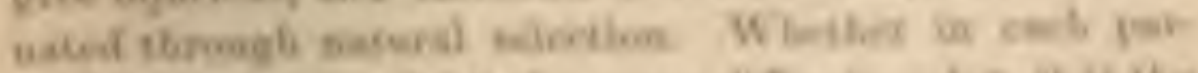

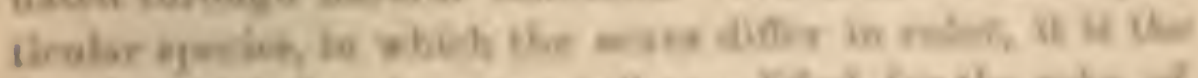

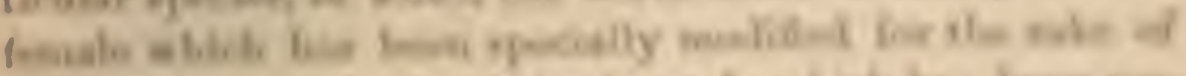

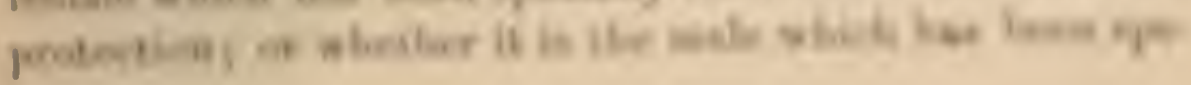


cially modified for the salic of sexual attraction, the female having retained her primordial coloring only slightly changed through the agencies before alluded to; or whether again both sexes have been molified, the female for protection and the male for sexual attraction, can only be definitely decided when we know the life-history of each species.

Without distinct evidence, I am unwilling to almit that a double process of selection has loug been going on with a multitude of species-the males having been renlered more brilliant by beating their rivals; and the females more dull-colored by having escaped from their enemies. We may take as an instance the common brimstone butterfly (Gonepteryx), which appears early in the spring before any other kind. The male of this species is of a fin more intense yellow than the female, though she is almost equally conspicuous; and in this case it does not seem probable that she specially acquired her pale tints as a protection, though it is probable that the ruale acquired his bright colors as a sexual attraction. The female of Anthocaris carlamines does not possess the bealltiful orange tips to her wings with which the male is ornamented; consequently she closely resembles the white butterflies (Pieris) so common in our gardens; but we have no evidence that this resemblance is beneficial. On the contrary, as she resembles both sexes of several species of the same genus inhabiting various quarters of the workl, it is more probable that she has simply retained to a large extent her primordial colors.

Various facts support the conclusion that, with the greater number of brilliantly-colored Lepidoptera, it is the male which has been modified; the two sexes having come to difter from each other, or to resemble cach other, according to which form of inleritance has prevailed. Inheritance is groverned bv so many unkwown laws or con- 
ditious, that they secon to us to be mo-t capricious in their action; ${ }^{\text {a }}$ and we can so far understand how it is that with closely-allied species the sexes of some difier to an astonishing degree, while the sexes of others are identical in color. As the successive steps in the procens of variation are necessarily all tramsmitted through the female, a greater or less number of such steps might readily become developed in her; and thus we can understand the frequent gradations from an extreme diflirence to no diffirence at all between the sexes of the ppecies within the same group. Theac cases of gralation are much too com. mon to favor the supposition that we here see fumales actually undergoiug the process of transition and losiug their brightnese for the sake of protection; for we have "very reason to conclude that at any one time the greater number of specices are in a fixel comlition. Wish respect 16) the diflereneces between the fromales of the species in the same genus or timbly, we eam pereeise flat they depend, at leat in part, on the fomales partaking of the col. ors of their respective males. This is well illustrated in those group in which the males are ormanomed to an $\mathrm{x}$.

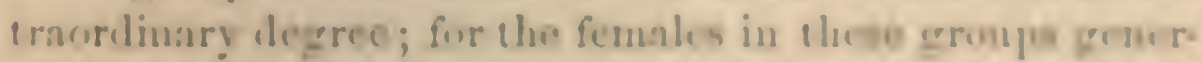

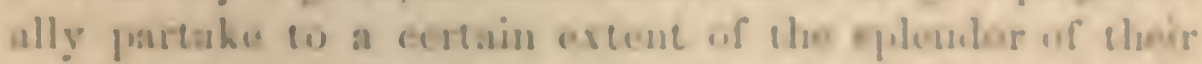
unle partuers. Iasty, we comimully find, as already muarked, tlat the feumales of alumet all tlus spovics in the came grum, or eren fomil!, restuble cach other makh

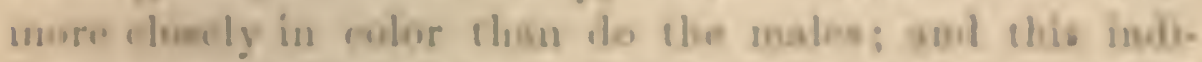

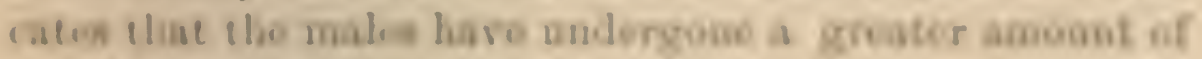
molitication thun the forabirs.

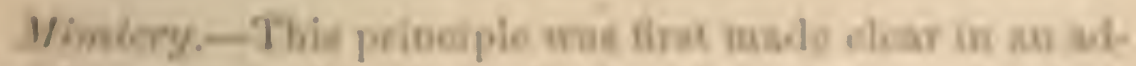

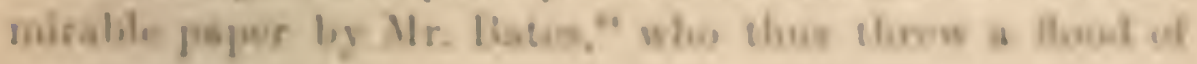

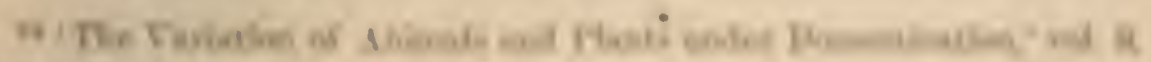
(t)y- kil-ge 18.

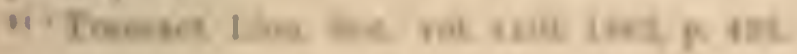


light on many obscure problems. It had previously been observed that certain butterflies in Sonth Anerica, belonging to quite distinct families, resembled the Heliconidie so closely, in every stripe and shate of color, that. they conld not be distinguished except by an experienced entomologist. As the Helicouidae are colored in their usual manner, while the others depart from the usual coloring of the groups to which they belong, it is clear that the latter are the initators, and the Heliconidie the imitated. Mr. Bates further observed that the initating species are comparatively rare, while the imitated swarm in large numbers; the two sets living mingled together. From the fact of the Helicouida being conspicurous and beautiful insects, yet so numerous in individuals and species, he conchuded that they must be protected from the attacks of birds by some secrution or odor; and this hypothesis has now been coufirmed by a considerable body of curions eridence. ${ }^{30}$ From these considurations Mr. Bates inferred that the butterflies which initate the protected species had acquired their present marvellously deceptive appearance through variation and natural selection, in order to he mistaken for the protected hinds and thus to escape being devourcd. No explanation is lere attempted of the brilliant colors of the imitated, but only of the imitating butterflies. We must accomut for the colors of the former in the same general manner as in the cases previously discussed in this chapter. Since the publication of Mr. Bates's paper, similar and equally striking facts have been observed by $\mathrm{Mr}$. Wallace ${ }^{20}$ in the Malayan region, and hy Mr. Trimen in South Africa.

As some writcs ${ }^{27}$ lave felt much difficulty in under-

" 'Jroc. Ene. Soc.' Dec. 3, 1n66, p. siv

s6 'Tramact. J.im. Sinc.' Vul. xxv. 1S65, 1'. 1; also 'Trantact. Fint.

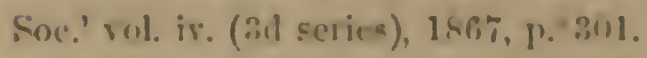

" Sce an ingenious article entitled "Diflicultice of the Theory of Nar. 
standisg how the first steps in the procen of mimiory crould have been eflected shrowgh matural welection, it mos be well to resuark thit the procent problobls bas sever cusumenced with forms widely disuinilar in color. lius,

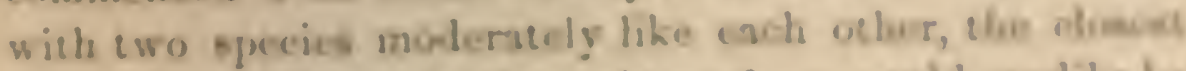
reseurblunee, if benefieial es ulther form, emild resulily to thos gained; aul, if the imitatoul form was onlonguent! sul prachally molitiod through secual selvetion or ans other menos, the imitating forse woubl be bed slowg the kane traok, and thos be minlified to almost ang extest, no

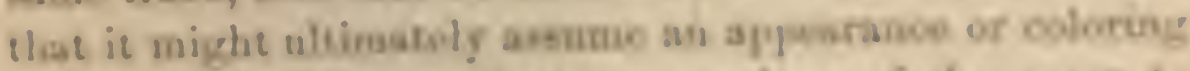
wholly nulibe that of the ntber moviber of the srum th

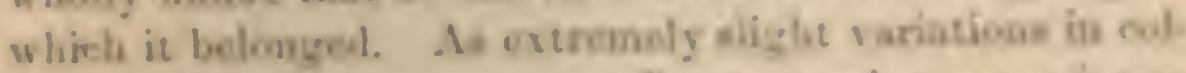

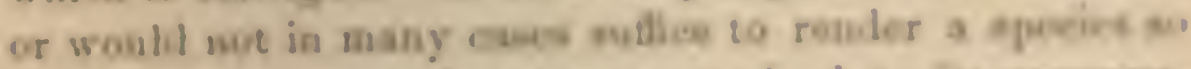

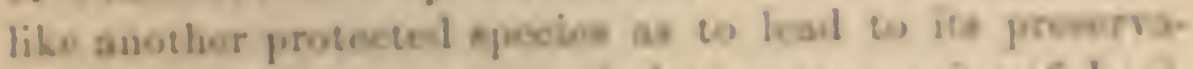

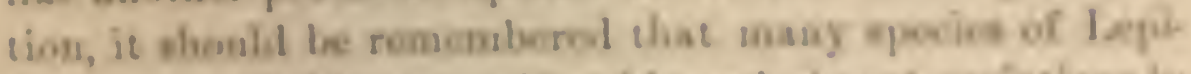

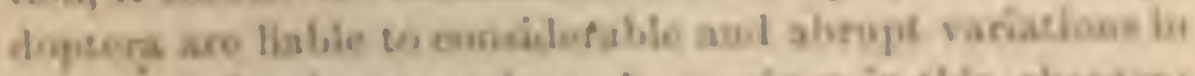

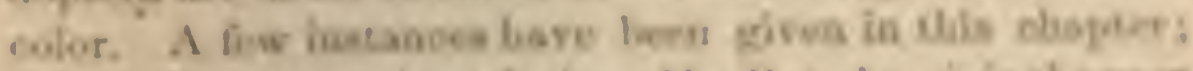

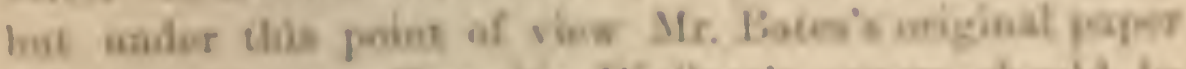

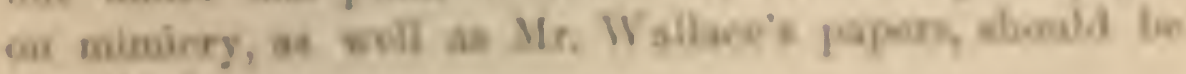
conasulited.

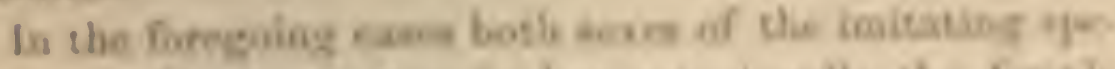

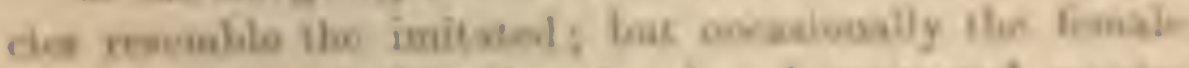

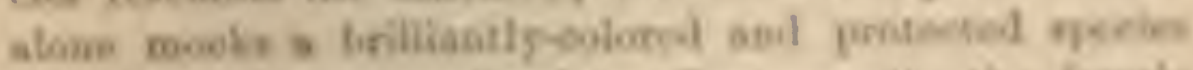

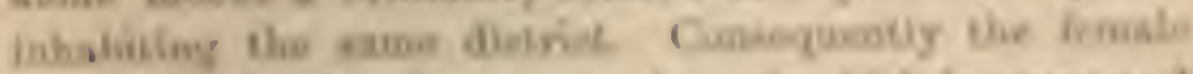

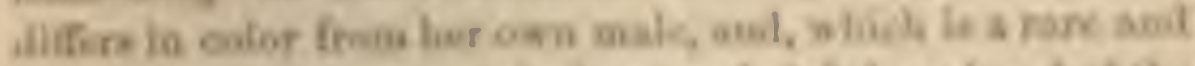

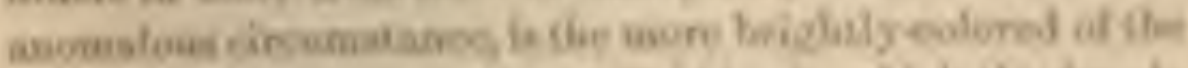

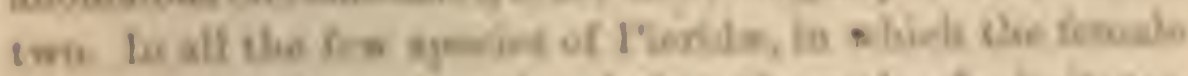

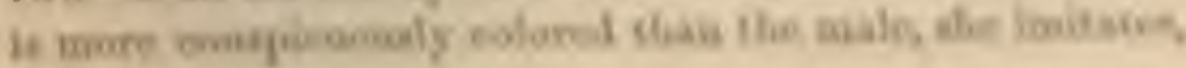

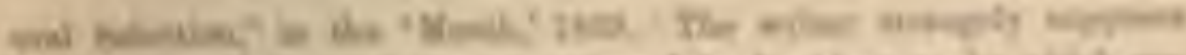

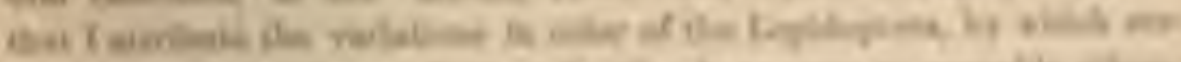

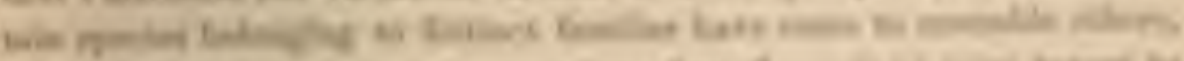

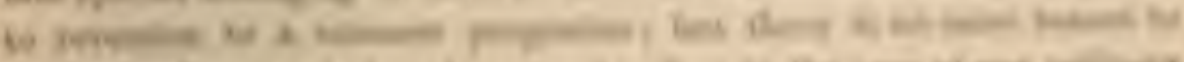

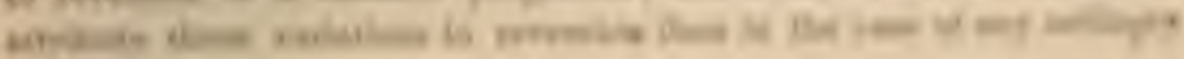
nomine 
as I am informed by Mr. Wallace, some protected species inhabiting the same regrion. The female of Diallema anomala is rich purple-brown with almost the whole surfice glossed with satiny blue, and she closely imitates the Euplace midamus, "one of the commonest buttertlies of the East;" while the male is bron\%y or olivebrown, with only a slight blue gloss on the outer parts of the wings. ${ }^{28}$ Both sexes of this Diadema and of $D$. bolinc follow the same habits of life, so that the differences in color between the sexes camnot be accounted for by exposure to different conditions; ${ }^{20}$ eren if this explanation were admissible in other instances. ${ }^{30}$

The above cases, of female butterflies which are niore hrightly-colored than the males, show us, firstly, that variations have arisen in a state of nature in the fomale sex, and have been transmitted exclusively, or almost exclusirely, to the same sex; and, secondly, that this form of inheritance has not been determined through natural selection. For, if we assume that the females, before they became brightly colored in initation of some protected kind, trere exposed during each season for a longer periol to danger than the males, or if we assume that they could not escape so swiftly from their enemics, we can molerstand how they alone might originally have acquired through natural selection and sexually-limited inheritance their present protective colors. But, execpt on the principle of these variations having been transmitted exchsively to the feniale offspring, we camnot understand why the males should have remaincd dull-colored; for it woulil

¿8 Wallace, "Xotes on Lastern Butterflies," 'Transact. Fut. Soc.' 1568, p. $25 \%$.

29 Wallace, in 'Westminster lecriew, .July, 15f5, p. 27; and in 'Journal of Trarel and Nat. Hist.' rol. i. 186,8, p. 88.

${ }^{20}$ Sce remarks, ly Messrz. liates and Wallace, in 'Hroc. Ent. Soc.' Nor. 1?, 18çi, p. xxrix. 
eurely uot have been in ang was injurious to rach iulisilual male to have partaken by iulieritance of the gro- tecelive coluon of the fomale, aud thus to hare bal a better chance of esapjing destruction. In a group in which frilliant colors are so common as with buttertlics, it canuet besupposcel that the males have heen bepe dull-ent. oret through serual welection by the females rejecting the indisiluals which were renderol as beagiful as the anefres. We smay, therefore, conclude that in theso cants inheritase log we sex is not lise to the nodifiestion through satural election of a iendeney $10 \mathrm{equal}$ isherieanew lig both keres.

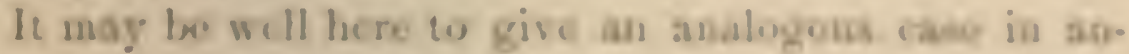
colser Oriler, of charaeturn anquired anly by tbo fouale, thoigh not in the least injurious, an far an we can julgh, to the male. Among the Phasmidas, or ppectro-imoces, Mr. Wallace veates that it is often the females aloun that oc strihingly remuble learrs, while the moles tbow onls a nude approsimation." Now, whaceser mag be the hal.

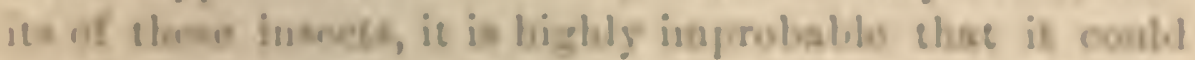

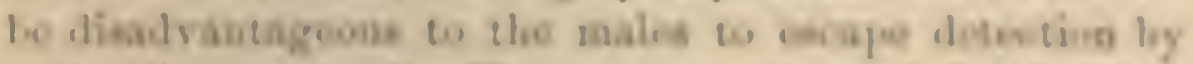

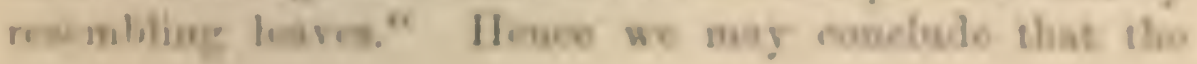

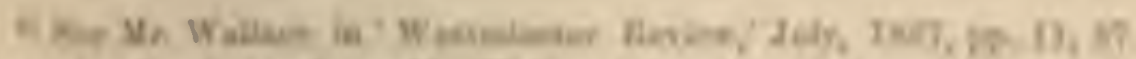

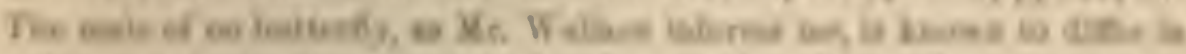

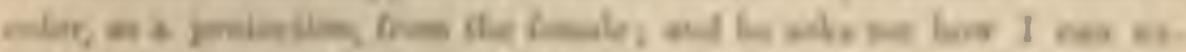

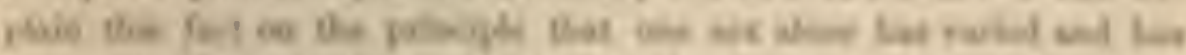

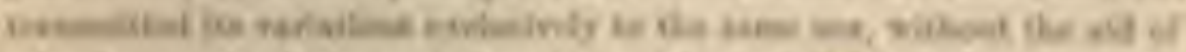

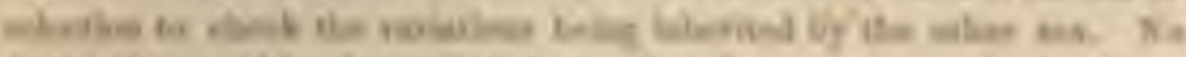

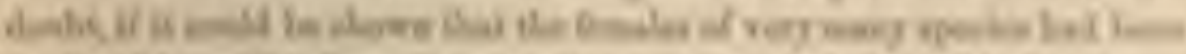

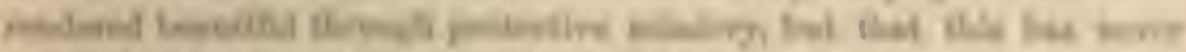

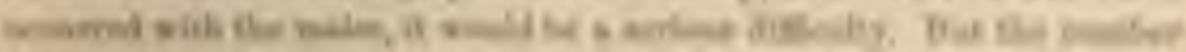

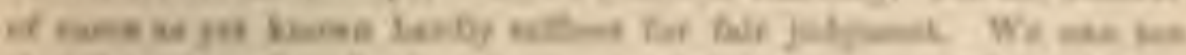

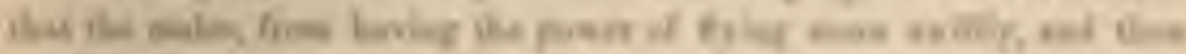

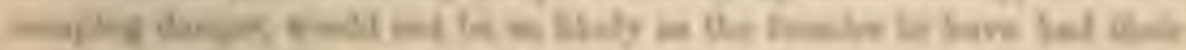

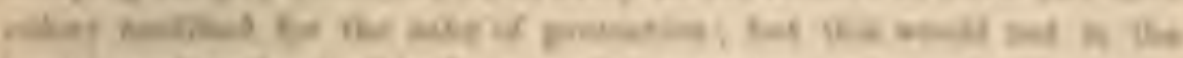

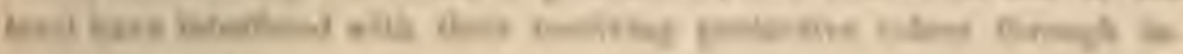


females alone in this latter as in the previous cases originally raried in certain characters; these characters having been preserved and augmented throngh ordinary selection for the sake of protection, and from the first transmitted to the female offspring alone.

Bright Colors of Cuterpillars.-While reflecting on the beauty of many butterflies, it occurred to me that some caterpillars were splendidly colored, and as scxual selection could not possibly have here acted, it appeared rash to attribute the beauty of the mature insect to this agency, unless the bright colors of their larvese could be in some manner cxplained. In the first place, it may be observed that the colors of eaterpillars do not stand in any close correlation with those of the mature insect. Siecondly, their bright colors do not serve in any ordinary manner as a protection. As an instance of this, Mr. Batcs informs me that the most conspicuous caterpillar which he ever beheld (that of a Sphinx) lived on the large green leaves of a trece on the open llanos of Sonth America; it was about four inches in length, transversely banded with black and yellow, and with its head, legs, and tail of a bright red. Hence it caughtit the eye of any man who

licritance from the females. In the second place, it is probable that sexual selection wonld actually tend to prevcrit a beautiful male from becoming obscure, for the less brilliant individuals would be leas attractire to the females. Supposing that the beauty of the male of any fpecios had been mainly acquired through sexual selection, yet if this beanty likewise served as a protection, the aç̨nitition would have been aident hy natural selection. But it wonld be quite begond our power to dis. lingnith between the two proceses of ecrual aul orlinary ectetion. Hence it is not likely that we klould be alile to alduce cavein of the males lazving been rendered brilliant exclusively through protectire minicry, though this is comparatirely eat! with the feunales, which have rarily or never been rendered beautiful, as fur as we can judee, for the take of sexual attraction, although they liare of cu reccired beanty throngh in. heritance from their mole parent. 


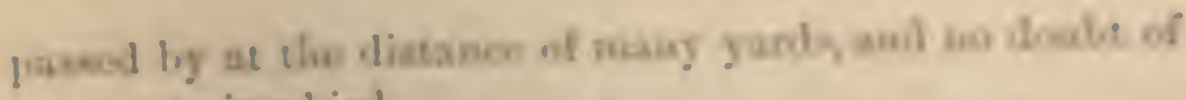
every jasaing hind.

I then applion to Mr. Wallaces, whe lise as iobace

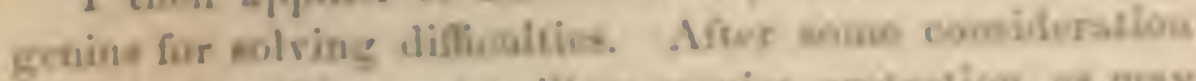

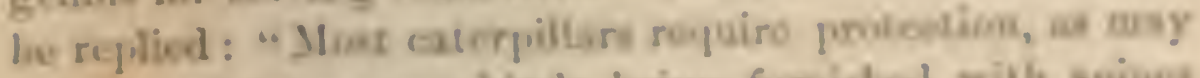

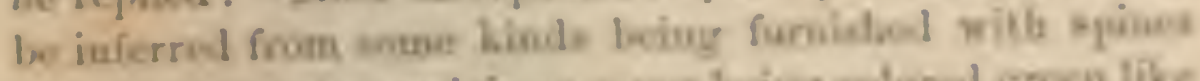

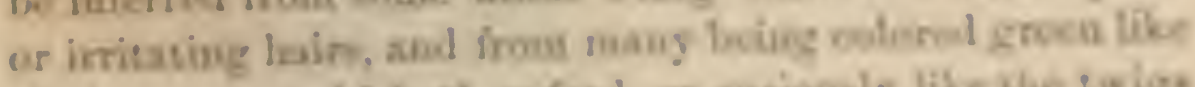

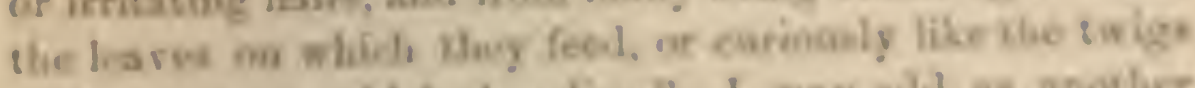
"f the troes on whide they live," I may ald as anower iestanes of protoction, that there it a estergellar of a enoth,

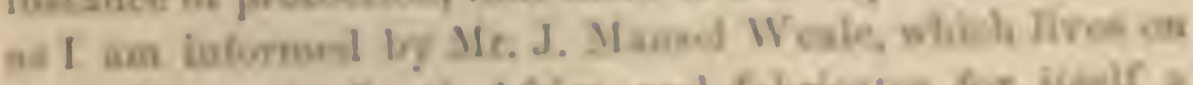

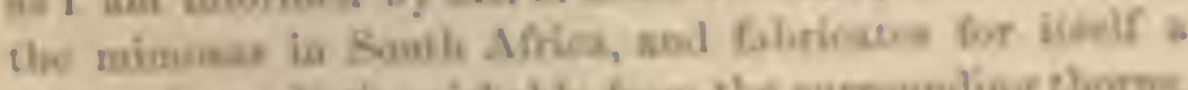

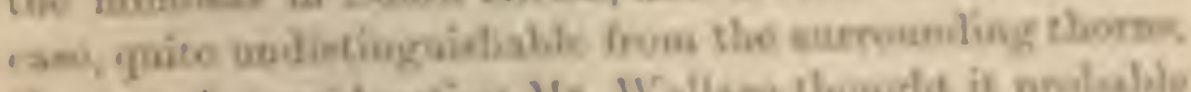

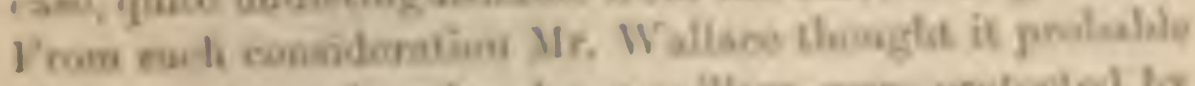

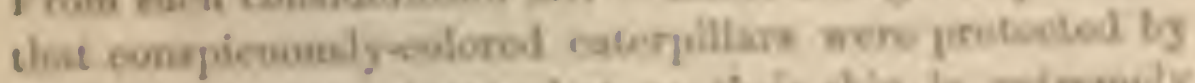

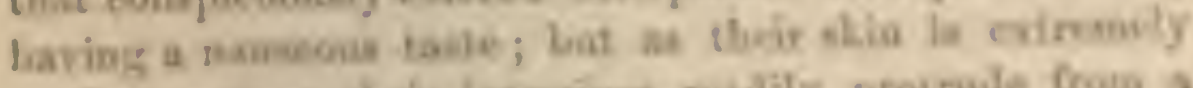

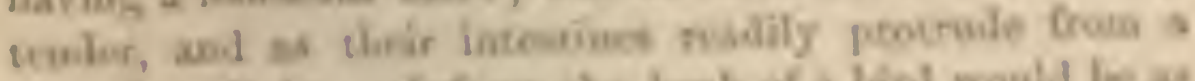

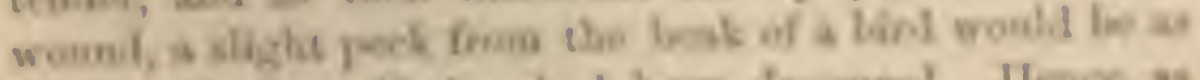

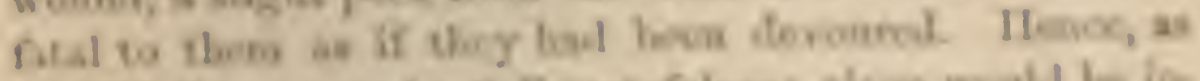

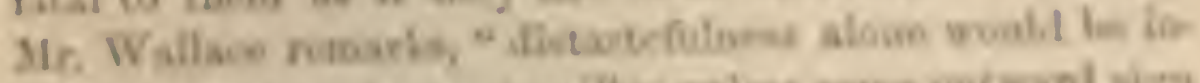

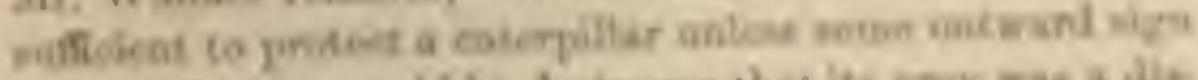

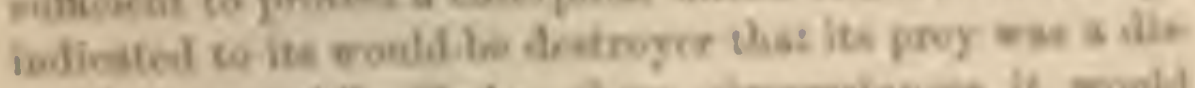
gosting coonet." Voder these circooselasiose it woobl

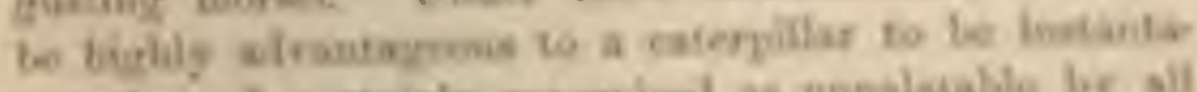

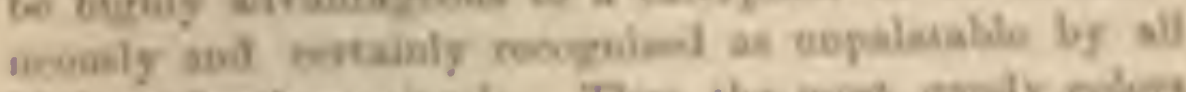

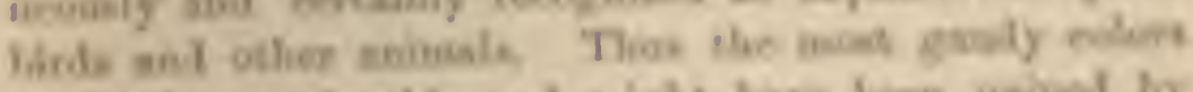

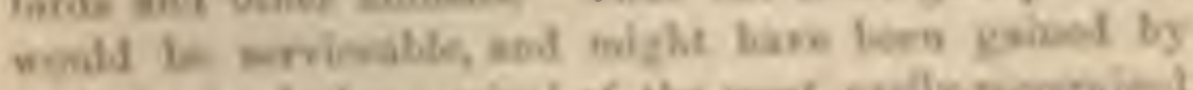

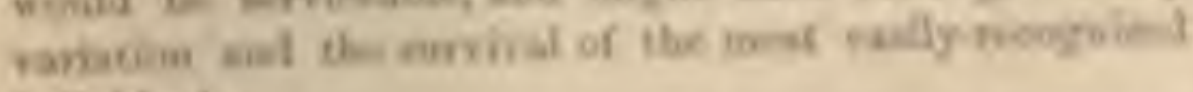
foalivilosib

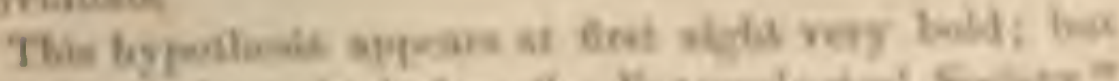

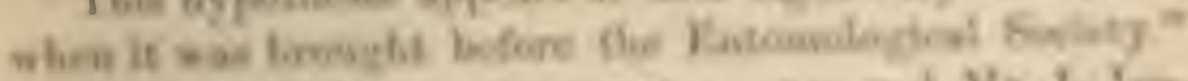

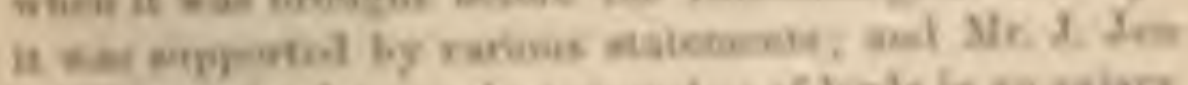

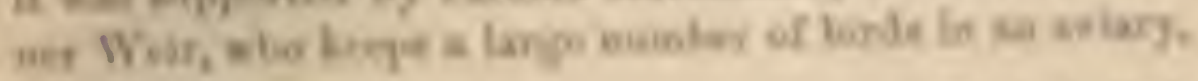

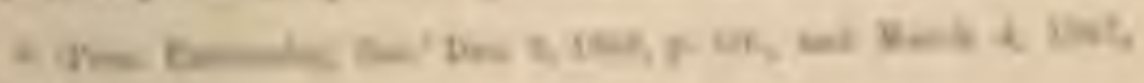


las made, as he informs me, numerous triale, and finds no "sception to the rule, that all caterjillars of nocturnal amel retiring habits with smooth shins, all of a green color, and all which imitate twigh, are grecdily dercured by his birls. The hairy and spinose kinds are invariahly rejected, as were four conspicuously-colored species. Whien the hirily rojected a caterpillar, they plainly showed, by shaking their liends and cleansing their beaks, that they were disgusted by the taste." Three conspicuous hinds of caterpillars and moths were also given by Mr. A. Butler to soune lizards and frogs, and were rejected; thonghts other kinds were eagerly catch. Thus the probable truth of $\mathrm{Mr}$. Wallace's vicw is confirmed, namely, that certain eatcrpillars lawe been made conspienous for their own good, so as to be easily recognized by their enemies, on me'arly the same principle that certain poisons are colored by druggists for the good of man. 'This riew will, it is probshle, be lecreafter extended to nany animals, which are colored in a conspicuous manner.

Siemmary and Conchuting Remarlis on Tuscets.Looking back to the several Orders, we have secu that the sexes often differ in various characters, the meaning of which is not understood. The sexes, also, often diffir in their organs of sense or locomotion, so that the males may quickly discover or reach the females, and still oftener in the males possessing diversified contrivances for retaining the females when found. But we are not here muth ronecrned with sexual diflierenees of these hinds.

In almost all the Oriters, the males of some species, even of weak and delicate kinds, are known to be highly puguacious; and some fow are furnished with special wesp ons for fighting with their rivals. But the law of battle

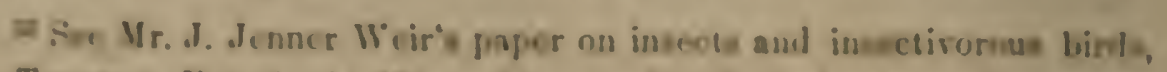
in 'Trantact. Kan. Son?' 18e?, P. 21 ; aloo Mr. Butler's Maper, ibid, p. 27. 
Aloce toot prevail marly wo widvly wide insect as wath ile

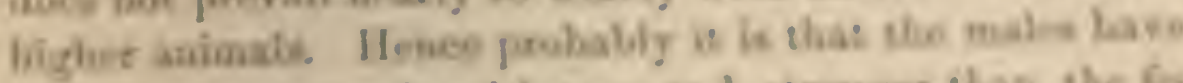

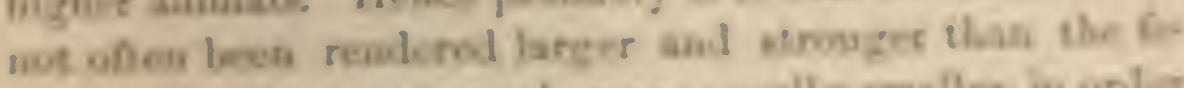
malos. Un the coutrofy, ibey are nusally roullec, in onder

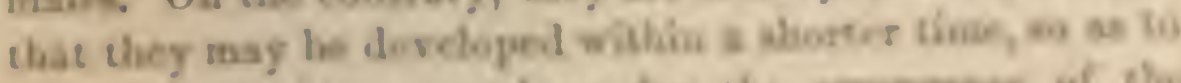

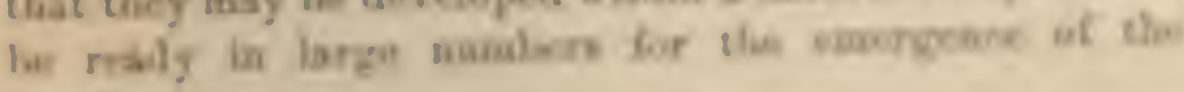
fousales.

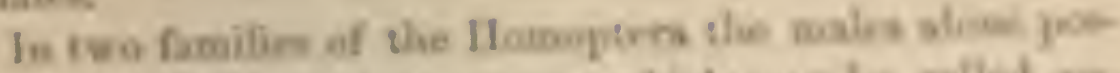

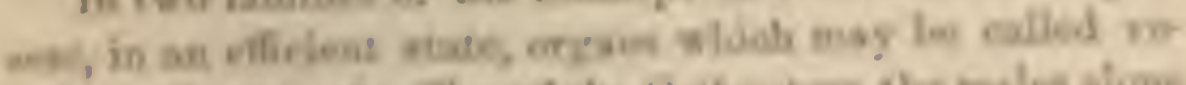

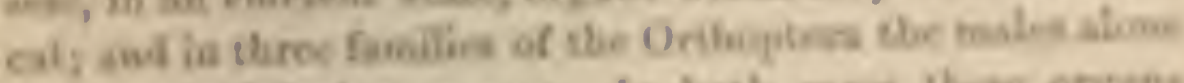

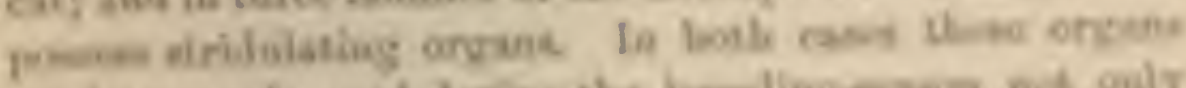

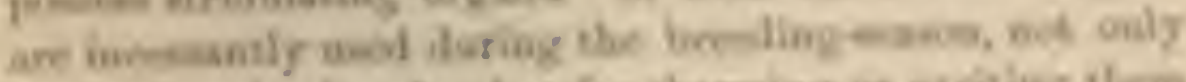

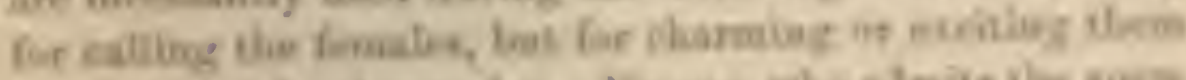

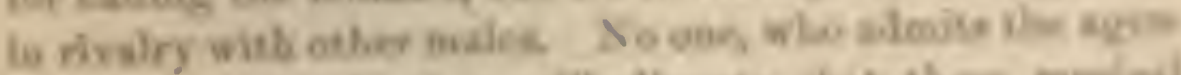

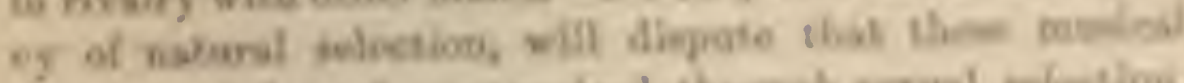

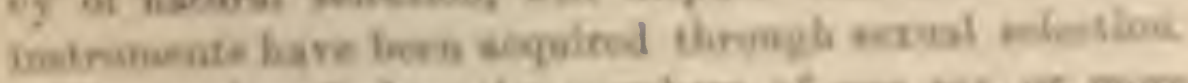

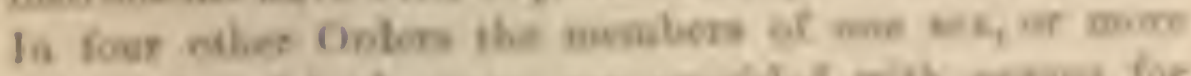

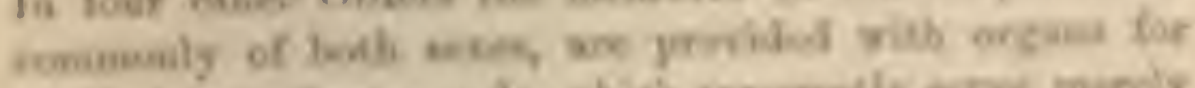

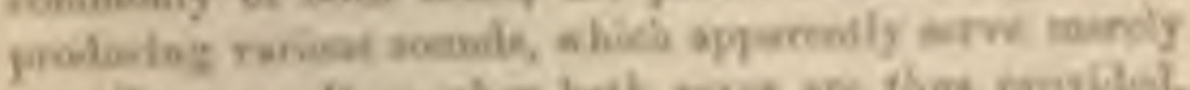

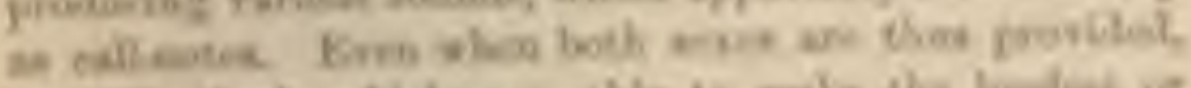

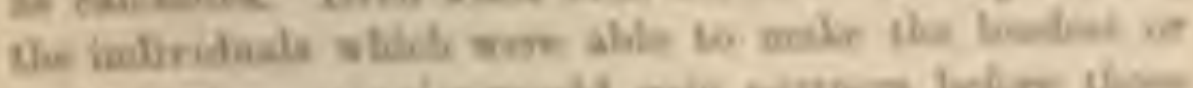

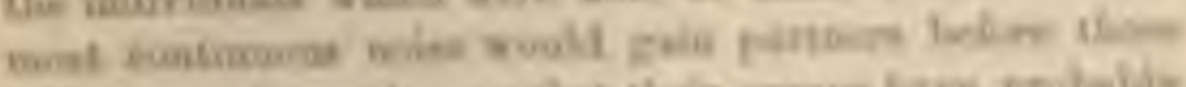

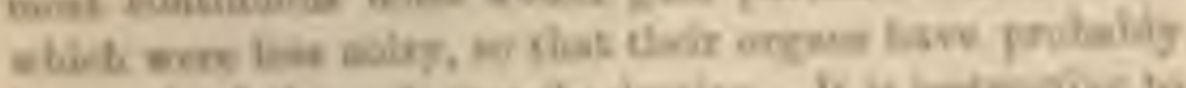

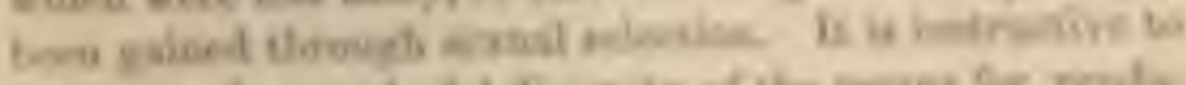

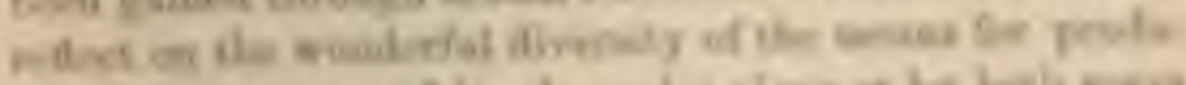

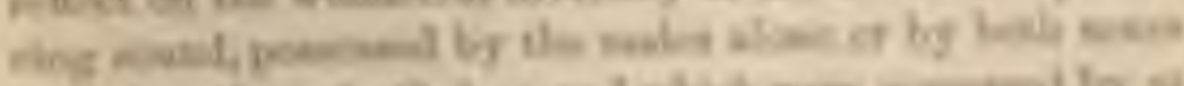

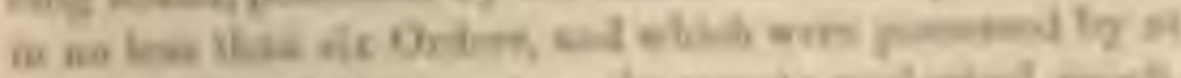

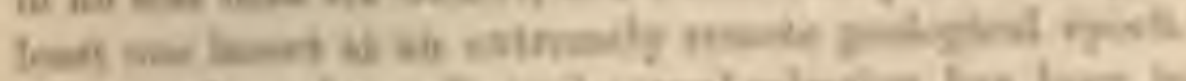

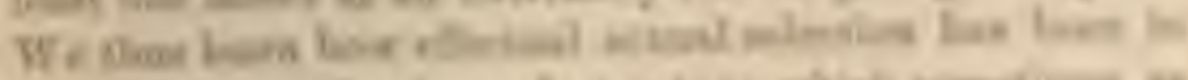

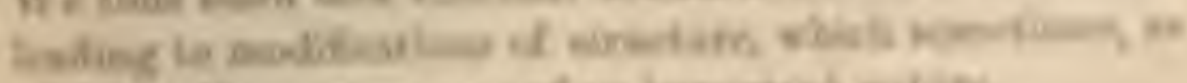

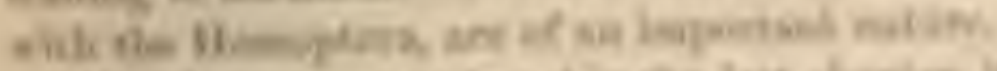

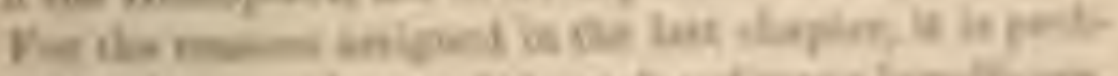

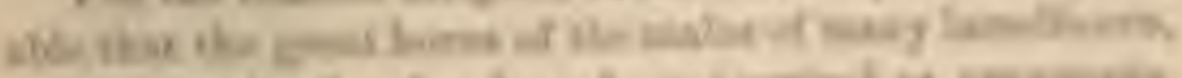

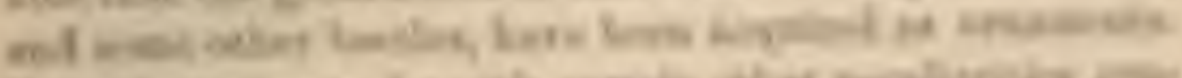

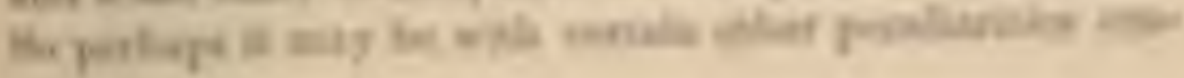


fined to the male sex. From the small size of insects, we are apt to undervalue their appearance. If we could iniagine a male Chalcosoma (fig. 15) with its polished, bronzed coat-of-mail, and rast complex horns, magnified to the size of a horse or eren of a dog, it would lie one of the most imposing animals in the workd.

The coloring of insects is a complex and obscure sulbject. When the male differs slightly from the female, and noither is brilliantly colored, it is probalble that the two se:ses have varied in a slightly different manner, with the variations transmitted to the same sco, without any benefit having been thus derived or evil sulfered. Whien the male is brilliantly colored and diflers conspicuonsly from the female, as with some dragon-flies and many luntterflies, it is probable that he alone has been modified, and that he owes his colors to sexual selection; while the female has retained a primordial or very ancient type of coloring, slightly modified by the agencies before explained, and has therefore not been rendered obscure, at least in most cases, for the sake of protection. But the female alone has sometimes been colored brilliantly so as to imitate other protected species inlabiting the same district. When the sexes resemble each other and both are obscureIy colored, there is no doubt that they have been in a multitude of cases colored for the sake of protection. So it is in some instances when both are brightly colorecl, cansing them to resemble surrounding objects such as flowers, or other protected species, or indirectly ly giving notice to their enemies that they are of an unpalatable nature. In many othere cases in which the seses resenble ('ach other and are brilliantly colored, especially when the colors are arranged for display, we may conclude that they have been gained by the male sex as an attraction, and have been transferred to both sexes. We are more especially led to this conclusion whenever the same type of 


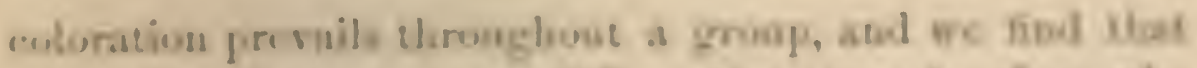
the malen of some fpecies duli $r$ widely in cular frum dar

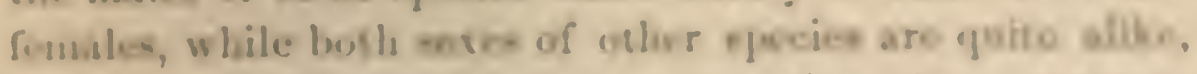
with internediate gradations connecting thepe estrean situt.

In the catne wasner as hrighte colors have wîn lexn fartially uraneferred from tbo wales to the fomales, 6 it has lwen wible the e rtraundinary home of magy twaetliearer

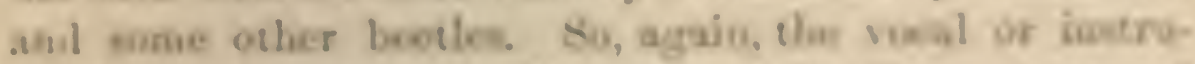
montal argans proper to the males of the Hrasopiers mil

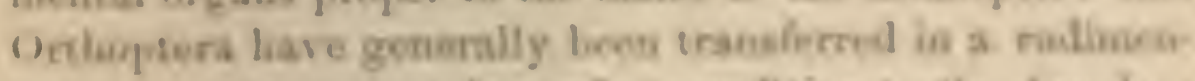
ary, or eres in a searly perfoer condition to the femsles:

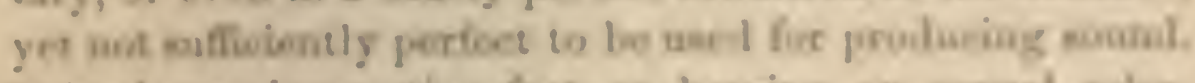
it if abo an intereseing fach as bering on nowal whetium, that the stridalating orgeas of orctain malo Orthop. tere are pot fully develojed uatil die last mouls; and thas

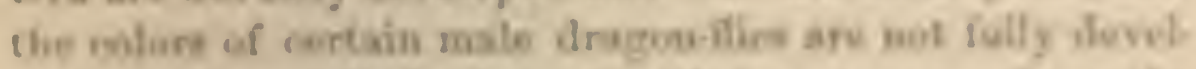

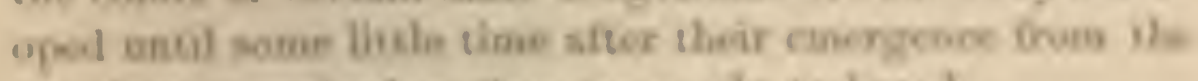
paipal staw, and wion they are nesily to limed.

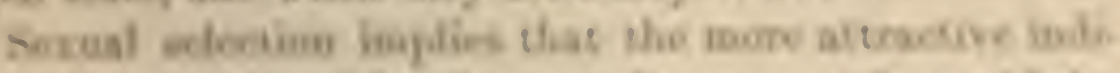

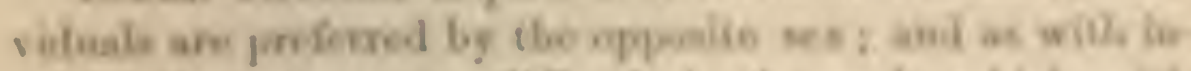

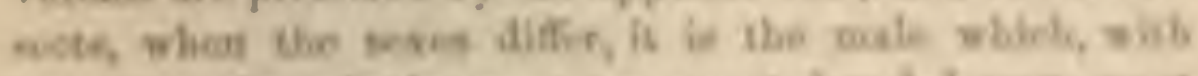

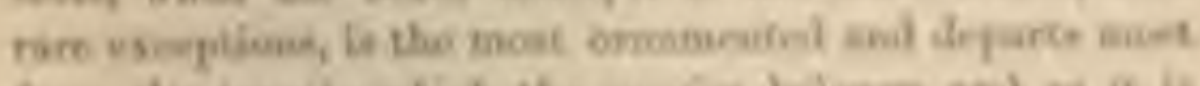

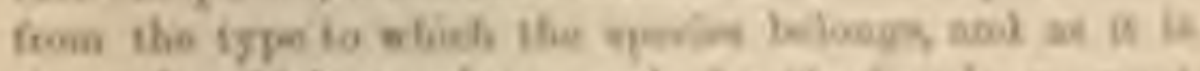

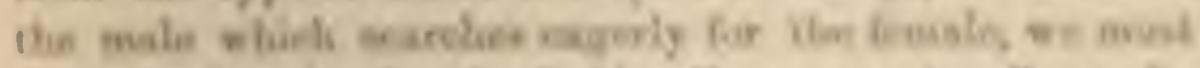

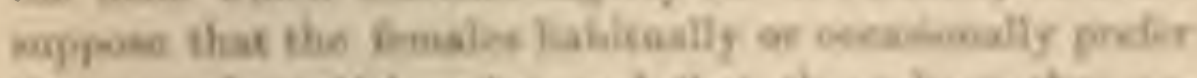

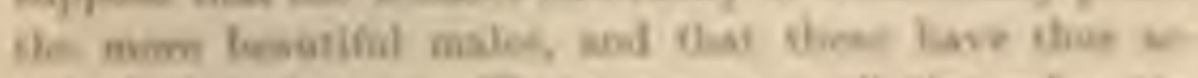

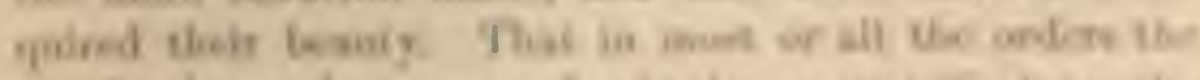

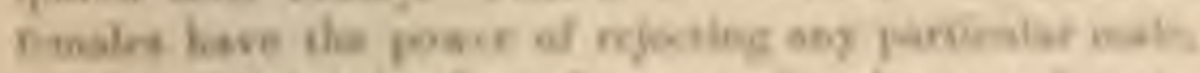

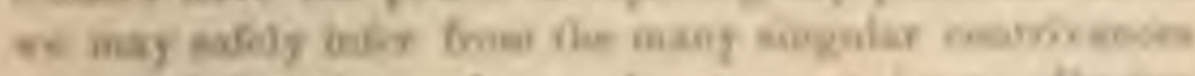

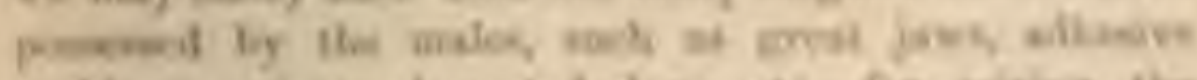

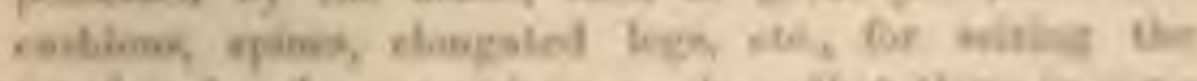

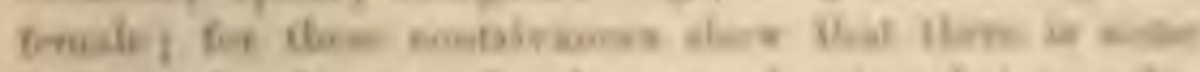

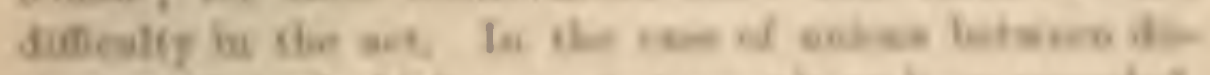

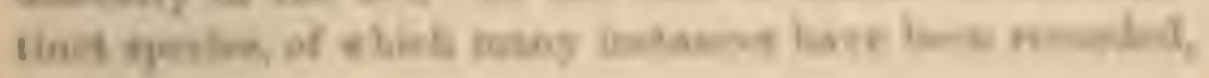


the female must have been a consenting party. Julging from what we know of the pereeptive powers and affections of various insects, there is no antecedent improba. bility in sexual selection having come largely into action; but we have as yet no direct evidence on this head, and some facts are opposed to the belief. Nevertheless, when we see many males pursuing the same female, we cau hardly believe that the pairing is left to blind chancethat the female exerts no choice, and is not influenced by the gorgeous colors or other ornaments with which the male alone is decorated.

If we admit that the females of the Homoptera and Orthoptera appreciate the musical tones emitted by their male partners, and that the various instruments for this purpose have been perfected through sexual selection, there is little improbability in the females of other insects appreciating beauty in form or color, and consequently in such characters having been thus gained by the males. But, from the circumstance of color being so variable, and from its having been so often modified for the sake of protection, it is extremely difficult to decide in how large a proportion of cases sexual selection has come into play. This is more especially difficult in those Orders such as the Orthoptera, Hymenoptera, and Coleoptera, in which the two sexes rarely differ much in color; for we are thus cut off from our best evidence of some relation between the reproduction of the species and color. With the Coleoptera, however, as before remarked, it is in the great lamellicorn group, placed by some authors at the head of the Order, and in which we sometimes see a mutual attachment between the sexes, that we find the males of some species possessing weapons for sexual strife, others furnished with wonderful horns, many with stridulating organs, and others ornamented with splendid metallic tints. Hence it seems probable that all these characters havo 
been grained though the same means, namely, scrual -celece tion.

When we troat of Birds, we slall sce that they present in their secondary sexual characters the closest analogy with insects. 'Thus, many male hirds are highly purgnacious, and some are furnished with special weapous fur fighting with their rivals. They posess organs which are nsed during the breetingasenson for producing vocal and instrumental music. 'They are frequently ormanenteel with combs, horna, wattles, and plumes, of the mo-t divere sitied kimls, and are decorated with beantiful wors, all eviclently for the salie of di-play. We shall fiml that, as with insects, hoth scxes, iu certain group, aro equally beatiful, and are equally provided with ormameus which are usually confined to the male sex. In other gromp buth sexes are equally plain-colored aml umormamented. Jandly, in some few anomalons eases, the females are more beantiful than the malces. We shall ofren fime, in the sitnce group of birels, erery gradation from un dillireneo between the sexes to an extreme ditlierence. In the lateer rase we shall sce that the females, like fomale insects, of fur puseses more or los plain traces of elue characers which properts belome en the moles. The amologe, imelest, in all

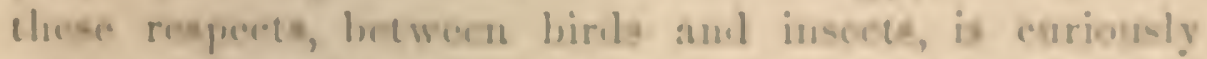

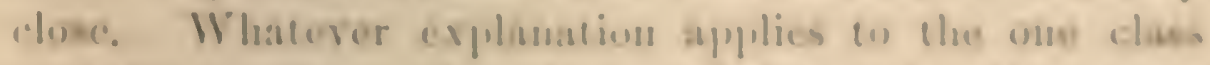

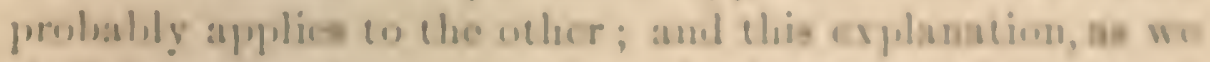

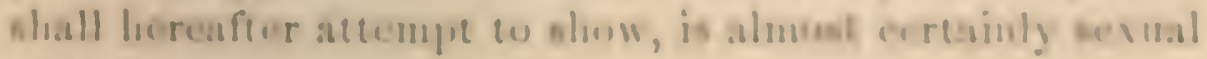
solection. 


$$
5700 \quad 4
$$







\section{DUE DATE}

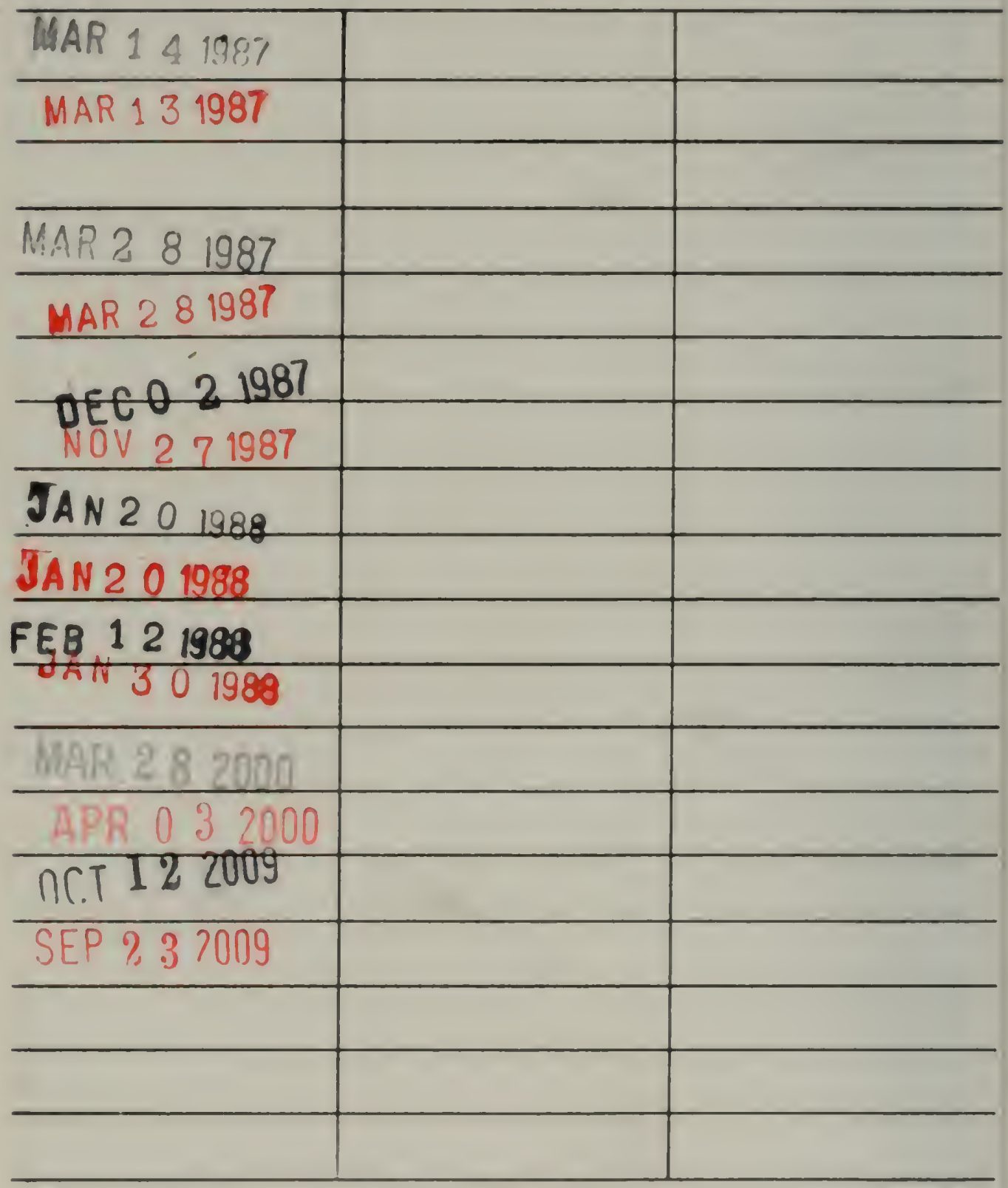




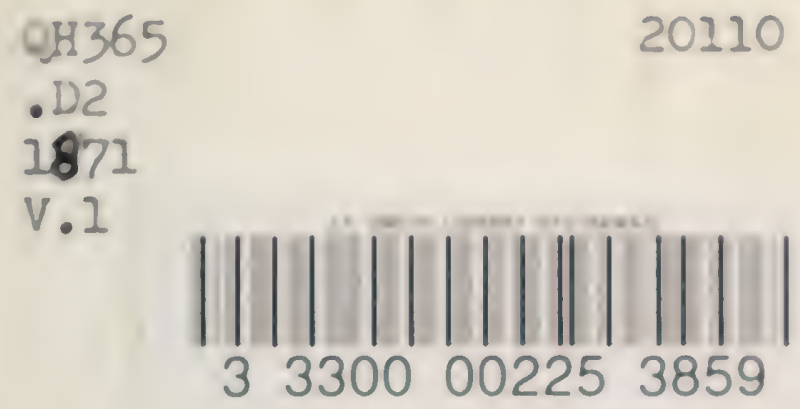

Darwin, Charles

The Deicent of Man 


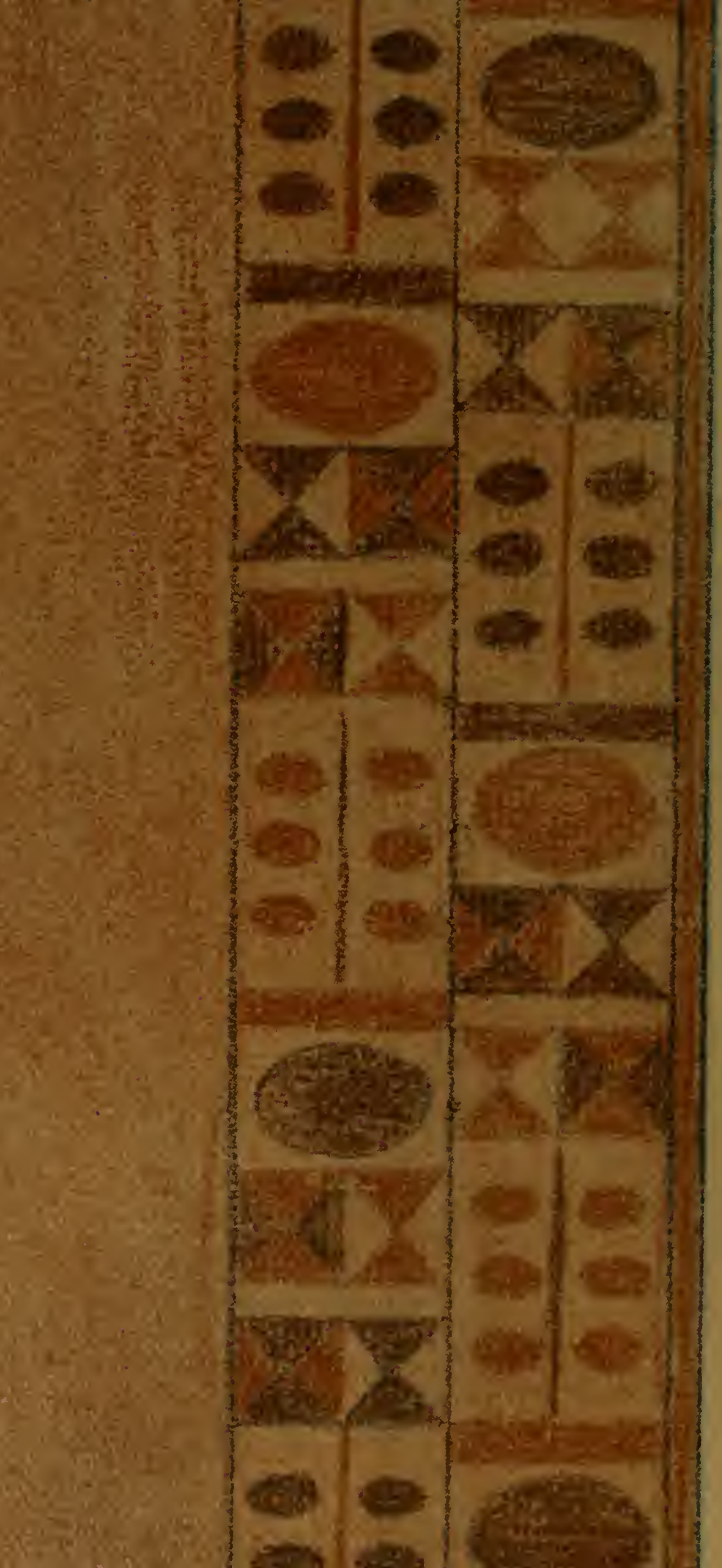

